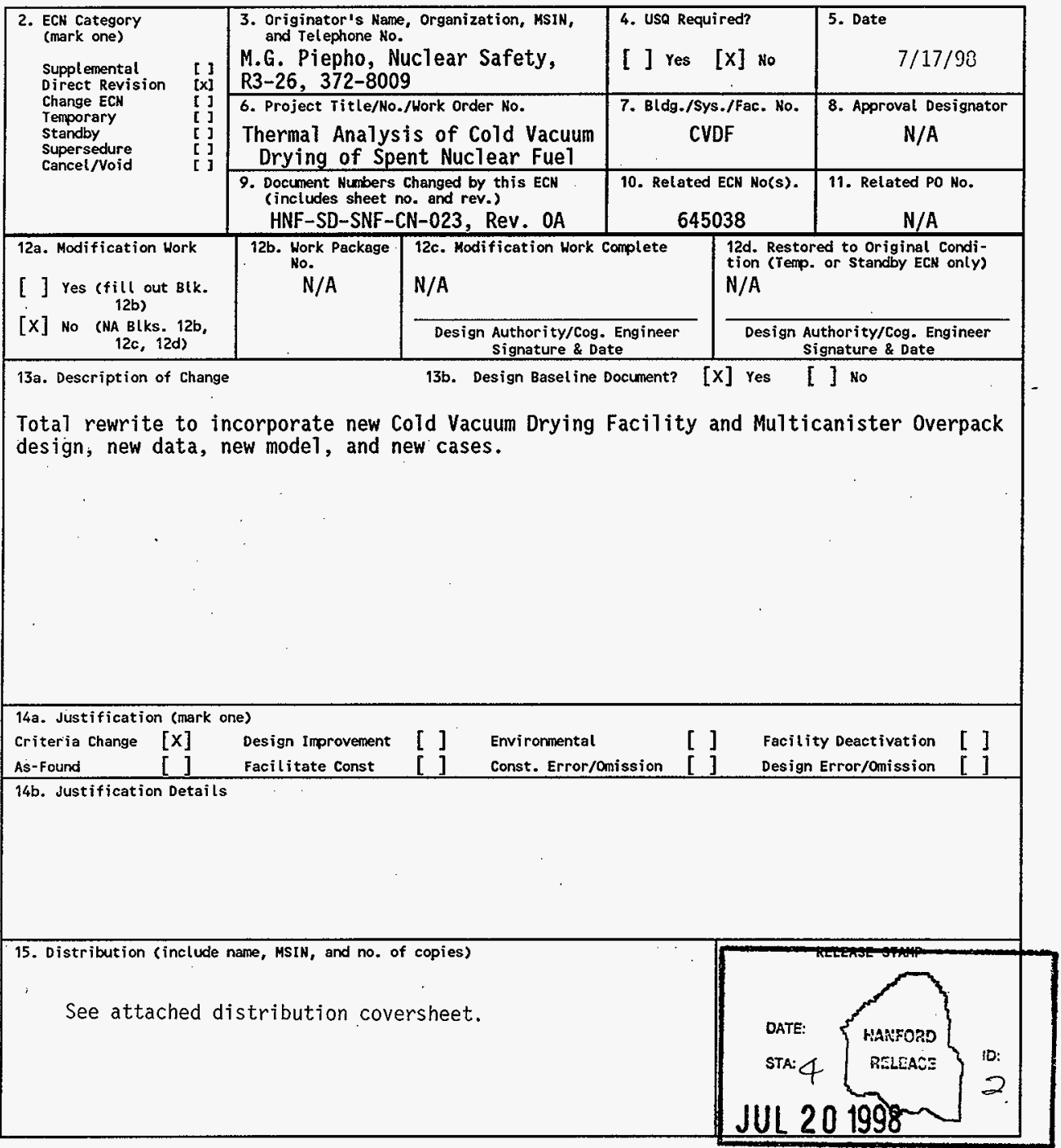




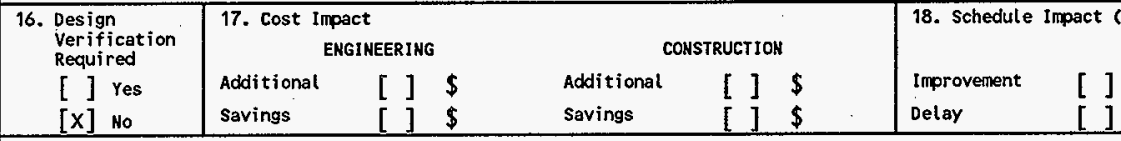

19. Change Impact Review: Indicate the related documents (other than the engineering documents identified on side 1 ) that will be affected by the change described in Block 13 . Enter the affected document number in 8 lock 20 . SDD/DD

Functional Design Criteria

[] N/A Seismic/Stress Analysis

Operating Specification

Criticality Specification

[]

[]

Conceptuat Design Report

[]

Equipment Spec.

Const. Spec.

Procurement Spec.

Vendor Information

OM Manual

FSAR/SAR

Safety Equipment List

Radiation Work Permit

Environmental Impact Statement

Environmental Report

Environmental Permit
[] $N / A$

[]

Interface Control Drawing

Calibration Procedure

Inatallation Procedure

Maintenance Procedure

Engineering Procedure

Operating Instruction

Operating Procedure

Operational Safoty Requirement

IEFD Drawing

Coll Arrangement Drawing

Essential Material Specification

Fac. Proc. Samp. Schedule

Inspection Plan

Inventory Adjustment Request

Tank Calibration Manual

Health Physics Procedure

Spares Multiplo Unit Lieting

Test Procedures/Specification

Component Index

ASME Coded Item

Human Factor Consideration

Computer Software

Electric Circuit Schedule

ICRS Procedure

Process Control Manual/Plan

Process Flow Chart

Purchase Requisition

Tickler File

20, Other Affected Documents: (NOTE: Doctments (isted below will not be revised by this ECN.) Signatures below indicate that the signing organization has been notified of other affected documents listed below. Document Number/Revision Document Number/Revision

Document Number Revision

$N / A$

21. Approvals

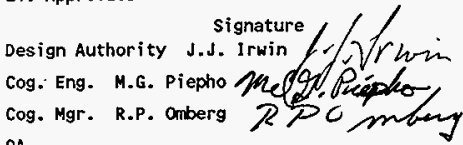
QA

Safety

c. Pili-Vincens

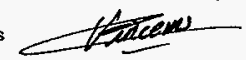

Environ.
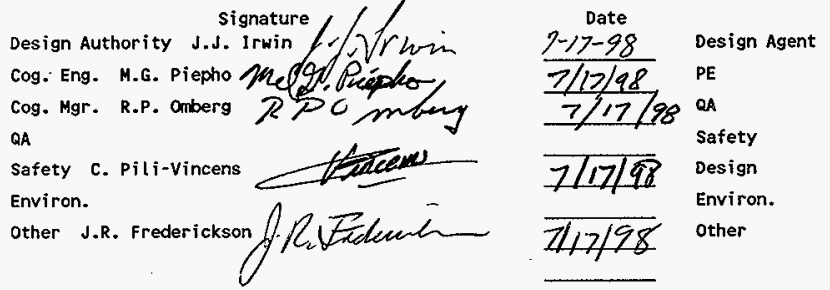

signature

Date

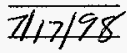

other

DEPARTMENT OF ENERGY

Signature or a Control Number that

tracks the Approval Signature

ADDITIONAL 


\section{Thermal Analysis of Cold Vacuum Drying of Spent Nuclear Fuel}

M.G. Piepho, R.D. Crowe

Fluor Danie1 Northwest, Inc., Richland, WA 99352

U.S. Department of Energy Contract DE-AC06-96RL13200

ECN: 637183

Org Code: 2T930

B\&R Code: 39EW40400
UC: 620

Charge Code: LH062

Total Pages: $4 / 10$

Key Words: MCO thermal analysis, CVD thermal analysis, N-Reactor fuel, spent nuclear fuel

Abstract: The thermal analysis examined transient thermal and chemical behavior of the Multicanister Overpack (MCO) container for a broad range of cases that represent the Cold Vacuum Drying (CVD) processes. The cases were defined to consider both normal and off-normal operations at the CVD Facility for an MCO with Mark IV N Reactor spent fuel in four fuel baskets and one scrap basket. This analysis provides the basis for the MCO thermal behavior at the CVD Facility for its Phase 2 Safety Analysis Report (revision 4).

TRADEMARK DISCLAIMER. Reference herein to any specific commercial product, process, or service by trade name, trademark, manufacturer, or otherwise, does not necessarity constitute or imply its endorsement, recommendation, or favoring by the United States Government or any agency thereof or its contractors or subcontractors.

Printed in the United States of Anerica. To obtain copies of this document, contact: Document Control Services, P.0. Box 950, Mailstop H6-08, Richland WA 99352, Phone (509) 372-2420;

Fax (509) 376-4989.
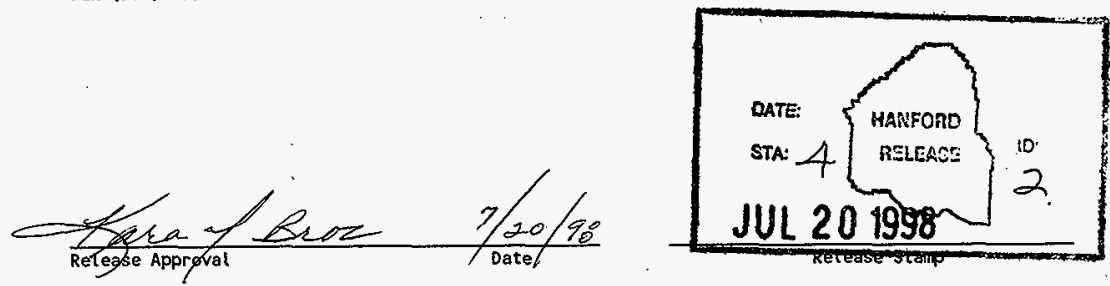


\begin{tabular}{|c|c|c|c|}
\hline \multicolumn{2}{|r|}{ RECORD OF REVISION } & $\begin{array}{l}\text { (1) Document Number } \\
\text { HNF-SD-SNF-CN- } \\
023, \operatorname{Rev}, 1\end{array}$ & $\begin{array}{c}\mathrm{CN}- \\
1\end{array}$ \\
\hline \multicolumn{4}{|c|}{$\begin{array}{l}\text { (2) Title } \\
\text { Thermal Analysis of Cold Vacuum Drying of Spent Nuclear Fuel }\end{array}$} \\
\hline \multicolumn{4}{|c|}{ CHANGE CONTROL RECORD } \\
\hline \multirow{2}{*}{ (3) Revision } & \multirow{2}{*}{ (4) Description of Change - Replace, Add, and Delete Pages } & \multicolumn{2}{|c|}{ Authorized for Release } \\
\hline & & (5) Cog. Engr. & (6) Cog. Mgr. Date \\
\hline & (7) & & \\
\hline$O A$ & $\begin{array}{l}\text { ECN: } 645038 \\
\text { Replace Table of Contents }\end{array}$ & & \\
\hline 1 RS & $\begin{array}{l}\text { ECN: } 637183 \\
\text { Total rewrite to incorporate new Cold } \\
\text { Vacuum Drying Facility and Multicanister } \\
\text { Overpack design, new data, new model, and } \\
\text { new cases. }\end{array}$ & $\begin{array}{l}\text { M.G. Piepho } \\
\text { MGP }\end{array}$ & $\begin{array}{l}\text { R.P. Omberg } \\
\text { RPO } \\
\qquad / / 7 / 98\end{array}$ \\
\hline & & & \\
\hline & & & \\
\hline & & & \\
\hline & & & \\
\hline & & & \\
\hline & & & \\
\hline & & & \\
\hline & & & \\
\hline & & & \\
\hline & & & \\
\hline & & & \\
\hline & & & \\
\hline & & & \\
\hline & & & \\
\hline & & & \\
\hline & & & \\
\hline & & & \\
\hline & & & \\
\hline & & & \\
\hline & & & \\
\hline & & & \\
\hline & & & \\
\hline & & & \\
\hline & & & \\
\hline & & & \\
\hline & & & \\
\hline & & & \\
\hline
\end{tabular}




\title{
THERMAL ANALYSIS OF COLD VACUUM DRYING OF SPENT NUCLEAR FUEL
}

\author{
HNF-SD-SNF-CN-023 \\ Revision 1
}

\author{
Mel G. Piepho \\ Ralph D. Crowe \\ Fluor Daniel Northwest, Incorporated \\ Richland, Washington
}

Prepared for .

DE\&S Hanford, Incorporated

Richland, Washington

July 1998 


\section{HNF-SD-SNF-CN-023 REV 1}

This page intentionally left blank. 


\section{THERMAL ANALYSIS OF COLD VACUUM DRYING OF SPENT NUCLEAR FUEL}

\section{EXECUTIVE SUMMARY}

This report documents the analysis of transient thermal and chemical behavior of the multi-canister overpack (MCO) for a broad range of cases postulated to occur during cold vacuum drying. To perform this analysis, the HANSF $\operatorname{code}^{1}$ and its previous input ${ }^{2}$ were updated and new models were developed for both normal operation and off-normal operation of the cold vacuum drying processes. More off-normal cases were run than normal operation cases in order to determine the effectiveness of the MCO thermal design for bounding parameter values under off-normal conditions.

\section{CONCLUSIONS}

The following conclusions have been drawn from the thermal analysis.

1. Vacuum drying is inherently stable. Vacuum drying with no helium purge is inherently stable forever for all annulus water conditions including the hot $\left(85^{\circ} \mathrm{C}\right)$ annulus water and loss of coolant (annulus water) cases. Radiative heat transfer is

${ }^{1}$ Plys, M. G., S. J. Lee, B. Malinovic, and M. Epstein, 1998, Hanford Spent Nuclear Fuel Safety Analysis Model HANSF 1.2: User's Manual, FAI/98-40, Rev. 0, Fauske \& Associates, Incorporated, Burr Ridge, Illinois.

${ }^{2}$ Duncan, D. R., and D. E. Ball, 1997, Thermal Analysis of Cold Vacuum Drying of Spent Nuclear Fuel, HNF-SD-SNF-CN-023, Rev. OA, Fluor Daniel Hanford, Incorporated, Richland, Washington. 


\section{HNF-SD-SNF-CN-023 REV 1}

sufficient under vacuum to remove enough heat to maintain stable fuel temperatures. Even for air ingress scenarios, the fuel temperatures are stable under vacuum except for the hot annulus water and loss of coolant cases. However, even for these major features of the tempered water (annulus) system, the fuel temperatures are stable for more than 2 days. Vacuum drying is the most inherently stable physical process occurring at the Cold Vacuum Drying Facility.

2. Helium purge is stable ùnder normal conditions. The helium purge only (i.e., no vacuum) process has stable temperatures for the normal $\left(50^{\circ} \mathrm{C}\right)$ annulus water and loss of annulus water flow cases, but it is not stable for the hot annulus water and loss of coolant cases. The helium purge only process is not stable for air ingress cases with bounding hydrides, which have unstable scrap fuel temperatures in less than 2 hours primarily because of the large bounding hydride mass.

3. Open MCOs are stable under most conditions. An open $\mathrm{MCO}$ with no vacuum and no helium purge is stable forever for the normal annulus water and loss of annulus water flow cases, but it is very unstable (fuel temperature $>1,000^{\circ} \mathrm{C}$ ) for the hot annulus water and loss of coolant cases after 30 hours if enough residual water is available.

4. Closed MCOs with bounding parameter values take a long time to pressurize under most conditions. A closed (isolated) MCO will pressurize and eventually reach the rupture disk burst pressure for all annulus water conditions, but reaching the rupture disk burst pressure will take 3 days for the normal $\left(50^{\circ} \mathrm{C}\right)$ annulus water case and 6 days for the loss of annulus water flow case (stationary annulus water is cooler than $50^{\circ} \mathrm{C}$ because of the lower room temperature of the process bay and the 


\section{HNF-SD-SNF-CN-023 REV 1}

good thermal conductivity of water). If no rupture disk were used, very high fuel temperatures $\left(>900^{\circ} \mathrm{C}\right)$ would result for the hot annulus water and loss of coolant cases after 30 hours if enough residual water were available.

5. Closed MCOs with nominal parameter values are inherently stable. A closed MCO with nominal parameter values for decay heat, chemical reaction rates, and reaction surface area pressurizes very slowly for the loss of coolant case. The MCO gas pressure and the temperatures in the bottom fuel basket are shown in Figure ES-1 for both the bounding MCO and nominal MCO under loss of coolant conditions (with no rupture disk included). Clearly, even under loss of coolant conditions, the nominal $\mathrm{MCO}$ does not heat up or pressurize very much in 2 days, whereas the bounding $\mathrm{MCO}$ reaches very high pressures and temperatures in less than 2 days.

6. Introducing water into the annulus can prevent bursting of the rupture disk. For the bounding $\mathrm{MCO}$ under loss of coolant conditions, the $\mathrm{MCO}$ pressurization can be stopped very quickly (less than 60 seconds) by introducing $25^{\circ} \mathrm{C}$ water into the annulus. The cool water injected into the annulus cools the stainless steel MCO wall and bottom very quickly, and the water vapor inside the MCO starts to condense on the cooler MCO wall and bottom immediately. The condensation of water vapor lowers the gas pressure immediately and prevents the pressure from reaching the rupture disk burst pressure, as shown in Figure ES-2. Figure ES-2 also shows that the inner fuel element temperature does not decrease immediately; it takes about 2 hours to show a significant decrease in temperature. Nevertheless, the water vapor condensing on the cooler MCO wall and bottom keeps the MCO pressure below the rupture disk burst pressure for as long as 8 hours if the annulus 


\section{HNF-SD-SNF-CN-023 REV 1}

water is stationary and more than 24 hours if the annulus water is flowing. Furthermore, the $\mathrm{MCO}$ wall temperature is only about $85^{\circ} \mathrm{C}$ when the $\mathrm{MCO}$ pressure reaches rupture disk burst pressure, $11.2 \mathrm{~atm}\left(150 \mathrm{lb} / \mathrm{in}^{2}\right.$ gauge), so there is no danger of the water flashing or boiling when introduced into the annulus.

\section{Favorable annulus water conditions promote stability for all operating} conditions. The normal annulus water condition $\left(50^{\circ} \mathrm{C}\right.$ and flowing) and the loss of annulus water flow condition result in stable temperatures forever for all normal and off-normal conditions analyzed. The loss of annulus water flow condition promotes lower fuel temperatures than the $50^{\circ} \mathrm{C}$ annulus water condition.

8. Scrap fuel is generally cooler than fuel elements. The scrap basket design with compartments created by copper fins is efficient for heat removal purposes. Most of the off-normal cases that resulted in high temperatures had higher fuel element temperatures than scrap fuel temperatures, except for the helium purge only off-normal cases. The helium purge only cases with unfavorable annulus conditions have high fuel-water (steam) reaction rates in the scrap fuel because water vapor is blown from the fuel baskets into the scrap basket, which has a high surface area to volume ratio, causing the maximum scrap fuel temperature to be greater than the maximum fuel element temperature. Also, the latest scrap basket design, ${ }^{3}$ which does not have copper fin spokes in the fine scrap portion, causes even higher scrap temperatures for off-normal helium purge only cases than the design used in the previous thermal analysis, ${ }^{2}$ which included copper fin spokes in the fine scrap portion.

${ }^{3}$ Smith, K. E., 1998, Multi-Canister Overpack Design Report, HNF-SD-SNF-DR-003, Rev. OC, Fluor Daniel Hanford, Incorporated, Richland, Washington. 


\section{HNF-SD-SNF-CN-023 REV 1}

In summary, the results of this analysis show that the bounding MCO has stable temperatures for all cold vacuum drying processes after draining if the annulus water is kept at $50^{\circ} \mathrm{C}$ or cooler by the tempered water (annulus) system, or if the annulus water is stationary (not flowing). 
Figure ES-1. Thermal Runaway Reaction with Nominal and Bounding Values Caused by Loss of Coolant Condition and Closed Multi-Canister Overpack.
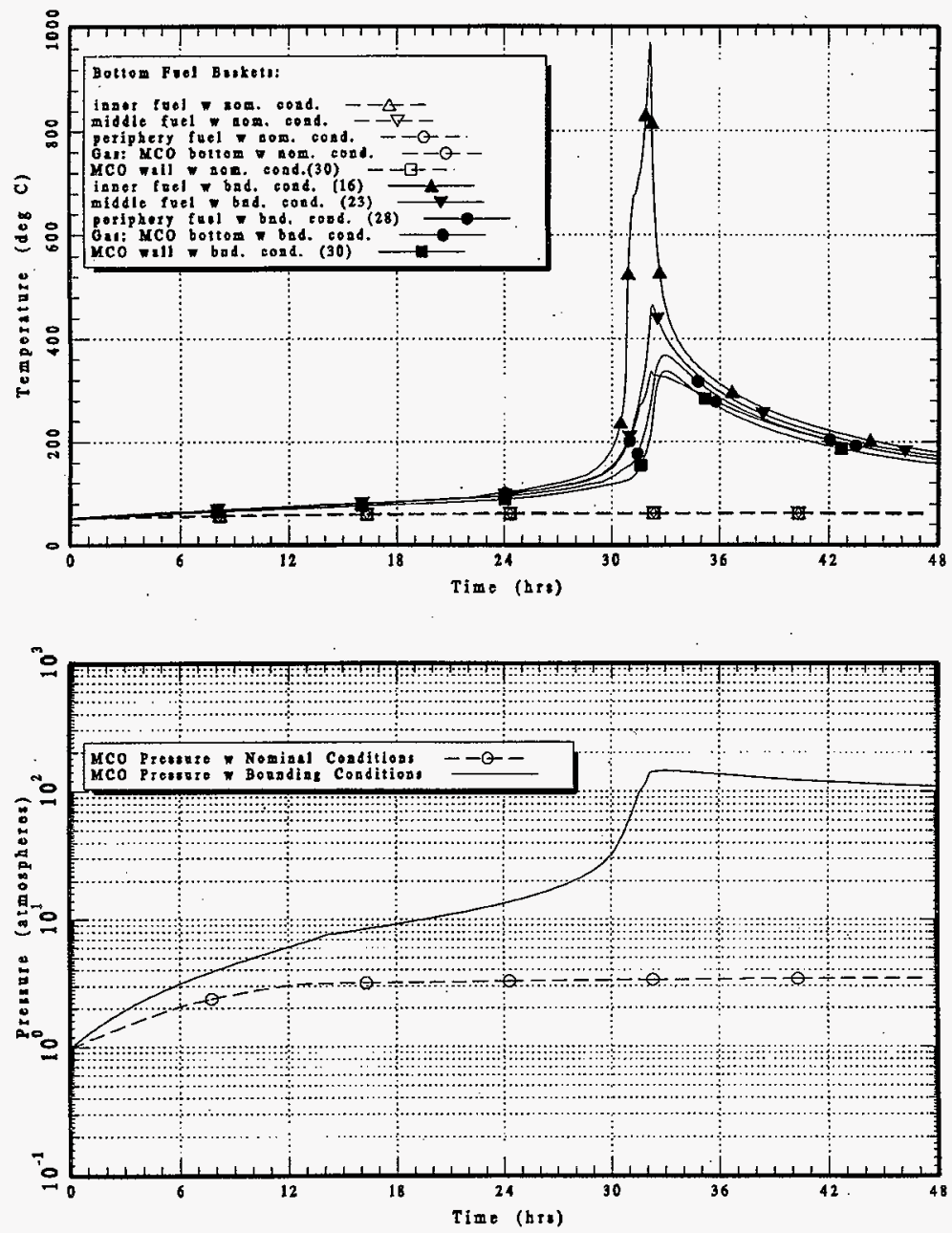
Figure ES-2. Thermal Runaway Reaction Caused by Loss of Coolant Condition and Closed Multi-Canister Overpack with Annulus Water Recovery.
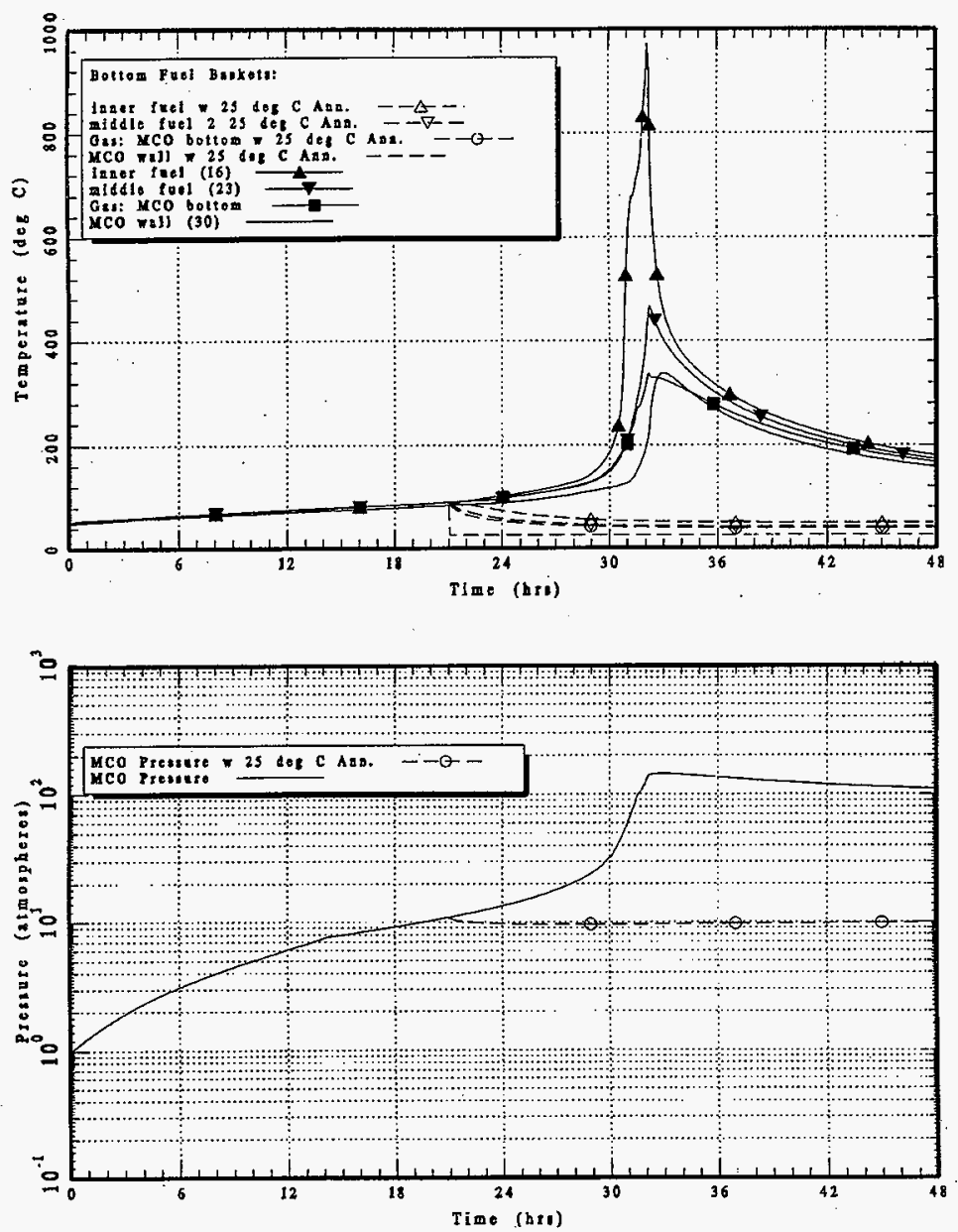


\section{HNF-SD-SNF-CN-023 REV 1}

This page intentionally left blank. 
HNF-SD-SNF-CN-023 REV 1

CONTENTS

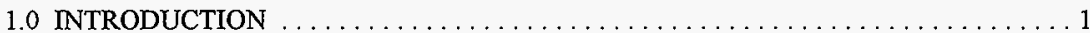

2.0 COLD VACUUM DRYING PROCESSES AND MODELS $\ldots \ldots \ldots \ldots \ldots \ldots \ldots$

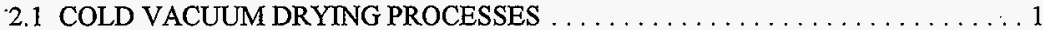

2.2 CONCEPTUAL AND NUMERICAL MODELS $\ldots \ldots \ldots \ldots \ldots \ldots \ldots \ldots \ldots$

2.3 DIFFERENCES BETWEEN THIS REPORT AND EARLIER VERSIONS . . . . . 3

2.4 MODEL AND CODE LIMITATIONS $\ldots \ldots \ldots \ldots \ldots \ldots \ldots \ldots \ldots \ldots$

3.0 COLD VACUUM DRYING PROCESSING CASES ANALYZED $\ldots \ldots \ldots \ldots \ldots \ldots$

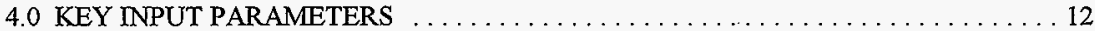

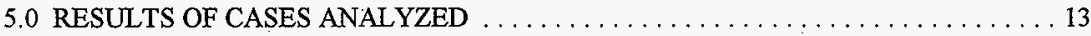

5.1 NORMAL COLD VACUUM DRYING OPERATIONS SUITE OF RUNS

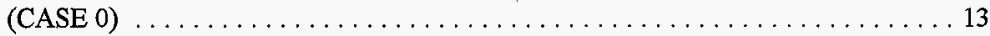

5.2 GROUP I, VACUUM DRYING AND HELIUM PURGE WITH NORMAL

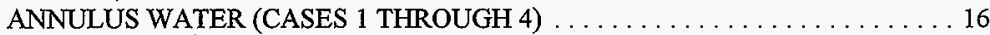

5.3 GROUP II, VACUUM DRYING AND HELIUM PURGE WITH HOT

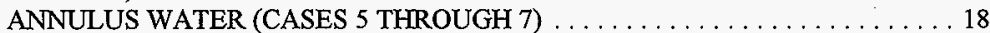

5.4 GROUP III, VACUUM DRYING AND HELIUM PURGE WITH MAJOR FLOW FAILURES OF THE TEMPERED WATER (ANNULUS) SYSTEM (CASES 8 THROUGH 13) . . . . . . . . . . . . . . . . . . . . . 19

5.5 GROUP IV, DRAINING STOP AND GAS BLOCKAGE (CASES 14 THROUGH 31) . . . . . . . . . . . . . . . . . . . . . . . . . . 19

5.6 GROUP V, VACUUM DRYING AND HELIUM PURGE WITH AIR INGRESS (CASES 32 THROUGH 37) ............................ 22

5.7 GROUP VI, COLD VACUUM DRYING FACILITY SAFETY ANALYSIS REPORT CASES (CASES 38 THROUGH 42) 24

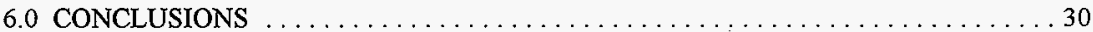

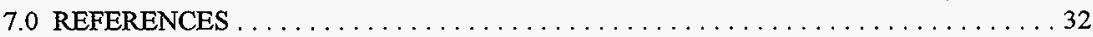




\section{HNF-SD-SNF-CN-023 REV 1}

\section{CONTENTS (Continued)}

\section{APPENDIXES}

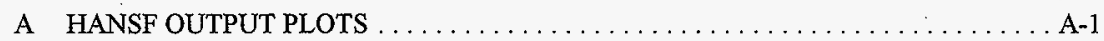

B INPUT FILE AND INPUT DIFFERENCES $\ldots \ldots \ldots \ldots \ldots \ldots \ldots \ldots \ldots \ldots$ B-1

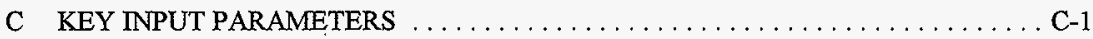

D DERIVATION OF VIEW FACTORS FOR RADIATIVE THERMAL MODEL . . . . . D-1

E HANSF CODE QUALITY ASSURANCE $\ldots \ldots \ldots \ldots \ldots \ldots \ldots \ldots \ldots \ldots \ldots \ldots \ldots$

F PEER REVIEW CHECKLIST $\ldots \ldots \ldots \ldots \ldots \ldots \ldots \ldots \ldots \ldots \ldots \ldots \ldots \ldots \ldots \ldots \ldots \ldots$ 


\section{HNF-SD-SNF-CN-023 REV 1}

\section{LIST OF FIGURES}

1. Schematic of Thermal Scrap Basket Model $\ldots \ldots \ldots \ldots \ldots \ldots \ldots \ldots \ldots \ldots$

2. Time to Reach Rupture Disk Burst Pressure versus Temperature of Annulus Water . . . . 23

\section{LIST OF TABLES}

1. Brief Descriptions of Simulated Cases . . . . . . . . . . . . . . . . . 7

2. Key Input Parameters for Bounding and Nominal Multi-Canister Overpack $\ldots \ldots \ldots \ldots 14$

3. Hydrogen Generation Rates and Particulate Formation under Normal Cold Vacuum Drying Operations for Bounding Multi-Canister Overpack with Nominal Hydrides . . . . . 17

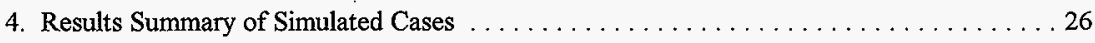




\section{HNF-SD-SNF-CN-023 REV 1}

\section{LIST OF TERMS}

CSB Canister Storage Building

CVDF Cold Vacuum Drying Facility

MCO multi-canister overpack

TWS tempered water (annulus) system 
HNF-SD-SNF-CN-023 REV 1

\section{THERMAL ANALYSIS OF COLD VACUUM DRYING OF SPENT NUCLEAR FUEL}

\subsection{INTRODUCTION}

This report documents the analysis of transient thermal and chemical behavior of the multi-canister overpack (MCO) for a broad range of cases postulated to occur during the cold vacuum drying process. The analysis supports the Cold Vacuum Drying Facility (CVDF) Safety Analysis Report (Pili-Vincens 1998), and the safety analysis documentation (Crowe et al. 1998) associated with it. To perform the analysis, the HANSF code (Plys et al. 1998) was updated and models were developed that support both normal and off-normal operation of the cold vacuum drying processes. More off-normal than normal operation cases were run in order to determine the effectiveness of the MCO thermal design with bounding parameter values under off-normal conditions.

The cold vacuum drying processes and models are described in Section 2.0; the cases that were analyzed are presented in Section 3.0 with the key input for them presented in Section 4.0. The results of the cases are described in Section 5.0, and the conclusions are discussed in Section 6.0. Appendix A shows all of the plots from the cases. Appendix B provides a representative input file. The input files are too large to include all of them in Appendix B, so a list of the differences between the representative input file and the others is provided. Key input parameters used in this analysis are provided in Appendix C, and the derivation of the view factors for the radiative thermal model is provided in Appendix D. Quality assurance for the HANSF code at the Hanford Site is handled in Appendix E.

\subsection{COLD VACUUM DRYING PROCESSES AND MODELS}

\subsection{COLD VACUUM DRYING PROCESSES}

The basic cold vacuum drying process involves receipt of a fuel-loaded, water-flooded MCO confined within a shipping cask. The MCO is drained of most of the free water it contains and then dried under vacuum, with and without helium purge cycles and with some helium purge only cycles (Irwin et al. 1998). During the multistep drying process, the temperature of the MCO and fuel is controlled by the tempered water (annulus) system (TWS), which circulates tempered water in the annulus between the $\mathrm{MCO}$ and the shipping cask, and by the helium purge system, which pushes helium into the bottom of the MCO (via the long process tube) and out through the high-efficiency particulate air filter at the top of the MCO. There is also a safety-class helium purge system, which would only be used under certain off-normal conditions (Pili-Vincens 1998). After several drying cycles, the MCO is tested for dryness (Pajunen 1998a); if the drying tests are satisfactory, the MCO is prepared for shipment to the Canister Storage Building (CSB). 


\subsection{CONCEPTUAL AND NUMERICAL MODELS}

The conceptual model for the cold vacuum drying process needs to incorporate heat and mass transfer mechanisms that include (1) thermal conduction in solids, liquids, and gas mixtures, (2) radiative heat transfer from solid to solid, (3) convection of gases, (4) water evaporation and condensation, (5) dynamic gas-solid chemical reactions in confined spaces, and (6) thermal decomposition of hydrates.

The primary heat sources for the MCO at the CVDF are the decay heat of the spent fuel and the chemical heat from (1) the main fuel-water reaction, $\mathrm{U}+2 \mathrm{H}_{2} \mathrm{O} \rightarrow \mathrm{UO}_{2}+2 \mathrm{H}_{2}+$ heat, (2) the main uranium hydride-water reaction, $\mathrm{UH}_{3}+2 \mathrm{H}_{2} \mathrm{O} \rightarrow \mathrm{UO}_{2}+3.5 \mathrm{H}_{2}+$ heat, and (3) the thermal decomposition of uranium hydrates, $\mathrm{UO}_{3} \cdot 2 \mathrm{H}_{2} \mathrm{O} \rightarrow \mathrm{UO}_{3} \cdot 1 \mathrm{H}_{2} \mathrm{O}+\mathrm{H}_{2} \mathrm{O}+$ heat $\rightarrow \mathrm{UO}_{3}$. $0.5 \mathrm{H}_{2} \mathrm{O}+1.5 \mathrm{H}_{2} \mathrm{O}+$ heat $\rightarrow \mathrm{UO}_{3}+2 \mathrm{H}_{2} \mathrm{O}+$ heat. The primary function of the TWS is to remove heat from the $\mathrm{MCO}$, but it also serves to add heat to the $\mathrm{MCO}$ for the predraining heatup process, which is not modeled here, and for the vacuum drying process, which cools the fuel by evaporation.

Air ingress into the MCO, an off-normal process, is included in the conceptual model for this report. If the fuel in the MCO contacts air because of some off-normal event or process, the MCO will gain heat from the main fuel-oxygen reaction, $\mathrm{U}+\mathrm{O}_{2} \rightarrow \mathrm{UO}_{2}+$ heat, the main hydride-oxygen reaction, $2 \mathrm{UH}_{3}+3.5 \mathrm{O}_{2} \rightarrow 2 \mathrm{UO}_{2}+3 \mathrm{H}_{2} \mathrm{O}+$ heat, and the fuel-nitrogen reaction (only at very high temperatures), $2 \mathrm{U}+1.5 \mathrm{~N}_{2} \rightarrow \mathrm{U}_{2} \mathrm{~N}_{3}+$ heat.

The chemical reactions listed above (both water and gas types of reactions) are the primary reactions occurring at the temperatures of interest during cold vacuum drying, but they certainly are not the only ones. For example, another hydride-oxygen reaction is $\mathrm{UH}_{3}+\mathrm{O}_{2} \rightarrow \mathrm{UO}_{2}+$ $1.5 \mathrm{H}_{2}+$ heat, but this reaction is believed to be secondary (Plys et al. 1998). All of the fuel reaction rates depend on the fuel surface temperature and the exposed surface area. The evaporation, condensation, and hydrate decomposition rates depend not only on the surface temperature and area of the solid (not just the fuel), but also on the composition and temperature of the gas around the surface of the solid.

On the relatively short time scales of interest (less than a week) at CVDF, radiolysis, which is a very slow reaction, was considered unimportant and not included in the conceptual model. Also, the free water in particulate-filled cracks in the fuel was not included in the model. The free water in particulate-filled cracks will evaporate more slowly than free water on a surface. Furthermore, the hydrogen gettering by fuel reaction, $\mathrm{U}+1.5 \mathrm{H}_{2} \rightarrow \mathrm{UH}_{3}+$ heat, also was not included in the conceptual model because oxygen, and then water, will react with the fuel first and block out the fuel-hydrogen reaction (Baker et al. 1966). All the cases analyzed here have water, oxygen, or both present initially. The isolated $\mathrm{MCO}$ cases eventually run out of water, have no oxygen, and have lots of hydrogen, but the peak containment pressure and temperature and the times to reach the peak pressure and temperature were the main outputs of interest. In such cases, hydrogen gettering, if included, would cause a more rapid decrease in pressure, which is already decreasing because of the absence of water and the lower chemical heat. 
The HANSF code, version 1.2 (Plys et al. 1998), is a computer code that numerically and/or analytically solves all of the mathematical equations used to model the physical processes in the conceptual model described above. The code has gone through a validation exercise (Plys et al. 1998) that compared specific code results to experimental results and/or analytical solutions (see Appendix E). The HANSF code is very fast, and as a result, many cases having long time periods of interest could be simulated.

\subsection{DIFFERENCES BETWEEN THIS REPORT AND EARLIER VERSIONS}

The main differences between this analysis and the earlier revision (Duncan and Ball 1997) of this report are listed below. This analysis includes

- Lower bounding decay heat

- Heat capacity of free residual water

- Lower cladding emissivity for fuel element instead of higher uranium emissivity

- No copper fin spokes in fine portion of scrap basket

- Mass-based, instead of mole-based, evaporation and condensation rates

- Uranium hydrides.

The first two differences result in slower increases of temperature with the current analysis. The use of the lower cladding emissivity for fuel elements results in higher fuel temperatures. The mass-based evaporation and condensation rates result in a hydrogen blanket that is less effective in slowing down the evaporation rate. The addition of uranium hydrides to the model results in higher hydrogen generation rates and higher fuel temperatures. The exclusion of the copper fin spokes in the fine scrap portion of the scrap basket results in higher temperatures for the fine scrap in some cases. The new scrap basket model with no copper fins in the fine scrap portion is described in HNF-2256, Simulation of Normal and Off-Normal Multi-Canister Overpack Behavior (Plys and Duncan 1998). A schematic of the new scrap basket model is shown in Figure 1.

The reaction surface area for scrap fuel and fuel elements and the free residual water mass after draining are lower in HNF-2256 (Plys and Duncan 1998), which looks at two scrap baskets per $\mathrm{MCO}$, than the surface area used in this report for one scrap basket per MCO. The higher reaction surface areas in this report provide an extra margin of safety and are consistent with HNF-SD-SNF-TI-015, Spent Nuclear Fuel Project Technical Databook (Reilly 1998), and HNF-SD-SNF-SAR-002, Safety Analysis Report for the Cold Vacuum Drying Facility, Phase 2, Supporting Installation of Processing Systems (Pili-Vincens 1998). 


\section{HNF-SD-SNF-CN-023 REV 1}

Figure 1. Schematic of Thermal Scrap Basket Model.

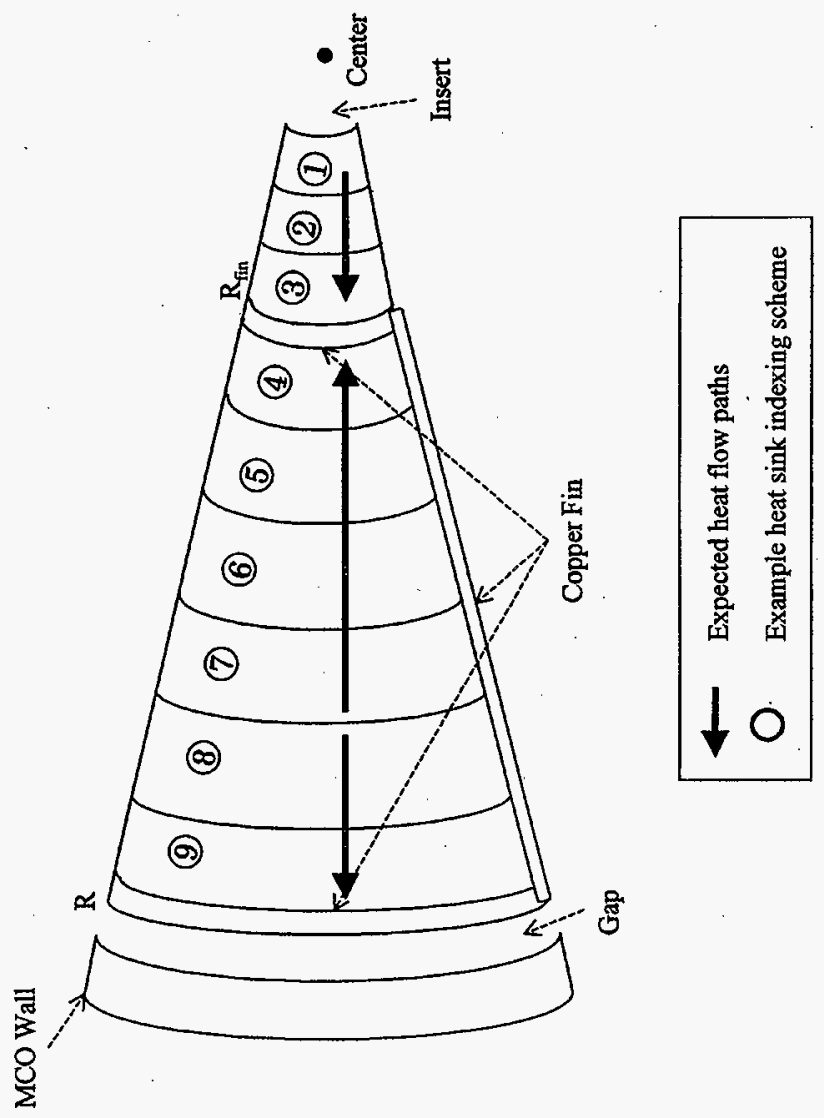




\section{HNF-SD-SNF-CN-023 REV 1}

\subsection{MODEL AND CODE LIMITATIONS}

Since all models are simpler than the real physical and chemical processes, there must be limitations on all models. The following paragraphs discuss the limitations for the current model and code.

The axial dependence of temperature and thermal conduction is ignored, with only the radial direction of heat transfer considered. However, the emissivity of the upper shield plug was increased to enhance the heat transfer rate from the scrap basket to the shield plug. Flow paths in the axial direction, with counter-current flow, are included in order to model the changing gas compositions and temperatures in the axial direction.

The heat capacity of the stainless steel inside the MCO (i.e., baskets, support rods, long process tube) is excluded from the model, which promotes more rapid temperature increases and is considered conservative. The heat capacity (or specific heat) of the inner stainless steel is relatively small compared to the heat capacity of the fuel, shield plug, MCO wall and bottom, and the cask wall. In the future, the long process tube and insert casing should be added to the input, but their effects are not expected to be significant.

The solid material properties are constant over time (i.e., the material properties are independent of temperature during the simulation). Most of the material property values were chosen at a reference temperature of $100^{\circ} \mathrm{C}$. Since the thermal conductivity of uranium and stainless steel increases with temperature, it is conservative to use the lower temperature values.

The effects of fuel damage are not considered. Most of the off-normal conditions do not result in temperatures high enough to cause fuel damage. The calculation of very high temperatures $\left(>1,000^{\circ} \mathrm{C}\right)$ for the extreme off-normal cases is not accurate because the data taken from RD/B/6231/R89, A Review of the Rates of Reaction of Unirradiated Uranium in Gaseous Atmospheres (Pearce 1989), are only good up to $1,000^{\circ} \mathrm{C}$. For fuel temperatures above $1,000^{\circ} \mathrm{C}$, the reaction rates are calculated higher than reality, which is conservative. The thermal conductivity of uranium and stainless steel is also held to its lower value at $100^{\circ} \mathrm{C}$, which makes the calculations at high temperatures more conservative. The extreme off-normal cases, which do result in very high temperatures, are prevented by safety-class and safetysignificant systems (Pili-Vincens 1998, Chapter 3.0).

Gaseous diffusion is not included. The gases are homogeneous over each volume in the model and are assumed to instantaneously mix all incoming and outgoing sources in each volume and flows between volumes. For cases with no induced convection between volumes and with the bottom fuel baskets wetter than the upper scrap basket (i.e., not the vacuum or purge cases), this assumption may not be conservative because it reduces the water vapor transfer rate into the scrap basket. If diffusion were included, it might enhance the transfer of water vapor to the dry scrap basket. In conjunction with diffusion, the effects of hot and cold surfaces on convection (i.e., heat-induced flow) between volumes also is excluded from the model. However, with copper fins included in the scrap basket (Smith 1998), the scrap basket is cooler, or has better heat transfer ability, than the fuel baskets for most, but not all, scenarios or 


\section{HNF-SD-SNF-CN-023 REV 1}

cases. Hence, having more water vapor with the hotter fuel elements is more conservative for those cases.

In summary, most of the current model's limitations are conservative or not important to the concerns of interest. However, improvements to the current model can be made and will be considered in the future, especially for the limitations that are not conservative.

\subsection{COLD VACUUM DRYING PROCESSING CASES ANALYZED}

Forty-two different cold vacuum drying processing cases, case numbers 1 through 42 in Table 1, have been analyzed; most of these cases are for off-normal conditions. These 42 cases are divided into 6 groups and described briefly in Table 1 .

- Group I, Vacuum Drying and Helium Purge with Normal Annulus Water

Cases 1 through 4 include the main vacuum drying processes of vacuum only, vacuum with helium purge, helium purge only, and a vacuum only case with $75 \mathrm{~kg}$ of residual water. The annulus water temperature is $50^{\circ} \mathrm{C}$ and flowing for all the cases. The orifice used in the model is $0.00635 \mathrm{~m}(0.25 \mathrm{in}$.) in diameter.

- Group II, Vacuum Drying and Helium Purge with Hot Annulus Water

Cases 5 through 7 look at vacuum drying processes with a major failure of the TWS. These cases include the vacuum only, vacuum with helium purge, and helium purge only cases with the annulus water heated to $85^{\circ} \mathrm{C}$ and flowing. Other major failures of the TWS are covered in Group III. In the case names, the word HOT refers to the annulus water temperature of $85^{\circ} \mathrm{C}$. The orifice is $0.00635 \mathrm{~m}(0.25 \mathrm{in}$.) in diameter.

- Group III, Vacuum Drying and Helium Purge with Major Flow Failures of the Tempered Water (Annulus) System

Cases 8 through 13 look at loss of annulus water flow and loss of coolant (annulus water), which are considered major failures of the TWS. These cases include vacuum drying with loss of annulus flow for initial annulus temperatures of $50^{\circ} \mathrm{C}$ and $85^{\circ} \mathrm{C}$, and with loss of coolant). This group also includes a vacuum drying with helium purge and loss of coolant case and two helium purge only cases, one with loss of flow and one with loss of coolant. The orifice is $0.00635 \mathrm{~m}(0.25 \mathrm{in}$.) in diameter. The letters LOF (loss of flow) and LOC (loss of coolant) appear in the appropriate case names. 
Table 1. Brief Descriptions of Simulated Cases. (4 sheets)

\begin{tabular}{|c|c|c|c|c|c|c|c|c|}
\hline \multirow{2}{*}{$\begin{array}{l}\text { Case } \\
\text { number }\end{array}$} & \multirow{2}{*}{ Case name } & \multirow{2}{*}{ Operating mode description } & \multirow{2}{*}{$\begin{array}{l}\text { Residual free } \\
\text { water mass }\end{array}$} & \multirow{2}{*}{ CVDF process } & \multicolumn{3}{|c|}{ Annulus water } & \multirow{2}{*}{ Notes } \\
\hline & & & & & Flow & Temperature & Lost & \\
\hline \multicolumn{9}{|c|}{ 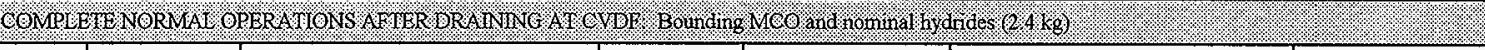 } \\
\hline 0 & NORMAL & $\begin{array}{l}\text { Complete CVDF cycle after draining } \\
\text { and before shipping to CSB }\end{array}$ & $26.5 \mathrm{~kg}$ & $\begin{array}{l}\text { CVDF drying } \\
\text { operations }\end{array}$ & \multicolumn{3}{|c|}{$\begin{array}{l}\text { Normal conditions } \\
\text { throughout normal drying }\end{array}$} & See Table 3 \\
\hline \multicolumn{9}{|c|}{ 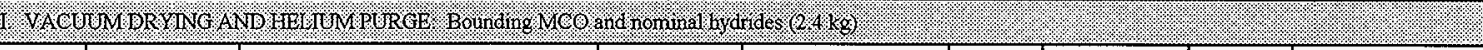 } \\
\hline 1 & $\begin{array}{l}\text { VACUUM } \\
\text { (CVD3B) }\end{array}$ & Vacuum drying & $26.5 \mathrm{~kg}$ & Vacuum & Yes & $50^{\circ} \mathrm{C}$ & No & CVD3B in Rev, OA \\
\hline 2 & $\begin{array}{l}\text { VAC75KG } \\
\text { (CVD3C) }\end{array}$ & Vacuum drying - $75 \mathrm{~kg}$ free water & $75 \mathrm{~kg}$ & Vacuum & Yes & $50^{\circ} \mathrm{C}$ & No & CVD3C in Rev. 0 \\
\hline 3 & VACPUR & Vacuum drying - helium purge & $26.5 \mathrm{~kg}$ & $\begin{array}{l}\text { Vacuum and helium } \\
\text { purge }\end{array}$ & Yes & $50^{\circ} \mathrm{C}$ & No & Purge is $1.6 \mathrm{scfm}$ \\
\hline 4 & $\begin{array}{l}\text { PURGE } \\
\text { (CVD2A) }\end{array}$ & Helium purge & $26.5 \mathrm{~kg}$ & Helium purge & Yes & $50^{\circ} \mathrm{C}$ & No & $\begin{array}{l}\text { Purge is } 1.6 \mathrm{scfm} \\
\text { CVD2A in Rev. } 0 \mathrm{~A}\end{array}$ \\
\hline \multicolumn{9}{|c|}{ 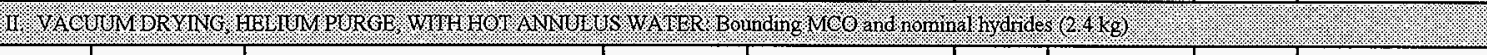 } \\
\hline 5 & VACHOT & $\begin{array}{l}\text { Vacutum drying - hot annulus water } \\
\text { without helium purge }\end{array}$ & $26.5 \mathrm{~kg}$ & Vacuum & Yes & $85^{\circ} \mathrm{C}$ & No & + \\
\hline 6 & VPURHOT & $\begin{array}{l}\text { Vacuum drying - hot annulus water } \\
\text { with helium purge }\end{array}$ & $26.5 \mathrm{~kg}$ & $\begin{array}{l}\text { Vacuum and helium } \\
\text { purge }\end{array}$ & Yes & $85^{\circ} \mathrm{C}$ & No & - \\
\hline 7 & PURHOT & Helium purge - hot annulus water & $26.5 \mathrm{~kg}$ & Helium purge & Yes & $85^{\circ} \mathrm{C}$ & No & Purge is $1.6 \mathrm{scfm}$ \\
\hline \multicolumn{9}{|c|}{ 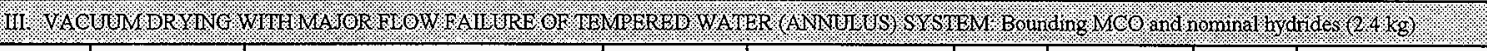 } \\
\hline 8 & VACLOF & $\begin{array}{l}\text { Vacuum drying - no annulus flow } \\
\end{array}$ & $26.5 \mathrm{~kg}$ & Vacuum & No & $\begin{array}{l}50^{\circ} \mathrm{C} \\
\text { initially }\end{array}$ & No & - \\
\hline 9 & VLOFHOT & $\begin{array}{l}\text { Vacuum drying - no annulus flow and } \\
\text { hot annulus water }\end{array}$ & $26.5 \mathrm{~kg}$ & Vacuum & No & $\begin{array}{l}85^{\circ} \mathrm{C} \\
\text { initially }\end{array}$ & No & $\rightarrow$ \\
\hline 10 & VACLOC & $\begin{array}{l}\text { Vacuum drying - loss of coolant } \\
\text { (annulus water) }\end{array}$ & $26.5 \mathrm{~kg}$ & Vacuum & Air & $\begin{array}{l}50^{\circ} \mathrm{C} \\
\text { initially }\end{array}$ & Yes & -- \\
\hline 11 & VPURLOC & $\begin{array}{l}\text { Vacuum - loss of coolant with helium } \\
\text { purge }\end{array}$ & $26.5 \mathrm{~kg}$ & $\begin{array}{l}\text { Vacuum and helium } \\
\text { purge }\end{array}$ & Air & $\begin{array}{l}50^{\circ} \mathrm{C} \\
\text { initially }\end{array}$ & Yes & Purge is $1.6 \mathrm{scfm}$ \\
\hline
\end{tabular}


Table 1. Brief Descriptions of Simulated Cases. (4 sheets)

\begin{tabular}{|c|c|c|c|c|c|c|c|c|}
\hline \multirow{2}{*}{$\begin{array}{l}\text { Case } \\
\text { number }\end{array}$} & \multirow{2}{*}{ Case name } & \multirow{2}{*}{ Operating mode description } & \multirow{2}{*}{$\begin{array}{l}\text { Residual free } \\
\text { water mass }\end{array}$} & \multirow{2}{*}{ CVDF process } & \multicolumn{3}{|c|}{ Annulus water } & \multirow{2}{*}{ Notes } \\
\hline & & & & & Flow & Temperature & Lost & \\
\hline 12. & $\begin{array}{l}\text { PURLOF } \\
\text { (CVD2B) }\end{array}$ & Helium purge - no annulus water & $26.5 \mathrm{~kg}$ & Helium purge & No & $\begin{array}{l}50^{\circ} \mathrm{C} \\
\text { initially }\end{array}$ & No & $\begin{array}{l}\text { Purge is } 1.6 \mathrm{scfm} \\
\text { CVD2B in Rev. } 0\end{array}$ \\
\hline 13 & $\begin{array}{l}\text { PURLOC } \\
\text { (CVD2C) }\end{array}$ & Helium purge - loss of coolant & $26.5 \mathrm{~kg}$ & Helium purge & Air & - & Yes & $\begin{array}{l}\text { Purge is } 1.6 \mathrm{scfm} \\
\text { CVD2C in Rev. } 0\end{array}$ \\
\hline \multicolumn{9}{|c|}{ 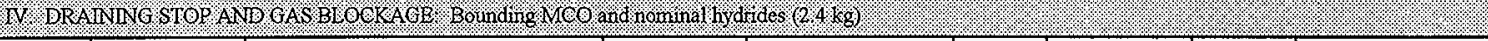 } \\
\hline 14 & $\begin{array}{l}\text { DSTOP } \\
\text { (CVD2A) }\end{array}$ & $\begin{array}{l}\text { Draining and gas blockage - normal } \\
\text { annulus water }\end{array}$ & $26.5 \mathrm{~kg}$ & $\begin{array}{l}\text { Drain and closed } \\
\text { MCO }\end{array}$ & Yes & $50^{\circ} \mathrm{C}$ & No & CVD2A in Rev. $0 A$ \\
\hline 15 & DS75KG & $\begin{array}{l}\text { Draining and gas blockage - normal } \\
\text { annulus water, } 75 \mathrm{~kg} \text { residual water }\end{array}$ & $75 \mathrm{~kg}$ & $\begin{array}{l}\text { Drain and closed } \\
\text { MCO }\end{array}$ & Yes & $50^{\circ} \mathrm{C}$ & No & -- \\
\hline 16 & DSTOPOV & $\begin{array}{l}\text { Draining and gas blockage - normal } \\
\text { annulus water, with open vent }\end{array}$ & $26.5 \mathrm{~kg}$ & $\begin{array}{l}\text { Drain with open } \\
\text { vent }\end{array}$ & Yes & $50^{\circ} \mathrm{C}$ & No & -- \\
\hline 17 & $\begin{array}{l}\text { DSLOF } \\
\text { (CVD1F) }\end{array}$ & $\begin{array}{l}\text { Draining and gas blockage - loss of } \\
\text { annulus water flow }\end{array}$ & $26.5 \mathrm{~kg}$ & $\begin{array}{l}\text { Drain and closed } \\
\text { MCO }\end{array}$ & No & $\begin{array}{l}50^{\circ} \mathrm{C} \\
\text { initially }\end{array}$ & No & CVDIF in Rev. OA \\
\hline 18 & DLOF75KG & $\begin{array}{l}\text { Draining and gas blockage - loss of } \\
\text { annulus water flow, } 75 \mathrm{~kg} \text { residual } \\
\text { water }\end{array}$ & $75 \mathrm{~kg}$ & $\begin{array}{l}\text { Drain and closed } \\
\text { MCO }\end{array}$ & No & $\begin{array}{c}50^{\circ} \mathrm{C} \\
\text { initially }\end{array}$ & No & - \\
\hline 19 & DSLOFOV & $\begin{array}{l}\text { Draining and gas blockage - loss of } \\
\text { annulus water flow, with open vent }\end{array}$ & $26.5 \mathrm{~kg}$ & $\begin{array}{l}\text { Drain with open } \\
\text { vent }\end{array}$ & No & $\begin{array}{c}50^{\circ} \mathrm{C} \\
\text { initially }\end{array}$ & No & - \\
\hline 20 & $\begin{array}{l}\text { DSLOC } \\
\text { (CVD1C) }\end{array}$ & $\begin{array}{l}\text { Draining and gas blockage - loss of } \\
\text { coolant }\end{array}$ & $26.5 \mathrm{~kg}$ & $\begin{array}{l}\text { Drain and closed } \\
\text { MCO }\end{array}$ & Air & - & Yes & CVD1C in Rev. 0A \\
\hline 21 & DLOC75KG & $\begin{array}{l}\text { Draining and gas blockage - loss of } \\
\text { coolant, } 75 \mathrm{~kg} \text { residual water }\end{array}$ & $75 \mathrm{~kg}$ & $\begin{array}{l}\text { Drain and closed } \\
\text { MCO }\end{array}$ & Air & - & Yes & - \\
\hline 22 & DSLOCNOM & $\begin{array}{l}\text { Draining and gas blockage - loss of } \\
\text { coolant }\end{array}$ & $26.5 \mathrm{~kg}$ & $\begin{array}{l}\text { Drain and closed } \\
\text { MCO }\end{array}$ & Air & - & Yes & Nominal MCO \\
\hline 23 & DSLOCREC & $\begin{array}{l}\text { Draining and gas blockage - recovery } \\
\text { from loss of coolant }\end{array}$ & $\begin{array}{l}23.7 \mathrm{~kg} \text { at } \\
\text { restart }\end{array}$ & $\begin{array}{l}\text { Closed MCO } \\
\text { recovery from loss } \\
\text { of coolant }\end{array}$ & Yes & $\begin{array}{l}25^{\circ} \mathrm{C} \text { at } \\
\text { restart }\end{array}$ & Restored & $\begin{array}{l}\text { Flowing annulus } \\
\text { recovery at } 21 \text { hours }\end{array}$ \\
\hline 24 & DSLOCRE2 & $\begin{array}{l}\text { Draining and gas blockage - recovery } \\
\text { from loss of coolant }\end{array}$ & $\begin{array}{l}23.7 \mathrm{~kg} \text { at } \\
\text { restart }\end{array}$ & $\begin{array}{l}\text { Closed MCO } \\
\text { recovery from loss } \\
\text { of coolant }\end{array}$ & No & $\begin{array}{l}25^{\circ} \mathrm{C} \text { at } \\
\text { restart }\end{array}$ & Restored & $\begin{array}{l}\text { Stationary annulus } \\
\text { recovery at } 21 \text { hours }\end{array}$ \\
\hline
\end{tabular}




\begin{tabular}{|c|c|c|c|c|c|c|c|c|}
\hline \multirow{2}{*}{$\begin{array}{l}\text { Case } \\
\text { number }\end{array}$} & \multirow{2}{*}{ Case name } & \multirow{2}{*}{ Operating mode description } & \multirow{2}{*}{$\begin{array}{l}\text { Residual free } \\
\text { water mass }\end{array}$} & \multirow{2}{*}{ CVDF process } & \multicolumn{3}{|c|}{ Annulus water } & \multirow{2}{*}{ Notes } \\
\hline & & & & & Flow & Temperature & Lost & \\
\hline 25 & DSLOCOV & $\begin{array}{l}\text { Draining and gas blockage - loss of } \\
\text { coolant }\end{array}$ & $26.5 \mathrm{~kg}$ & $\begin{array}{c}\text { Drain with open } \\
\text { vent }\end{array}$ & Air & - & Yes & -. \\
\hline 26 & DS46DEG & $\begin{array}{l}\text { Draining and gas blockage }-46^{\circ} \mathrm{C} \\
\text { annulus }\end{array}$ & $26.5 \mathrm{~kg}$ & $\begin{array}{l}\text { Drain and closed } \\
\text { MCO }\end{array}$ & Yes & $46^{\circ} \mathrm{C}$ & No & - \\
\hline 27 & DS55DEG & $\begin{array}{l}\text { Draining and gas blockage }-55^{\circ} \mathrm{C} \\
\text { annulus }\end{array}$ & $26.5 \mathrm{~kg}$ & $\begin{array}{l}\text { Drain and closed } \\
\text { MCO }\end{array}$ & Yes & $55^{\circ} \mathrm{C}$ & No & -- \\
\hline 28 & DS75DEG & $\begin{array}{l}\text { Draining and gas blockage }-75^{\circ} \mathrm{C} \\
\text { annulus }\end{array}$ & $26.5 \mathrm{~kg}$ & $\begin{array}{c}\text { Drain and closed } \\
\text { MCO }\end{array}$ & Yes & $75^{\circ} \mathrm{C}$ & No & - \\
\hline 29 & DSHOT & $\begin{array}{l}\text { Draining and gas blockage - hot } \\
\text { annulus water }\end{array}$ & $26.5 \mathrm{~kg}$ & $\begin{array}{l}\text { Drain and closed } \\
\text { MCO }\end{array}$ & Yes & $85^{\circ} \mathrm{C}$ & No & $\cdots$ \\
\hline 30 & DHOT75KG & $\begin{array}{l}\text { Draining and gas blockage - hot } \\
\text { annulus water, } 75 \mathrm{~kg} \text { residual water }\end{array}$ & $75 \mathrm{~kg}$ & $\begin{array}{l}\text { Drain and closed } \\
\text { MCO }\end{array}$ & Yes & $85^{\circ} \mathrm{C}$ & No & - \\
\hline 31 & DSHOTOV & $\begin{array}{l}\text { Draining and gas blockage - hot } \\
\text { annulus water, with open vent }\end{array}$ & $26.5 \mathrm{~kg}$ & $\begin{array}{l}\text { Drain with open } \\
\text { vent }\end{array}$ & Yes & $85^{\circ} \mathrm{C}$ & No & - \\
\hline \multicolumn{9}{|c|}{ 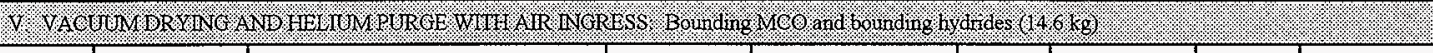 } \\
\hline 32 & VACAIRI & $\begin{array}{l}\text { Vacuum drying - air ingress and } \\
\text { bounding hydrides }\end{array}$ & $26.5 \mathrm{~kg}$ & Vacuum & Yes & $50^{\circ} \mathrm{C}$ & No & - \\
\hline 33 & VAIRIHOT & $\begin{array}{l}\text { Vacuum drying - air ingress, } \\
\text { bounding hydrides, and hot annulus } \\
\text { water }\end{array}$ & $26.5 \mathrm{~kg}$ & Vacuum & Yes & $85^{\circ} \mathrm{C}$ & No & -- \\
\hline 34 & VAIRIOC & $\begin{array}{l}\text { Vacuum drying - air ingress, } \\
\text { bounding hydrides, and loss of } \\
\text { coolant }\end{array}$ & $26.5 \mathrm{~kg}$ & Vacuum & No & $\begin{array}{l}50^{\circ} \mathrm{C} \\
\text { initially }\end{array}$ & Yes & - \\
\hline 35 & PURAIRI & $\begin{array}{l}\text { Helium purge - air ingress, bounding } \\
\text { hydrides }\end{array}$ & $26.5 \mathrm{~kg}$ & Helium purge & Yes & $50^{\circ} \mathrm{C}$ & No & - \\
\hline 36 & PAIRIHOT & $\begin{array}{l}\text { Helium purge - air ingress, bounding } \\
\text { hydrides, and hot annulus water }\end{array}$ & $26.5 \mathrm{~kg}$ & Helium purge & Yes & $85^{\circ} \mathrm{C}$ & No & - \\
\hline 37 & VACAIRI2 & $\begin{array}{l}\text { Vacuum drying - air ingress without } \\
\text { hydrides }\end{array}$ & $26.5 \mathrm{~kg}$ & Vacuum & Yes & $50^{\circ} \mathrm{C}$ & No & -- \\
\hline
\end{tabular}


Table 1. Brief Descriptions of Simulated Cases. (4 sheets)

\begin{tabular}{|c|c|c|c|c|c|c|c|c|}
\hline \multirow{2}{*}{$\begin{array}{l}\text { Case } \\
\text { number }\end{array}$} & \multirow{2}{*}{ Case name } & \multirow{2}{*}{ Operating mode description } & \multirow{2}{*}{$\begin{array}{l}\text { Residual free } \\
\text { water mass }\end{array}$} & \multirow{2}{*}{ CVDF process } & \multicolumn{3}{|c|}{ Annulus water } & \multirow{2}{*}{ Notes } \\
\hline & & & & & Flow & Temperature & Lost & \\
\hline \multicolumn{9}{|c|}{ 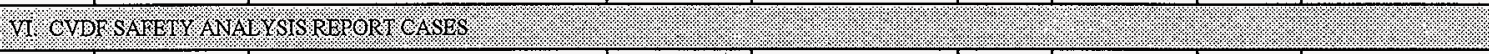 } \\
\hline 38 & DSLOCSA4 & $\begin{array}{l}\text { High-pressure thermal runaway (drain } \\
\text { interrupt and gas blockage) - loss of } \\
\text { coolant }\end{array}$ & $35.5 \mathrm{~kg}$ & $\begin{array}{l}\text { Drain interrupt and } \\
\text { closed MCO }\end{array}$ & Air & $50^{\circ} \mathrm{C}$ & yes & $\begin{array}{l}\text { Reaches burst } \\
\text { pressure at } 21 \text { hours }\end{array}$ \\
\hline 39 & BLOW4N & $\begin{array}{l}\text { Blowdown of high-pressure thermal } \\
\text { runaway at } 11.2 \mathrm{~atm}\left(150 \mathrm{lb} / \mathrm{in}^{2}\right. \\
\text { gauge) }\end{array}$ & $\begin{array}{c}32.6 \mathrm{~kg} \\
\text { at restart }\end{array}$ & $\begin{array}{l}\text { Rupture disk opens } \\
\text { releasing gas and } \\
\text { particulate }\end{array}$ & Air & $\begin{array}{l}64{ }^{\circ} \mathrm{C} \\
\text { at restart }\end{array}$ & yes & Restart at 21 hours \\
\hline 40 & DSSA4REC & $\begin{array}{l}\text { Recovery of high-pressure thermal } \\
\text { runaway - stationary annulus water }\end{array}$ & $\begin{array}{l}32.6 \mathrm{~kg} \\
\text { at restart }\end{array}$ & $\begin{array}{l}\text { Closed MCO } \\
\text { recovery from loss } \\
\text { of coolant }\end{array}$ & No & $\begin{array}{l}25^{\circ} \mathrm{C} \\
\text { at restart }\end{array}$ & restored & $\begin{array}{l}\text { Stationary annulus } \\
\text { recovery at } 21 \text { hours }\end{array}$ \\
\hline 41 & BLOWREOV & $\begin{array}{l}\text { Recovery of low-pressure thermal } \\
\text { runaway after blowdown occurs }\end{array}$ & $\begin{array}{l}31.7 \mathrm{~kg} \\
\text { at restart }\end{array}$ & $\begin{array}{l}\text { Open MCO } \\
\text { blowdown with } \\
\text { recovery from loss } \\
\text { of coolant }\end{array}$ & No & $\begin{array}{l}25^{\circ} \mathrm{C} \\
\text { at restart }\end{array}$ & restored & $\begin{array}{l}\text { Stationary annulus } \\
\text { recovery at } 22 \text { hours }\end{array}$ \\
\hline 42 & DSLOCOV2 & $\begin{array}{l}\text { Low-pressure thermal runaway (drain } \\
\text { interupt with loss of coolant and } \\
\text { open vent) }\end{array}$ & $35.5 \mathrm{~kg}$ & $\begin{array}{l}\text { Drain interrupt } \\
\text { with open vent }\end{array}$ & Air & $50^{\circ} \mathrm{C}$ & yes & Filtered release \\
\hline
\end{tabular}

$\mathrm{CSB}=$ Canister Storage Building.

$\mathrm{CVDF}=$ Cold Vacuum Drying Facility.

$\mathrm{MCO}=$ multi-canister overpack.

scfm $=$ standard cubic feet per minute. 


\section{HNF-SD-SNF-CN-023 REV 1}

- Group IV, Draining Stop and Gas Blockage

Cases 14 through 31 all involve an isolated (closed) MCO, which allows gas pressure to increase, or an open $\mathrm{MCO}$ with only an open vent (i.e., no vacuum or helium purge), or a closed MCO with a recovery from the loss of coolant condition (i.e., annulus water is restored). The isolated $\mathrm{MCO}$ cases include normal and off-normal TWS conditions, including $85^{\circ} \mathrm{C}$ annulus water, loss of flow and loss of coolant conditions. The time to reach the rupture disk burst pressure of 11.2 atmospheres $\left(150 \mathrm{lb} / \mathrm{in}^{2}\right.$ gauge $)$ is the main output of interest for the closed MCO cases, and the fuel temperatures versus time are the key outputs of interest for the open MCO cases. These cases demonstrate the importance of the TWS in keeping the MCO fuel temperatures stable under the off-normal cold vacuum drying conditions of no vacuum drying and no helium purge, with large amounts of free water. These cases also demonstrate the importance of the $\mathrm{MCO}$ valves in keeping the MCO open under off-normal TWS conditions.

- Group V, Vacuum Drying and Helium Purge with Air Ingress

Cases 32 through 37 include the vacuum drying and helium purge processes with air ingress at the bottom of the MCO (via the long process tube) for normal and off-normal annulus conditions. The main outputs of interest are the hydrogen generation rates and fuel temperatures versus time. These cases also have increased hydride loads, which are considered bounding here. The orifice is $0.00635 \mathrm{~m}$ ( 0.25 in.) in diameter. The letters AIRI, which stand for air ingress, appear in all of the air ingress case names.

- Group VI, CVDF Safety Analysis Report Cases

Cases 38 through 42 include the cases used for Revision 4 of the CVDF Safety Analysis Report (Pili-Vincens 1998) and for the accident analysis documentation supporting it (Crowe et al. 1998). The primary case, case 38, is an isolated MCO with a loss of coolant condition after a drain interrupt; as a result of the drain interrupt, there is $35.5 \mathrm{~kg}$ of free residual water available instead of $26.5 \mathrm{~kg}$, which is the bounding free water after a normal drain. Case 39 simulates both the actual blowdown resulting from the rupture disk opening and the fuel-water reactions after the blowdown. The rupture disk opening used in the model is $0.0254 \mathrm{~m}$ (1.0 in.) in diameter. Cases 40 and 41 simulate a recovery of the loss of coolant condition by restoring stationary water into the annulus at 21 hours, just before the rupture disk bursts open (case 40), and at 22 hours, one hour after the rupture disk bursts open (case 41). The purpose of the two recovery cases is to show the effectiveness of restoring the annulus water just before the blowdown and one hour after the blowdown. The last case, case 42 , looks at the temperature behavior of the an open MCO with $35.5 \mathrm{~kg}$ of residual water and a loss of coolant condition. 
All of the cases above, except the CVDF safety analysis report cases, have either the bounding amount of free water, $26.5 \mathrm{~kg}$ (Duncan and Ball 1997) after normal draining, or a larger free water mass of $75 \mathrm{~kg}$, representing an incomplete drain or drain interrupt. All cases use bounding parameter values except for case 22 (DSLOCNOM), which uses nominal parameter values. Every case includes the uranium hydride mass, nominal for most cases and bounding for the air ingress cases, except case 37 (VACAIRI2), which is a vacuum case with air ingress and no hydride loading. The key parameter values are described in Section 4.0. All of the simulation times are long enough to show when the peak temperatures of scrap and fuel elements occur. Most of the cases have simulation times extended to 1 week in order to show long-term effects, even though such long times are not anticipated or expected for any cold vacuum drying process.

In addition to the six groups of cases, a suite of 13 cases was connected in time to simulate all the primary normal vacuum drying processes from the end of draining until the $\mathrm{MCO}$ is ready for shipment to the CSB, a total time period of 53.25 hours. This suite is called the 'normal' case and is identified in Table 1 as case 0 . The complete set of processes includes the helium purge only, vacuum only, vacuum with helium purge processes, the rebound and proof tests for water content, the cooling down process and the preparation for CSB shipment process. Altogether, 13 different processes or steps were identified in the normal vacuum drying sequence after draining (Crowe et al. 1998, Chapter 2.0), requiring one distinct run for each case, and resulting in a total of 13 different runs. A detailed description of all of the processes is available in the CVDF operations manual (Irwin et al. 1998). These cases are itemized later in Section 5.0 .

\subsection{KEY INPUT PARAMETERS}

This analysis was based upon key input parameters and specific process and equipment designs. Some of the postulated processing cases require operator actions within a reasonable time to maintain safe conditions. Most of the simulated cases exclude any operator intervention in order to estimate the behavior of an off-normal case based on just the physics and chemistry of the MCO under the off-normal condition.

The most important input parameters affecting the thermal analysis of the MCO during CVDF processing are the ones pertaining to the uranium-water reaction rate, the rate of heat removal from the $\mathrm{MCO}$, and the decay heat. The parameters affecting the chemical reaction rate are the reaction surface area and the reaction rate multiplier. All but one of the cases use bounding values for chemical reaction rates and decay heat because a thermal design that is good enough for the bounding $\mathrm{MCO}$ will be good enough for all MCOs. The effects of uranium hydride were included in the thermal analysis because uranium hydride reacting with water or oxygen will generate heat and hydrogen. All of the cases include a large nominal value of initial uranium hydride $(2.4 \mathrm{~kg})$ except for the air ingress cases, which include a very large bounding value of initial hydride $(14.6 \mathrm{~kg})$. These hydride mass loadings have been compared to 


\section{HNF-SD-SNF-CN-023 REV 1}

preliminary data from some damaged fuel elements (Appendix C, Note 4). The values used in this report are much larger than those observed and, hence, contain some margin of safety.

The thermal analysis used only Mark IV fuel because the Mark IV fuel conservatively bounds the Mark IA fuel from a thermal perspective. The Mark IV fuel element mass per MCO is $25 \%$ larger than the Mark IA fuel element mass per MCO. The Mark IV scrap basket has a maximum load of $980 \mathrm{~kg}$, whereas the Mark IA has a maximum load of $575 \mathrm{~kg}$ (Kessler and Peck 1998) because of criticality concerns. There are also fewer Mark IA fuel elements (and mass) per basket, therefore there is less decay heat per basket (and element), a smaller reaction area per basket, and a shorter conduction distance from the inner to outer regions; all of which make the Mark IA fuel more favorable in regards to thermal behavior in the MCO.

The key input parameters used in the analysis for the bounding and nominal MCO with one scrap basket and four Mark IV fuel baskets are shown in Table 2 and in Appendix C.

\subsection{RESULTS OF CASES ANALYZED}

The results of the cases analyzed are discussed in this section. All of the cases involving vacuum drying or helium purge processes are restarted from an initialization run that includes the first 0.42 hour after draining and a helium purge rate of 1.6 standard $\mathrm{ft}^{3} / \mathrm{min}$ for 0.33 hour after that, for a total time of 0.75 hour after draining. The time of the maximum hydrogen generation rate does not include this 0.75 hour for the initialization run, but the dry out time does include the 0.75 hour.

\subsection{NORMAL COLD VACUUM DRYING OPERATIONS SUITE OF RUNS (CASE 0)}

For the series of normal vacuum drying steps, the MCO is completely dry about 20.5 hours after draining is completed. This dry-out time is longer than the dry-out time realized with only the vacuum drying process or the vacuum with helium purge process (for details see Section 5.2) because the helium purge only process is not an effective drying process. This is because the pressure in the MCO is greater than atmospheric pressure and prevents any boiling or rapid evaporation. However, the helium purge only process may be necessary to keep the free water from freezing for fuel with a much lower decay heat rate than the bounding decay rate (740.8 W per MCO [Table 2]).

The particulate $\left(\mathrm{UO}_{2}\right)$ generated during the entire suite of cold vacuum drying operations after draining is $5.15 \mathrm{~kg}$ (for a time period of 53.25 hours, see Table 3). Most of the particulate $(80 \%)$ is generated during the first 20.5 hours when free water is still present in the MCO. The rest of the particulate (about $20 \%$ ) is generated from the uranium hydrate water, which decomposes because the fuel temperature increases after the free water is gone. The initial 
Table 2. Key Input Parameters for Bounding and Nominal Multi-Canister Overpack. (2 sheets)

\begin{tabular}{|c|c|c|}
\hline Parameter & Value & Reference \\
\hline \multicolumn{3}{|c|}{ 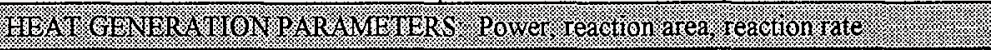 } \\
\hline $\begin{array}{l}\text { Bounding decay power } \\
\text { ( } 776 \mathrm{~W} \text { for five fuel baskets) }\end{array}$ & $740.8 \mathrm{~W}$ per MCO & $\begin{array}{l}\text { Reilly } 1998 \\
\text { Note 1, Appendix C }\end{array}$ \\
\hline $\begin{array}{l}\text { Nominal decay power } \\
\text { ( } 403 \text { W for five fuel baskets) }\end{array}$ & $384.7 \mathrm{~W}$ per $\mathrm{MCO}$ & $\begin{array}{c}\text { Reilly } 1998 \\
\text { Note 2, Appendix C }\end{array}$ \\
\hline Scrap fuel reaction surface area & $\begin{array}{l}6 \mathrm{~m}^{2}-\text { bounding } \\
1.7 \mathrm{~m}^{2}-\text { nominal }\end{array}$ & Reilly 1998 \\
\hline Fuel reaction area & $\begin{array}{l}7 \mathrm{~m}^{2} \text { - bounding } \\
0.3 \mathrm{~m}^{2} \text { - nominal }\end{array}$ & Reilly 1998 \\
\hline Reaction rate multiplier & $\begin{array}{l}10 \text { - bounding } \\
3 \text { - nominal }\end{array}$ & Reilly 1998 \\
\hline $\begin{array}{l}\text { Nominal effective rate multiplier for } \\
\text { hydrides (nominal hydride mass) }\end{array}$ & $\begin{array}{l}13.7 \text { - fuel basket } \\
13.7 \text { - scrap basket } \\
(2.4 \text { kg per MCO })\end{array}$ & $\begin{array}{l}\text { Plys and Duncan1998 } \\
\text { Note 3, Appendix C }\end{array}$ \\
\hline $\begin{array}{l}\text { Bounding effective rate multiplier for } \\
\text { hydrides (bounding hydride mass) }\end{array}$ & $\begin{array}{c}59.2 \text { - fuel basket } \\
111 \text { - scrap basket } \\
\text { (14.6 kg per MCO) }\end{array}$ & $\begin{array}{l}\text { Plys and Duncan1998 } \\
\text { Note 4, Appendix C }\end{array}$ \\
\hline \multicolumn{3}{|c|}{ 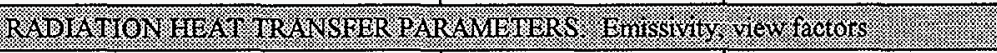 } \\
\hline Scrap fuel emissivity & 0.7 & Reilly 1998 \\
\hline Cladding emisssivity & 0.43 & $\begin{array}{c}\text { Scott } 1965 \\
\text { Note 5, Appendix C } \\
\end{array}$ \\
\hline Inner shield plug emissivity & 1.0 & $\begin{array}{c}\text { Plys et al. } 1998 \\
\text { Note 6, Appendix C } \\
\end{array}$ \\
\hline MCO wall emissivity & 0.3 & Reilly 1998 \\
\hline $\begin{array}{l}\text { Cask, MCO bottom, and outer shield } \\
\text { plug emissivity }\end{array}$ & 0.25 & $\begin{array}{c}\text { Plys et al. } 1998 \\
\text { Note 7, Appendix C } \\
\end{array}$ \\
\hline $\begin{array}{l}\text { View factors between fuel rods and } \\
\text { MCO wall }\end{array}$ & $8 \times 8$ matrix & $\begin{array}{c}\text { Plys et al. } 1998 \\
\text { Note 8, Appendix C }\end{array}$ \\
\hline \multicolumn{3}{|c|}{ 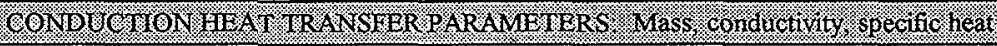 } \\
\hline Effective fuel-cladding mass density & $18,573.3 \mathrm{~kg} / \mathrm{m}^{3}$ & Note 9, Appendix C \\
\hline $\begin{array}{l}\text { Uranium (scrap) mass density at } \\
100^{\circ} \mathrm{C}\end{array}$ & $19,000 \mathrm{~kg} / \mathrm{m}^{3}$ & $\begin{array}{c}\text { Holden } 1958 \\
\text { Note } 10, \text { Appendix C }\end{array}$ \\
\hline Stainless steel mass density at $100^{\circ} \mathrm{C}$ & $8,000 \mathrm{~kg} / \mathrm{m}^{3}$ & $\begin{array}{c}\text { ORNL } 1987 \\
\text { Note 11, Appendix C }\end{array}$ \\
\hline
\end{tabular}


Table 2. Key Input Parameters for Bounding and Nominal Multi-Canister Overpack. (2 sheets)

\begin{tabular}{|c|c|c|}
\hline Parameter & Value & Reference \\
\hline $\begin{array}{l}\text { Maximum fuel mass load } \\
\text { (Mark IV fuel) }\end{array}$ & $\begin{array}{l}980 \mathrm{~kg} \text { - scrap basket } \\
1,268 \mathrm{~kg} \text { - fuel basket } \\
6,052 \mathrm{~kg} \text { per MCO }\end{array}$ & Reilly 1998 \\
\hline $\begin{array}{l}\text { Effective fuel/clad thermal } \\
\text { conductivity }\end{array}$ & $24.2 \mathrm{~W} / \mathrm{m} / \mathrm{K}$ & Note 12, Appendix C \\
\hline Stainless steel thermal conductivity & $16.0 \mathrm{~W} / \mathrm{m} / \mathrm{K}$ & ORNL 1987 \\
\hline $\begin{array}{l}\text { Effective fuel-cladding and uranium } \\
\text { specific heat }\end{array}$ & $122.67 \mathrm{~J} / \mathrm{kg} / \mathrm{K}$ & Note 13, Appendix C \\
\hline Stainless steel specific heat & $500.0 \mathrm{~J} / \mathrm{kg} / \mathrm{K}$ & ORNL 1987 \\
\hline $\begin{array}{l}\text { Free residual water after draining } \\
(1.5 \mathrm{~kg} \text { per scrap basket, } 6.0 \mathrm{~kg} \text { per } \\
\text { fuel basket, } 1.0 \mathrm{~kg} \text { per bottom) }\end{array}$ & $26.5 \mathrm{~kg}$ per $\mathrm{MCO}$ & Duncan and Ball 1997 \\
\hline $\begin{array}{l}\text { Water in uranium hydrates, } \\
\mathrm{UO}_{3} \cdot 2 \mathrm{H}_{2} \mathrm{O}\end{array}$ & $\begin{array}{c}1.16 \mathrm{~kg} \\
(0.72 \mathrm{~kg})^{*}\end{array}$ & Note 14, Appendix C \\
\hline $\begin{array}{l}\text { Helium purge and process bay } \\
\text { temperature }\end{array}$ & $\begin{array}{l}26.7^{\circ} \mathrm{C} \\
\left(80^{\circ} \mathrm{F}\right) \\
\end{array}$ & Irwin et al. 1998 \\
\hline Normal annulus water temperature & $50^{\circ} \mathrm{C}$ & Irwin et al. 1998 \\
\hline \multicolumn{3}{|c|}{ 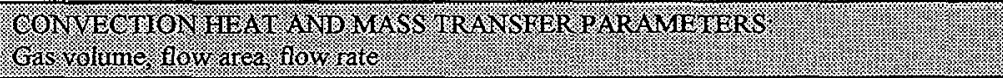 } \\
\hline Scrap basket gas volume & $0.153 \mathrm{~m}^{3}$ & Note 15, Appendix C \\
\hline Upper fuel ( 2 fuel baskets) volume & $0.186 \mathrm{~m}^{3}$ & Note 16, Appendix C \\
\hline Lower fuel ( 2 fuel baskets) volume & $0.199 \mathrm{~m}^{3}$ & Note 17, Appendix C \\
\hline Fine scrap porosity & 0.40 & Note 18, Appendix C \\
\hline Course scrap porosity & 0.7392 & Note 19, Appendix C \\
\hline Flow area in scrap basket bottom & $0.013 \mathrm{~m}^{2}$ & Note 20, Appendix C \\
\hline Vacuum pumping rate & $\begin{array}{c}0.01416 \mathrm{~m}^{3} / \mathrm{s} \\
(30 \mathrm{scfm})\end{array}$ & Irwin et al. 1998 \\
\hline Base helium mass purge rate & $\begin{array}{l}1.23 \mathrm{E}-04 \mathrm{~kg} / \mathrm{s} \\
(1.6 \mathrm{scfm})\end{array}$ & Irwin et al. 1998 \\
\hline
\end{tabular}

* The hydrate water mass for case 0 (NORMAI) is $0.72 \mathrm{~kg}$ MCO = multi-canister overpack. 


\section{HNF-SD-SNF-CN-023 REV 1}

amount of hydrate water is $0.72 \mathrm{~kg}$ for these normal operations. This is enough to produce about $20 \%$ of the particulate over the complete 53.25 -hour cycle, but also enough to keep the MCO from passing the pressure rebound tests (Pajunen 1998a). Not passing the rebound tests because of hydrate water is not a safety concern because so little of the hydrate water is available. However, the hydrates will tend to lengthen the vacuum drying operations time at the CVDF for the MCOs with high decay heat.

The maximum hydrogen generation rate is $3 \mathrm{mg} / \mathrm{sec}$, which occurs during the first purge right after draining and during the early stages of the first vacuum with helium purge process (see Table 3). This rate exceeds the design criteria of $2.4 \mathrm{mg} / \mathrm{sec}$ (Pajunen 1998b). As a result, the hydrogen concentration reaches about $1.25 \%$ of the gas space during the early stages after draining, which is more than one-quarter of the hydrogen flammability limit of $4 \%$. However, the maximum hydrogen concentration $(1.25 \%)$ is still less than one-third of the hydrogen flammability limit. The helium purge rate for this early time period is $1.6 \mathrm{standard} \mathrm{ft}^{3} / \mathrm{min}$.

The hydrogen generation rates and particulate generated during normal cold vacuum drying conditions are summarized in Table 3 . Table 3 shows annulus water temperature, helium purge rate, calculated maximum hydrogen generation rate, and generated particulate mass for each of the 13 cases identified as being part of normal operations.

\subsection{GROUP I, VACUUM DRYING AND HELIUM PURGE WITH NORMAL ANNULUS WATER (CASES 1 THROUGH 4)}

These four cases show the MCO is completely dry from free water in a little more than 14 hours for the indefinite vacuum only process (case 1, VACUUM), a little more than 16 hours for the vacuum with helium purge process (case 3 , VACPUR), and about 3 days for the helium purge only process (case 4, PURGE) (see Appendix A, Figures A-1 through A-4). As discussed previously, the helium purge only case (case 4, PURGE) takes much longer to dry the MCO because the pressure during purge is slightly above atmospheric pressure, so no boiling or rapid evaporation occurs. The scrap fuel and fuel elements are dry in about 7 hours and 31 hours, respectively, but the MCO wall and bottom are not dry for 3 days for case 4, PURGE. This is because the fuel temperature rises above $50^{\circ} \mathrm{C}$ after 16 hours, which causes the free water to evaporate from the fuel and condense on the cooler $\mathrm{MCO}$ wall $\left(50^{\circ} \mathrm{C}\right)$. When $75 \mathrm{~kg}$ of free water (case 2, VAC75KG) is present, instead of $26.5 \mathrm{~kg}$, for vacuum drying, the inner fuel temperature drops to $0^{\circ} \mathrm{C}$ after 3 days because of the extra cooling supplied by the extra $48.5 \mathrm{~kg}$ of evaporating water. Case 2 (VAC75KG) indicates the importance of having good thermal conduction from the $\mathrm{MCO}$ wall to the inner fuel assemblies in order to prevent the freezing of free water. The helium purge gas is expected to provide this good conduction and prevent the water from freezing for conditions involving very high amounts of free water or low decay heat. However, this issue needs more investigation and quantification. 
Table 3. Hydrogen Generation Rates and Particulate Formation under Normal Cold Vacuum Drying Operations for Bounding Multi-Canister Overpack with Nominal Hydrides.

\begin{tabular}{|c|c|c|c|c|c|c|c|c|c|}
\hline $\begin{array}{l}\text { Cold vacuum drying operation } \\
\text { on bounding } \mathrm{MCO}\end{array}$ & Case & $\begin{array}{l}\text { Duration of } \\
\text { operation }\end{array}$ & $\begin{array}{l}\text { Total elapsed } \\
\text { time }\end{array}$ & $\begin{array}{l}\text { Annulus } \\
\text { temperature }\end{array}$ & $\begin{array}{l}\text { Helium } \\
\text { purge rate }\end{array}$ & $\begin{array}{l}\text { Final MCO } \\
\text { pressure }\end{array}$ & $\begin{array}{l}\mathrm{Max} \mathrm{H}_{2} \\
\text { gen. rate }\end{array}$ & $\begin{array}{c}\mathrm{UO} 2 \\
\text { generated }\end{array}$ & $\begin{array}{c}\text { Cumulative } \\
\text { UO2 } \\
\text { generated }\end{array}$ \\
\hline $\begin{array}{l}\text { MCO drained with } 26.5 \mathrm{~kg} \text { free } \\
\text { water remaining }\end{array}$ & Name & hours & hours & ${ }^{\circ} \mathrm{C}$ & $\begin{array}{c}\text { standard } \\
\mathrm{ft}^{3} / \mathrm{min}\end{array}$ & $\mathrm{kPa}$ & $\mathrm{mg} / \mathrm{sec}$ & grams & grams \\
\hline Line flush (with helium) & \multirow[b]{2}{*}{ PURGEHO } & 0.42 & 0.42 & 50.0 & 0 & 101.3 & \multirow[b]{2}{*}{3.0} & \multirow[b]{2}{*}{366} & \multirow[b]{2}{*}{366} \\
\hline $\begin{array}{l}\text { Helium purge following } \mathrm{MCO} \\
\text { drain }\end{array}$ & & 0.33 & 0.75 & 50.0 & 1.6 & 101.8 & & & \\
\hline $\begin{array}{l}\text { Vacuum purge with NPV } \\
\text { checks }^{\mathrm{a}}\end{array}$ & VACPUR1 & 7.50 & 8.25 & 50.0 & 1.6 & 10.4 & 3.0 & 1,651 & 2,017 \\
\hline Helium purge (thermal reset) & PURGE2 & 4.00 & 12.25 & 50.0 & 1.6 & 101.6 & 1.5 & 878 & 2,895 \\
\hline $\begin{array}{l}\text { Helium purge (minimum purge } \\
\text { reset) }\end{array}$ & PURGE3 & 0.50 & 12.75 & 50.0 & 4.0 & 103.3 & 1.5 & 145 & 3,040 \\
\hline $\begin{array}{l}\text { Vacuum purge with NPV } \\
\text { checks }^{\mathrm{a}}\end{array}$ & VACPUR4 & 3.50 & 16.25 & 50.0 & 1.6 & 7.4 & 1.5 & 607 & 3,647 \\
\hline Helium purge (thermal reset) & PURGE5 & 4.00 & 20.25 & 50.0 & 1.6 & 101.5 & 0.80 & 546 & 4,193 \\
\hline $\begin{array}{l}\text { Helium purge (minimum purge } \\
\text { reset) }\end{array}$ & PURGE6 & 0.50 & 20.75 & $50.0^{-}$ & 4.0 & 102.5 & 0.56 & 30 & 4,223 \\
\hline $\begin{array}{l}\text { Vacuum purge with NPV } \\
\text { checks }^{\mathrm{a}}\end{array}$ & VACPUR7 & 1.00 & 21.75 & 50.0 & 1.6 & 5.6 & 0.18 & 21 & 4,244 \\
\hline Pressure rebound test & REBND8. & 1.00 & 22.75 & 50.0 & 0 & $\begin{array}{c}7.3 \\
\text { (55 torr) }\end{array}$ & 0.20 & 27 & 4,271 \\
\hline Proof test & PROOF & 19.00 & 41.75 & 50.0 & 0 & $\begin{array}{c}0.14 \\
\text { (1 torr) }\end{array}$ & 0.36 & 644 & 4,915 \\
\hline Second rebound test & REBND10 & 1.00 & 42.75 & 50.0 & 0 & $\begin{array}{c}1.72 \\
(13 \text { torr }) \\
\end{array}$ & 0.37 & 35 & 4,950 \\
\hline $\mathrm{Cool} \mathrm{MCO}$ to $25^{\circ} \mathrm{C}$ & $\mathrm{COOL}$ & 3.00 & 45.75 & 25.0 & 0.5 & 101.3 & 0.31 & 79 & 5,029 \\
\hline Ready for CSB ${ }^{b}$ & READY & 7.50 & 53.25 & 25.9 & $0^{\mathrm{b}}$ & $105.5^{b}$ & 0.21 & 125 & 5,154 \\
\hline TOTALS & & & 53.25 & & & & & 5,154 & 5,154 \\
\hline
\end{tabular}

aNPV checks are not included in simulations since they take up so little time.

'Helium pressurization is excluded from simulation, otherwise pressure would be around $150 \mathrm{kPa}$ with the extra helium.

$\mathrm{CSB}=$ Canister Storage Building.

$\mathrm{MCO}=$ multi-canister overpack.

NPV = no purge vacuum 


\section{HNF-SD-SNF-CN-023 REV 1}

The fuel temperatures are stable for all four cases, with the scrap fuel being cooler than the fuel elements. The scrap fuel holds less water $(1.5 \mathrm{~kg})$ than the fuel baskets $(6 \mathrm{~kg}$ per fuel basket) for the bounding MCO. Hence, the scrap fuel dries out first and starts to heat up after the water evaporates. With water vapor from the fuel baskets flowing through the scrap fuel, the scrap fuel has the potential to reach high temperatures. However, the scrap fuel basket has fins that make the heat removal in the scrap basket very good and better than the heat removal from the fuel baskets. Hence, if the top fuel basket had very little free residual water at the beginning of vacuum drying, it would dry early, be fed by water vapor from the lower fuel baskets and wall, and heat up more than the dry scrap fuel because heat removal for the fuel basket is not as good as heat removal for the scrap basket. The fuel temperatures in the upper fuel baskets for such a scenario could reach $200^{\circ} \mathrm{C}$ if more than $50 \mathrm{~kg}$ of residual water existed at the bottom of the MCO.

The maximum hydrogen generation rate among the four cases is $3.2 \mathrm{mg} / \mathrm{sec}$ for the helium purge only case (case 4, PURGE). The maximum rate occurs about 40 seconds after the helium purge only process begins. The maximum hydrogen generation rate for the vacuum and vacuum with helium purge processes (case 1, VACUUM, and case 3 , VACPUR) is $3.0 \mathrm{mg} / \mathrm{sec}$ at about 90 seconds after the start of these processes (see Table 4 for details).

The vacuum only case (case 1, VACUUM) compares well to case CVD3B in the previous revision of this document (Duncan and Ball 1997). Case CVD3B dries out in about 14 hours, which is a little sooner than for case 1 (VACUUM). Case 2 (VAC75KG) is similar to case CVD3C (Duncan and Ball 1997) except that the fuel reaches $0{ }^{\circ} \mathrm{C}$ in case 2 (VAC75KG) but not in case CVD3C. It is not clear why the two cases differ at this time. Case 4 (PURGE) is not really comparable to case CVD2A (Duncan and Ball 1997) since case CVD2A starts with a helium purge after 8 hours of vacuum drying. Hence, case CVD2A starts with less water than case 4 (PURGE), which starts 45 minutes after draining and has almost $26.5 \mathrm{~kg}$ of residual water.

\subsection{GROUP II, VACUUM DRYING AND HELIUM PURGE WITH HOT ANNULUS WATER (CASES 5 THROUGH 7)}

These three cases show that if the TWS overheats the annulus water to $85^{\circ} \mathrm{C}$, fuel temperatures will remain stable as long as the vacuum process is operational (see Appendix A, Figures A-5 through A-7). The vacuum only (case 5, VACHOT) and vacuum with helium purge (case 6, VPURHOT) processes provide stable fuel temperatures, but the helium purge only (case 7, PURHOT) process does not keep the fuel temperature stable in the inner parts of the fine and coarse scrap fuel regions. The helium purge only process feeds the scrap basket with water vapor at about $41 \mathrm{kPa}$ of pressure. This high water vapor pressure causes the reaction rate to be higher than the reaction rates under vacuum or under vacuum with helium purge (about $5 \mathrm{kPa}$ of water vapor) processes. 
HNF-SD-SNF-CN-023 REV 1

\subsection{GROUP III, VACUUM DRYING AND HELIUM PURGE WITH MAJOR FLOW FALURES OF THE TEMPERED WATER (ANNULUS) SYSTEM (CASES 8 THROUGH 13)}

The cases in this group represent a major failure in the TWS in providing annulus water flow (see Appendix A, Figures A-8 through A-13). In other words, this group of cases includes the loss of coolant failure and the loss of flow failure.

The loss of flow failure, resulting in a stationary annulus water condition, is rather benign because the process bay cools the stationary annulus water below $50^{\circ} \mathrm{C}$. The thermal conductivity of the stationary annulus water also is good enough to transfer the heat from inside the $\mathrm{MCO}$, to the cask, and to the process bay at a high rate under vacuum only and helium purge only conditions (case 8, VACLOF, and case 12, PURLOF). Even if the loss of flow failure occurs after the annulus has been heated up to $85^{\circ} \mathrm{C}$, the results are benign for the vacuum only condition (case 9, VLOFHOT) with fuel temperatures staying below $76{ }^{\circ} \mathrm{C}$.

The loss of coolant (annulus water) failure, resulting in air filling the annulus between the $\mathrm{MCO}$ and the cask, is a severe degradation of the heat transfer or heat removal capability of the annulus. Air is a poor thermal conductor, so heat from the $\mathrm{MCO}$ is not transferred to the cask and process bay very quickly. However, even with severe degradation of the cooling annulus, the fuel temperatures are stable for the vacuum only (case 10, VACLOC) and vacuum with helium purge (case 11, VPURLOC) processes. Fuel temperatures are not stable in the scrap basket, especially the inner fine scrap portion, for the helium purge only process (case 13, PURLOC). For the helium purge only case (case 13, PURLOC), the inner fine scrap basket temperature stays below $100^{\circ} \mathrm{C}$ for up to 1 day but reaches a peak of about $330^{\circ} \mathrm{C}$ in less than 2 days. Hence, even for the worst cold vacuum drying operations case, which is the helium purge only case (case 13, PURLOC) for the loss of coolant condition, the fuel temperatures are stable for up to 1 day. Comparing the vacuum only case (case 10, VACLOC) with the vacuum with helium purge case (case 11, VPURLOC) shows that the scrap basket temperature is cooler $\left(64{ }^{\circ} \mathrm{C}\right.$ versus $70^{\circ} \mathrm{C}$ ) for the vacuum with helium purge case, which demonstrates the better thermal conductivity effects of the helium gas (see Appendix A, Figures A-10 and A-11).

Case 12 (PURLOF) is similar to case CVD2B in the previous revision of this document (Duncan and Ball 1997) but not really comparable because case CVD2B starts after 8 hours of vacuuming and case 12 (PURLOF) starts 45 minutes after draining. The same is true for case 13 (PURLOC) and CVD2C (Duncan and Ball 1997).

\subsection{GROUP IV, DRAINING STOP AND GAS BLOCKAGE (CASES 14 THROUGH 31)}

This group of 18 cases could perhaps have been divided into smaller groups, but all these cases share the characteristic of having no vacuum drying or helium purge processes included. Most of the cases include an isolated or closed MCO, but some cases have an open MCO with no vacuum or helium purge taking place. All of the annulus conditions, both normal and 


\section{HNF-SD-SNF-CN-023 REV 1}

off-normal, are incorporated into this group of cases. Every case in this group is off-normal even though some of the annulus conditions are normal. The main output of interest for the isolated MCO cases is the time that it takes the pressure to reach $11.2 \mathrm{~atm}\left(150 \mathrm{lb} / \mathrm{in}^{2}\right.$ gauge), which is the burst pressure of the rupture disk.

The first case (case 14, DSTOP) in this group is an isolated MCO with normal annulus water ( $50^{\circ} \mathrm{C}$ and flowing). The pressure reaches 11.2 atm about 3 days after the $\mathrm{MCO}$ is closed. The fuel temperatures remain below $80^{\circ} \mathrm{C}$ forever because the heat removal rate is greater than the heat generation rate after 2.5 days. The next case (case 15, DS75KG) is the same except that $75 \mathrm{~kg}$ of free water remains after draining instead of $26.5 \mathrm{~kg}$. The extra $48.5 \mathrm{~kg}$ of free water is placed in the bottom fuel basket. This case takes longer ( 3.5 days instead of 3 days) for the pressure to reach $11.2 \mathrm{~atm}$ than case 14 (DSTOP) takes. The temperature increase is smaller than in case 14 (DSTOP) because of the additional heat capacity provided by the extra $48.5 \mathrm{~kg}$ of free water. Eventually the temperatures rise to about the same levels and are stable. The next case (case 16, DSTOPOV) is the same as case 14 (DSTOP), except that the MCO is not isolated because a valve is open. Case 16 (DSTOPOV) has no pressure increase due to the open valve, but the temperatures are higher than the temperatures of the two previous cases with isolated MCOs (see Appendix A, Figures A-14, A-15, and A-16). This is because the pressure builds up in isolated MCOs as the hydrogen builds up, slows down the evaporation rate, and provides a better thermal conductor to the MCO wall than steam containing low hydrogen content. Hence the $\mathrm{MCO}$ with an open valve reaches higher temperatures, but the temperatures are still stable and below $105^{\circ} \mathrm{C}$. The scrap fuel temperatures are lower than the innermost fuel element temperature for all of the cases discussed in this paragraph.

The next three cases (case 17, DSLOF; case 18, DLOF75KG; and case 19, DSLOFOV) are the same as the previous three cases except that the annulus water is stationary (not flowing). Since the stationary annulus water is cooled by the process bay, which has a low gas temperature $\left(26.7^{\circ} \mathrm{C}\right)$, these cases are more benign than the previous cases with normal flowing annulus water (see Appendix A, Figures A-17 to A-19). The time required for the pressure to reach $11.2 \mathrm{~atm}$ is 6 days for case 17 (DSLOF), and a little more than 6 days for case 18 (DLOF75KG), which has $75 \mathrm{~kg}$ of free water. The fuel temperatures are below $71^{\circ} \mathrm{C}$ forever because the heat removal rate is greater than the heat generation rate after a couple of days. The case with an open MCO (case 19, DSLOFOV) has stable fuel temperatures that are higher than the fuel temperatures in an isolated $\mathrm{MCO}\left(80^{\circ} \mathrm{C}\right.$ versus $\left.71^{\circ} \mathrm{C}\right)$. Case 17 (DSLOF) differs from the corresponding case CVDIF in the previous revision of this document (Duncan and Ball 1997) by having much lower fuel temperatures and a much slower rise in pressure (6 days to $11.2 \mathrm{~atm}$ versus 20.5 hours to $11.2 \mathrm{~atm}$ in case CVD1F). The lower decay heat used in case 17 (DSLOF) and the inclusion of the heat capacity of the residual water and annulus water in case 17 (DSLOF) are certainly factors that would cause such a difference. Also, the thermal conductivity of the annulus water is more accurate for case 17 (DSLOF).

The next six cases involve a loss of coolant (annulus water) failure.

- Case 20 (DSLOC) is an isolated MCO with a loss of coolant failure in which air takes the place of the flowing water in the annulus. The gas pressure reaches 


\section{HNF-SD-SNF-CN-023 REV 1}

11.2 atm in a little more than 21 hours when the maximum fuel temperature is still only $95{ }^{\circ} \mathrm{C}$. If there is no rupture disk, then the maximum fuel temperature reaches about $900^{\circ} \mathrm{C}$ in about 32 hours. The MCO pressurizes more slowly ( 21 hours to $11.2 \mathrm{~atm}$ ) in case 20 (DSLOC) than in case CVD1C (approximately 18 hours to $11.2 \mathrm{~atm}$ ) in the previous revision of this document (Duncan and Ball 1997). This is primarily because the decay heat is lower and the heat capacity of the residual water is included in case 20 (DSLOC).

- Case 21 (DLOC75KG) is the same as case 20 (DSLOC), except that $75 \mathrm{~kg}$ of free water is present at the time of the cooling failure. The pressure reaches $11.2 \mathrm{~atm}$ in about 25 hours, which is longer than in the previous case because the extra $48.5 \mathrm{~kg}$ of free water provides added heat capacity and causes a lower rate of temperature increase (see Appendix A, Figures A-20 and A-21). However, the peak fuel temperature is greater than $1,000^{\circ} \mathrm{C}$, which is greater than the peak fuel temperature in case 20 (DSLOC) because of the extra free water.

- Case 22 (DSLOCNOM) is the same as case 20 (DSLOC), except that it simulates an MCO with nominal parameter values (see Table 2) instead of bounding parameter values. The hydride loading $(2.4 \mathrm{~kg})$, free water $(26.5 \mathrm{~kg})$, and hydrate water $(1.16 \mathrm{~kg})$ are the same as in previous cases. Basically, the results are very benign, with a very slow pressure increase and temperature rise compared to the same case with an MCO with bounding parameter values (case 20, DSLOC). See Appendix A, Figure A-22, which shows both cases (case 22, DSLOCNOM and case 20, DSLOC).

- Case 23 (DSLOCREC) examines a recovery of the loss of coolant failure by restoring flowing annulus water at a cooler temperature of $25^{\circ} \mathrm{C}$ at 21 hours after failure, which is just before the pressure reaches the rupture disk burst pressure. Since the water in the annulus cools down the MCO wall very quickly, the water vapor or steam starts to condense almost immediately on the cooler MCO wall and bottom, which are in contact with the annulus water. The condensing steam reduces the number of gas molecules in the $\mathrm{MCO}$, and the pressure decreases. The pressure stays below the pressure at the time of the recovery ( 21 hours) for at least 24 hours (see Appendix A, Figure A-23).

- Case 24 (DSLOCRE2) is the same as the previous recovery case, except that the recovery consists of filling the annulus with stationary water at a cooler temperature of $25^{\circ} \mathrm{C}$. The effects of the cooler annulus are the same as in the previous case, except that the stationary annulus water heats up over time and the MCO pressure exceeds the pressure at the time of recovery (21 hours) in about 8 hours (see Appendix A, Figure A-24 for both case 24, DSLOCRE2, and case 20, DSLOC). If the recovery can take place earlier, then it will take the pressure longer to reach $11.2 \mathrm{~atm}$. In other words, the recovery from the TWS failure is only minutes before the rupture disk would burst open for the two recovery cases. If the recovery were one hour or more before blowdown instead of few minutes, then the pressure would take a much longer time to reach the burst pressure. 


\section{HNF-SD-SNF-CN-023 REV 1}

- Case 25 (DSLOCOV) is the same as case 20 (DSLOC), except that a valve remains open at the time of the loss of coolant failure. As expected, the fuel temperatures are larger $\left(>900^{\circ} \mathrm{C}\right)$ than the temperatures in case 20 (DSLOC) and the peak occurs later, at more than 36 hours, instead of at 32 hours (see Appendix A, Figures A-25 and $\mathrm{A}-20$ ).

The next four cases analyze the effects of different temperatures of annulus water on an isolated MCO. The annulus water temperatures are $46^{\circ} \mathrm{C}$ for case 26 (DS46DEG), $55^{\circ} \mathrm{C}$ for case 27 (DS55DEG), $75^{\circ} \mathrm{C}$ for case 28 (DS75DEG), and $85^{\circ} \mathrm{C}$ for case 29 (DSHOT). The time for the pressure to reach $11.2 \mathrm{~atm}$ is plotted in Figure 2, which clearly shows the nonlinear effects of temperature on the pressurization time.

Case 30 (DHOT75KG) is the same as case 29 (DSHOT with an $85^{\circ} \mathrm{C}$ annulus), except that $75 \mathrm{~kg}$ of free residual water, instead of $26.5 \mathrm{~kg}$, is available at the time of TWS failure. Because of the hot annulus, the residual water is heated up quickly and the pressure reaches $11.2 \mathrm{~atm}$ in slightly less time, 11.5 hours, than the time realized (12 hours) in case 29 (DSHOT) (see Appendix A, Figures A-30 and A-29). Normally, the additional heat capacity of the extra $48.5 \mathrm{~kg}$ of water slows down the temperature increase and the resulting pressure increase. However, a hot annulus $\left(85^{\circ} \mathrm{C}\right)$ supplies more heat to the lower temperature $\mathrm{MCO}$, and this extra heat more than makes up for the extra heat capacity. This phenomenon is different for the loss of coolant cases (case 20, DSLOC, and case 21, DLOC75KG) because the annulus water in those cases does not supply heat to the MCO but, instead, slows down the heat removal rate, which makes the extra heat capacity more noticeable (see Appendix A, Figures A-20 and A-21). It should be noted that the $85^{\circ} \mathrm{C}$ annulus acts as a heater in the early stages of the thermal runaway reaction but acts as a coolant in the later stages of the thermal runaway reaction with the peak fuel temperatures being much lower $\left(<215^{\circ} \mathrm{C}\right)$ than the peak temperature $\left(>900^{\circ} \mathrm{C}\right)$ for the thermal runaway reaction with loss of coolant condition (case 20, DSLOC).

Case 31 (DSHOTOV), the last case in this group, is the same as case 29 (DSHOT), except that a valve is open at the time of the TWS temperature failure. Hence, this case does not have an isolated MCO like case 29 (DSHOT). As expected, the fuel temperatures are higher $\left(>1,000^{\circ} \mathrm{C}\right)$ than they are in case 29 (DSHOT) $\left(<215^{\circ} \mathrm{C}\right)$, and the peak temperature occurs later in time (see Appendix A, Figures A-31 and A-29).

\subsection{GROUP V, VACUUM DRYING AND HELIUM PURGE WITH AIR INGRESS (CASES 32 THROUGH 37)}

This group of cases examines the effects of air ingress during the vacuum drying processes. Air is assumed to enter the MCO through a very small hole $\left(0.1 \mathrm{~cm}^{2}\right)$ (Plys et al. 1997), so the operators cannot detect it by observing an increase in pressure during the vacuum drying processes. Major TWS failures - loss of coolant and a hot $\left(85^{\circ} \mathrm{C}\right)$ annulus - are included with the air ingress effects. Since the hydrides reacting with air (oxygen) can be significant in contributing heat to the fuel, the hydride loading for the air ingress case was increased from $2.4 \mathrm{~kg}$ to $14.6 \mathrm{~kg}$ ( $9.0 \mathrm{~kg}$ for the scrap basket, $5.6 \mathrm{~kg}$ for four fuel baskets). This higher hydride loading results in an effective reaction rate multiplier of 111 for the scrap fuel and 59.2 for the fuel elements (see Appendix C, Note 4). 
Figure 2. Time to Reach Rupture Disk Burst Pressure versus Temperature of Annulus Water.

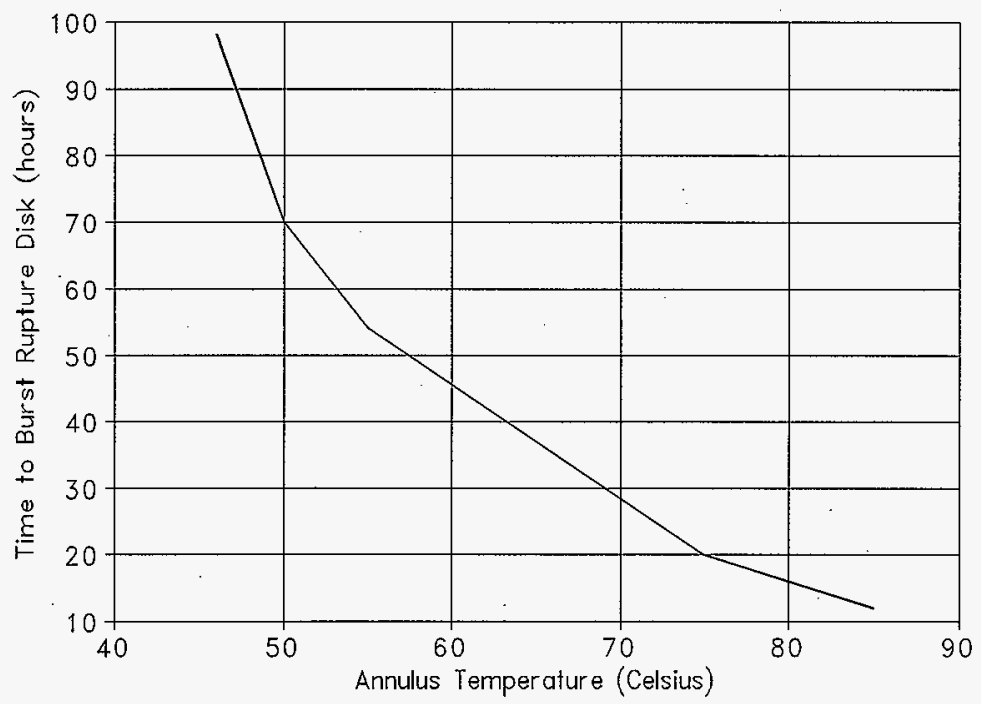

The drying time of the MCO for the vacuum only process (case 32, VACAIRI) is longer with air ingress than without it (19 hours for case 32, VACAIRI, versus 14 hours for case 1, VACUUM). This is because the fuel-air reaction rates are lower than the fuel-water reaction rates and less heat is generated as a result. With less heat, the fuel temperatures and evaporation and boiling rates are lower, and the dryout time is longer (see Appendix A, Figure A-32). However, the helium purge only process (case 35, PURAIRI) with air ingress is not stable. The fuel temperatures for this case stay below $105^{\circ} \mathrm{C}$, but the innermost fine scrap fuel temperature reaches $700{ }^{\circ} \mathrm{C}$ in less than 1.4 hours. This peak temperature lasts only for a few minutes and is due to the high hydride mass loading on the scrap fuel (see Appendix A, Figure A-35). The scrap fuel temperatures are expected to be stable for the helium purge only process with the large nominal value of $1.1 \mathrm{~kg}$ for hydrides in the scrap instead of the bounding value of $9.0 \mathrm{~kg}$ as in this case.

The hot water annulus $\left(85^{\circ} \mathrm{C}\right)$ and loss of coolant conditions under vacuum processes (case 33, VAIRIHOT, and case 34 , VAIRILOC) produce very unstable temperatures $\left(>900^{\circ} \mathrm{C}\right.$ ), after 2.5 days for case 33 (VAIRIHOT), and after 4 days for case 34 (VAIRMLC). In all the vacuum only cases, the fuel heats up after the free water is gone. Combining air ingress with 


\section{HNF-SD-SNF-CN-023 REV 1}

poor heat removal conditions causes the fuel temperature to increase greatly and react with the incoming oxygen continuously at increasing reaction rates. The temperatures eventually become very unstable after a couple of days. However, when free water is present, the cooling effects of evaporation keep the fuel temperatures low as long as the free water is available; and it takes more than a day after the free water is gone to start reaching high fuel temperatures (see Appendix A, Figures A-33 and A-34). For the helium purge only process (case 36, PAIRIHOT) with the hot annulus condition, the inner fine scrap fuel becomes unstable very quickly $\left(<1\right.$ hour), but the temperatures of the fuel elements remain stable and stay below $115^{\circ} \mathrm{C}$.

The maximum hydrogen generation rates for these cases are higher than the corresponding cases with no air ingress. The main reason for this is the increased bounding hydride loading used in the air ingress cases compared to the other cases with nominal hydride loading. An air ingress case with no hydrides for the vacuum only process (case 37, VACAIRI2) was simulated to show the effects of hydrides on the hydrogen generation rate during air ingress. The maximum hydrogen generation rate for this case is only $1.9 \mathrm{mg} / \mathrm{sec}$ compared to $21.2 \mathrm{mg} / \mathrm{sec}$ for the same case with bounding hydrides (case 32, VACAIRI). Hence, the bounding hydrides with air produce about 11.2 times as much hydrogen as the uranium-air reaction produces during the initial stage of vacuum drying with air ingress. The maximum hydrogen generation rate was $3.0 \mathrm{mg} / \mathrm{sec}$ for the vacuum only case (case 1, VACUUM) with no air ingress and $2.4 \mathrm{~kg}$ of hydrides (see Appendix A, Figures A-32 and A-1). Hence, the amount of hydrides is a very important factor in hydrogen production and scrap fuel temperature stability.

\subsection{GROUP VI, COLD VACUUM DRYING FACILITY SAFETY ANALYSIS REPORT CASES (CASES 38 THROUGH 42)}

The CVDF Safety Analysis Report (Pili-Vincens 1998) included a high-pressure thermal runaway scenario with the MCO rupture disk bursting open at a pressure of $11.2 \mathrm{~atm}\left(150 \mathrm{lb} / \mathrm{in}^{2}\right.$ gauge). The blowdown release of particulate and the continuous release of particulate following the blowdown were included in the Safety Analysis Report (Pili-Vincens 1998) in order to estimate the dose to people at onsite and offsite locations. The only difference between the primary SAR case, case 38 (DSLOCSA4), and case 20 (DSLOC) is that $35.5 \mathrm{~kg}$ of free residual water, instead of $26.5 \mathrm{~kg}$, is present when the loss of coolant failure occurs. An extra $9 \mathrm{~kg}$ of free water was postulated to exist between the bottom of the lowest fuel basket and the surface of MCO bottom (a 1.5-in. gap). This extra water can be caused by a drain interrupt or a blockage of the long process tube intake at the bottom of the MCO.

The high-pressure thermal runaway scenario (case 38, DSLOCSA4) reaches the rupture disk burst pressure of $11.2 \mathrm{~atm}$ in a little more than 21 hours after the loss of coolant failure. The maximum fuel temperature at this point in time is only about $95{ }^{\circ} \mathrm{C}$. If there were no rupture disk in the MCO (there is none in case 38, DSLOCSA4), the pressure would start to increase very rapidly 30 hours after the loss of coolant condition. The pressure peaks at around $230 \mathrm{~atm}$ at 32 hours (assuming no pressure relief), and the inner fuel temperatures peak above $1,000{ }^{\circ} \mathrm{C}$ at about the same time. The pressures and temperatures would continue to increase after 32 hours except that all of the free water and all of hydrate water are consumed. Hence, there are no more 
oxidants left for the fuel after the water is depleted. Hydrogen gettering was not included in the case but would take place mainly after the water is consumed and would lower the pressure more quickly than illustrated in Appendix A, Figure A-38. Since the main interest in this case was to provide the conditions for the blowdown release, which occurs around 21 hours, hydrogen gettering was not important to this scenario.

The blowdown release, the continuous release, and the reactions after the blowdown are included is case 39 (BLOW4N). The free water and hydrated water are depleted about 16 hours after the blowdown (about 37 hours after the loss of coolant failure) although there is a small amount $(0.037 \mathrm{~kg})$ of hydrate water left on the scrap fuel because the scrap fuel is not hot enough to decompose the last water molecule in a hydrate molecule. The inner fuel element temperature surpasses $1,000^{\circ} \mathrm{C}$ about 15 hours after the blowdown ( 36 hours after the loss of coolant failure [see Appendix A, Figure A-39]). After the water is gone, the fuel continues to react with the air constituents (oxygen, water vapor, and nitrogen) that enter the $\mathrm{MCO}$ through the rupture disk orifice. Since air outside the MCO is cooler and more dense than the hot MCO gases exiting the orifice, a small amount of the air will flow counter to the exiting gases. After the water is depleted, the MCO will cool down and draw in more air at a faster rate. Since some of the fuel elements are hot $\left(<700^{\circ} \mathrm{C}\right)$, nitrogen will react with the hot fuel to form uranium nitride. However, only about $0.55 \mathrm{~kg}$ of nitride is formed during the entire 24-hour time period after the blowdown, whereas about $250 \mathrm{~kg}$ of $\mathrm{UO}_{2}$ is generated over the same 24 -hour time period. Less than $22 \mathrm{~kg}$ of particulate is generated after draining and before the blowdown at 21 hours.

Since the recovery of the loss of coolant failure is of interest, two recovery cases were analyzed. One recovery case takes place 21 hours after the loss of coolant condition (case 40, DSSA4REC) and just before the rupture disk bursts open. The recovery consists of restoring the annulus water with stationary (not flowing) water that is around room temperature $\left(25^{\circ} \mathrm{C}\right)$. The result of the recovery that the MCO gas pressure quickly decreases because of the water vapor (steam) condensing on the cooler MCO wall. The gas pressure stays below the rupture disk burst pressure for another 8 hours, thus preventing the blowdown release for at least that long (see Appendix A, Figure A-40). If the annulus water is recovered sooner than just before the blowdown, the blowdown will be prevented for more than 24 hours. The second recovery case (case 41, BLOWREOV) investigated the effect of restored anmulus water after the blowdown had occurred (which includes an opened rupture disk). The stationary annulus water is put in place 1 hour after the blowdown release ( 22 hours after loss of coolant condition). The result is stable fuel temperatures forever. The cooler annulus causes condensation of steam on the cooler MCO wall, which lowers the water vapor pressure and the ensuing reaction rates. With lower reaction rates and good heat transfer from the MCO to the cask and process bay, the fuel temperatures stay stable and lower than they were initially at the time of recovery (see Appendix A, Figure A-41). Furthermore, the amount of particulate generated for 24 hours after the blowdown is only about $2.5 \mathrm{~kg}$, compared with $250 \mathrm{~kg}$ when there is no recovery (case 39 , BLOW4N). Hence, the recovery of the lost anmulus water by filling the annulus with stationary water is very effective in preventing the blowdown (case 40, DSSA4REC) and reducing the continuous release after the blowdown by a factor of 10 (case 41, BLOWREOV). 
Table 4. Results Summary of Simulated Cases. (4 sheets)

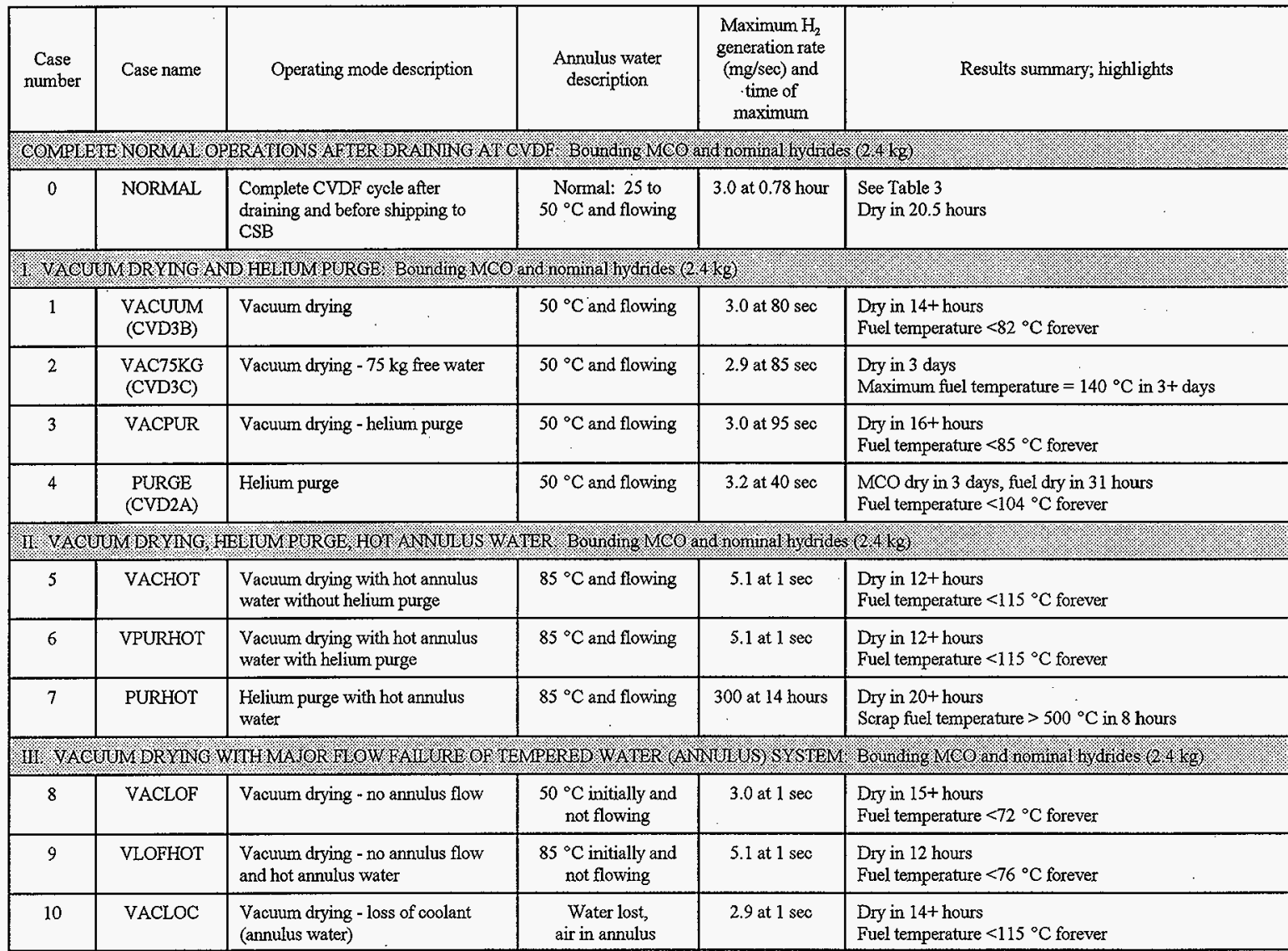




\begin{tabular}{|c|c|c|c|c|c|}
\hline $\begin{array}{l}\text { Case } \\
\text { number }\end{array}$ & Case name & Operating mode description & $\begin{array}{l}\text { Annulus water } \\
\text { description }\end{array}$ & $\begin{array}{c}\text { Maximum } \mathrm{H}_{2} \\
\text { generation rate } \\
\text { (mg/sec) and } \\
\text { time of } \\
\text { maximum }\end{array}$ & Results summary; highlights \\
\hline 11 & VPURLOC & $\begin{array}{l}\text { Vacuum drying - loss of coolant } \\
\text { with helium purge }\end{array}$ & $\begin{array}{l}\text { Water lost, } \\
\text { air in annulus }\end{array}$ & 2.9 at $1 \mathrm{sec}$ & $\begin{array}{l}\text { Dry in } 16+\text { hours } \\
\text { Fuel temperature }<120^{\circ} \mathrm{C} \text { forever }\end{array}$ \\
\hline 12 & $\begin{array}{l}\text { PURLOF } \\
\text { (CVD2B) }\end{array}$ & Helium purge - no annulus water & $\begin{array}{l}50^{\circ} \mathrm{C} \text { initially and } \\
\text { not flowing }\end{array}$ & 3.0 at $1 \mathrm{sec}$ & $\begin{array}{l}\text { Dry in almost } 6 \text { days } \\
\text { Fuel temperature }<82{ }^{\circ} \mathrm{C} \text { forever. }\end{array}$ \\
\hline 13 & $\begin{array}{l}\text { PURLOC } \\
\text { (CVD2C) }\end{array}$ & Helium purge - loss of coolant & $\begin{array}{l}\text { Water lost, } \\
\text { air in annulus }\end{array}$ & 22 at 14 hours & $\begin{array}{l}\text { Dry in } 2 \text { days } \\
\text { Maximum scrap fuel temperature }=330^{\circ} \mathrm{C} \text { in } 2 \text { days }\end{array}$ \\
\hline \multicolumn{6}{|c|}{ 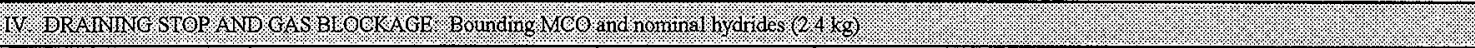 } \\
\hline 14 & $\begin{array}{c}\text { DSTOP } \\
\text { (CVD2A) }\end{array}$ & $\begin{array}{l}\text { Draining and gas blockage - normal } \\
\text { annulus water }\end{array}$ & $50^{\circ} \mathrm{C}$ and flowing & 3.1 at 1.2 hours & $\begin{array}{l}\text { Gas pressure }=11.2 \mathrm{~atm} \text { in } 3 \text { days } \\
\text { Fuel temperature }<80^{\circ} \mathrm{C} \text { forever }\end{array}$ \\
\hline 15 & DS75KG & $\begin{array}{l}\text { Draining and gas blockage - normal } \\
\text { annulus water, } 75 \mathrm{~kg} \text { free water }\end{array}$ & $50^{\circ} \mathrm{C}$ and flowing & 3.1 at 1.2 hours & $\begin{array}{l}\text { Gas pressure }=11.2 \mathrm{~atm} \text { in } 3.5+\text { days } \\
\text { Fuel temperature }<80^{\circ} \mathrm{C} \text { forever }\end{array}$ \\
\hline 16 & DSTOPOV & $\begin{array}{l}\text { Draining and gas blockage - normal } \\
\text { annulus water, with open vent }\end{array}$ & $50^{\circ} \mathrm{C}$ and flowing & 3.2 at 0.7 hour & Fuel temperature $<105^{\circ} \mathrm{C}$ forever \\
\hline 17 & $\begin{array}{l}\text { DSLOF } \\
\text { (CVDIF) }\end{array}$ & $\begin{array}{l}\text { Draining and gas blockage - loss of } \\
\text { annulus water flow }\end{array}$ & $\begin{array}{l}50^{\circ} \mathrm{C} \text { initially and } \\
\text { not flowing }\end{array}$ & 3.1 at 0.6 hour & $\begin{array}{l}\text { Gas pressure }=11.2 \mathrm{~atm} \text { in } 6 \text { days } \\
\text { Fuel temperature }<71^{\circ} \mathrm{C} \text { forever }\end{array}$ \\
\hline 18 & DLOF75KG & $\begin{array}{l}\text { Draining and gas blockage - loss of } \\
\text { annulus water flow, } 75 \mathrm{~kg} \text { free } \\
\text { water }\end{array}$ & $\begin{array}{l}50^{\circ} \mathrm{C} \text { initially and } \\
\text { not flowing }\end{array}$ & 3.1 at 0.6 hour & $\begin{array}{l}\text { Gas pressure }=11.2 \mathrm{~atm} \text { in } 6+\text { days } \\
\text { Fuel temperature }<71^{\circ} \mathrm{C} \text { forever }\end{array}$ \\
\hline 19 & DSLOFOY & $\begin{array}{l}\text { Draining and gas blockage - loss of } \\
\text { annulus water flow, with open vent }\end{array}$ & $\begin{array}{l}50^{\circ} \mathrm{C} \text { initially and } \\
\text { not flowing }\end{array}$ & 3.1 at 0.5 hour & Fuel temperature $<80^{\circ} \mathrm{C}$ forever \\
\hline 20 & $\begin{array}{l}\text { DSLOC } \\
\text { (CVD1C) }\end{array}$ & $\begin{array}{l}\text { Draining and gas blockage - loss of } \\
\text { coolant }\end{array}$ & $\begin{array}{l}\text { Water lost, } \\
\text { air in annulus }\end{array}$ & 540 at 32 hours & $\begin{array}{l}\text { Gas pressure }=11.2 \mathrm{~atm} \text { in } 21 \text { hours } \\
\text { Maximum fuel temperature }>900^{\circ} \mathrm{C} \text { in } 32 \text { hours }\end{array}$ \\
\hline 21 & DLOC75KG & $\begin{array}{l}\text { Draining and gas blockage - loss of } \\
\text { coolant, } 75 \mathrm{~kg} \text { free water }\end{array}$ & $\begin{array}{l}\text { Water lost, } \\
\text { air in annulus }\end{array}$ & $\begin{array}{l}163,000 \text { at } \\
40 \text { hours }\end{array}$ & $\begin{array}{l}\text { Gas pressure }=11.2 \mathrm{~atm} \text { in } 25 \text { hours } \\
\text { Maximum fuel temperature }>1,000^{\circ} \mathrm{C} \text { in } 39+\text { hours }\end{array}$ \\
\hline 22 & DSLOCNOM & $\begin{array}{l}\text { Draining and gas blockage - loss of } \\
\text { coolant }\end{array}$ & $\begin{array}{l}\text { Water lost, } \\
\text { air in annulus }\end{array}$ & 2.1 at 5.5 hours & $\begin{array}{l}\text { Gas pressure }<3.5 \mathrm{~atm} \text { for } 2 \text { days } \\
\text { Fuel temperature }<77^{\circ} \mathrm{C} \text { for } 2 \text { days }\end{array}$ \\
\hline 23 & DSLOCREC & $\begin{array}{l}\text { Draining and gas blockage - loss of } \\
\text { coolant recovery }\end{array}$ & $\begin{array}{l}25^{\circ} \mathrm{C} \text { and flowing at } \\
\text { restart }\end{array}$ & 6.0 at 21 hours & $\begin{array}{l}25^{\circ} \mathrm{C} \text { flowing annulus water in } 21 \text { hours prevents } \\
\text { blowdown release and cools down fuel }\end{array}$ \\
\hline
\end{tabular}


Table 4. Results Summary of Simulated Cases. (4 sheets)

\begin{tabular}{|c|c|c|c|c|c|}
\hline $\begin{array}{c}\text { Case } \\
\text { number }\end{array}$ & Case name & Operating mode description & $\begin{array}{l}\text { Annulus water } \\
\text { description }\end{array}$ & $\begin{array}{c}\text { Maximum } \mathrm{H}_{2} \\
\text { generation rate } \\
\text { (mg/sec) and } \\
\text { time of } \\
\text { maximum }\end{array}$ & Results summary; highlights \\
\hline 24 & DSLOCRE2 & $\begin{array}{l}\text { Draining and gas blockage - loss of } \\
\text { coolant recovery }\end{array}$ & $\begin{array}{l}\text { Stationary and } 25^{\circ} \mathrm{C} \\
\text { at } 21 \text { hours }\end{array}$ & 6.0 at 21 hours & $\begin{array}{l}\text { Stationary annulus recovery at } 21 \text { hours delays } \\
\text { blowdown for } 14 \text { hours }\end{array}$ \\
\hline 25 & DSLOCOV & $\begin{array}{l}\text { Draining and gas blockage - loss of } \\
\text { coolant }\end{array}$ & $\begin{array}{l}\text { Water lost, } \\
\text { air in annulus }\end{array}$ & $\begin{array}{l}8,100 \text { at } \\
32 \text { hours }\end{array}$ & Maximum fuel temperature $>900^{\circ} \mathrm{C}$ in $36+$ hours \\
\hline 26 & DS46DEG & $\begin{array}{l}\text { Draining and gas blockage }-46^{\circ} \mathrm{C} \\
\text { annulus }\end{array}$ & $46^{\circ} \mathrm{C}$ and flowing & 3.1 at $120 \mathrm{sec}$ & $\begin{array}{l}\text { Gas pressure }=11.2 \mathrm{~atm} \text { in } 4+\text { days } \\
\text { Fuel temperature }<76^{\circ} \mathrm{C} \text { forever }\end{array}$ \\
\hline 27 & DS55DEG & $\begin{array}{l}\text { Draining and gas blockage }-55^{\circ} \mathrm{C} \\
\text { annulus }\end{array}$ & $55^{\circ} \mathrm{C}$ and flowing & 4.0 at 2.3 hours & $\begin{array}{l}\text { Gas pressure }=11.2 \mathrm{~atm} \text { in } 2+\text { days } \\
\text { Fuel temperature }<85^{\circ} \mathrm{C} \text { forever }\end{array}$ \\
\hline 28 & DS75DEG & $\begin{array}{l}\text { Draining and gas blockage }-75^{\circ} \mathrm{C} \\
\text { annulus }\end{array}$ & $75^{\circ} \mathrm{C}$ and flowing & 8.6 at 3.8 hours & $\begin{array}{l}\text { Gas pressure }=11.2 \mathrm{~atm} \text { in } 20+\text { hours } \\
\text { Fuel temperature }<120^{\circ} \mathrm{C} \text { forever }\end{array}$ \\
\hline 29 & DSHOT & $\begin{array}{l}\text { Draining and gas blockage - hot } \\
\text { annulus water }\end{array}$ & $85^{\circ} \mathrm{C}$ and flowing & 25 at 4.9 hours & $\begin{array}{l}\text { Gas pressure }=11.2 \mathrm{~atm} \text { in } 12 \text { hours } \\
\text { Fuel element temperature }<151^{\circ} \mathrm{C} \text { forever } \\
\text { Maximum scrap fuel temperature }=215^{\circ} \mathrm{C} \text { in } 5 \text { hours }\end{array}$ \\
\hline 30 & DHOT75KG & $\begin{array}{l}\text { Draining and gas blockage - hot } \\
\text { annulus, water } 75 \mathrm{~kg} \text { free water }\end{array}$ & $85^{\circ} \mathrm{C}$ and flowing & 24 at 4.9 hours & $\begin{array}{l}\text { Gas pressure }=11.2 \mathrm{~atm} \text { in } 11.5 \text { hours } \\
\text { Fuel element temperature }<157^{\circ} \mathrm{C} \text { forever } \\
\text { Maximum scrap fuel temperature }=210^{\circ} \mathrm{C} \text { in } 5 \text { hours }\end{array}$ \\
\hline 31 & DSHOTOV & $\begin{array}{l}\text { Draining and gas blockage - hot } \\
\text { annulus water, with open vent }\end{array}$ & $85^{\circ} \mathrm{C}$ and flowing & $\begin{array}{l}13,600 \text { at } \\
29 \text { hours }\end{array}$ & Fuel temperature $>1,000^{\circ} \mathrm{C}$ in $28+$ hours \\
\hline \multicolumn{6}{|c|}{ 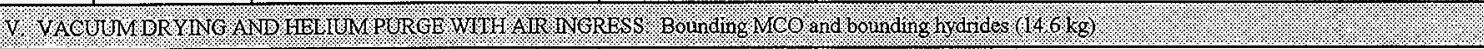 } \\
\hline 32 & VACAIRI & $\begin{array}{l}\text { Vacuum drying - air ingress and } \\
\text { bounding hydrides }\end{array}$ & $50^{\circ} \mathrm{C}$ and flowing & 21.2 at $1 \mathrm{sec}$ & $\begin{array}{l}\text { Dry in } 19 \text { hours } \\
\text { Fuel temperature }<120^{\circ} \mathrm{C} \text { forever }\end{array}$ \\
\hline 33 & VAIRIHOT & $\begin{array}{l}\text { Vacuum drying - air ingress, } \\
\text { bounding hydrides, and hot annulus } \\
\text { water }\end{array}$ & $85^{\circ} \mathrm{C}$ and flowing & 49 at 1 second & $\begin{array}{l}\text { Dry in } 16 \text { hours } \\
\text { Fuel temperature }>900^{\circ} \mathrm{C} \text { in } 2.5 \text { days }\end{array}$ \\
\hline 34 & VAIRILOC & $\begin{array}{l}\text { Vacuum drying - air ingress, } \\
\text { bounding hydrides, and loss of } \\
\text { coolant }\end{array}$ & $\begin{array}{l}\text { Water lost, } \\
\text { air in annulus }\end{array}$ & 49 at 108 hours & $\begin{array}{l}\text { Dry in } 20 \text { hours } \\
\text { Fuel temperature }>900^{\circ} \mathrm{C} \text { in } 4+\text { days }\end{array}$ \\
\hline
\end{tabular}


Table 4. Results Summary of Simulated Cases. (4 sheets)

\begin{tabular}{|c|c|c|c|c|c|}
\hline $\begin{array}{l}\text { Case } \\
\text { number }\end{array}$ & Case name & Operating mode description & $\begin{array}{l}\text { Annulus water } \\
\text { description }\end{array}$ & $\begin{array}{c}\text { Maximum } \mathrm{H}_{2} \\
\text { generation rate } \\
\text { (mg/sec) and } \\
\text { time of } \\
\text { maximum }\end{array}$ & Results summary; highlights \\
\hline 35 & PURAIRI & $\begin{array}{l}\text { Helium purge - air ingress and } \\
\text { bounding hydrides }\end{array}$ & $50^{\circ} \mathrm{C}$ and flowing & $\begin{array}{l}2,390 \text { at } \\
1.4 \text { hours }\end{array}$ & $\begin{array}{l}\text { Dry in } 3+\text { days } \\
\text { Fuel temperature }<105^{\circ} \mathrm{C} \text { forever } \\
\text { Maximum scrap fuel temperature }>700^{\circ} \mathrm{C} \text { in } 1.4 \text { hours }\end{array}$ \\
\hline 36 & PAIRIHOT & $\begin{array}{l}\text { Helium purge - air ingress, } \\
\text { bounding hydrides, and hot annulus } \\
\text { water }\end{array}$ & $85^{\circ} \mathrm{C}$ and flowing & $\begin{array}{l}8,670 \text { at } \\
0.9 \text { hour }\end{array}$ & $\begin{array}{l}\text { Diy in } 19+\text { hours } \\
\text { Fuel temperature }<115^{\circ} \mathrm{C} \text { forever } \\
\text { Maximum scrap fuel temperature }>750^{\circ} \mathrm{C} \text { in } 0.9 \text { hour }\end{array}$ \\
\hline 37 & VACAIRI2 & $\begin{array}{l}\text { Vacuum drying - air ingress without } \\
\text { hydrides }\end{array}$ & $50^{\circ} \mathrm{C}$ and flowing & 1.9 at $I \mathrm{sec}$ & $\begin{array}{l}\text { Dry in } 20 \text { hours } \\
\text { Fuel temperature }<115^{\circ} \mathrm{C} \text { forever }\end{array}$ \\
\hline \multicolumn{6}{|c|}{ YI CYOF SAFETY ANAYYSIS REPORT YASES } \\
\hline 38 & DSLOCSA4 & $\begin{array}{l}\text { High-pressure thermal runaway } \\
\text { (drain intertupt and gas blockage) - } \\
\text { loss of coolant }\end{array}$ & $\begin{array}{l}\text { Water lost: air.at } \\
50^{\circ} \mathrm{C} \text { initially }\end{array}$ & $\begin{array}{l}1,600 \text { at } \\
32 \text { hours }\end{array}$ & $\begin{array}{l}\text { Gas pressure }=11.2 \mathrm{~atm} \text { in } 21+\text { hours } \\
\text { Fuel temperature }>1000^{\circ} \mathrm{C} \text { in } 32 \text { hours, } 22 \mathrm{~kg} \text { of } \mathrm{UO}_{2} \\
\text { generated in } 21 \text { hours after loss of coolant }\end{array}$ \\
\hline 39 & BLOW4N & $\begin{array}{l}\text { Blowdown of high-pressure thermal } \\
\text { runaway at } 11.2 \mathrm{~atm}\left(150 \mathrm{lb} / \mathrm{in}^{2}\right. \\
\text { gauge) }\end{array}$ & $\begin{array}{l}\text { Air at } 64^{\circ} \mathrm{C} \text { initially } \\
\text { at restart at } 21 \text { hours }\end{array}$ & $\begin{array}{l}35,800 \text { at } \\
36 \text { hours }\end{array}$ & $\begin{array}{l}\text { Fuel temperature }>1000^{\circ} \mathrm{C} \text { in } 36 \text { hours, } \sim 250 \mathrm{~kg} \text { of } \\
\mathrm{UO}_{2} \text { generated in } 24 \text { hours after rupture disk opens }\end{array}$ \\
\hline 40 & DSSA4REC & $\begin{array}{l}\text { Recovery of high-pressure thermal } \\
\text { runaway - stationary annulus water }\end{array}$ & $\begin{array}{c}25^{\circ} \mathrm{C} \text { and not } \\
\text { flowing at restart at } \\
21 \text { hours }\end{array}$ & 6.2 at 21 hours & $\begin{array}{l}\text { Stationary annulus recovery delays blowdown release } \\
8 \text { hours and keeps fuel temperature }<100^{\circ} \mathrm{C} \text { forever }\end{array}$ \\
\hline 41 & BLOWREOV & $\begin{array}{l}\text { Recovery of low-pressure thermal } \\
\text { runaway after blowdown occurs }\end{array}$ & $\begin{array}{l}25^{\circ} \mathrm{C} \text { and not } \\
\text { flowing at } 21 \text { hours }\end{array}$ & $\begin{array}{l}1,000 \text { at } \\
22 \text { hours }\end{array}$ & $\begin{array}{l}\text { Stationary annulus water keeps fuel temperatures } \\
<100^{\circ} \mathrm{C} \text { after blowdown }\end{array}$ \\
\hline 42 & DSLOCOV2 & $\begin{array}{l}\text { Low-pressure thermal runaway } \\
\text { (drain interrupt with loss of coolant } \\
\text { and open vent) }\end{array}$ & $\begin{array}{l}\text { Annulus water lost: } \\
\text { air at } 50^{\circ} \mathrm{C} \text { initially }\end{array}$ & $\begin{array}{l}35,600 \text { at } \\
37+\text { hours }\end{array}$ & Fuel temperature $>1000^{\circ} \mathrm{C}$ in $37+$ hours \\
\hline
\end{tabular}

$\mathrm{CSB}=$ Canister Storage Building. $\mathrm{CVDF}=$ Cold Vacuum Drying Facility. $\mathrm{MCO}=$ multi-canister overpack 
Case 42 (DSLOCOV2) is the last case included in this report. This case is the same as case 25 (DSLOCOV), except that the free residual water is $35.5 \mathrm{~kg}$ instead of $26.5 \mathrm{~kg}$. Both cases look at the thermal behavior of an open MCO (not isolated and no vacuum or purge processes) with a loss of coolant condition. As expected, the fuel temperatures in case 42 (DSLOCOV2) are unstable and are greater than $1,000^{\circ} \mathrm{C}$ in a little more than 37 hours after the loss of coolant condition. The fuel temperatures are larger than those in case 25 (DSLOCOV) because more free water is available for the fuel-water reactions (see Appendix A, Figures A-42 and $\mathrm{A}-25$ ).

\subsection{CONCLUSIONS}

The following conclusions, which are also presented in the Executive Summary, can be drawn from the thermal analysis.

1. Vacuum drying is inherently stable. Vacuum drying with no helium purge is inherently stable forever for all annulus water conditions including the hot $\left(85^{\circ} \mathrm{C}\right)$ annulus water and loss of coolant (annulus water) cases. Radiative heat transfer is sufficient under vacuum to remove enough heat to maintain stable fuel temperatures. Even for air ingress scenarios, the fuel temperatures are stable under vacuum except for the hot annulus water and loss of coolant cases. However, even for these major failures of the tempered water (annulus) system, the fuel temperatures are stable for more than 2 days. Vacuum drying is the most inherently stable physical process occurring at the Cold Vacuum Drying Facility.

2. Helium purge is stable under normal conditions. The helium purge only (i.e., no vacuum) process has stable temperatures for the normal $\left(50^{\circ} \mathrm{C}\right)$ annulus water and loss of annulus water flow cases, but it is not stable for the hot annulus water and loss of coolant cases. The helium purge only process is not stable for air ingress cases with bounding hydrides, which have unstable scrap fuel temperatures in less than 2 hours primarily because of the large bounding hydride mass.

3. Open MCOs are stable under most conditions. An open $M C O$ with no vacuum and no helium purge is stable forever for the normal annulus water and loss of annulus water flow cases, but it is very unstable (fuel temperature $>1,000^{\circ} \mathrm{C}$ ) for the hot annulus water and loss of coolant cases after 30 hours if enough residual water is available.

4. Closed MCOs with bounding parameter values take a long time to pressurize under most conditions. A closed (isolated) MCO will pressurize and eventually reach the rupture disk burst pressure for all annulus water conditions, but reaching the rupture disk burst pressure will take 3 days for the normal $\left(50^{\circ} \mathrm{C}\right)$ annulus water case and 6 days for the loss of annulus water flow case (stationary annulus water is 
cooler than $50^{\circ} \mathrm{C}$ because of the lower room temperature of the process bay and the good thermal conductivity of water). If no rupture disk were used, very high fuel temperatures $\left(>900^{\circ} \mathrm{C}\right.$ ) would result for the hot annulus water and loss of coolant cases after 30 hours if enough residual water were available.

5. Closed MCOs with nominal parameter values are inherently stable. A closed MCO with nominal parameter values for decay heat, chemical reaction rates, and reaction surface area pressurizes very slowly for the loss of coolant case. The MCO gas pressure and the temperatures in the bottom fuel basket are shown in Appendix A, Figure A-22 for both the bounding MCO and nominal MCO under loss of coolant conditions (with no rupture disk included): Clearly, even under loss of coolant conditions, the nominal MCO does not heat up or pressurize very much in 2 days, whereas the bounding $\mathrm{MCO}$ reaches very high pressures and temperatures in less than 2 days.

6. Introducing water into the annulus can prevent bursting of the rupture disk. For the bounding $\mathrm{MCO}$ under loss of coolant conditions, the MCO pressurization can be stopped very quickly (less than 60 seconds) by introducing $25^{\circ} \mathrm{C}$ water into the annulus. The cool water injected into the annulus cools the stainless steel MCO wall and bottom very quickly, and the water vapor inside the MCO starts to condense on the cooler MCO wall and bottom immediately. The condensation of water vapor lowers the gas pressure immediately and prevents the pressure from reaching the rupture disk burst pressure, as shown in Appendix A, Figure A-23. Figure A-23 also shows that the inner fuel element temperature does not decrease immediately; it takes about 2 hours to show a significant decrease in temperature. Nevertheless, the water vapor condensing on the cooler $\mathrm{MCO}$ wall and bottom keeps the MCO pressure below the rupture disk burst pressure for as long as 8 hours if the annulus water is stationary and more than 24 hours if the annulus water is flowing. Furthermore, the MCO wall temperature is only about $85^{\circ} \mathrm{C}$ when the MCO pressure reaches rupture disk burst pressure, $11.2 \mathrm{~atm}\left(150 \mathrm{lb} / \mathrm{in}^{2}\right.$ gauge), so there is no danger of the water flashing or boiling when introduced into the annulus.

7. Favorable annulus water conditions promote stability for all operating conditions. The normal annulus water condition $\left(50^{\circ} \mathrm{C}\right.$ and flowing) and the loss of annulus water flow condition result in stable temperatures forever for all normal and off-normal conditions analyzed. The loss of annulus water flow condition promotes lower fuel temperatures than the $50^{\circ} \mathrm{C}$ annulus water condition.

8. Scrap fuel is generally cooler than fuel elements. The scrap basket design with compartments created by copper fins is efficient for heat removal purposes. Most of the off-normal cases that resulted in high temperatures had higher fuel element temperatures than scrap fuel temperatures, except for the helium purge only off-normal cases. The helium purge only cases with unfavorable annulus conditions have high fuel-water (steam) reaction rates in the scrap fuel because water vapor is blown from the fuel baskets into the scrap basket, which has a high surface area to 


\section{HNF-SD-SNF-CN-023 REV 1}

volume ratio, causing the maximum scrap fuel temperature to be greater than the maximum fuel element temperature. Also, the latest scrap basket design (Smith 1998), which does not have copper fin spokes in the fine scrap portion, causes even higher scrap temperatures for off-normal helium purge only cases than the design used in the previous thermal analysis (Duncan and Ball 1997), which included copper fin spokes in the fine scrap portion.

In summary, the results of this analysis show that the bounding MCO has stable temperatures for all cold vacuum drying processes after draining if the annulus water is kept at $50^{\circ} \mathrm{C}$ or cooler by the tempered water (annulus) system, or if the annulus water is stationary (not flowing). Air ingress with bounding hydride loadings $(9.0 \mathrm{~kg})$ in the scrap fuel results in unstable scrap fuel temperatures for the helium purge only process but not for the vacuum only process unless the TWS has major failures lasting for more than 2 days.

\subsection{REFERENCES}

Baker, M., L. N. Less, and S. Orman, 1966, Uranium Computability Studies Part 6: The Products and Mechanisms of the Uranium-Water and Uranium Hydride-Water Reaction, AWRE-O-45/65, Atomic Weapons Research Establishment, Aldermaston, Berkshire, England.

Crowe, R. D., S. D. Kopelic, M. G. Piepho, P. D. Rittmann, D. L. Scott, and W. T. Watson, 1998, Cold Vacuum Drying Facility Design Basis Accident Analysis Documentation, SNF-2770, Rev. 0, Fluor Daniel Hanford, Incorporated, Richland, Washington.

Duncan, D. R., and D. E. Ball, 1997, Thermal Analysis of Cold Vacuum Drying of Spent Nuclear Fuel, HNF-SD-SNF-CN-023, Rev. 0A, Fluor Daniel Hanford, Incorporated, Richland, Washington.

Holden, A. N., 1958, Physical Metallurgy of Uranium, Addison-Wesley Publishing Company, Reading, Massachusetts.

Irwin, J. J., C. R. Miska, C. C. Pitkoff, and R. Whitehurst, 1998, Spent Nuclear Fuel Project Cold Vacuum Drying Facility Operations Mamual, SNF-2356, Rev. OA, Fluor Daniel Hanford Incorporated, Richland, Washington.

Kessler, S., and S. Peck 1998, Criticality Safety Evaluation Report for the $K$ Basin Fuel Retrieval Subproject, HNF-SD-SNF-CSER-010, Rev. 0, Fluor Daniel Hanford, Incorporated, Richland, Washington.

ORNL, 1987, Nuclear Systems Material Handbook, Volume 1, "Design Data," TDD 26666, Oak Ridge National Laboratory, Oak Ridge, Tennessee. 
Pajunen, A. L., 1998a, Cold Vacuum Drying Residual Free Water Test Description, HNF-1851, Rev, 1, Fluor Daniel Hanford, Incorporated, Richland, Washington.

Pajunen, A. L., 1998b, Design Basis for Hydrogen Generation in the Cold Vacuum Drying Facility, HNF-2458, Rev. OA, Fluor Daniel Hanford, Incorporated, Richland, Washington.

Pearce, R. J., 1989, A Review of the Rates of Reaction of Unirradiated Uranium in Gaseous Atmospheres, RD/B/6231/R89, Central Electricity Generating Board, Berkeley Nuclear Laboratories.

Pili-Vincens, C., 1998, Safety Analysis Report for the Cold Vacuum Drying Facility, Phase 2, Supporting Installation of Processing Systems, HNF-SD-SNF-SAR-002, Rev. 4, Fluor Daniel Hanford, Incorporated, Richland, Washington.

Plys, M. G., and D. R. Duncan, 1998, Simulation of Normal and Off-Normal Multi-Canister Overpack Behavior, HNF-2256, Rev. 1, Fluor Daniel Hanford, Incorporated, Richland, Washington.

Plys, M. G., S. J. Lee, and M. Epstein, 1997, Application of N-Reactor Fuel Oxidation Data to Simulation of Air Ingress into a Multi-Canister Overpack, FAI/97-138, Fauske \& Associates, Inc., Burr Ridge, Illinois.

Plys, M. G., S. J. Lee, B. Malinovic, and M. Epstein, 1998, Hanford Spent Nuclear Fuel Safety Analysis Model HANSF 1.2: User's Manual, FAI/98-40, Rev. 0, Fauske \& Associates, Incorporated, Burr Ridge, Illinois.

Reilly, M. A., 1998, Spent Nuclear Fuel Project Technical Databook, HNF-SD-SNF-TI-015, Rev. 4, Fluor Daniel Hanford, Incorporated, Richland, Washington.

Scott, D. B., 1965, Physical and Mechanical Properties of Zircaloy-2 and 4, WCAP-3269-4I, Westinghouse Electric Corporation, Pittsburgh, Pennsylvania.

Smith, K. E., 1998, Multi-Canister Overpack Design Report, HNF-SD-SNF-DR-003, Rev. 1, Fluor Daniel Hanford, Incorporated, Richland, Washington. 


\section{HNF-SD-SNF-CN-023 REV 1}

This page intentionally left blank. 
HNF-SD-SNF-CN-023 REV 1

APPENDIX A

HANSF OUTPUT PLOTS 


\section{HNF-SD-SNF-CN-023 REV 1}

This page intentionally left blank. 


\section{HNF-SD-SNF-CN-023 REV 1}

\section{TABLE OF FIGURES}

A-1 VACUUM: Indefinite Vacuum with $50^{\circ} \mathrm{C}$ Annulus

A-2 VAC75KG: Indefinite Vacuum with $75 \mathrm{Kg}$ Water and $50^{\circ} \mathrm{C}$ Annulus $\ldots \ldots \ldots \mathrm{A}-13$

A-3 VACPUR: $\quad$ Vacuum with Helium Purge with $50^{\circ} \mathrm{C}$ Annulus . . . . . . . . . A-19

A-4 PURGE: $\quad$ Helium Purge with $50^{\circ} \mathrm{C}$ Annulus Water $\ldots \ldots \ldots \ldots \ldots \ldots$ A-25

A-5 VACHOT: Indefinite Vacuum with $85^{\circ} \mathrm{C}$ Annulus . . . . . . . . . . A-31

A-6 VPURHOT: Vacuum with Helium Purge with $85^{\circ} \mathrm{C}$ Annulus . . . . . . . . A-37

A-7 PURHOT: $\quad$ Helium Purge with $85^{\circ} \mathrm{C}$ Annulus Water $\ldots \ldots \ldots \ldots \ldots \ldots$. . . . . .

A-8 VACLOF: Indefinite Vacuum with Loss of Flow in Annulus . . . . . . . . . . A-49

A-9 VLOFHOT: Vacuum with Loss of Flow in Annulus at $85^{\circ} \mathrm{C} \ldots \ldots \ldots \ldots$

A-10 VACLOC: Indefinite Vacuum with Loss of Coolant in Annulus . . . . . . . . A-61

A-11 VPURLOC: Vacuum and Helium Purge with Loss of Coolant . . . . . . . . . A-67

A-12 PURLOF: : Helium Purge with Loss of Flow in Annulus . . . . . . . . . A-73

A-13 PURLOC: Helium Purge with Loss of Coolant - Annulus Water . . . . . . . A-79

A-14 DSTOP: $\quad$ High-Pressure Thermal Runaway with $50^{\circ} \mathrm{C}$ Annulus $\ldots \ldots \ldots$ A-85

A-15 DS75KG: $\quad$ High-Pressure Thermal Runaway with $75 \mathrm{Kg}$ Water and $50^{\circ} \mathrm{C}$

Annulus . . . . . . . . . . . . . .

A-16 DSTOPOV: Low-Pressure Thermal Runaway with $50^{\circ} \mathrm{C}$ Annulus ...... . . A A-97

A-17 DSLOF: High-Pressure Thermal Runaway with Loss of Flow in Annulus . A-103

A-18 DLOF75KG; High-Pressure Thermal Runaway with $75 \mathrm{Kg}$ Water and Loss of Flow in Annulus . . . . . . . . . . . . . . . . . A-109

A-19 DSLOFOV: Low-Pressure Thermal Runaway with Loss of Flow in Annulus . . A-115

A-20 DSLOC: $\quad$ High-Pressure Thermal Runaway with Loss of Coolant $\ldots \ldots \ldots$ A-121 


\section{HNF-SD-SNF-CN-023 REV 1}

\section{TABLE OF FIGURES (CONTINUED)}

A-21 DLOC75KG: High-Pressure Thermal Runaway with $75 \mathrm{Kg}$ Water and Loss of Coolant .............................. A-127

A-22 DSLOCNOM: High-Pressure Thermal Runaway with Nominal and Bounding Parameters and Loss of Coolant . . . . . . . . . . . . . . . . . . A-133

A-23 DSLOCREC: High-Pressure Thermal Runaway with Loss of Coolant and Recovery at 21 Hours $\ldots \ldots \ldots \ldots \ldots \ldots \ldots \ldots \ldots$. A-139

A-24 DSLOCRE2: High-Pressure Thermal Runaway with Loss of Coolant and Stationary Annulus Recovery at 21 Hours . . . . . . . . A 145

A-25 DSLOCOV: Low-Pressure Thermal Runaway with Loss of Coolant -

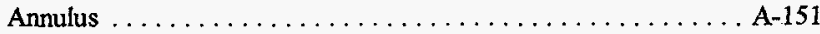

A-26 DS46DEG: High-Pressure Thermal Runaway with $46^{\circ} \mathrm{C}$ Annulus $\ldots \ldots \ldots$ A-157

A-27 DS55DEG: High-Pressure Thermal Runaway with $55^{\circ} \mathrm{C}$ Annulus . . . . . A-163

A-28 DS75DEG: High-Pressure Thermal Runaway with $75^{\circ} \mathrm{C}$ Annulus . . . . . . A A-169

A-29 DSHOT: High-Pressure Thermal Runaway with $85^{\circ} \mathrm{C}$ Annulus $\ldots \ldots \ldots$ A-175

A-30 DHOT75KG: High-Pressure Thermal Runaway with $75 \mathrm{Kg}$ Water and $85^{\circ} \mathrm{C}$ Annulus . . . . . . . . . . . . . . . . . . . . . .

A-31 DSHOTOV: Low-Pressure Thermal Runaway with $85^{\circ} \mathrm{C}$ Annulus . . . . . . . A-187

A-32 VACAIRI: Indefinite Vacuum with Air Ingress and $50^{\circ} \mathrm{C}$ Annulus $\ldots \ldots \ldots$ A-193

A-33 VAIRIHOT: Indefinite Vacuum with Air Ingress and $85^{\circ} \mathrm{C}$ Annulus . . . . . A-199

A-34 VAIRILOC: Indefinite Vacuum with Air Ingress and Loss of Coolant . . . . A A-205

A-35 PURAIRI: Indefinite Purge with Air Ingress and $50^{\circ} \mathrm{C}$ Annulus $\ldots \ldots \ldots$ A-211

A-36 PAIRIHOT: Helium Purge with Air Ingress and $85^{\circ} \mathrm{C}$ Annulus . . . . . . . A-217

A-37 VACAIRI2: Vacuum with No Hydrides, Air Ingress and $50{ }^{\circ} \mathrm{C}$ Annulus . . . A A-223

A-38 DSLOCSA4: High-Pressure Thermal Runaway with $35.5 \mathrm{Kg}$ Water and Loss of Coolant . . . . . . . . . . . . . . . . . . . . A-229 


\section{HNF-SD-SNF-CN-023 REV 1}

\section{TABLE OF FIGURES (CONTINUED)}

A-39 BLOW4N: High-Pressure Thermal Runaway Blowdown with Air Ingress . . A A-235

A-40 DSSA4REC: High-Pressure Thermal Runaway with Loss of Coolant, $35.5 \mathrm{Kg}$, and Recovery at 21 Hours ............. A-241

A-41 BLOWREOV; Blowdown with Stationary Annulus Recovery From Loss of Coolant at 1 Hour After Blowdown . . . . . . . . . . . . A-247

A-42 DSLOCOV2: Low-Pressure Thermal Runaway with 35.5 Kg Water, Loss of Coolant, and Open Vent . . . . . . . . . . . . . . 253 


\section{HNF-SD-SNF-CN-023 REV 1}

This page was intentionally left blank. 
HNF-SD-SNF-CN-023 REV 1

Figure A-1 VACUUM: Indefinite Vacuum with $50^{\circ} \mathrm{C}$ Annulus 


\section{HNF-SD-SNF-CN-023 REV 1}

This page intentionally left blank. 


\section{HNF-SD-SNF-CN-023 REV 1}
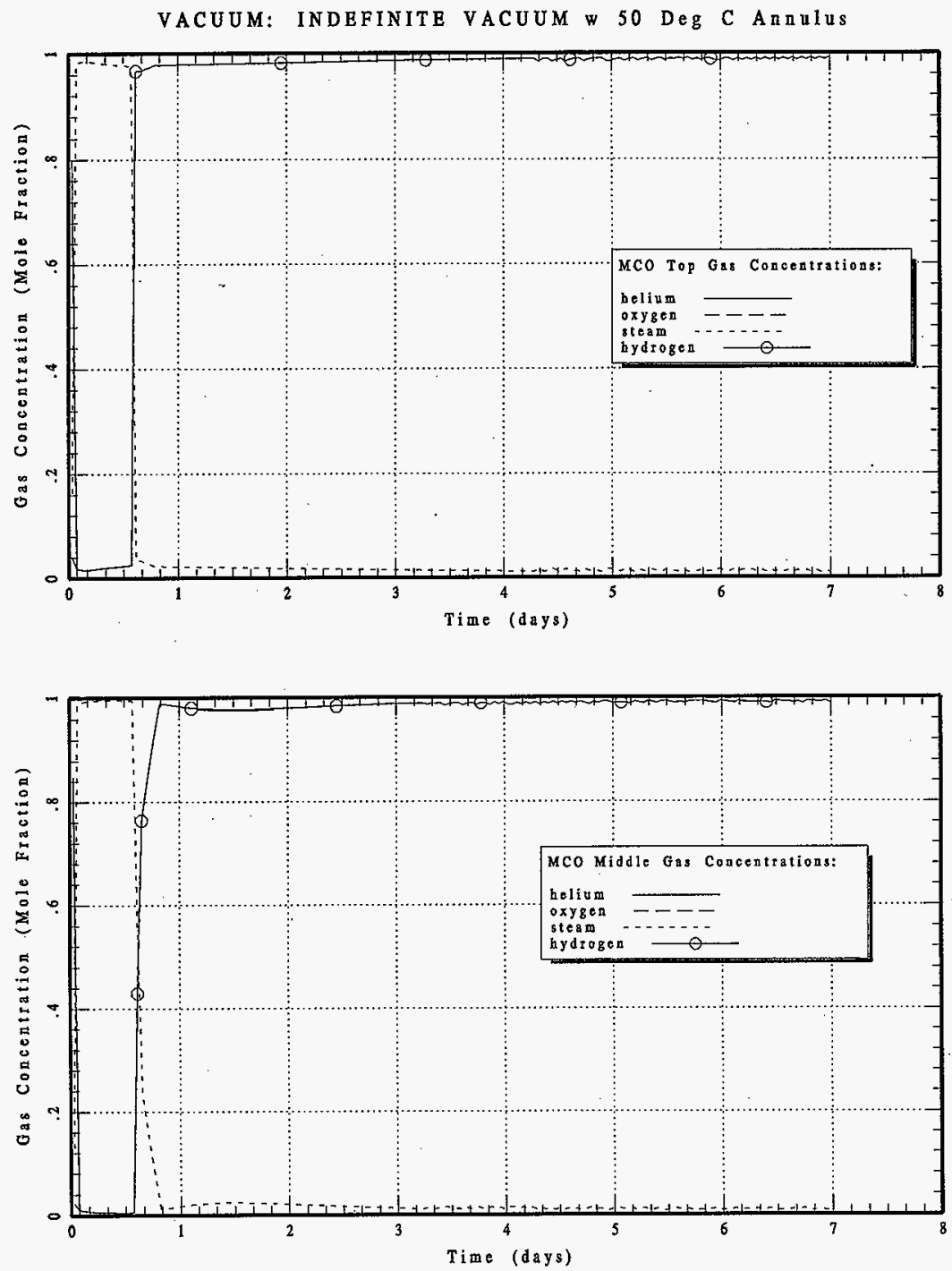
HNF-SD-SNF-CN-023 REV 1
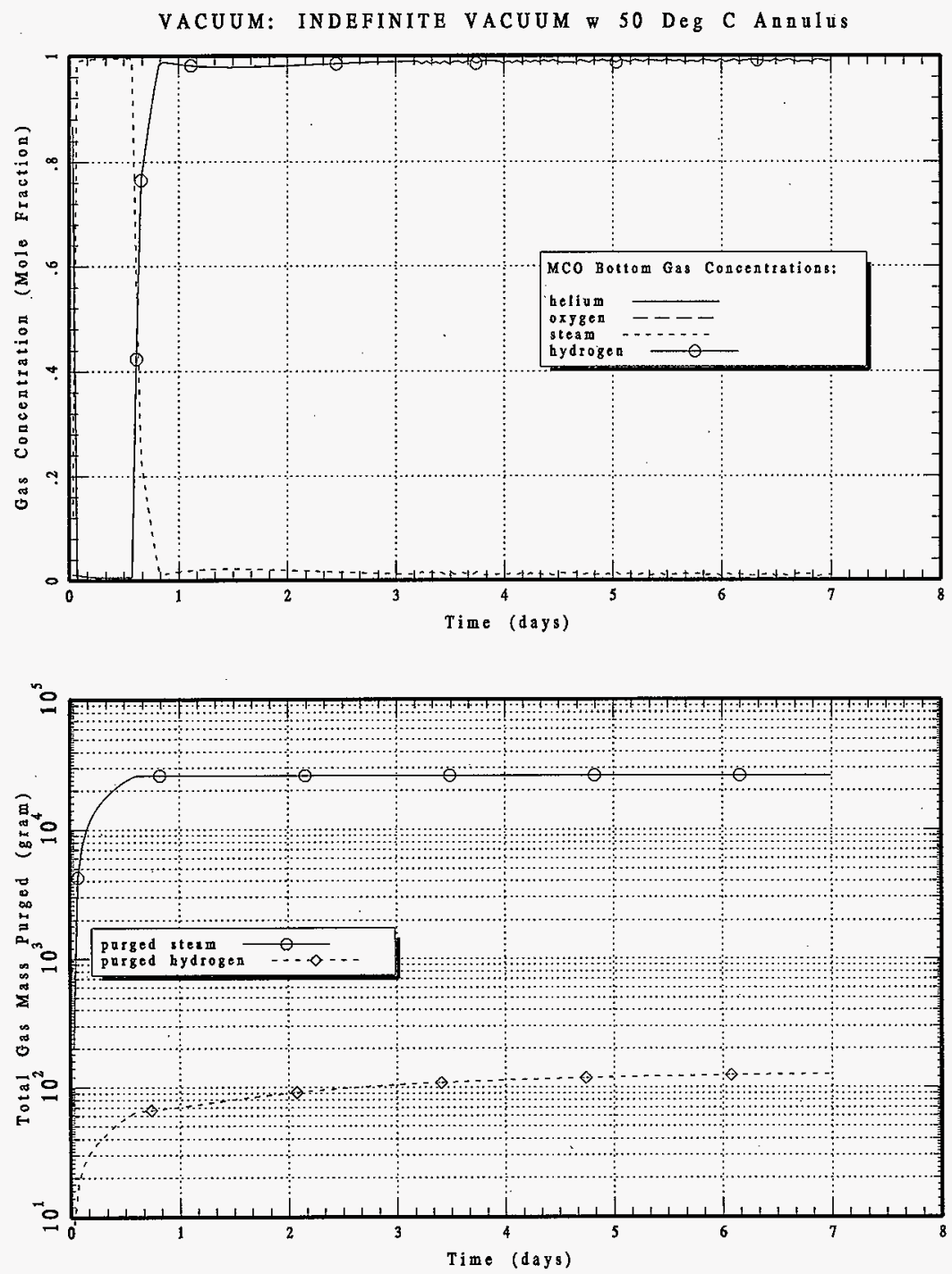


\section{HNF-SD-SNF-CN-023 REV 1}
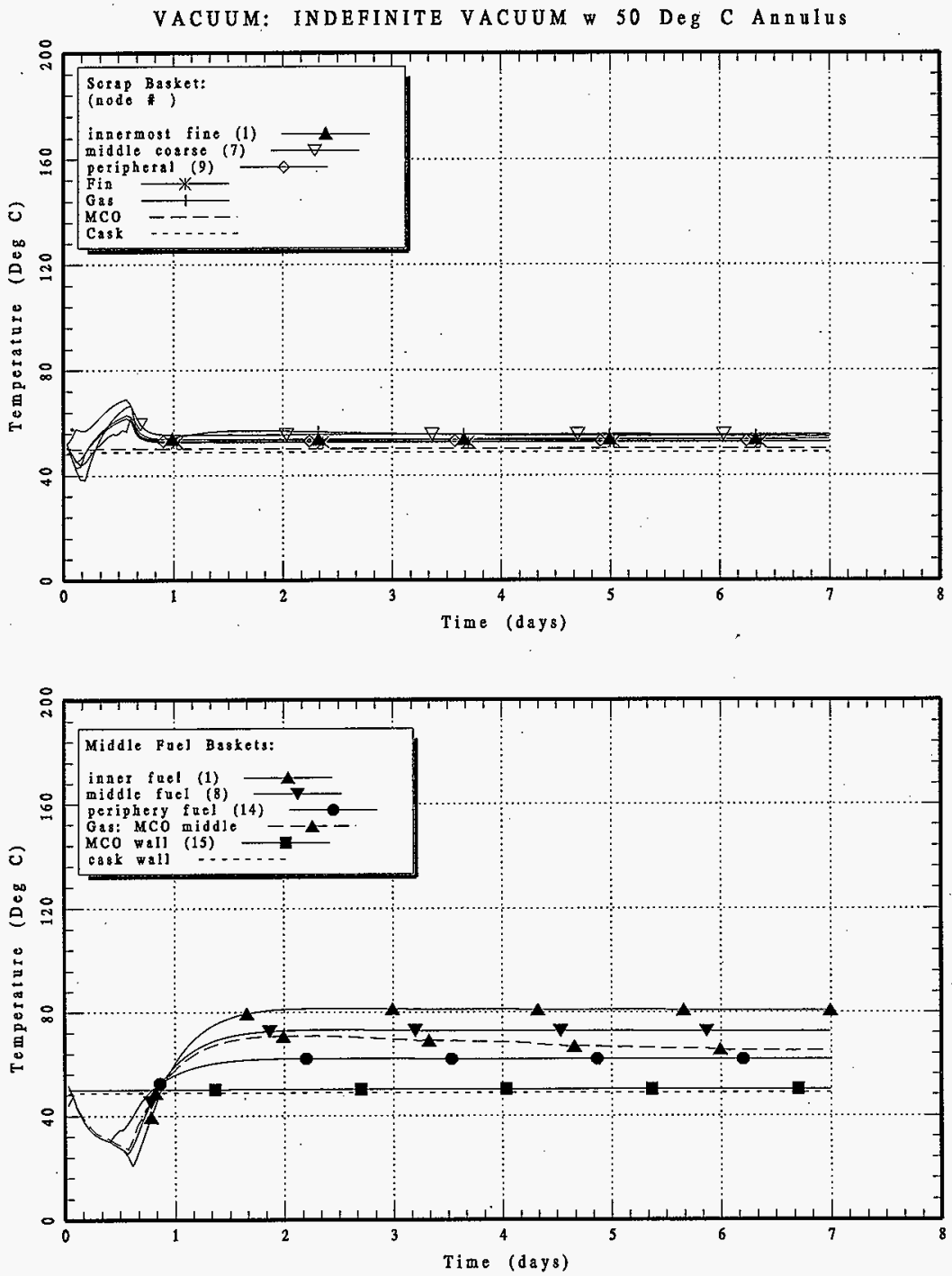
HNF-SD-SNF-CN-023 REV 1
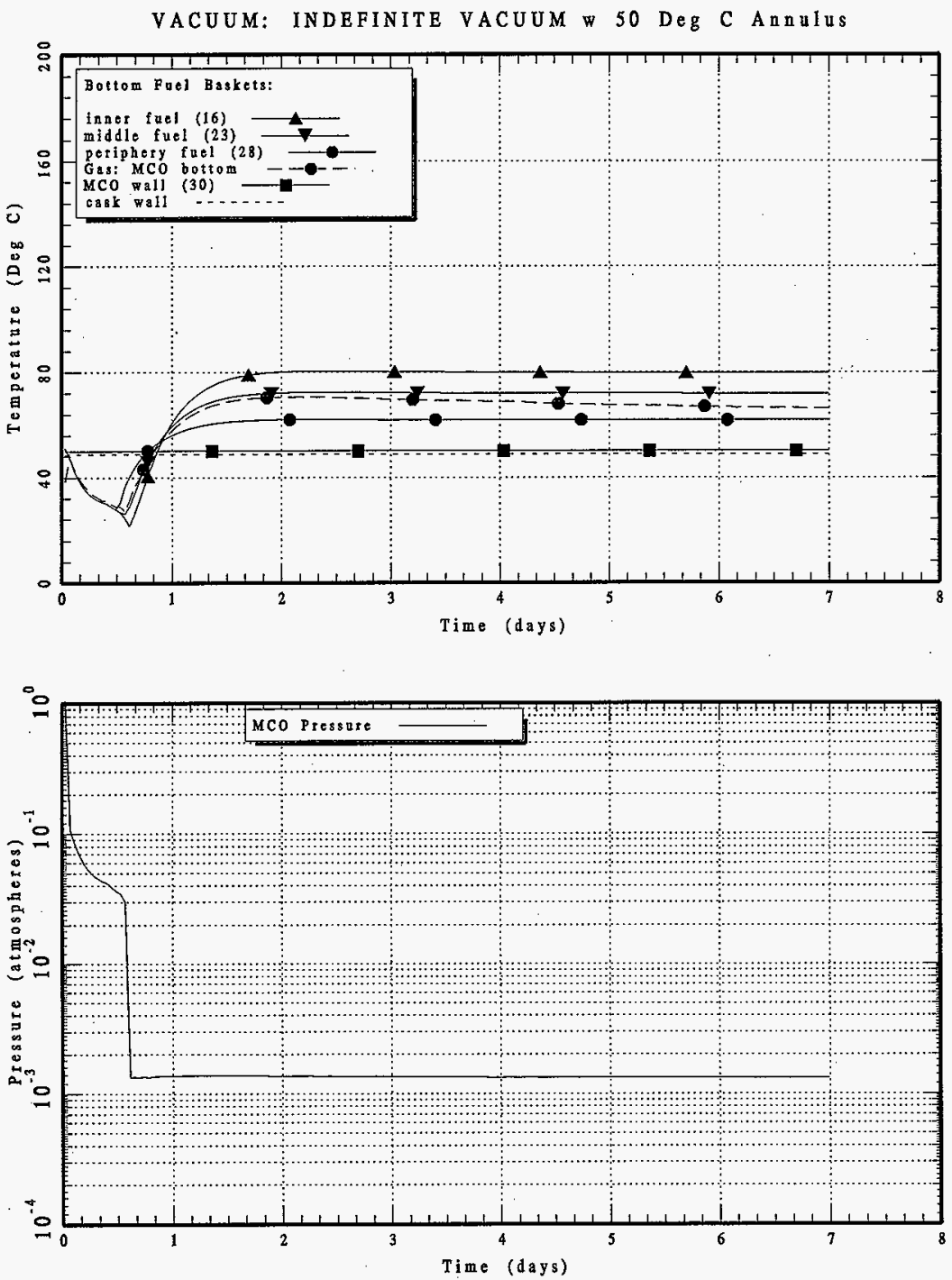


\section{HNF-SD-SNF-CN-023 REV 1}

Figure A-2 VAC75KG: Indefinite Vacuum with $75 \mathrm{Kg}$ Water and $50^{\circ} \mathrm{C}$ Annulus 


\section{HNF-SD-SNF-CN-023 REV 1}

This page intentionally left blank. 
HNF-SD-SNF-CN-023 REV 1

VAC75KG: INDEFINITE VACUUM W $75 \mathrm{Kg}$ Water \& 50 Deg C Annulus
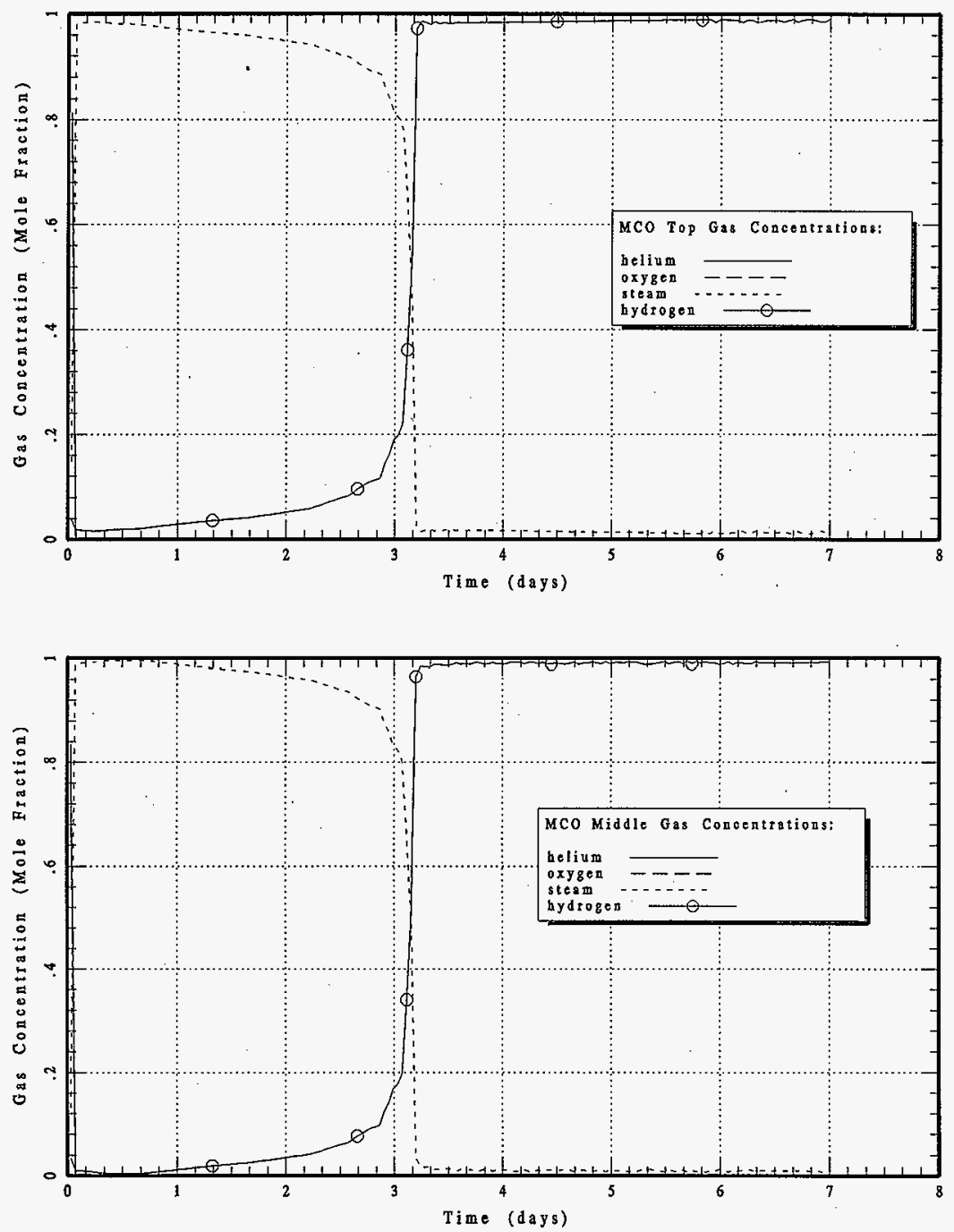
VAC75KG: INDEFINITE VACUUM w $75 \mathrm{Kg}$ Water \& 50 Deg C Annulus
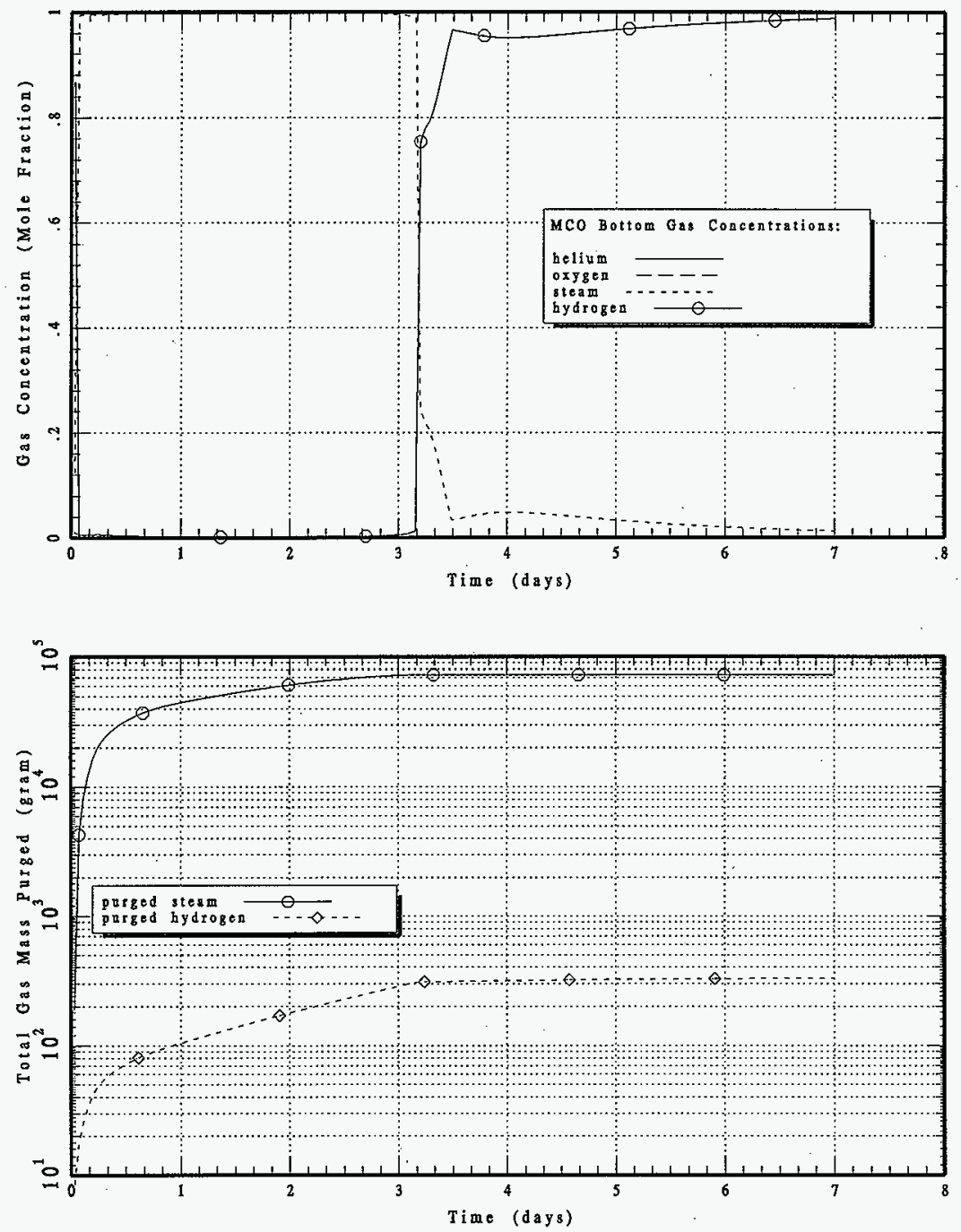

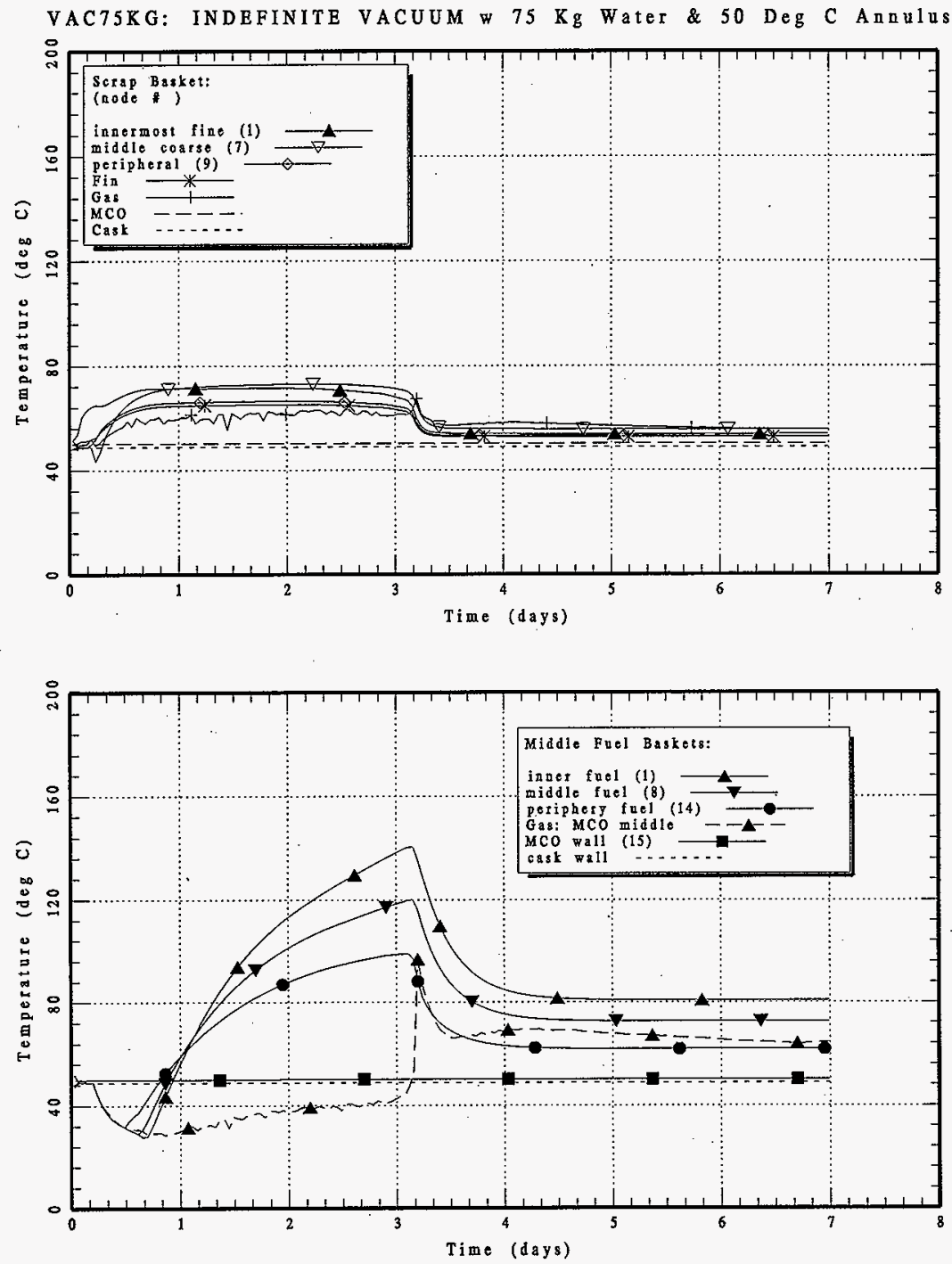


\section{HNF-SD-SNF-CN-023 REV 1}
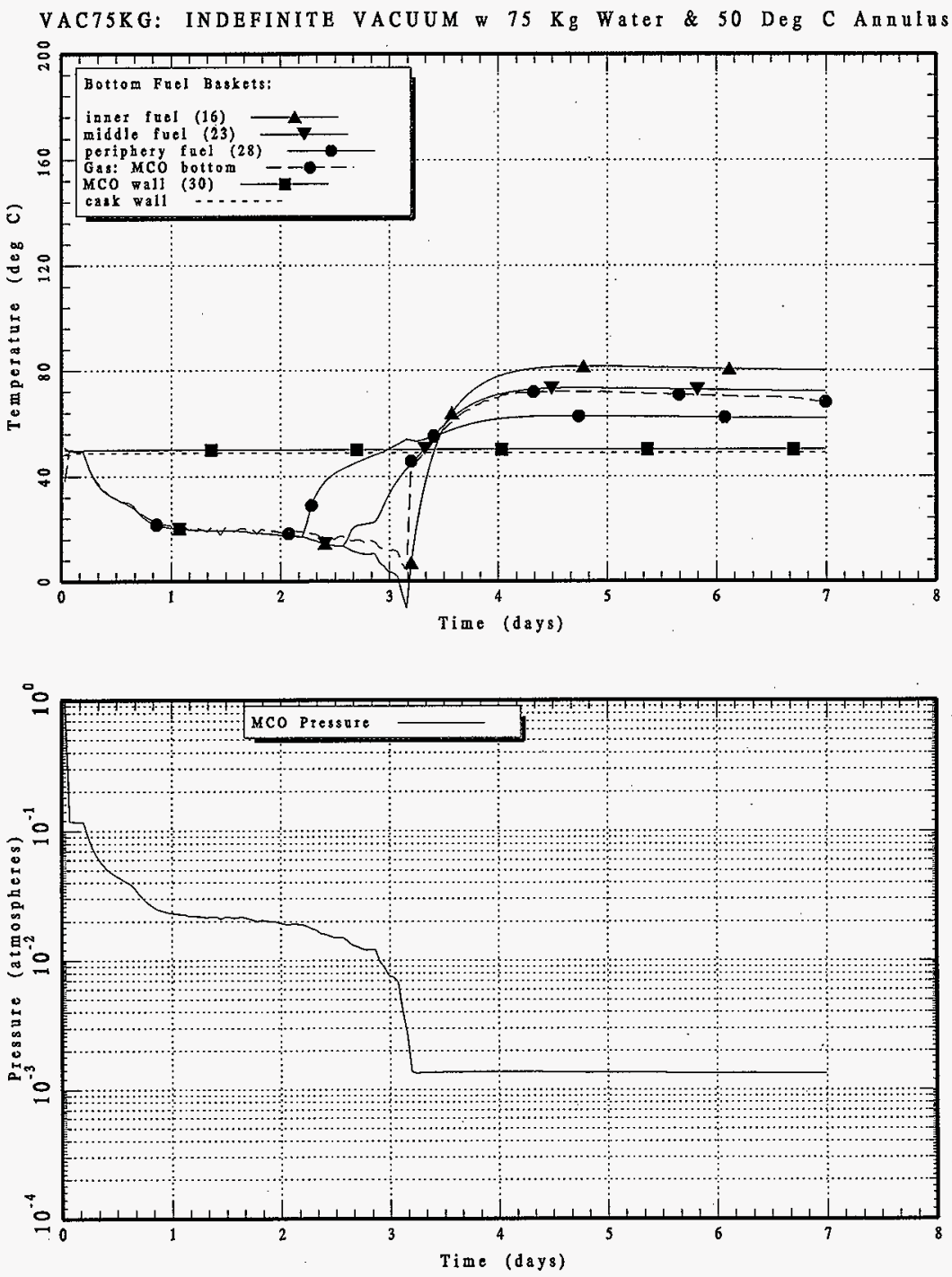


\section{HNF-SD-SNF-CN-023 REV 1}

Figure A-3 VACPUR: Vacuum with Helium Purge with $50^{\circ} \mathrm{C}$ Annulus 
HNF-SD-SNF-CN-023 REV 1

This page intentionally left blank. 


\section{HNF-SD-SNF-CN-023 REV 1}

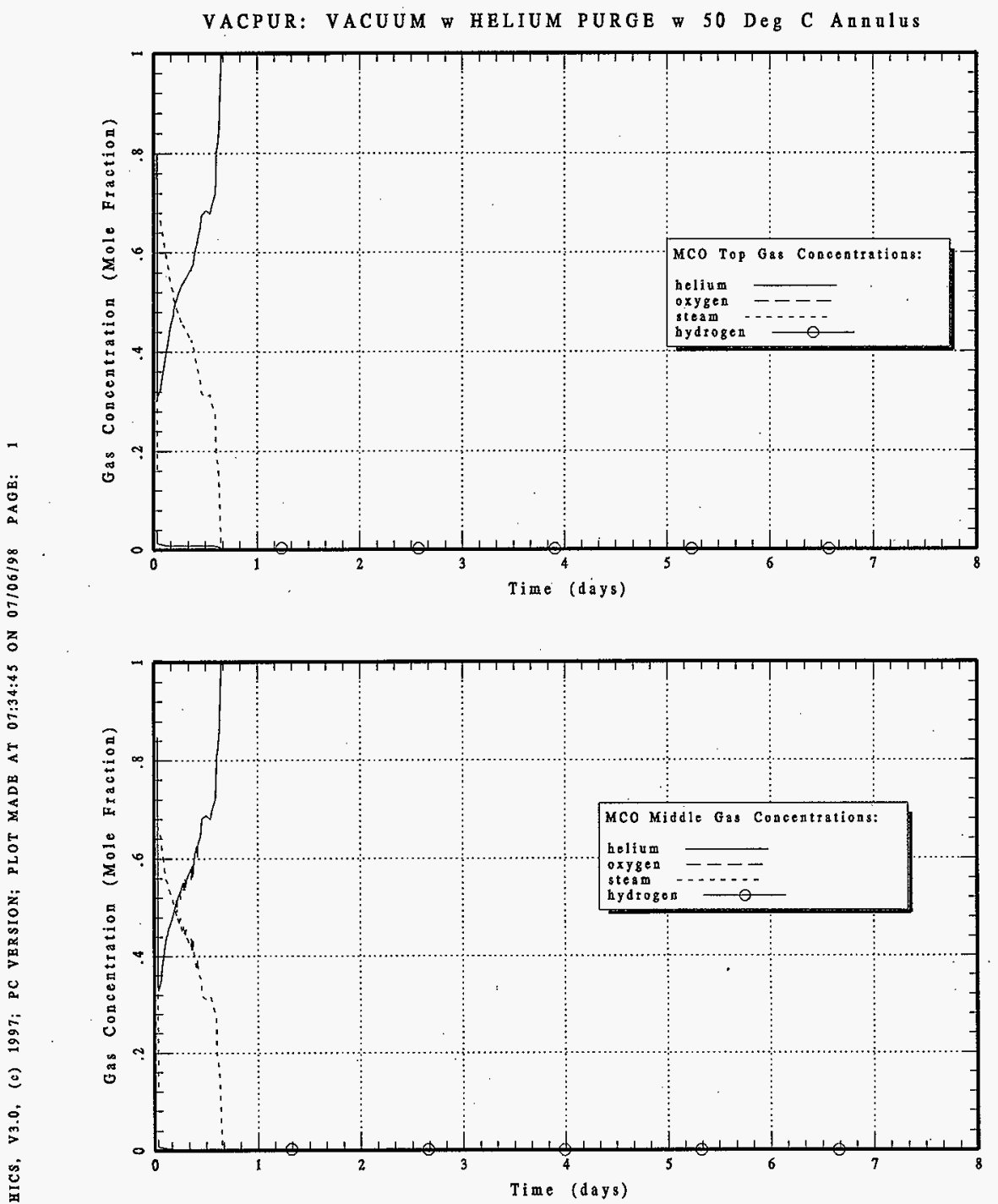


HNF-SD-SNF-CN-023 REV 1
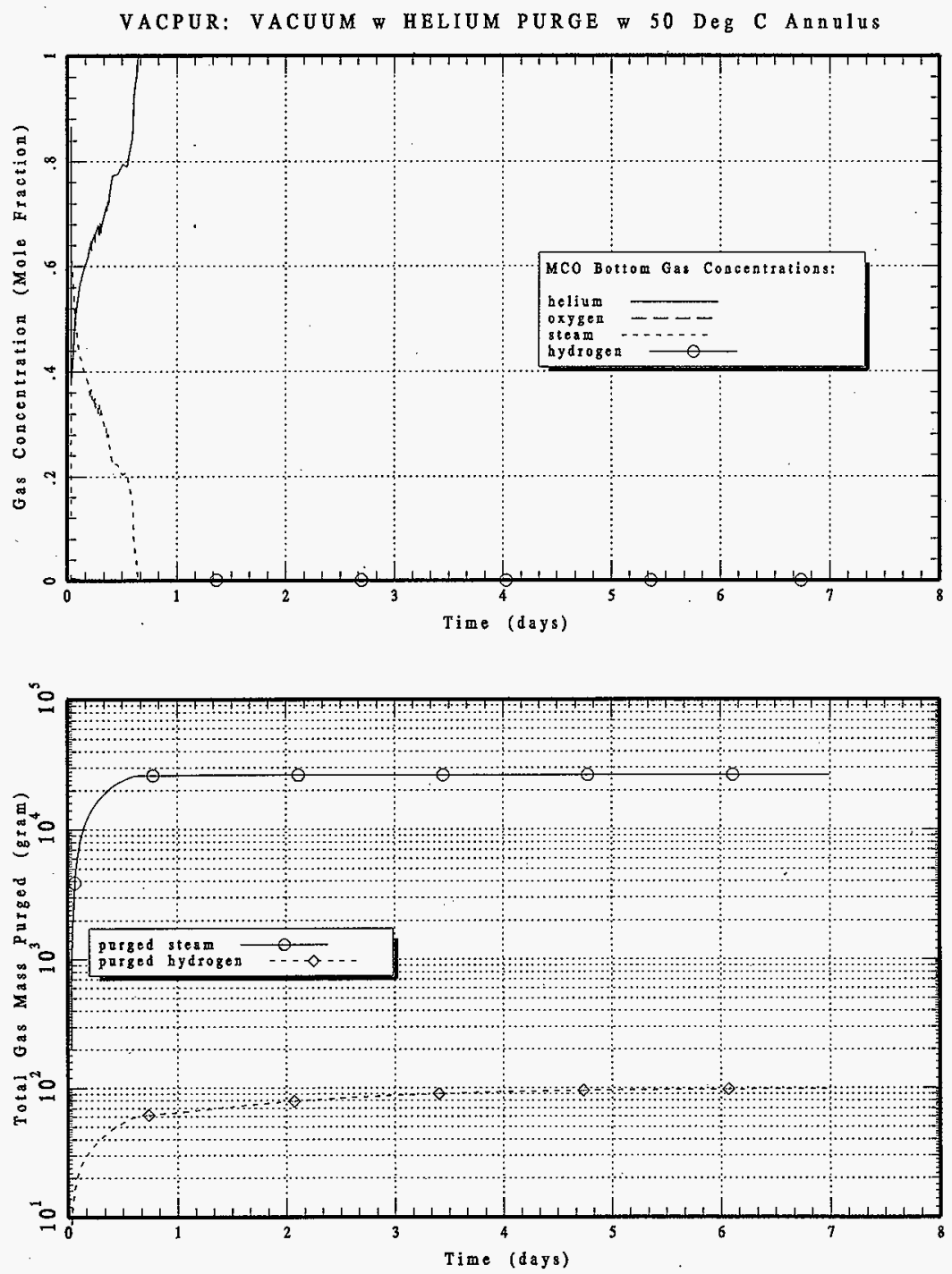


\section{HNF-SD-SNF-CN-023 REV 1}
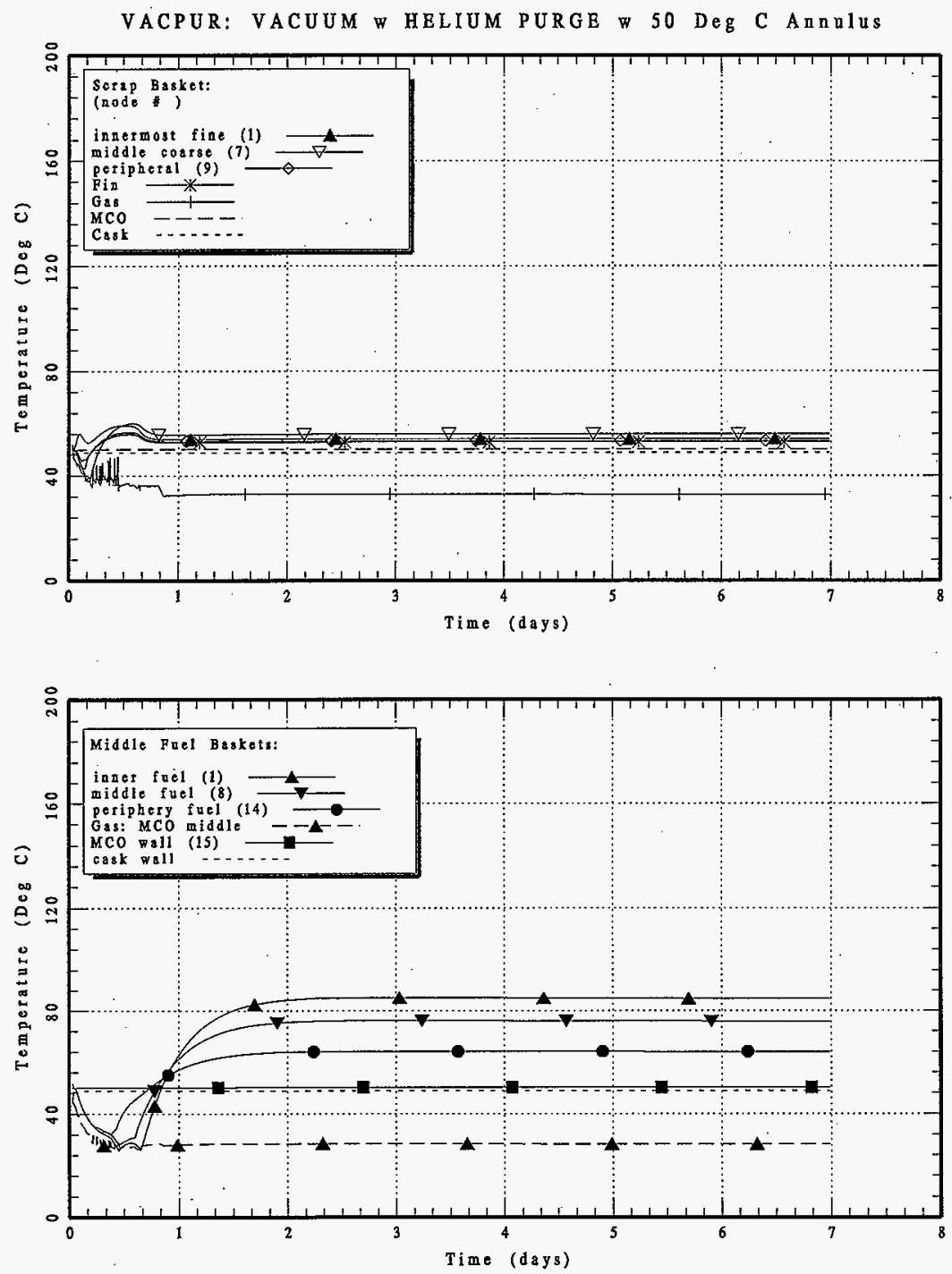


\section{HNF-SD-SNF-CN-023 REV I}
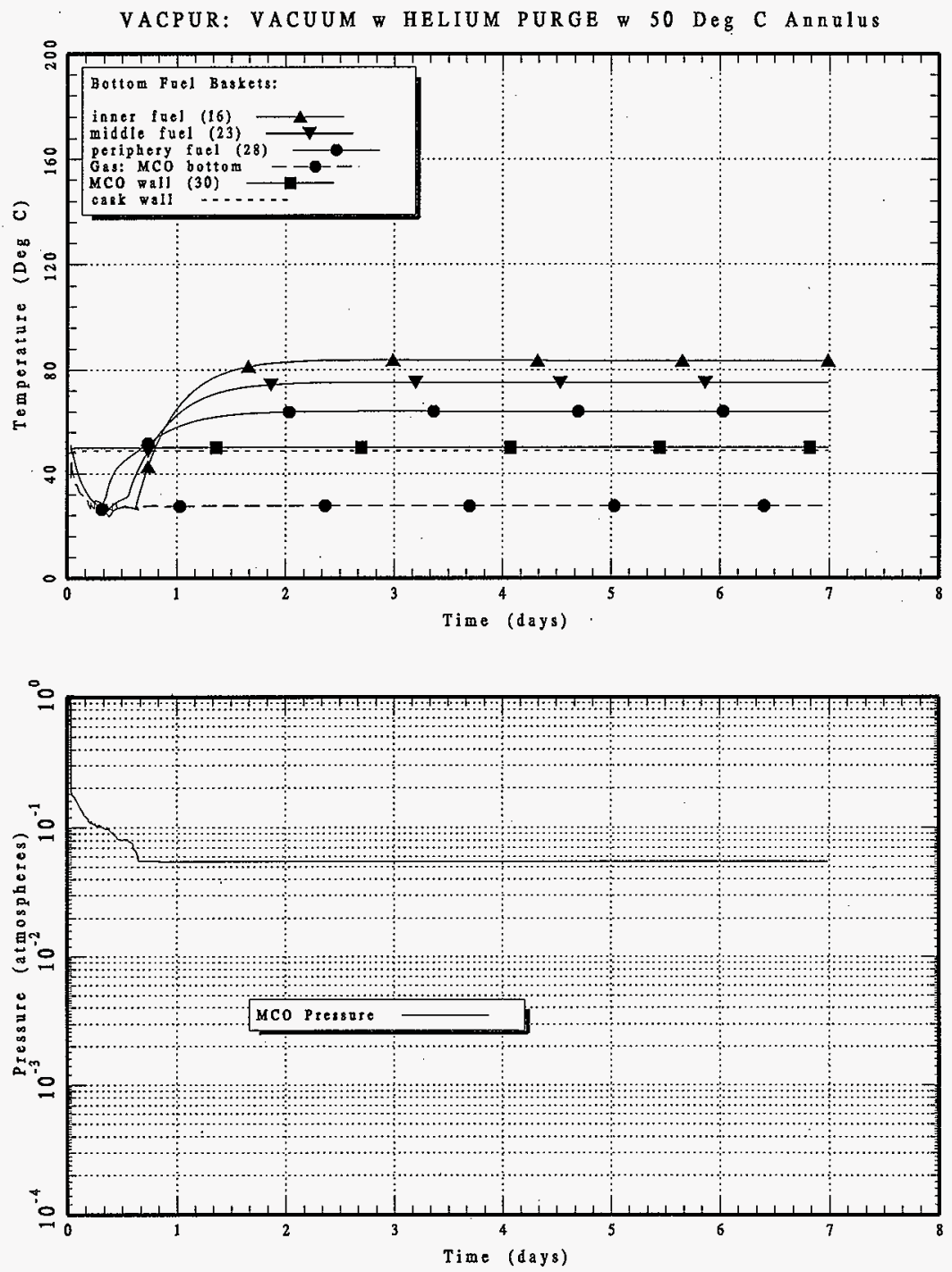


\section{HNF-SD-SNF-CN-023 REV 1}

Figure A-4 PURGE: Helium Purge with $50^{\circ} \mathrm{C}$ Annulus Water 


\section{HNF-SD-SNF-CN-023 REV 1}

This page intentionally left blank. 


\section{HNF-SD-SNF-CN-023 REV 1}
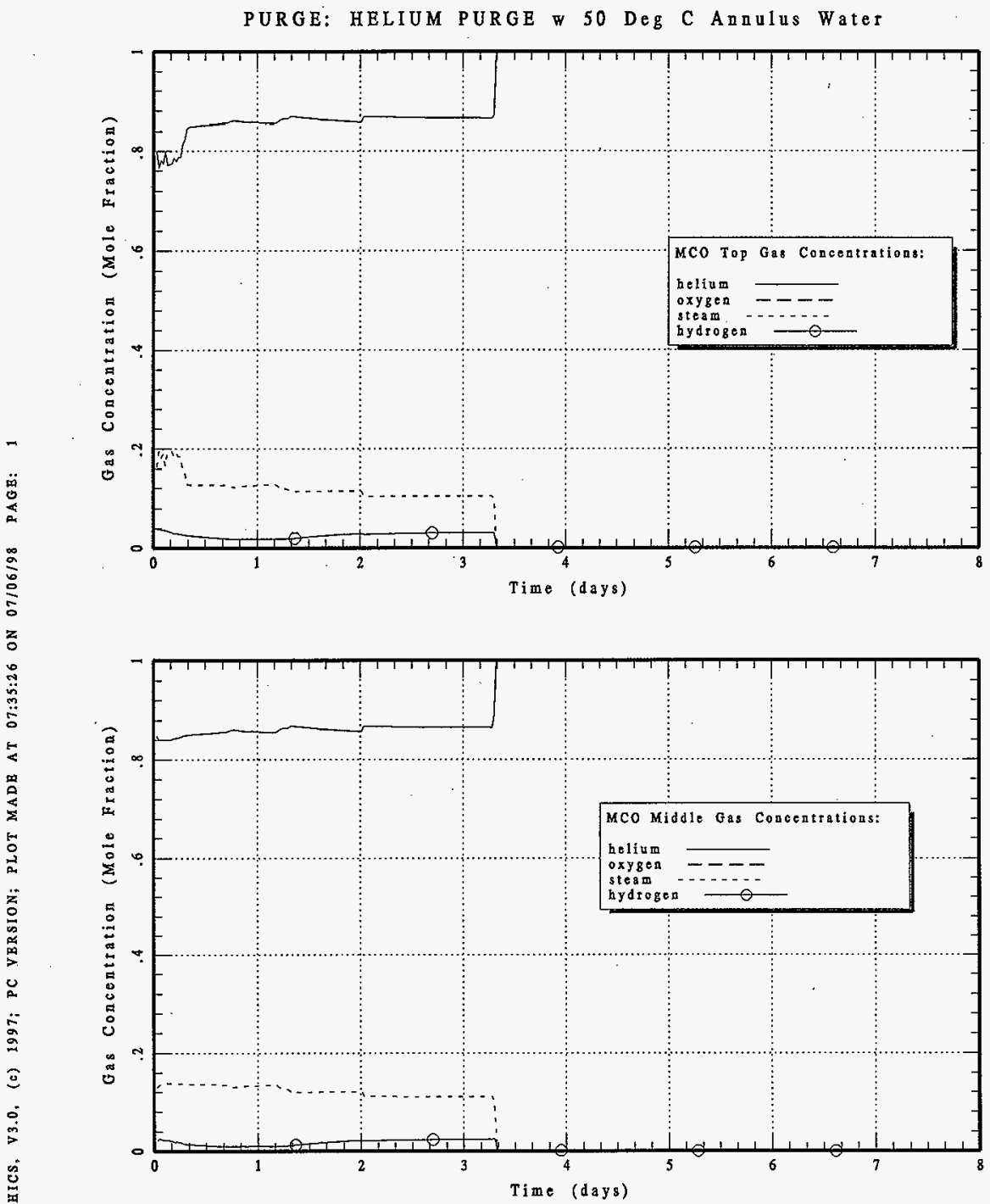


\section{HNF-SD-SNF-CN-023 REV 1}
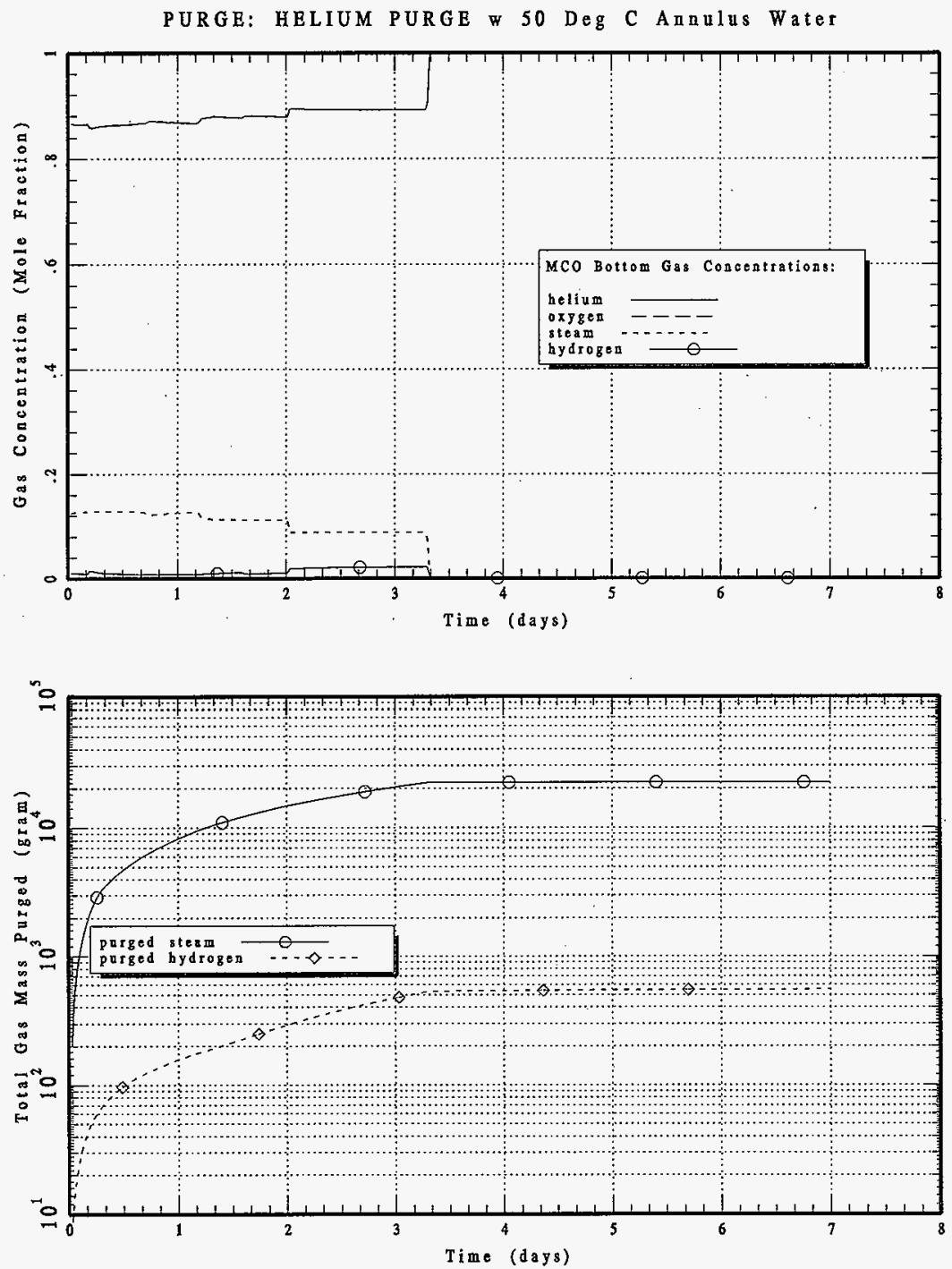


\section{HNF-SD-SNF-CN-023 REV 1}
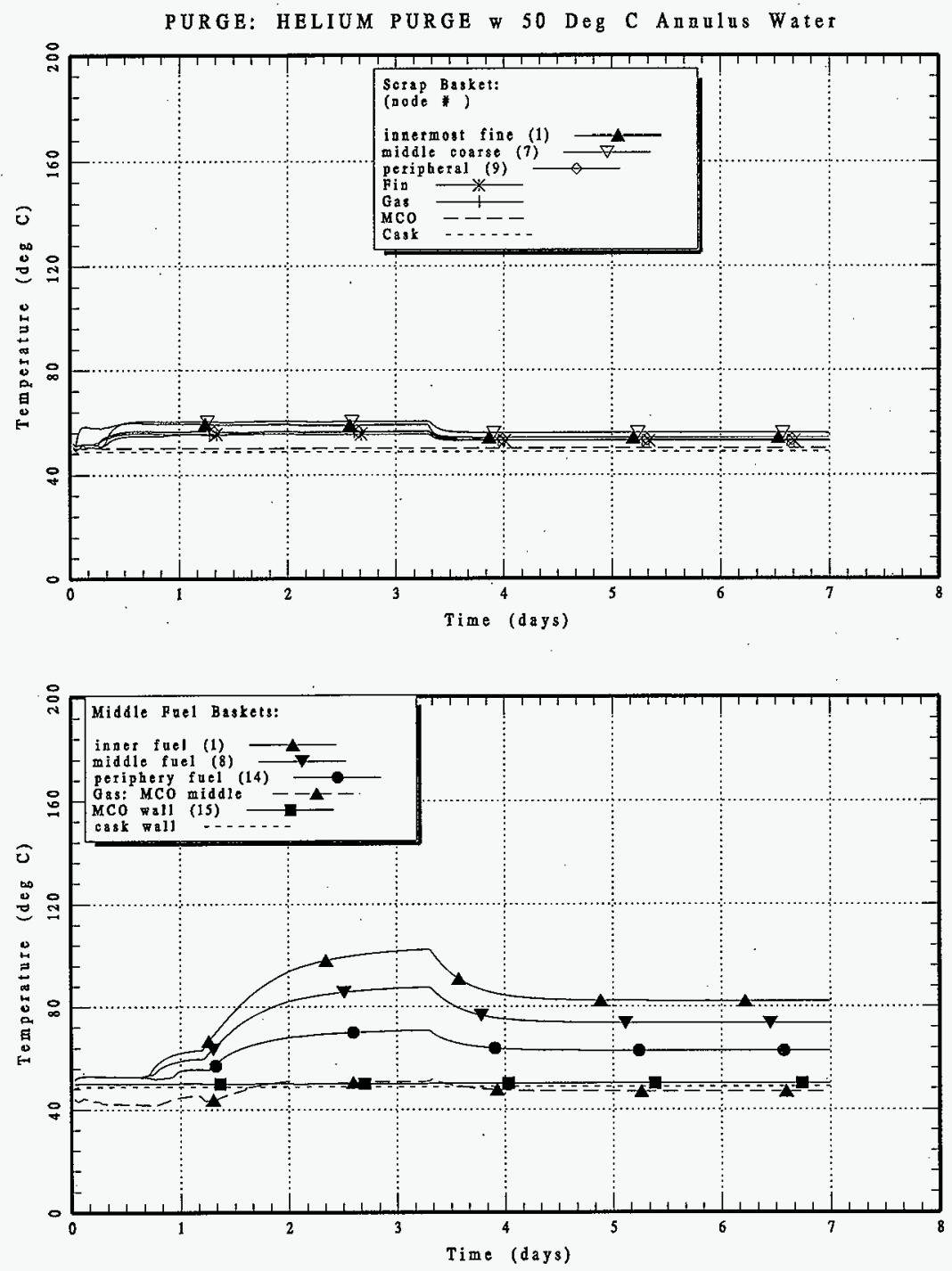

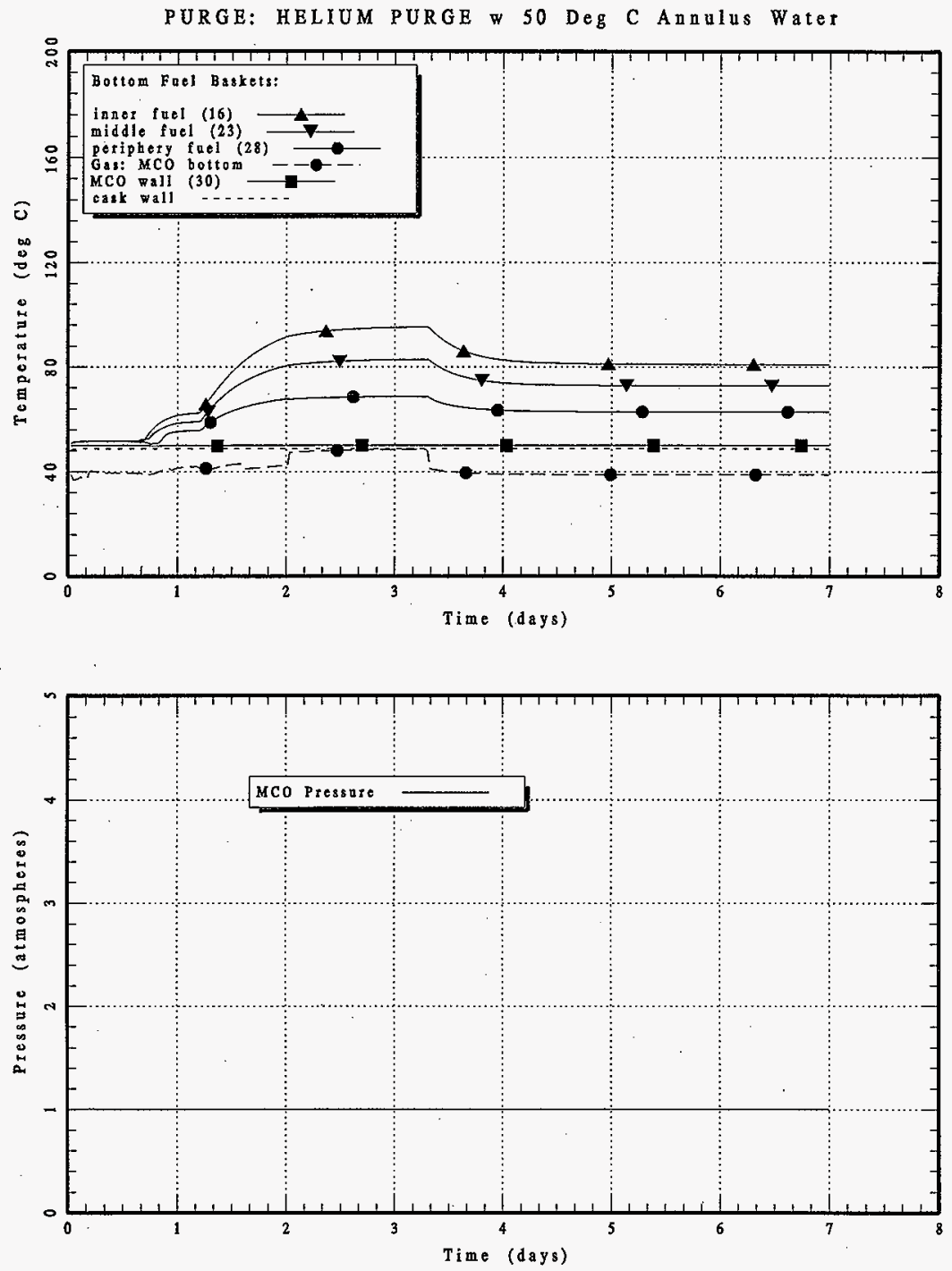


\section{HNF-SD-SNF-CN-023 REV 1}

Figure A-5 VACHOT: Indefinite Vacuum with $85^{\circ} \mathrm{C}$ Annulus 


\section{HNF-SD-SNF-CN-023 REV 1}

This page intentionally left blank. 


\section{HNF-SD-SNF-CN-023 REV 1}

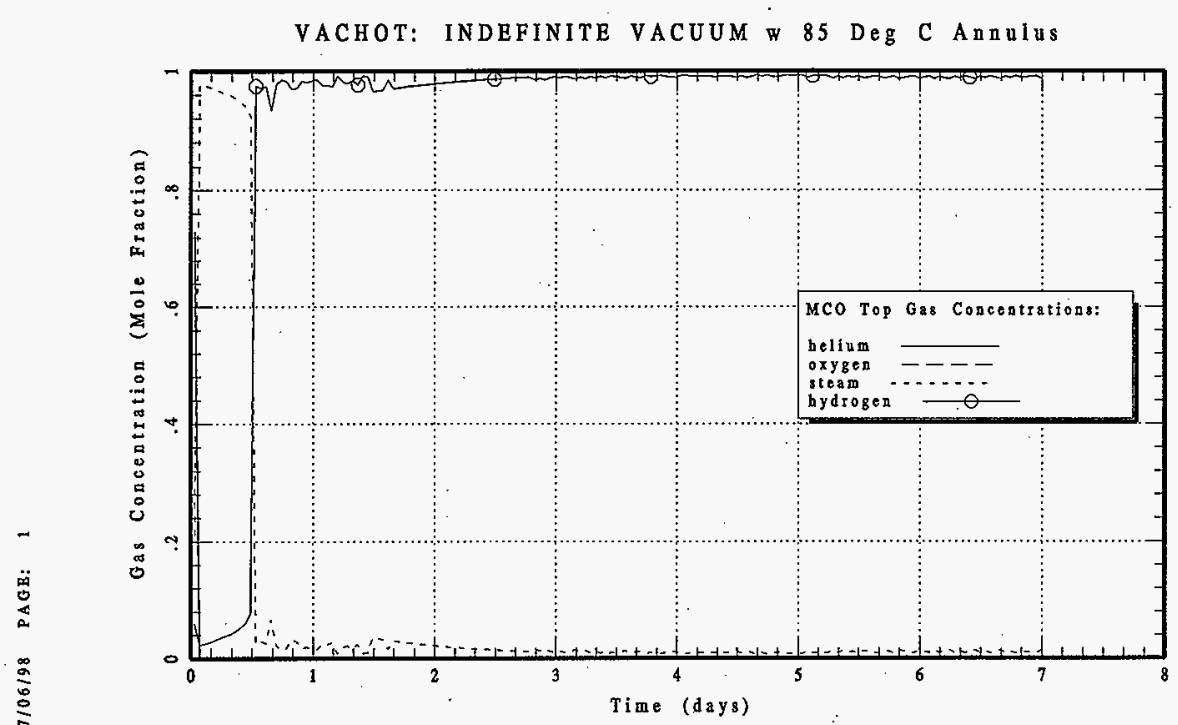

0
0
0
0
0
0
0
0
0
0
0
0
0
0
0
0
0
0
0
0
0
0
0
0
0
0
0
0
0
0
0
0
0

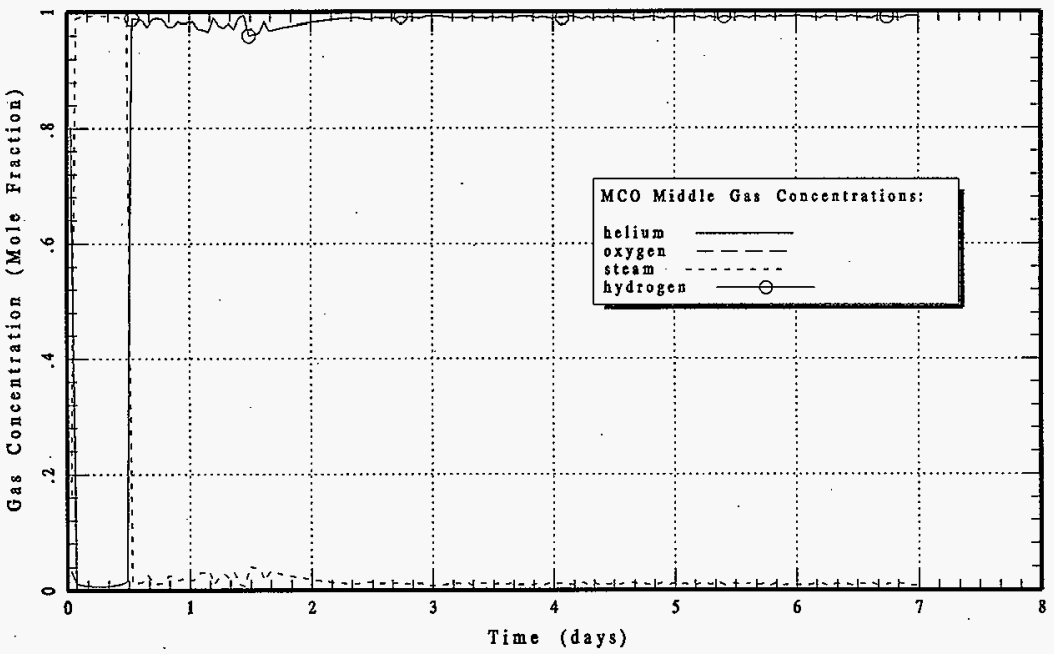




\section{HNF-SD-SNF-CN-023 REV 1}
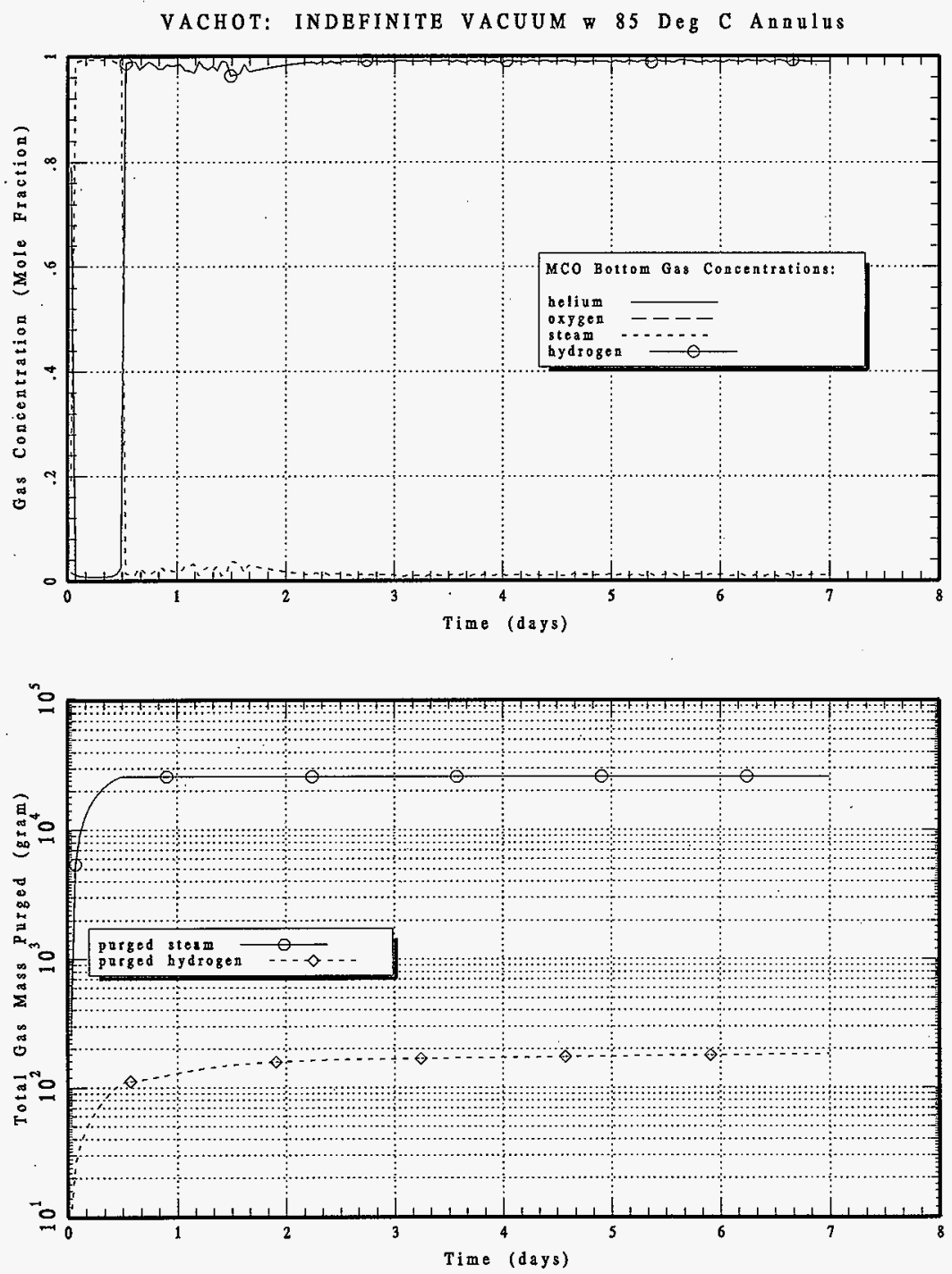


\section{HNF-SD-SNF-CN-023 REV 1}
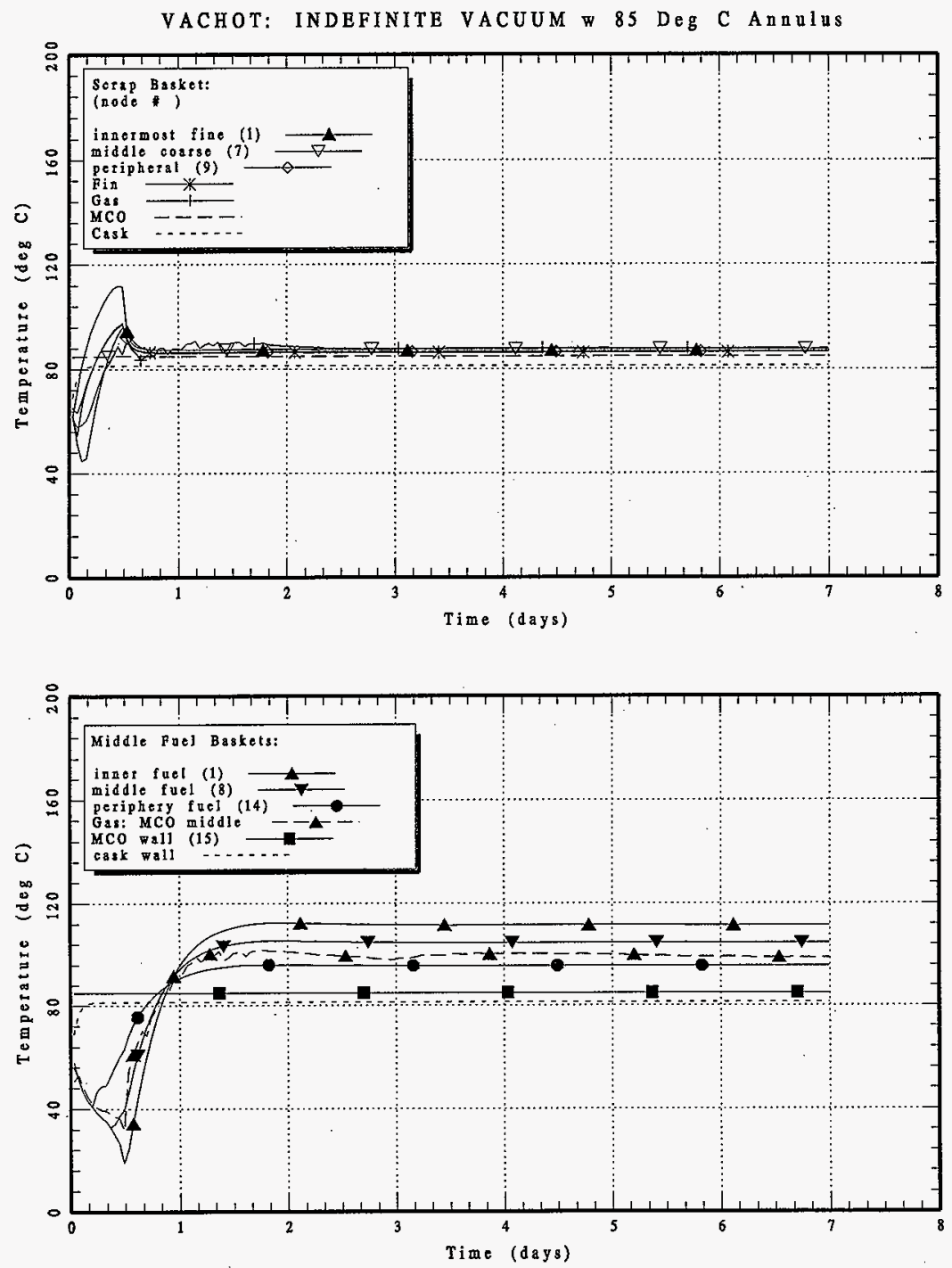
HNF-SD-SNF-CN-023 REV 1
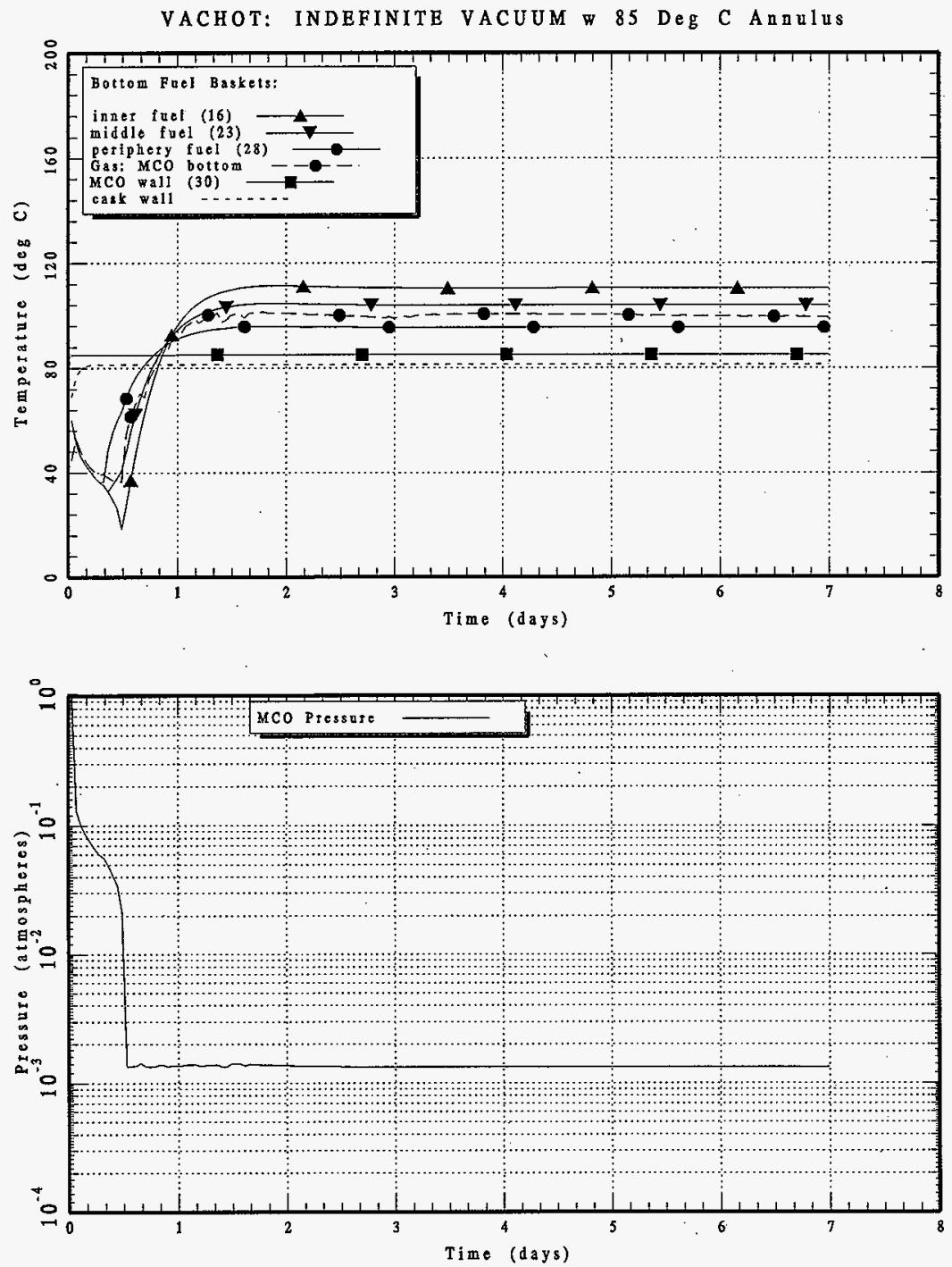


\section{HNF-SD-SNF-CN-023 REV 1}

Figure A-6 VPURHOT: Vacuum with Helium Purge with $85^{\circ} \mathrm{C}$ Annulus 


\section{HNF-SD-SNF-CN-023 REV 1}

This page intentionally left blank. 


\section{HNF-SD-SNF-CN-023 REV 1}

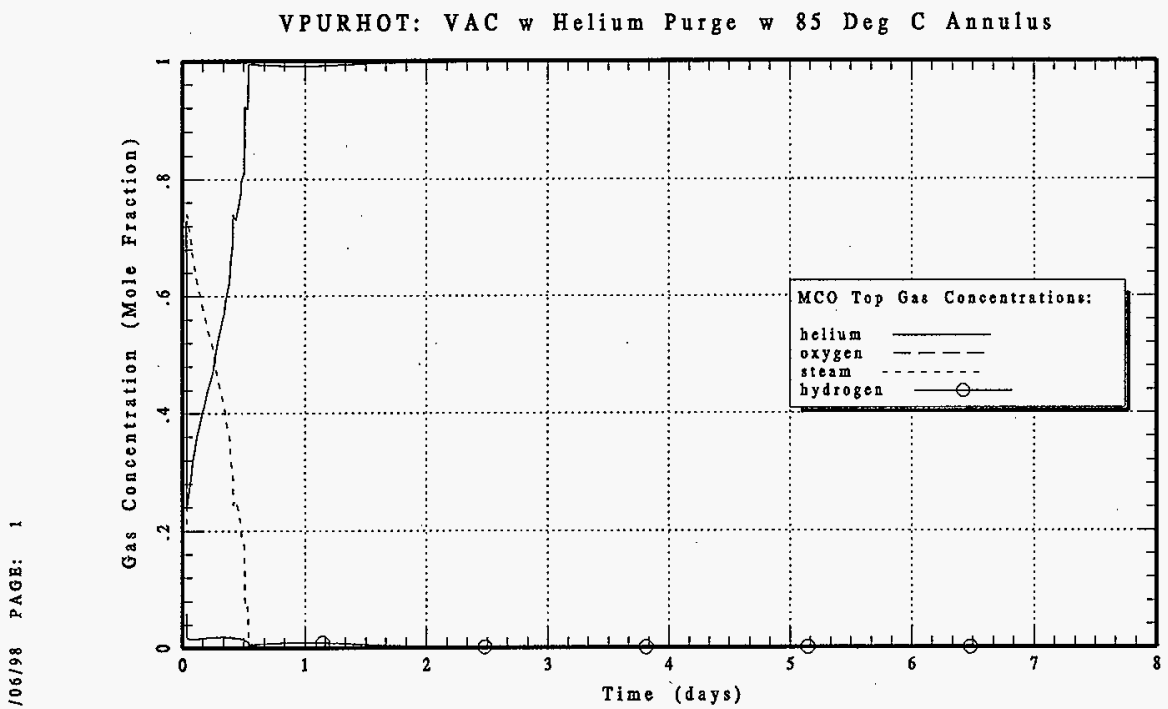

0

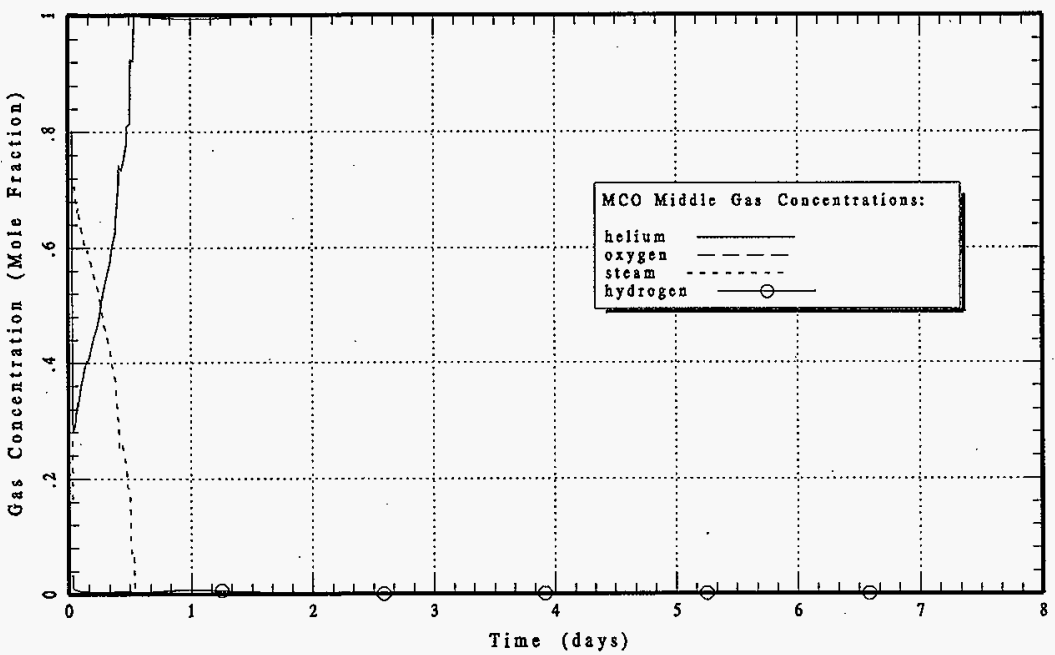




\section{HNF-SD-SNF-CN-023 REV 1}
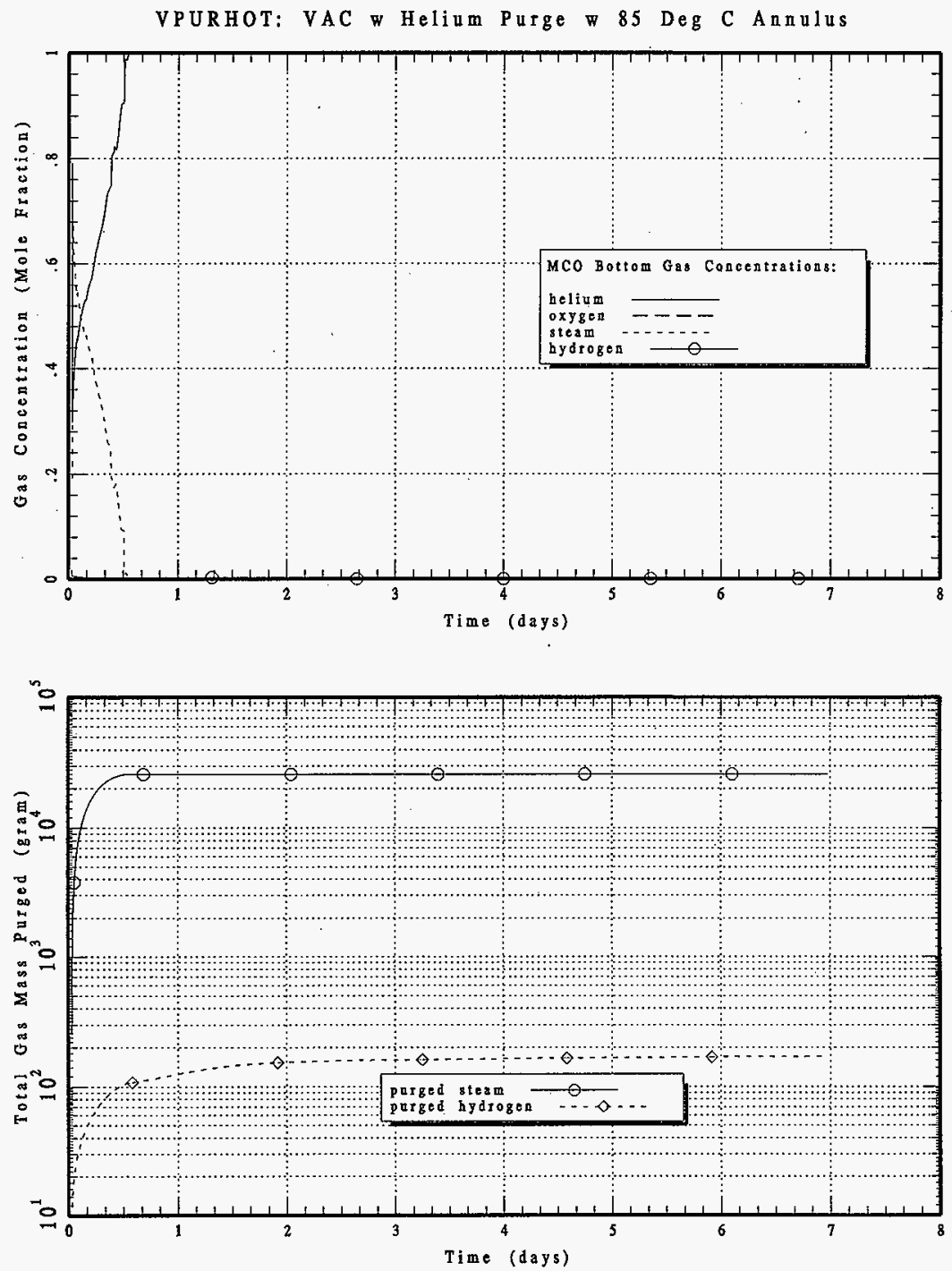


\section{HNF-SD-SNF-CN-023 REV 1}
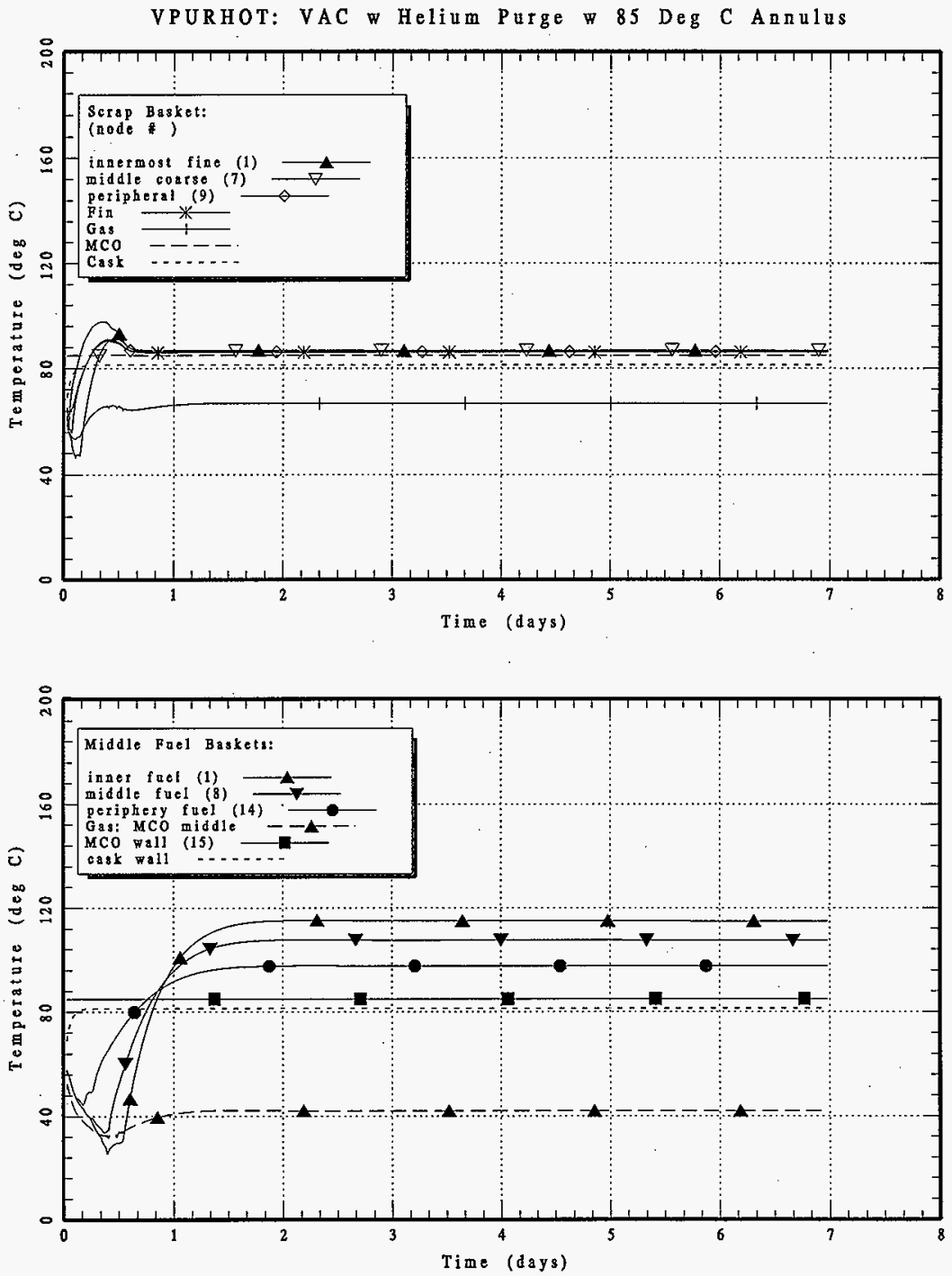


\section{HNF-SD-SNF-CN-023 REV 1}
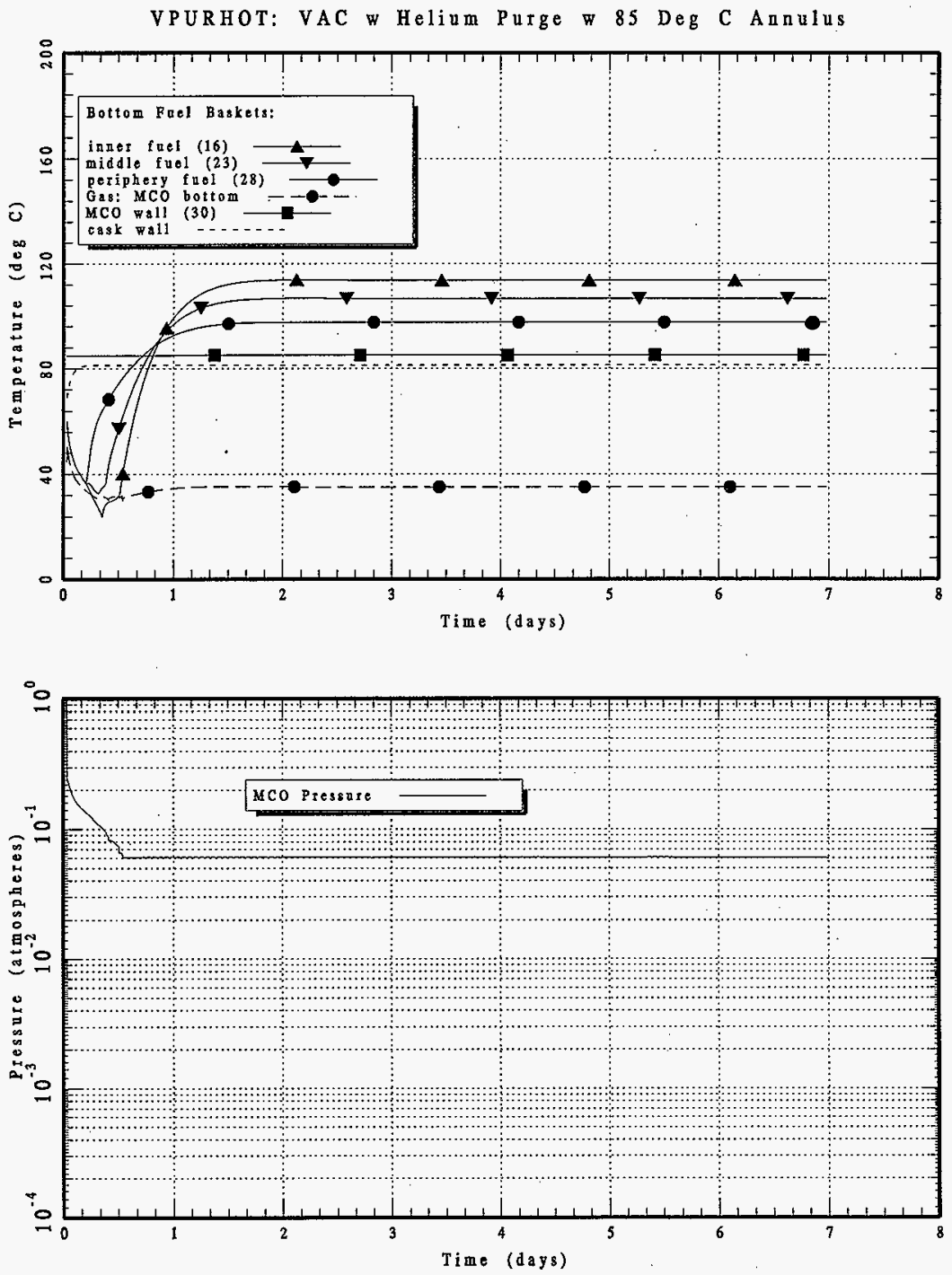


\section{HNF-SD-SNF-CN-023 REV 1}

Figure A-7 PURHOT: Helium Purge with $85^{\circ} \mathrm{C}$ Annulus Water 


\section{HNF-SD-SNF-CN-023 REV 1}

This page intentionally left blank. 

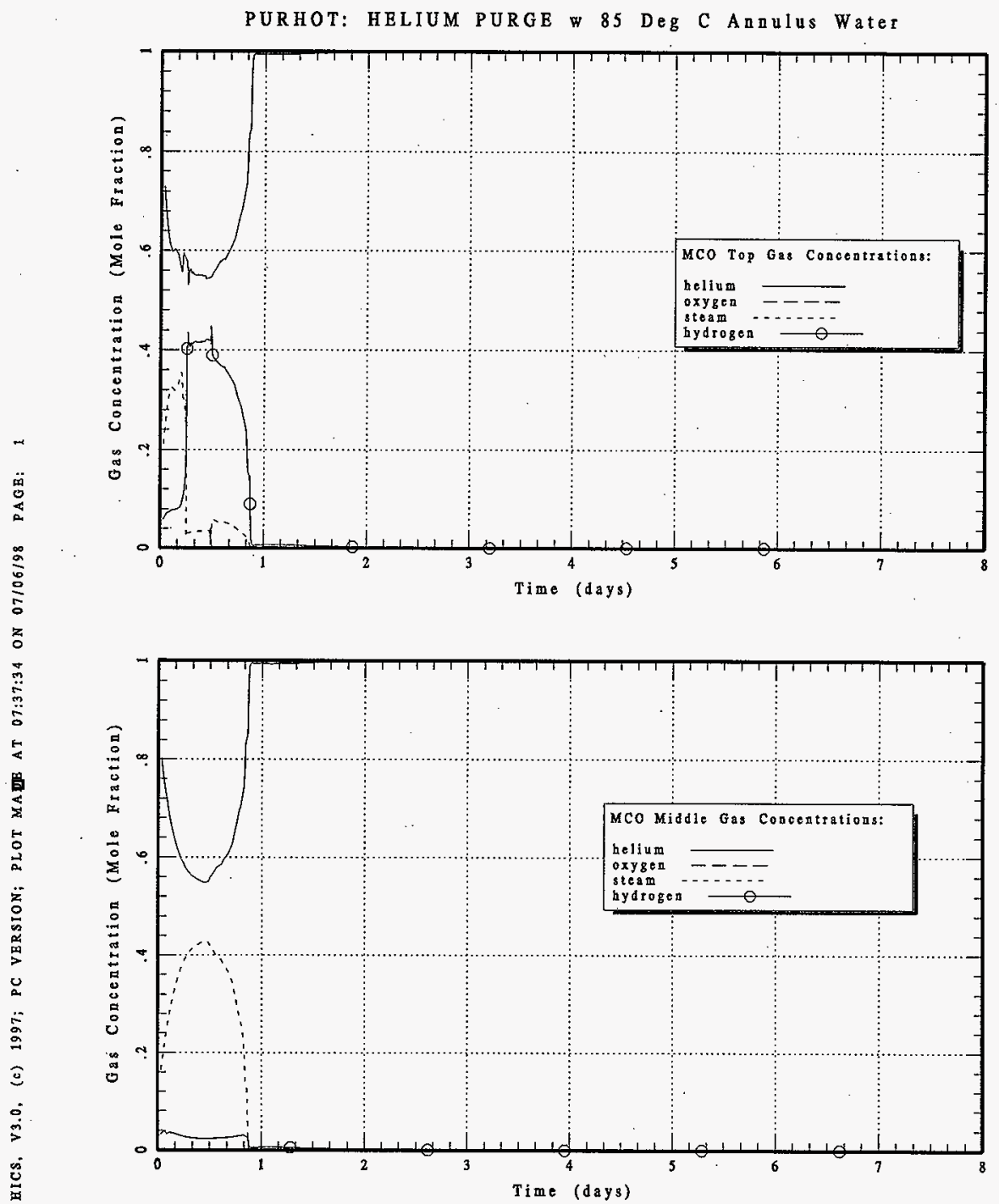


\section{HNF-SD-SNF-CN-023 REV 1}
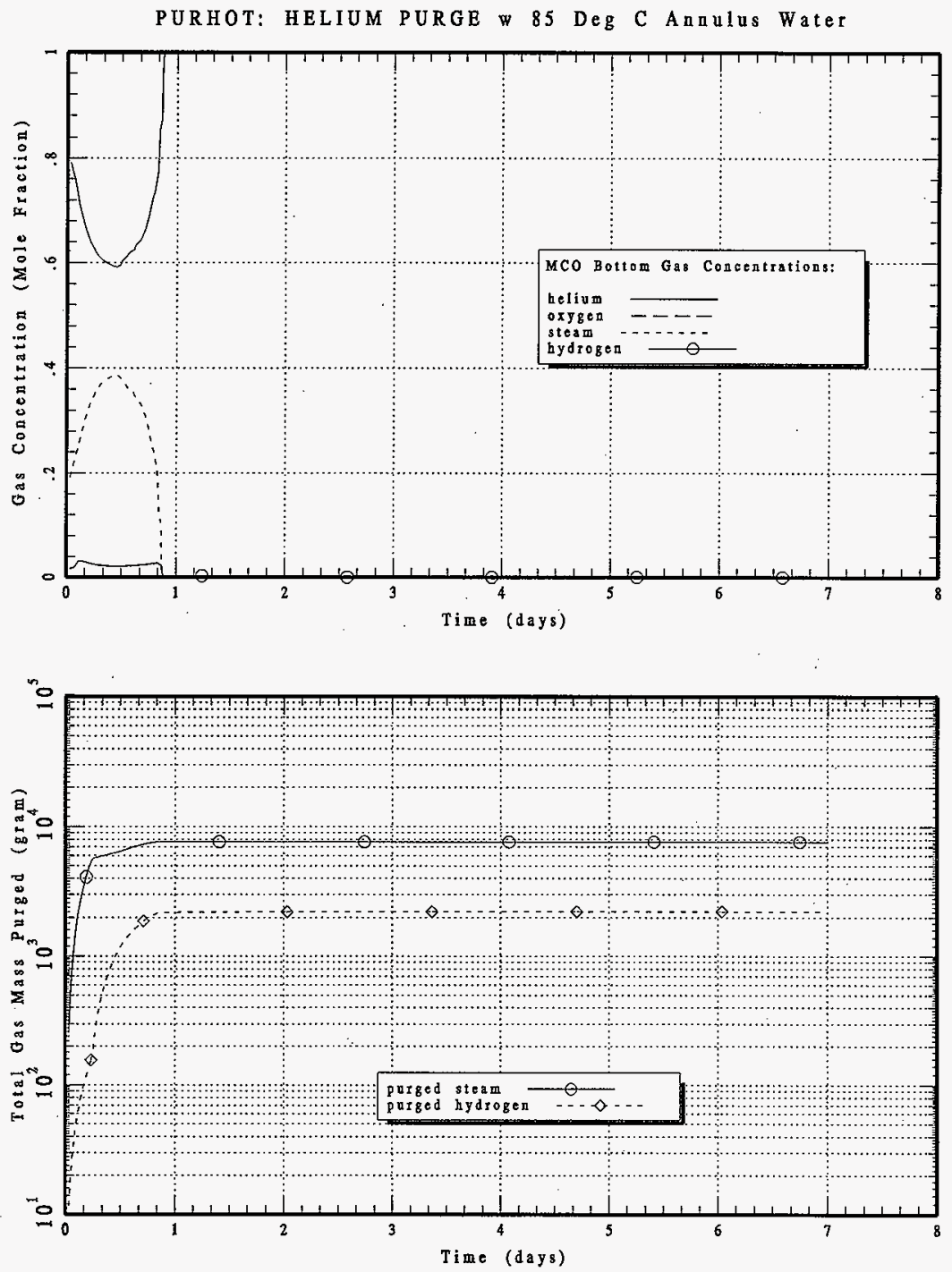
HNF-SD-SNF-CN-023 REV 1
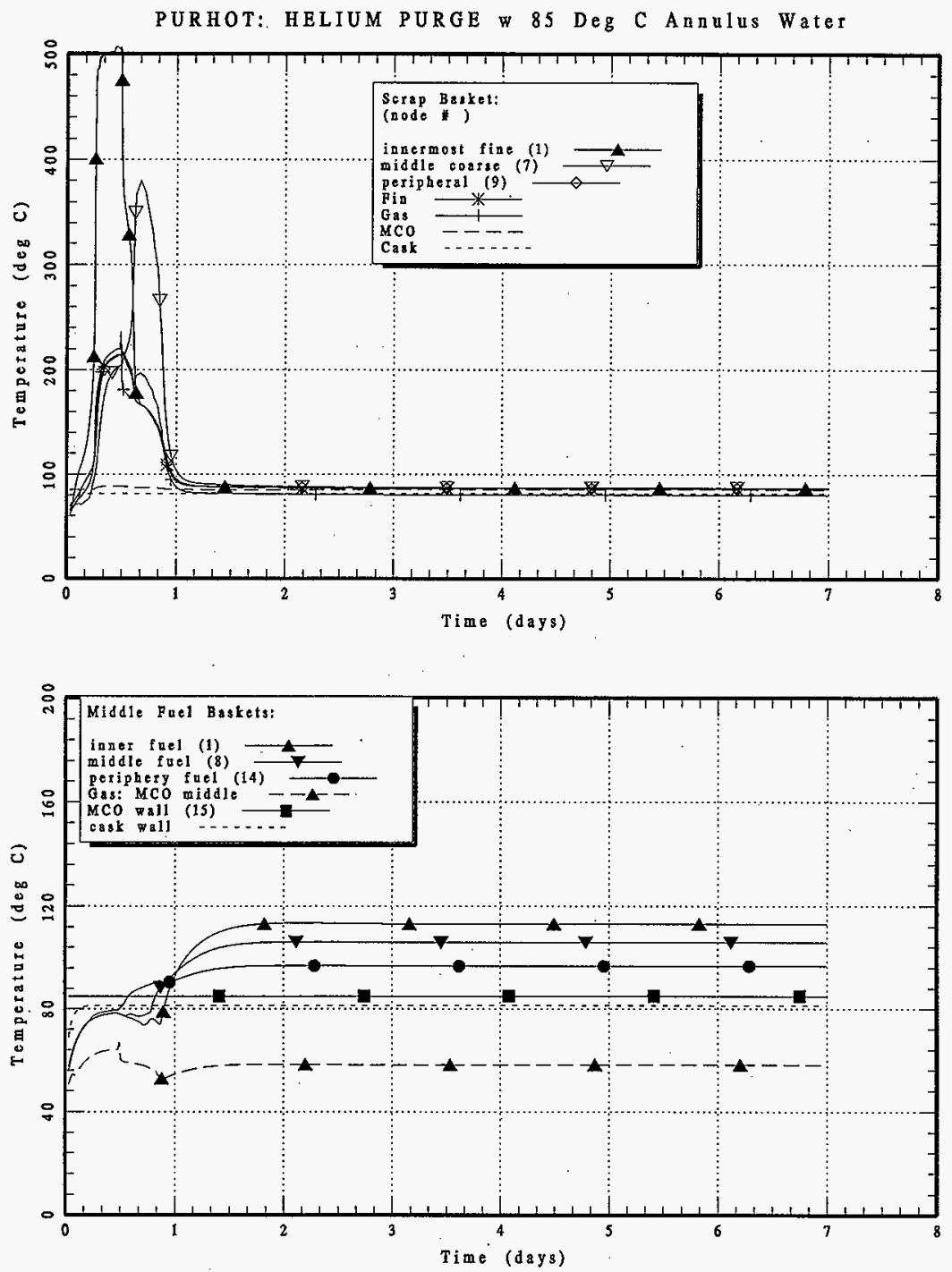
HNF-SD-SNF-CN-023 REV I
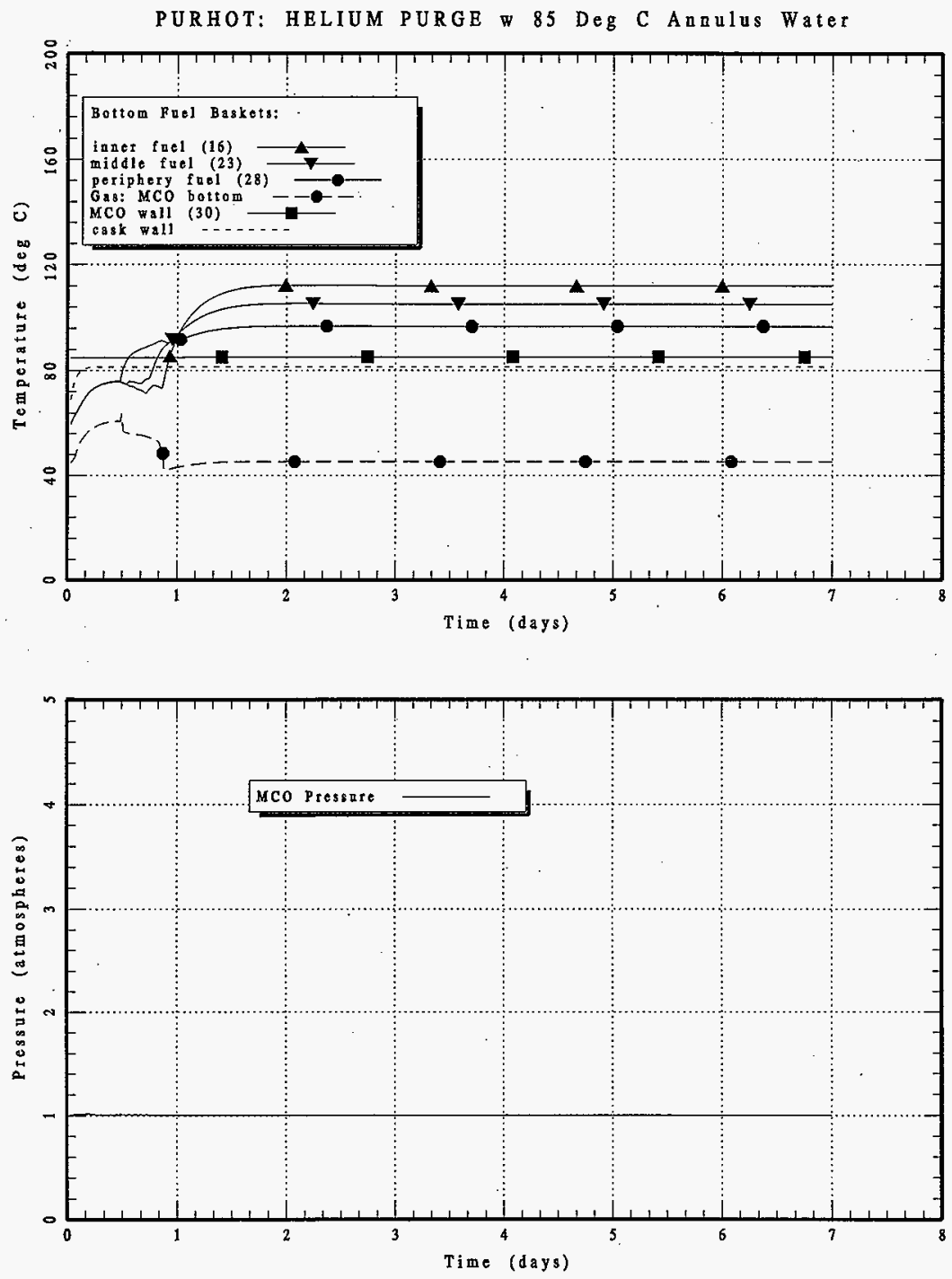


\section{HNF-SD-SNF-CN-023 REV 1}

Figure A-8 VACLOF: Indefinite Vacuum with Loss of Flow in Annulus 


\section{HNF-SD-SNF-CN-023 REV 1}

This page intentionally left blank. 
VACLOF: INDEFINITE VACUUM W LOSS of Flow in Annulus
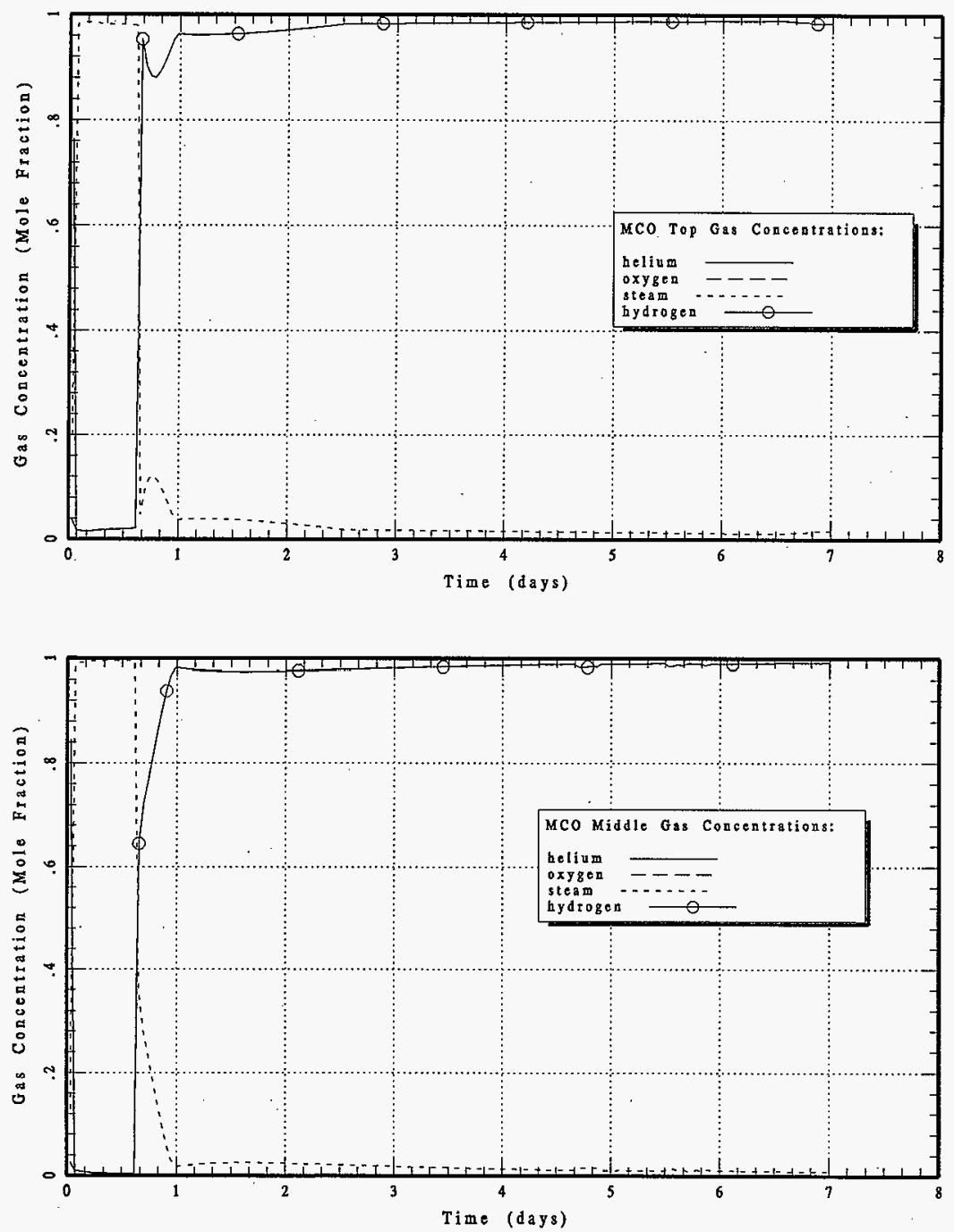
VACLOF: INDEFINITE VACUUM Loss of Flow in Annulus
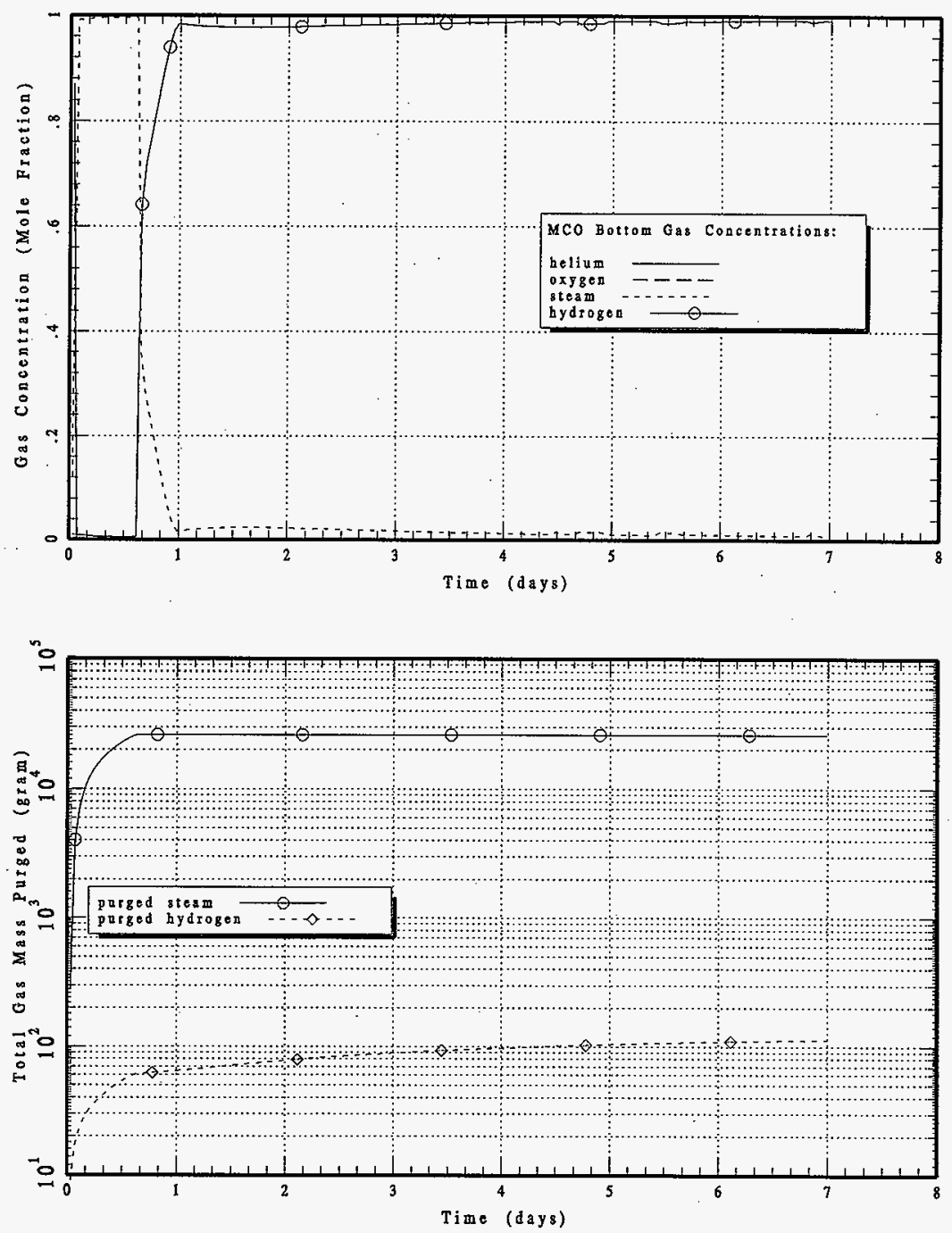

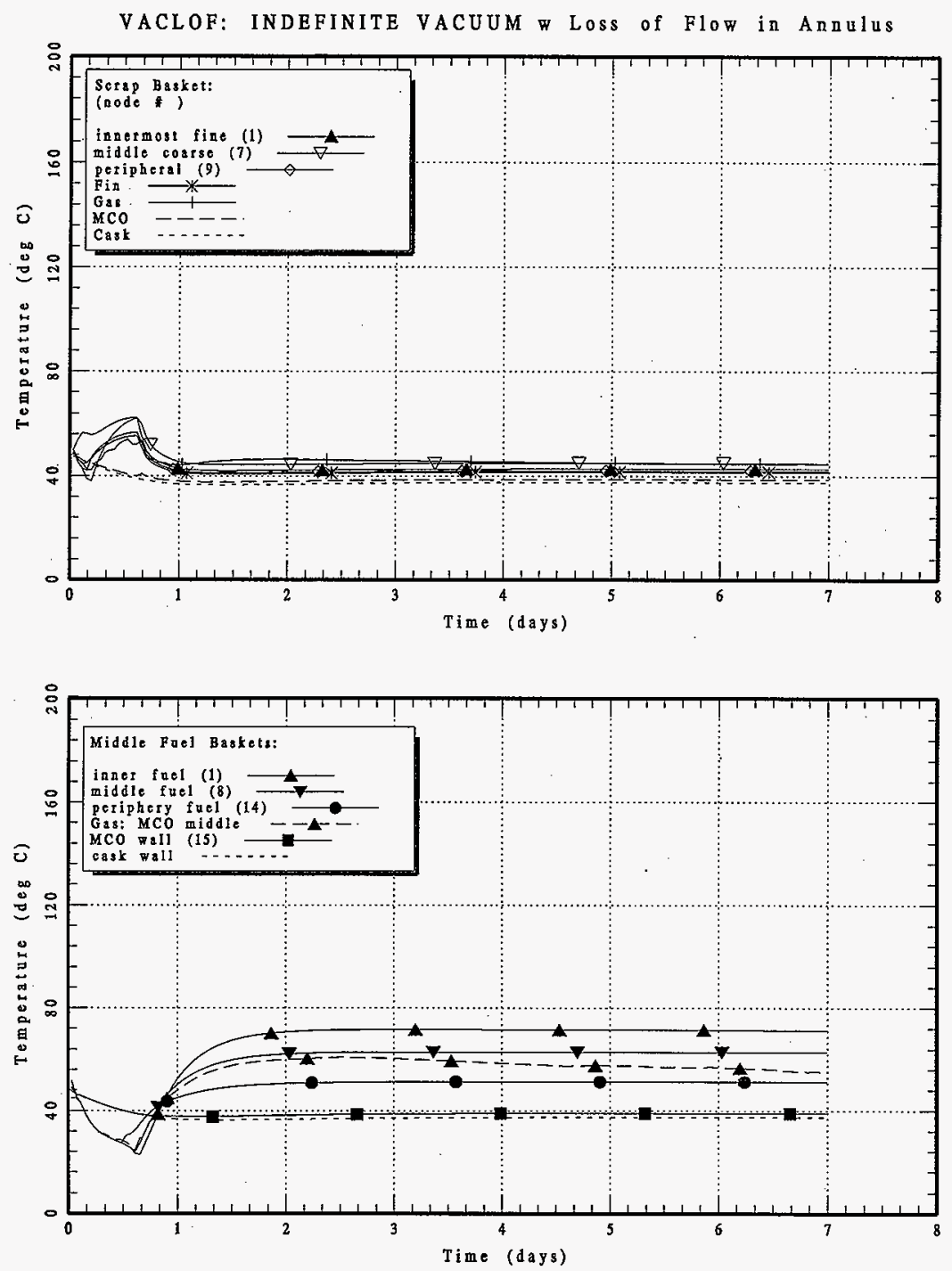
HNF-SD-SNF-CN-023 REV 1
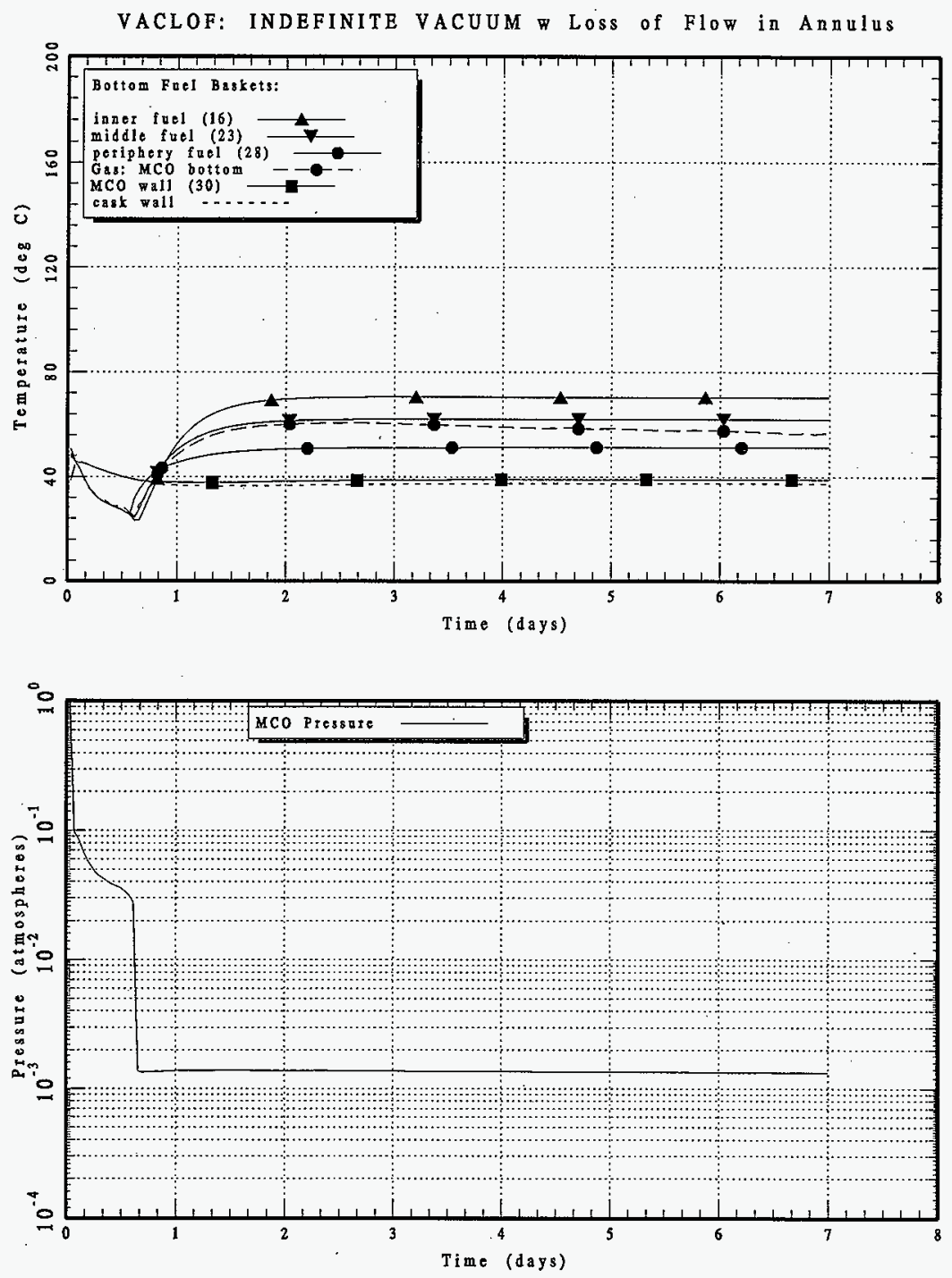
HNF-SD-SNF-CN-023 REV 1

Figure A-9 VLOFHOT: Vacuum with Loss of Flow in Annulus at $85^{\circ} \mathrm{C}$ 


\section{HNF-SD-SNF-CN-023 REV 1}

This page intentionally left blank. 


\section{HNF-SD-SNF-CN-023 REV 1}

VLOFHOT: VACUUM w Loss of Flow in Annulus @85 deg C
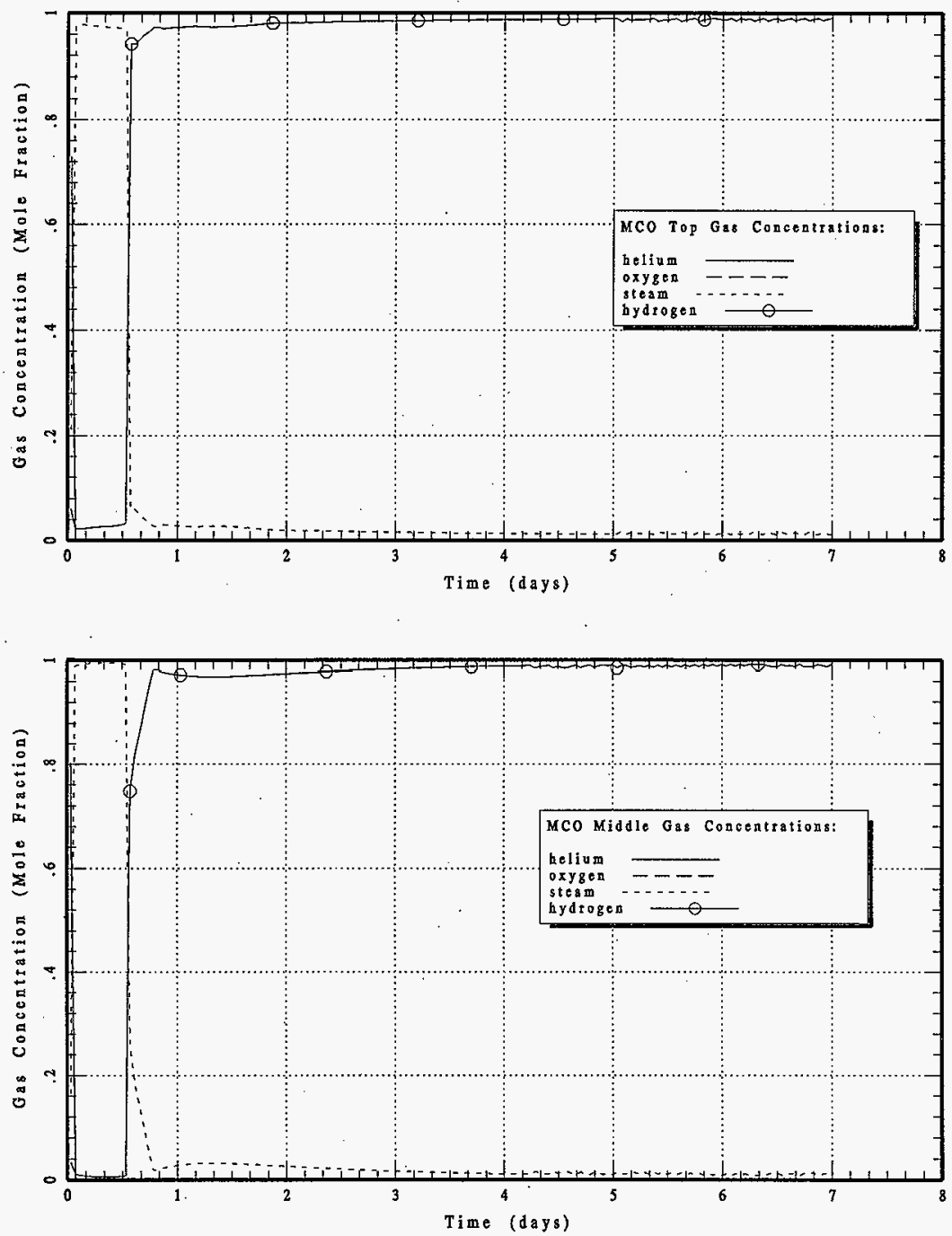


\section{HNF-SD-SNF-CN-023 REV 1}
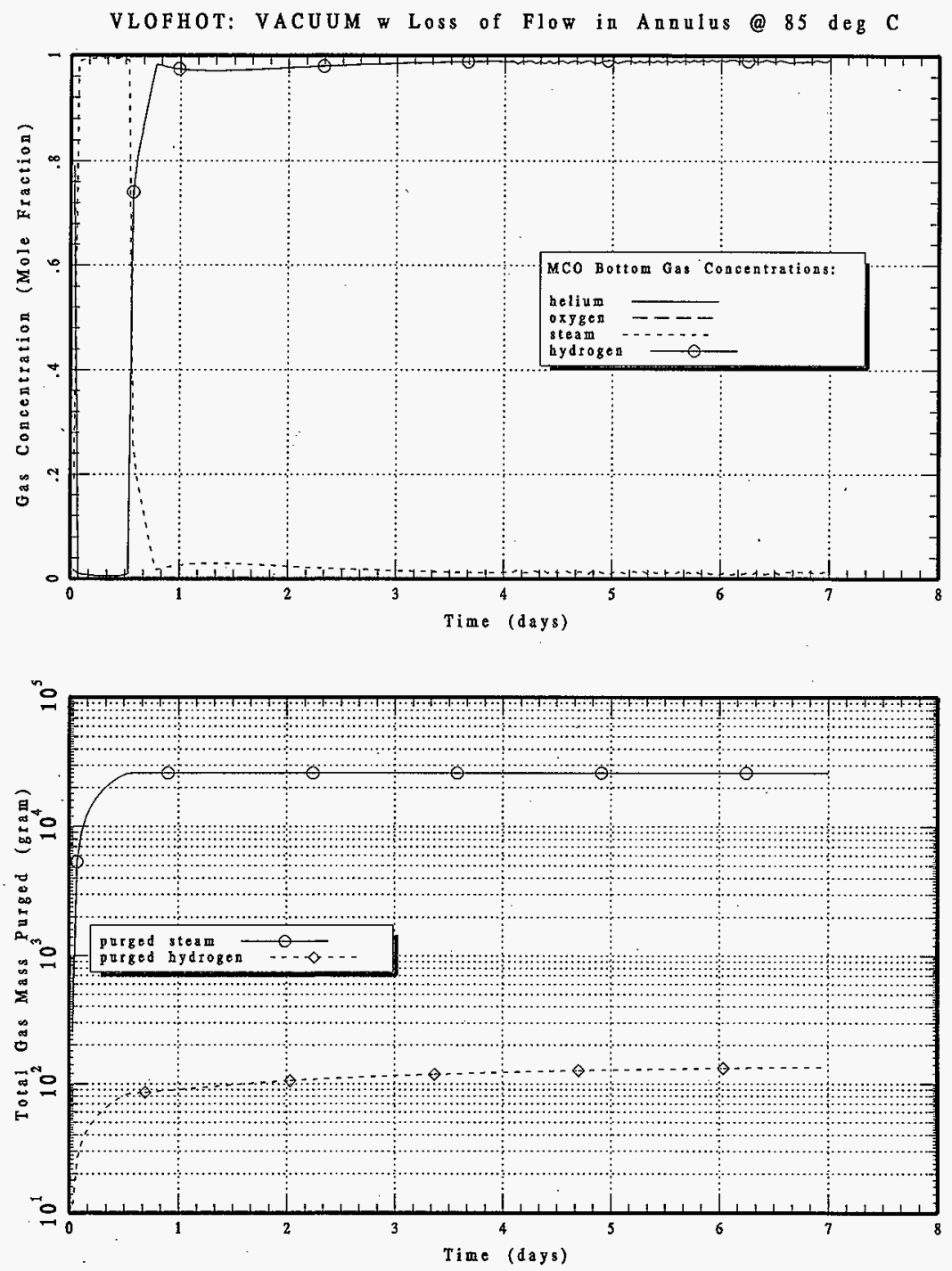

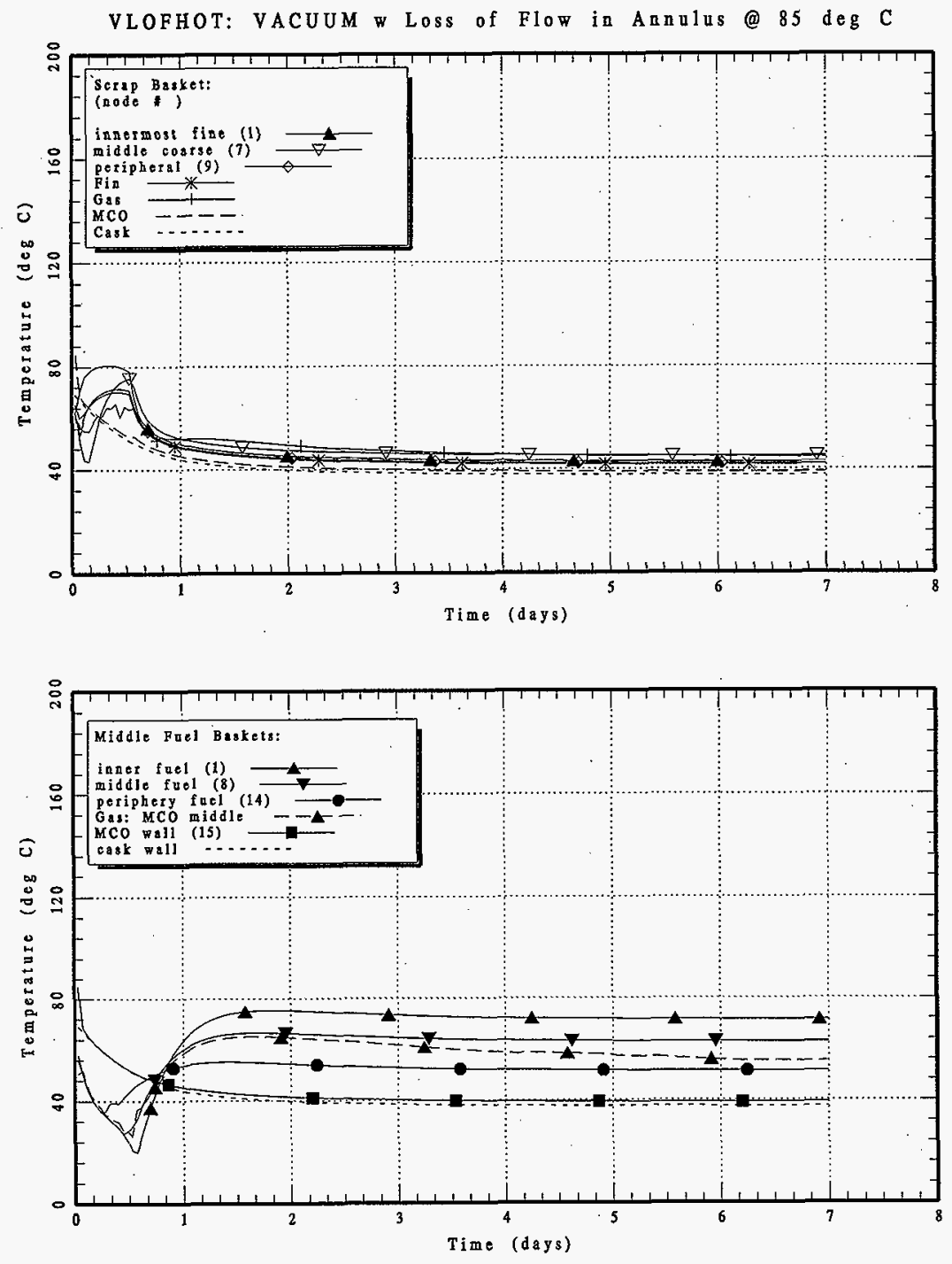


\section{HNF-SD-SNF-CN-023 REV 1}
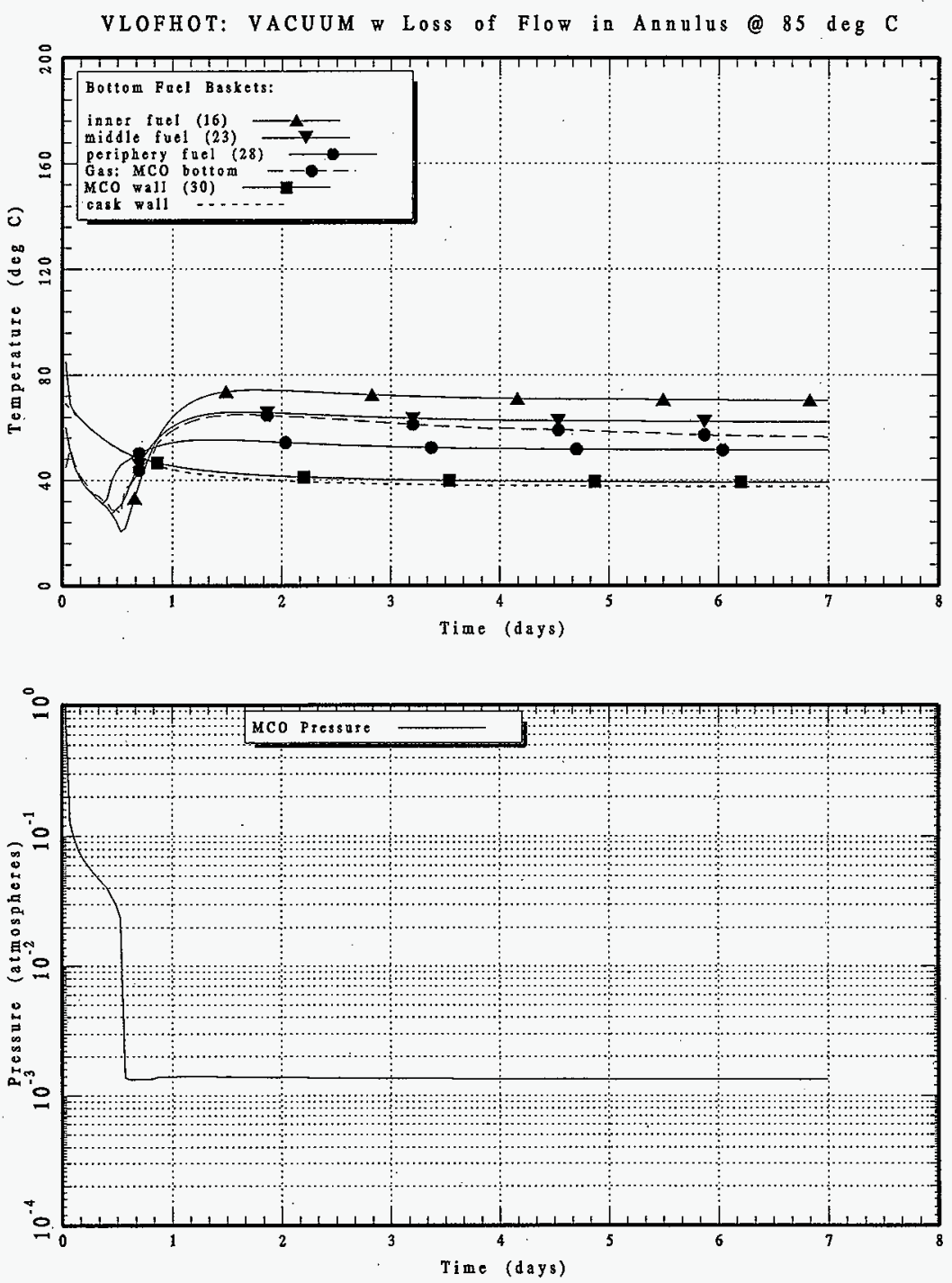
HNF-SD-SNF-CN-023 REV 1

Figure A-10 VACLOC: Indefinite Vacuum with Loss of Coolant (LOC) in Annulus 


\section{HNF-SD-SNF-CN-023 REV 1}

This page intentionally left blank. 


\section{HNF-SD-SNF-CN-023 REV 1}

VACLOC: INDEFINITE VACUUM Woss of Coolant in Annulus
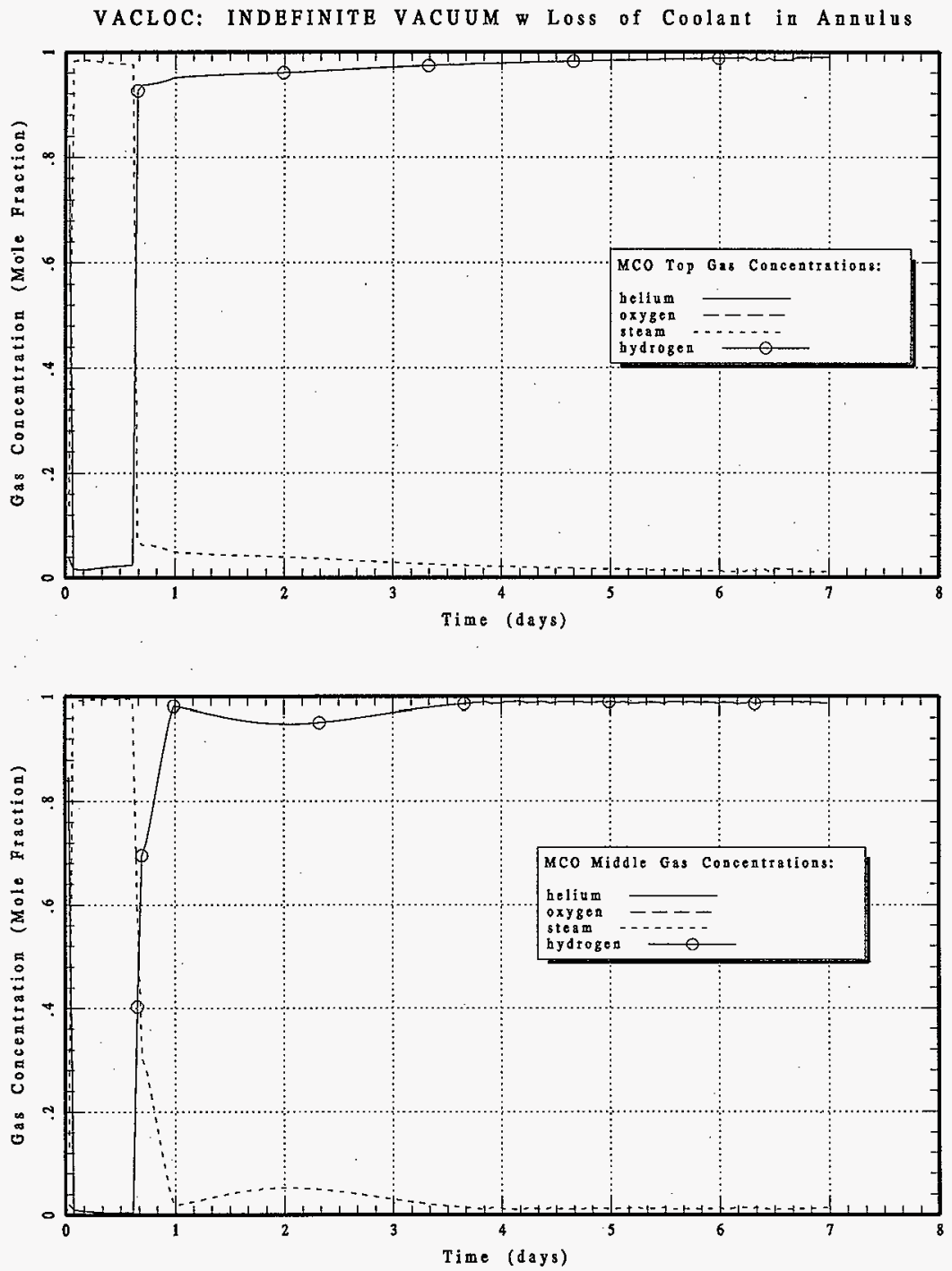


\section{HNF-SD-SNF-CN-023 REV 1}
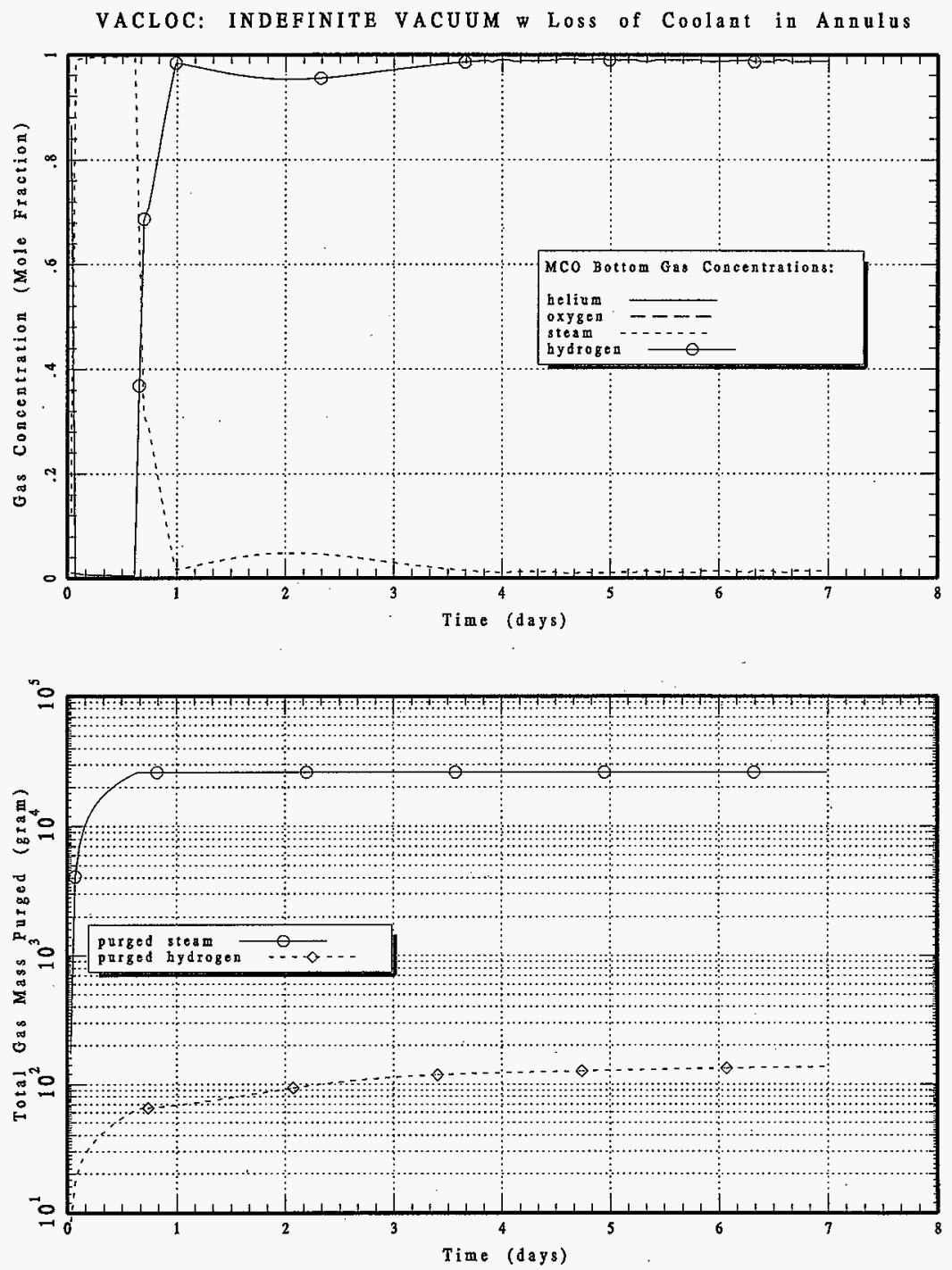
HNF-SD-SNF-CN-023 REV 1

VACLOC: INDEFINITE VACUUM w Loss of Coolant in Annu
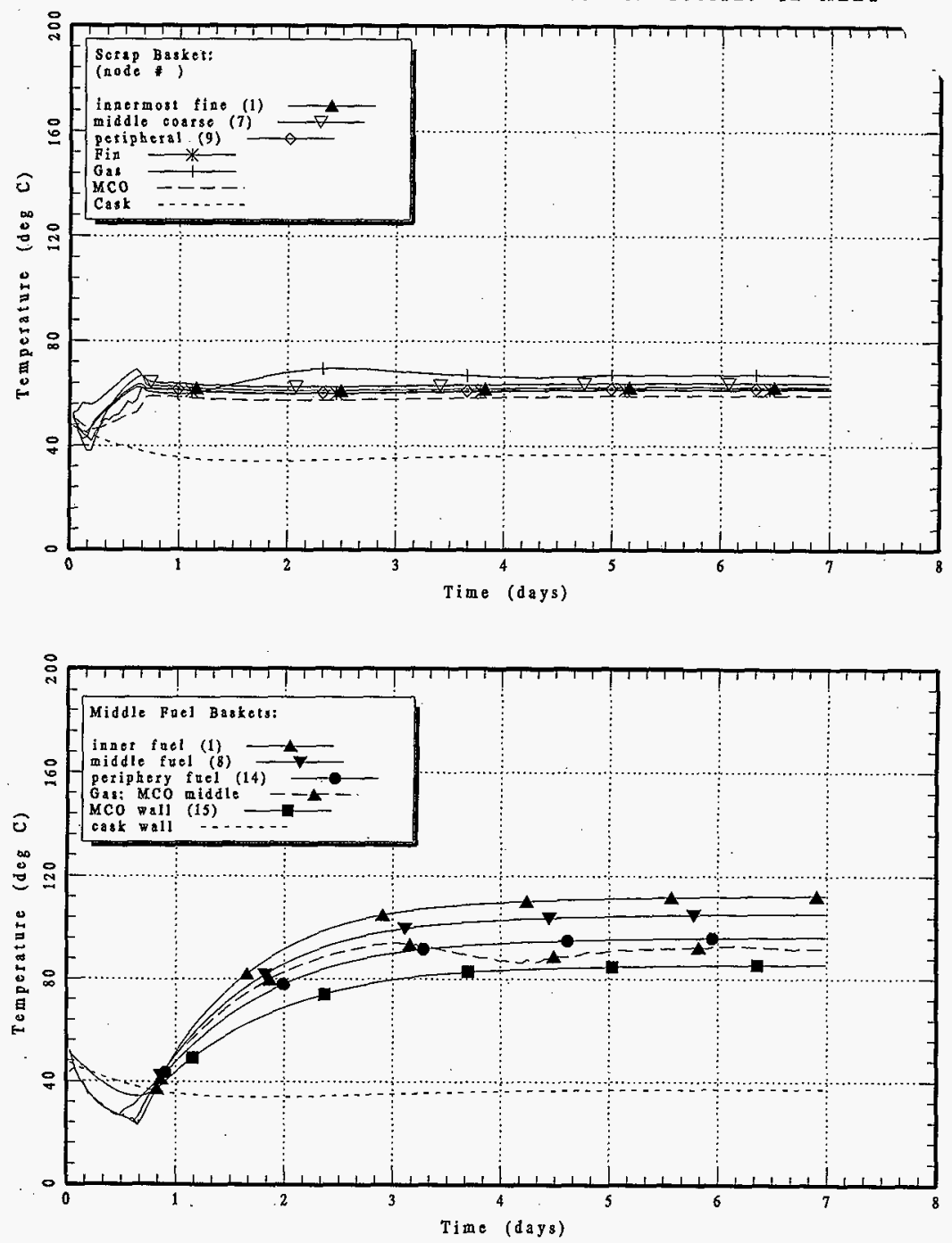


\section{HNF-SD-SNF-CN-023 REV 1}
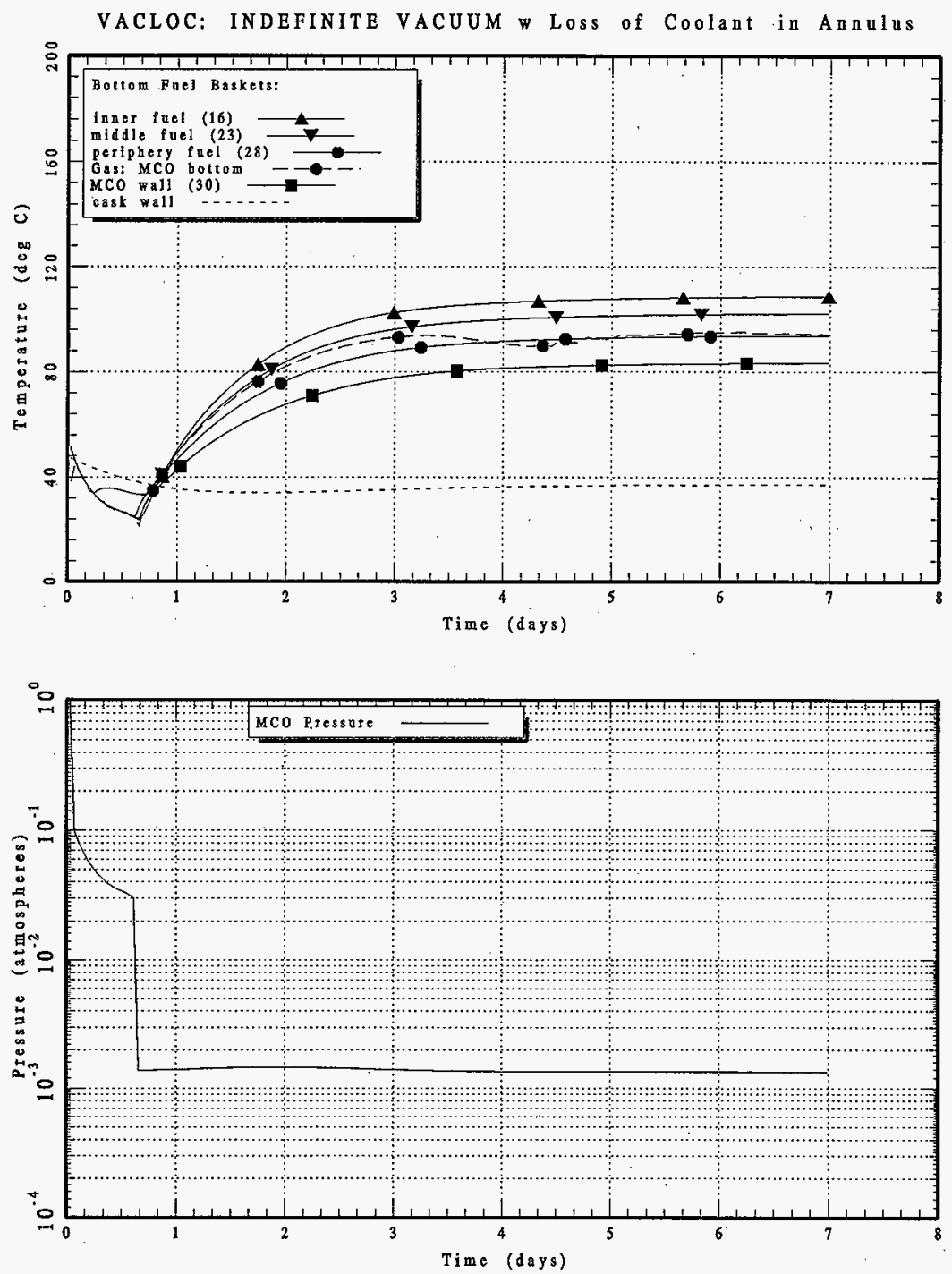
HNF-SD-SNF-CN-023 REV 1

Figure A-11 VPURLOC: Vacuum and Helium Purge with Loss of Coolant (LOC) 
HNF-SD-SNF-CN-023 REV 1

This page intentionally left blank. 

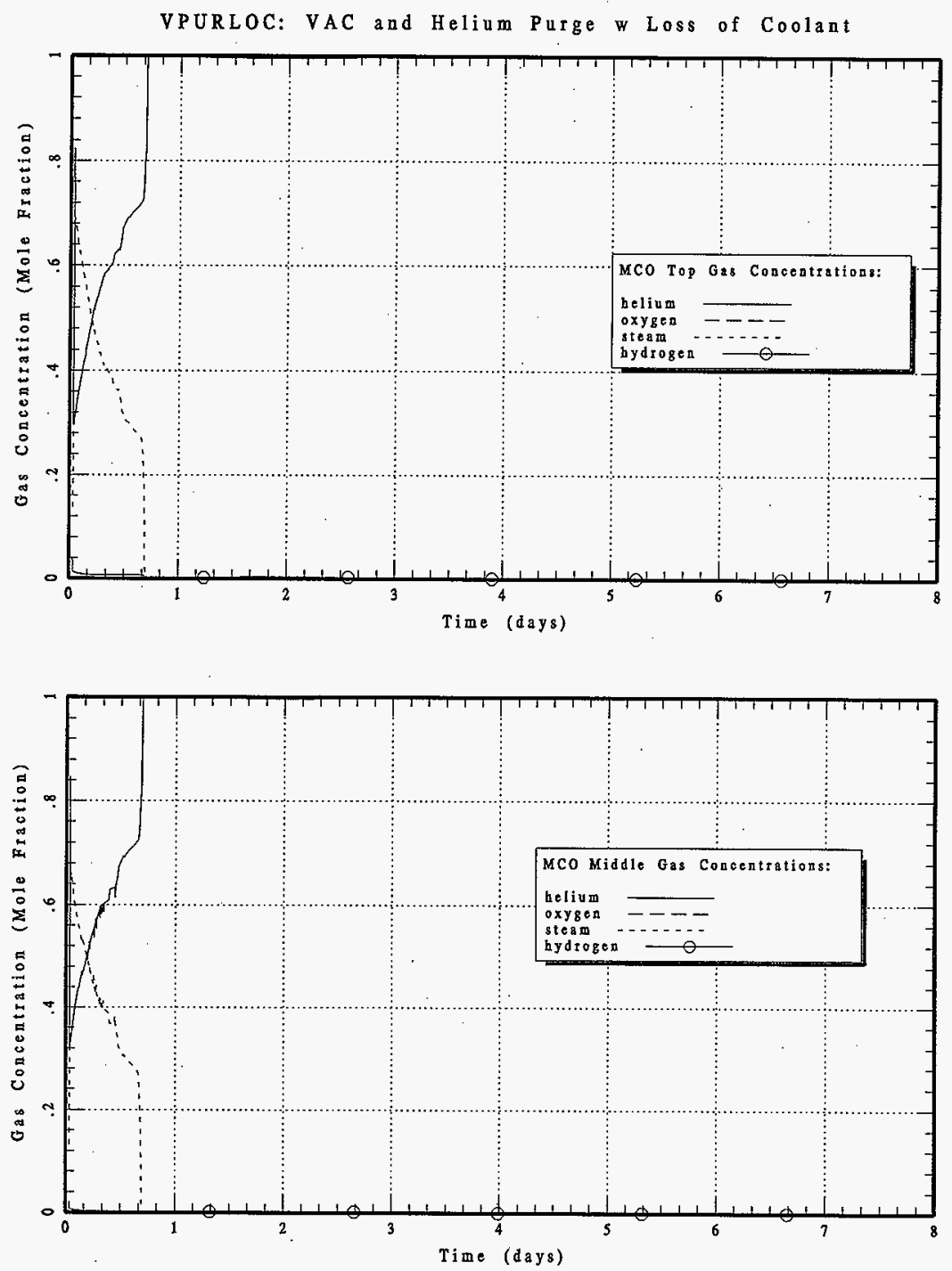


\section{HNF-SD-SNF-CN-023 REV 1}
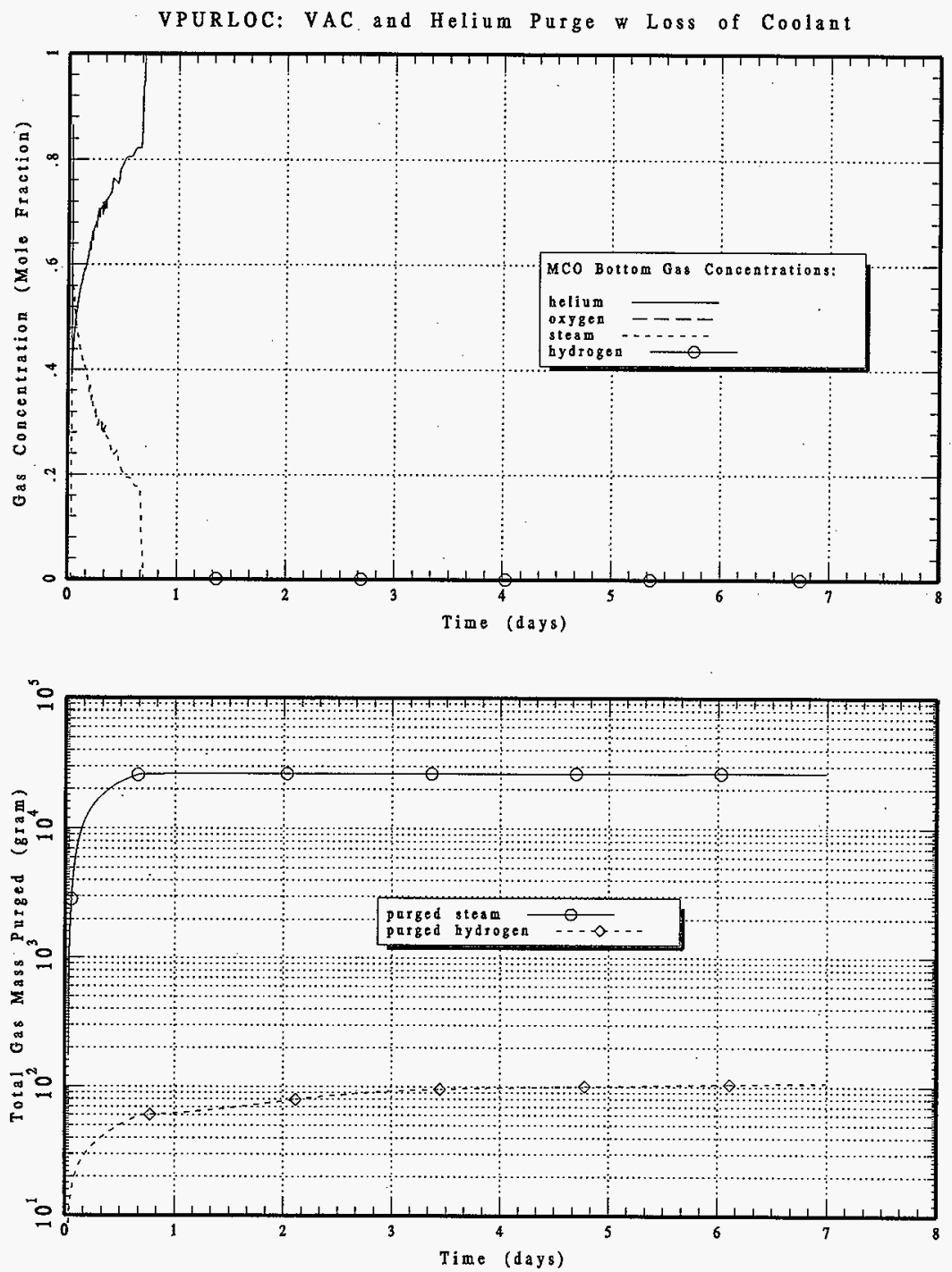

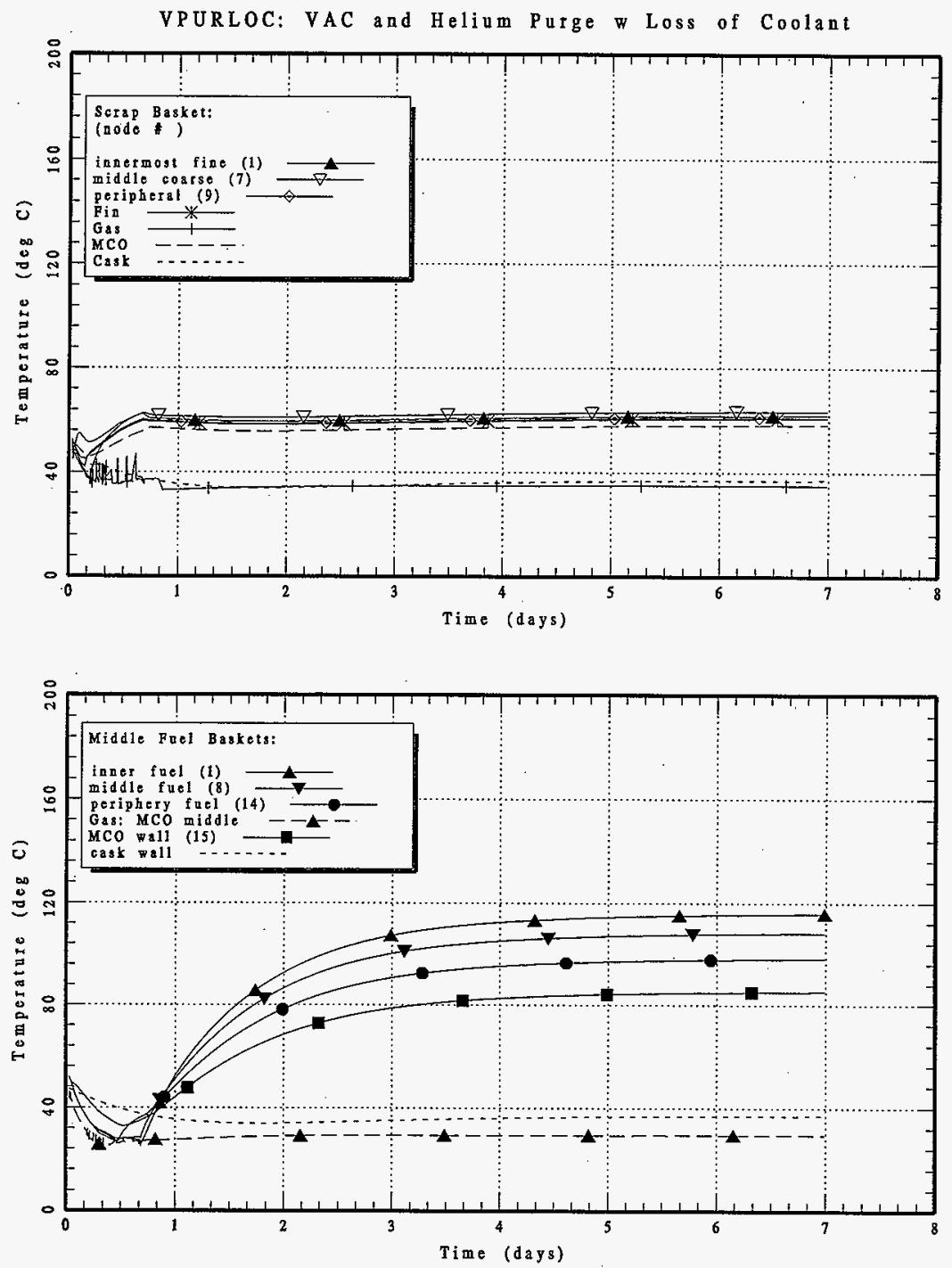


\section{HNF-SD-SNF-CN-023 REV 1}
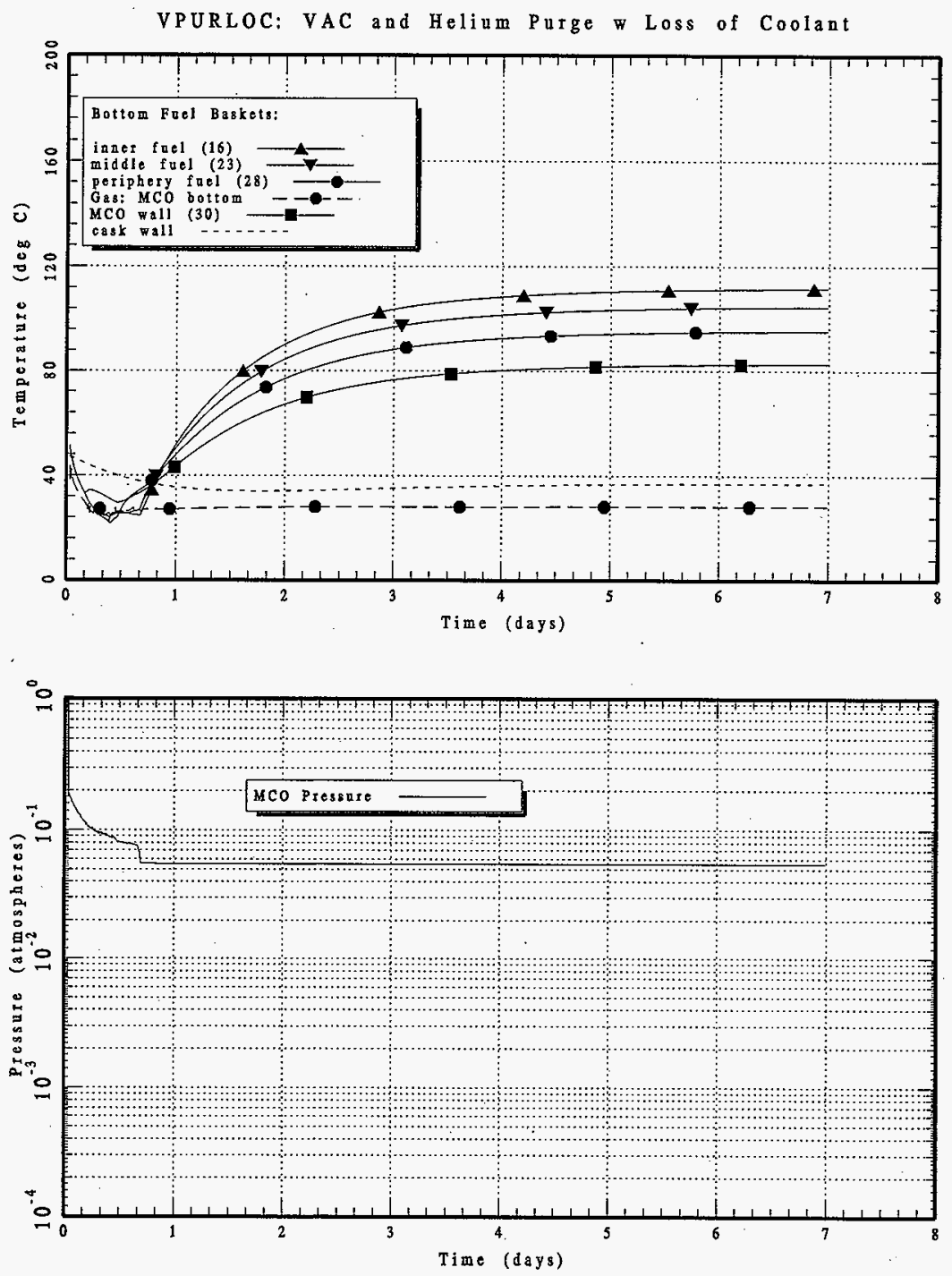


\section{HNF-SD-SNF-CN-023 REV 1}

Figure A-12 - PURLOF: Helium Purge with Loss of Flow in Annulus 


\section{HNF-SD-SNF-CN-023 REV 1}

This page intentionally left blank. 


\section{HNF-SD-SNF-CN-023 REV 1}
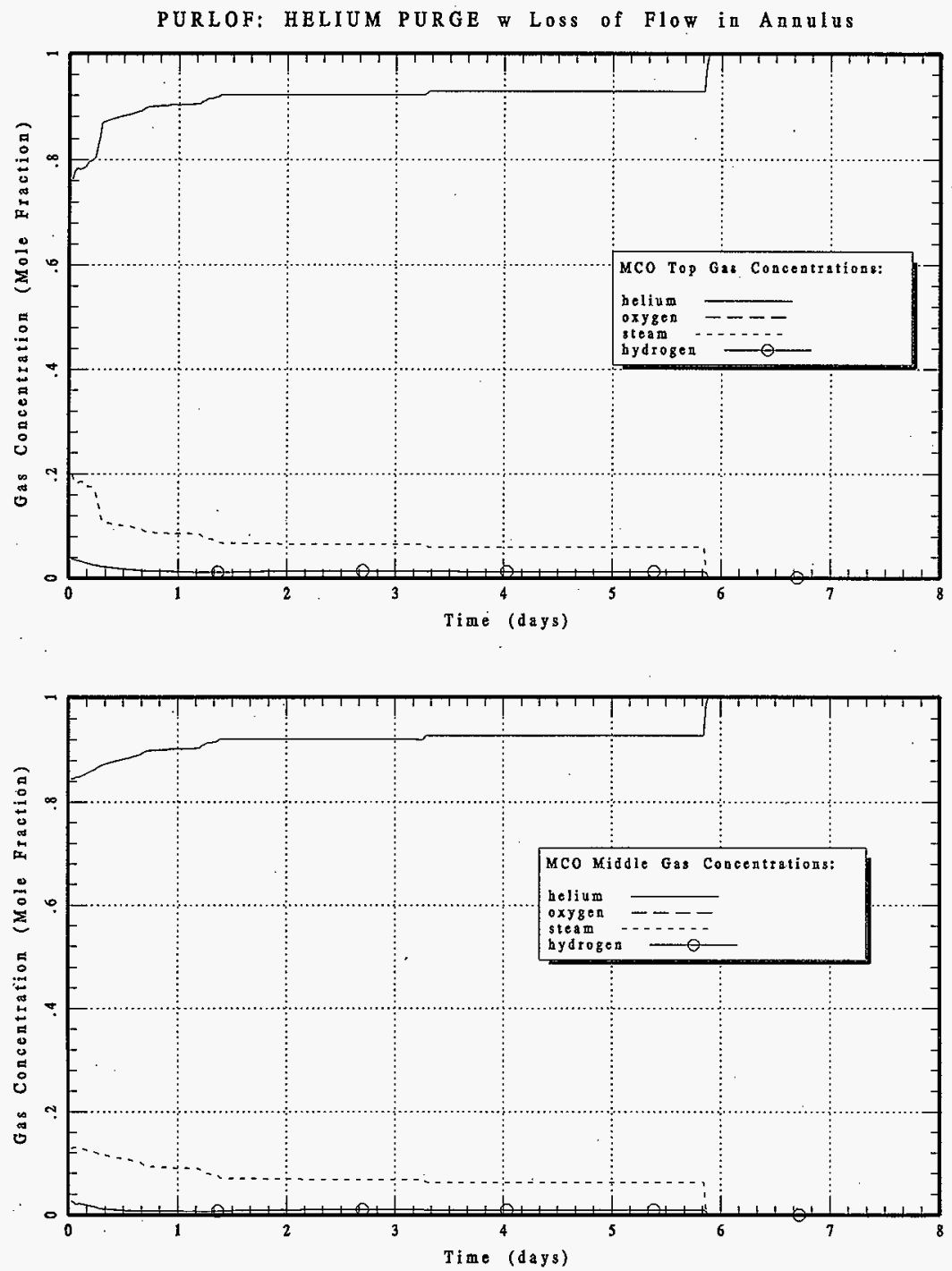
HNF-SD-SNF-CN-023 REV 1
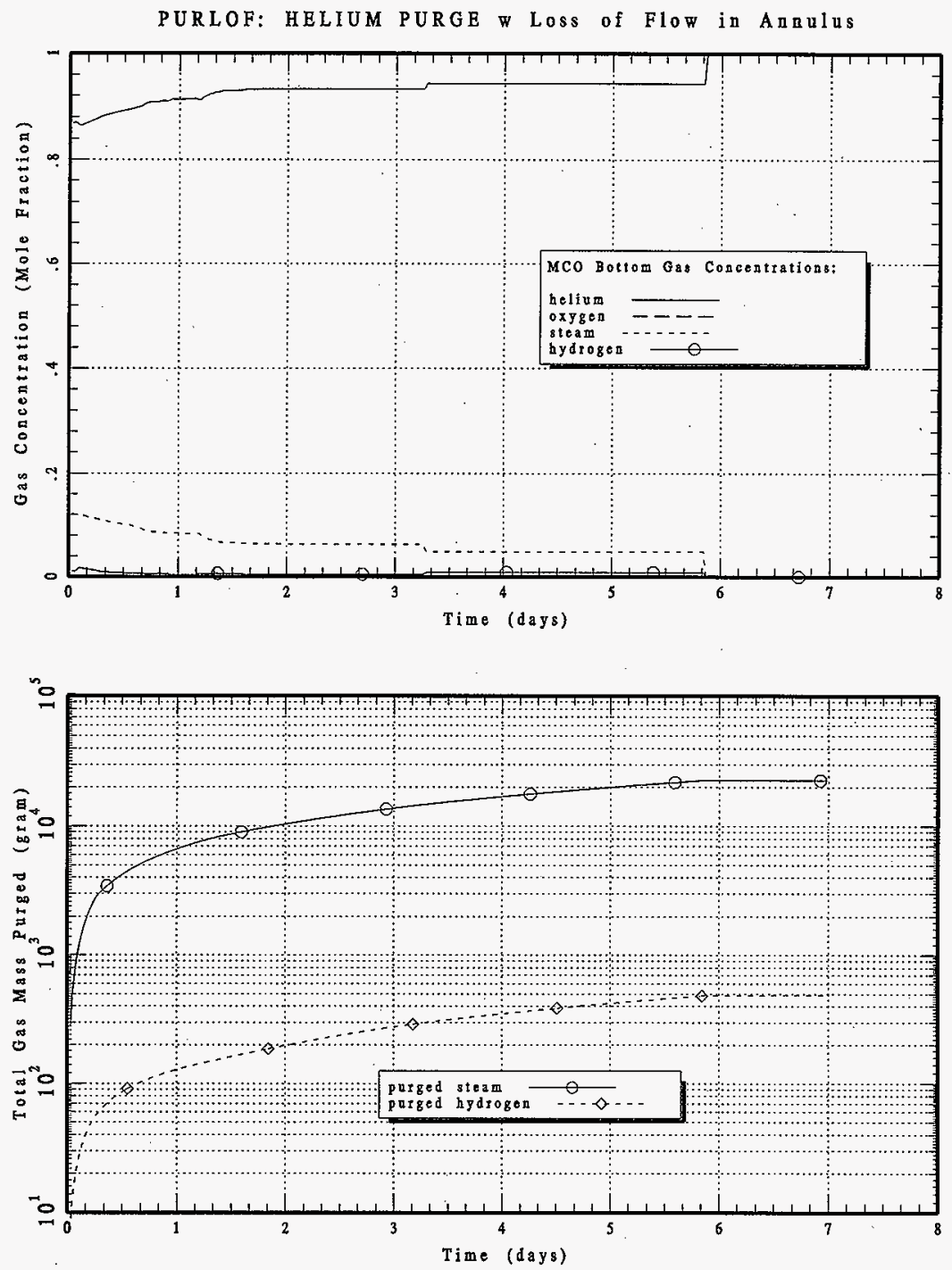

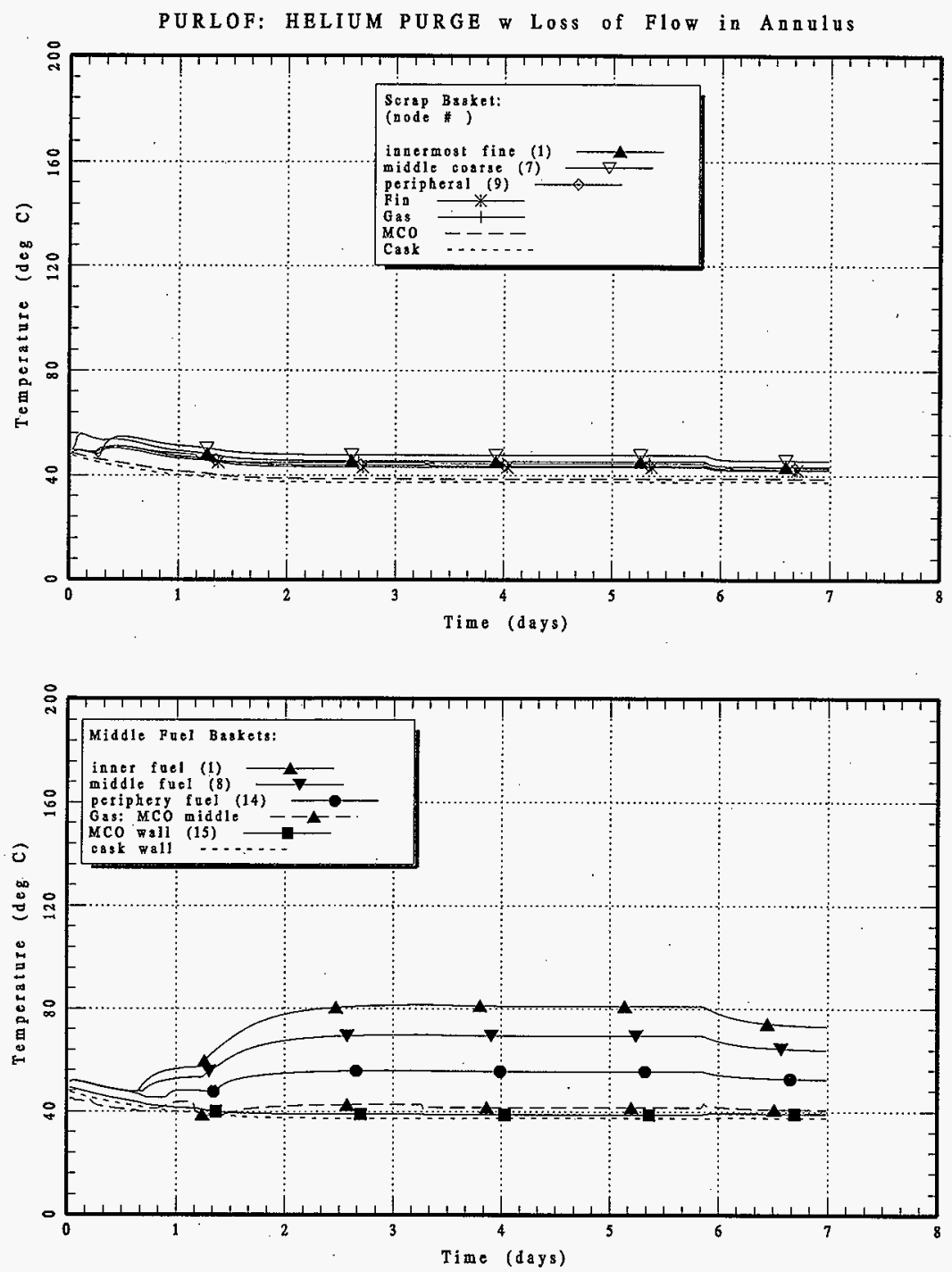
HNF-SD-SNF-CN-023 REV 1
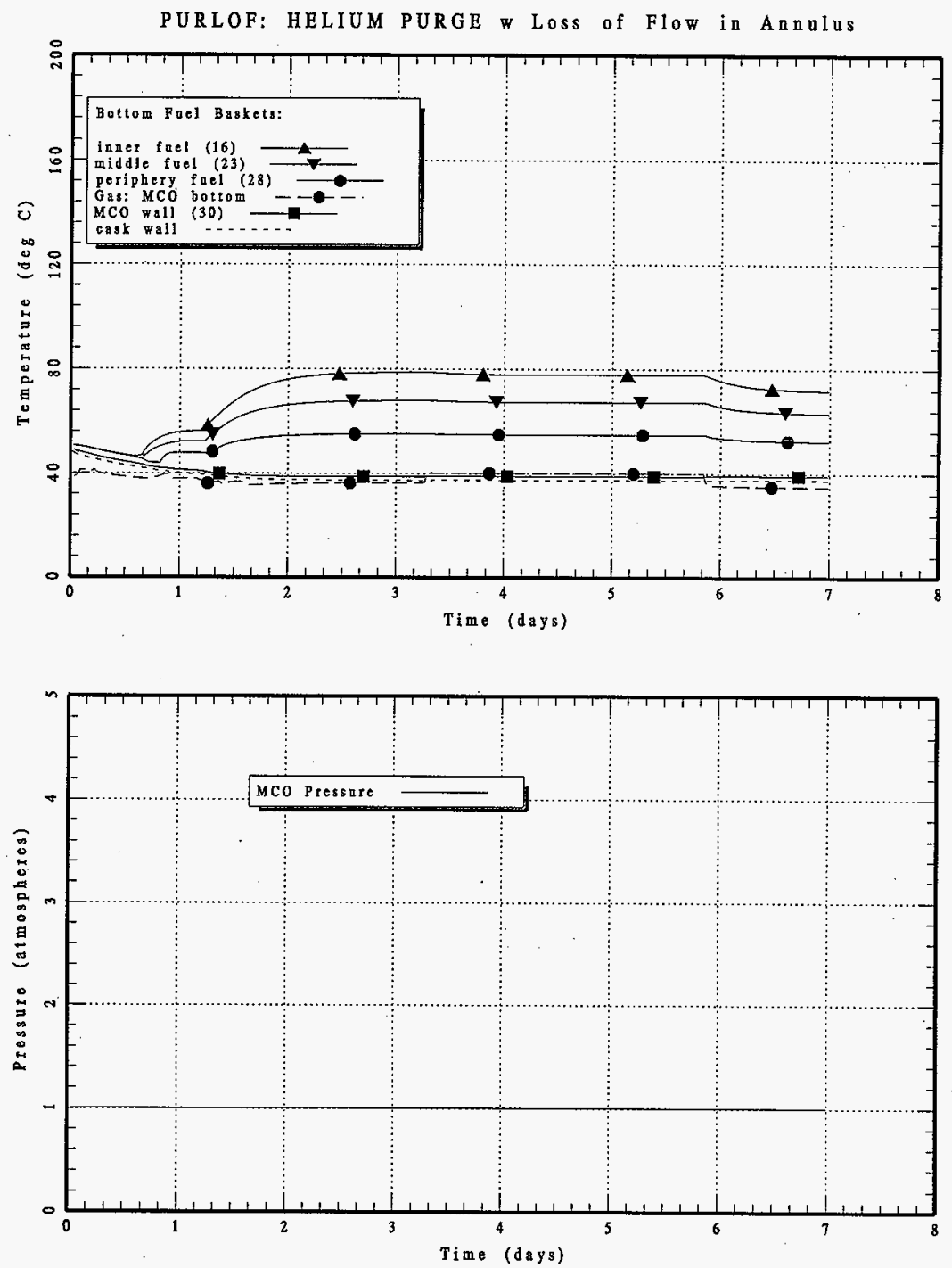
HNF-SD-SNF-CN-023 REV 1

Figure A-13 PURLOC: Helium Purge with Loss of Coolant (LOC) - Annulus Water 


\section{HNF-SD-SNF-CN-023 REV I}

This page intentionally left blank. 


\section{HNF-SD-SNF-CN-023 REV 1}

PURLOC: HELIUM PURGE w Loss of Coolant - Annulus Water
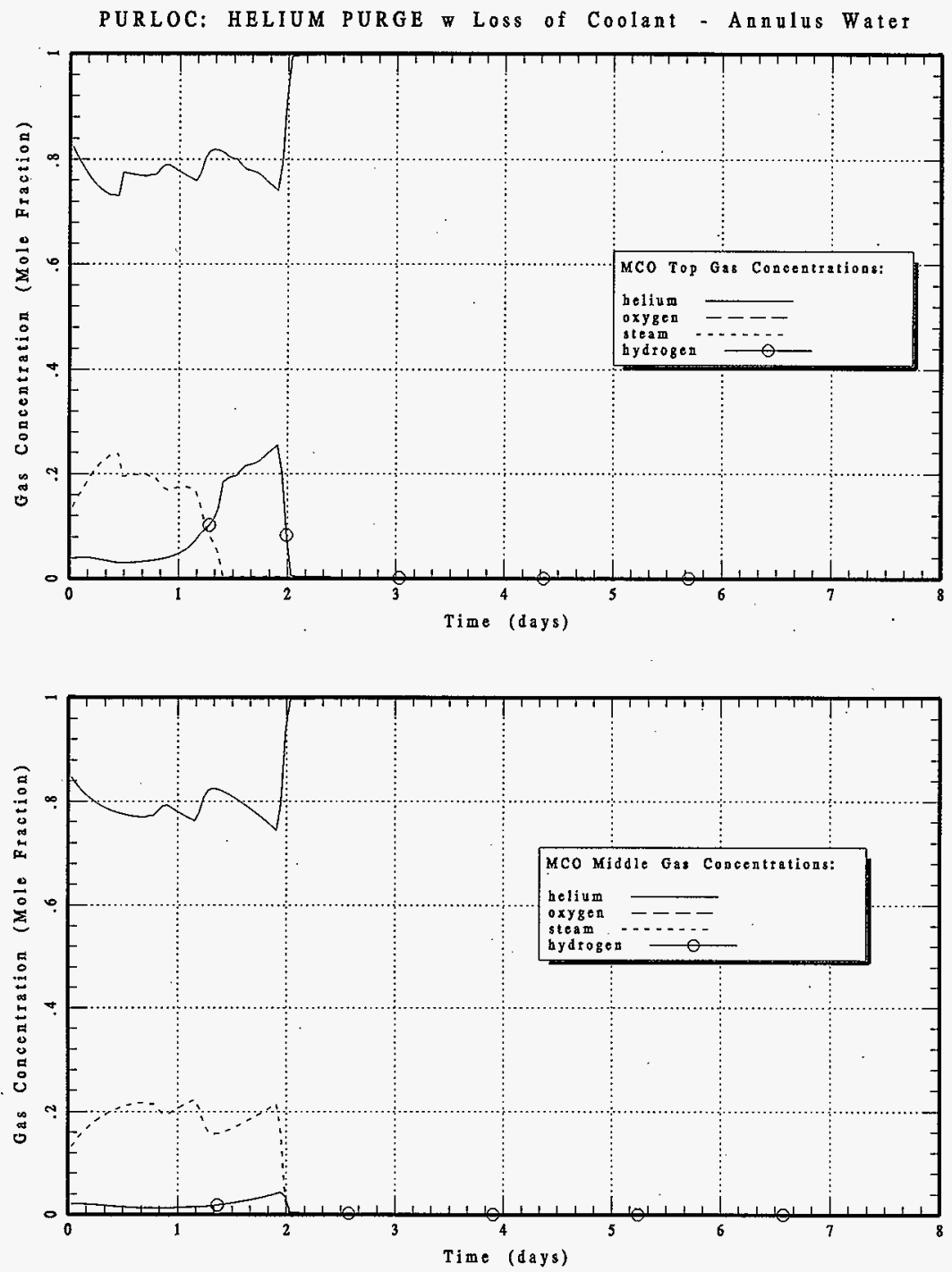


\section{HNF-SD-SNF-CN-023 REV 1}
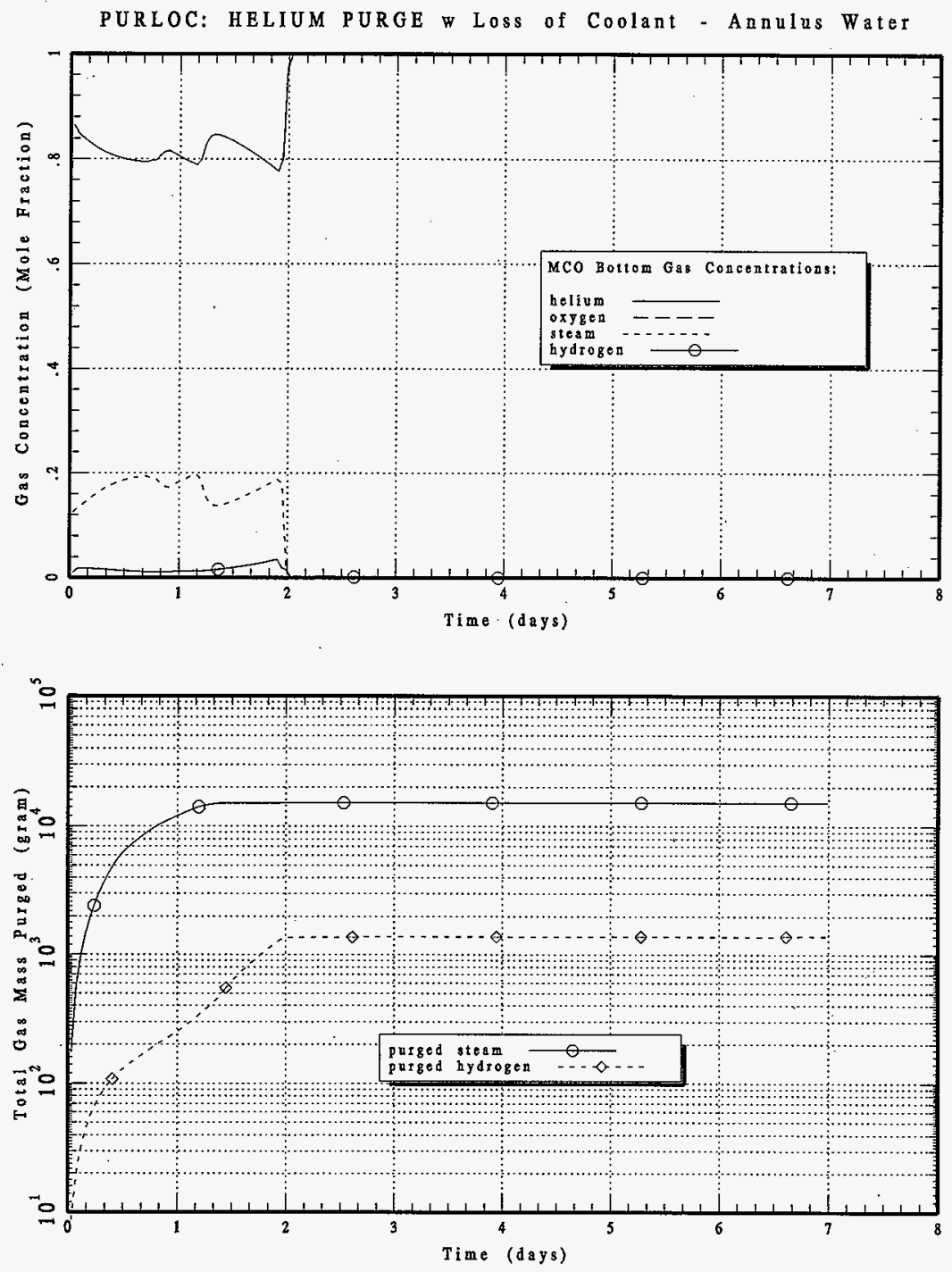

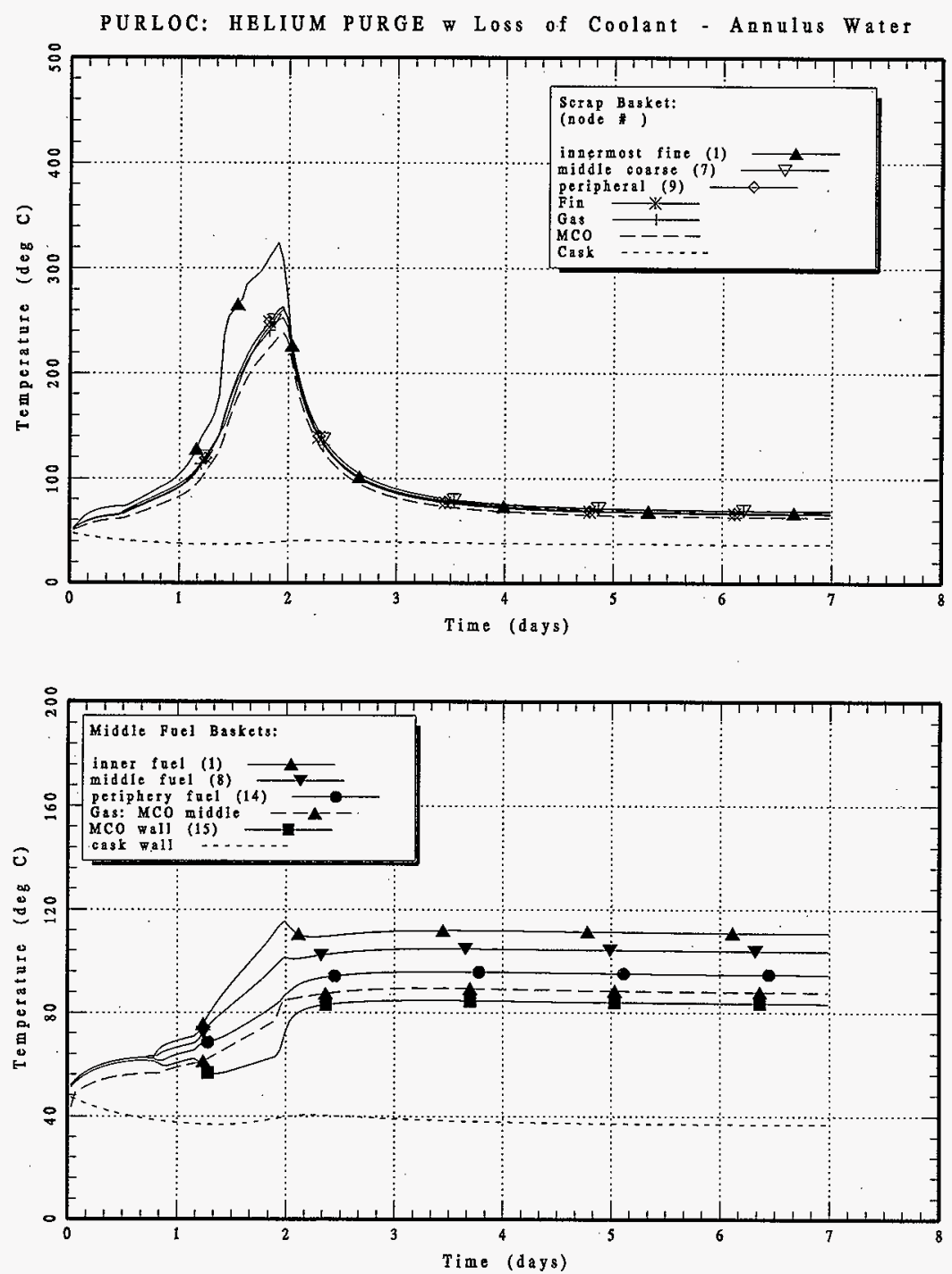

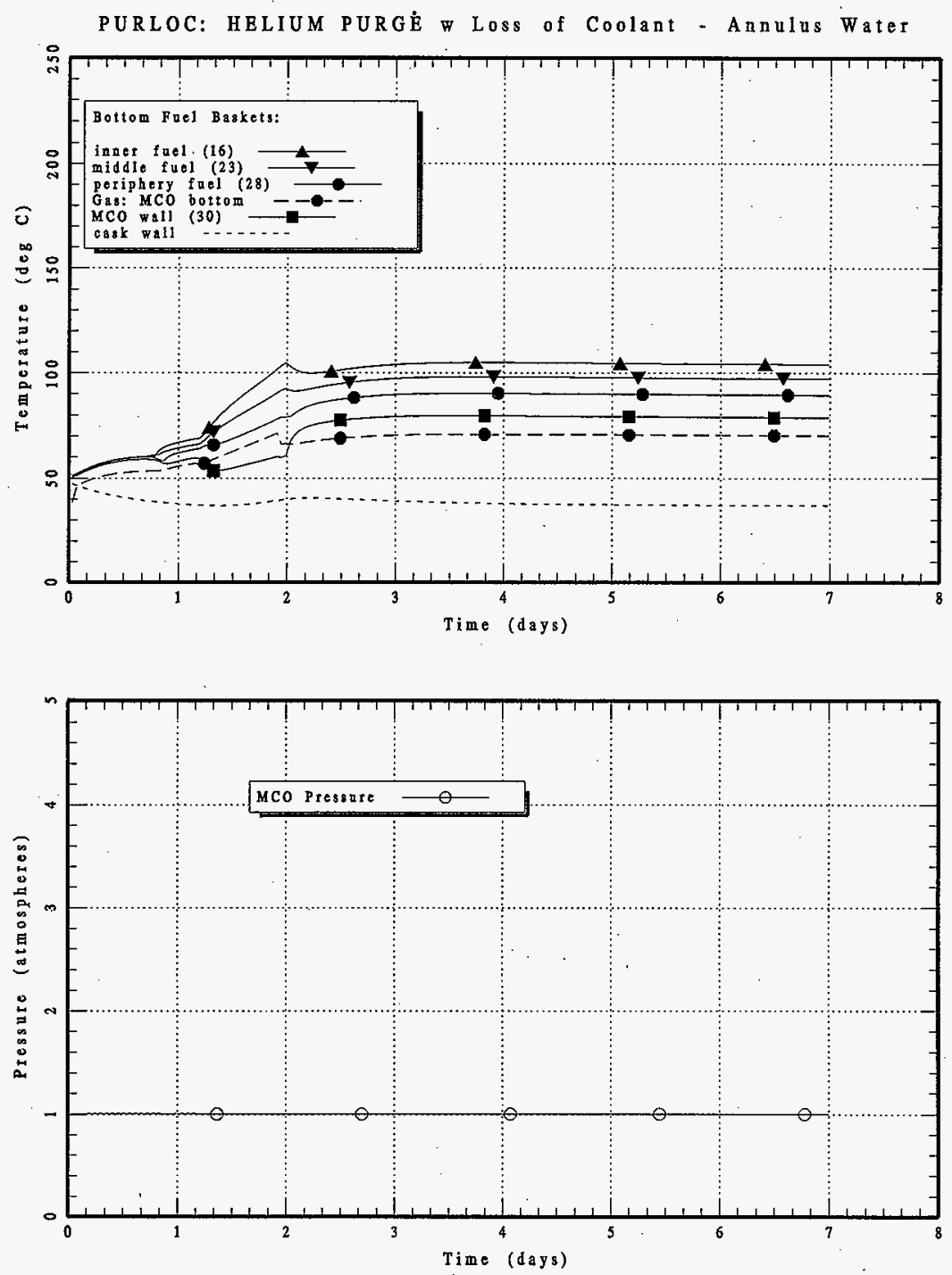
HNF-SD-SNF-CN-023 REV 1

Figure A-14 DSTOP: High-Pressure Thermal Runaway with $50^{\circ} \mathrm{C}$ Annulus 
HNF-SD-SNF-CN-023 REV 1

This page intentionally left blank. 


\section{HNF-SD-SNF-CN-023 REV 1}

DSTOP: HIGH-PRESSURE THERMAL RUNAWAY w 50 Deg C Annulus
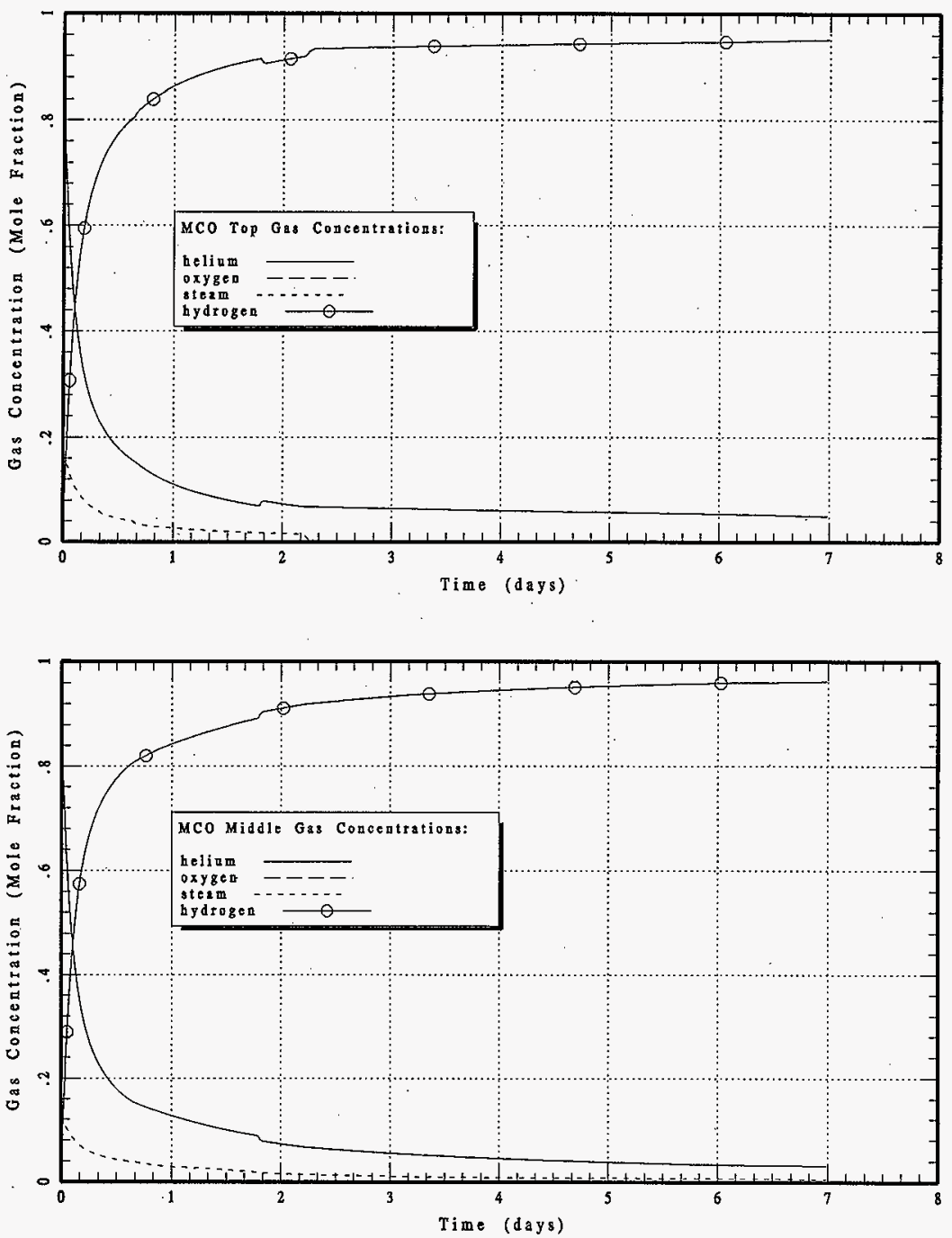


\section{HNF-SD-SNF-CN-023 REV 1}

DSTOP: HIGH-PRESSURE THERMAL RUNAWAY w 50 Deg C Analus
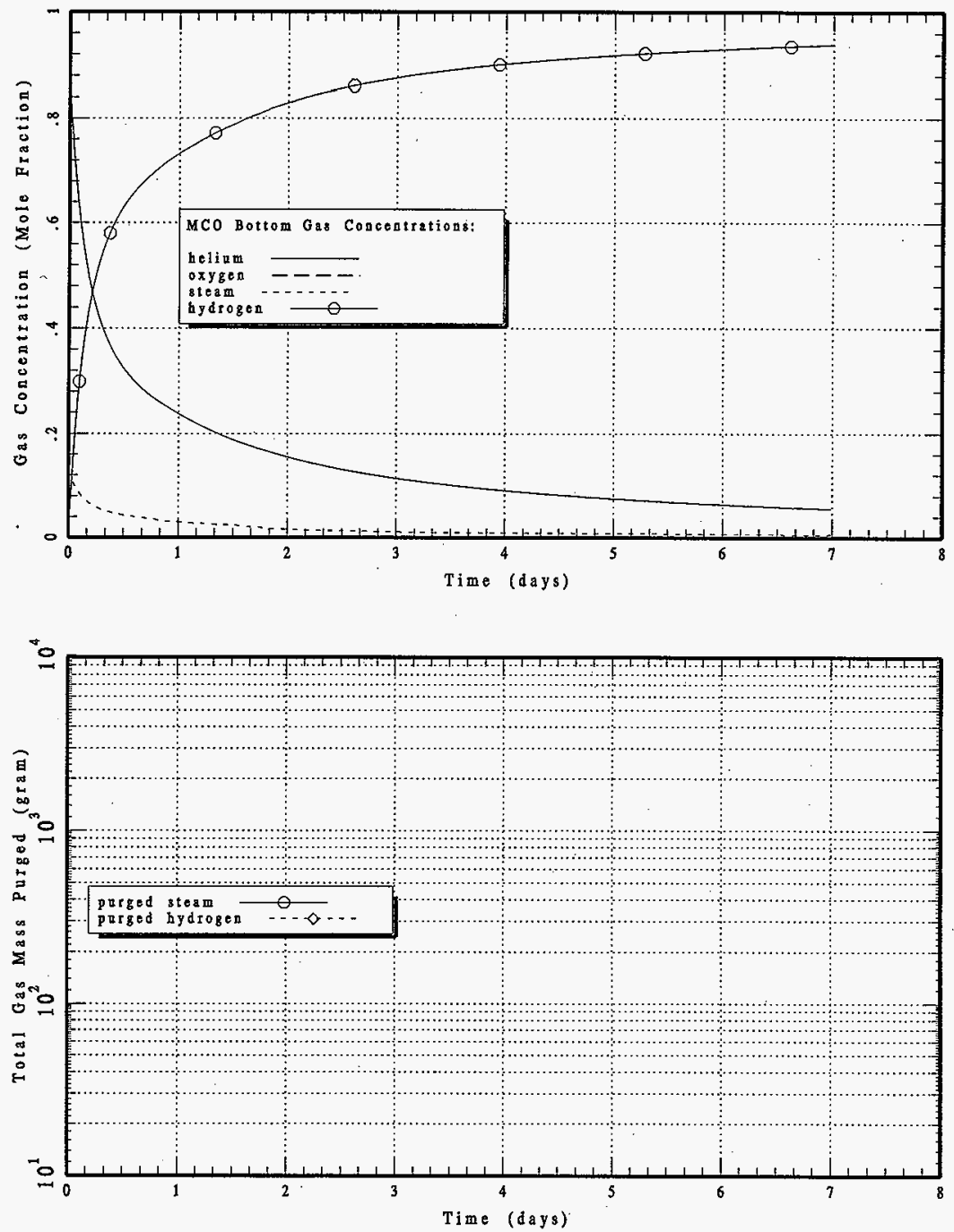

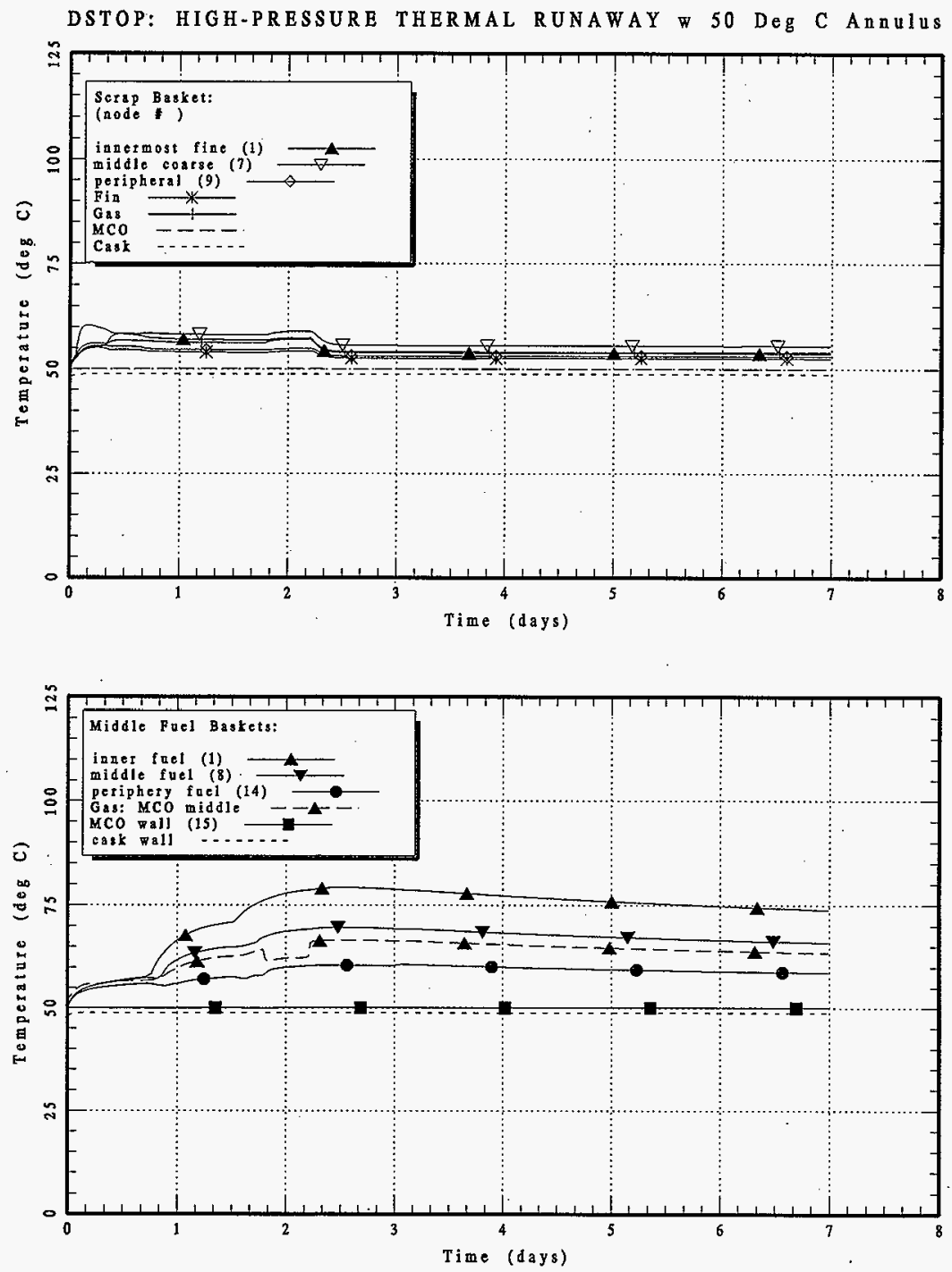


\section{HNF-SD-SNF-CN-023 REV 1}
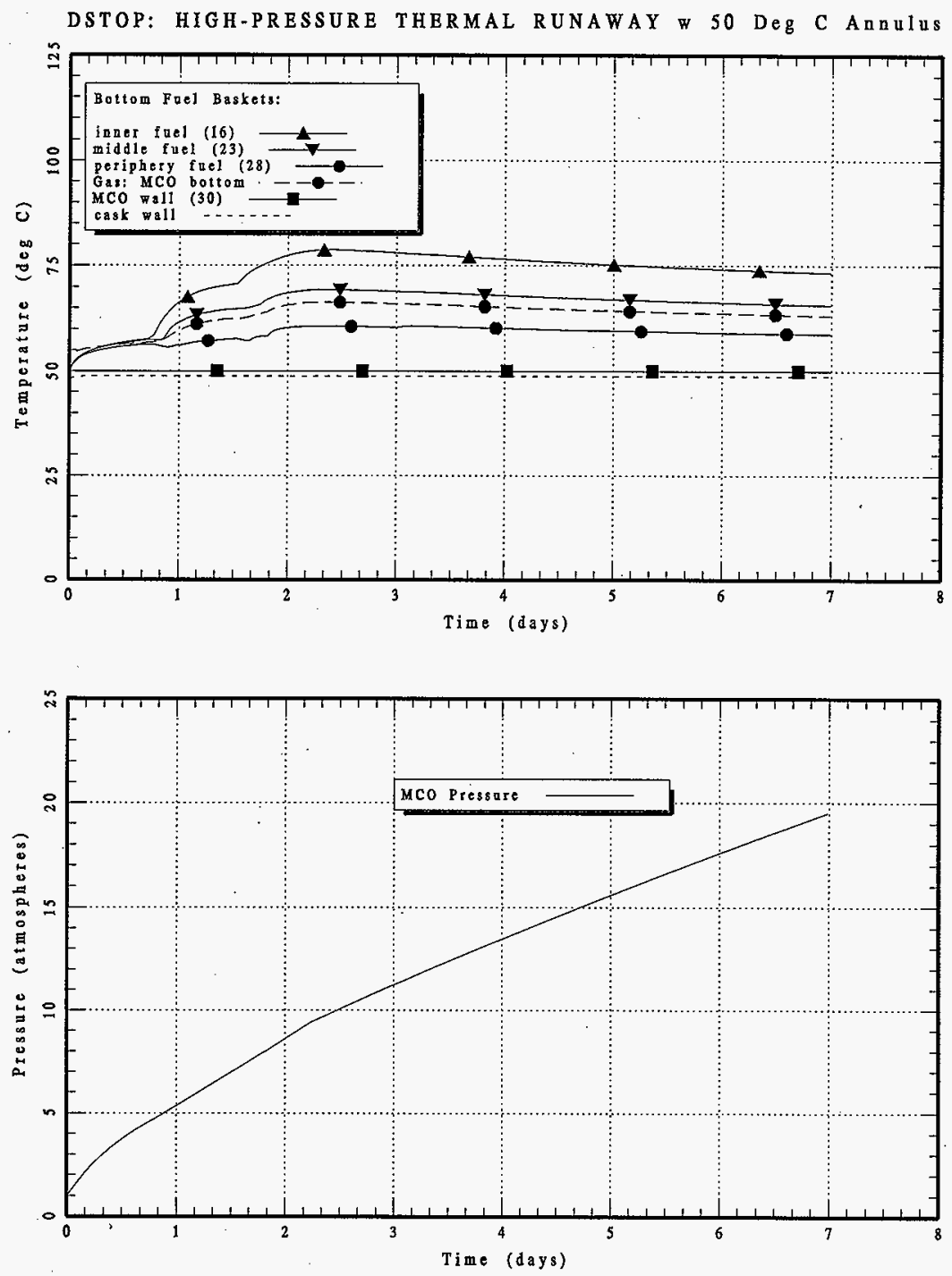


\section{HNF-SD-SNF-CN-023 REV 1}

Figure A-15 DS75KG: High-Pressure Thermal Runaway with $75 \mathrm{Kg}$ Water and $50{ }^{\circ} \mathrm{C}$ Annulus 


\section{HNF-SD-SNF-CN-023 REV 1}

This page intentionally left blank. 


\section{HNF-SD-SNF-CN-023 REV 1}

DS75KG: HI-PRES THERM RUNAWAY w $75 \mathrm{Kg}$ Water \& 50 Deg C Anaulus
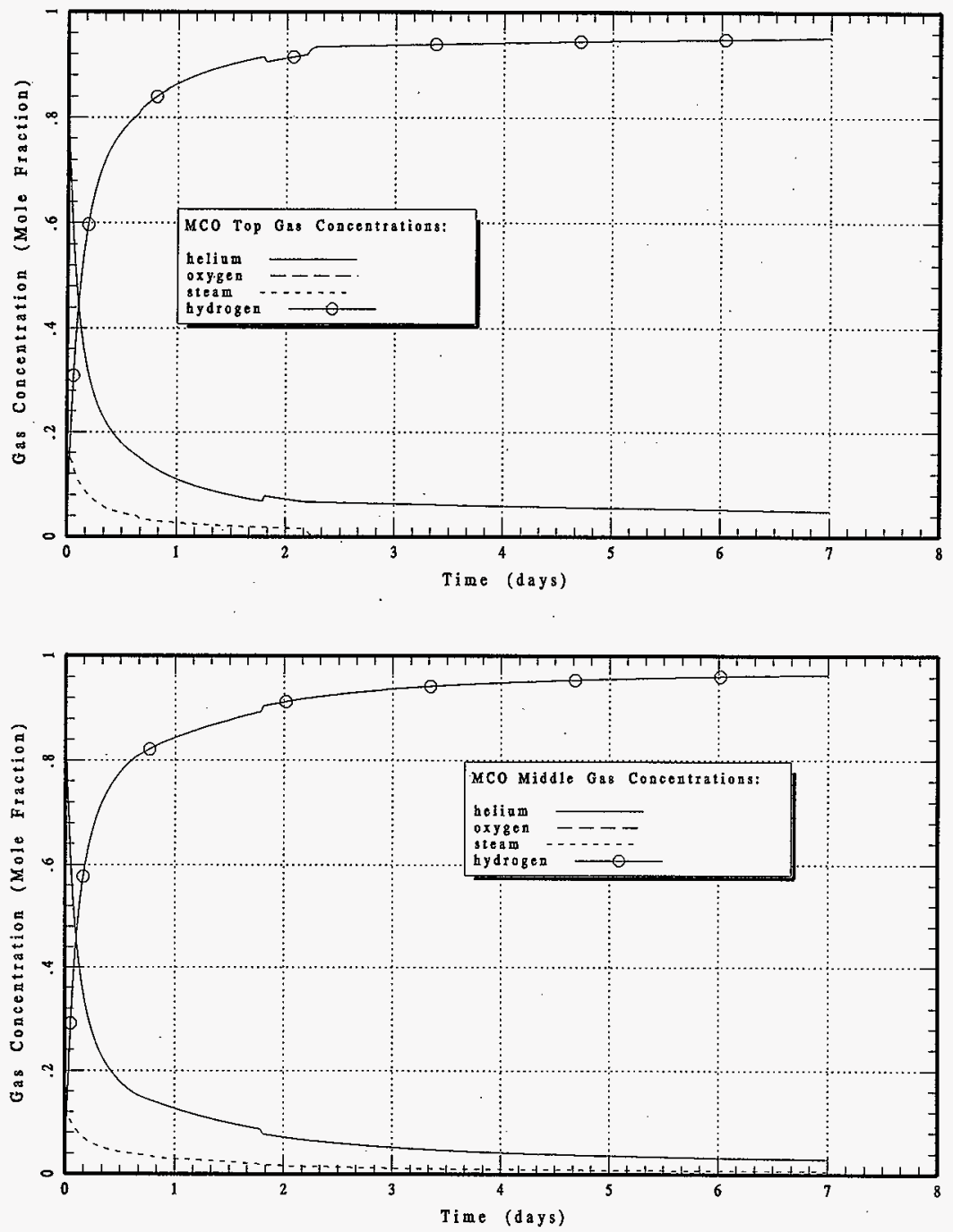


\section{HNF-SD-SNF-CN-023 REV 1}
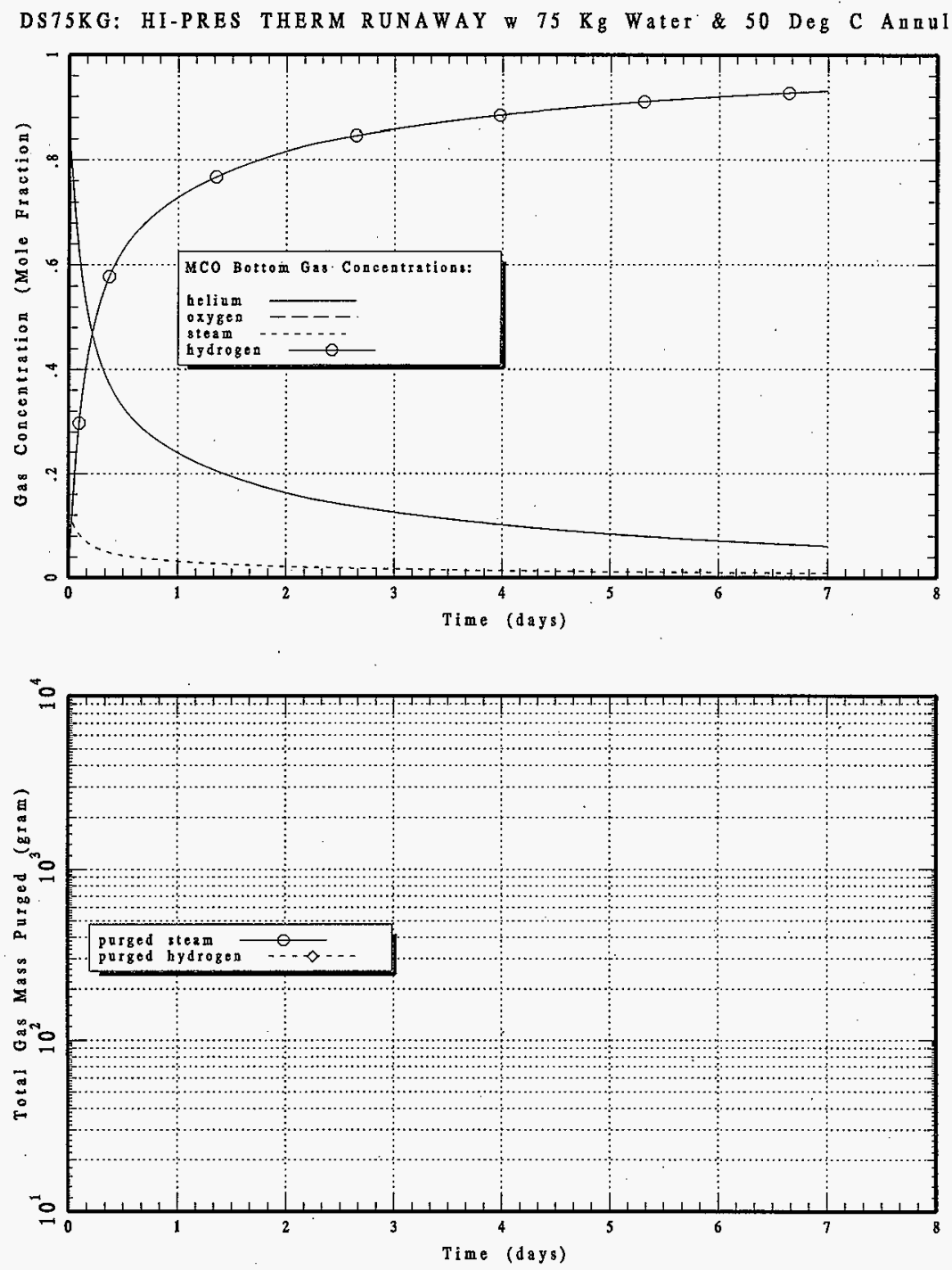


\section{HNF-SD-SNF-CN-023 REV 1}

DS75KG: HI-PRES THERM RUNAWAY w $75 \mathrm{Kg}$ Water \& 50 Deg C Anulus
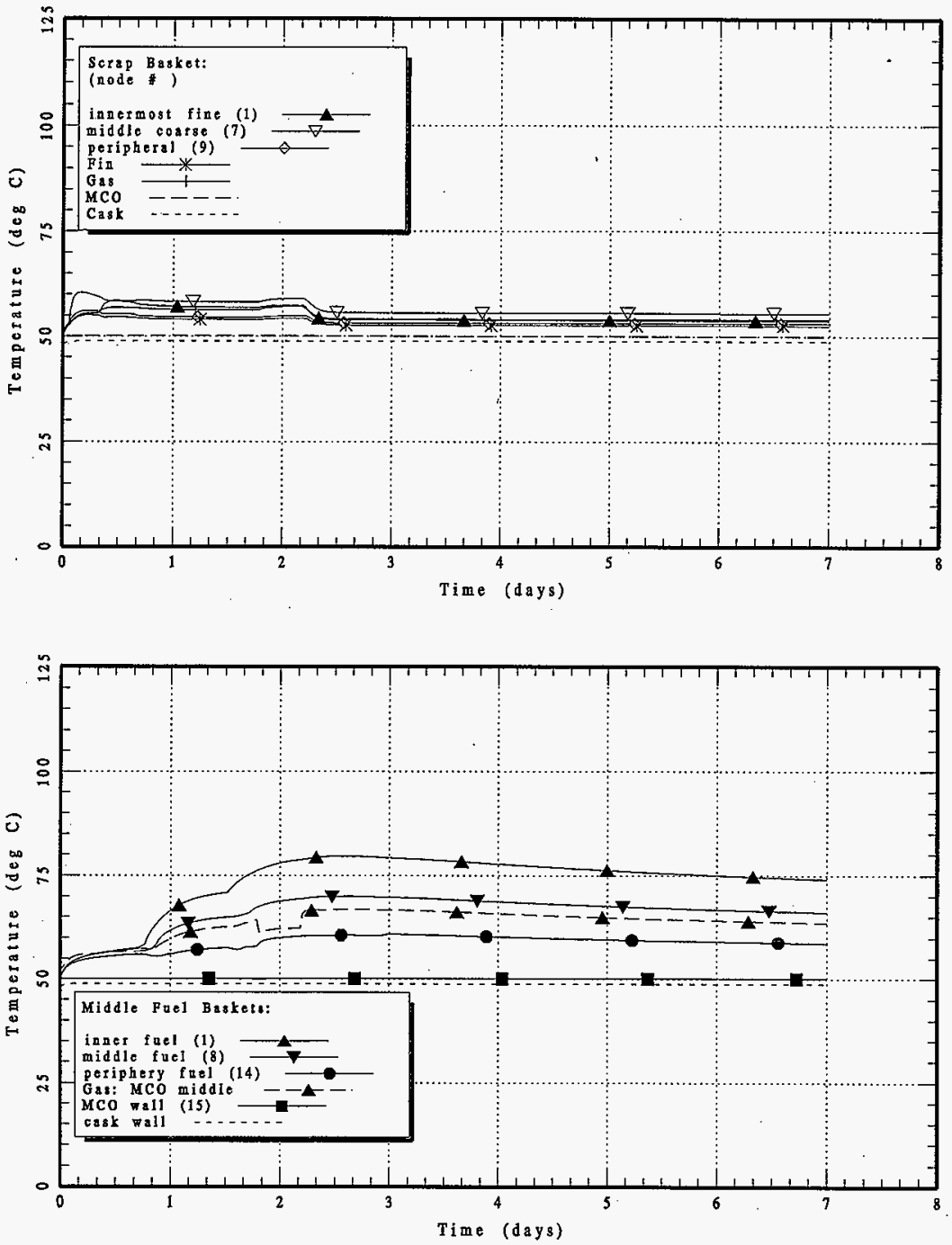


\section{HNF-SD-SNF-CN-023 REV 1}

DS75KG: HI-PRES THERM RUNAWAY w $75 \mathrm{Kg}$ Water \& 50 Deg C Annulus
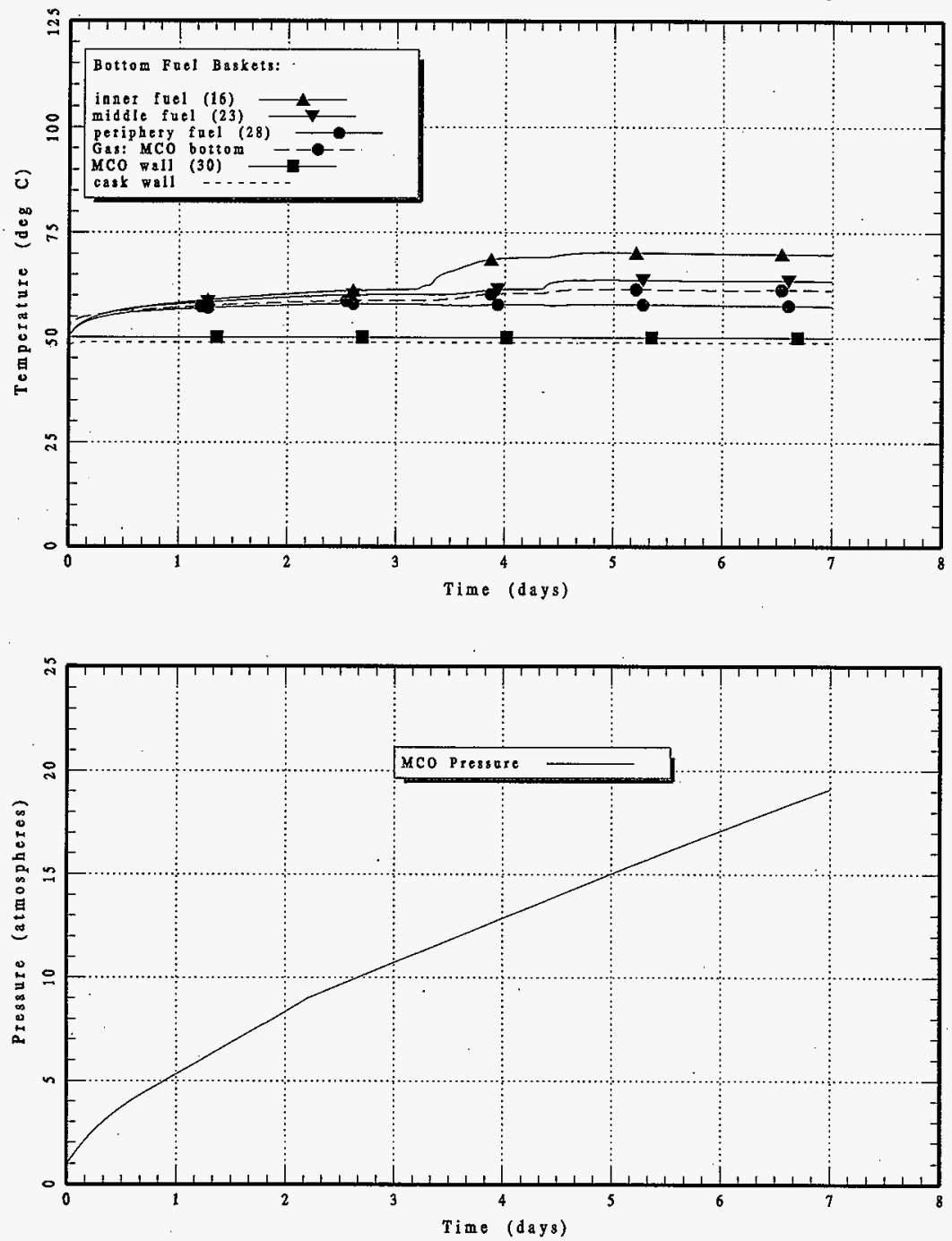


\section{HNF-SD-SNF-CN-023 REV 1}

Figure A-16 DSTOPOV: Low-Pressure Thermal Runaway with $50^{\circ} \mathrm{C}$ Annulus 


\section{HNF-SD-SNF-CN-023 REV 1}

This page intentionally left blank. 


\section{HNF-SD-SNF-CN-023 REV 1}

DSTOPOV: LOW-PRESSURE THERMAL RUNAWAY w 50 Deg C AnnUIUs
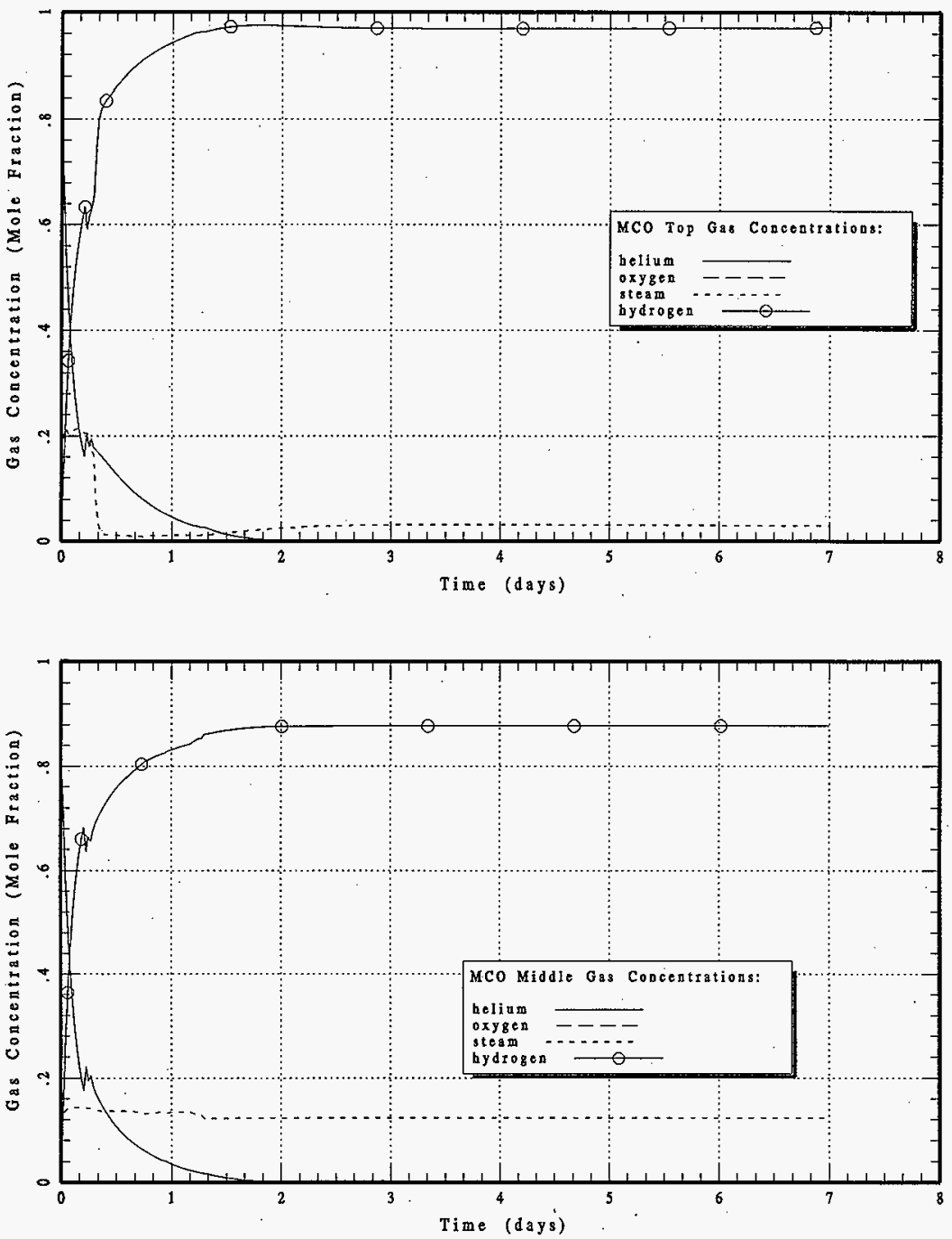
DSTOPOV: LOW-PRESSURE THERMAL RUNAWAY w 50 Deg C Annulus
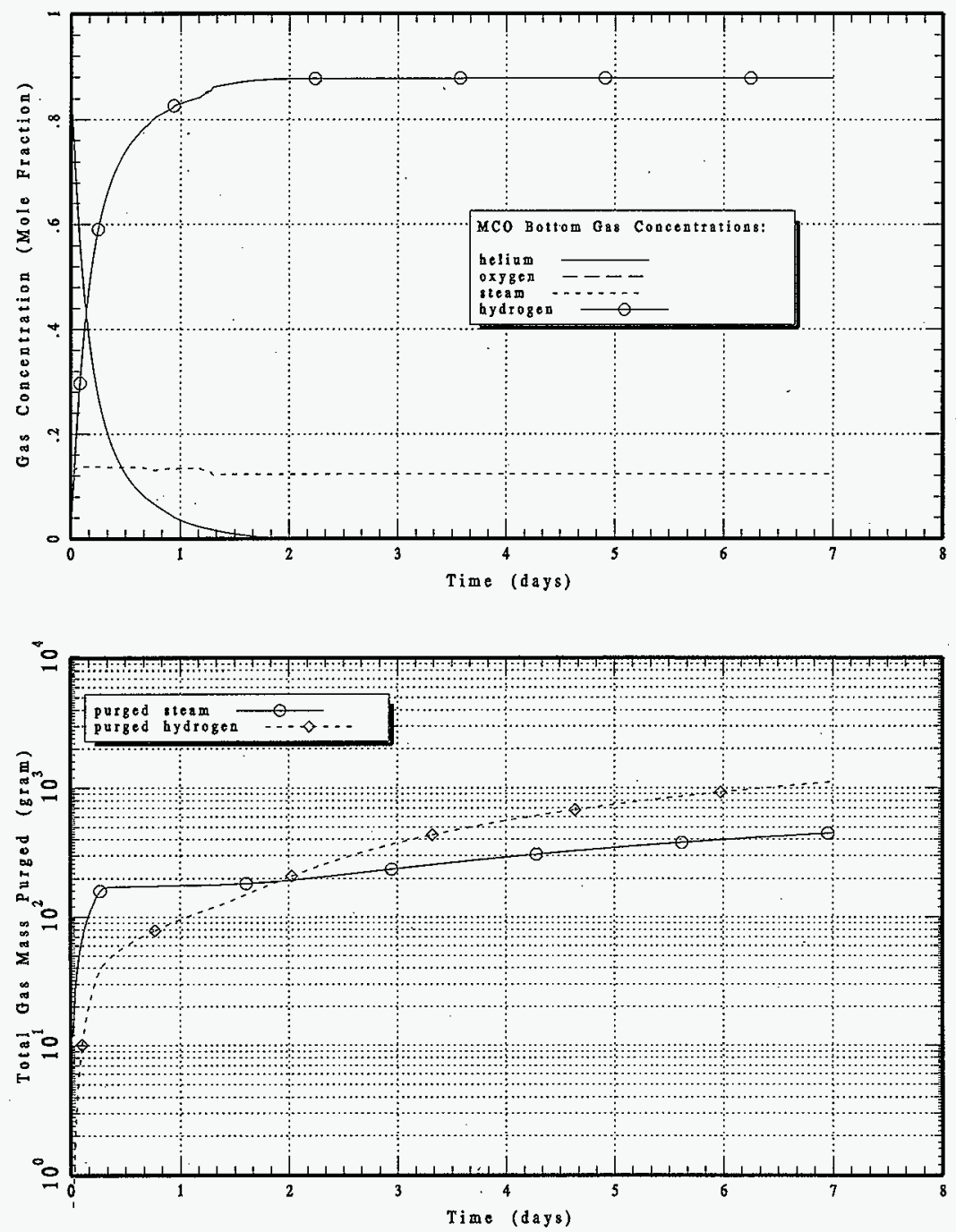
DSTOPOV: LOW-PRESSURE THERMAL RUNAWAY w 50 Deg C Annulus
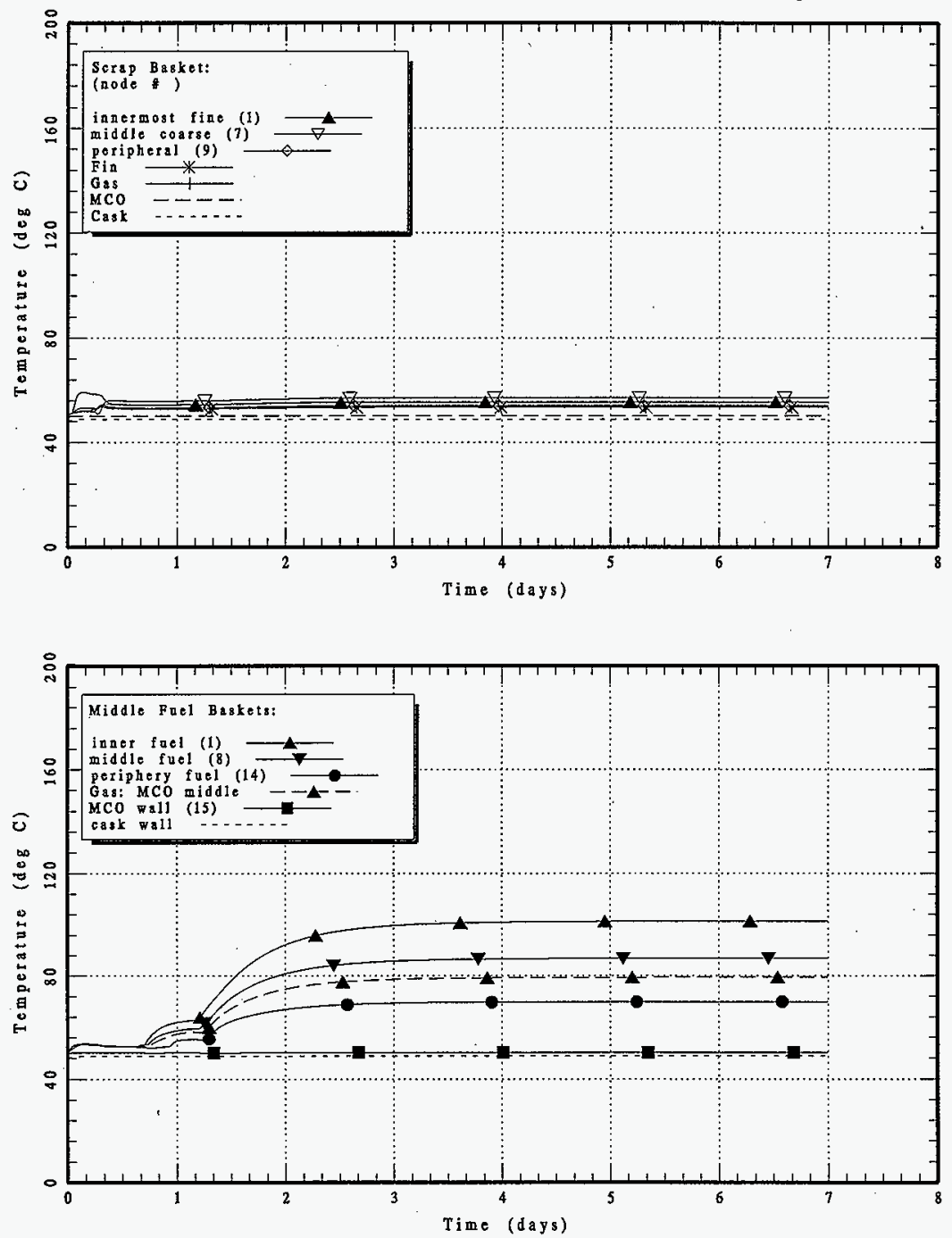


\section{HNF-SD-SNF-CN-023 REV 1}
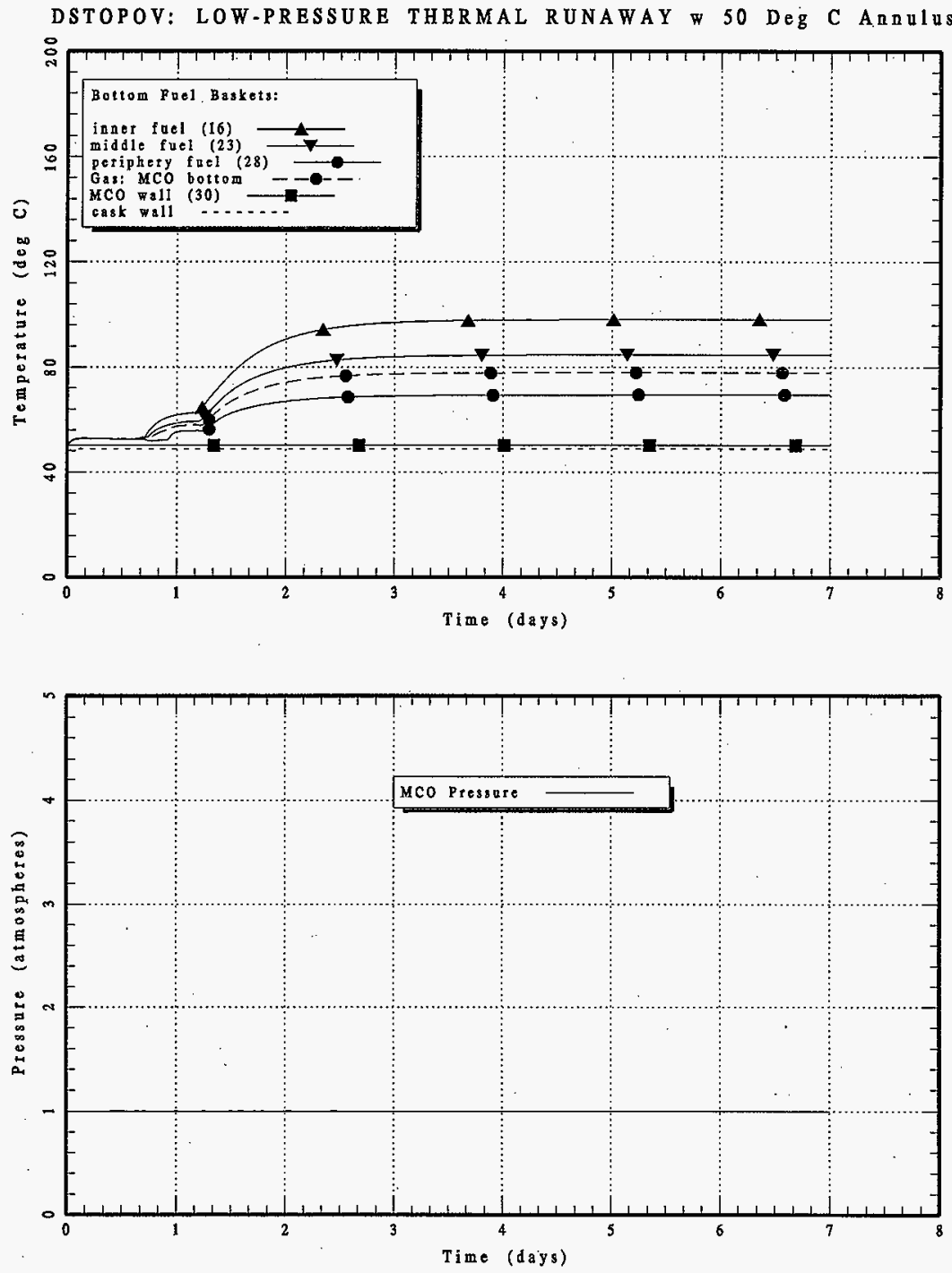
HNF-SD-SNF-CN-023 REV I

Figure A-17 DSLOF: High-Pressure Thermal Runaway with Loss of Flow in Annulus 


\section{HNF-SD-SNF-CN-023 REV 1}

This page intentionally left blank. 


\section{HNF-SD-SNF-CN-023 REV 1}

DSLOF: HIGH-PRESSURE THERMAL RUNAWAY LOSS of Flow in Annulus
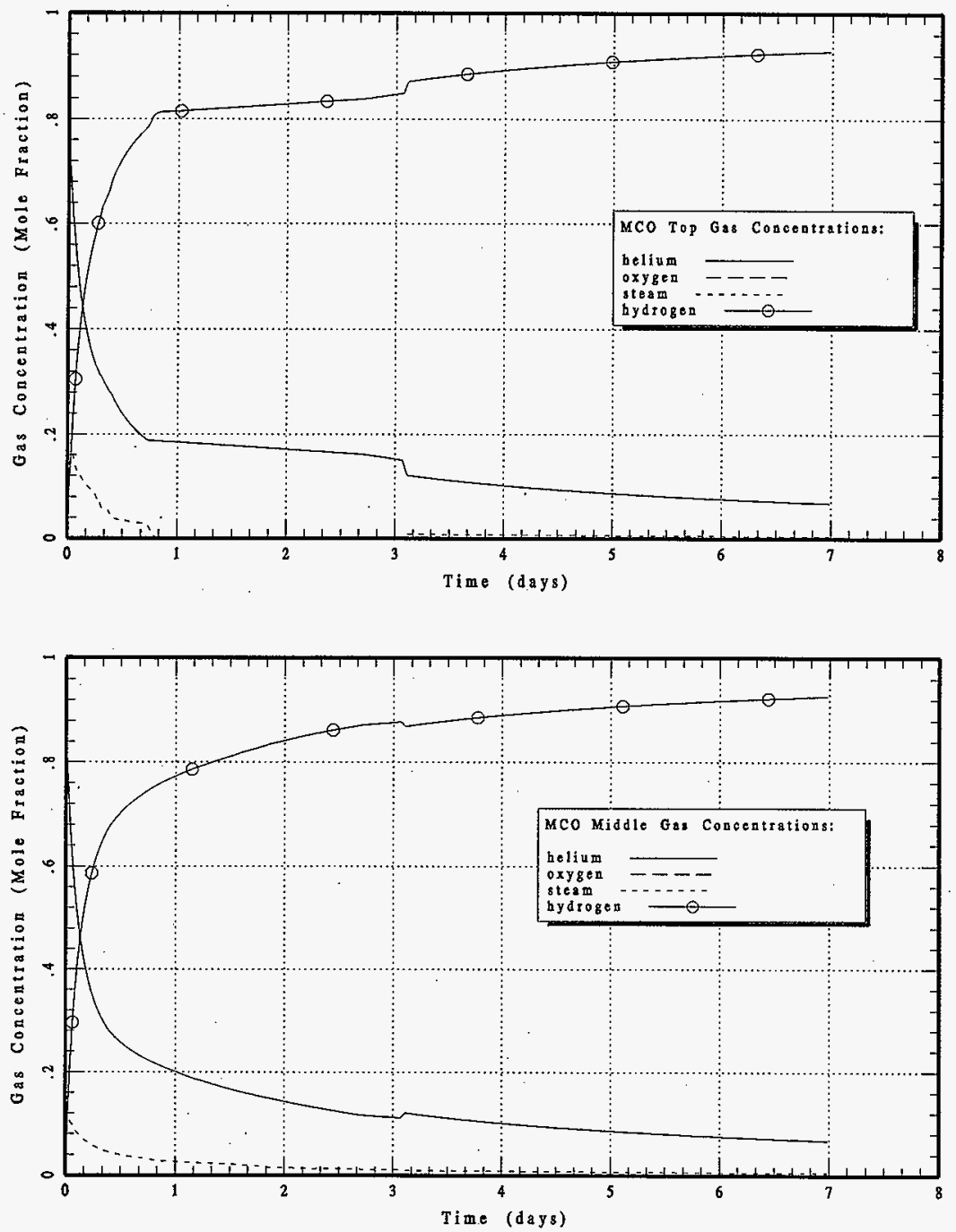
DSLOF: HIGH-PRESSURE THERMAL RUNAWAY w Loss of Flow in Annulus
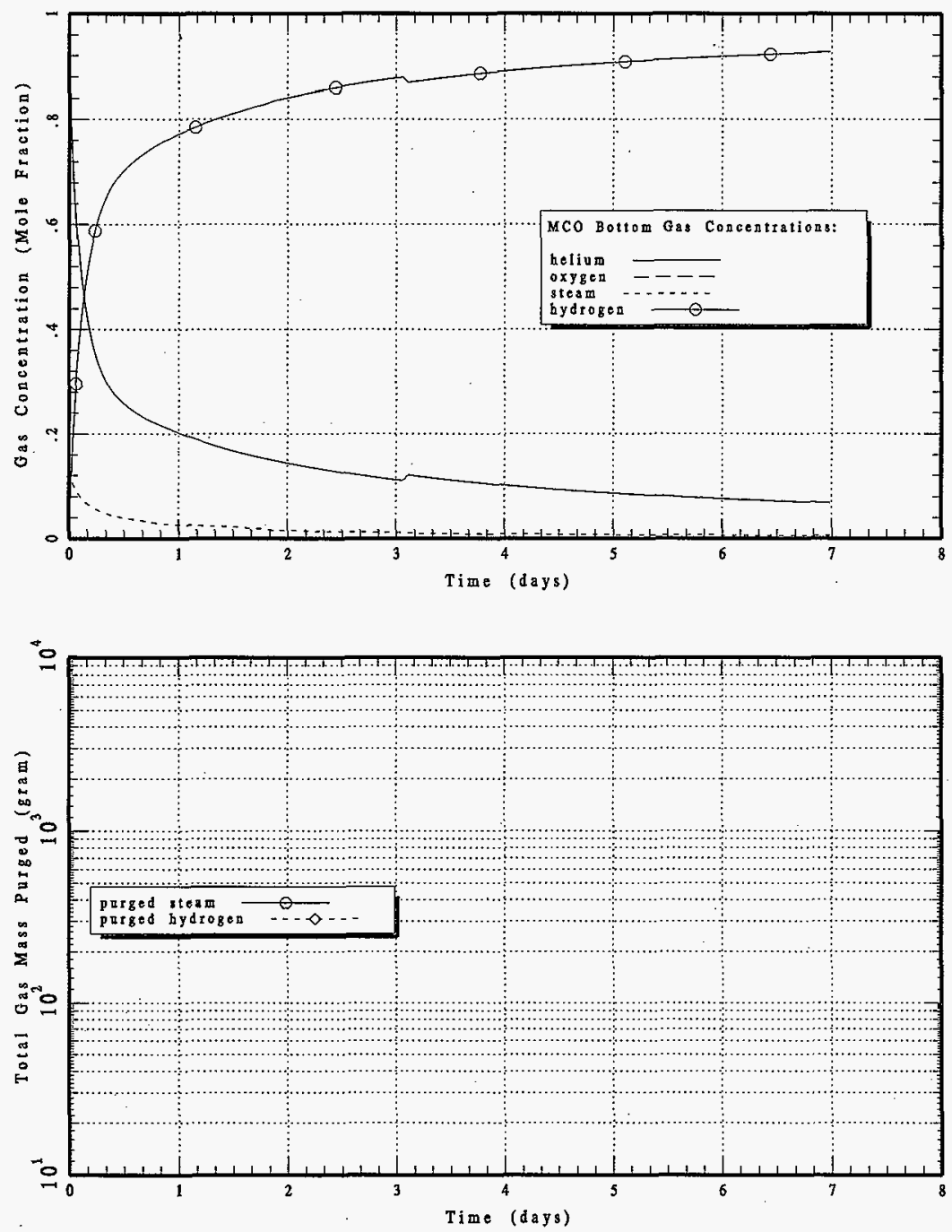


\section{HNF-SD-SNF-CN-023 REV 1}
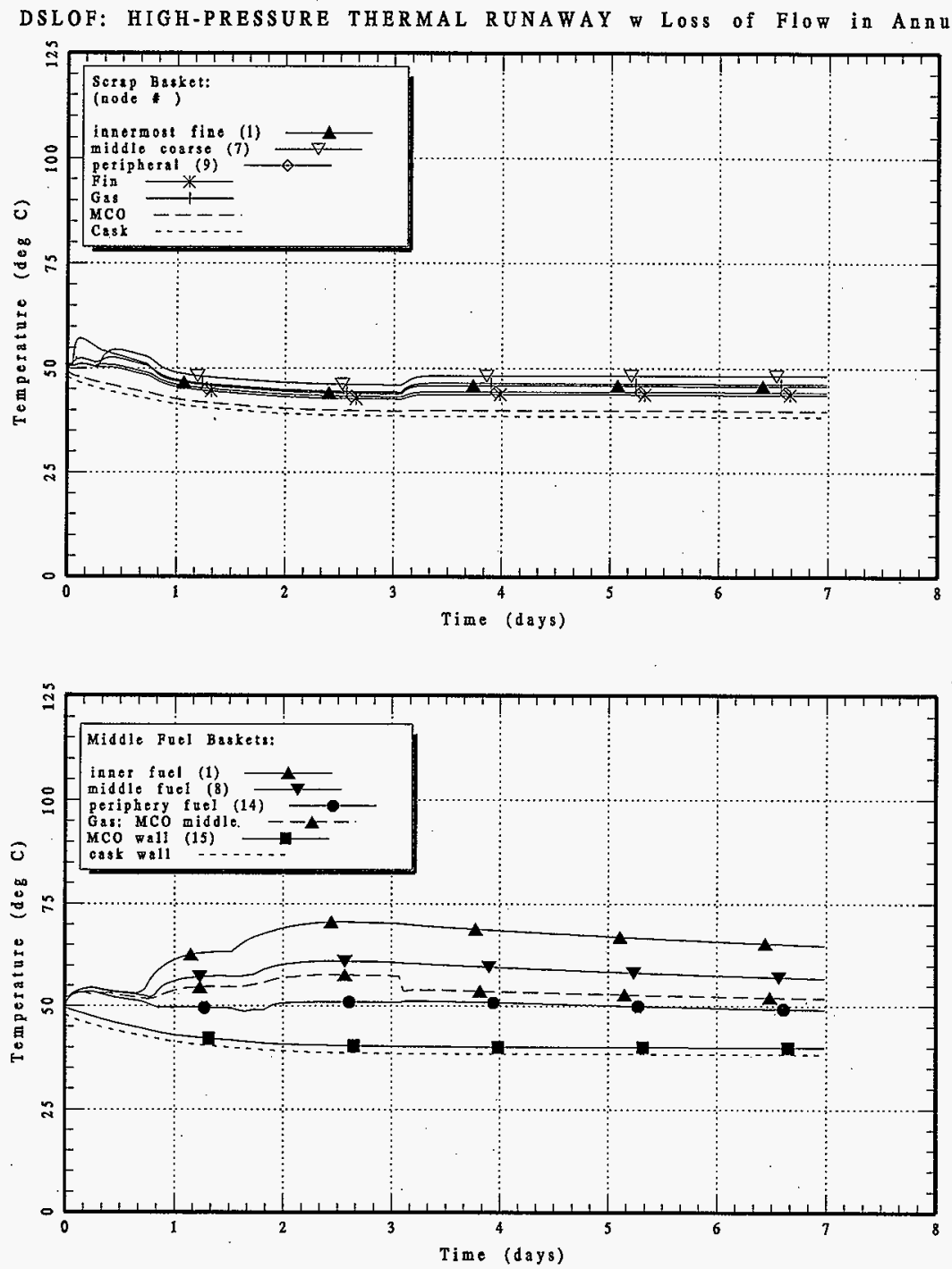


\section{HNF-SD-SNF-CN-023 REV 1}
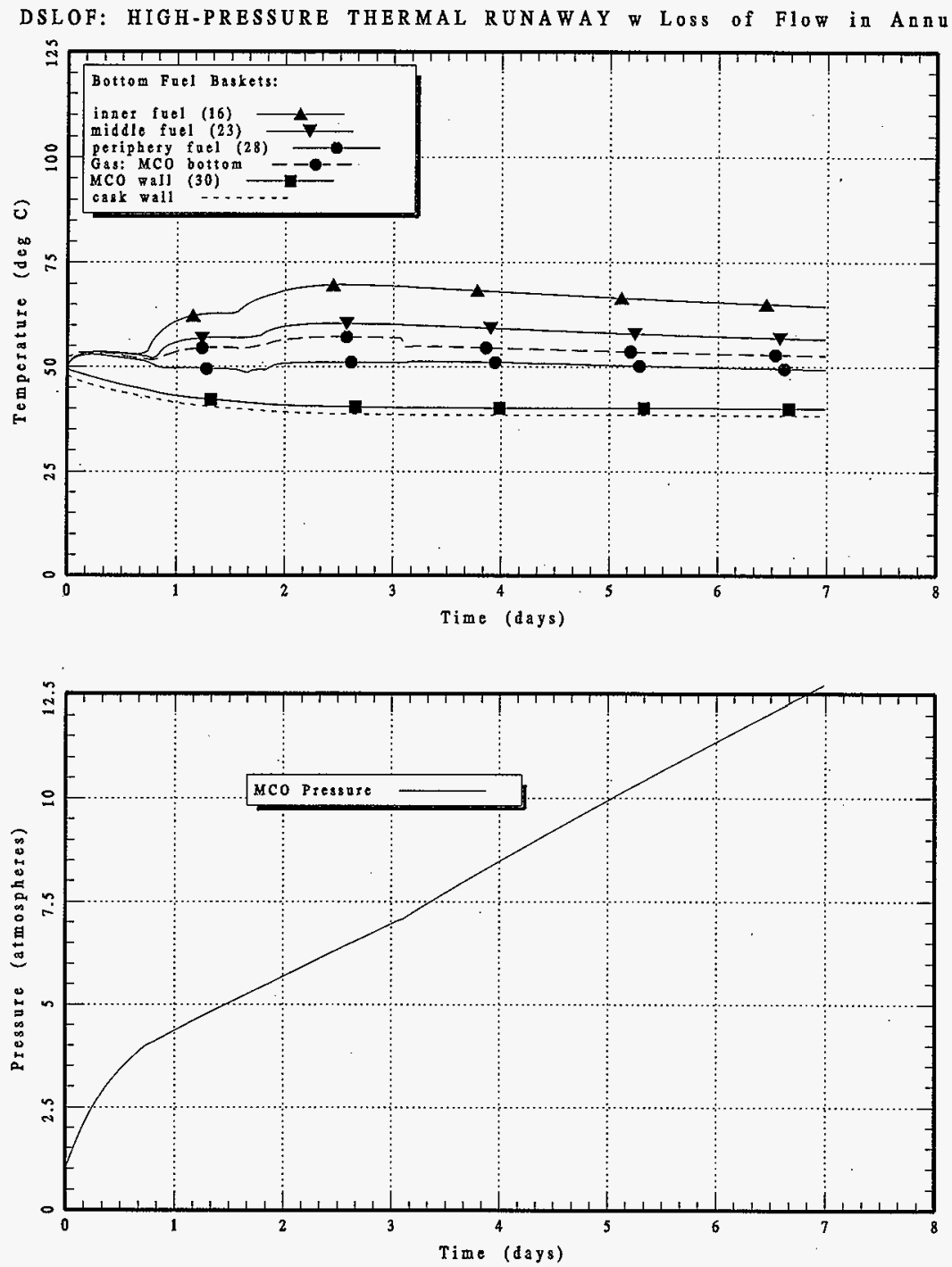
Figure A-18 DLOF75KG: High-Pressure Thermal Runaway with $75 \mathrm{Kg}$ Water and Loss of Flow in Annulus 


\section{HNF-SD-SNF-CN-023 REV 1}

This page intentionally left blank. 


\section{HNF-SD-SNF-CN-023 REV 1}

DLOF75RG: HI-PRES THERM RUNAWAY w $75 \mathrm{Kg}$ Water \& Loss of Flow in Annulus
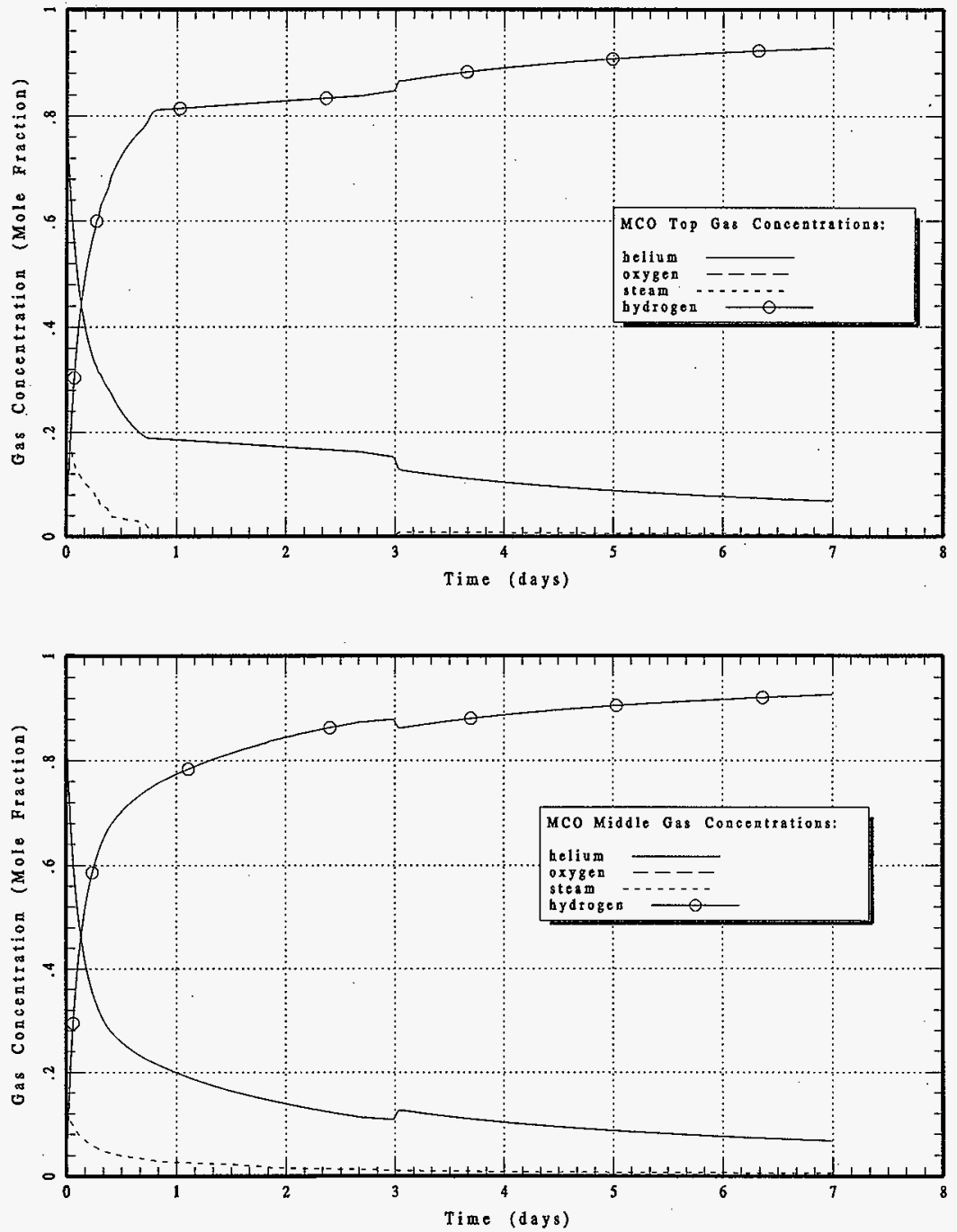

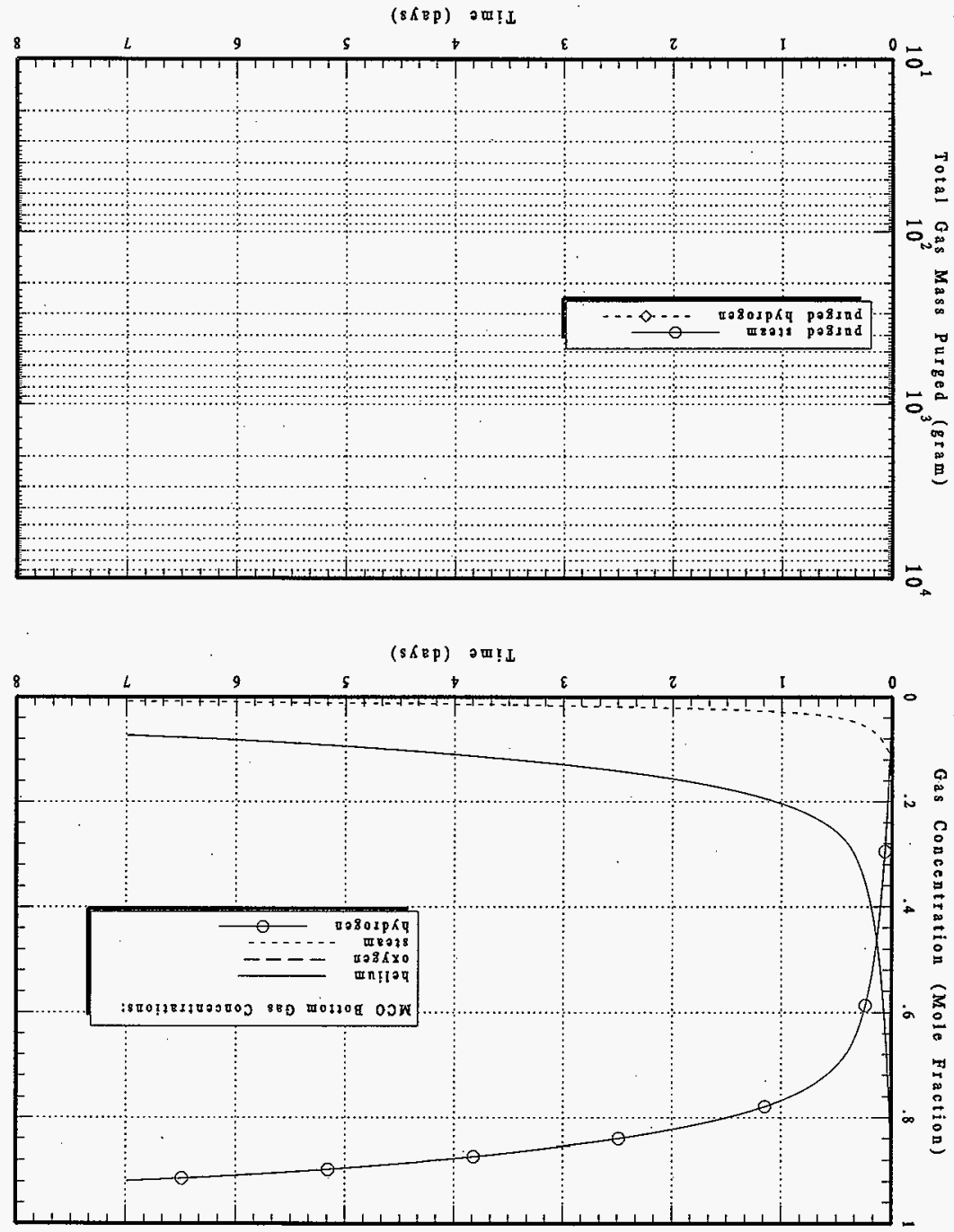

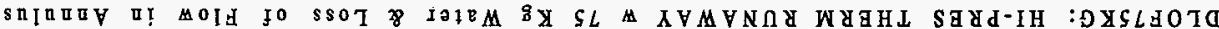


DLOF75KG：HI-PRES THERM RUNAWAY w $75 \mathrm{Kg}$ Water \& Loss of Flow in Annulus
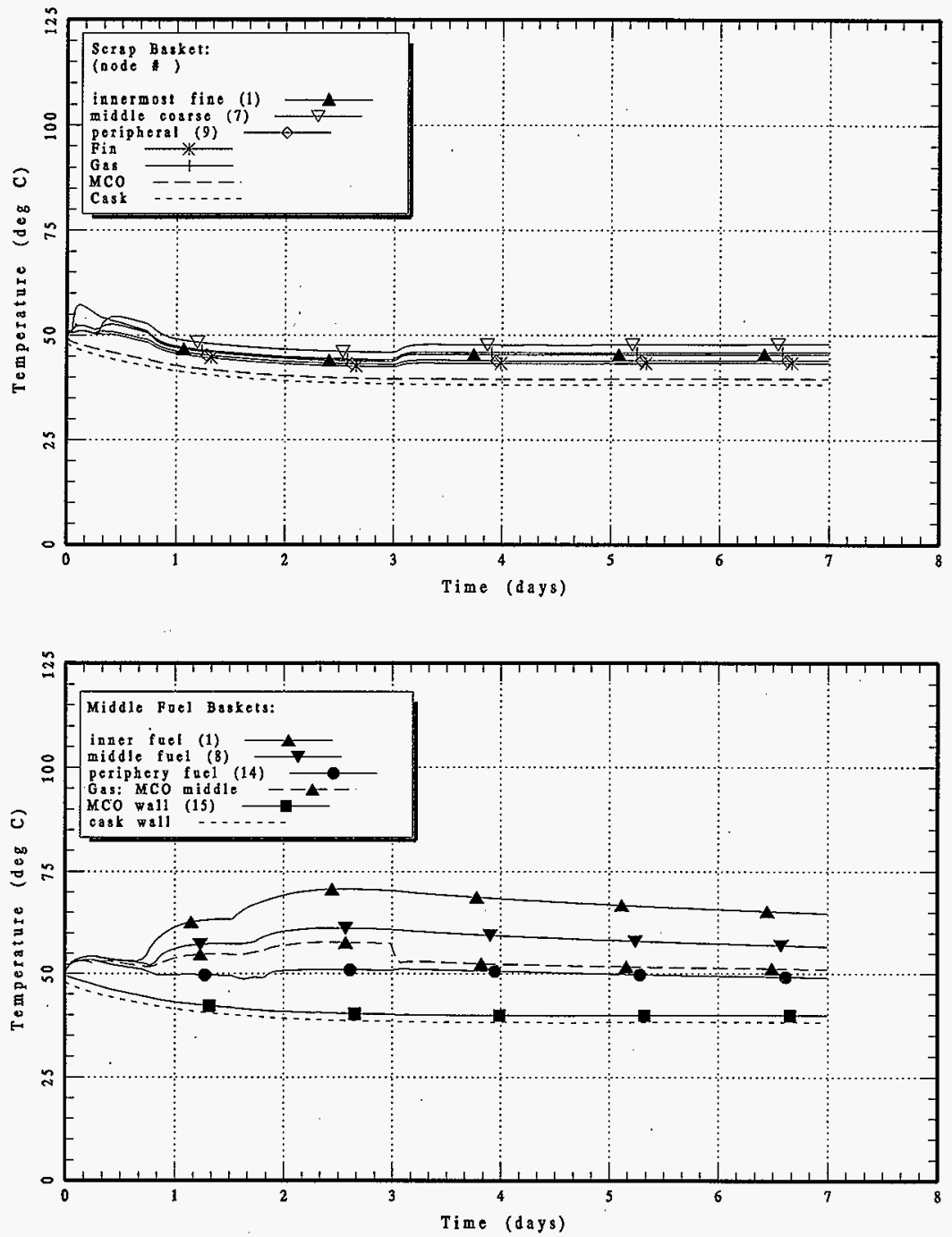
DLOF75KG: HI-PRES THERM RUNAWAY w $75 \mathrm{Kg}$ Water \& Loss of Flow in Analus
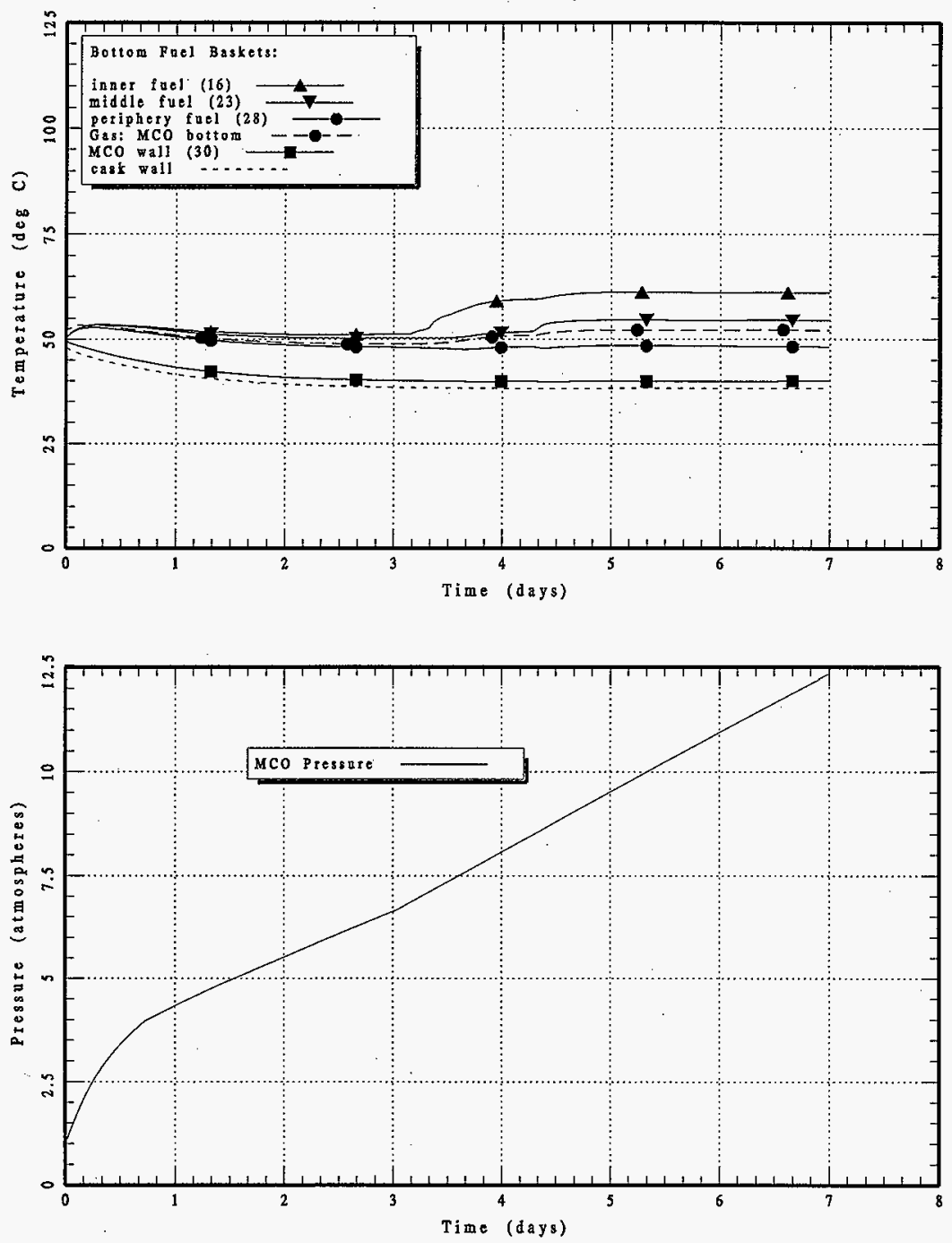
HNF-SD-SNF-CN-023 REV 1

Figure A-19 DSLOFOV: Low-Pressure Thermal Runaway with Loss of Flow in Annulus 


\section{HNF-SD-SNF-CN-023 REV 1}

This page intentionally left blank. 


\section{HNF-SD-SNF-CN-023 REV 1}

DSLOFOV: LOW-PRESSURE THERMAL RUNAWAY LOSS Of Flow in Angulus
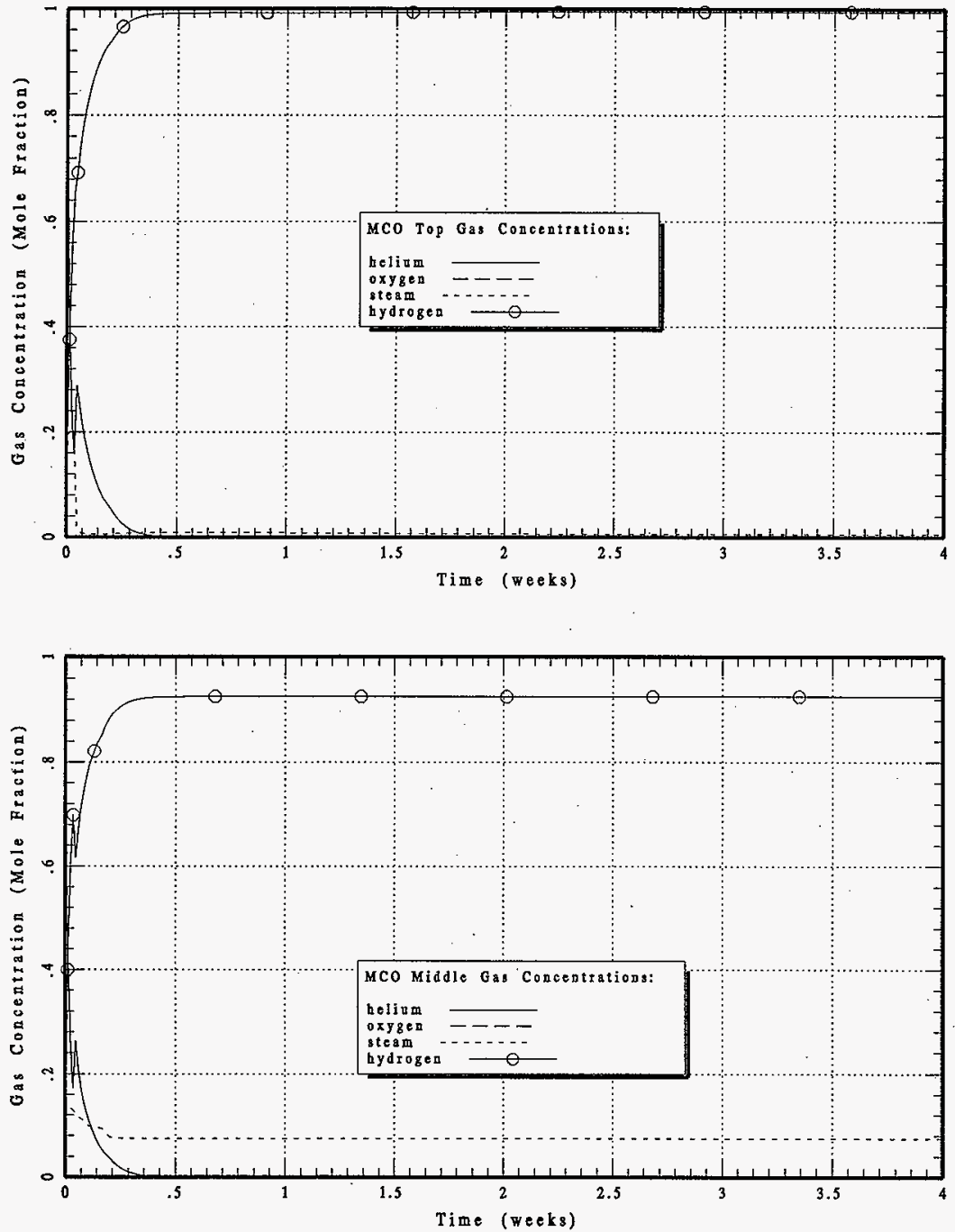


\section{HNF-SD-SNF-CN-023 REV 1}

DSLOFOV: LOW-PRESSURE THERMAL RUNAWAY w LOSS of Flow in Annulus
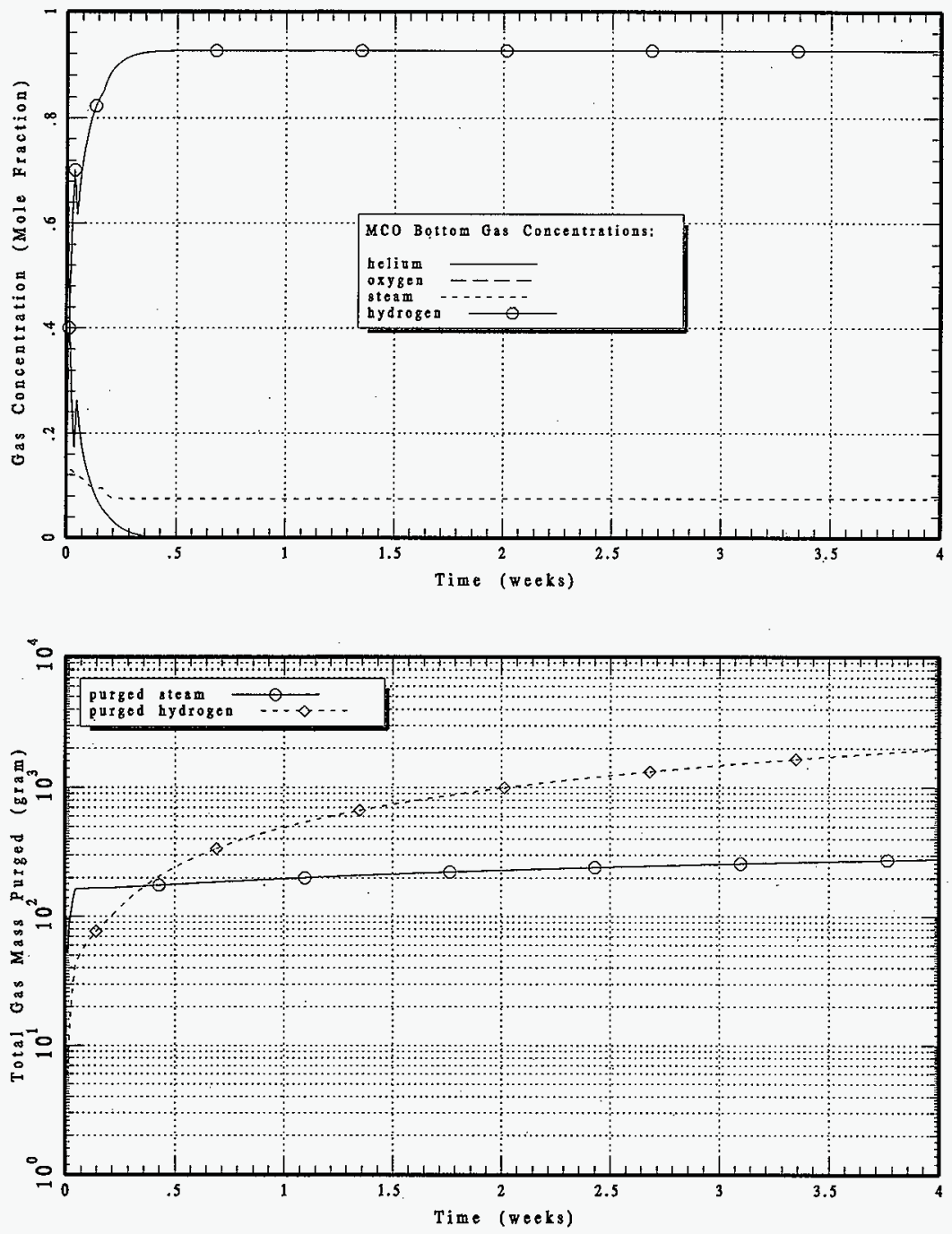
DSLOFOV: LOW-PRESSURE THERMAL RUNAWAY w LOSS of Flow in AnIUIUS
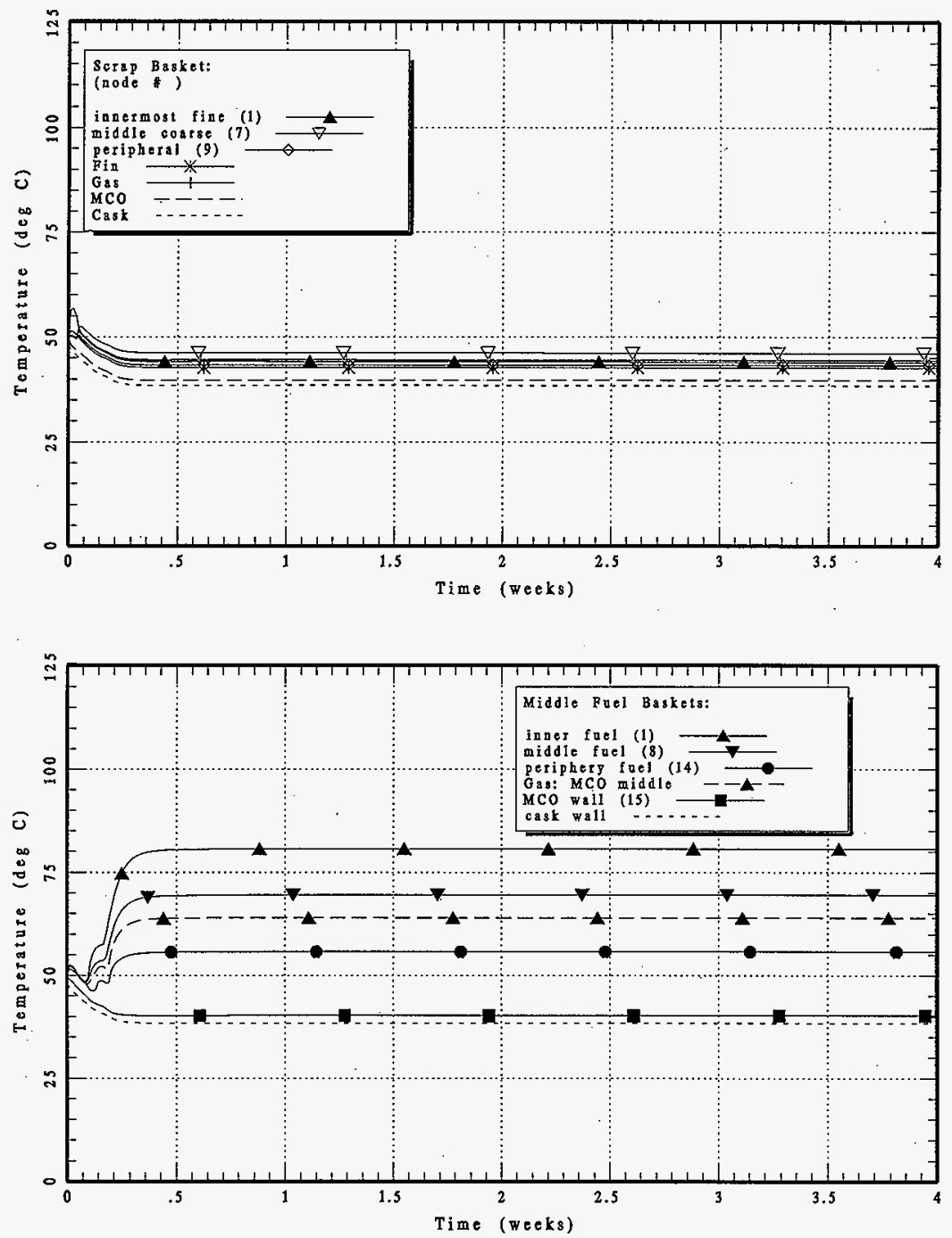


\section{HNF-SD-SNF-CN-023 REV 1}

DSLOFOV: LOW-PRESSURE THERMAL RUNAWAY w LOSS of Flow in Aninus
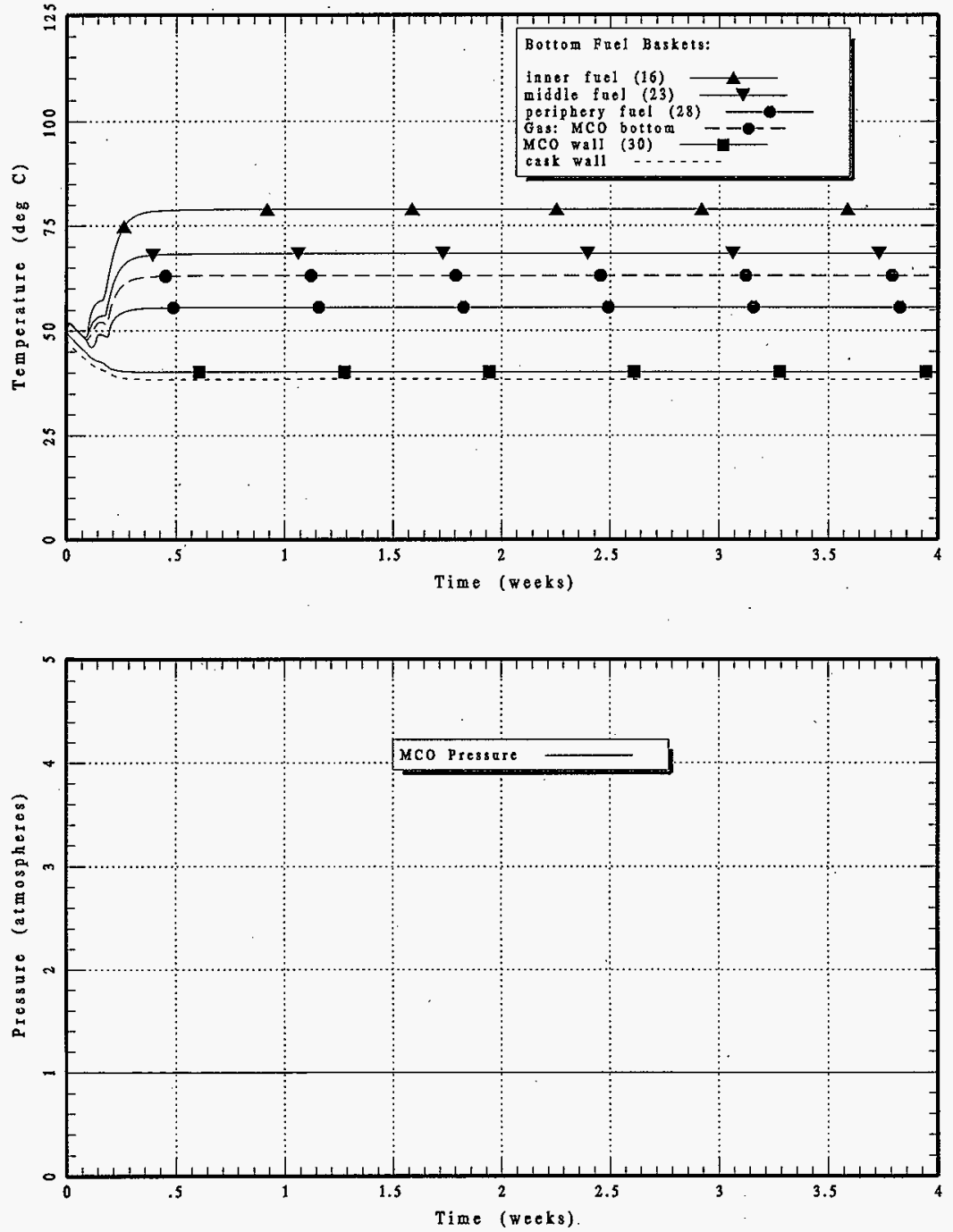


\section{HNF-SD-SNF-CN-023 REV 1}

Figure A-20 DSLOC: High-Pressure Thermal Runaway with Loss of Coolant (LOC) 


\section{HNF-SD-SNF-CN-023 REV 1}

This page intentionally left blank. 


\section{HNF-SD-SNF-CN-023 REV I}

DSLOC: HIGH-PRESSURE THERMAL RUNAWAY w LOSS of Coolant
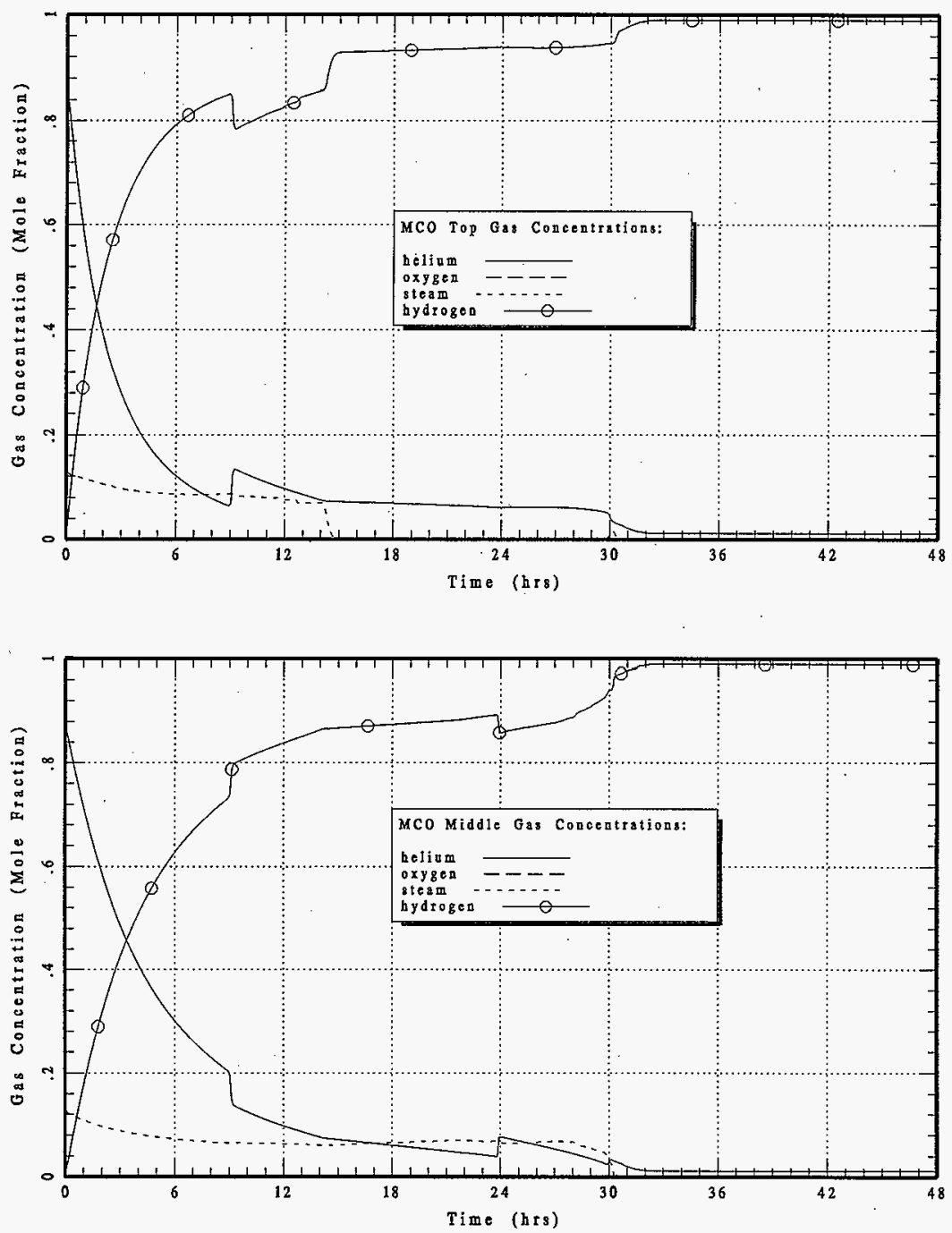


\section{HNF-SD-SNF-CN-023 REV 1}

DSLOC: HIGH-PRESSURE THERMAL RUNAWAY W LOSS of CoOlant
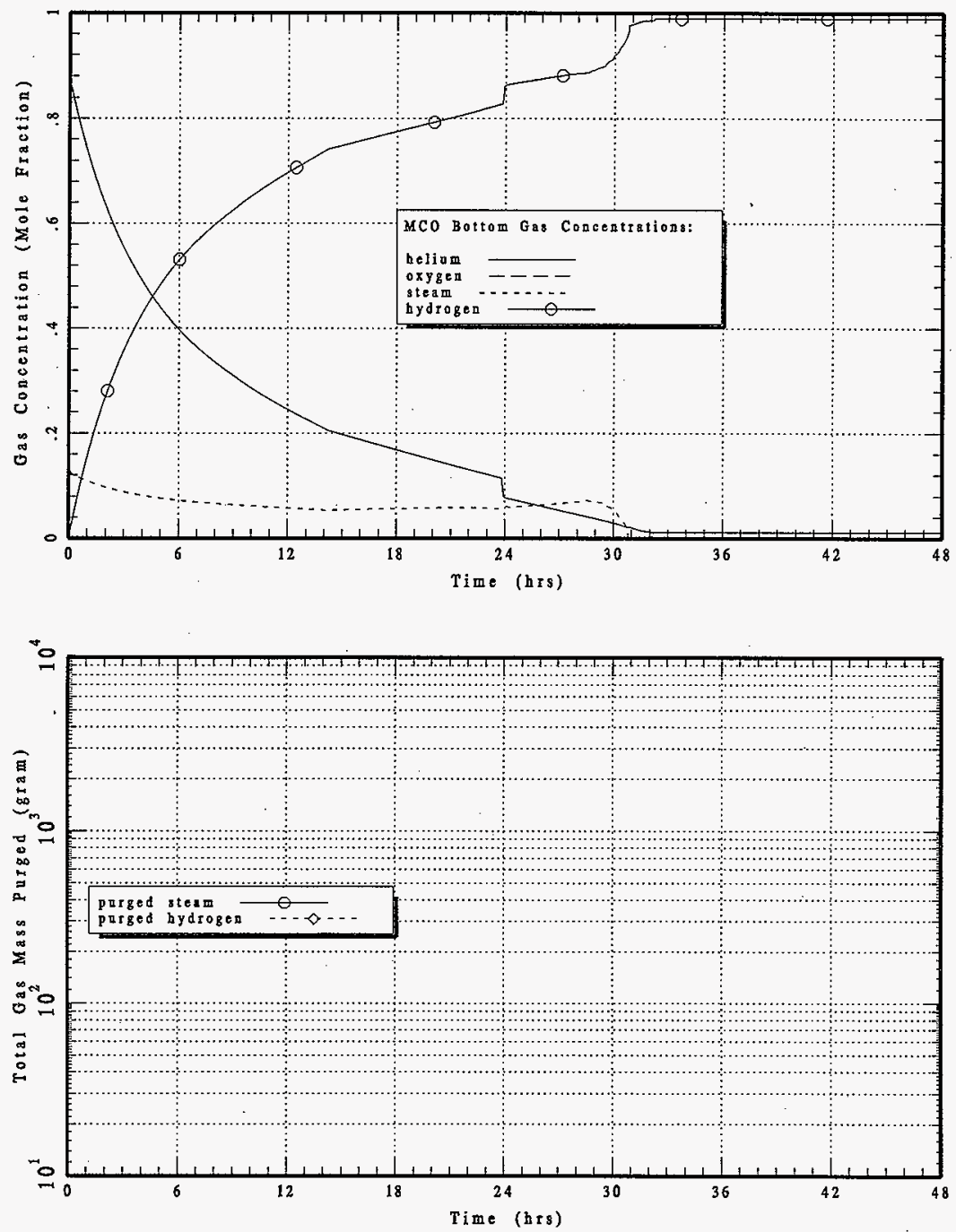
HNF-SD-SNF-CN-023 REV 1
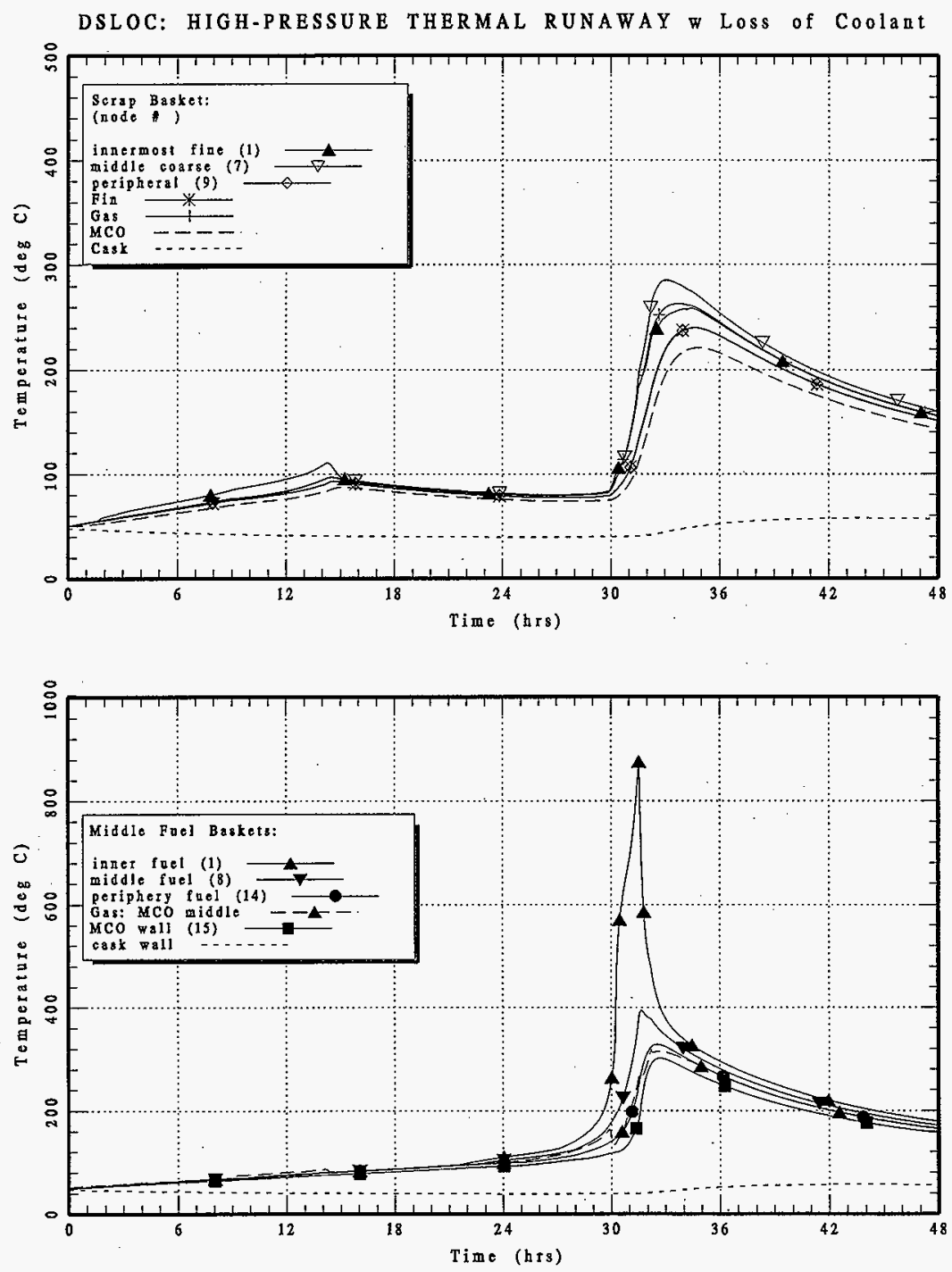

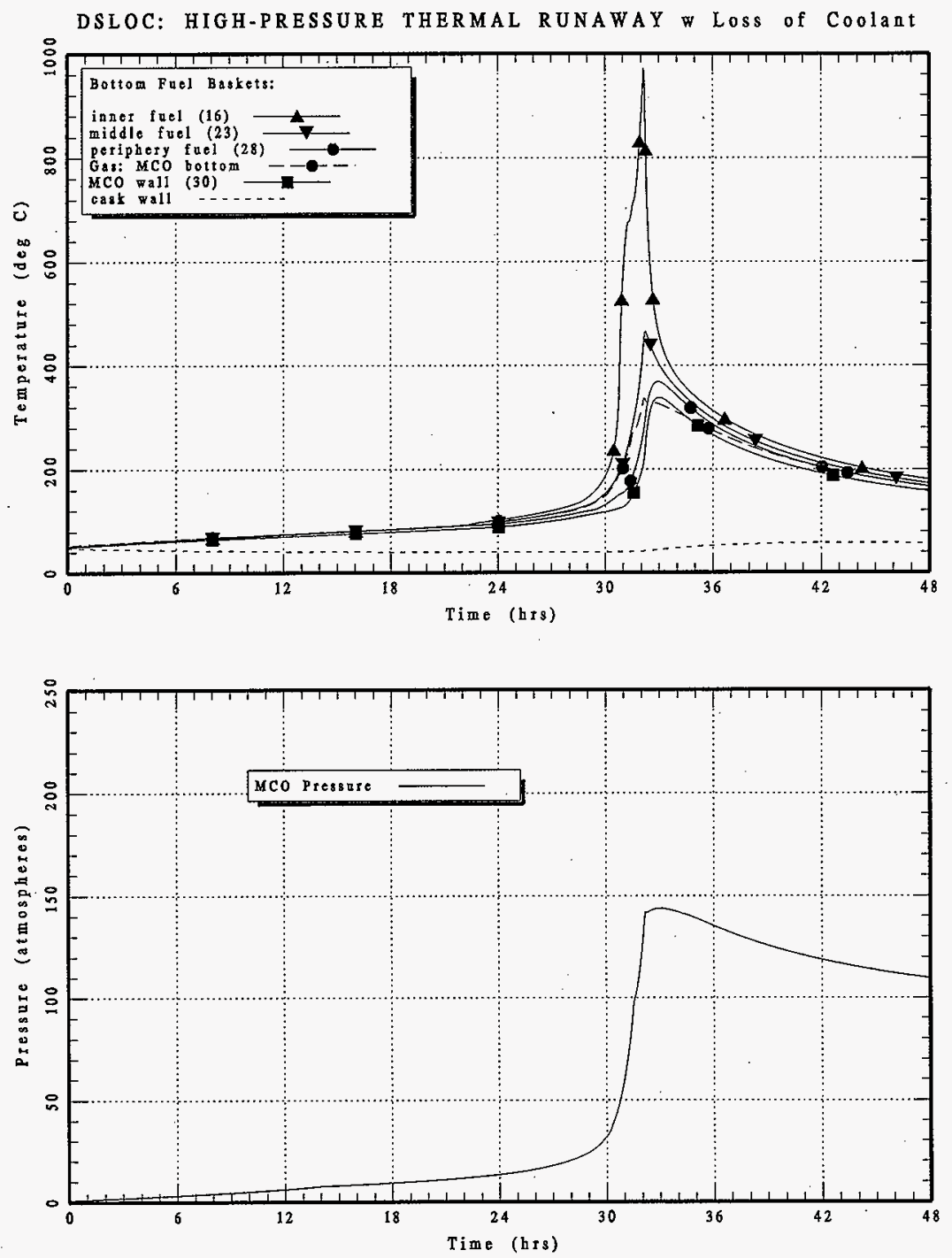
HNF-SD-SNF-CN-023 REV 1

Figure A-21 DLOC75KG: High-Pressure Thermal Runaway with $75 \mathrm{Kg}$ Water and Loss of Coolant (LOC) 


\section{HNF-SD-SNF-CN-023 REV 1}

This page intentionally left blank. 


\section{HNF-SD-SNF-CN-023 REV 1}

DLOC75KG: HI-PRES THERM RUNAWAY W $75 \mathrm{Kg}$ Water \& Loss of Coolant
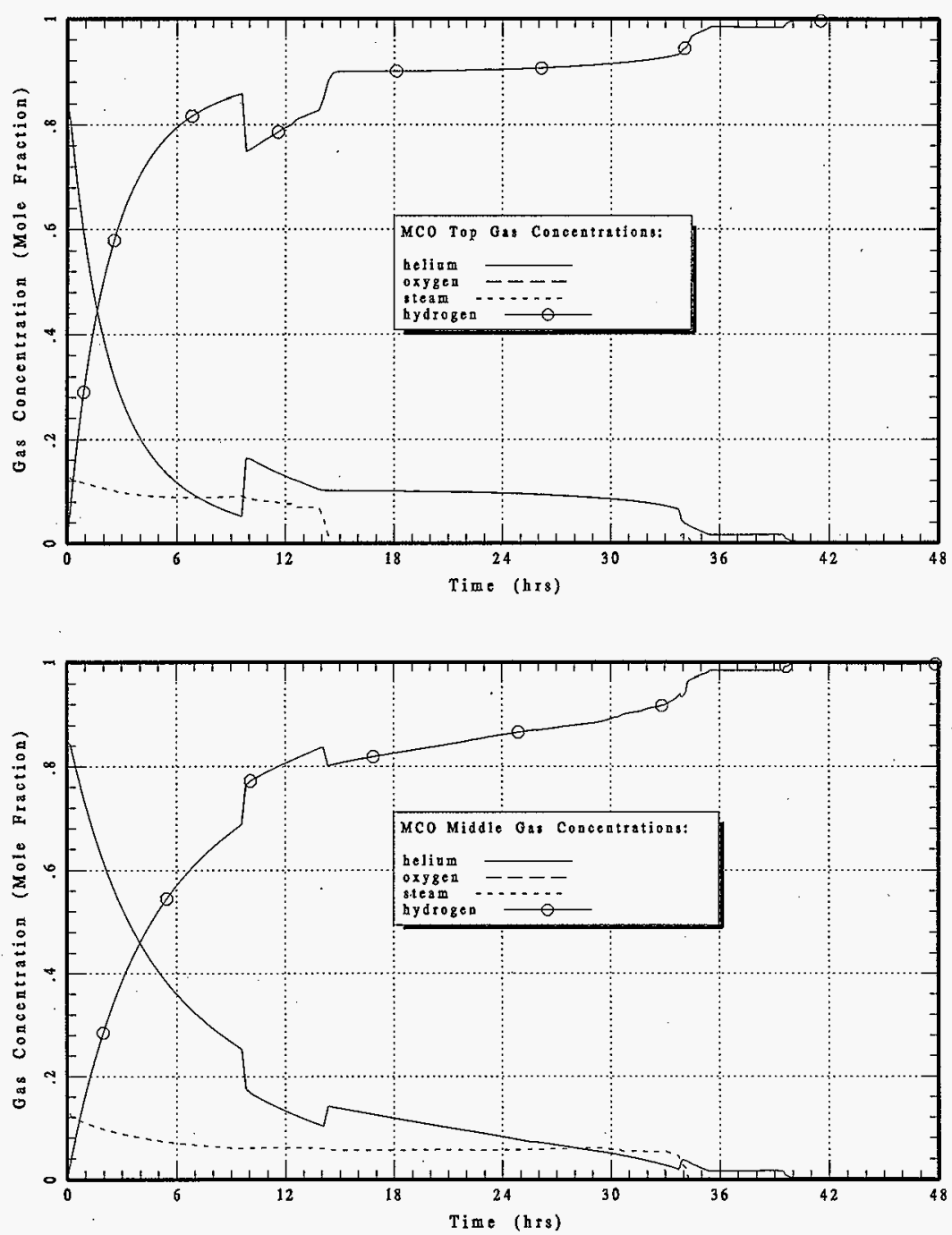


\section{HNF-SD-SNF-CN-023 REV 1}

DLOC75KG: HI-PRES THERM RUNAWAY w $75 \mathrm{Kg}$ Water \& Loss of Coolant
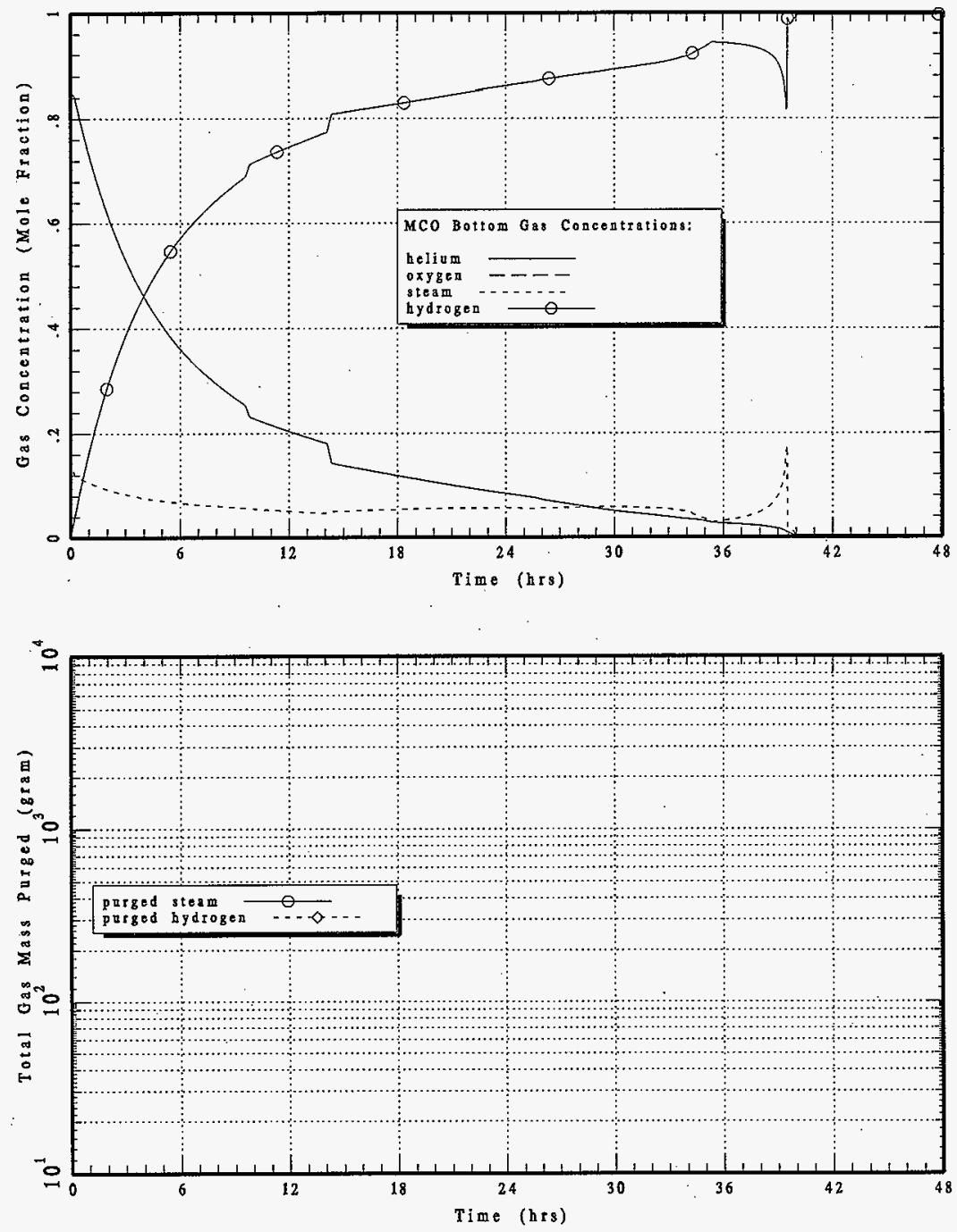
DLOC75KG: HI-PRES THERM RUNAWAY W $75 \mathrm{Kg}$ Water \& Loss of Coolant
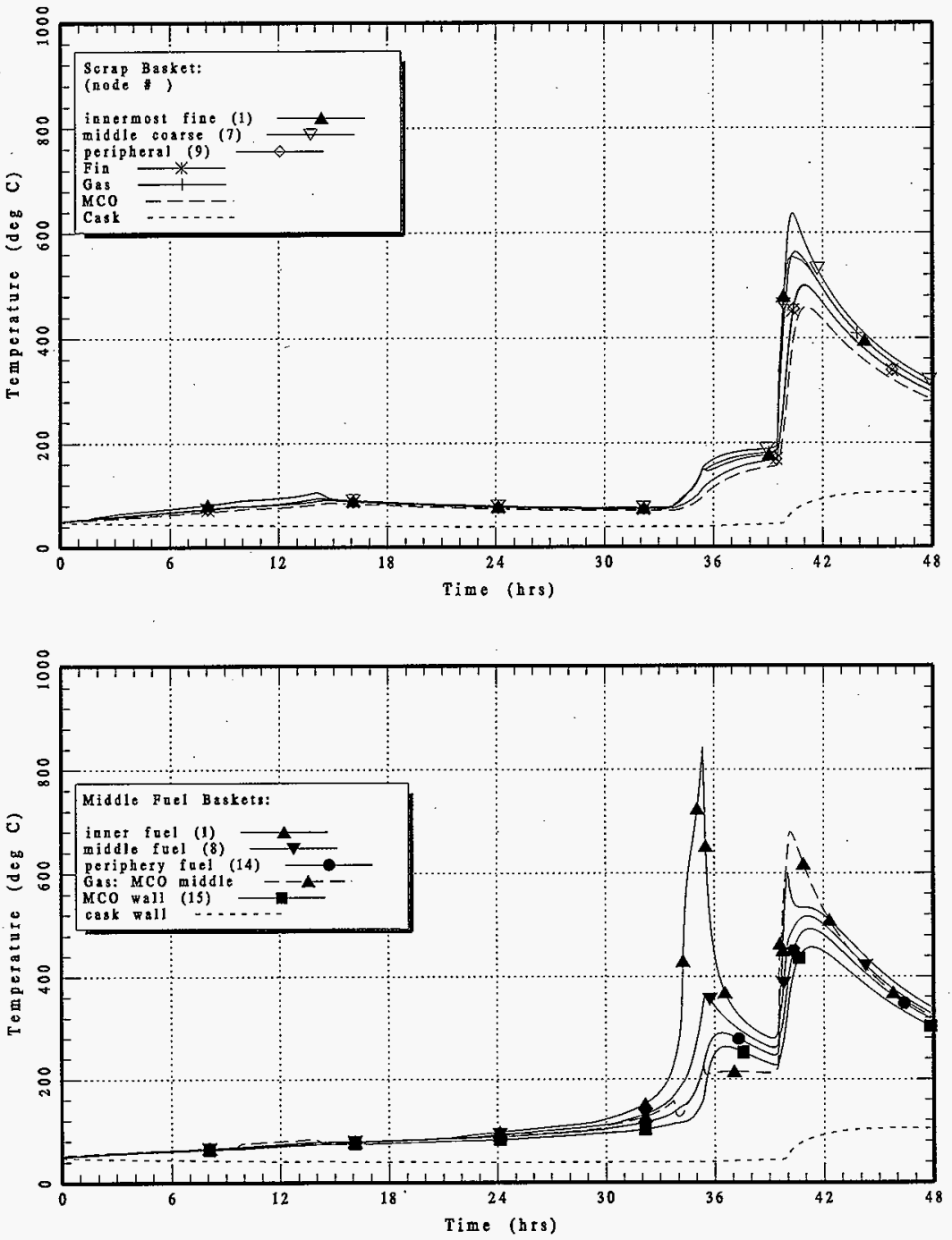


\section{HNF-SD-SNF-CN-023 REV 1}
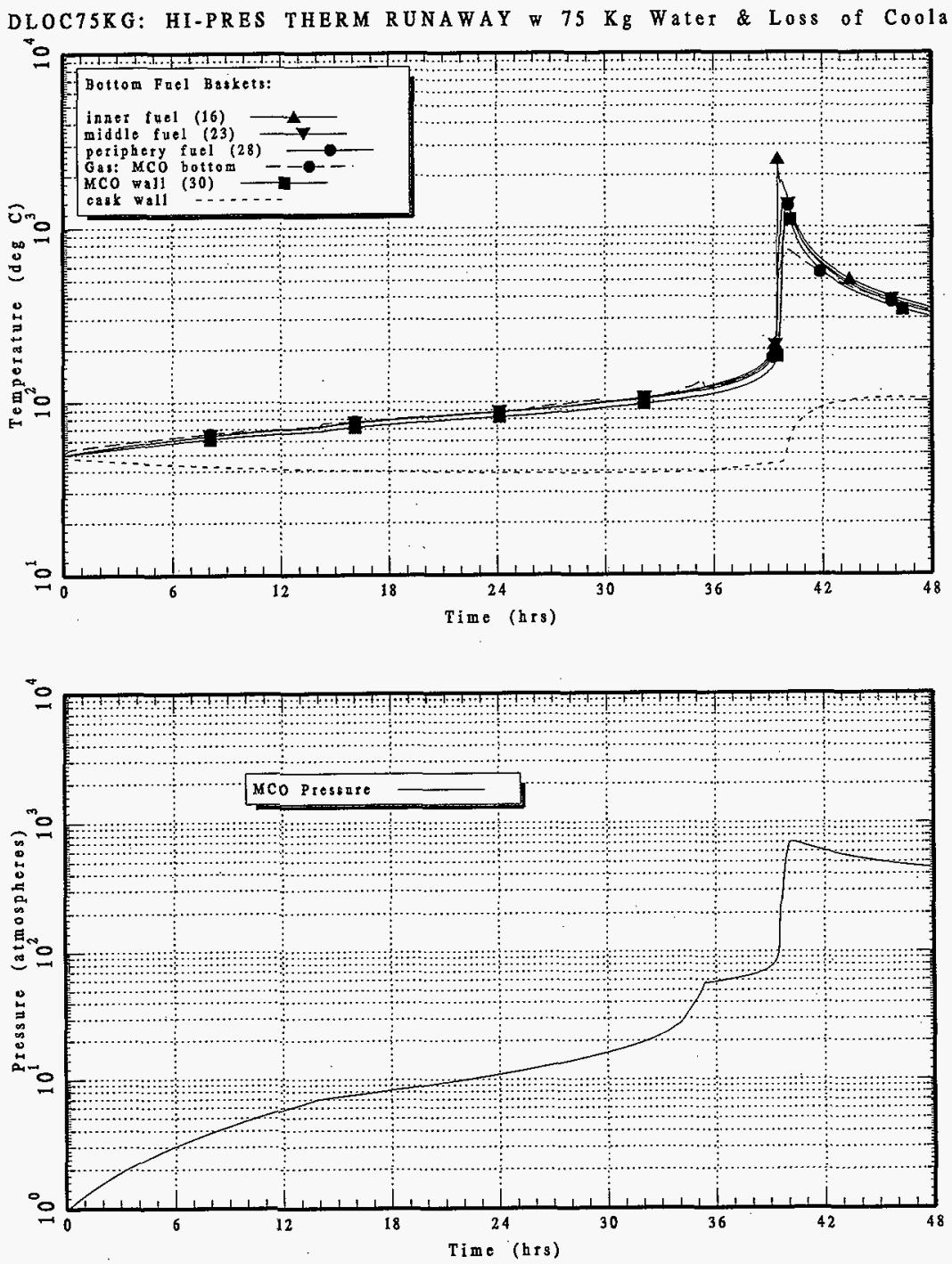


\section{HNF-SD-SNF-CN-023 REV 1}

Figure A-22 DSLOCNOM: High-Pressure Thermal Runaway with Nominal and Bounding Parameters and Loss of Coolant (LOC)

The long-dashed curves are from case 22, DSLOCNOM, which includes a loss of coolant condition for a Multi-Canister Overpack (MCO) with nominal parameter values. The solid and short-dashed curves are from case 22 except that the $\mathrm{MCO}$ has bounding parameter values. 


\section{HNF-SD-SNF-CN-023 REV 1}

This page intentionally left blank. 
DSLOCNOM: HI-PRES THERM RUNAWAY W Nom \& Bnd Param. \& Loss of Coolant
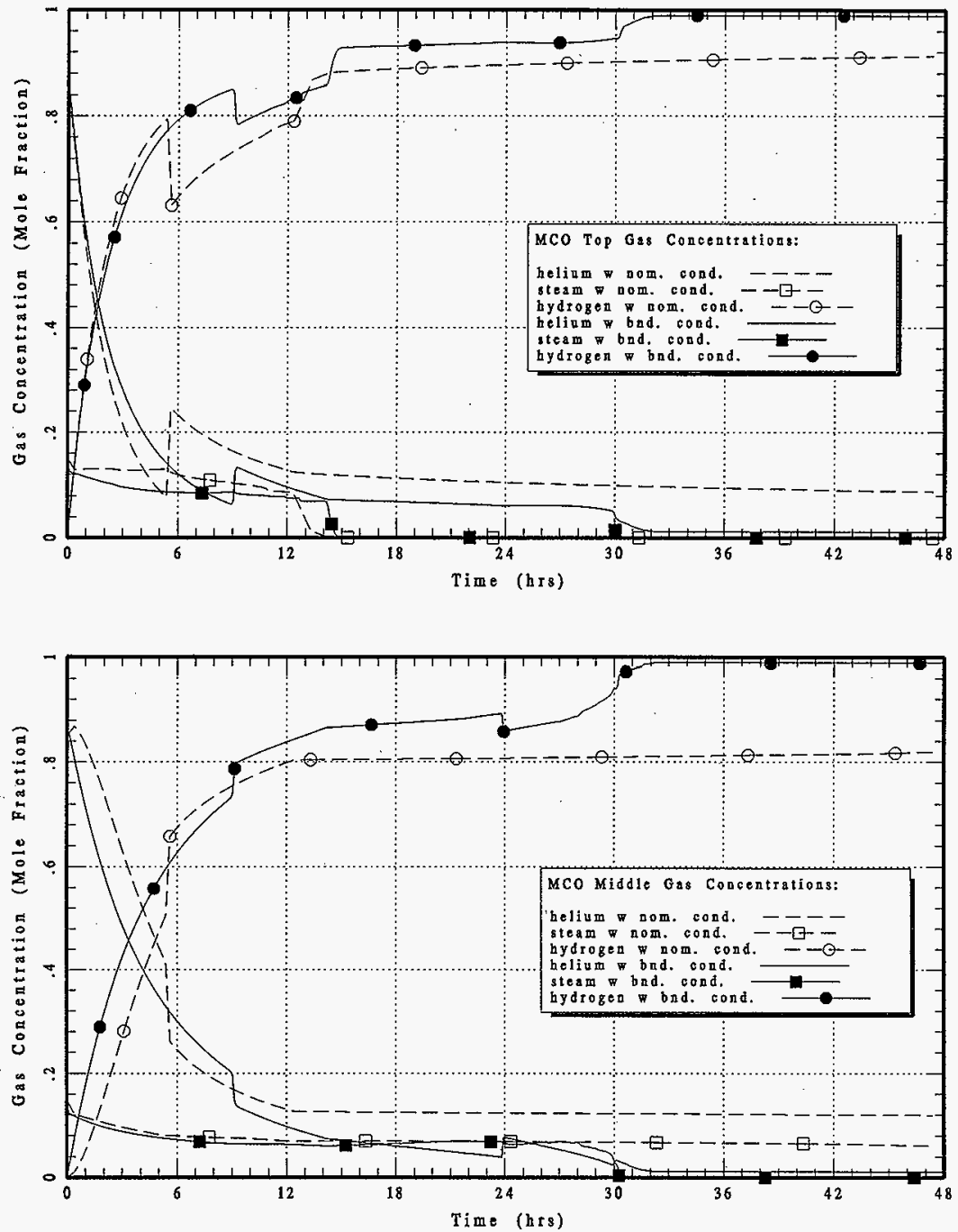


\section{HNF-SD-SNF-CN-023 REV 1}

DSLOCNOM: HI-PRES THERM RUNAWAY w Nom \& Bnd Param, \& Loss of Coolant
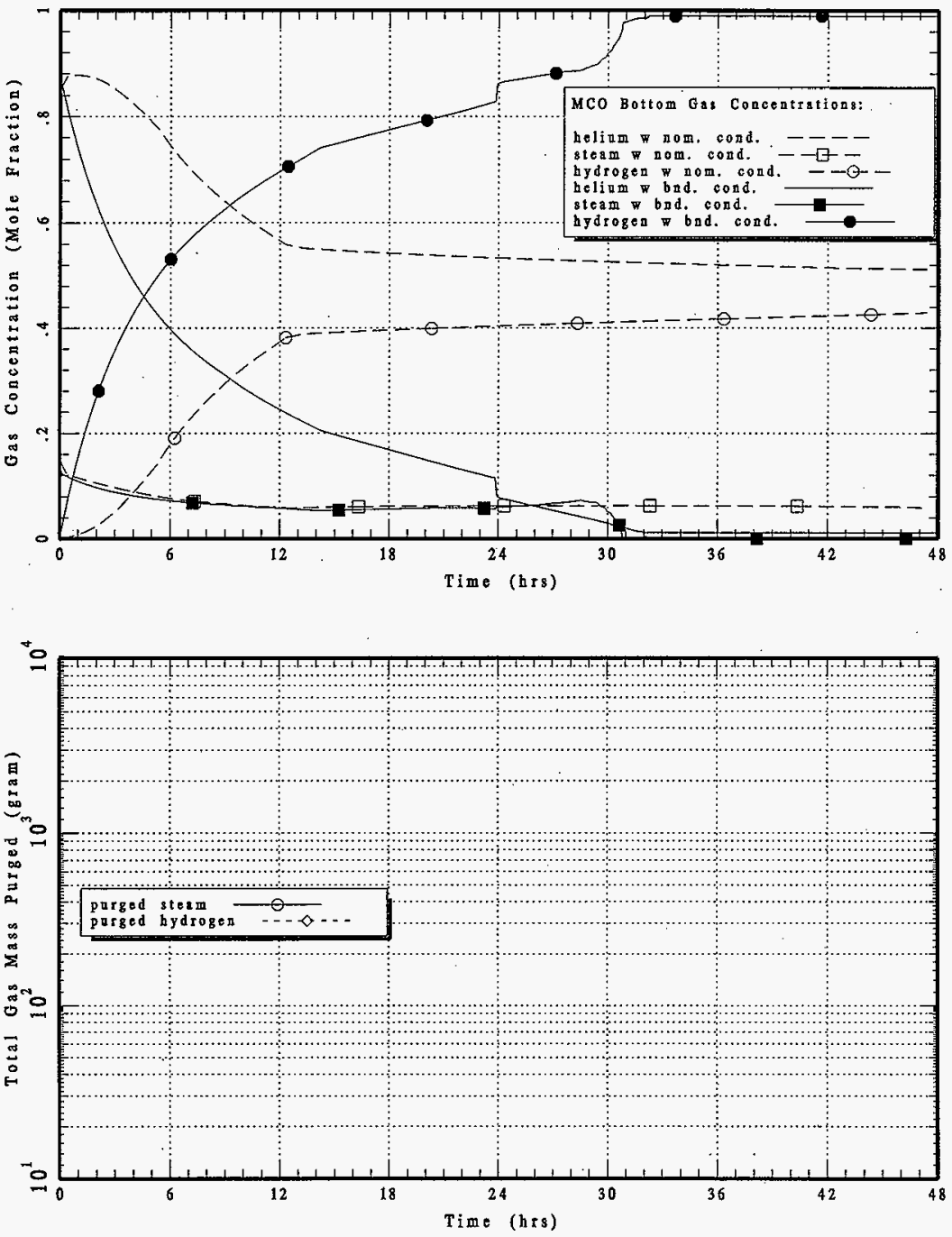
DSLOCNOM: HI-PRES THERM RUNAWAY w Nom \& Bnd Param, \& Loss of Coolant
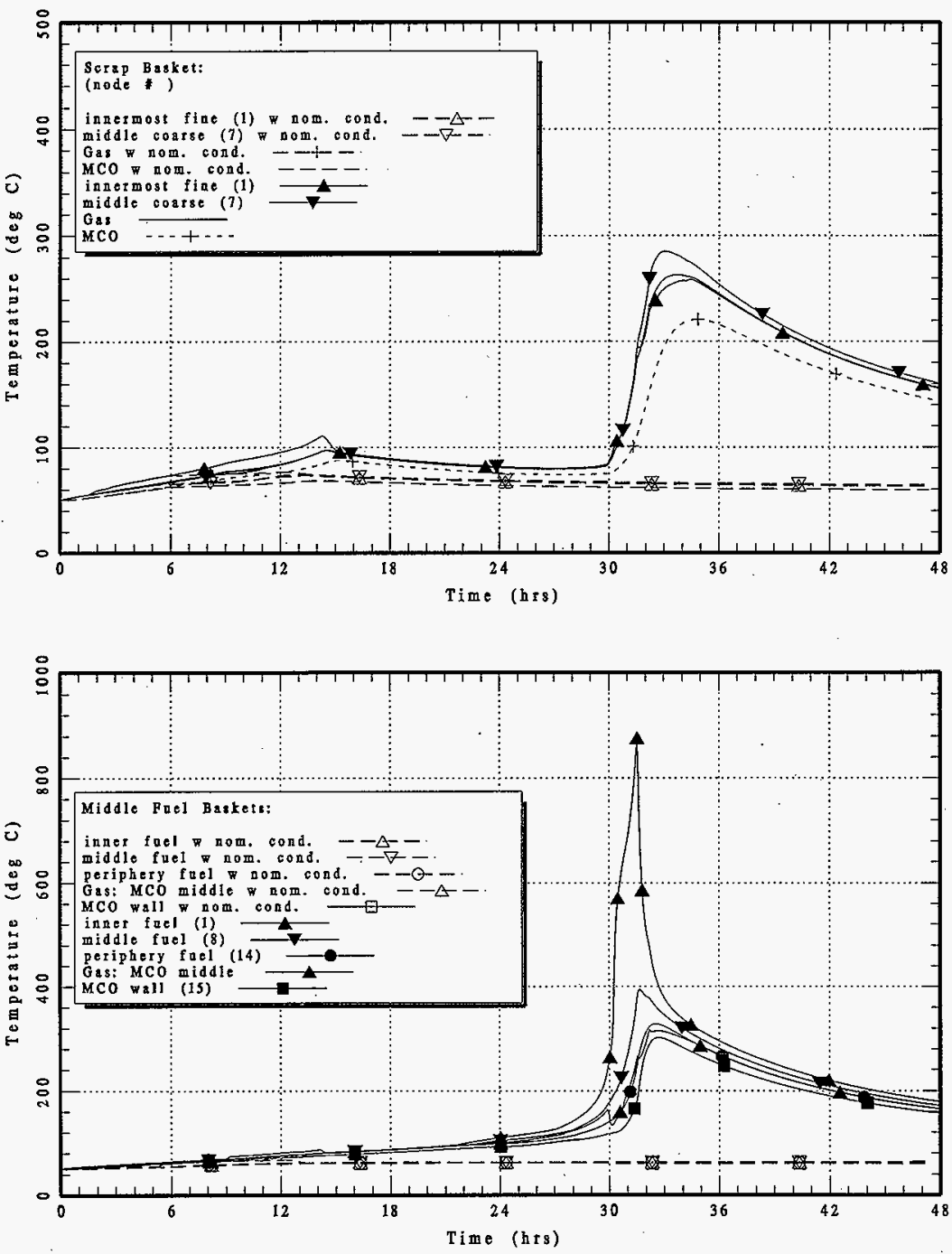


\section{HNF-SD-SNF-CN-023 REV I}

DSLOCNOM: HI-PRES THERM RUNAWAY w Nom \& Bnd Param. \& Loss of Coolant
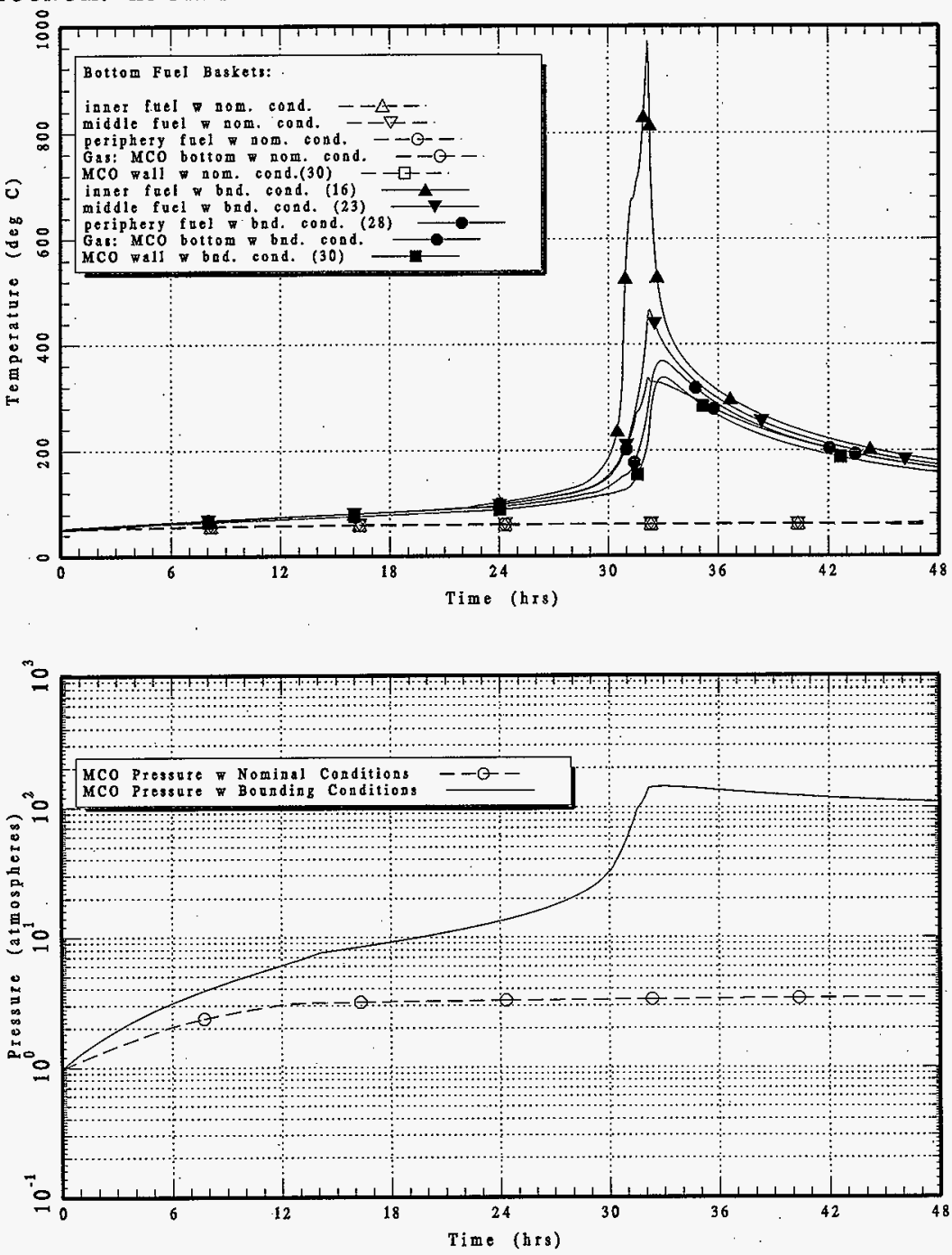
Figure A-23 DSLOCREC: High-Pressure Thermal Runaway with Loss of Coolant (LOC) and Recovery at 21 Hours

The long-dashed curves are from case 23, DSLOCREC, which includes a recovery from the loss of coolant condition by restoring $25^{\circ} \mathrm{C}$ flowing annulus water at 21 hours. The solid and short-dashed curves are from case 20, DSLOC, which includes a bounding MCO with a loss of coolant condition and provides the initial conditions for case 23 at 21 hours. 


\section{HNF-SD-SNF-CN-023 REV 1}

This page intentionally left blank. 


\section{HNF-SD-SNF-CN-023 REV 1}

DSLOCREC: HI-PRES THERM RUNAWAY w LOC \& Flowing Ann. Recovety@21 hrs
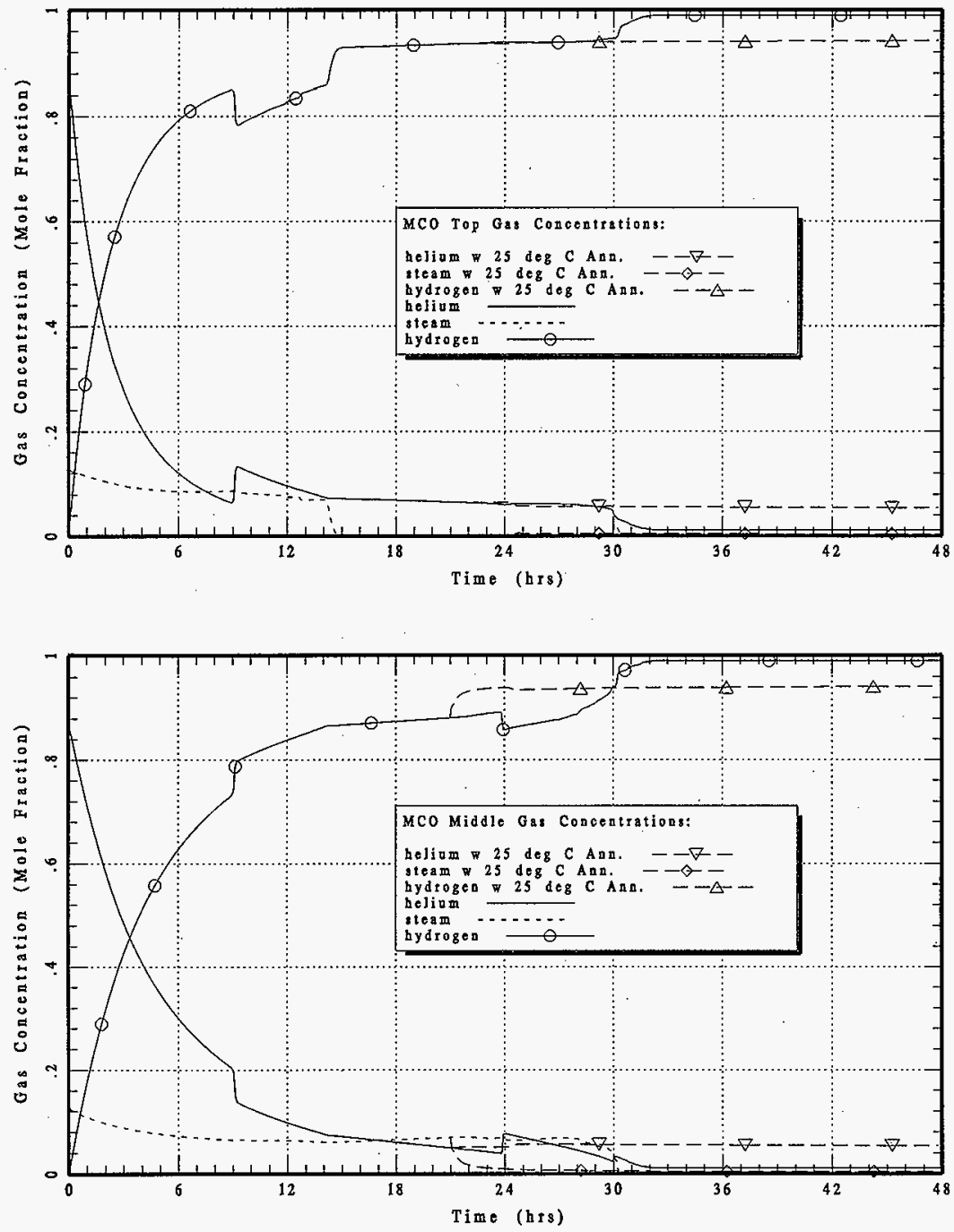


\section{HNF-SD-SNF-CN-023 REV 1}

DSLOCREC: HI-PRES THERM RUNAWAY w LOC \& Flowing Ann. Recovery@2I hrs
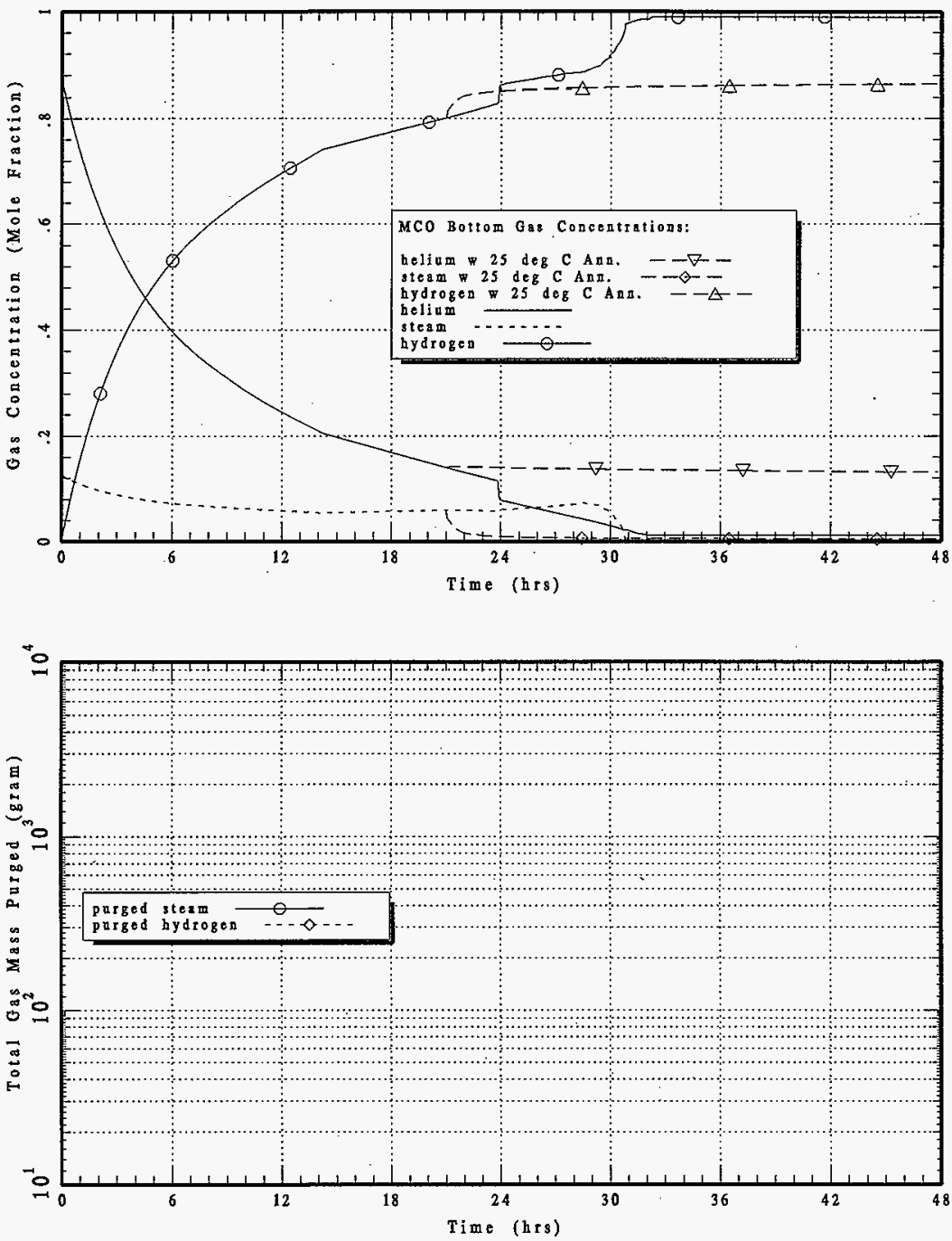
DSLOCREC: HI-PRES THERM RUNAWAY w LOC \& Flowing Ann. Recovery@21 hrs
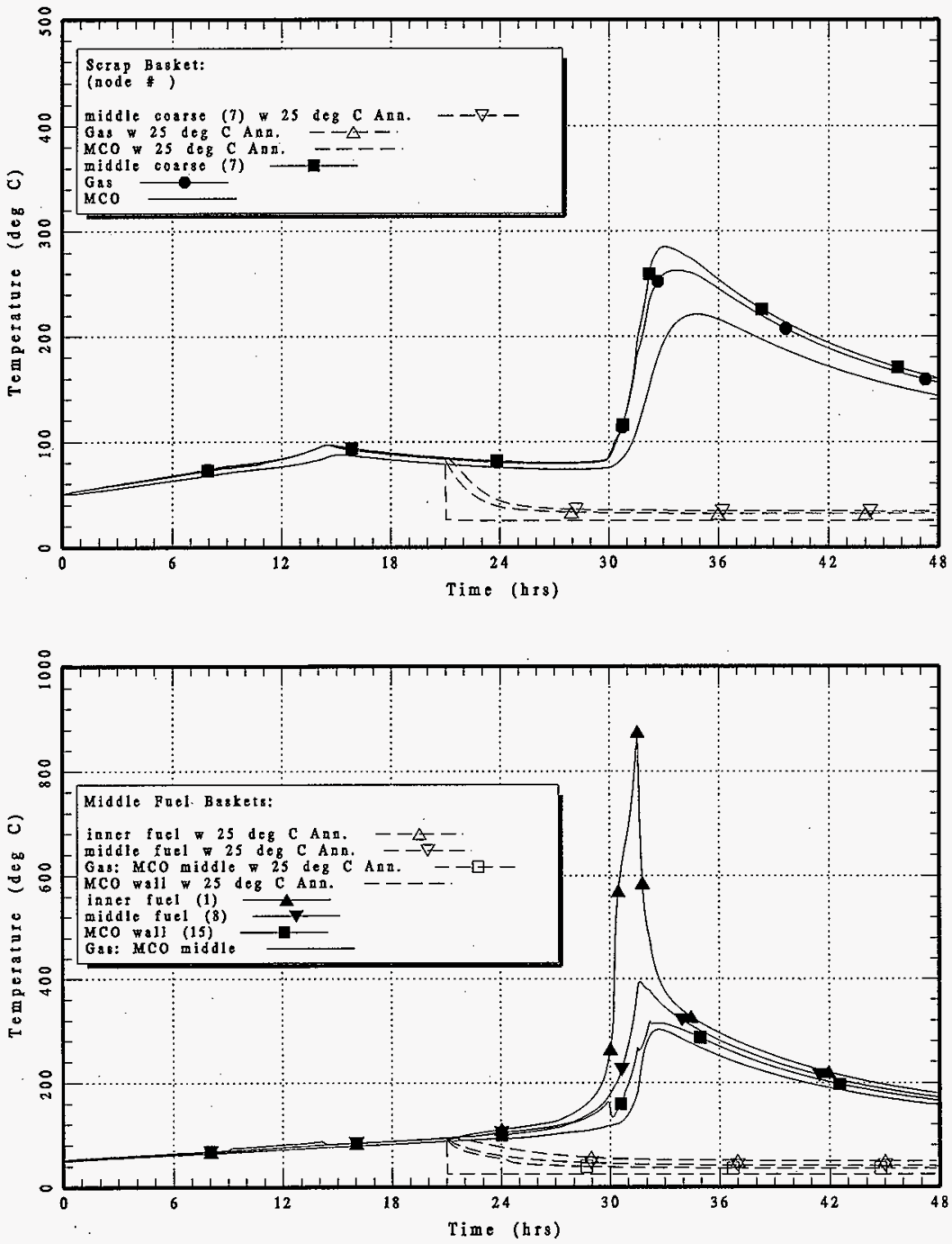
DSLOCREC: HI-PRES THERM RUNAWAY w LOC \& Flowing Ann. Recovery@21 hrs
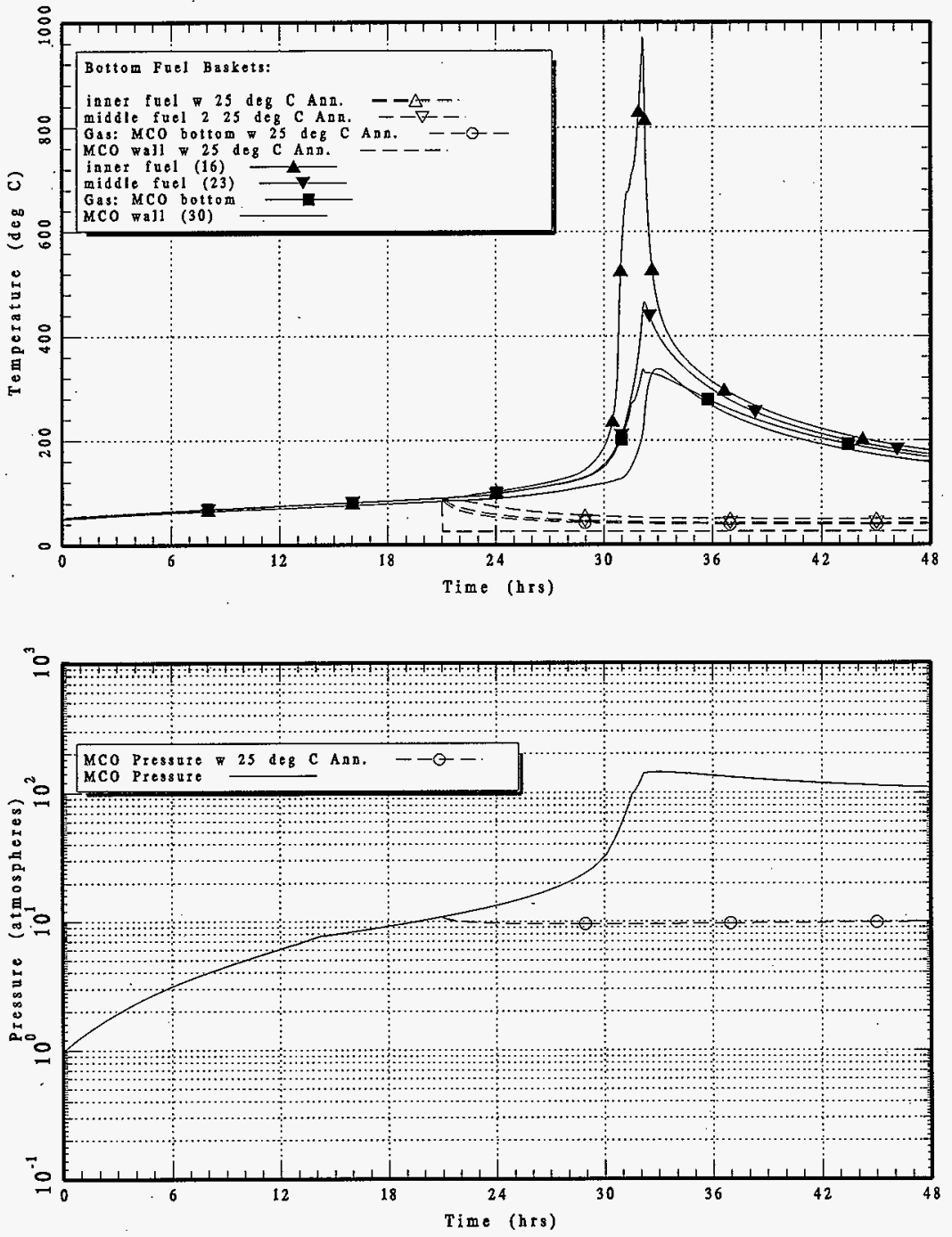
Figure A-24 DSLOCRE2: High-Pressure Thermal Runaway with Loss of Coolant (LOC) and Stationary Annulus Recovery at 21 Hours

The long-dashed curves are from case 24, DSLOCRE2, which includes a recovery from the loss of coolant condition by restoring $25^{\circ} \mathrm{C}$ stationary annulus water at 21 hours. This case is the same is case 23, DSLOCREC, except that the restored annulus water is stationary instead of flowing. The solid and short-dashed curves are from case 20, DSLOC, which includes a bounding MCO with a loss of coolant condition and provides the initial conditions for case 24 at 21 hours. 


\section{HNF-SD-SNF-CN-023 REV 1}

This page intentionally left blank. 
HNF-SD-SNF-CN-023 REV 1

DSLOCRE2: HI-PRES THERM RUNAWAY w LOC \& Stationary Ano. Recover. @ 21 hrs
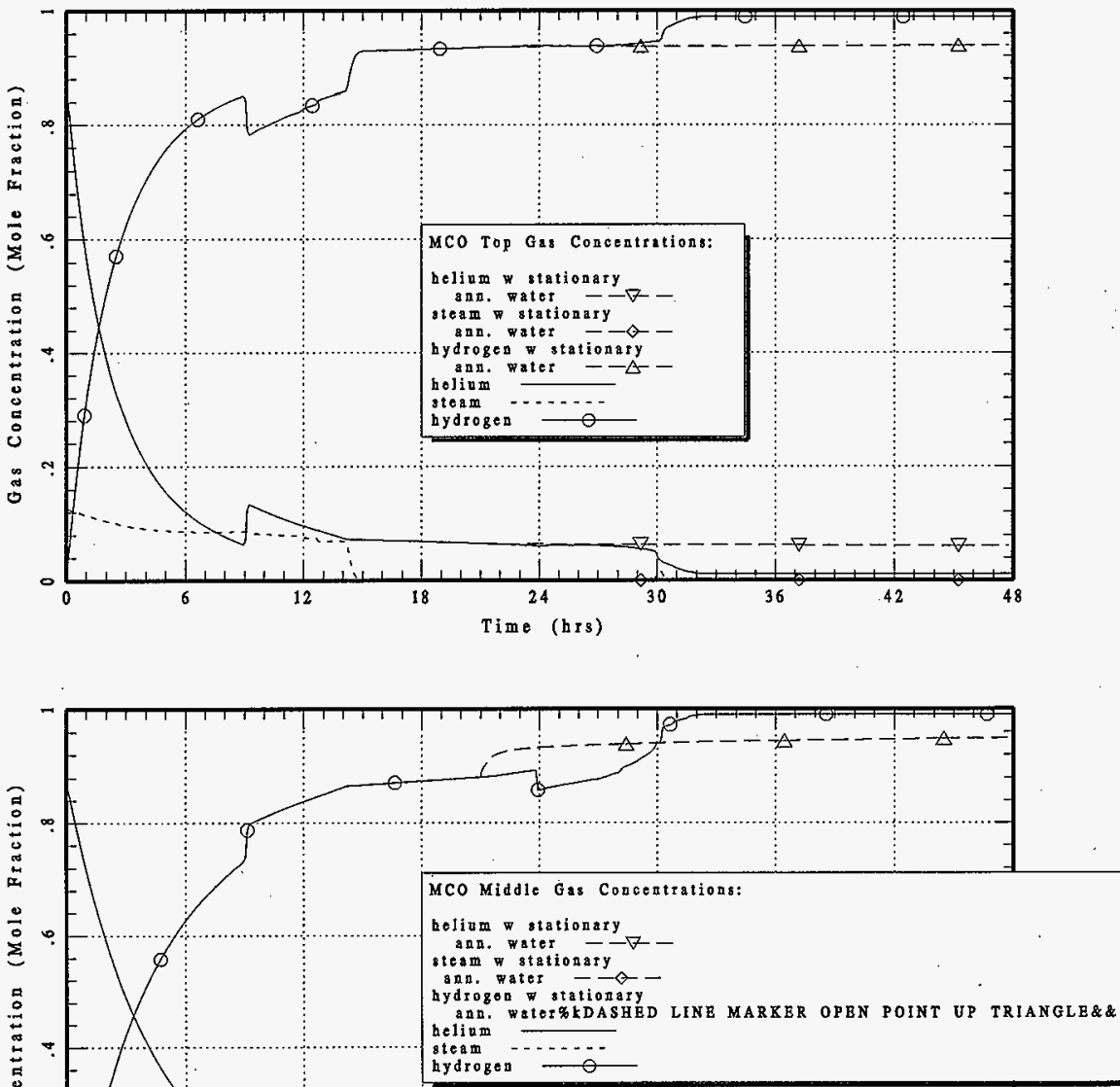


\section{HNF-SD-SNF-CN-023 REV 1}

DSLOCRE2: HI-PRES THERM RUNAWAY w LOC \& Stationary Ann. Recover. @21 hrs
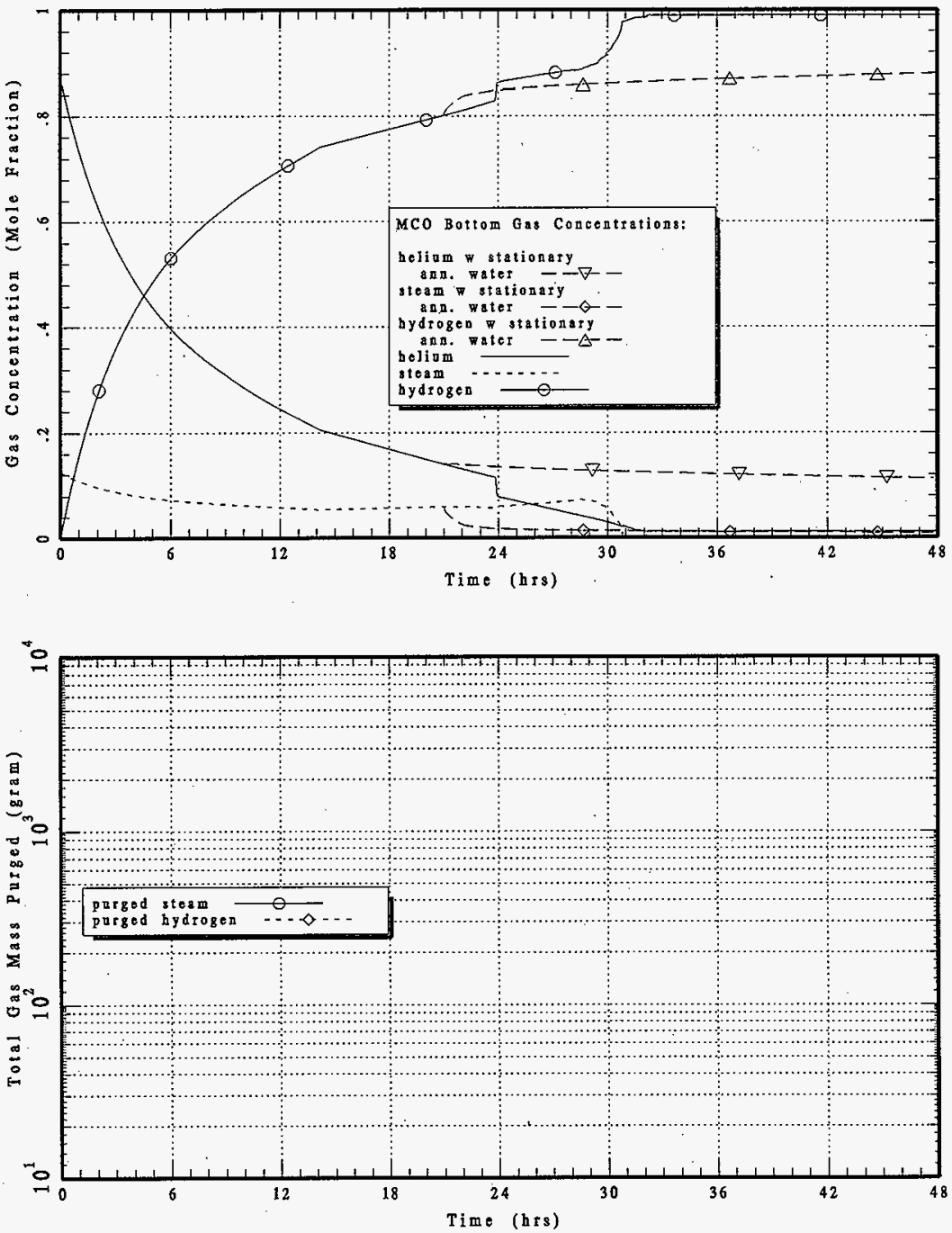
DSLOCRE2: HI-PRES THERM RUNAWAY WOC \& Stationary Ann. Recover. @21 hrs
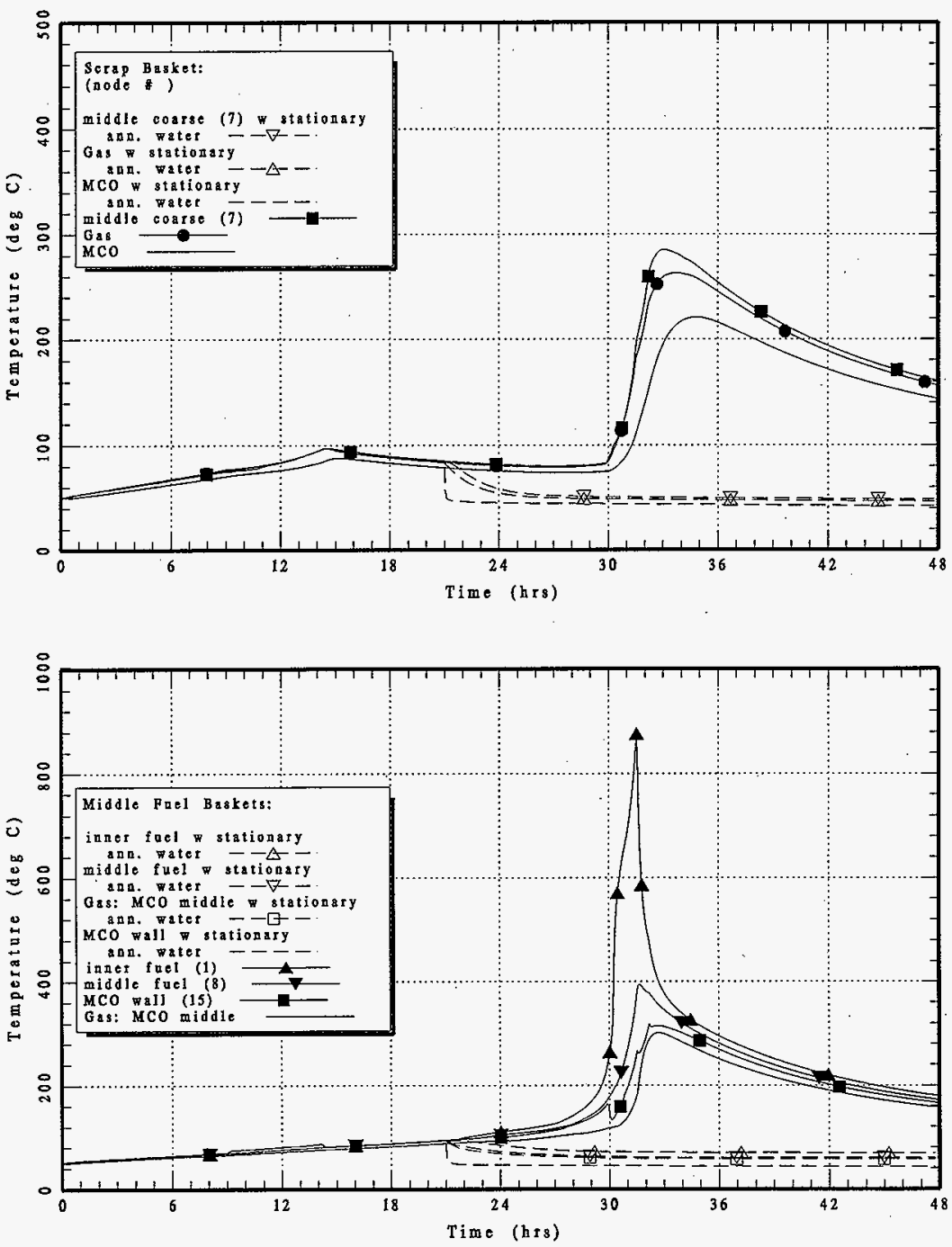


\section{HNF-SD-SNF-CN-023 REV 1}

DSLOCRE 2: HI-PRES THERM RUNAWAY w LOC \& Stationaty Ann. Recover. @21 hrs
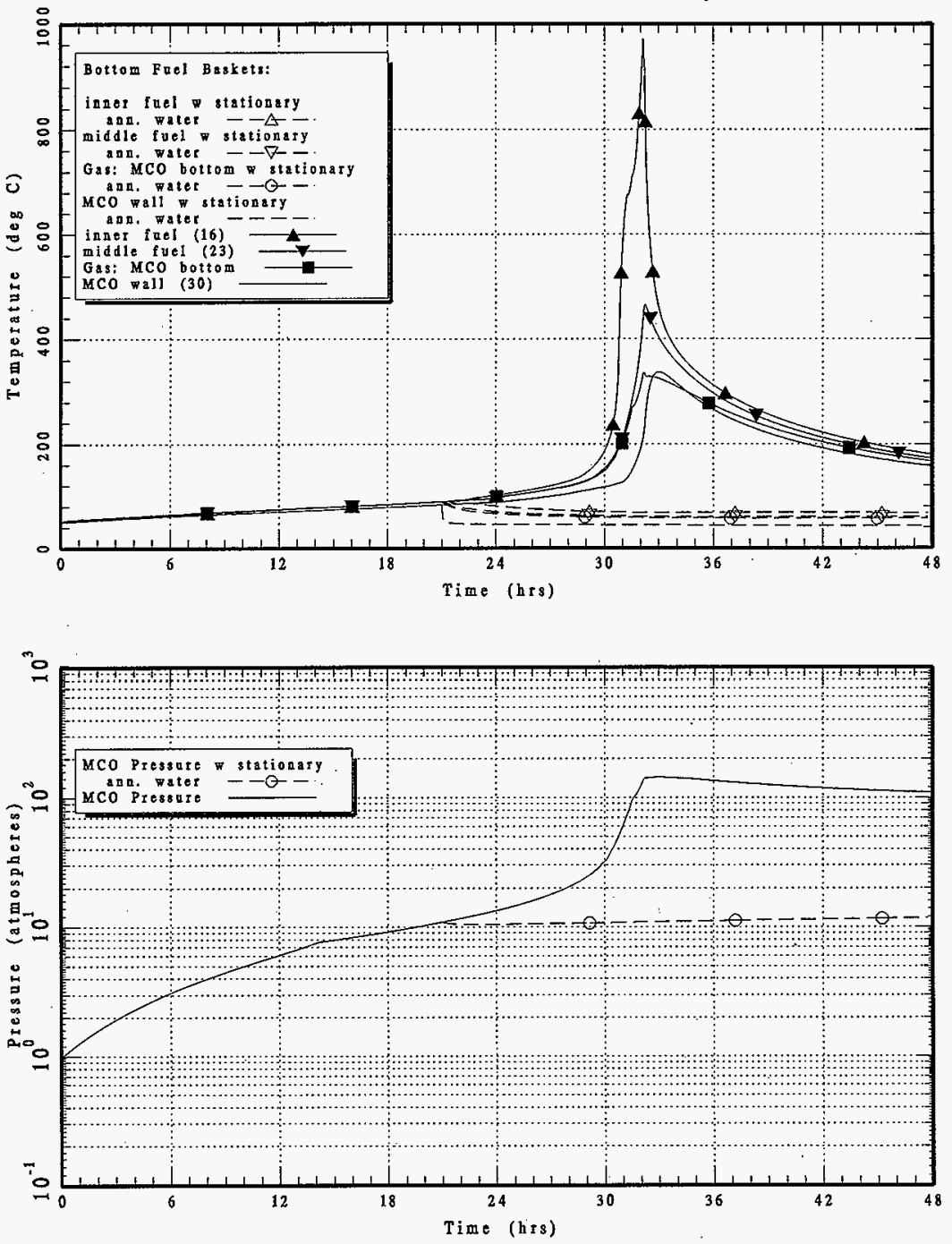


\section{HNF-SD-SNF-CN-023 REV 1}

Figure A-25 DSLOCOV: Low-Pressure Thermal Runaway with Loss of Coolant (LOC) Annulus 


\section{HNF-SD-SNF-CN-023 REV 1}

This page intentionally left blank. 


\section{HNF-SD-SNF-CN-023 REV 1}

DSLOCOV: LOW-PRESSURE THERMAL RUNAWAY w Loss of Coolant - Annulus
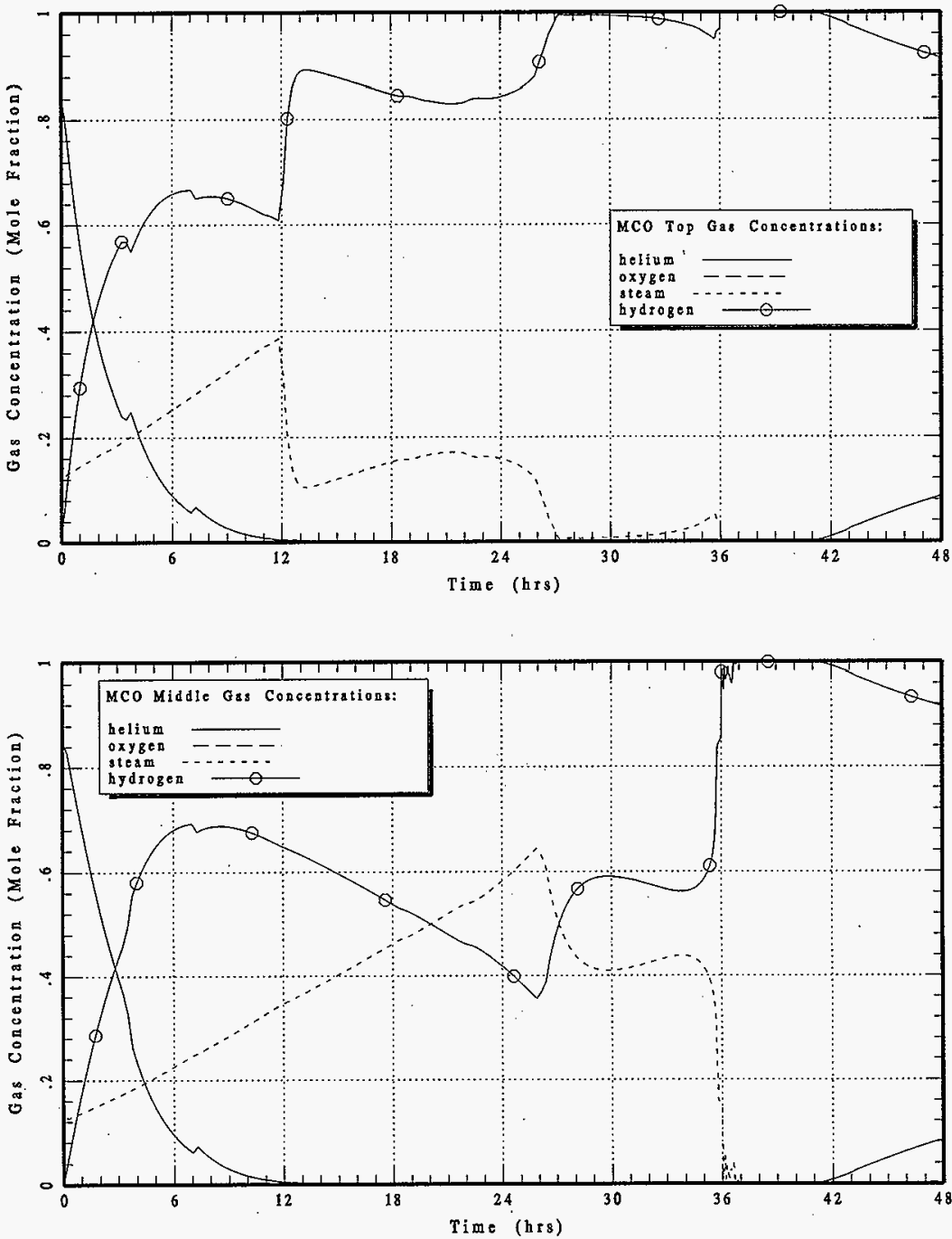
HNF-SD-SNF-CN-023 REV 1

DSLOCOV: LOW-PRESSURE THERMAE RUNAWAY w Loss of Coolant - Annulus
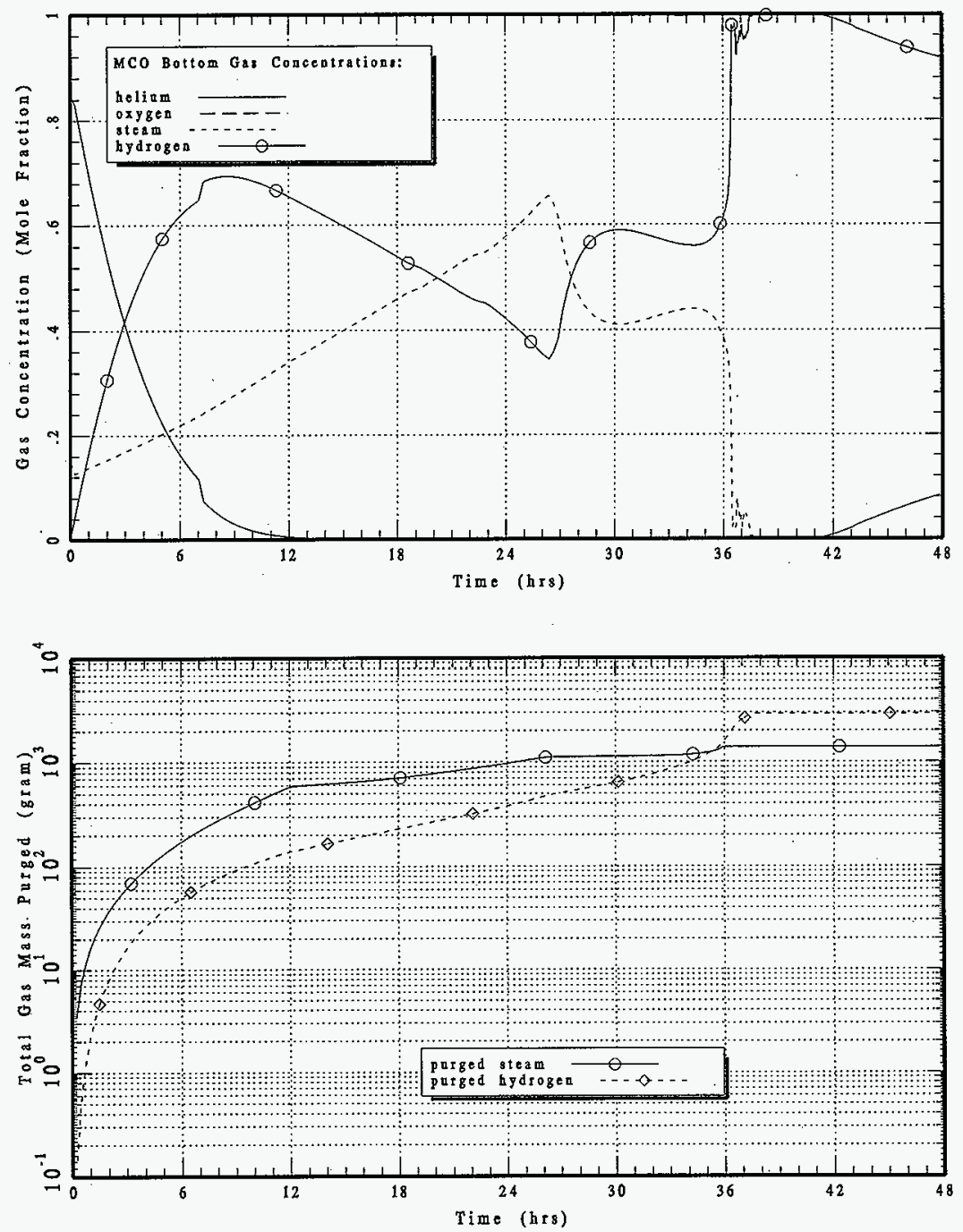
DSLOCOV: LOW-PRESSURE THERMAL RUNAWAY W LOSS of Coolant - Aniulus
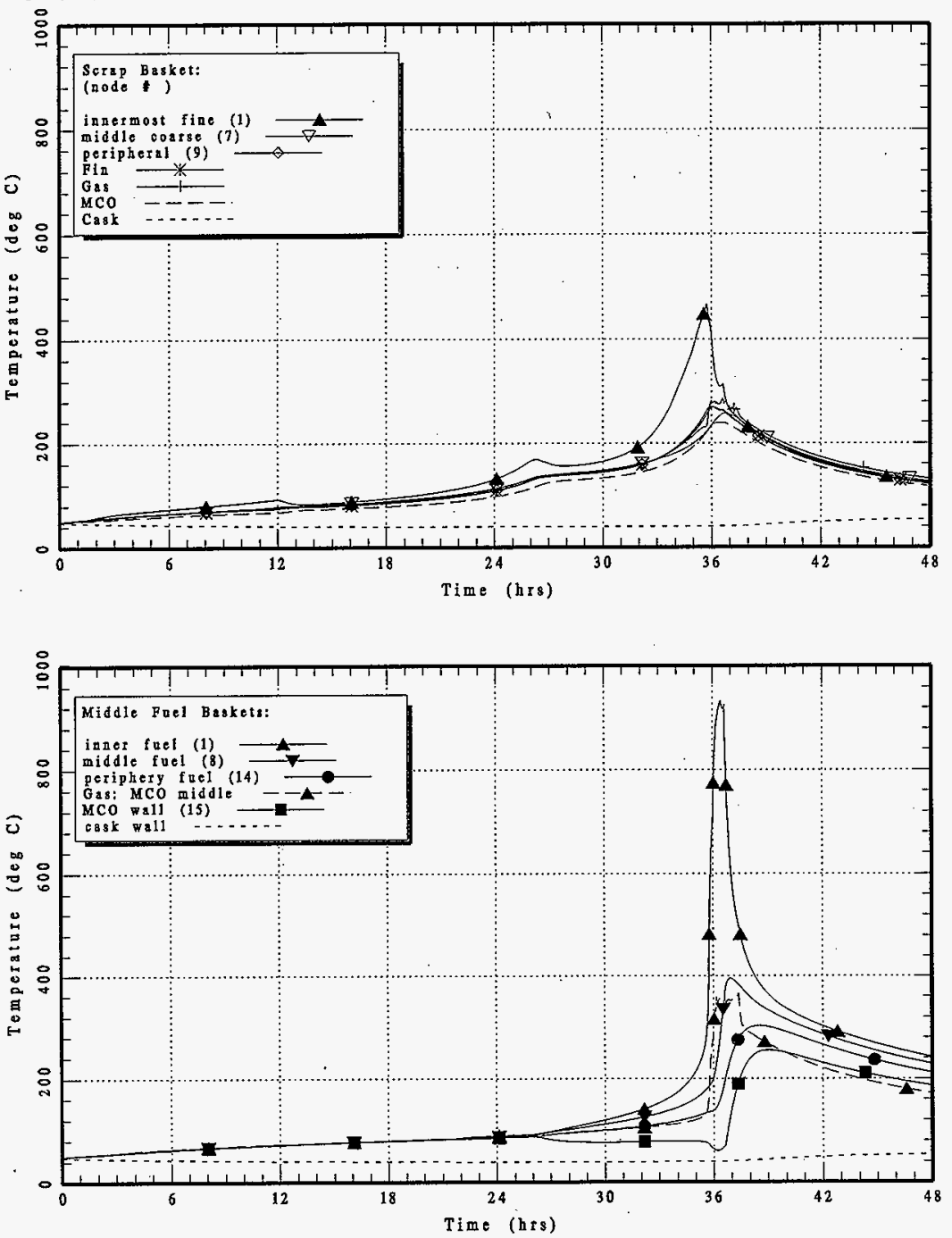


\section{HNF-SD-SNF-CN-023 REV 1}
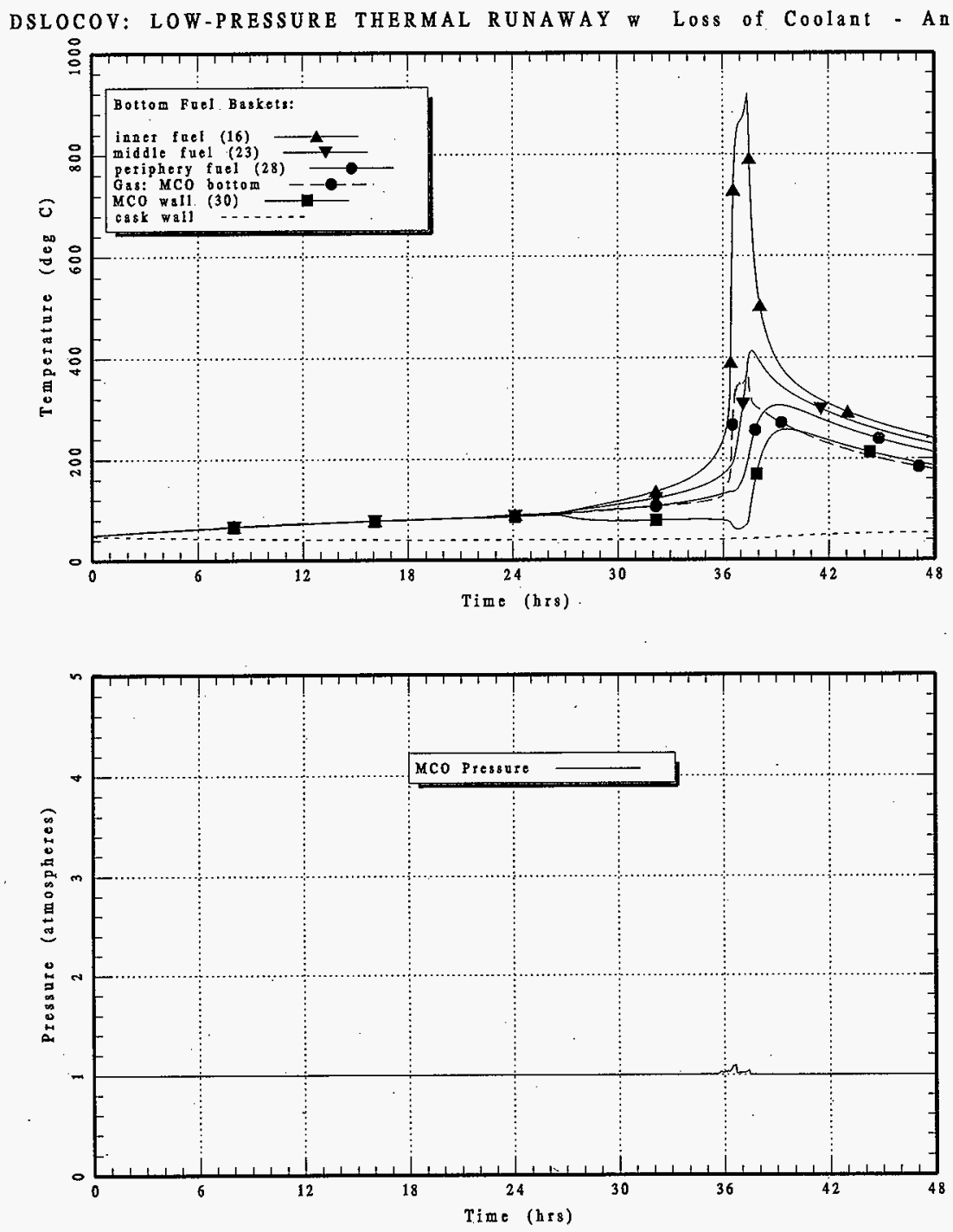


\section{HNF-SD-SNF-CN-023 REV 1}

Figure A-26 DS46DEG: High-Pressure Thermal Runaway with $46{ }^{\circ} \mathrm{C}$ Annulus 


\section{HNF-SD-SNF-CN-023 REV 1}

This page intentionally left blank. 
DS46DEG: HIGH-PRESSURE THERMAL RUNAWAY W 46 Deg C Annulus
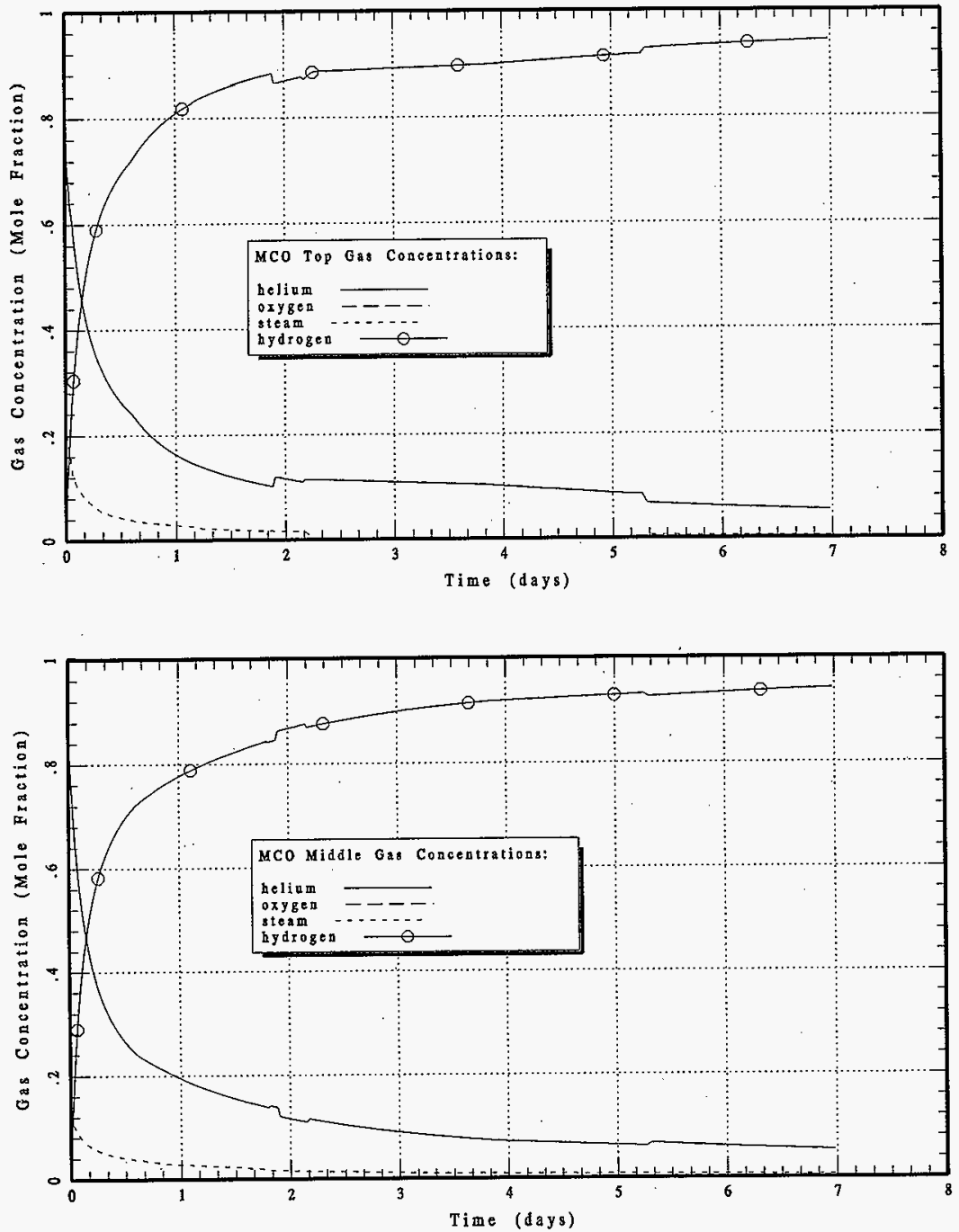


\section{HNF-SD-SNF-CN-023 REV 1}

DS46DEg: HIGH-PRESSURE THERMAL RUNAWAY w 46 Deg C Annulus
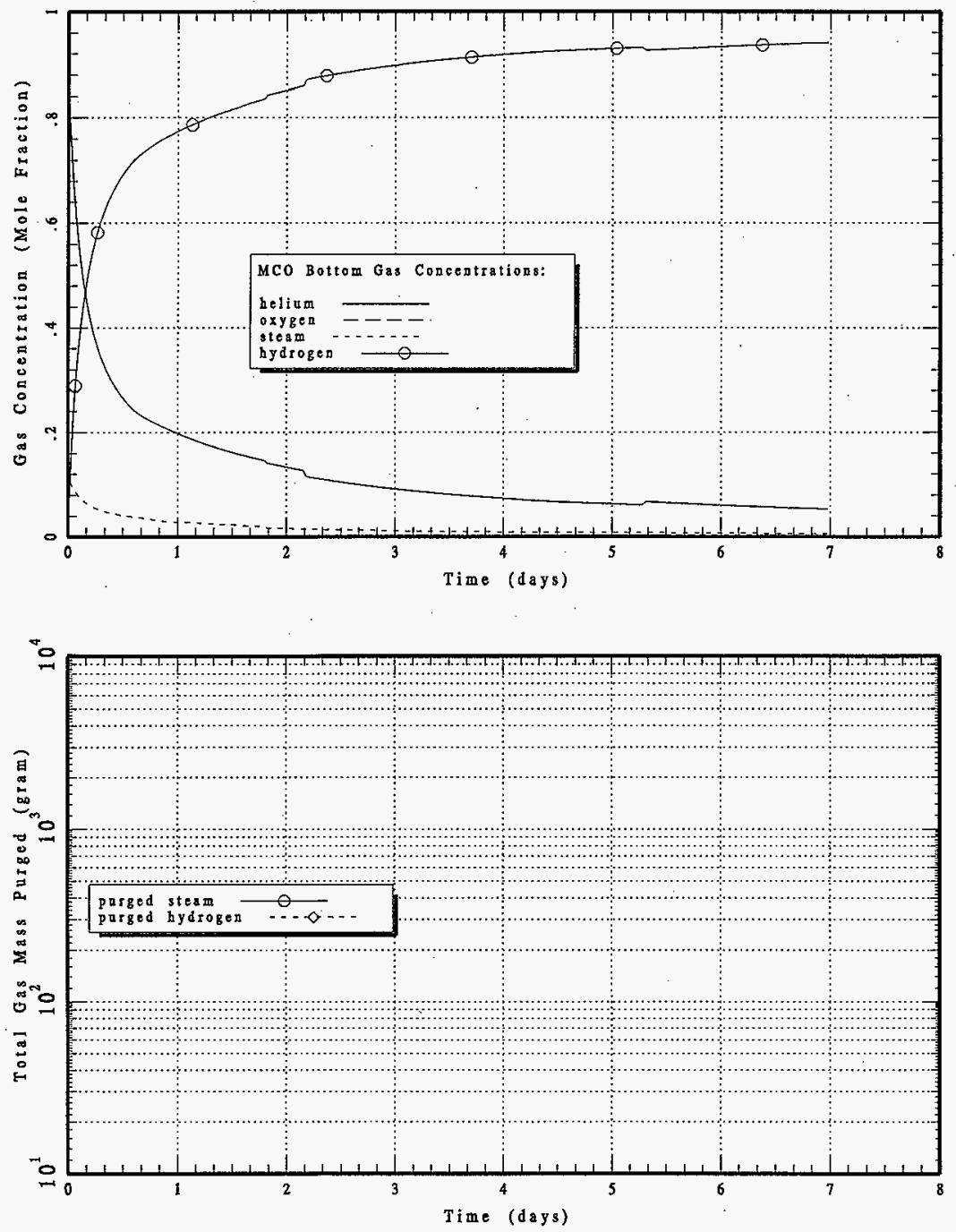


\section{HNF-SD-SNF-CN-023 REV 1}
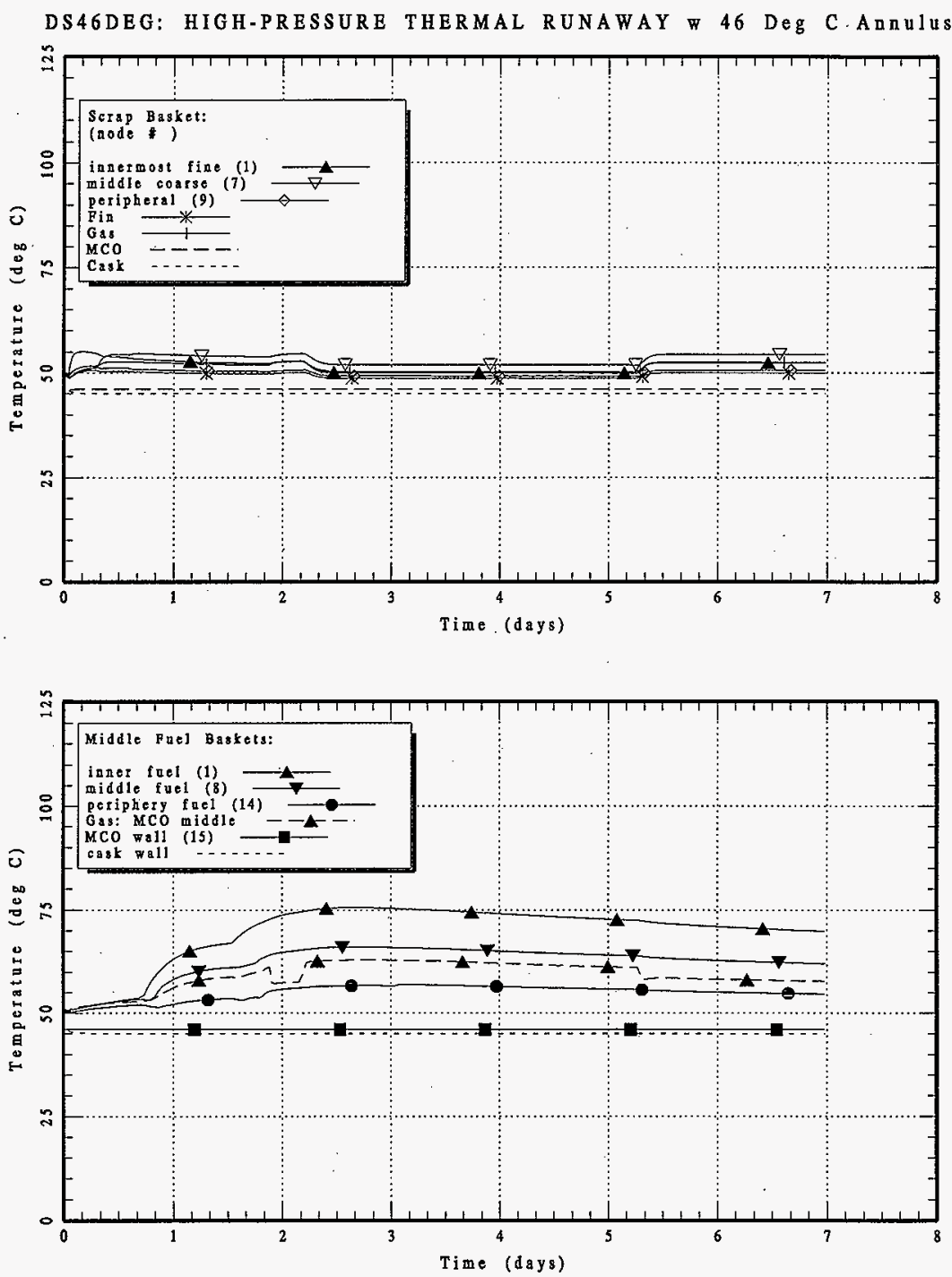

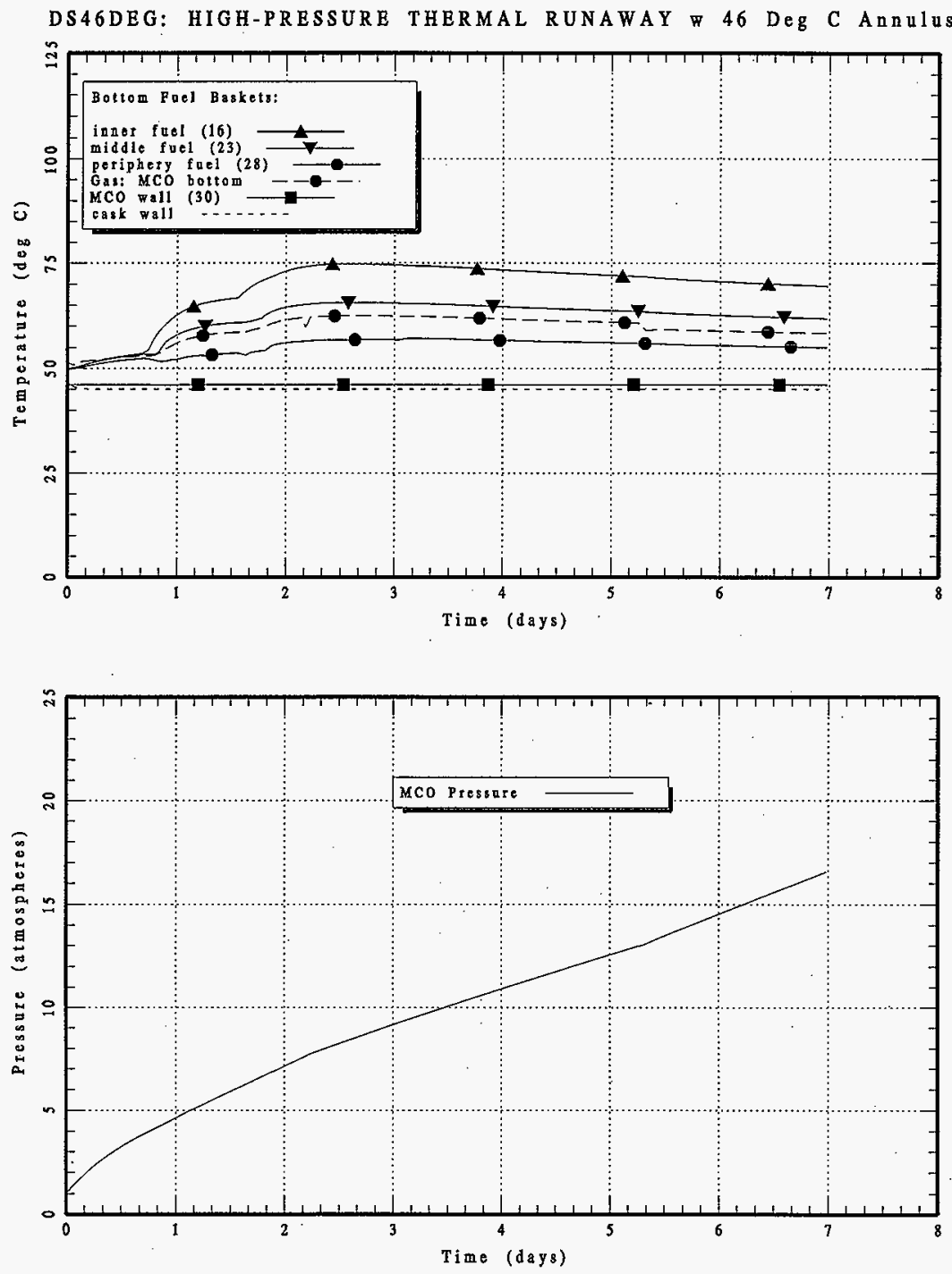


\section{HNF-SD-SNF-CN-023 REV 1}

Figure A-27 DS55DEG: High-Pressure Thermal Runaway with $55^{\circ} \mathrm{C}$ Annulus 


\section{HNF-SD-SNF-CN-023 REV 1}

This page intentionally left blank. 


\section{HNF-SD-SNF-CN-023 REV 1}

DS55DEG: HIGH-PRESSURE THERMAL RUNAWAY w 55 Deg C Annulus
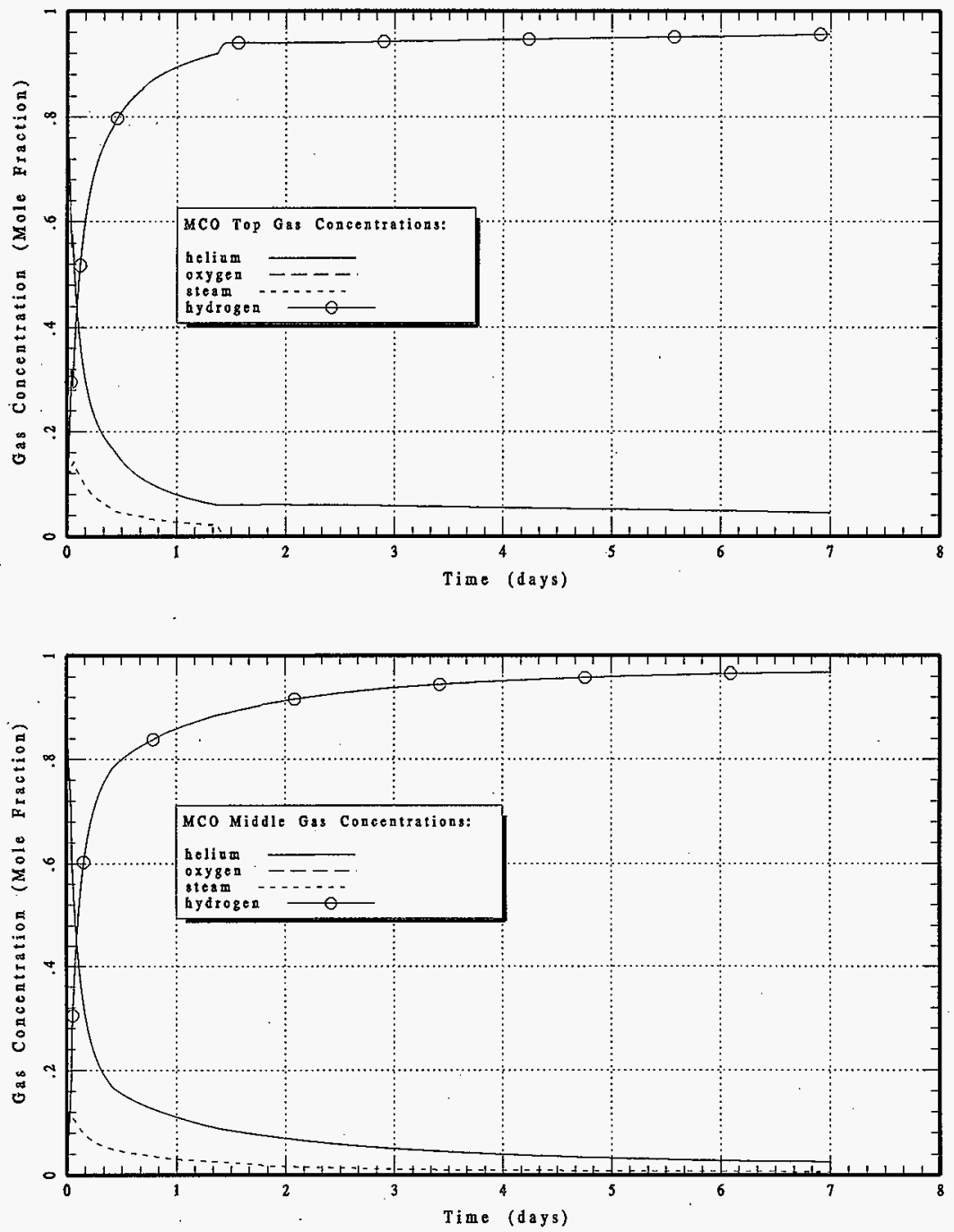


\section{HNF-SD-SNF-CN-023 REV 1}

DS55DEG: HIGH-PRESSURE THERMAL RUNAWAY w 55 Deg C Annulus
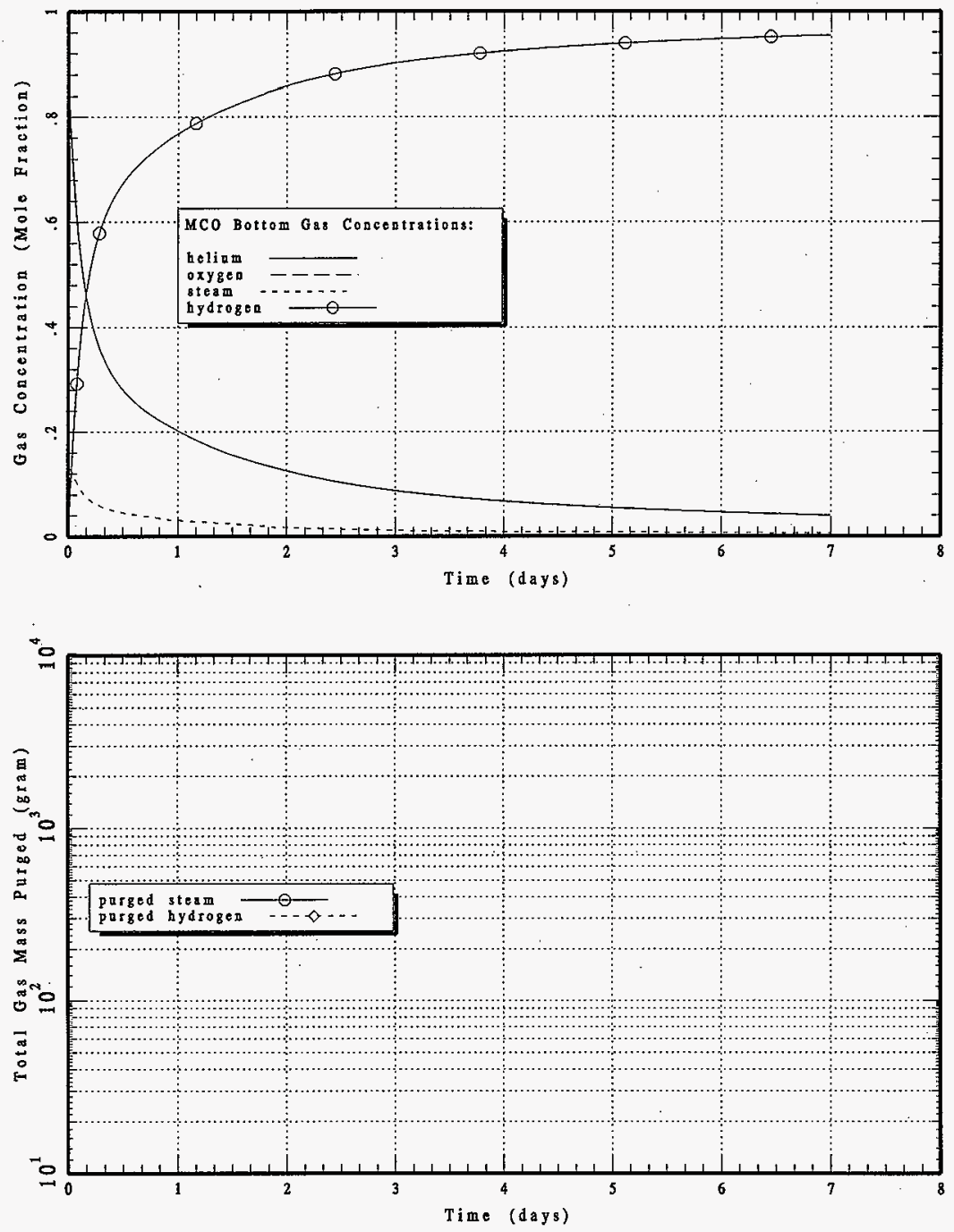
DS55DEG: HIGH-PRESSURE THERMAL RUNAWAY w 55 Deg C Annulus
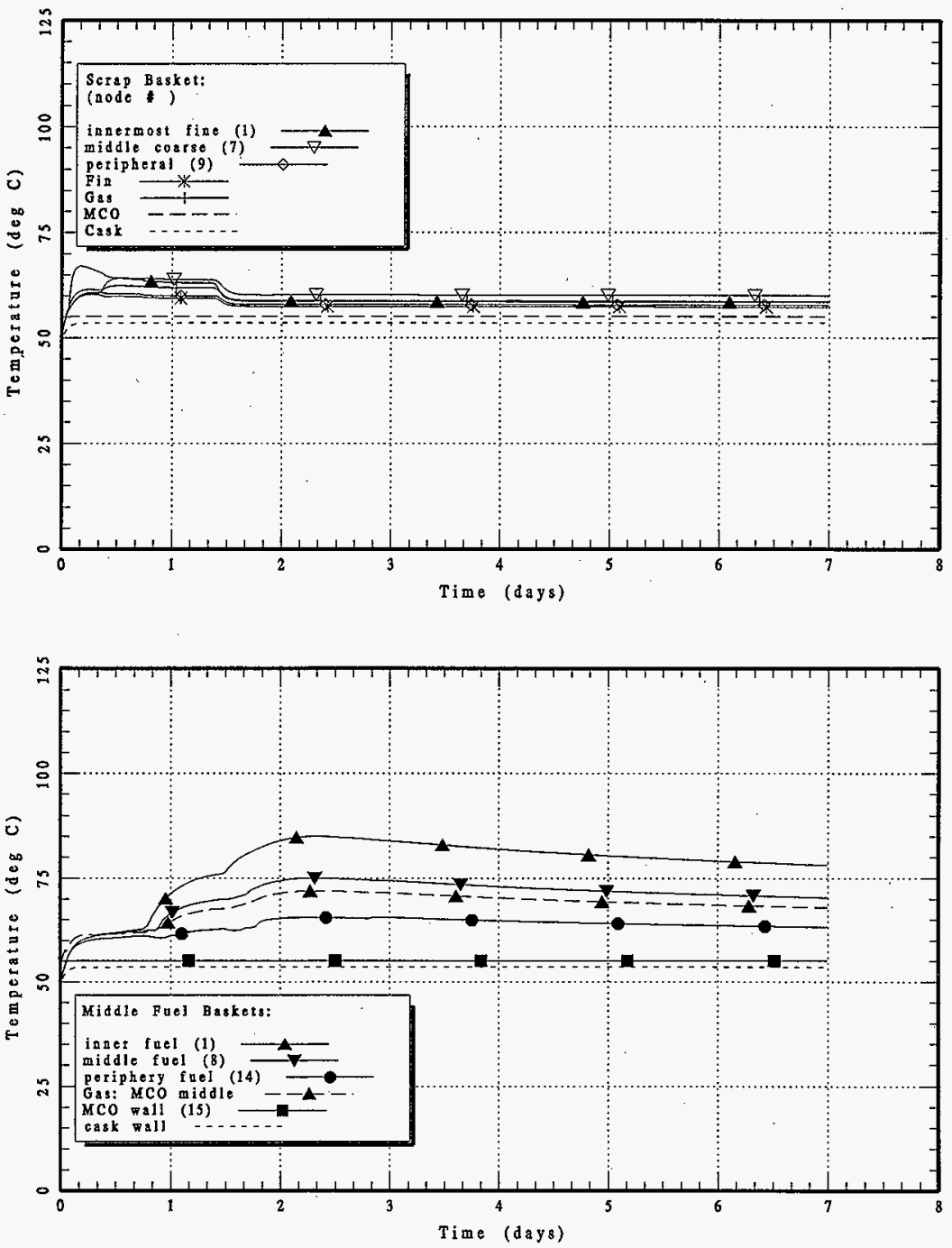


\section{HNF-SD-SNF-CN-023 REV 1}
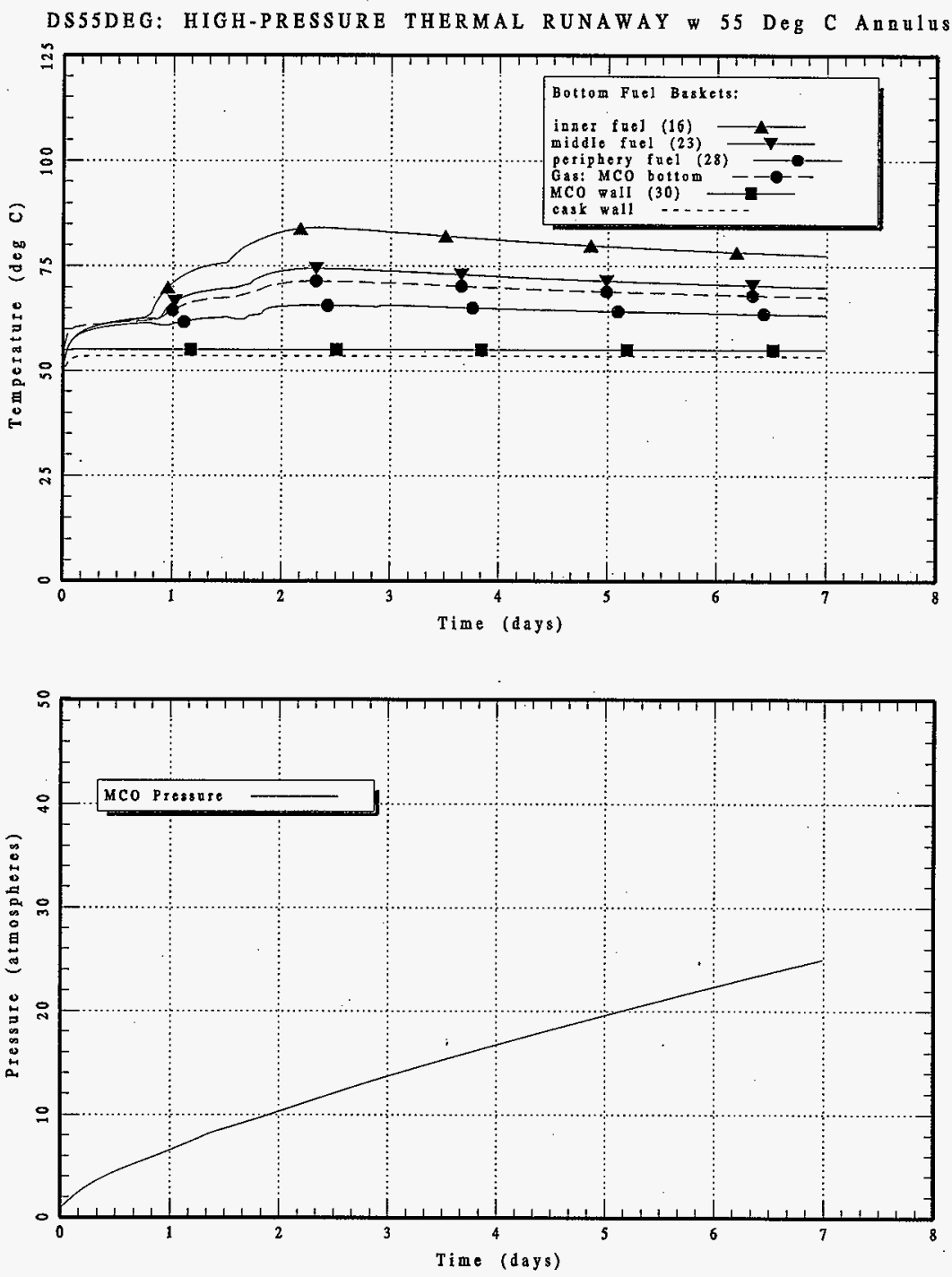


\section{HNF-SD-SNF-CN-023 REV 1}

Figure A-28 DS75DEG: High-Pressure Thermal Runaway w $75^{\circ} \mathrm{C}$ Annulus 
HNF-SD-SNF-CN-023 REV 1

This page intentionally left blank. 


\section{HNF-SD-SNF-CN-023 REV 1}

DS75DEG: HIGH-PRESSURE THERMAL RUNAWAY w 75 Deg C Annulus
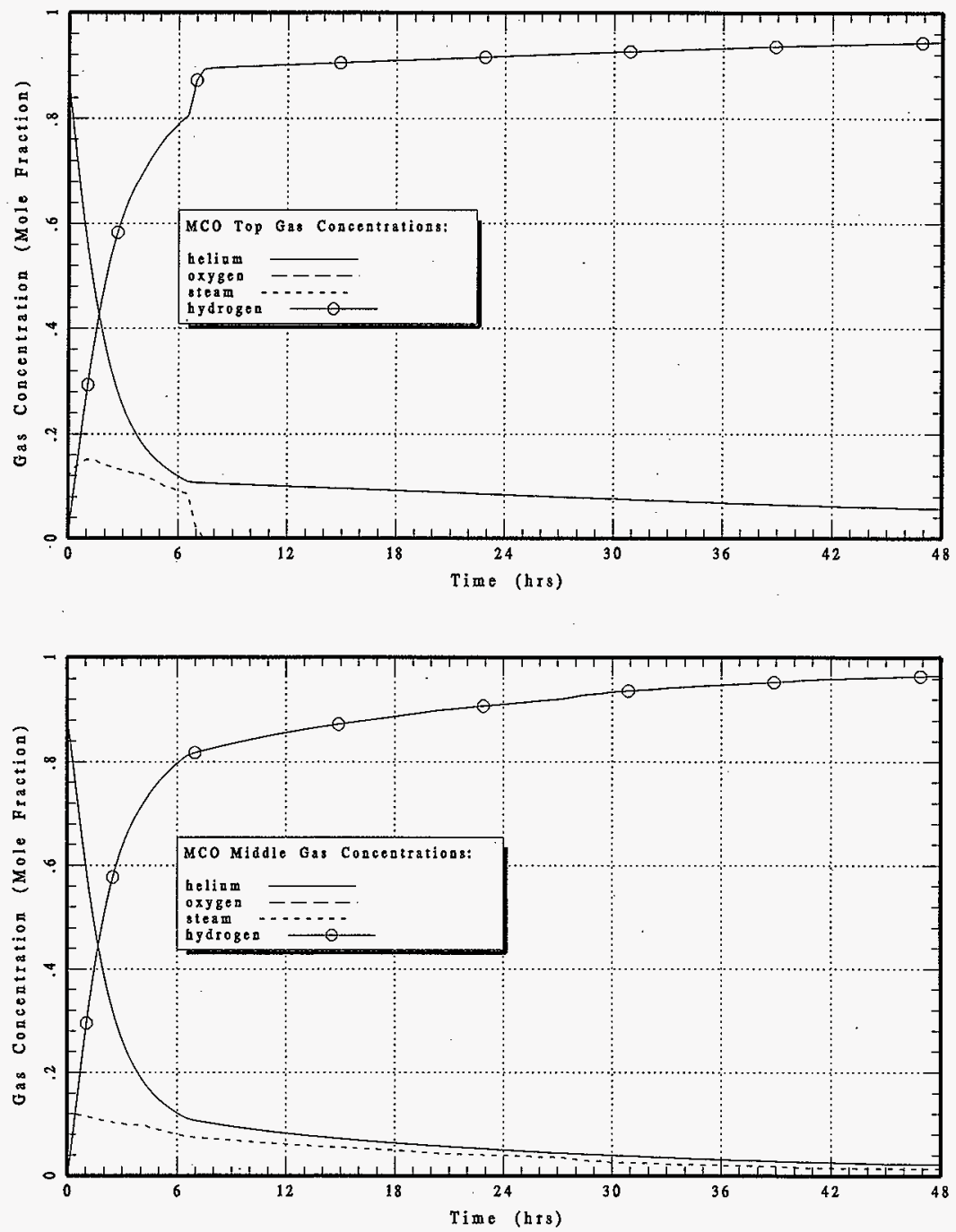


\section{HNF-SD-SNF-CN-023 REV 1}

DS75DEG: HIGH-PRESSURE THERMAL RUNAWAY w 75 Deg C Annulus
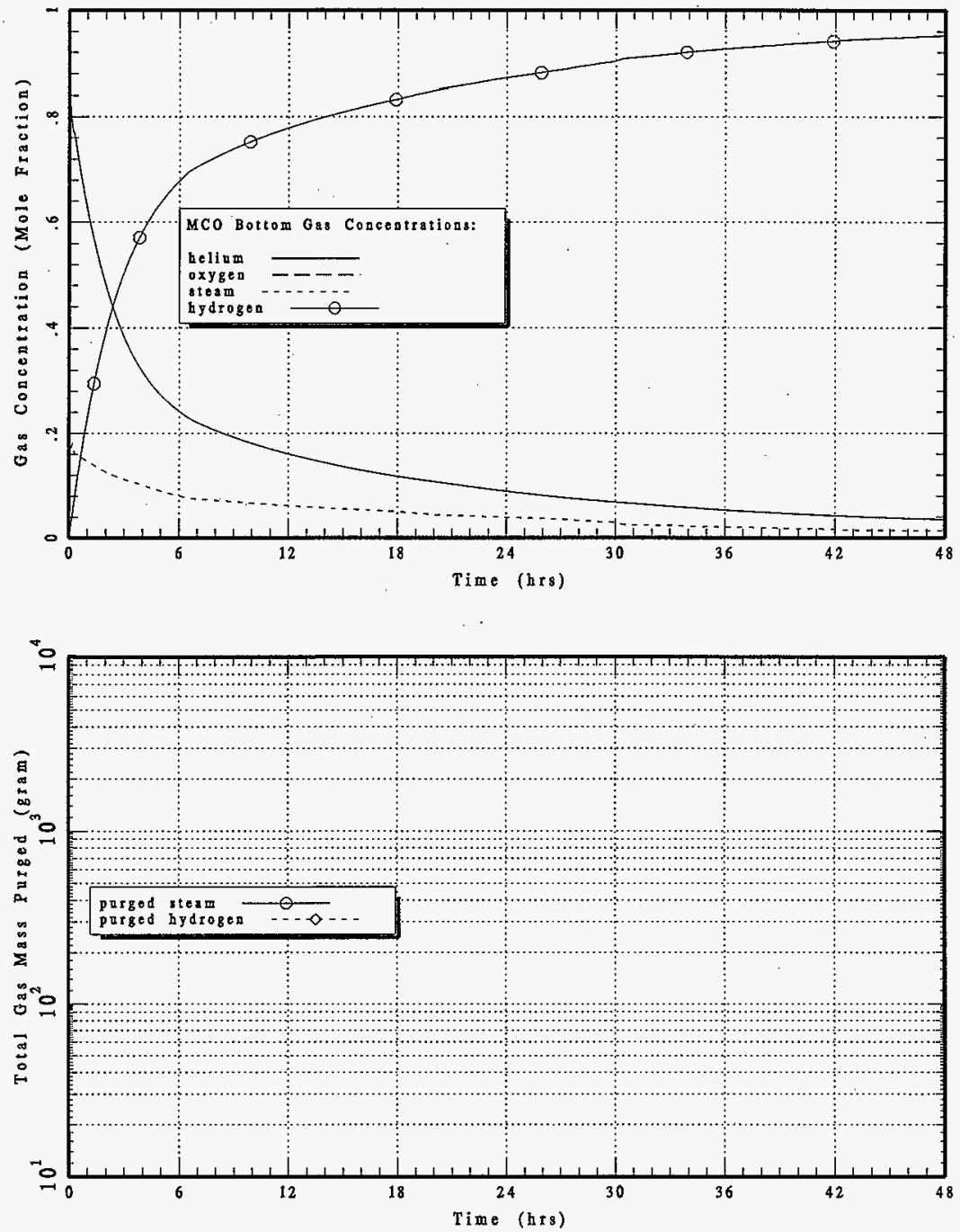


\section{HNF-SD-SNF-CN-023 REV 1}
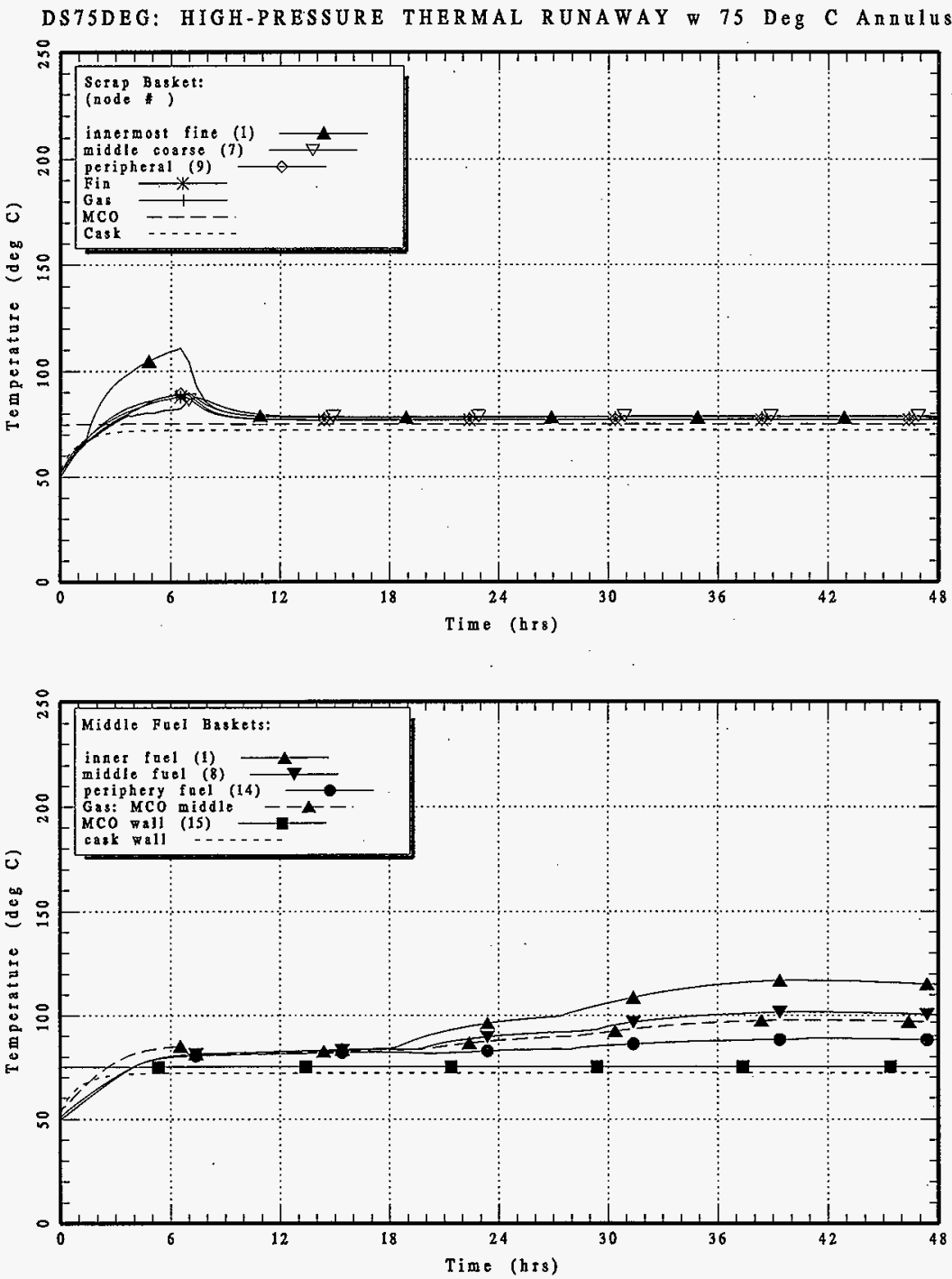


\section{HNF-SD-SNF-CN-023 REV 1}
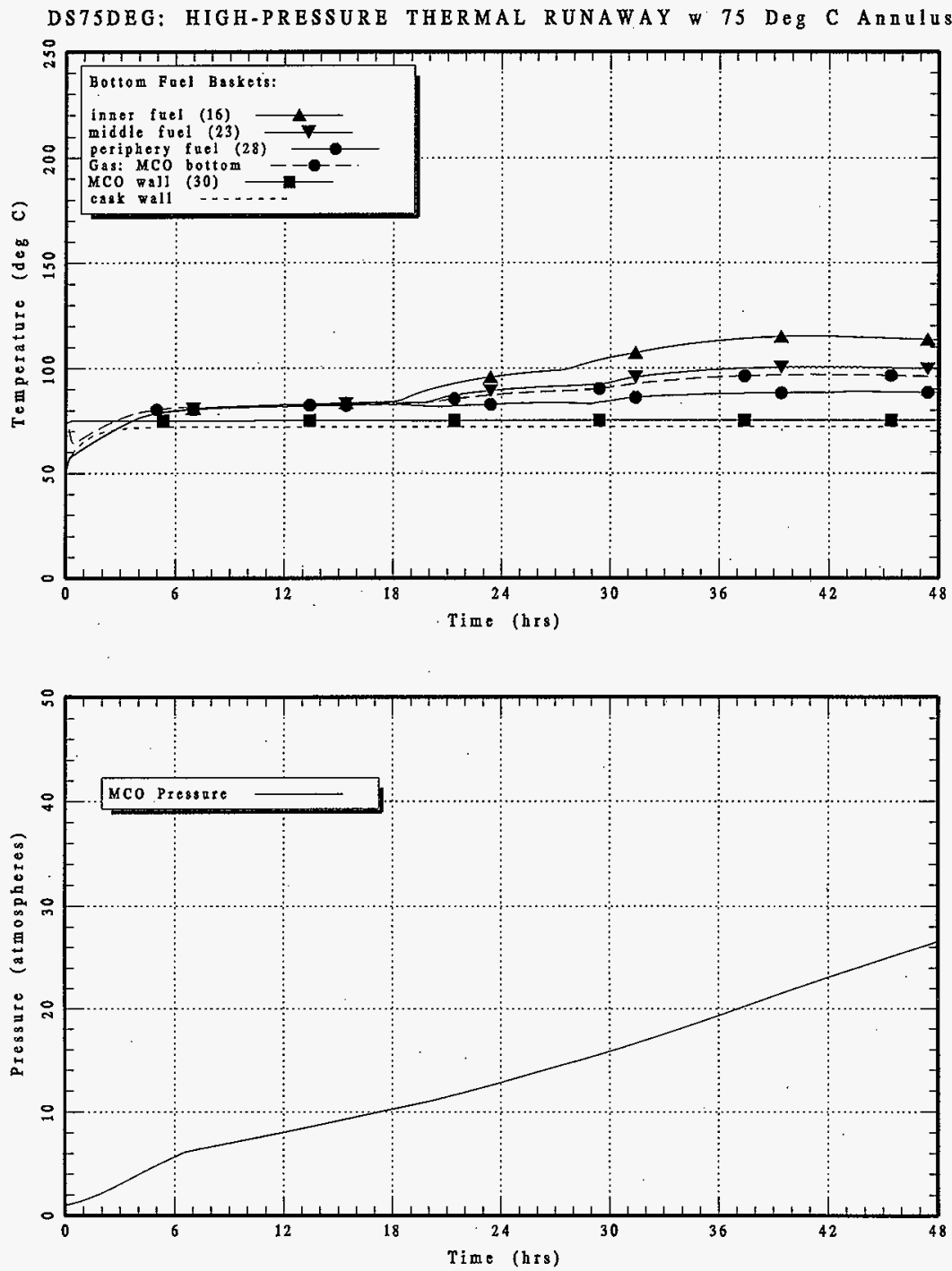


\section{HNF-SD-SNF-CN-023 REV 1}

Figure A-29 DSHOT: High-Pressure Thermal Runaway with $85^{\circ} \mathrm{C}$ Annulus 


\section{HNF-SD-SNF-CN-023 REV 1}

This page intentionally left blank. 


\section{HNF-SD-SNF-CN-023 REV 1}

DSHOT: HIGH-PRESSURE THERMAL RUNAWAY W 85 Deg C Annulus
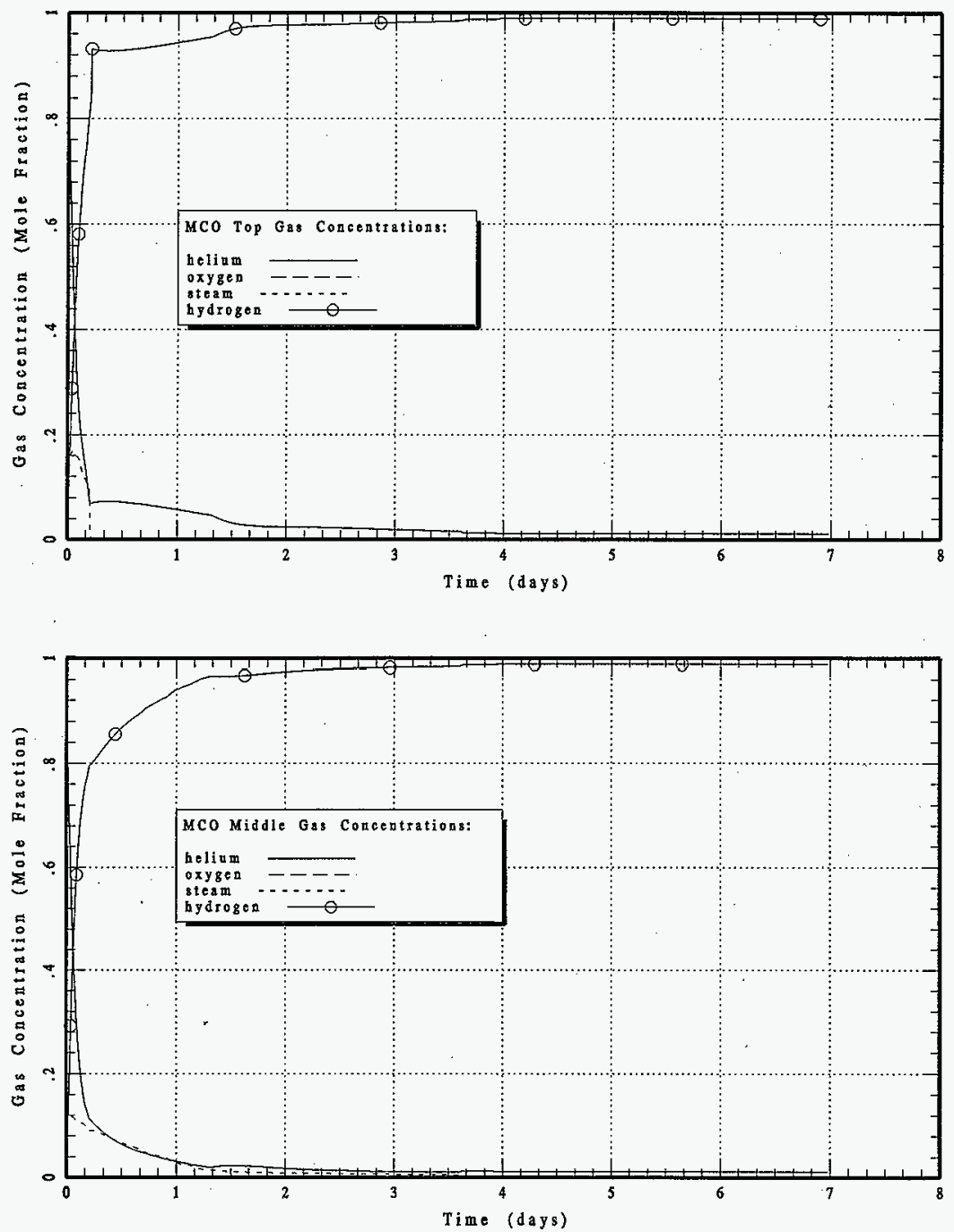


\section{HNF-SD-SNF-CN-023 REV 1}

DSHOT: HIGH-PRESSURE THERMAL RUNAWAY w 85 Deg C Annulus
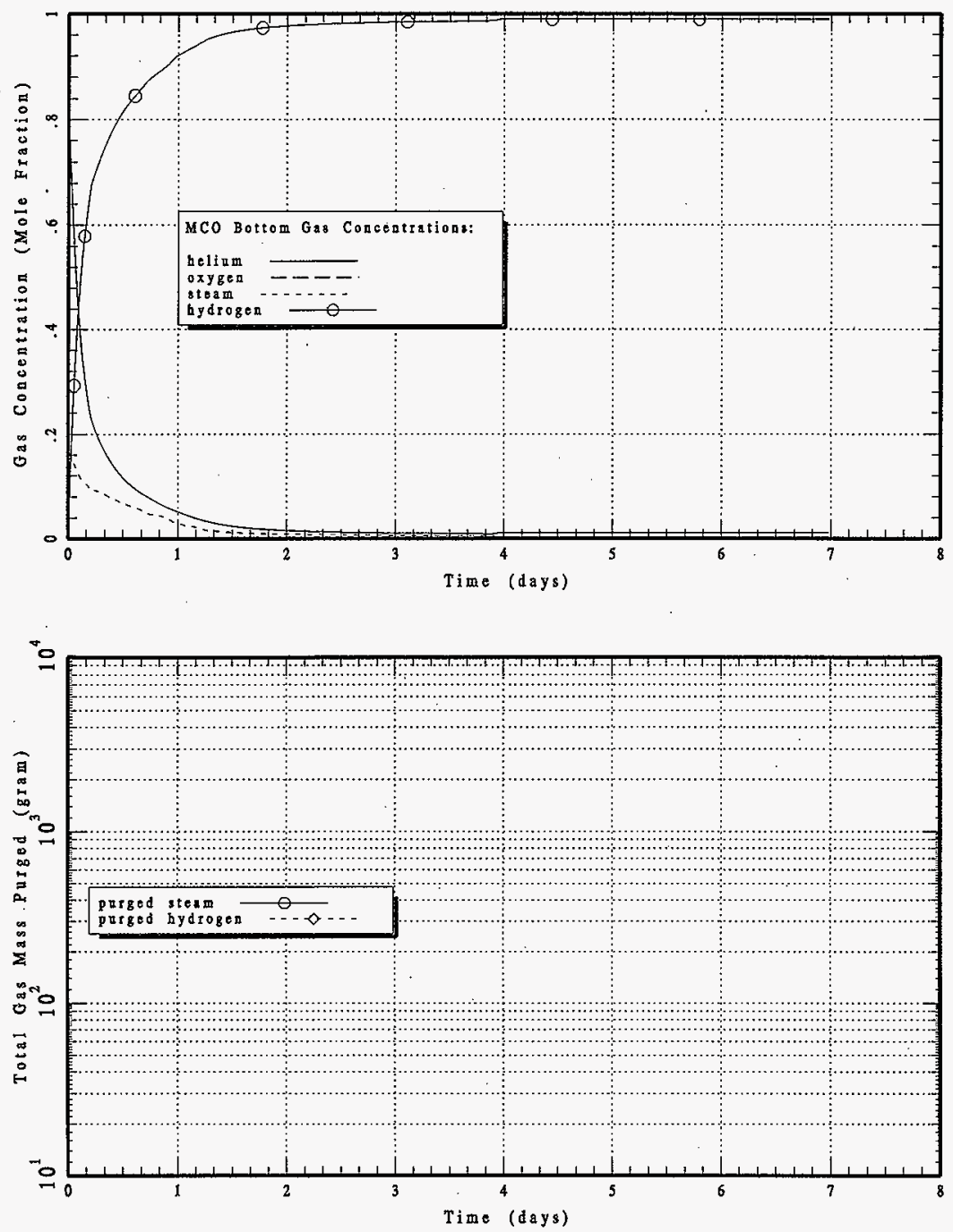


\section{HNF-SD-SNF-CN-023 REV 1}

DSHOT: HIGH-PRESSURE THERMAL RUNAWAY w 85 Deg C Annuls
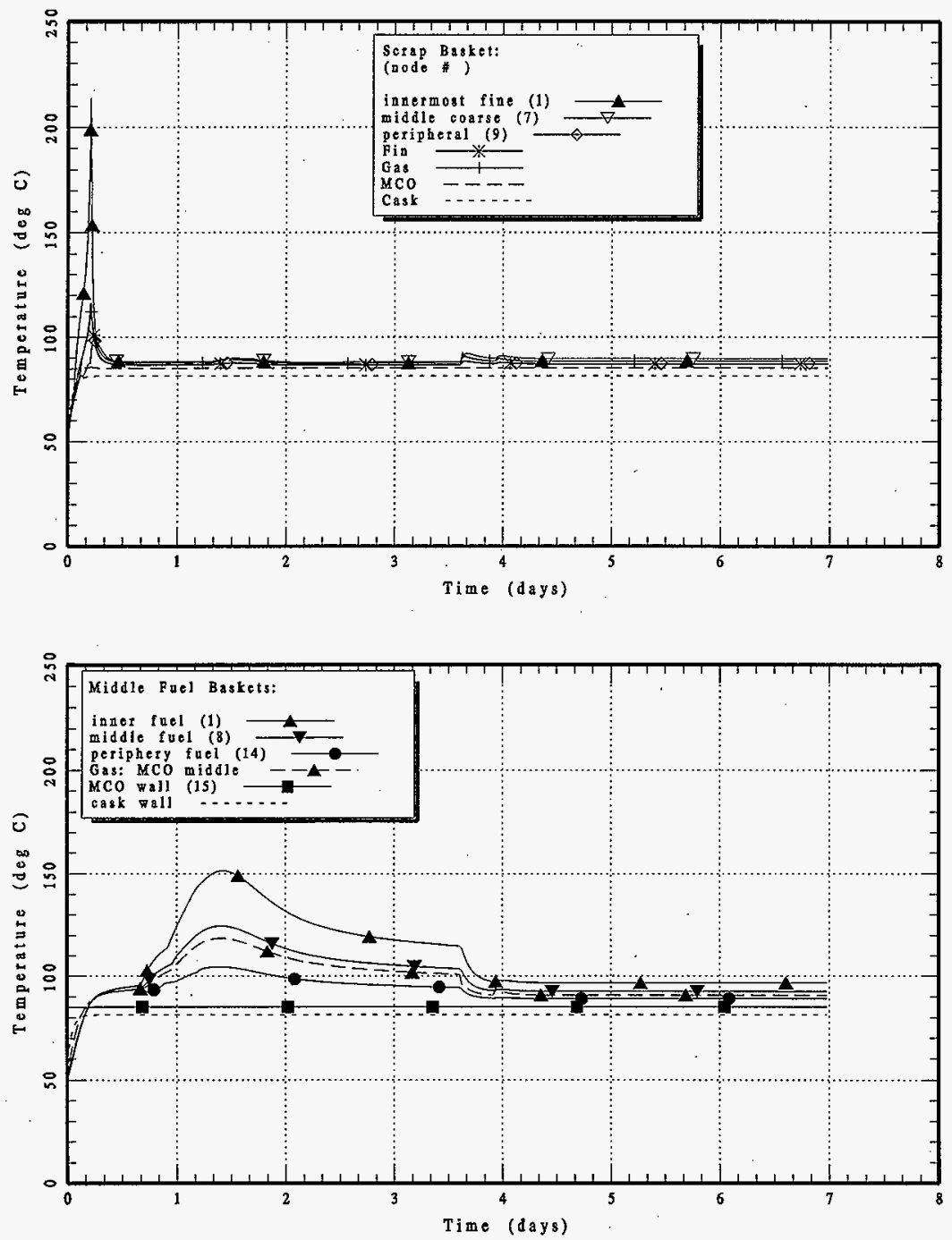


\section{HNF-SD-SNF-CN-023 REV 1}

DSHOT: HIGH-PRESSURE THERMAL RUNAWAY w 85 Deg C Annulus
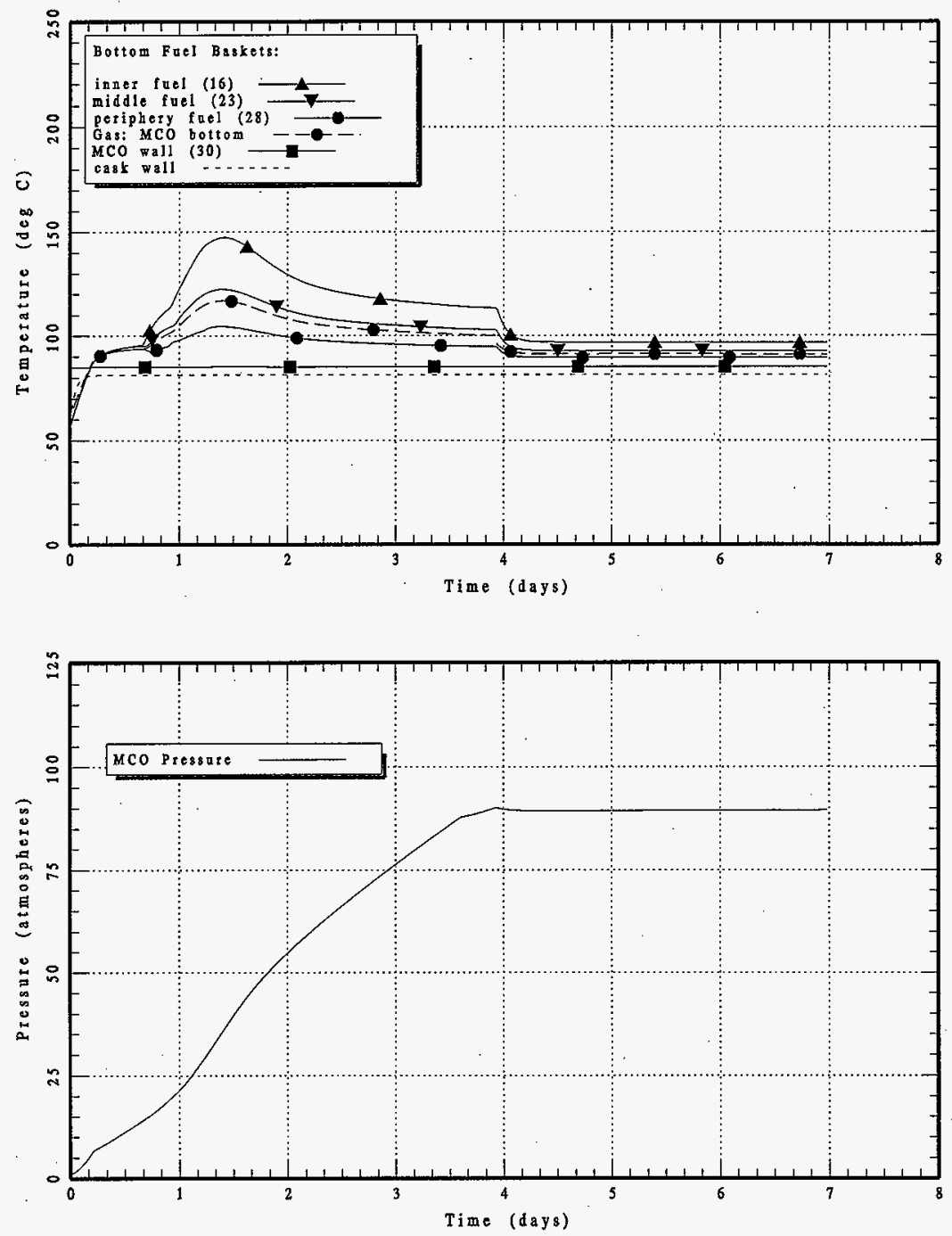


\section{HNF-SD-SNF-CN-023 REV 1}

Figure A-30 DHOT75KG: High-Pressure Thermal Runaway with $75 \mathrm{Kg}$ Water and $85^{\circ} \mathrm{C}$ Annulus 
HNF-SD-SNF-CN-023 REV 1

This page intentionally left blank. 


\section{HNF-SD-SNF-CN-023 REV 1}

DHOT75KG: HI-PRES THERM RUNAWAY $75 \mathrm{Kg}$ Water \& 85 Deg C Annulus
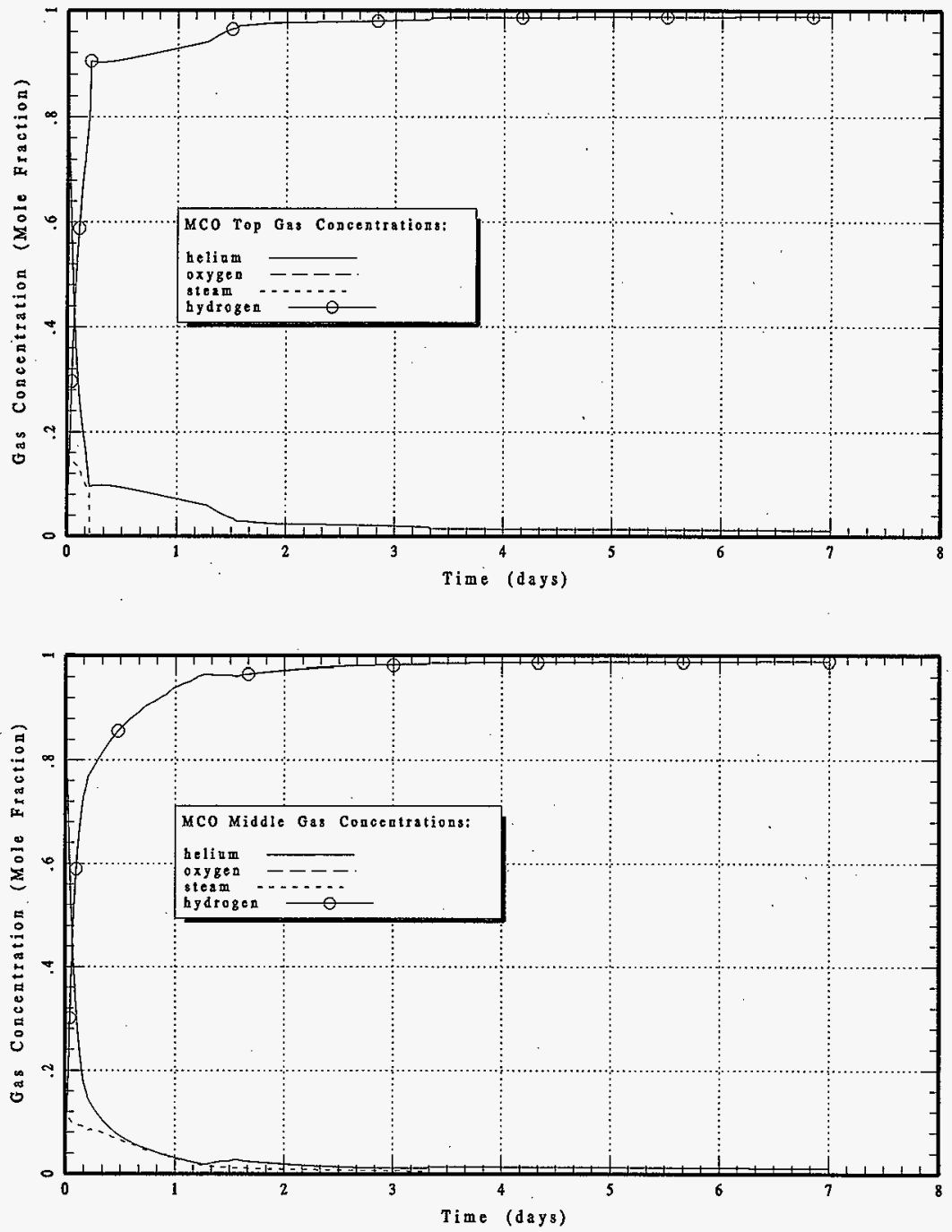
DHOT75KG: HI-PRES THERM RUNAWAY w $75 \mathrm{Kg}$ Water \& 85 Deg C Annulus
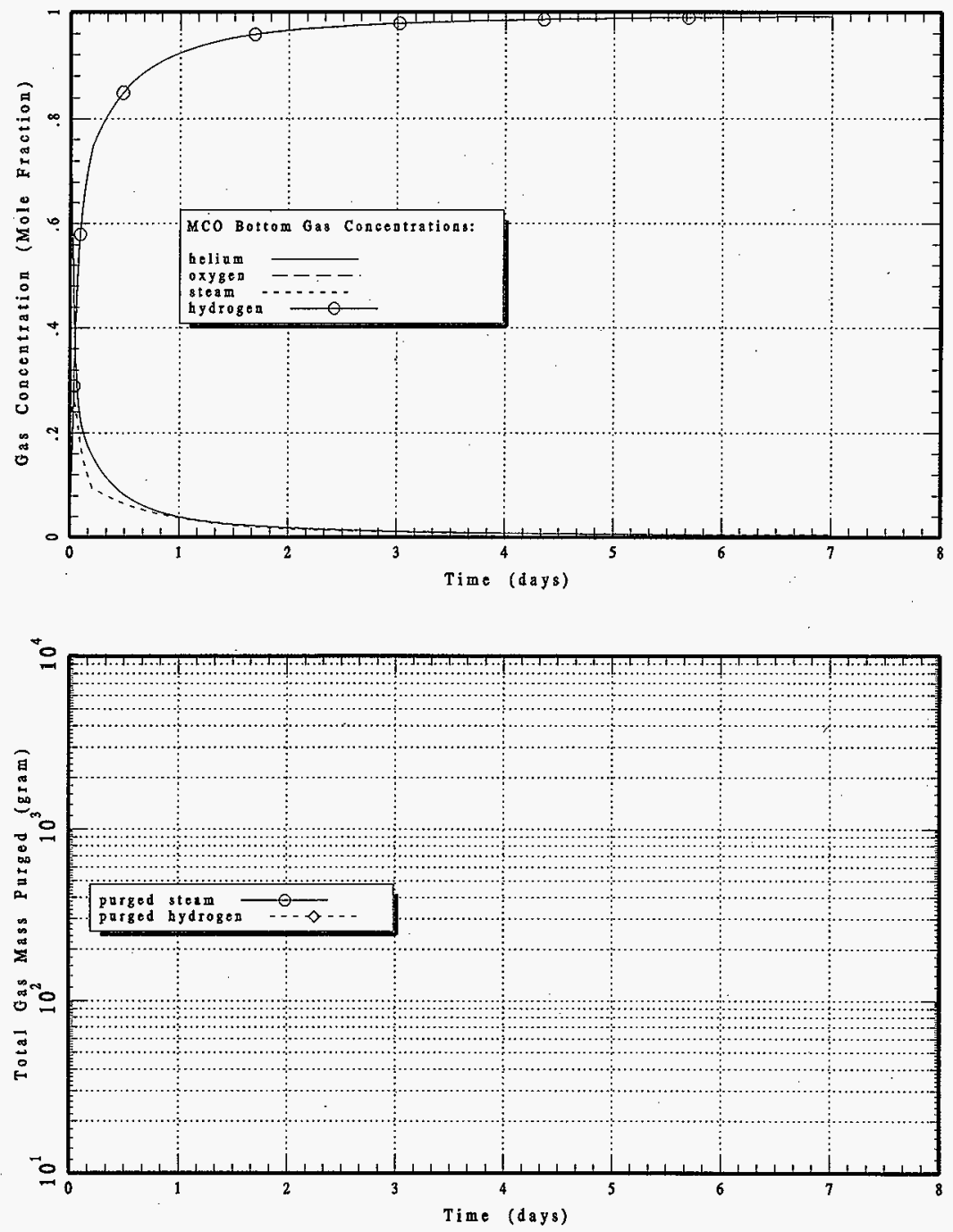


\section{HNF-SD-SNF-CN-023 REV 1}
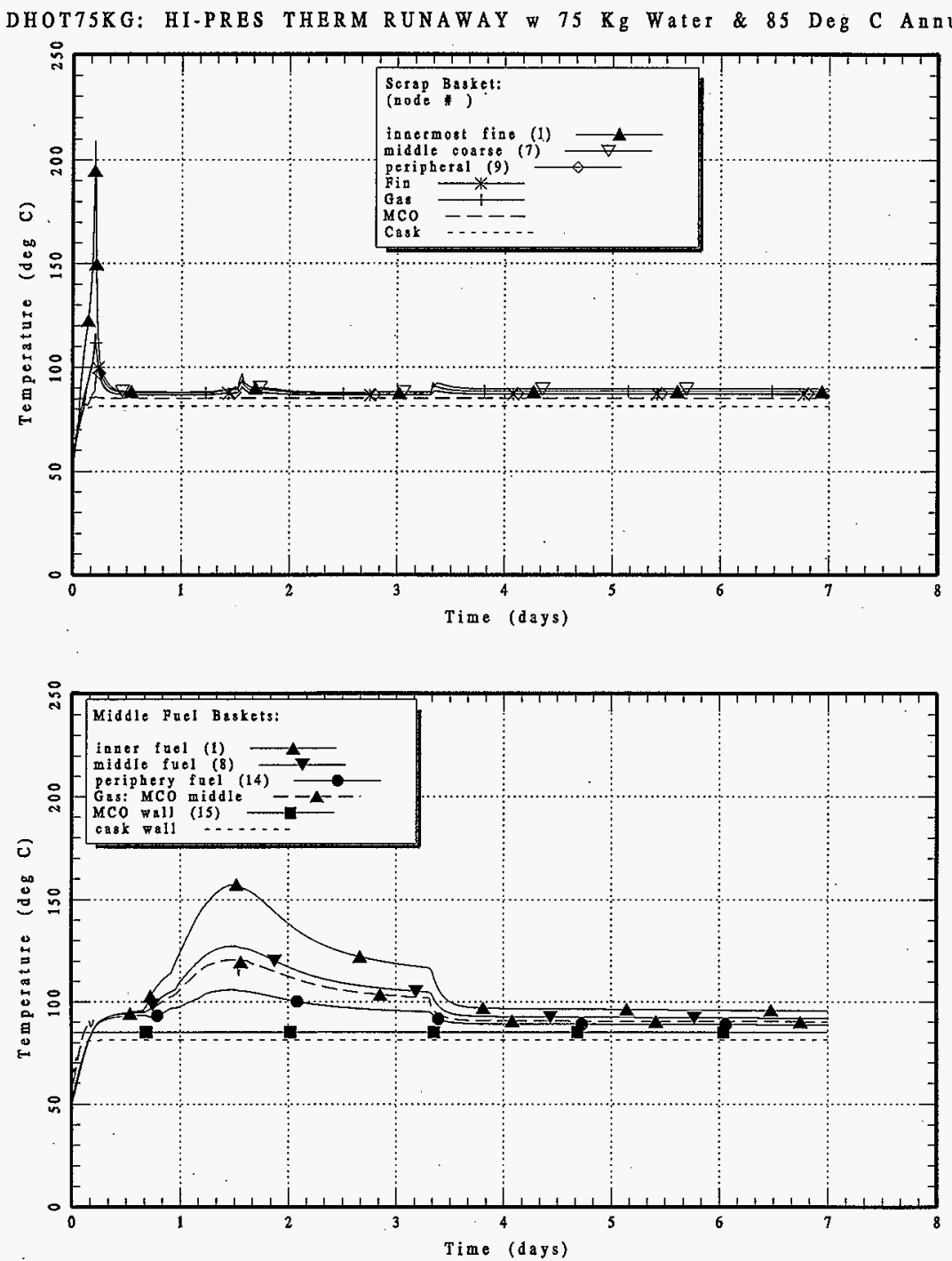

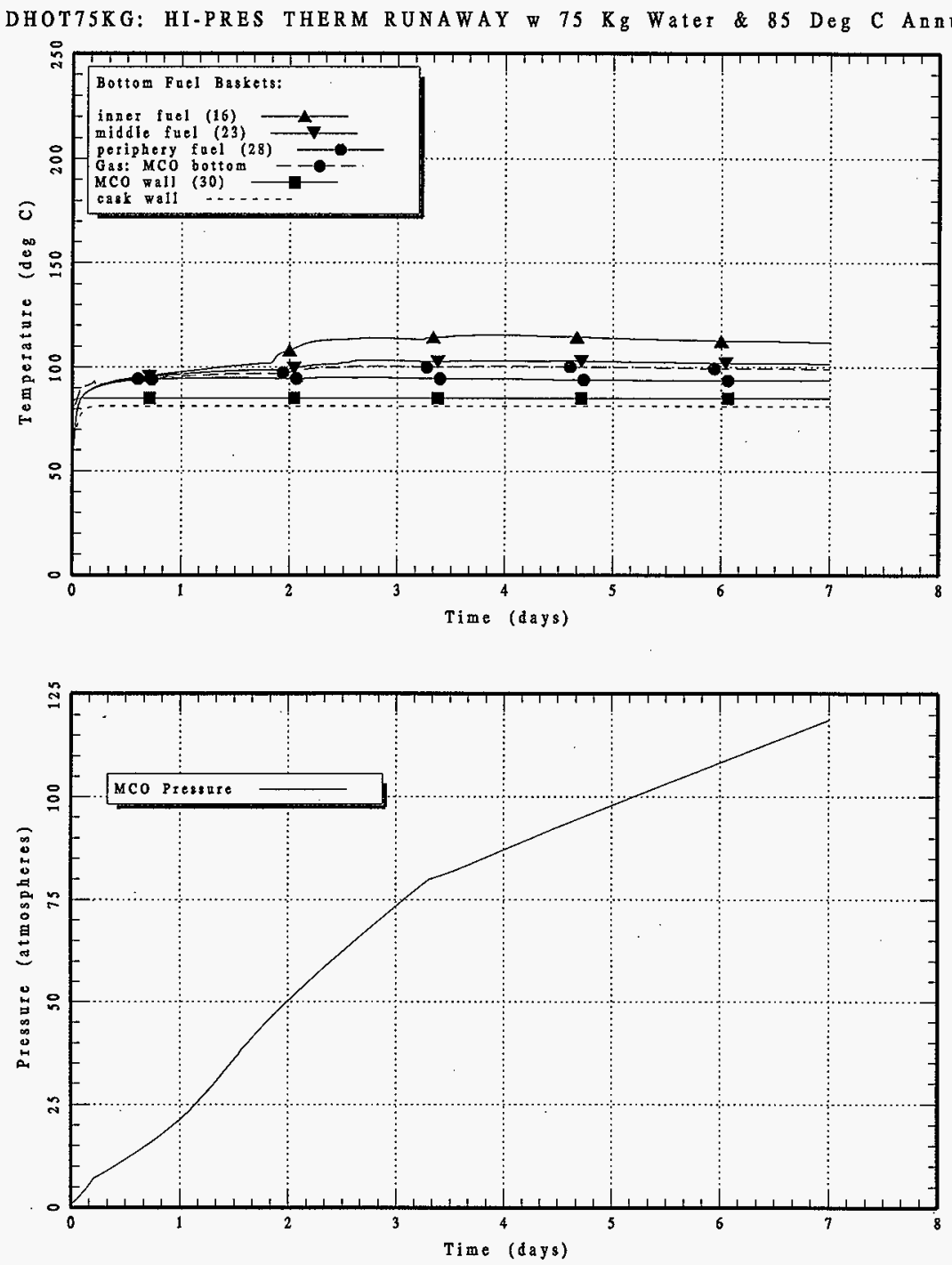


\section{HNF-SD-SNF-CN-023 REV 1}

Figure A-31 DSHOTOV: Low-Pressure Thermal Runaway with $85^{\circ} \mathrm{C}$ Annulus 


\section{HNF-SD-SNF-CN-023 REV 1}

This page intentionally left blank. 
DSHOTOV: LOW-PRESSURE THERMAL RUNAWAY w 85 Deg Annulus
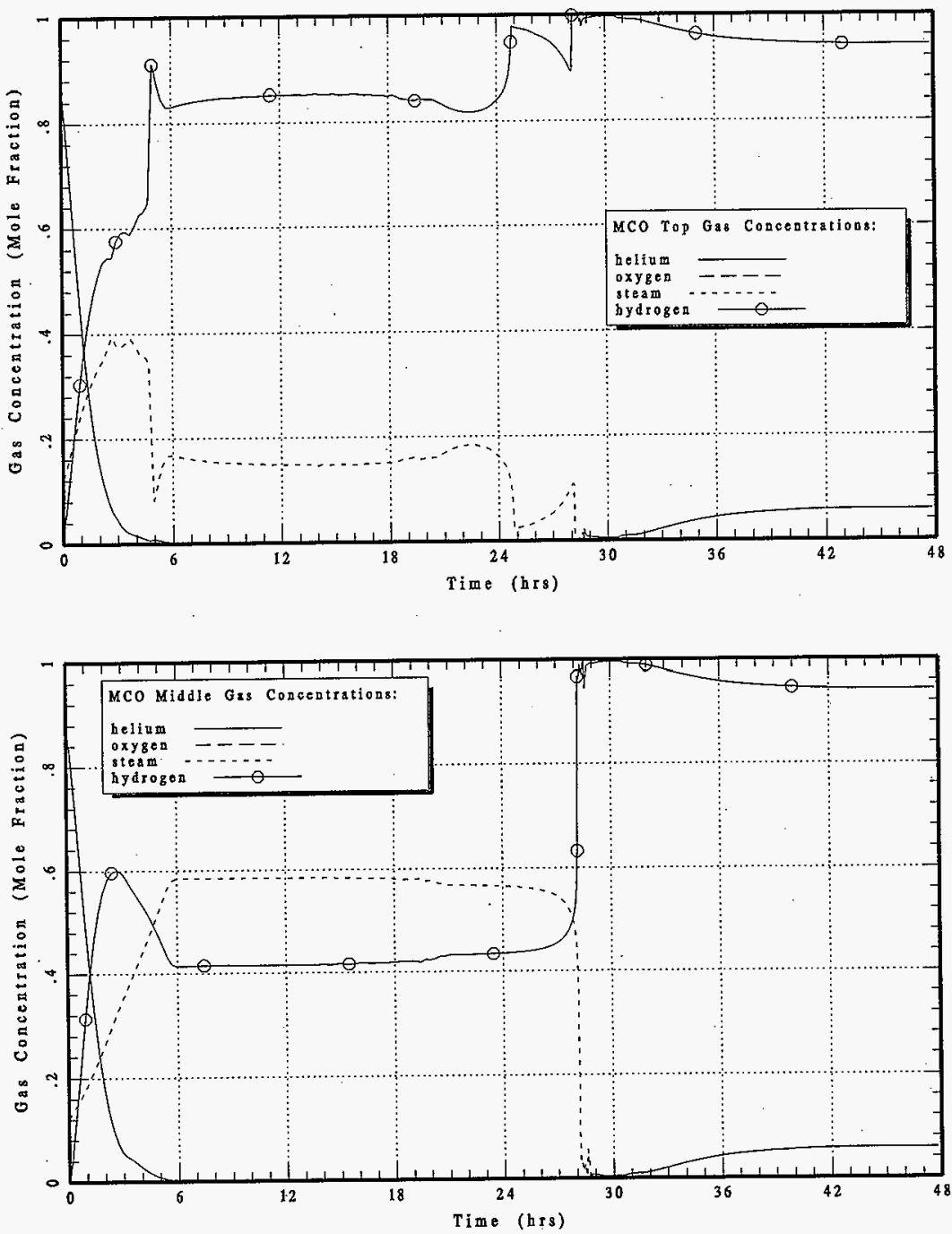
DSHOTOV: LOW-PRESSURE THERMAL RUNAWAY w 85 Deg Annulus
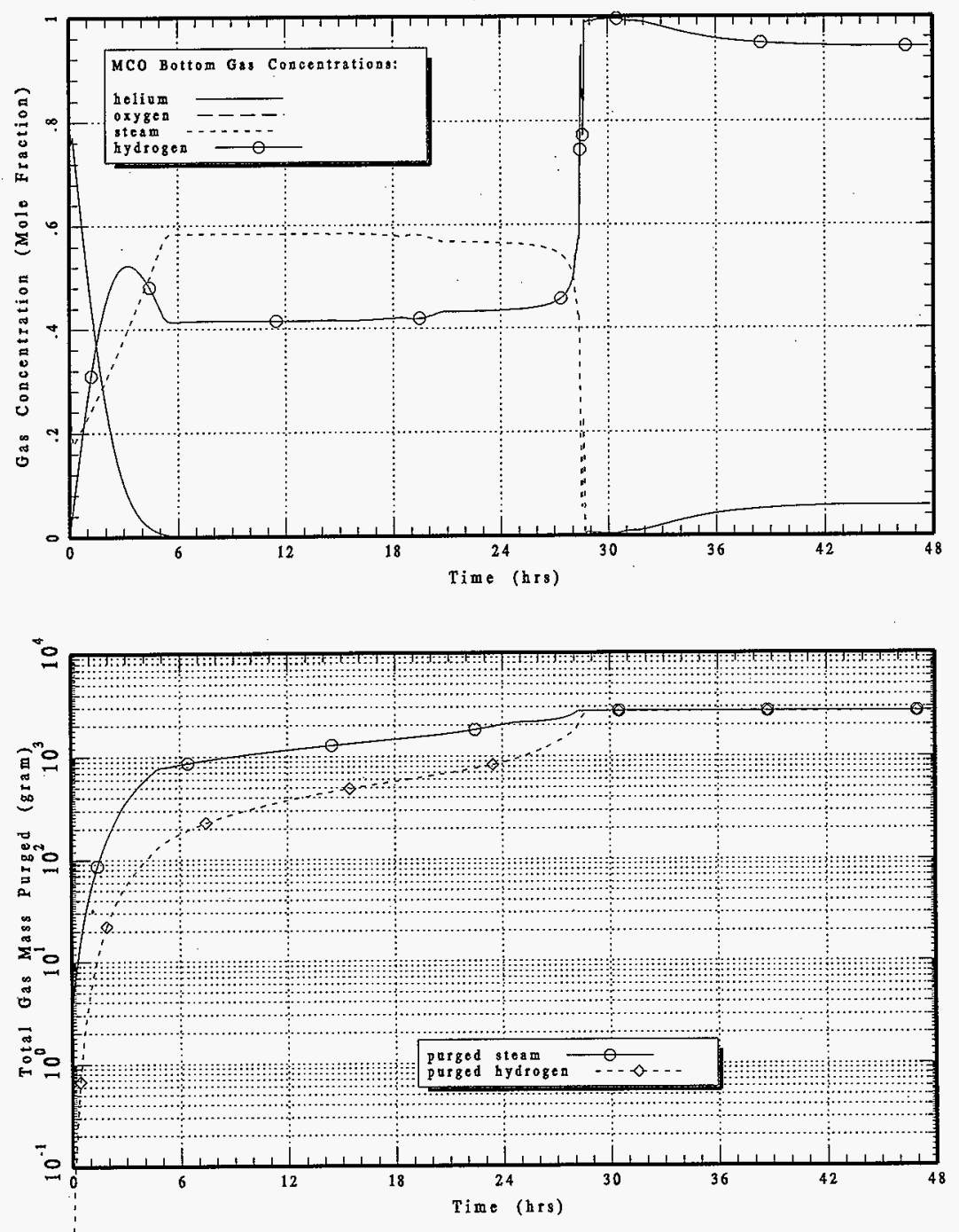


\section{HNF-SD-SNF-CN-023 REV 1}
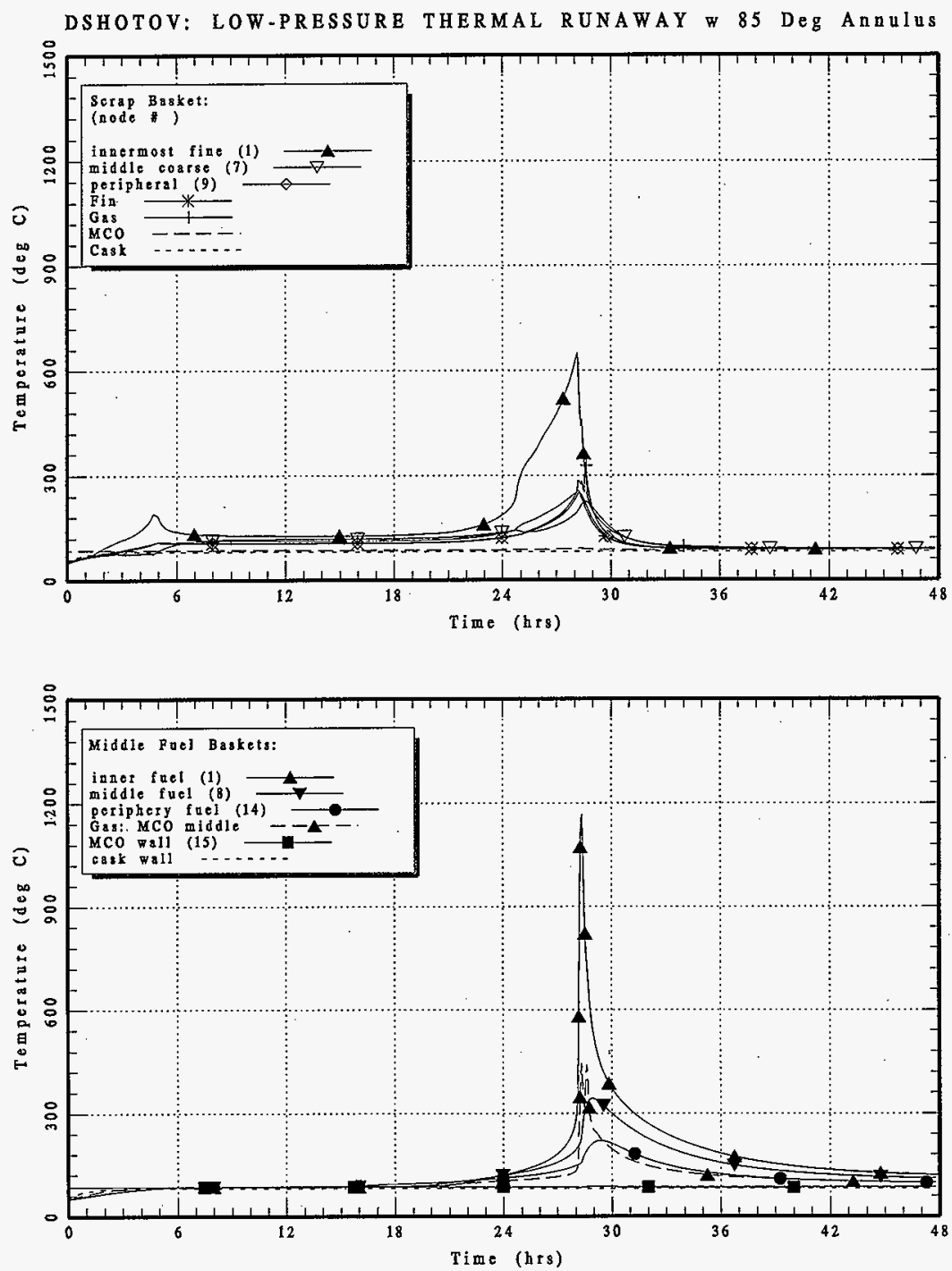


\section{HNF-SD-SNF-CN-023 REV 1}
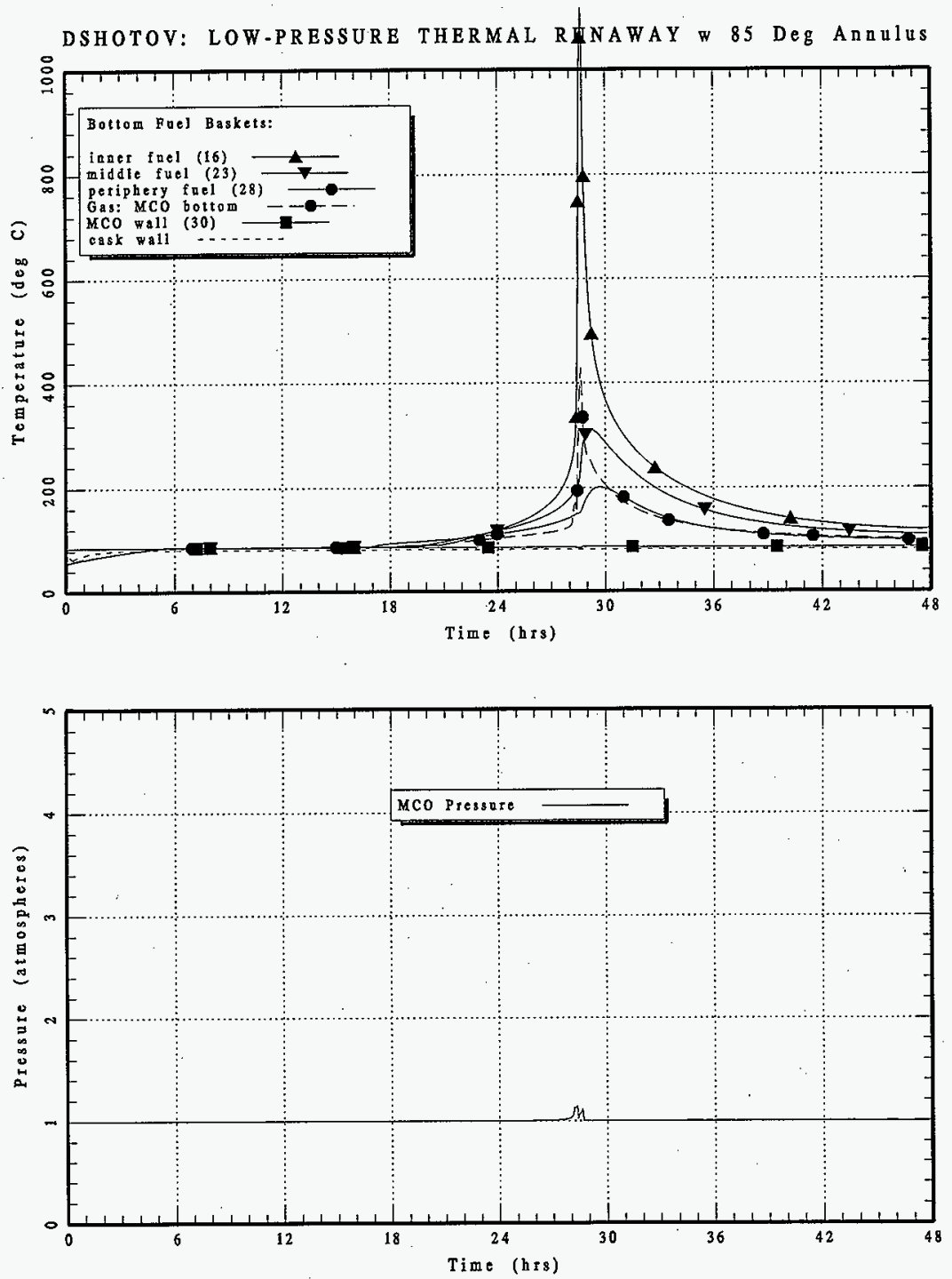


\section{HNF-SD-SNF-CN-023 REV 1}

Figure A-32 VACAIRI: Indefinite Vacuum with Air Ingress and $50{ }^{\circ} \mathrm{C}$ Annulus 


\section{HNF-SD-SNF-CN-023 REV 1}

This page intentionally left blank. 


\section{HNF-SD-SNF-CN-023 REV 1}

VACAIRI: INDEFINITE VACUUM $W$ Air Ingress \& 50 Deg C Annulus
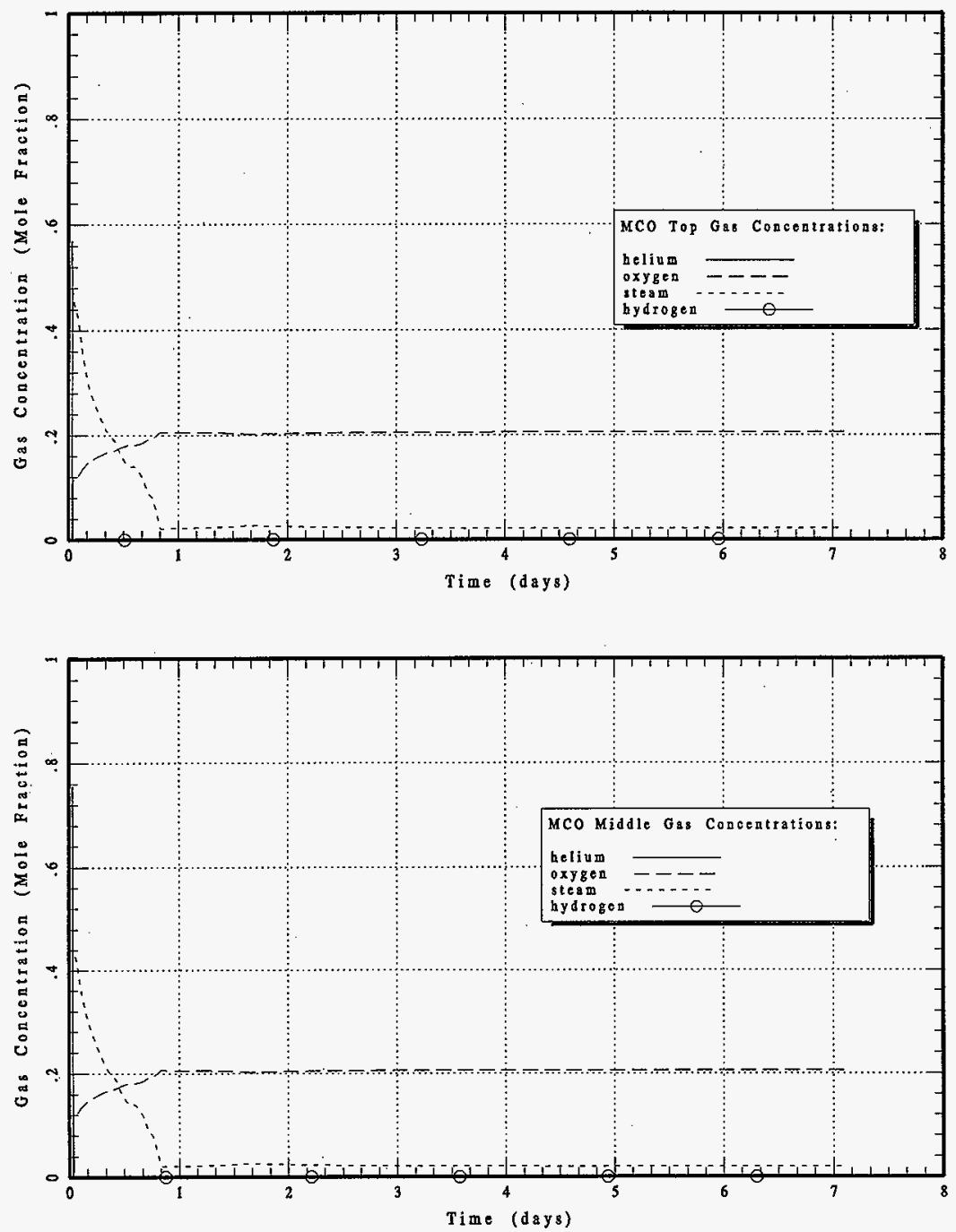


\section{HNF-SD-SNF-CN-023 REV 1}

VACAIRI: INDEFINITE VACUUM $w$ Air Ingress \& 50 Deg C Annulus
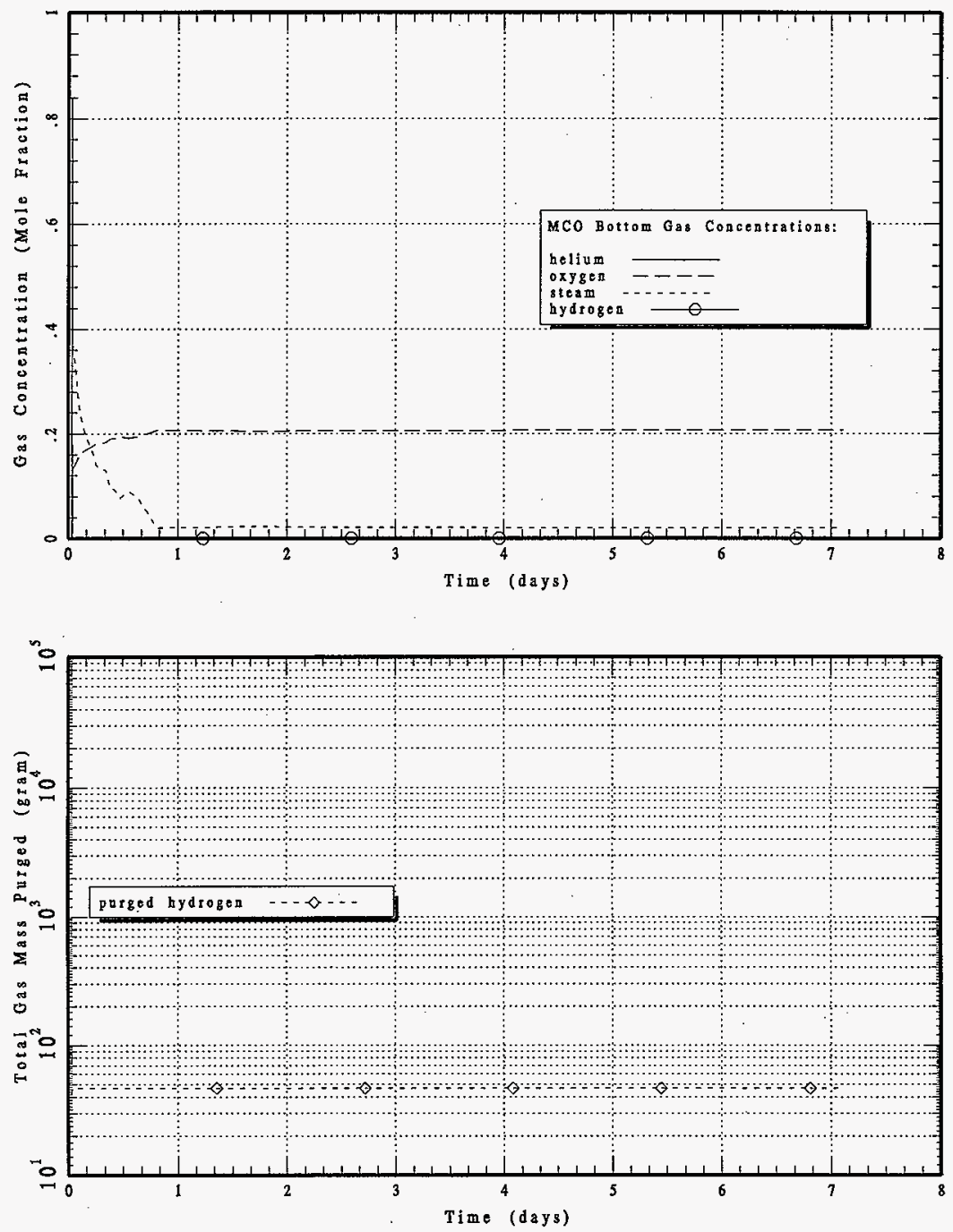


\section{HNF-SD-SNF-CN-023 REV 1}
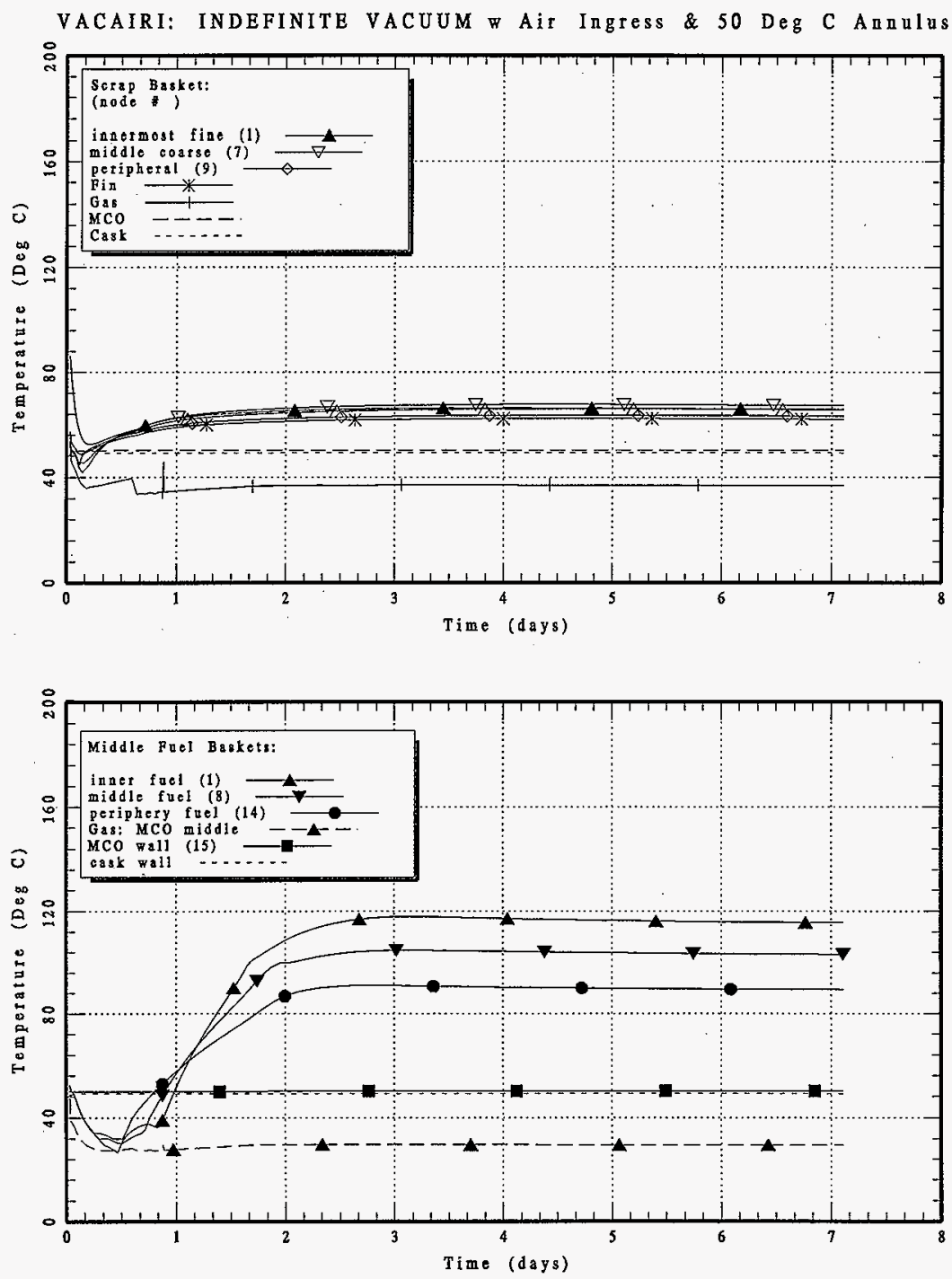


\section{HNF-SD-SNF-CN-023 REV 1}
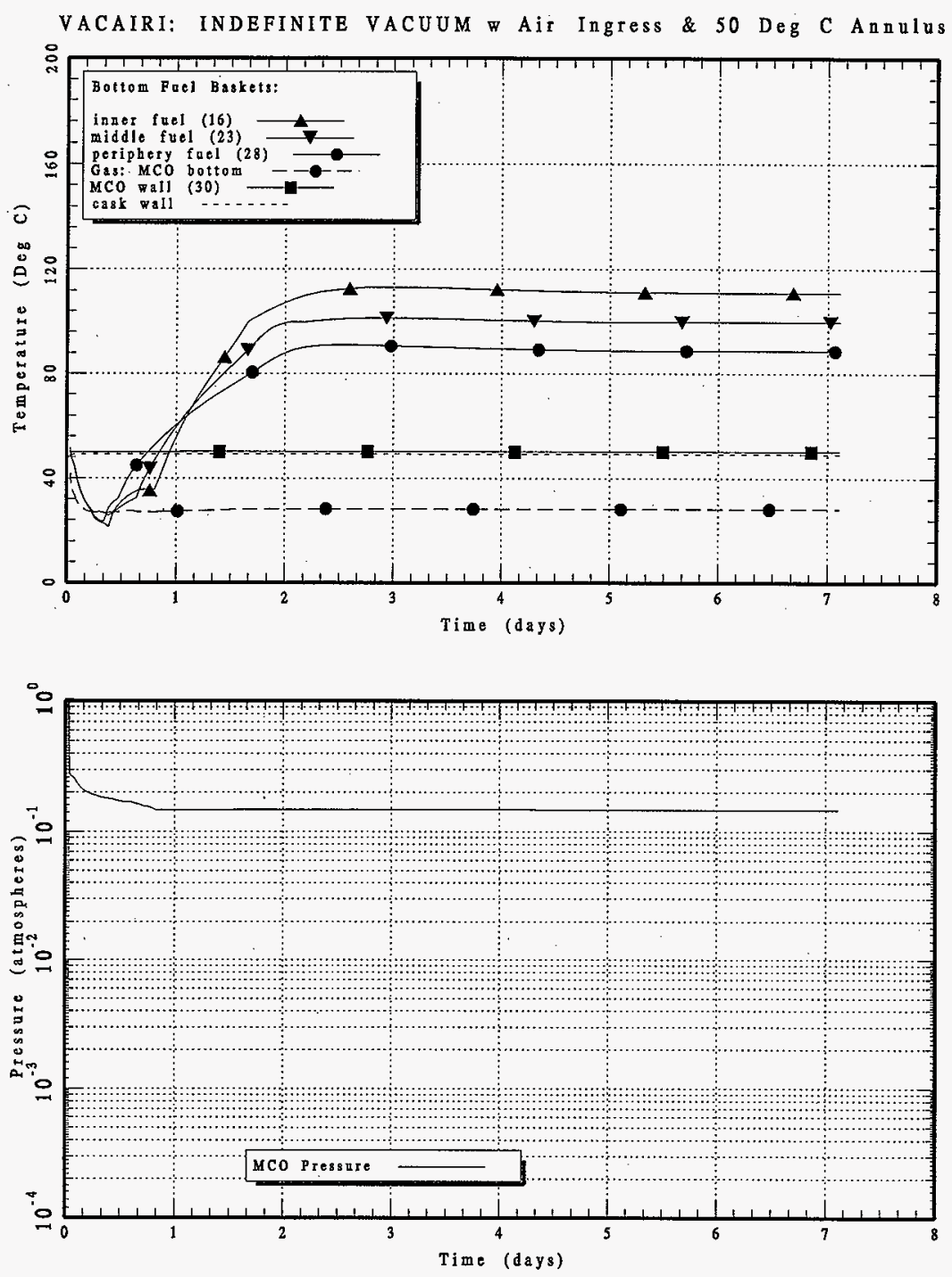


\section{HNF-SD-SNF-CN-023 REV 1}

Figure A-33 VAIRIHOT: Indefinite Vacuum with Air Ingress and $85^{\circ} \mathrm{C}$ Annulus 


\section{HNF-SD-SNF-CN-023 REV 1}

This page intentionally left blank. 


\section{HNF-SD-SNF-CN-023 REV 1}

VAIRIHOT: INDEFINITE VACUUM wir Ingress \& 85 Deg C Annulus

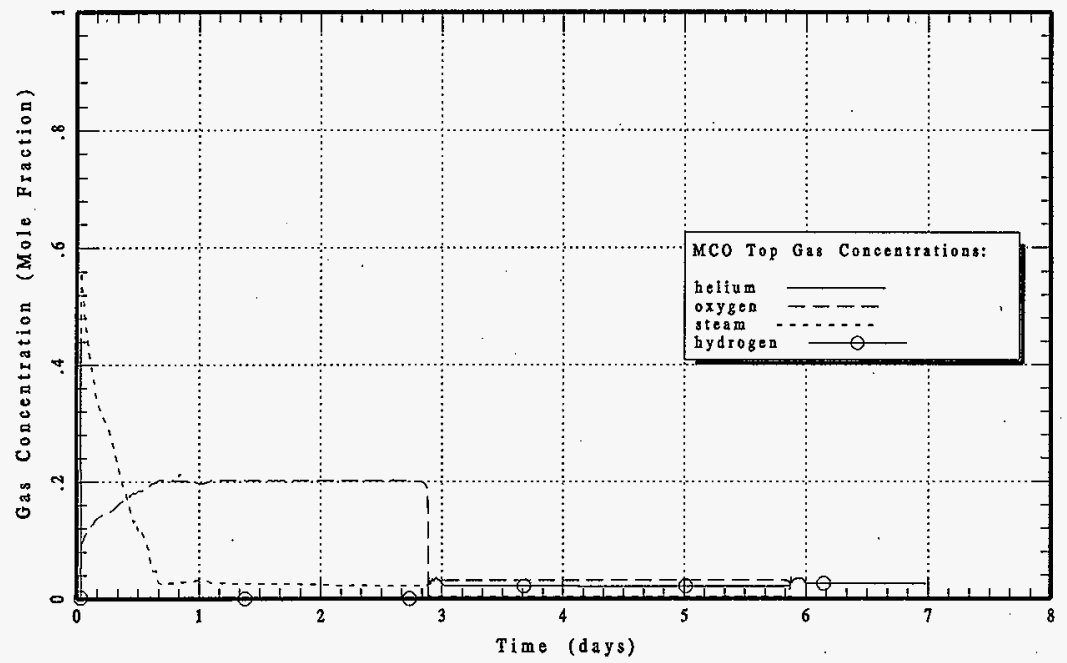

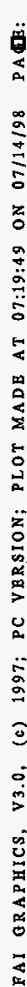

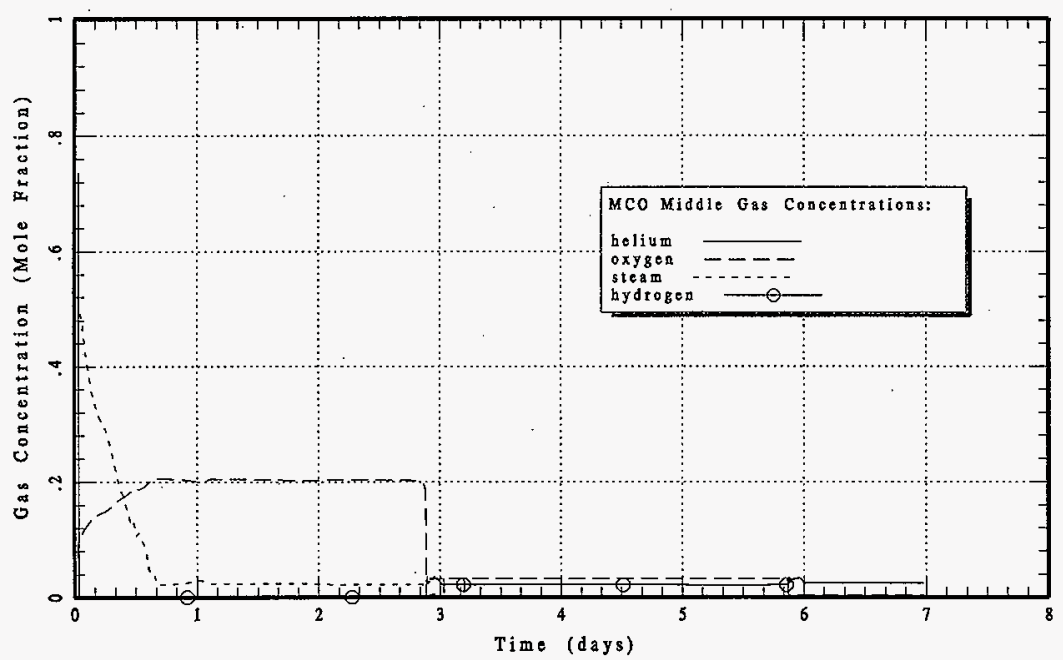




\section{HNF-SD-SNF-CN-023 REV 1}

VAIRIHOT: INDEFINITE VACUUM
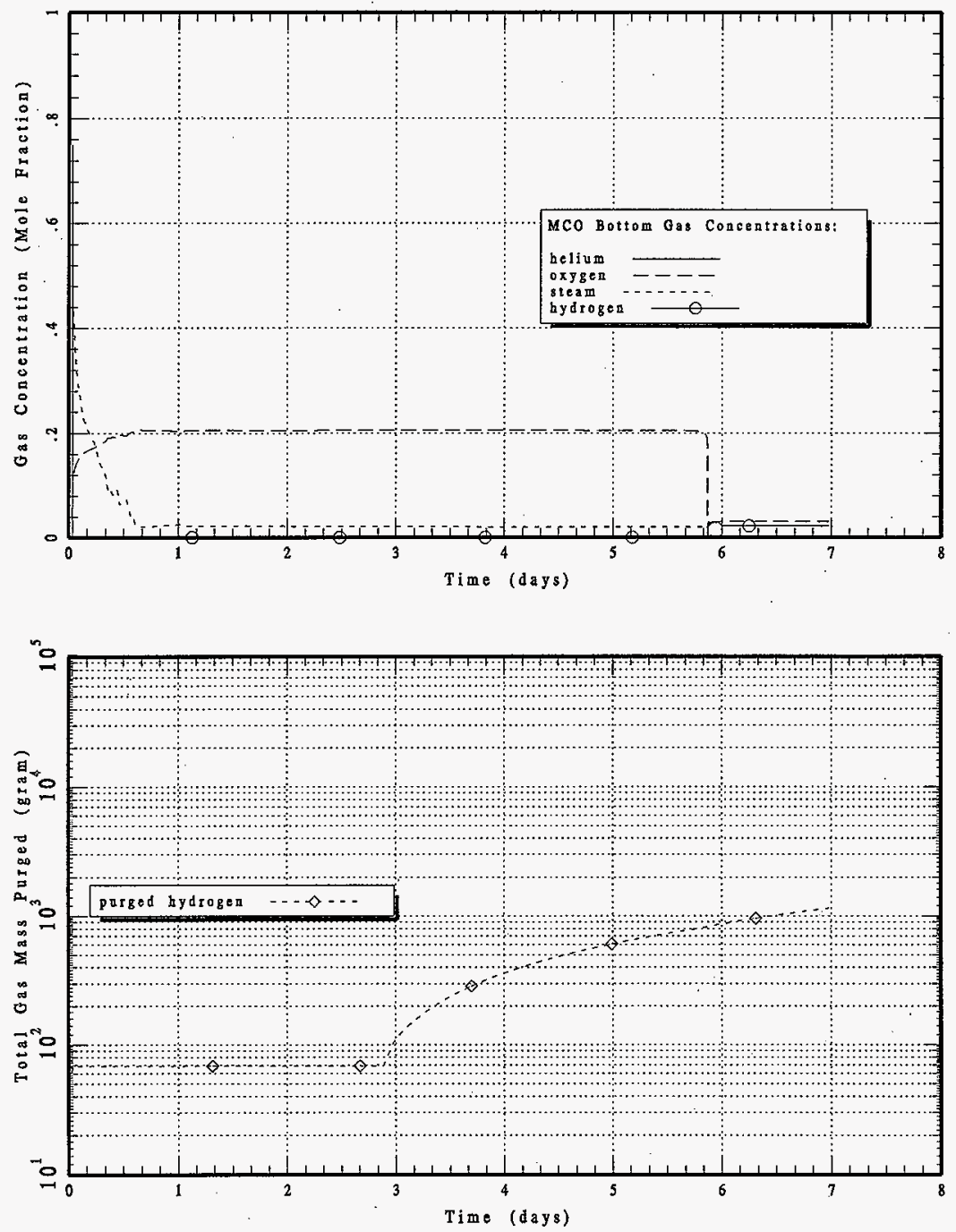


\section{HNF-SD-SNF-CN-023 REV 1}
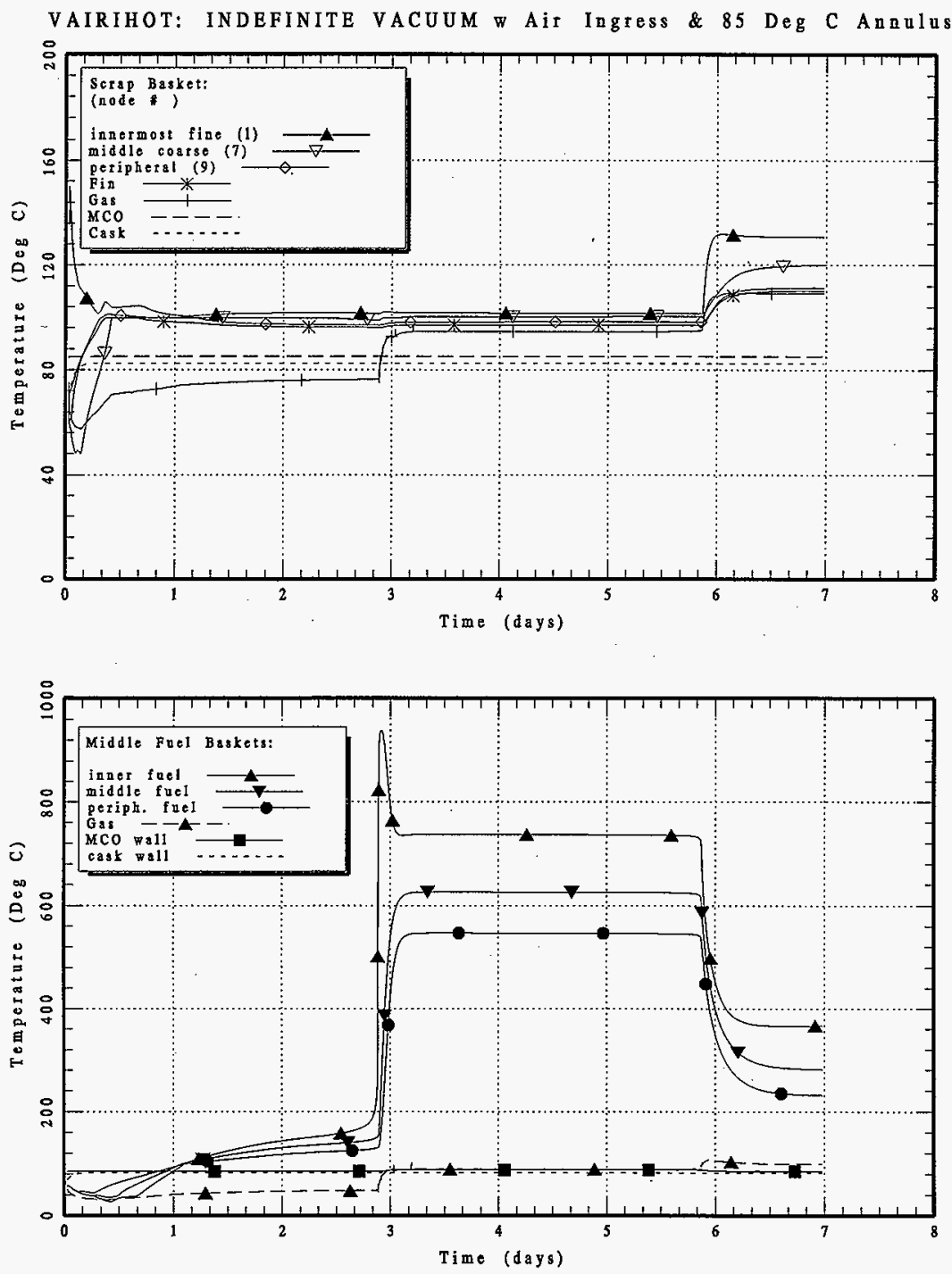


\section{HNF-SD-SNF-CN-023 REV 1}
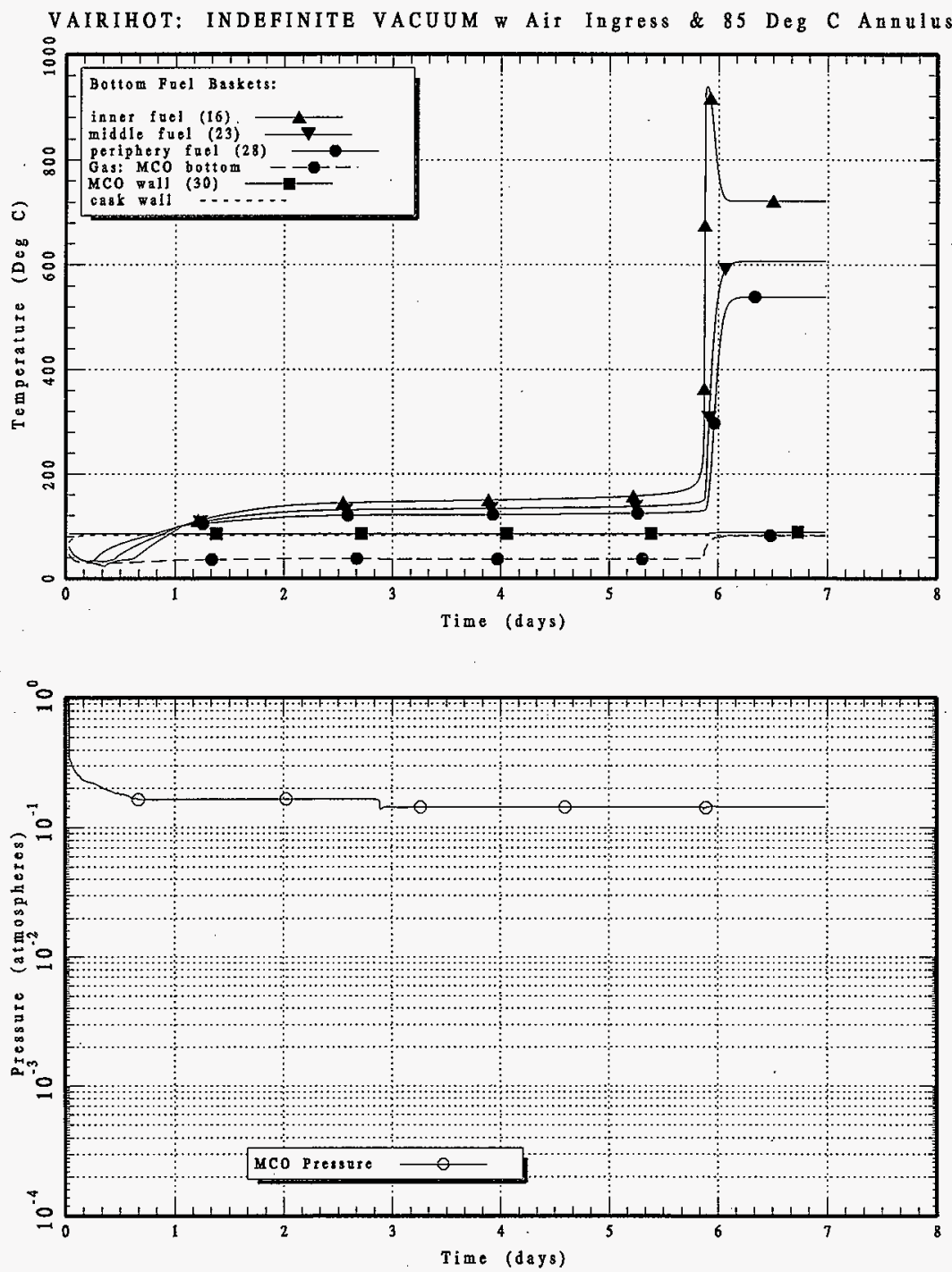


\section{HNF-SD-SNF-CN-023 REV 1}

Figure A-34 VAIRILOC: Indefinite Vacuum with Air Ingress and Loss of Coolant (LOC) 


\section{HNF-SD-SNF-CN-023 REV 1}

This page intentionally left blank. 
HNF-SD-SNF-CN-023 REV 1

VAIRILOC: INDEFINITE VACUUM W Ait Ingress \& Loss of Coolant
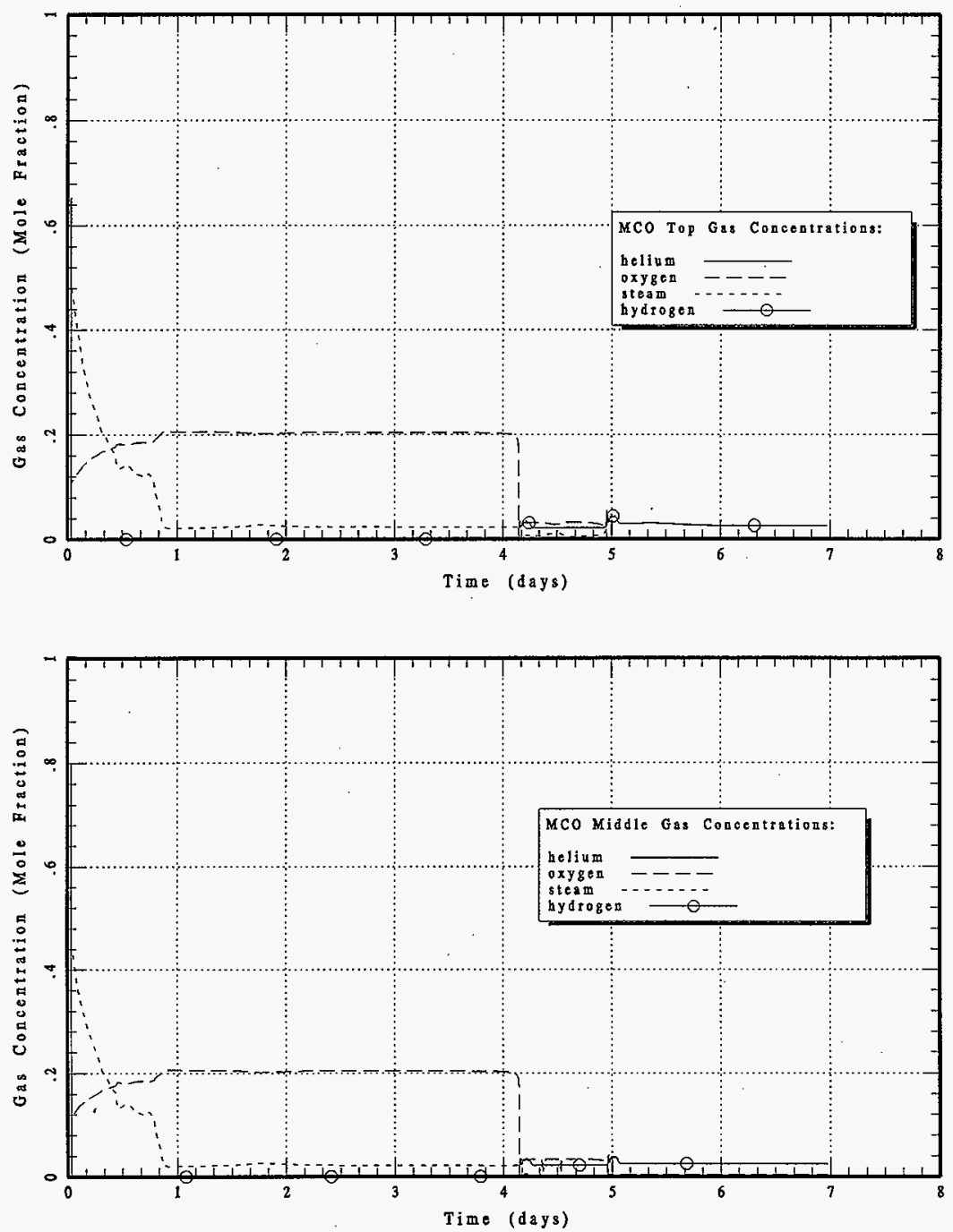
HNF-SD-SNF-CN-023 REV 1

VAIRILOC: INDEFINITE VACUUM w Air Ingress \& Loss of Coolant
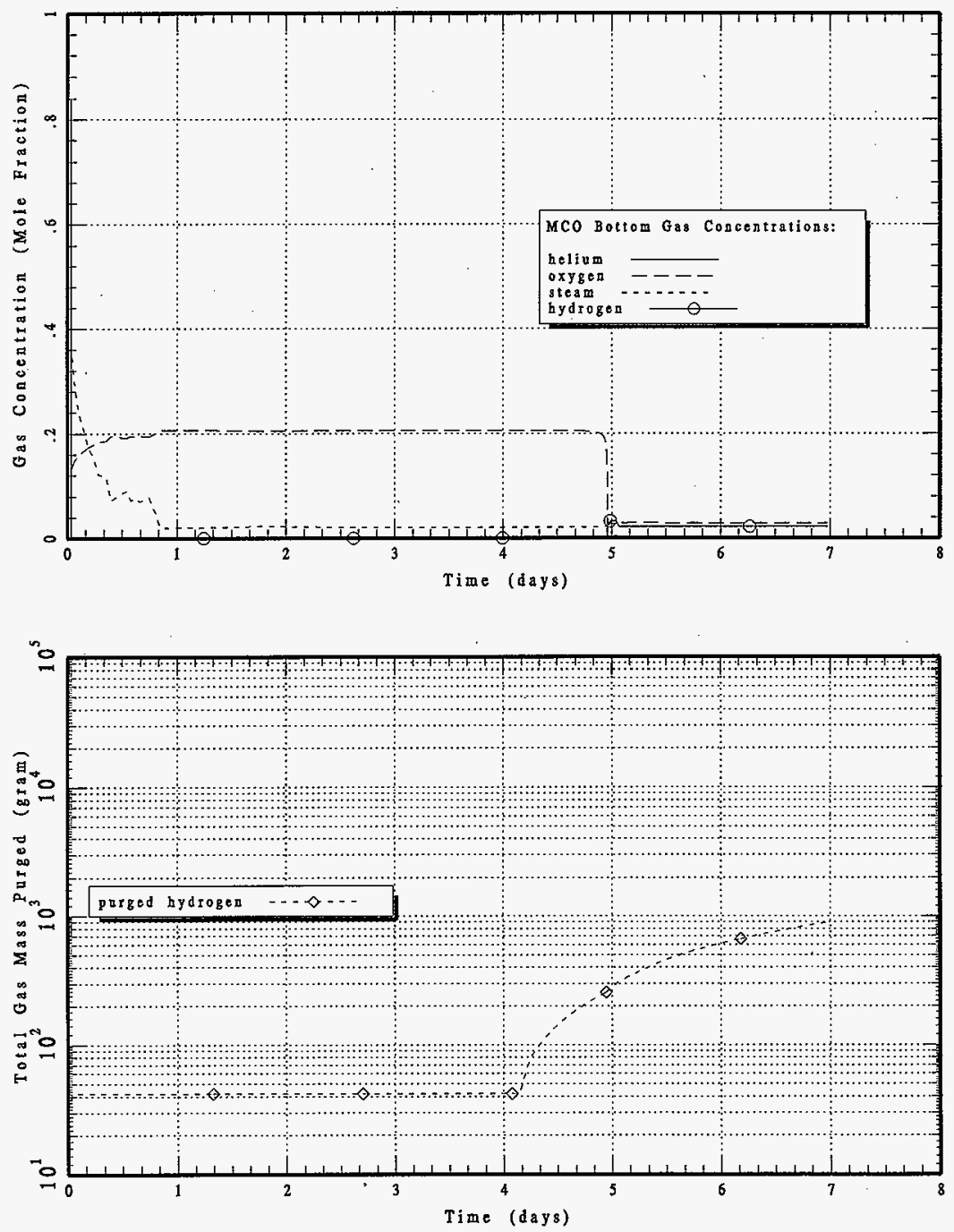


\section{HNF-SD-SNF-CN-023 REV 1}
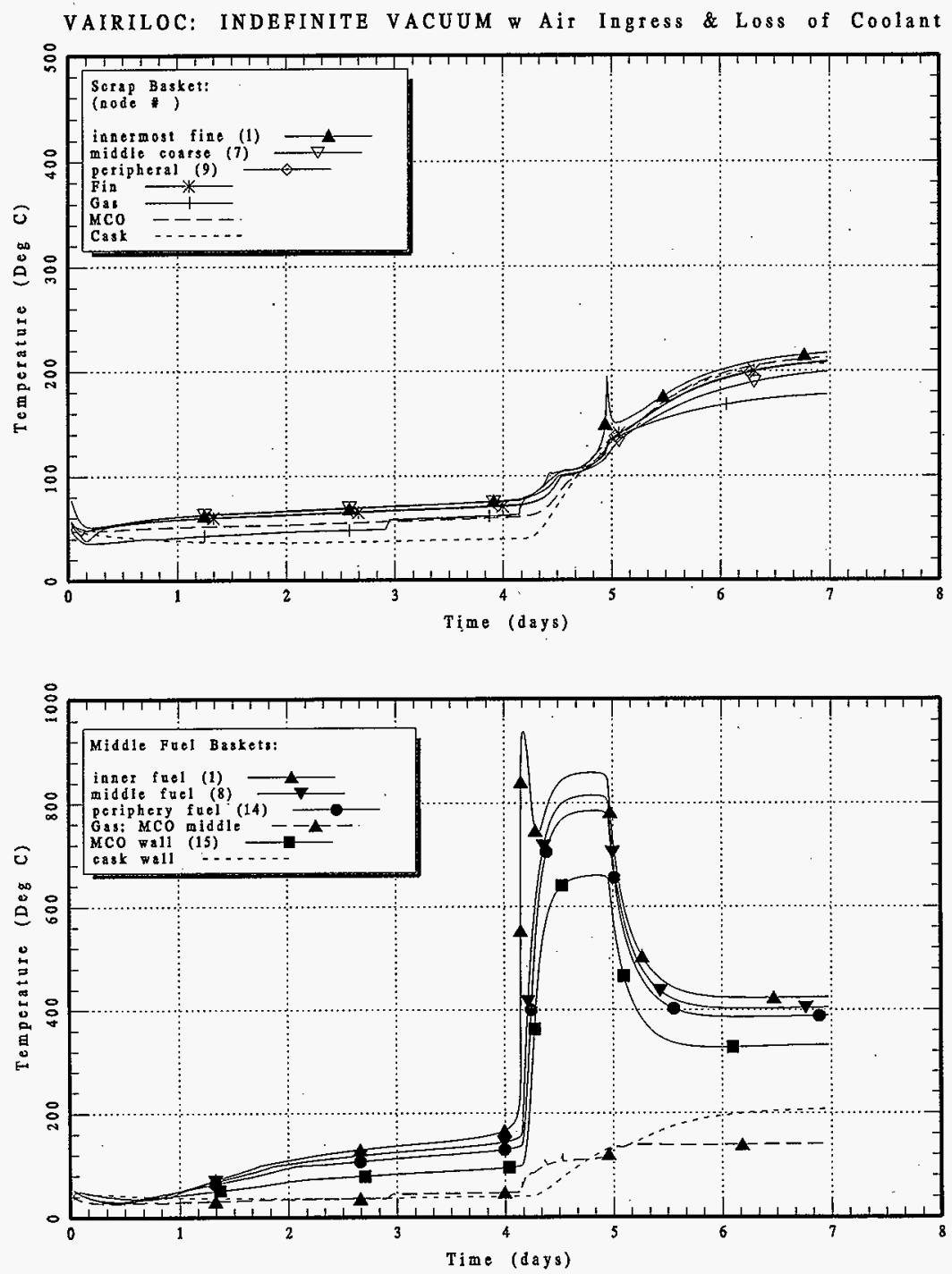


\section{HNF-SD-SNF-CN-023 REV 1}
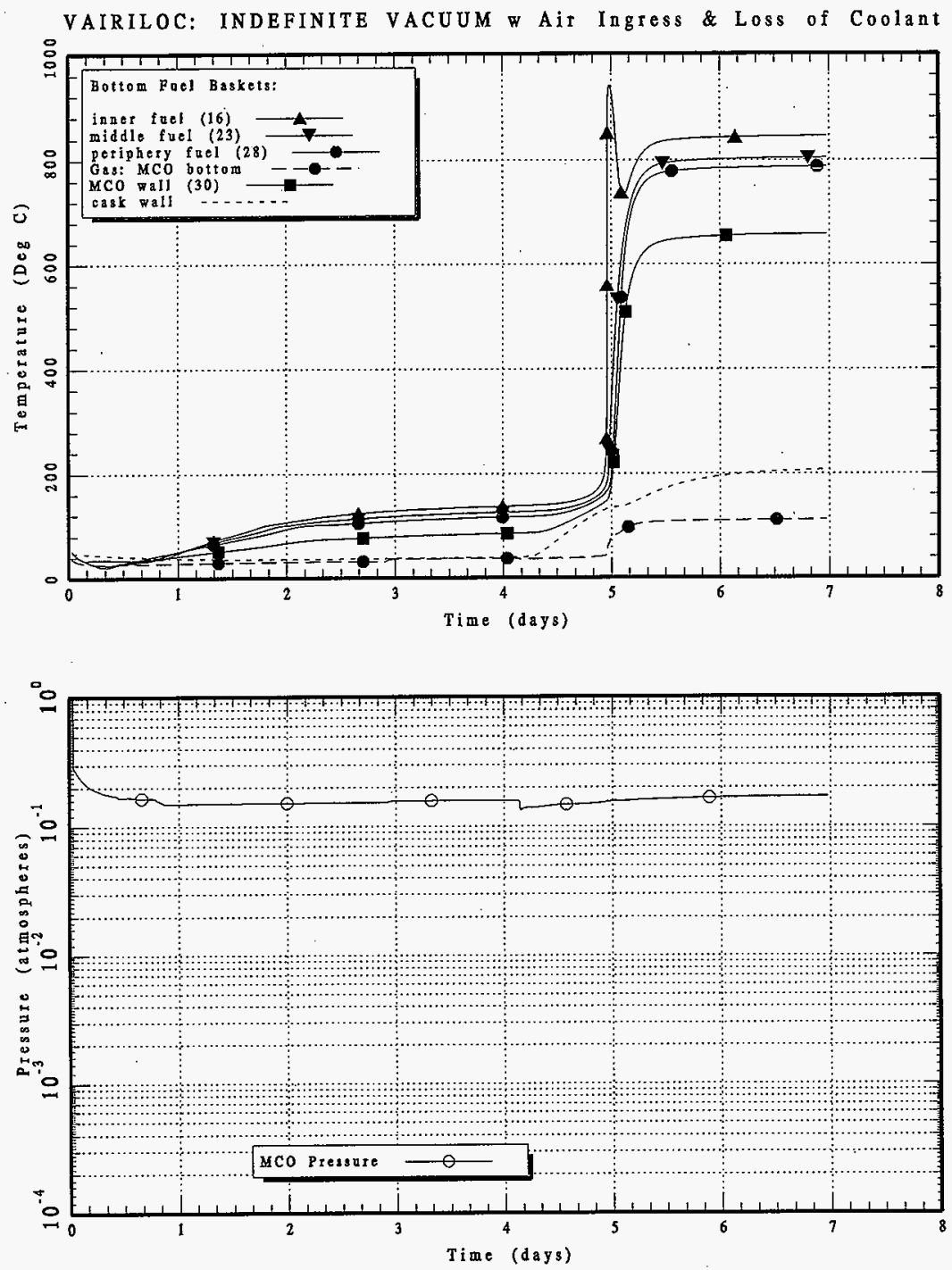


\section{HNF-SD-SNF-CN-023 REV 1}

Figure A-35 PURAIRI: Indefinite Purge with Air Ingress and $50^{\circ} \mathrm{C}$ Annulus 


\section{HNF-SD-SNF-CN-023 REV 1}

This page intentionally left blank. 

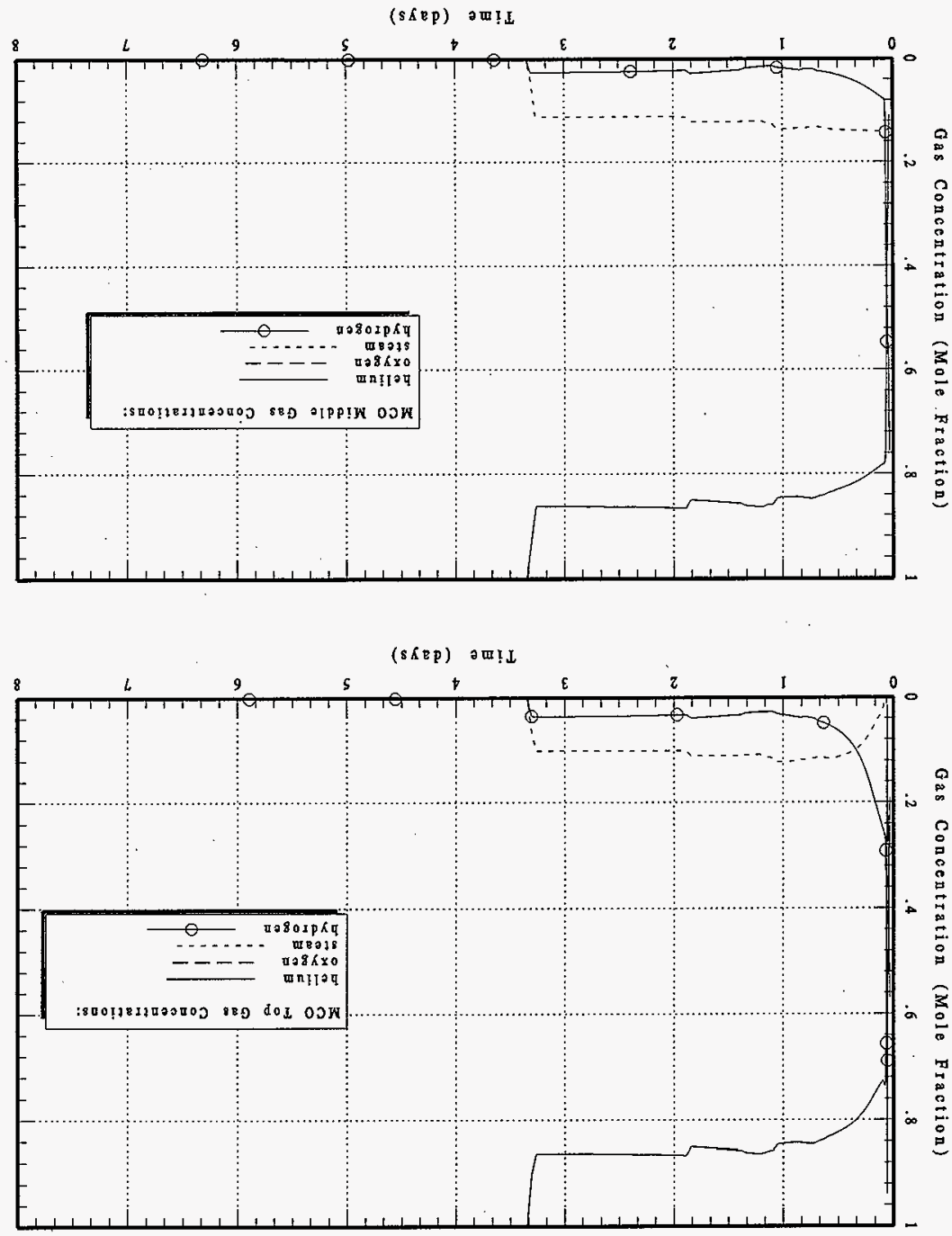

snโnuा $ว$ 8ə 


\section{HNF-SD-SNF-CN-023 REV 1}

PURAIRI: INDEFINITE PURGE w Ait Ingress \& 50 Deg C Annulus
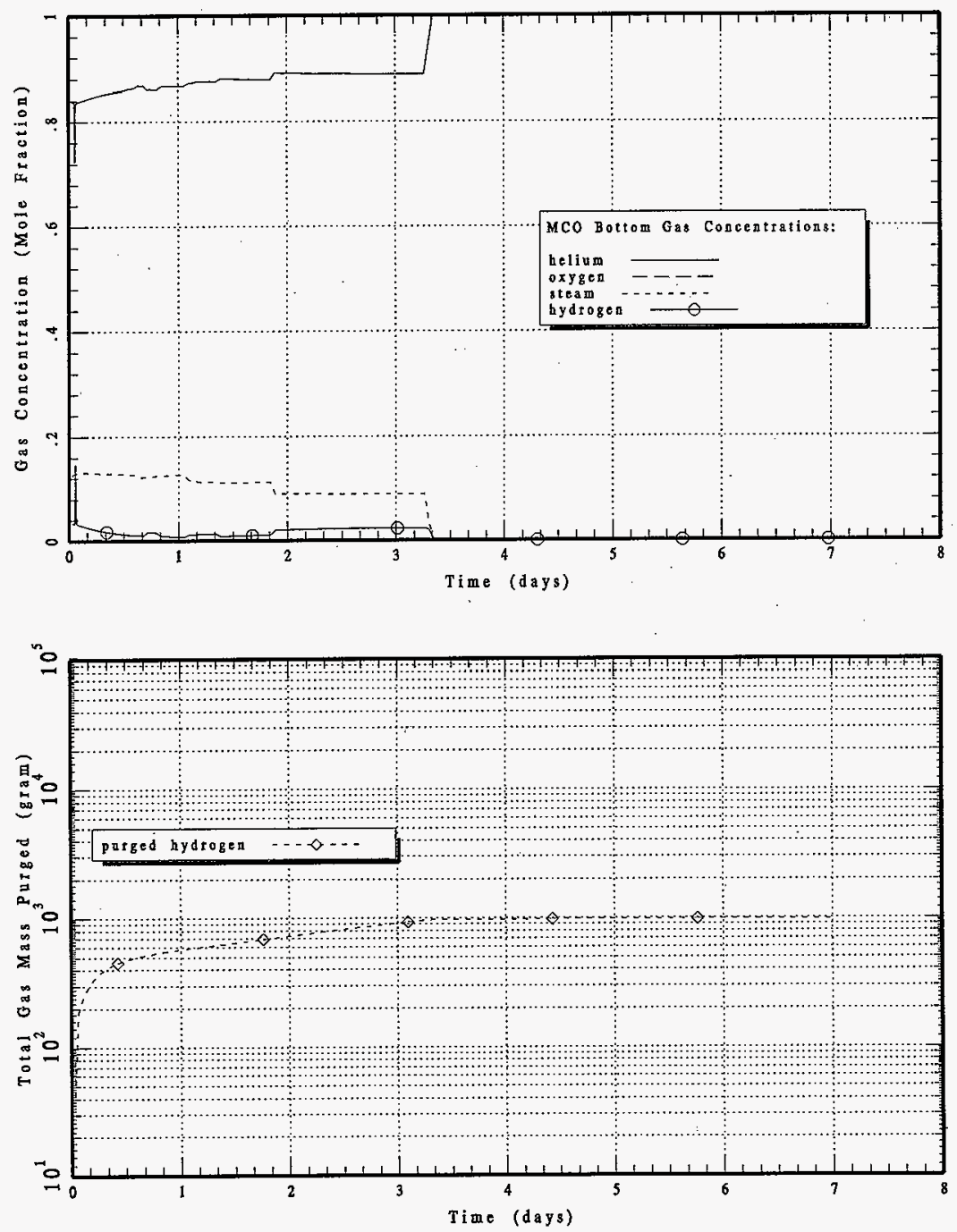


\section{HNF-SD-SNF-CN-023 REV 1}
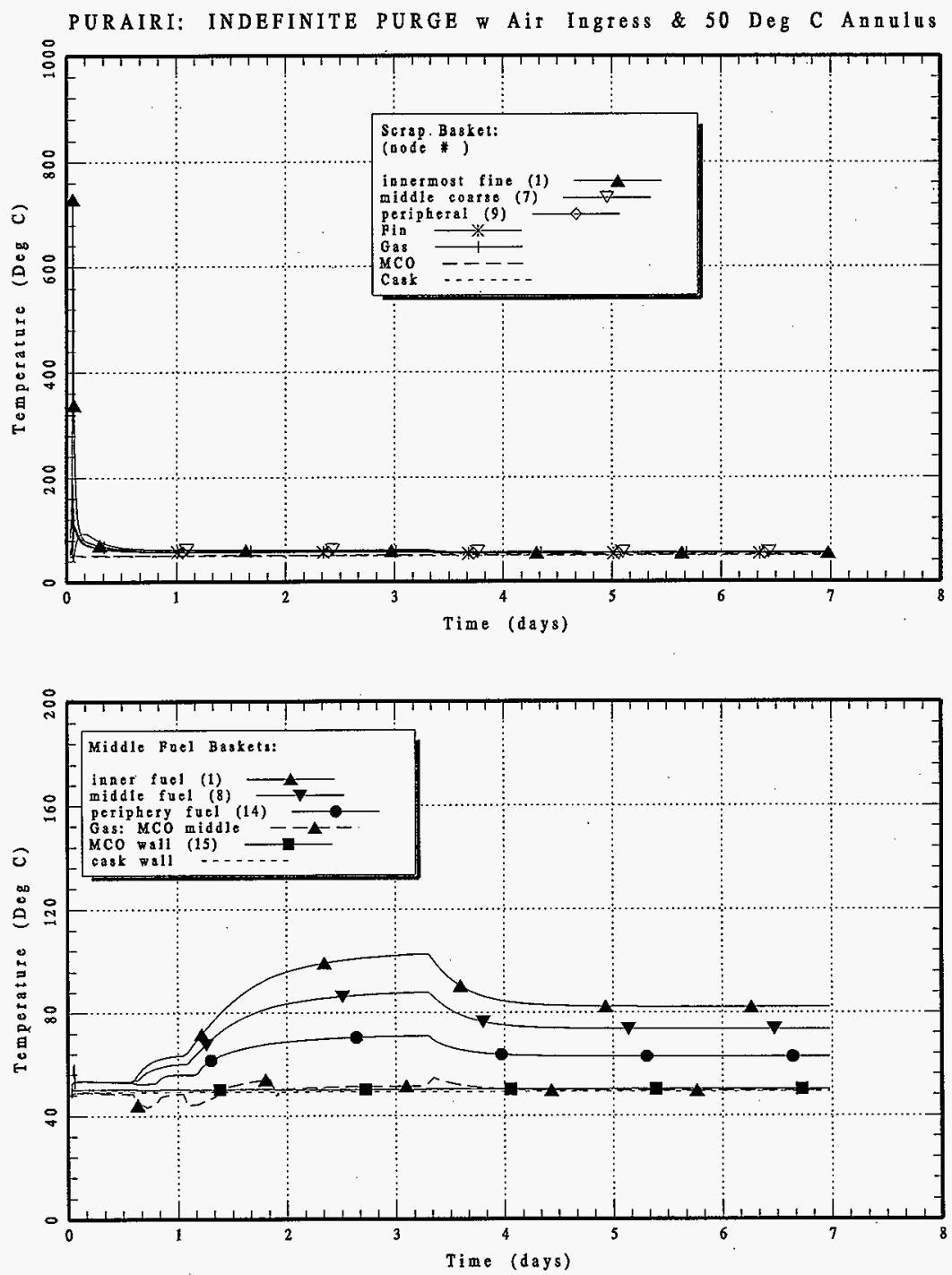


\section{HNF-SD-SNF-CN-023 REV 1}
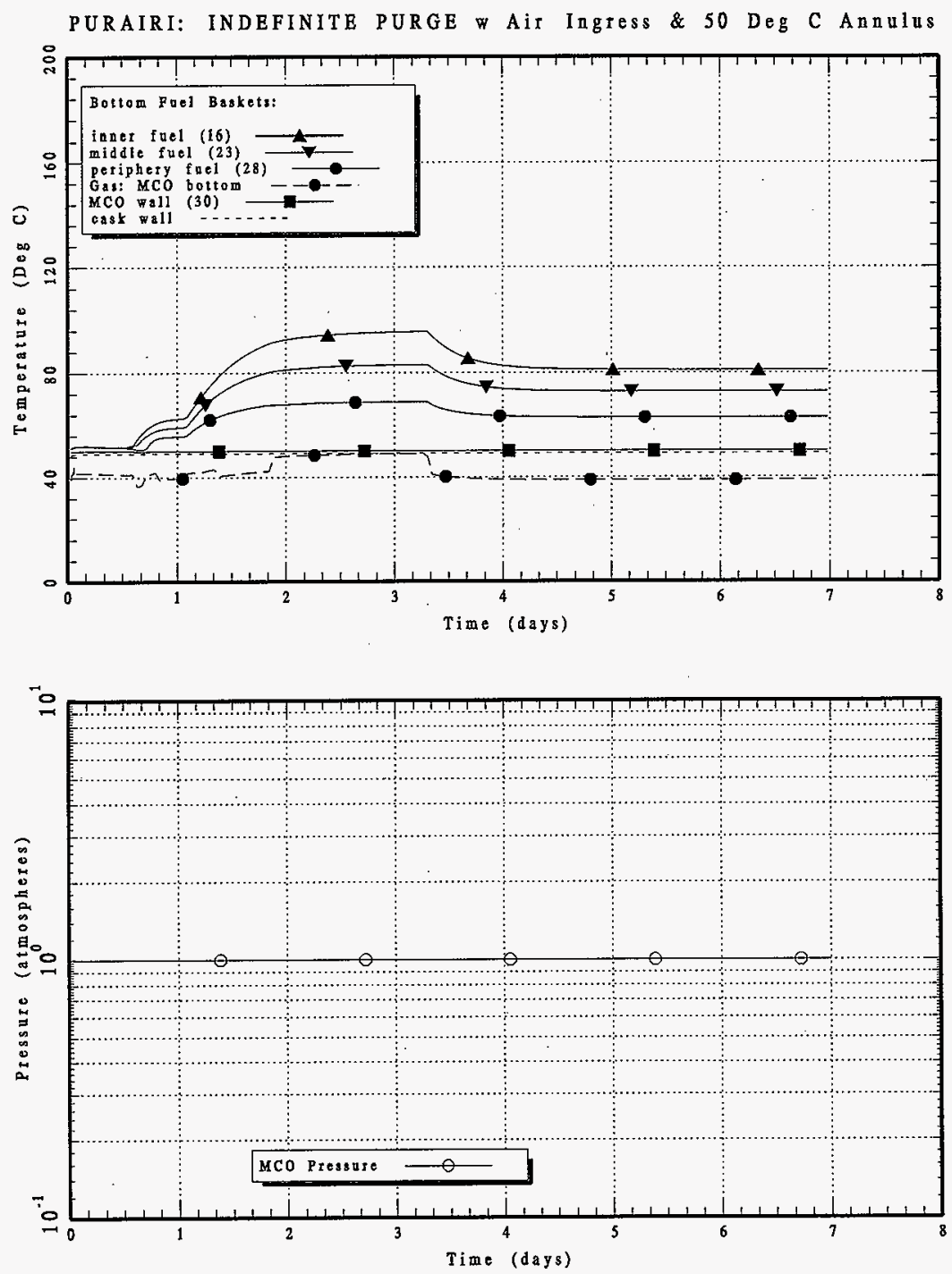


\section{HNF-SD-SNF-CN-023 REV 1}

Figure A-36 PAIRHOT: Helium Purge with Air Ingress and $85^{\circ} \mathrm{C}$ Annulus 
HNF-SD-SNF-CN-023 REV 1

This page intentionally left blank. 
HNF-SD-SNF-CN-023 REV 1

PAIRIHOT: He PURGE w Air Ingress \& 85 Deg C Annulus
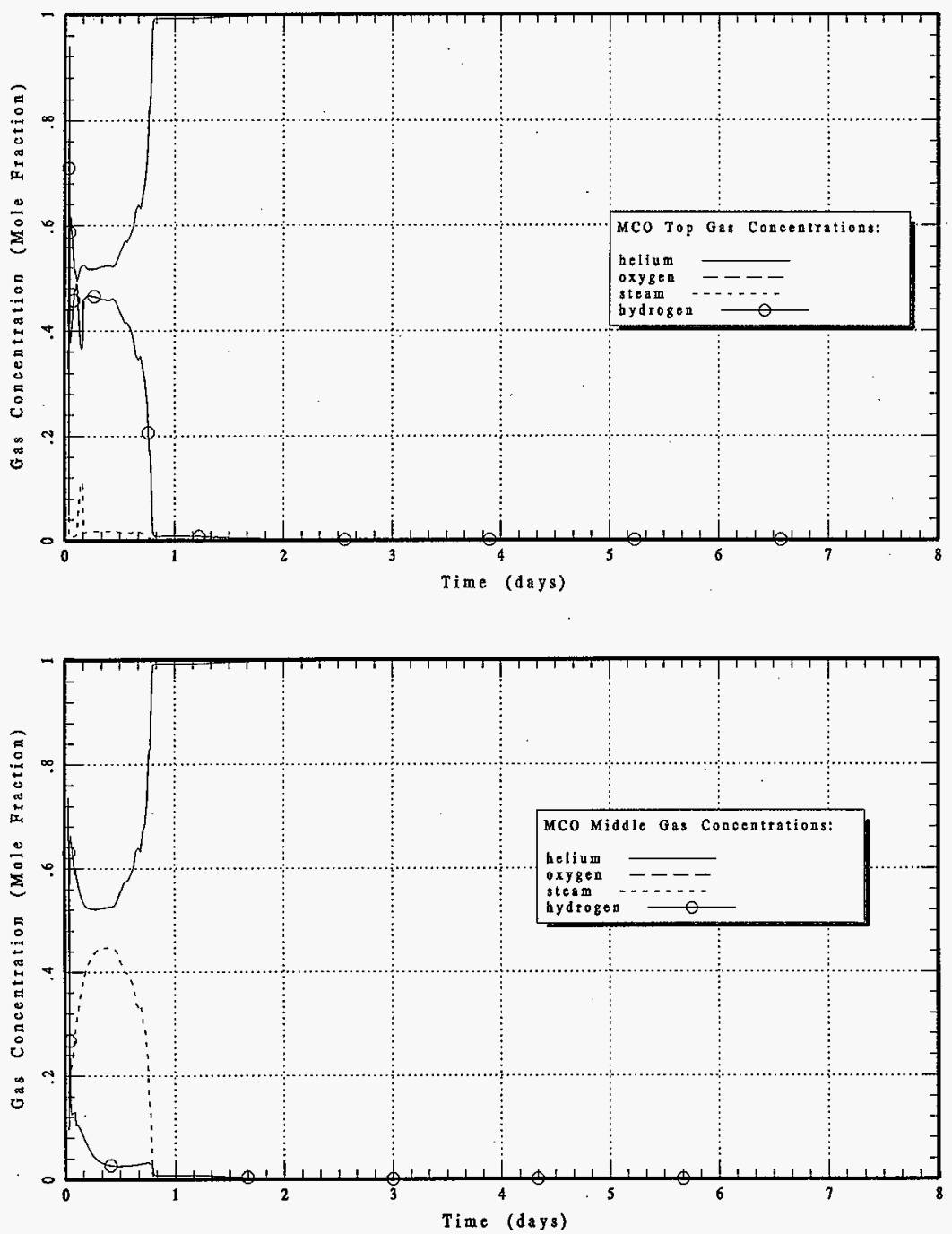


\section{HNF-SD-SNF-CN-023 REV 1}

PAIRIHOT: He PURGE w Ait Ingress \& 85 Deg C Annulus
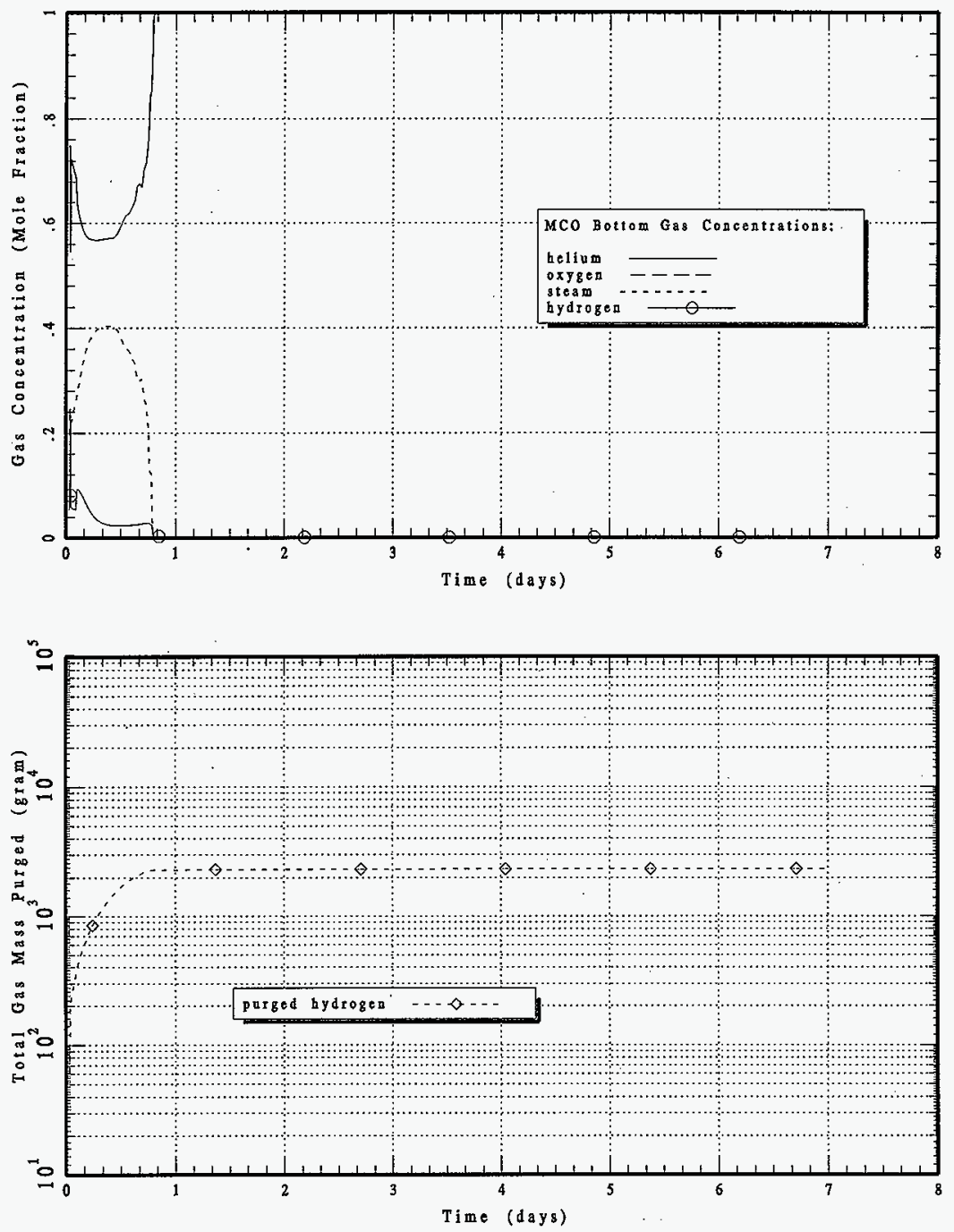


\section{HNF-SD-SNF-CN-023 REV 1}
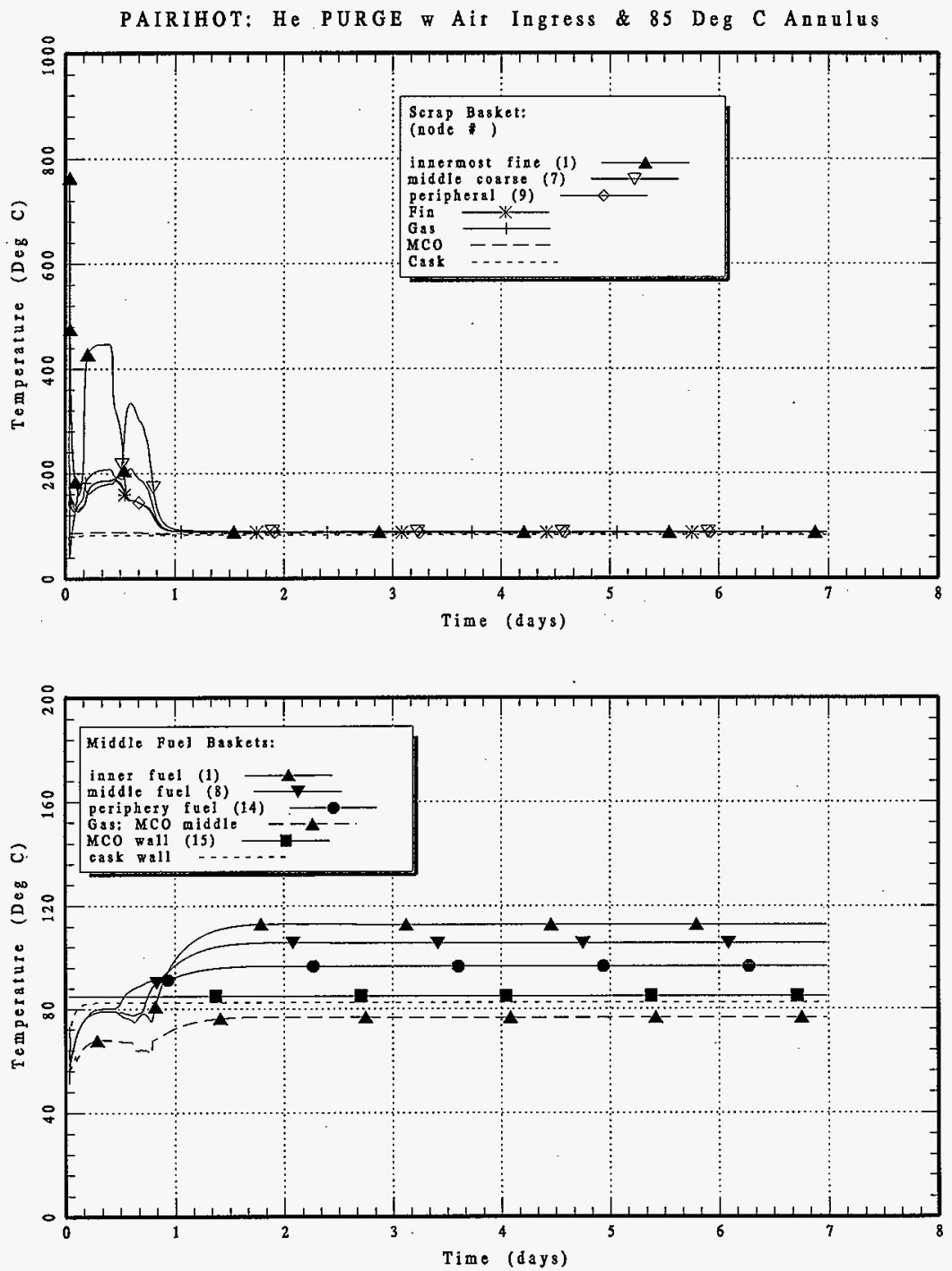

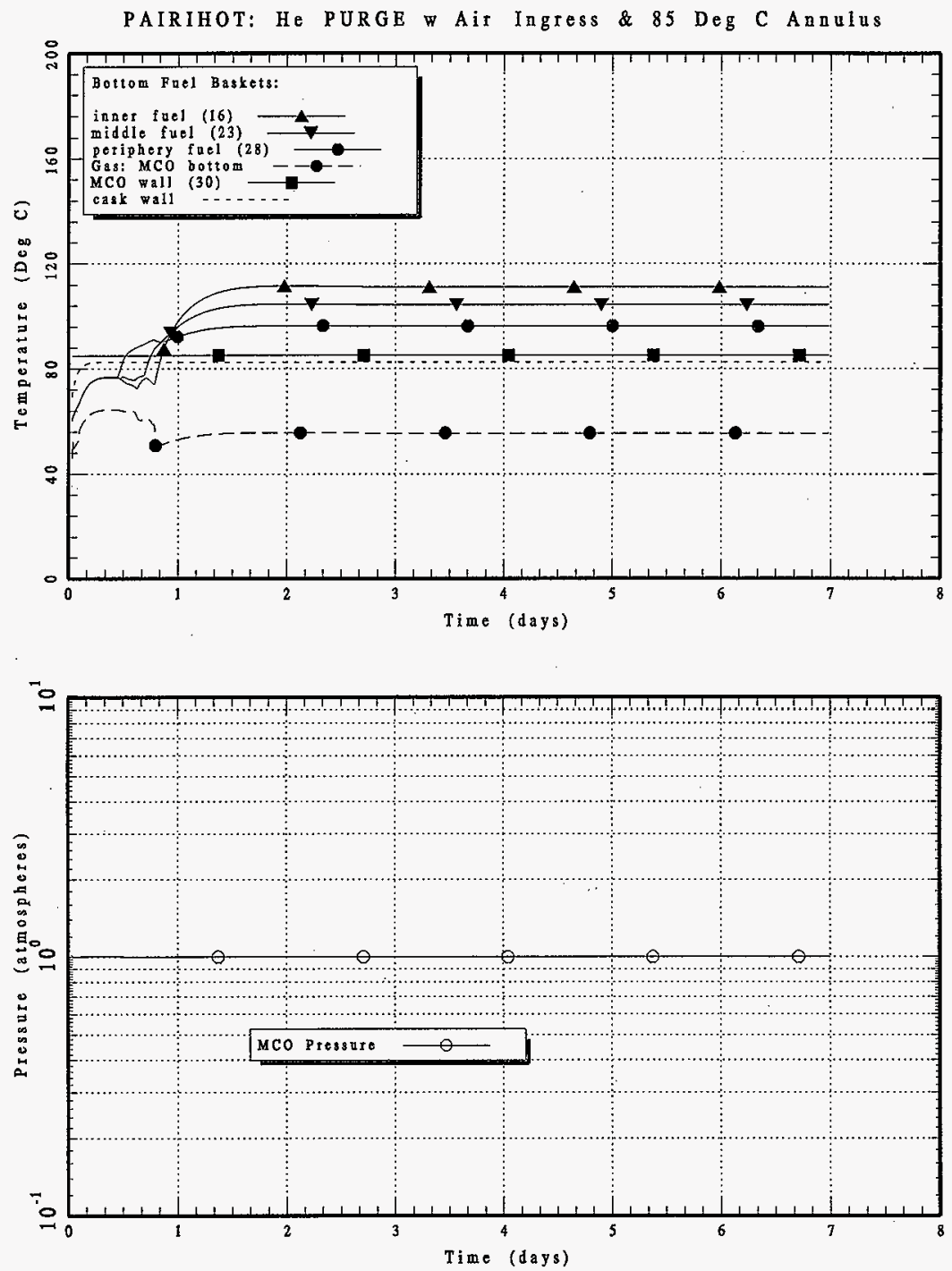


\section{HNF-SD-SNF-CN-023 REV 1}

Figure A-37 VACAIRI2: Vacuum with No Hydrides, Air Ingress and $50^{\circ} \mathrm{C}$ Annulus 
HNF-SD-SNF-CN-023 REV 1

This page intentionally left blank. 


\section{HNF-SD-SNF-CN-023 REV 1}

VACAIRI2: VACUUM No Hydrides, Ait Ingress \& 50 Deg C Annulus
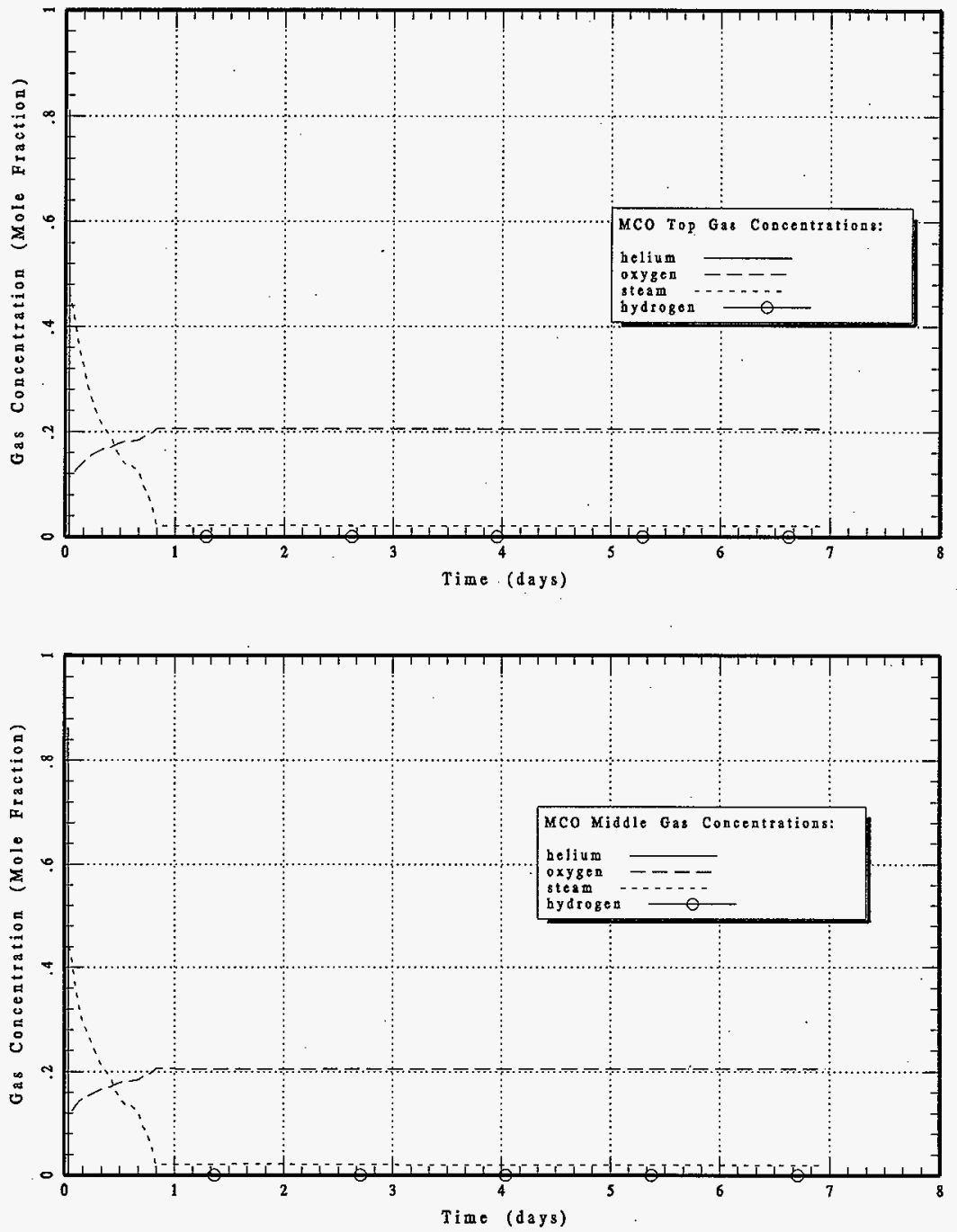


\section{HNF-SD-SNF-CN 023 REV 1}

VACAIRI2: VACUUM w No Hydrides, Air Ingress \& 50 Deg C Annulus
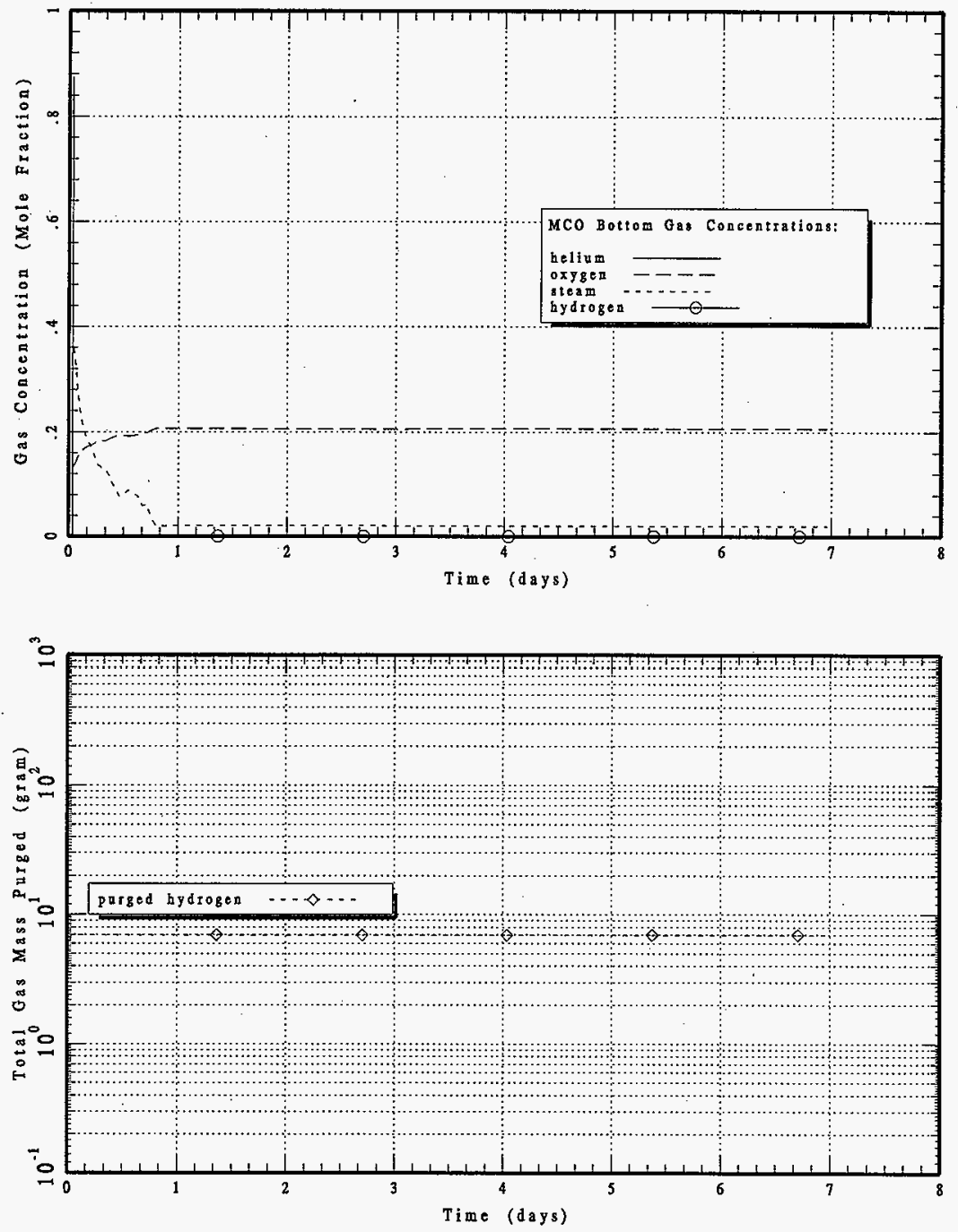

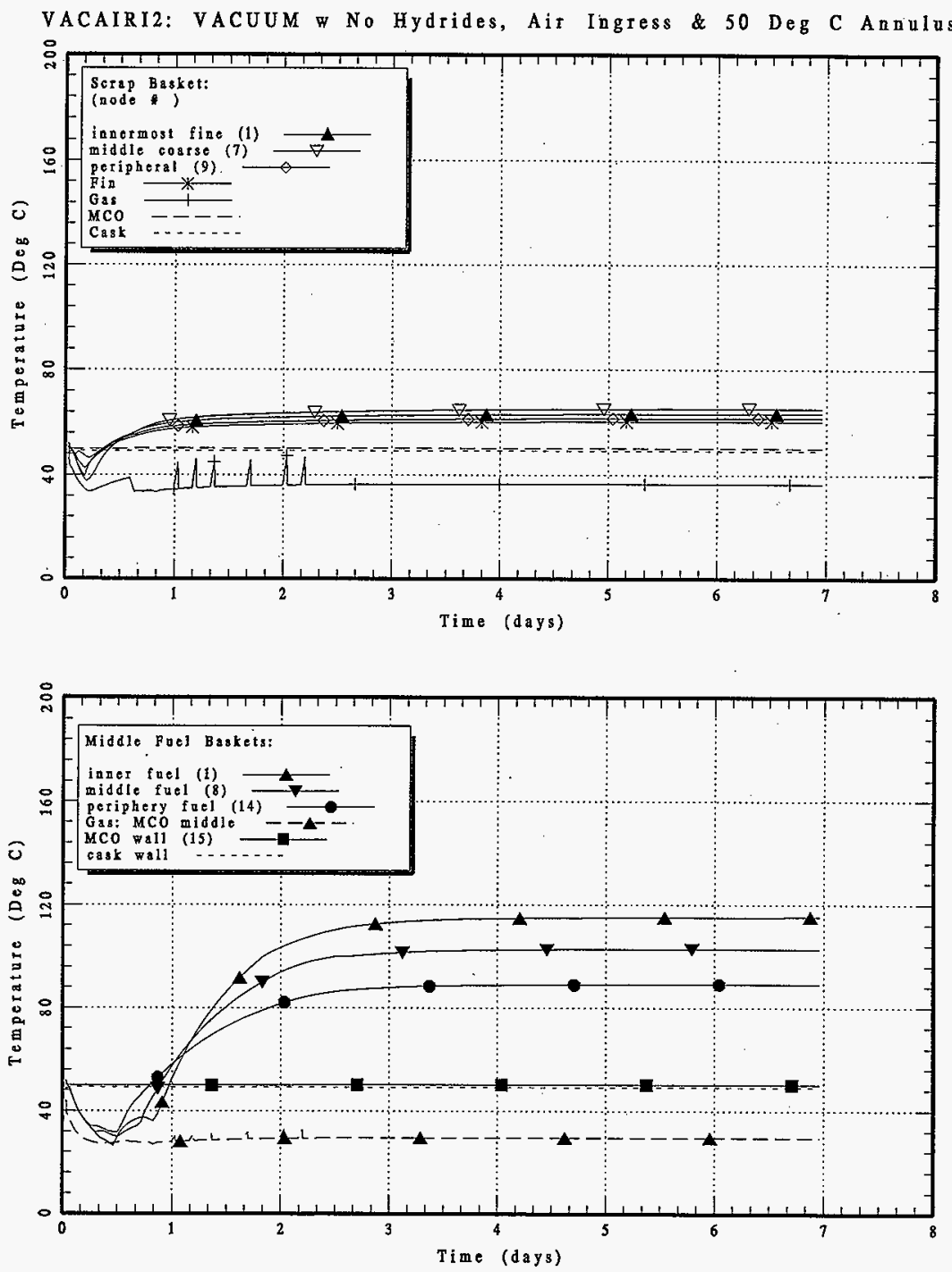


\section{HNF-SD-SNF-CN-023 REV 1}
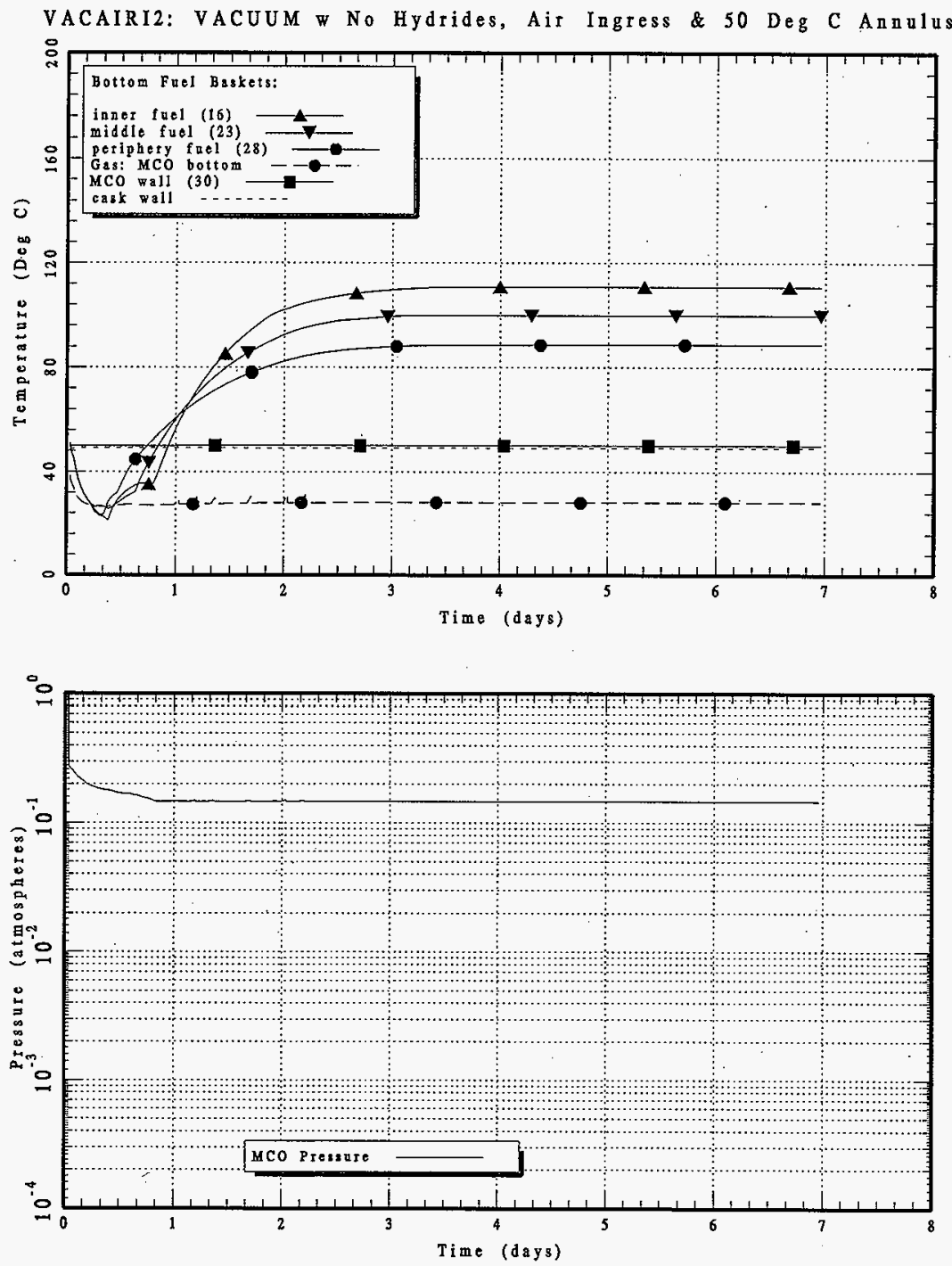


\section{HNF-SD-SNF-CN-023 REV 1}

Figure A-38 DSLOCSA4: High-Pressure Thermal Runaway with $35.5 \mathrm{Kg}$ Water and Loss of Coolant (LOC) 


\section{HNF-SD-SNF-CN-023 REV 1}

This page intentionally left blank. 


\section{HNF-SD-SNF-CN-023 REV 1}

DSLOCSA 4: HI-PRES THERM RUNAWAY W $35.5 \mathrm{Kg}$ Water \& Loss of Coolant
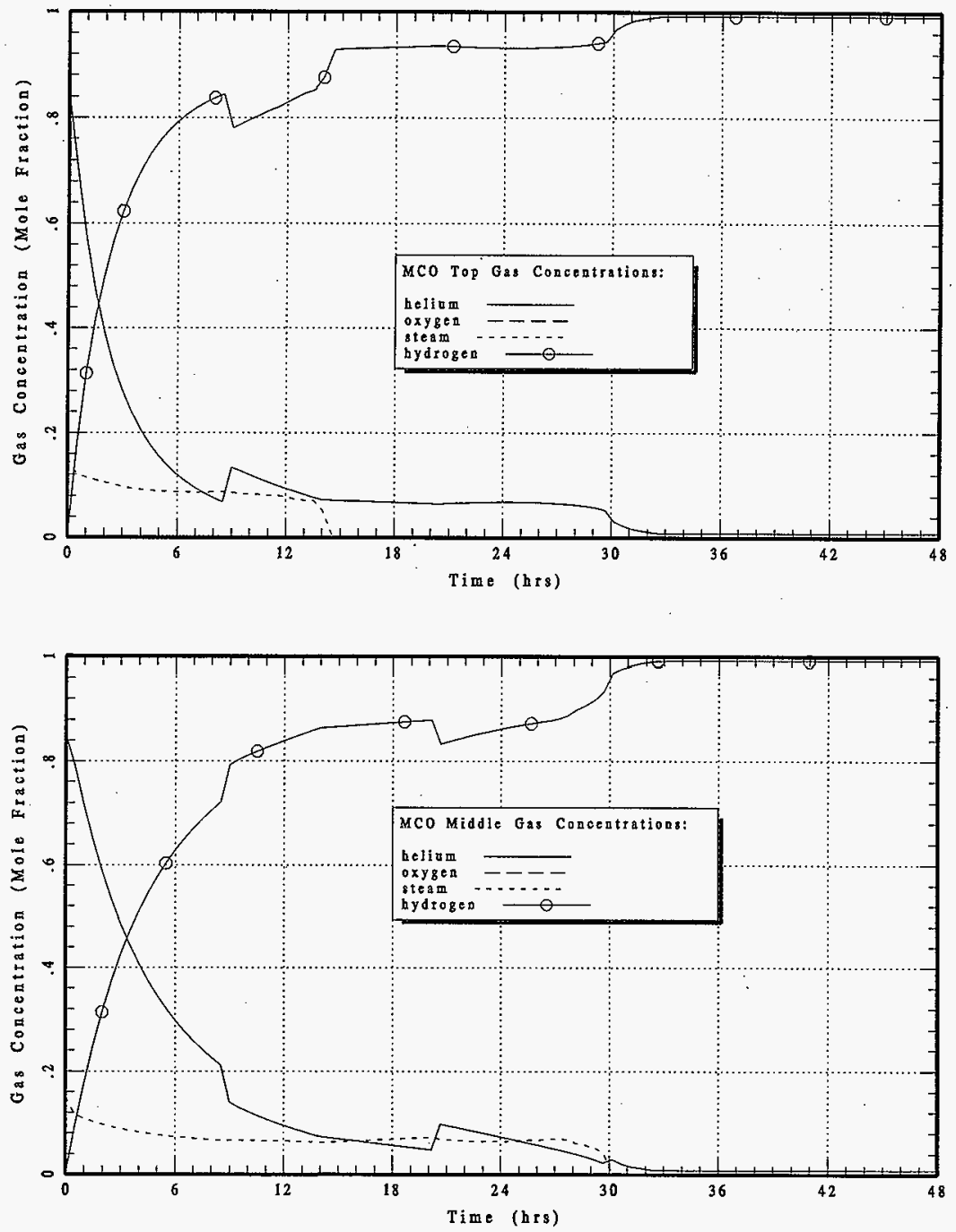


\section{HNF-SD-SNF-CN-023 REV 1}

DSLOCSA 4: HI-PRES THERM RUNAWAY W $35.5 \mathrm{Kg}$ Water \& Loss of Coolant
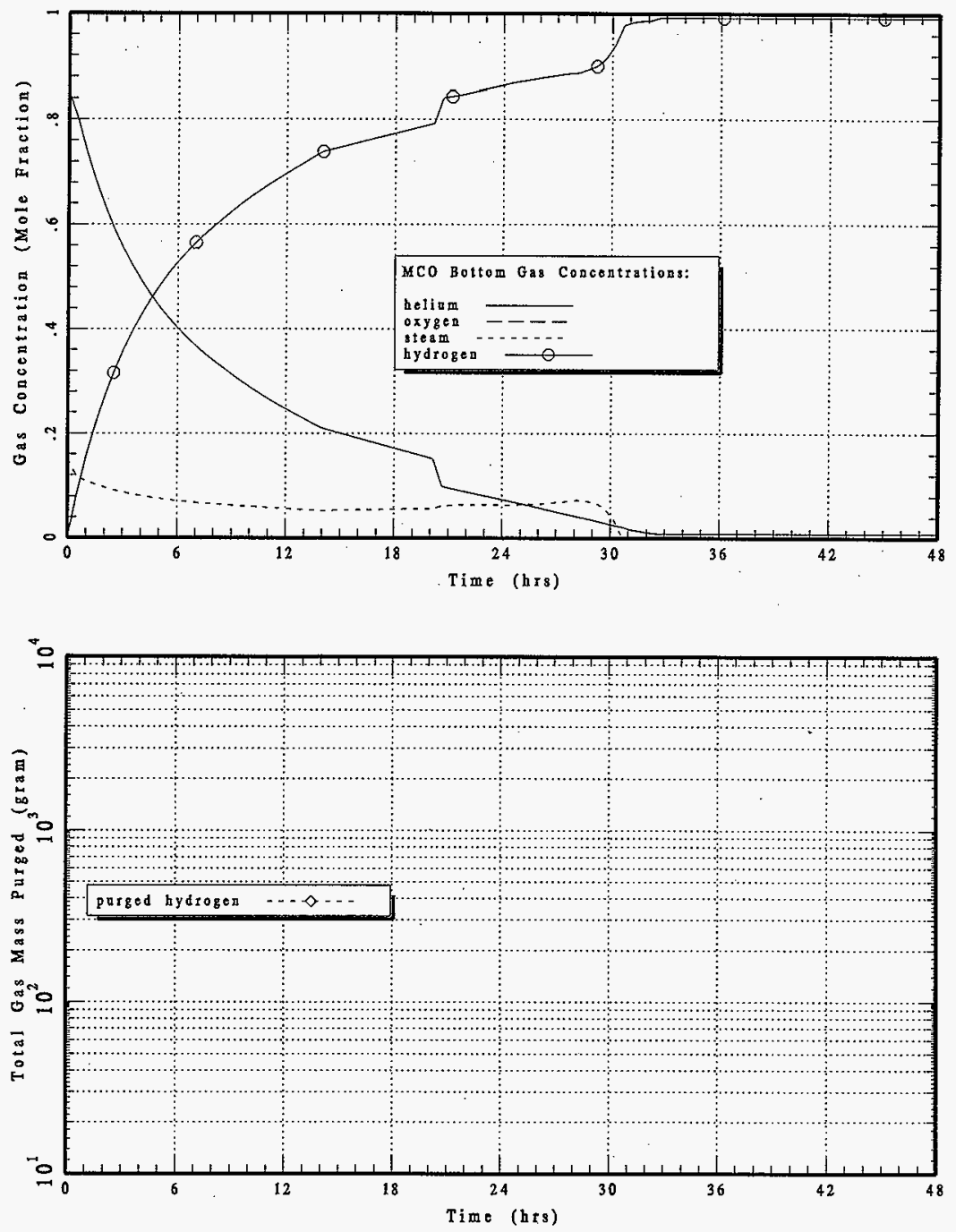


\section{HNF-SD-SNF-CN-023 REV 1}

DSLOCSA4: HI-PRES THERM RUNAWAY w $35.5 \mathrm{Kg}$ Watet \& Loss of Coolant
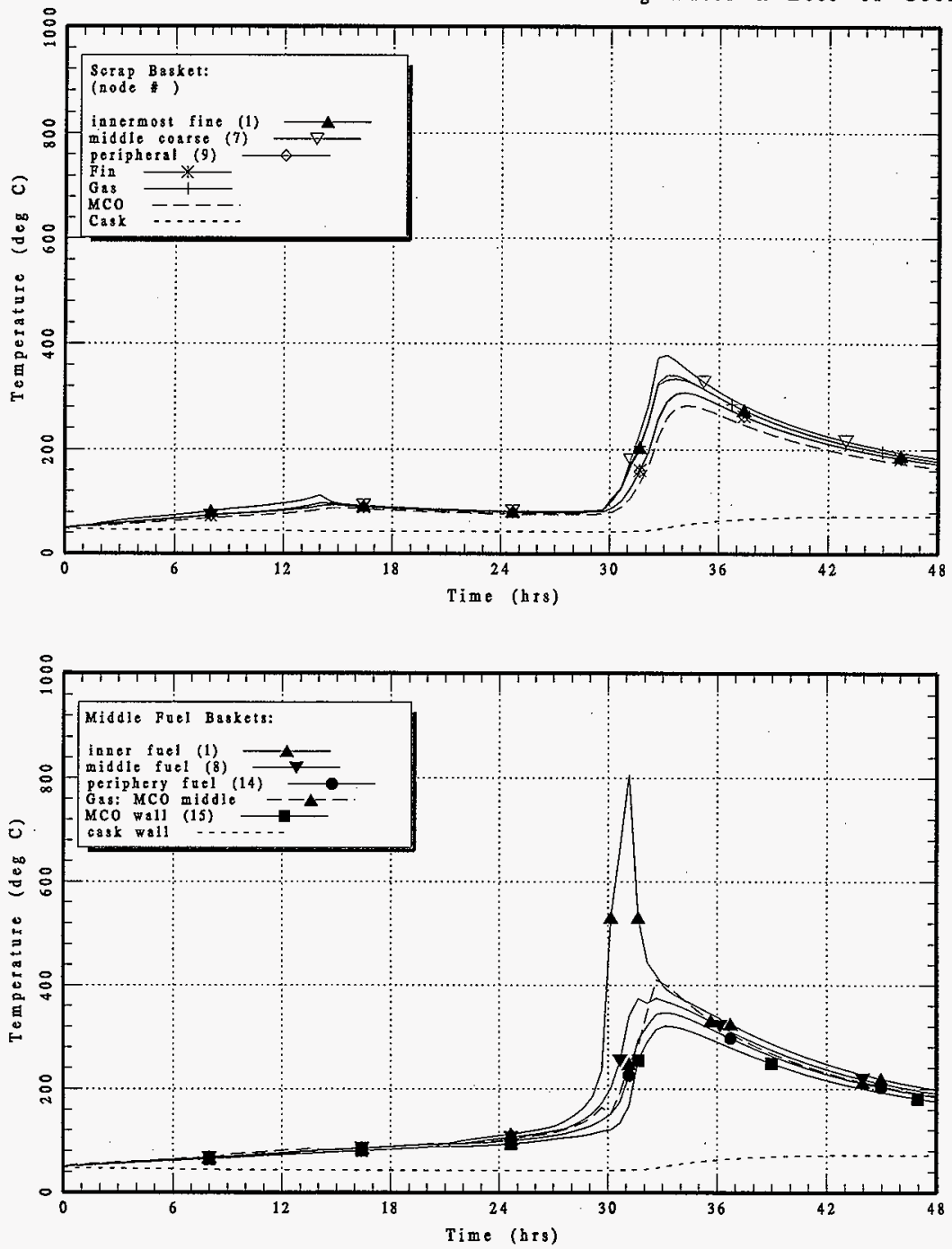


\section{HNF-SD-SNF-CN-023 REV 1}
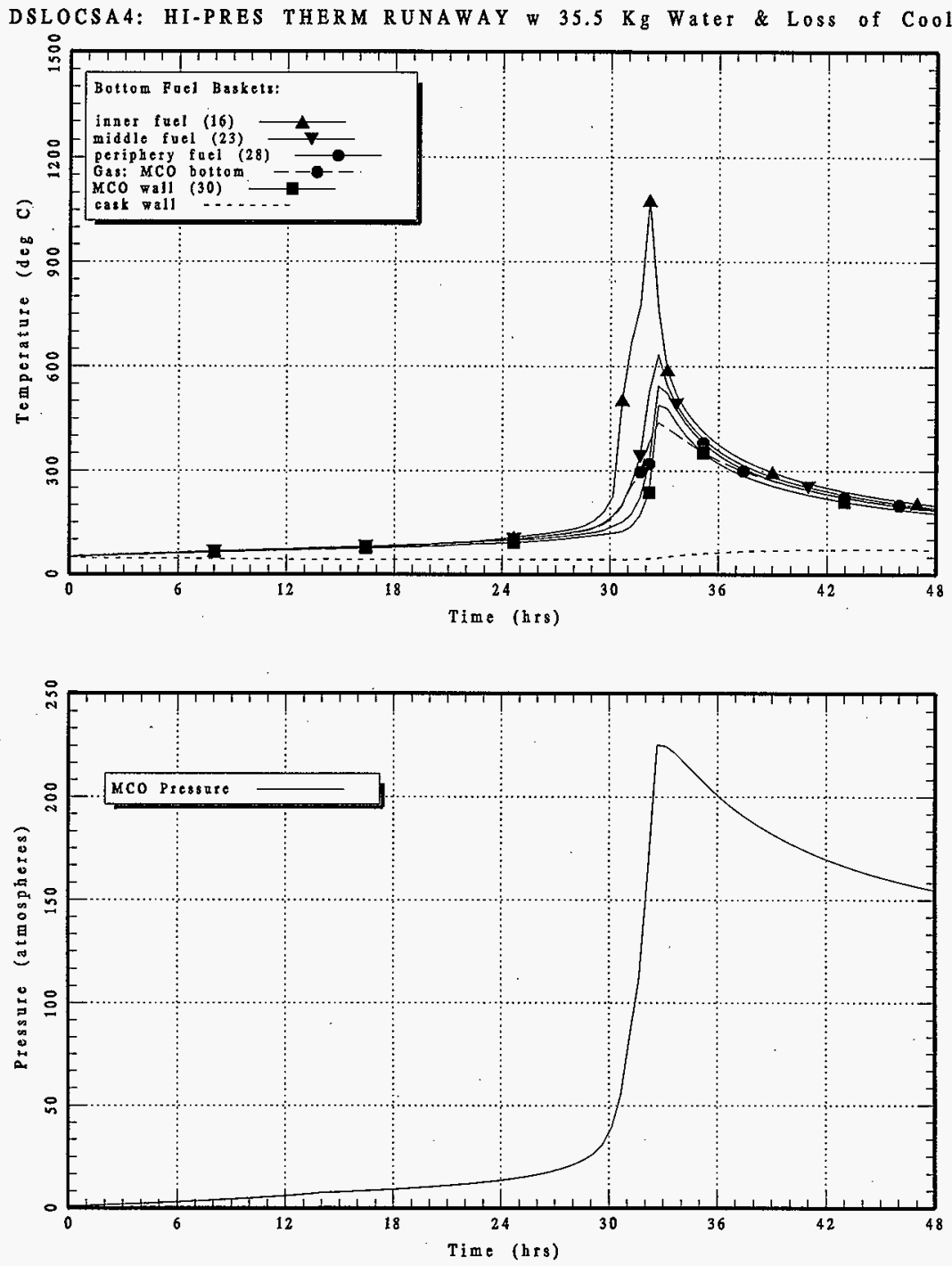


\section{HNF-SD-SNF-CN-023 REV 1}

Figure A-39 BLOW4N: High-Pressure Thermal Runaway Blowdown with Air Ingress 


\section{HNF-SD-SNF-CN-023 REV 1}

This page intentionally left blank. 


\section{HNF-SD-SNF-CN-023 REV 1.}

BLOW 4N: HIGH-PRESSURE THERMAL RUNAWAY BLOWDOWN W Air Ingtess
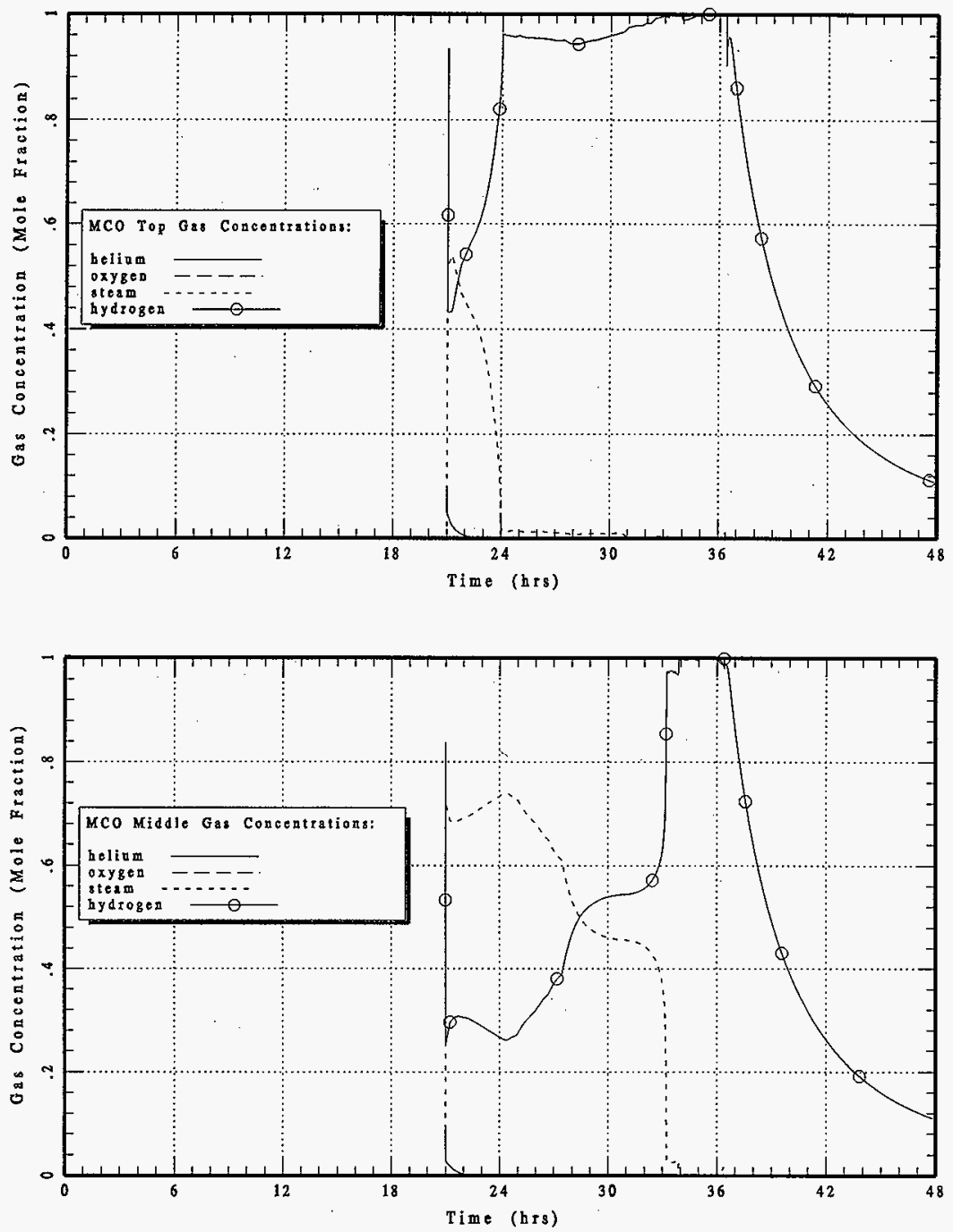


\section{HNF-SD-SNF-CN-023 REV 1}

BLOW 4N: HIGH-PRESSURE THERMAL RUNAWAY BLOWDOWN w Air Ingress
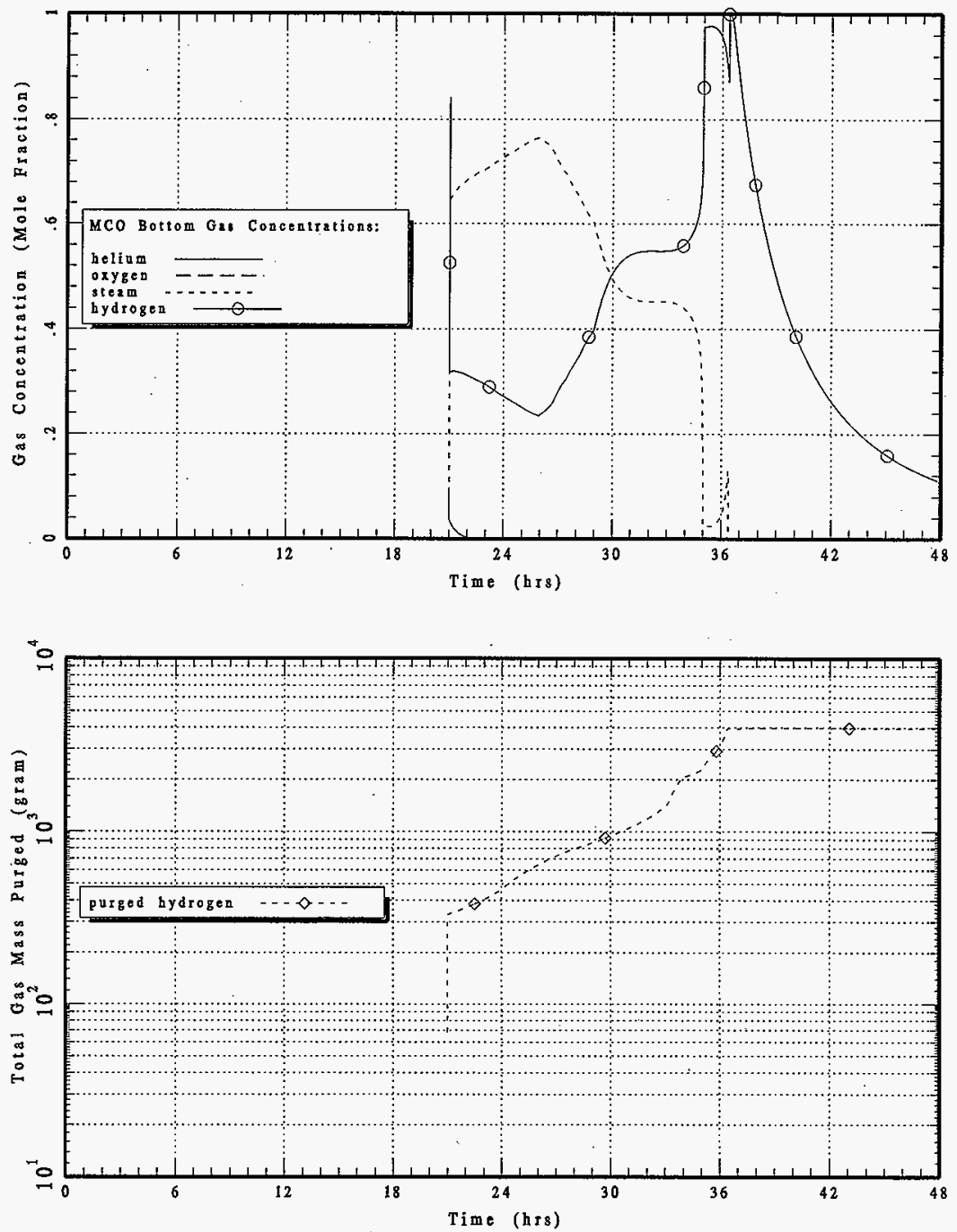

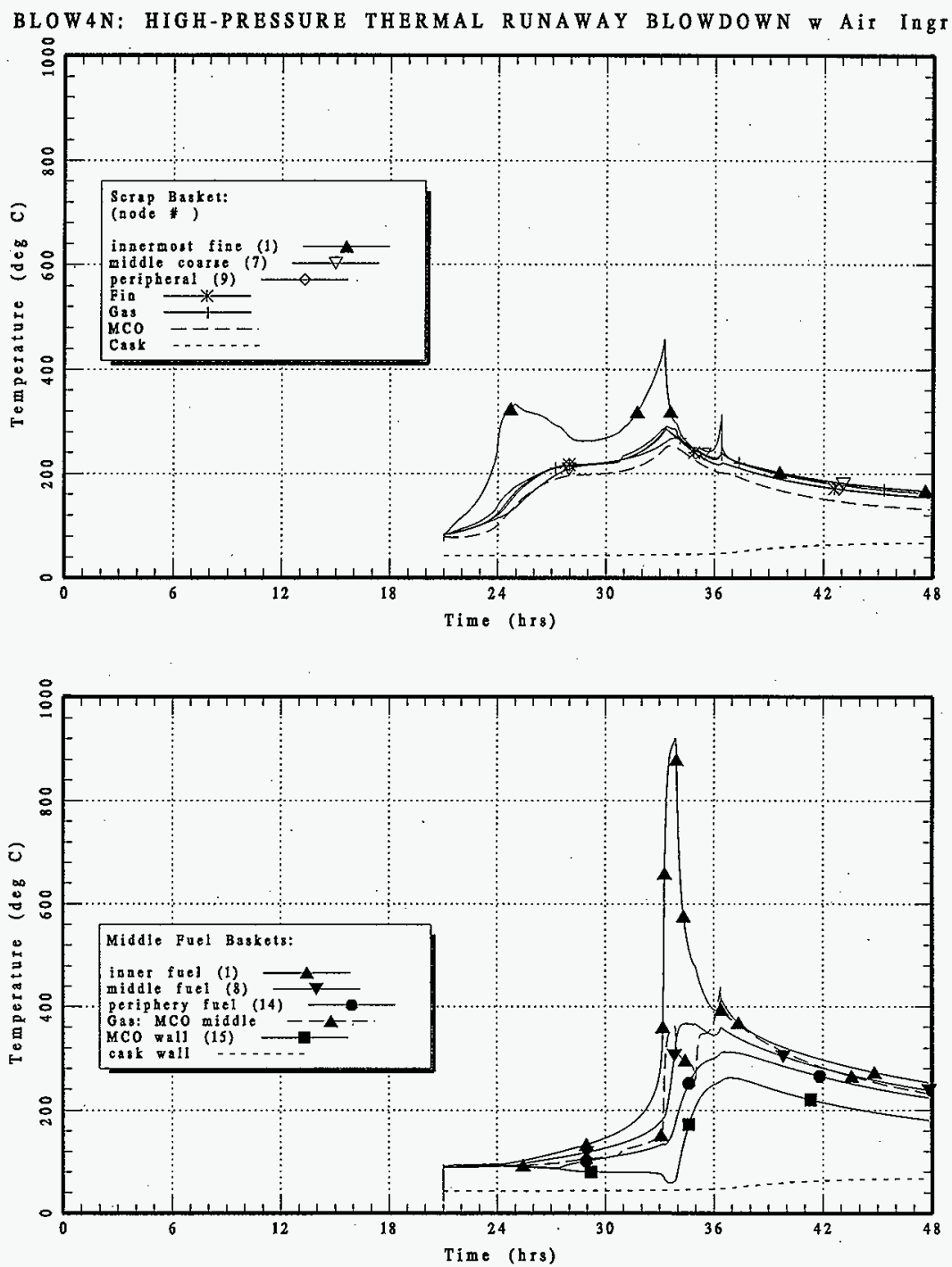


\section{HNF-SD-SNF-CN-023 REV 1}
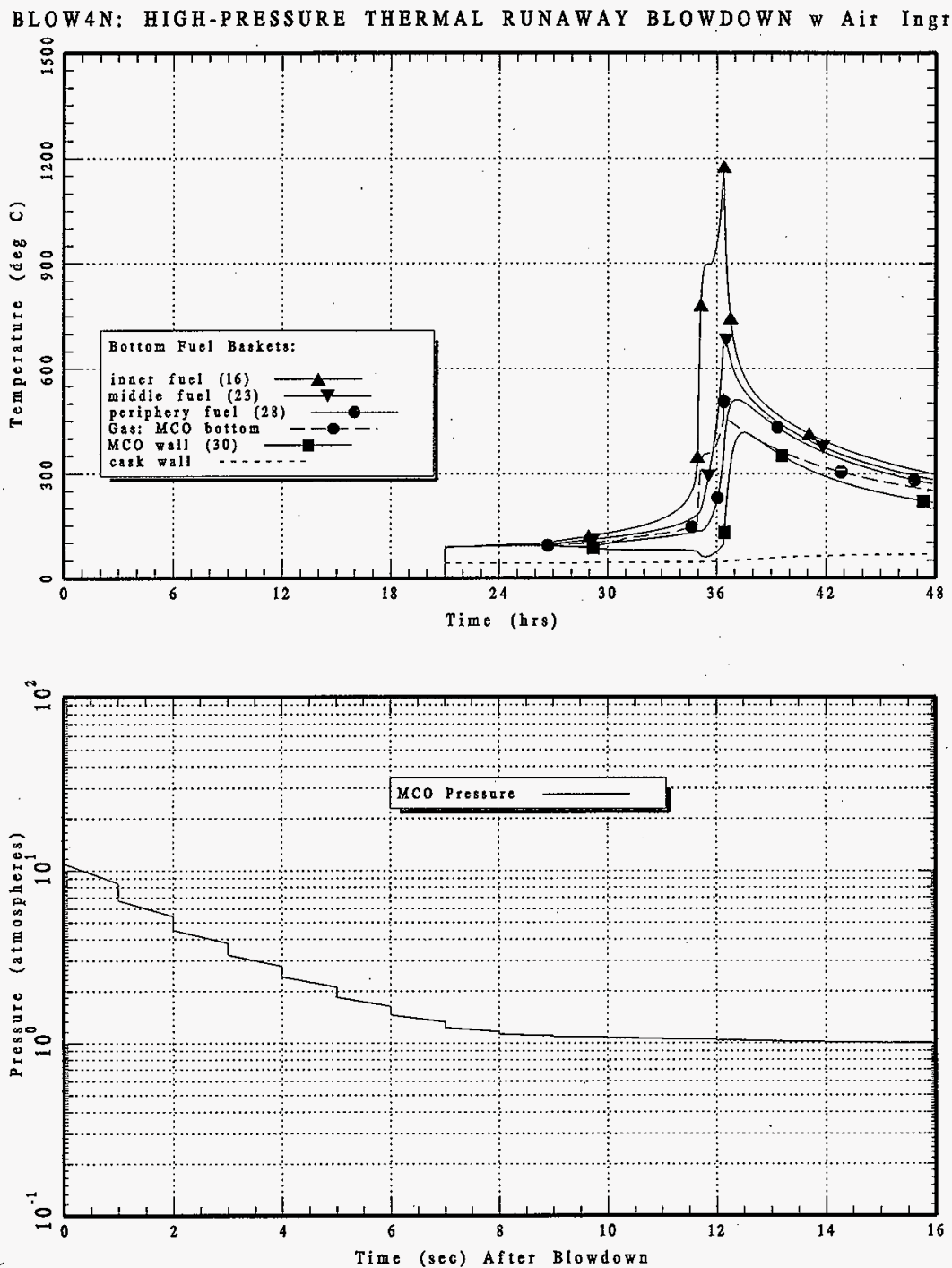
Figure A-40 DSSA4REC: High-Pressure Thermal Runaway with Loss of Coolant (LOC), $35.5 \mathrm{Kg}$, and Recovery at $21 \mathrm{hrs}$

The long-dashed curves are from case 40, DSSA4REC, which includes a recovery from the loss of coolant condition by restoring $25^{\circ} \mathrm{C}$ stationary annulus water. The solid and short-dashed curves are from case 38, DSLOCSA4, which includes a bounding MCO with a loss of coolant condition and provides the initial conditions for case 40 at 21 hours. 


\section{HNF-SD-SNF-CN-023 REV 1}

This page intentionally left blank. 


\section{HNF-SD-SNF-CN-023 REV 1}

DSSA 4REC: HI-PRES THERM RUNAWAY W LOC, $35.5 \mathrm{~kg} \&$ Ann, Recovery @ 21 hrs
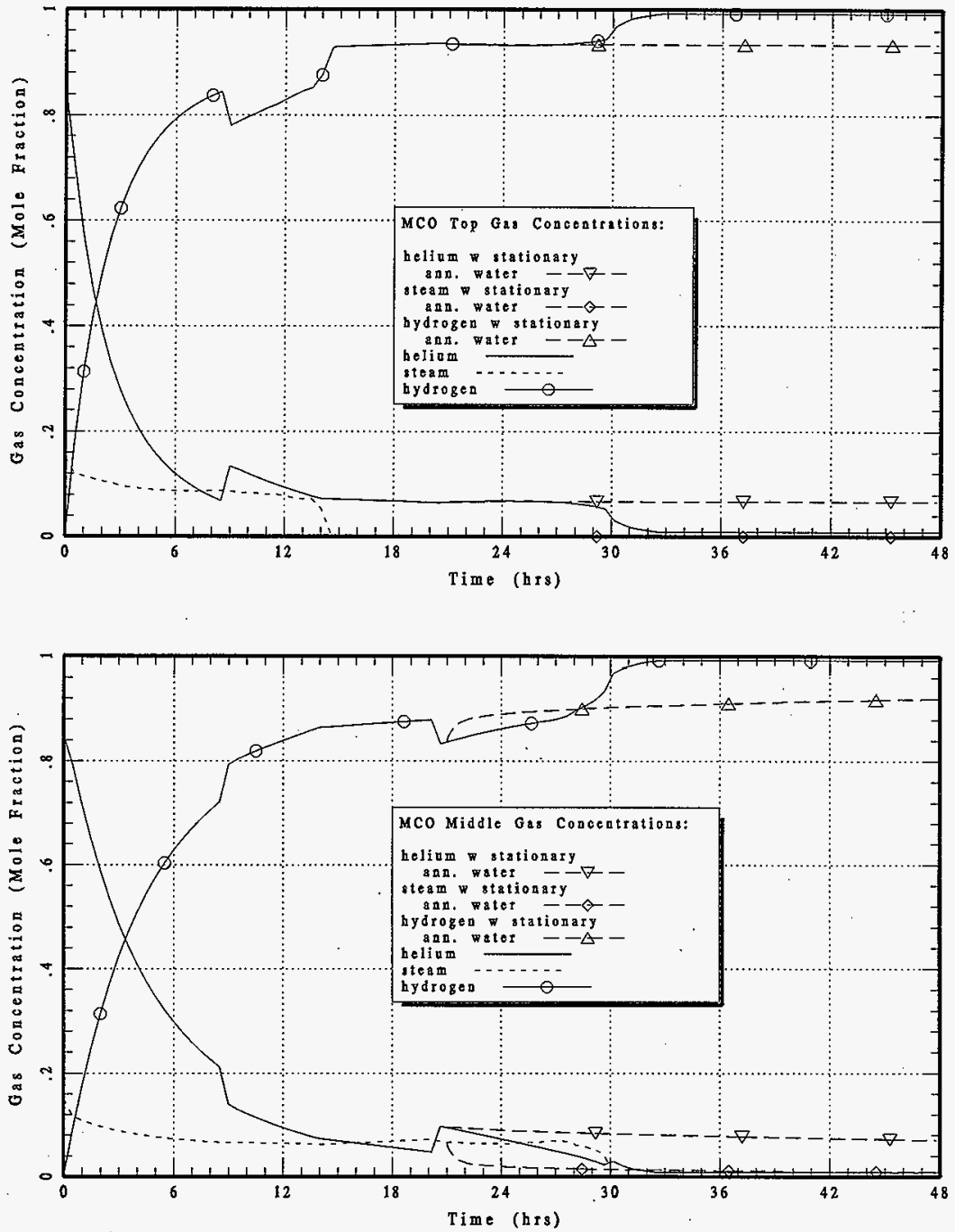
HNF-SD-SNF-CN-023 REV 1

DSSA4REC: HI-PRES THERM RUNAWAY w LOC, $35.5 \mathrm{~kg}$ \& Ann. Recovety @ 21 hrs
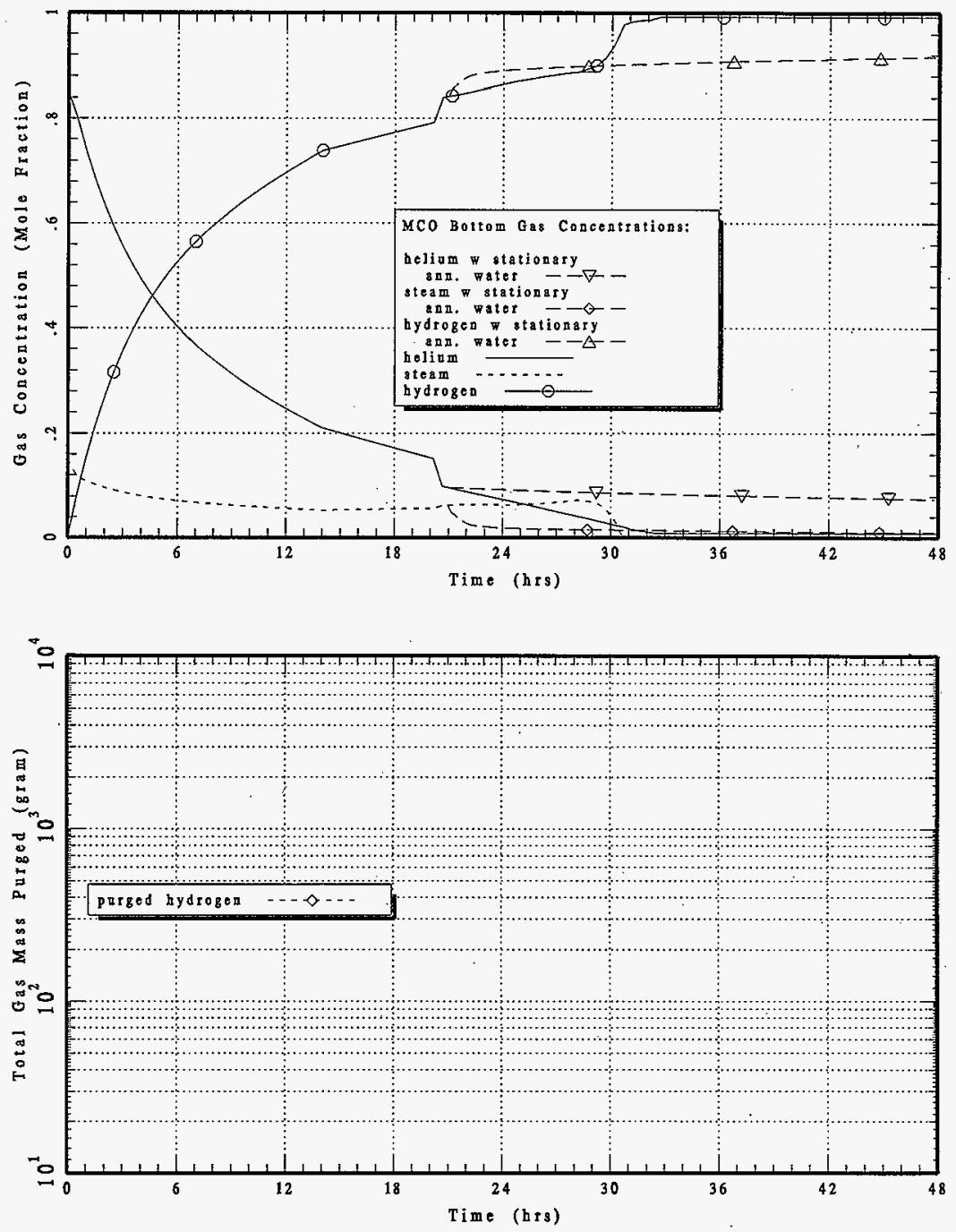


\section{HNF-SD-SNF-CN-023 REV 1}

DSSA 4REC: HI-PRES THERM RUNAWAY W LOC, $35.5 \mathrm{~kg} \&$ Ann. Recovery@ @ 21 hrs
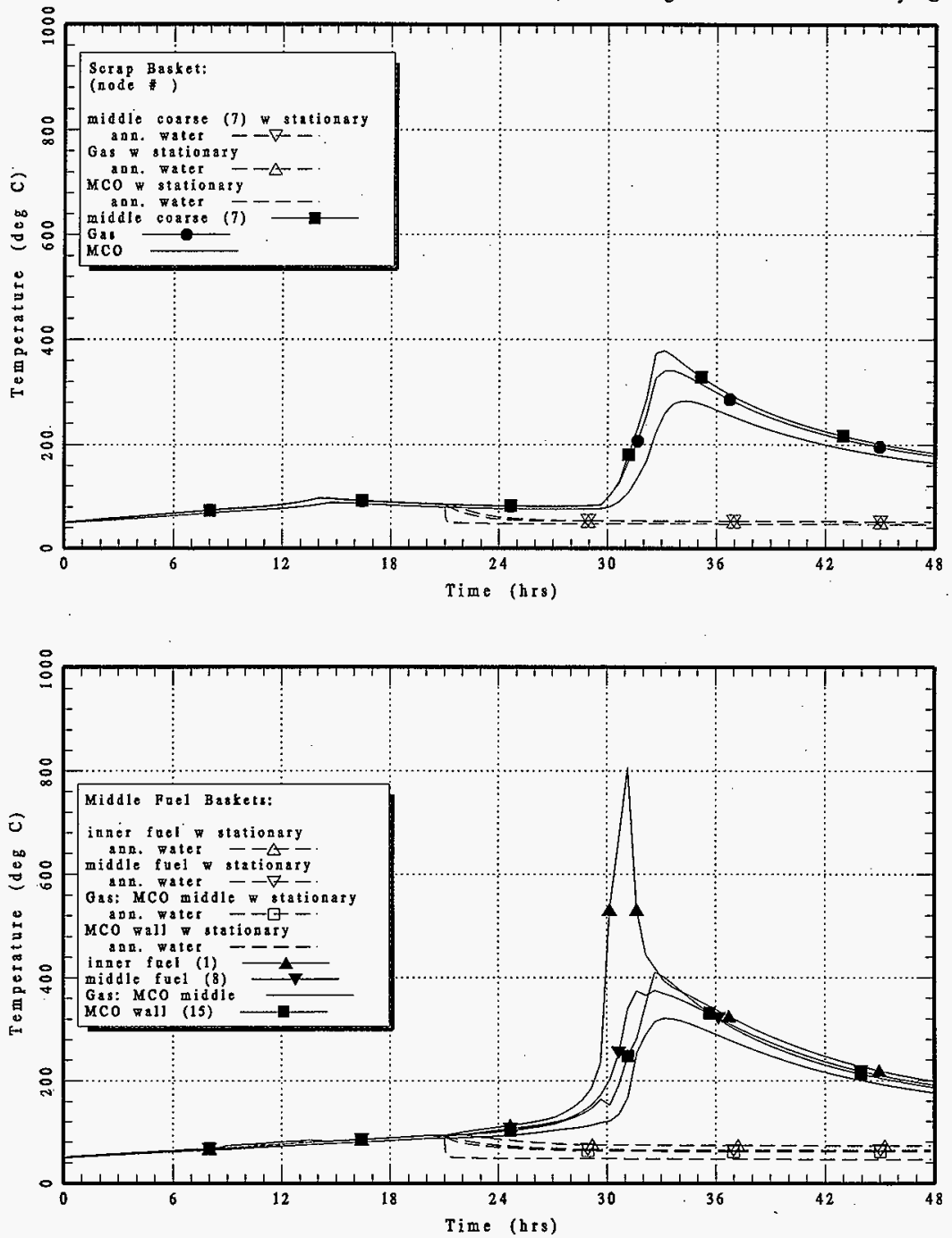


\section{HNF-SD-SNF-CN-023 REV 1}

DSSA4REC: HI-PRES THERM RUNAWAY WOC, $35.5 \mathrm{~kg} \&$ Ann, Recorety@21 hrs
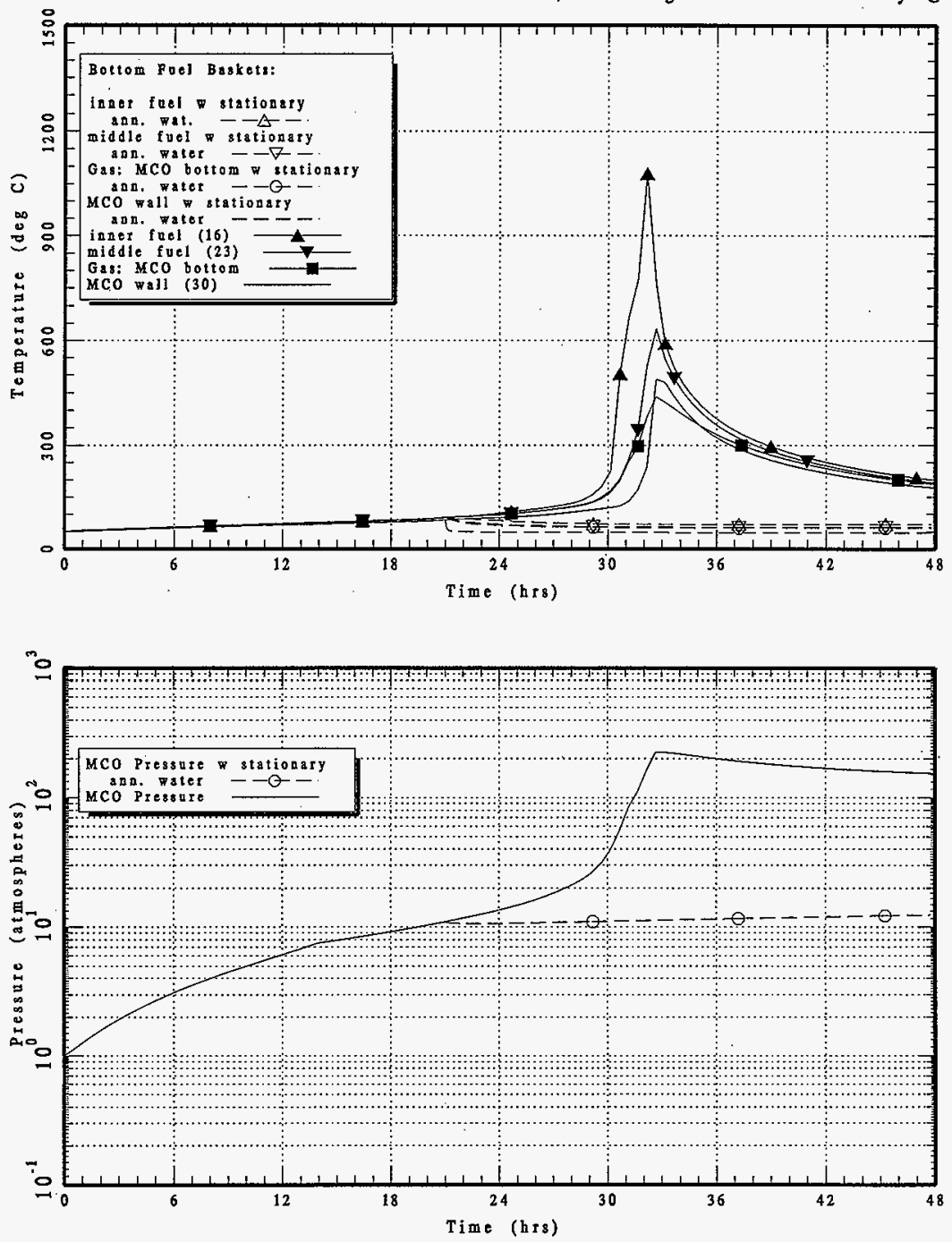
Figure A-41 BLOWREOV: Blowdown with Stationary Annulus Recovery From Loss of Coolant (LOC) at 1 Hour After Blowdown

The long-dashed curves are from case 41, BLOWREOV, which includes a recovery from the loss of coolant condition by restoring $25^{\circ} \mathrm{C}$ stationary annulus water at 22 hours, which is 1 hour after the blowdown. The blowdown of a bounding MCO is simulated by case 39, BLOW4N. The solid and short-dashed curves are from case 39 which provides the initial conditions for case $\mathbf{4 1}$ at 22 hours. 


\section{HNF-SD-SNF-CN-023 REV 1}

This page intentionally left blank. 


\section{HNF-SD-SNF-CN-023 REV 1}

BLOWREOV: BLOWDOWN w Station. Ann. Recovety from LOC @ 1 hr aft. blowdown
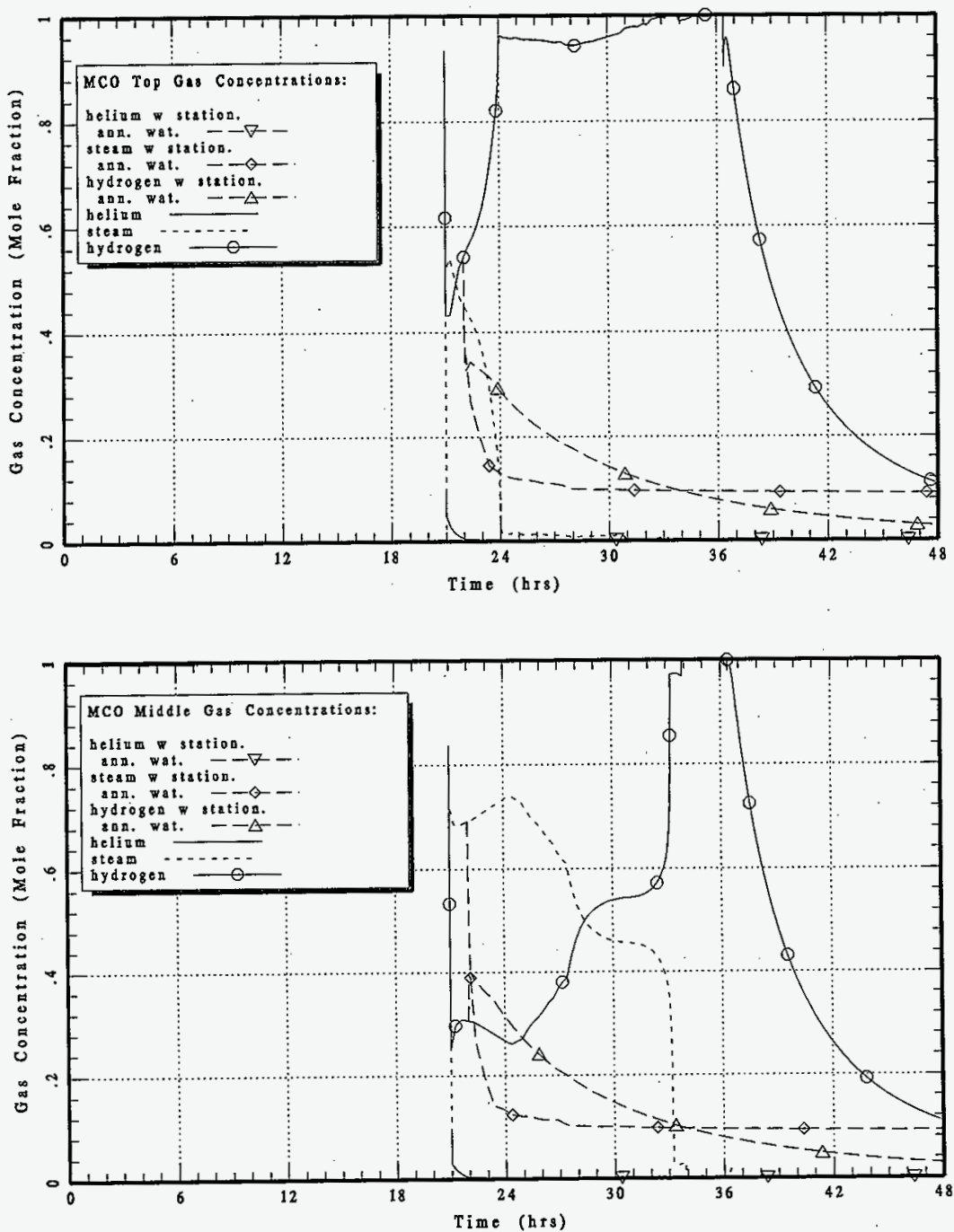
BLOWREOV: BLOWDOWN w Station. Ann. Recovery from LOC @ 1 hr aft. blowdown
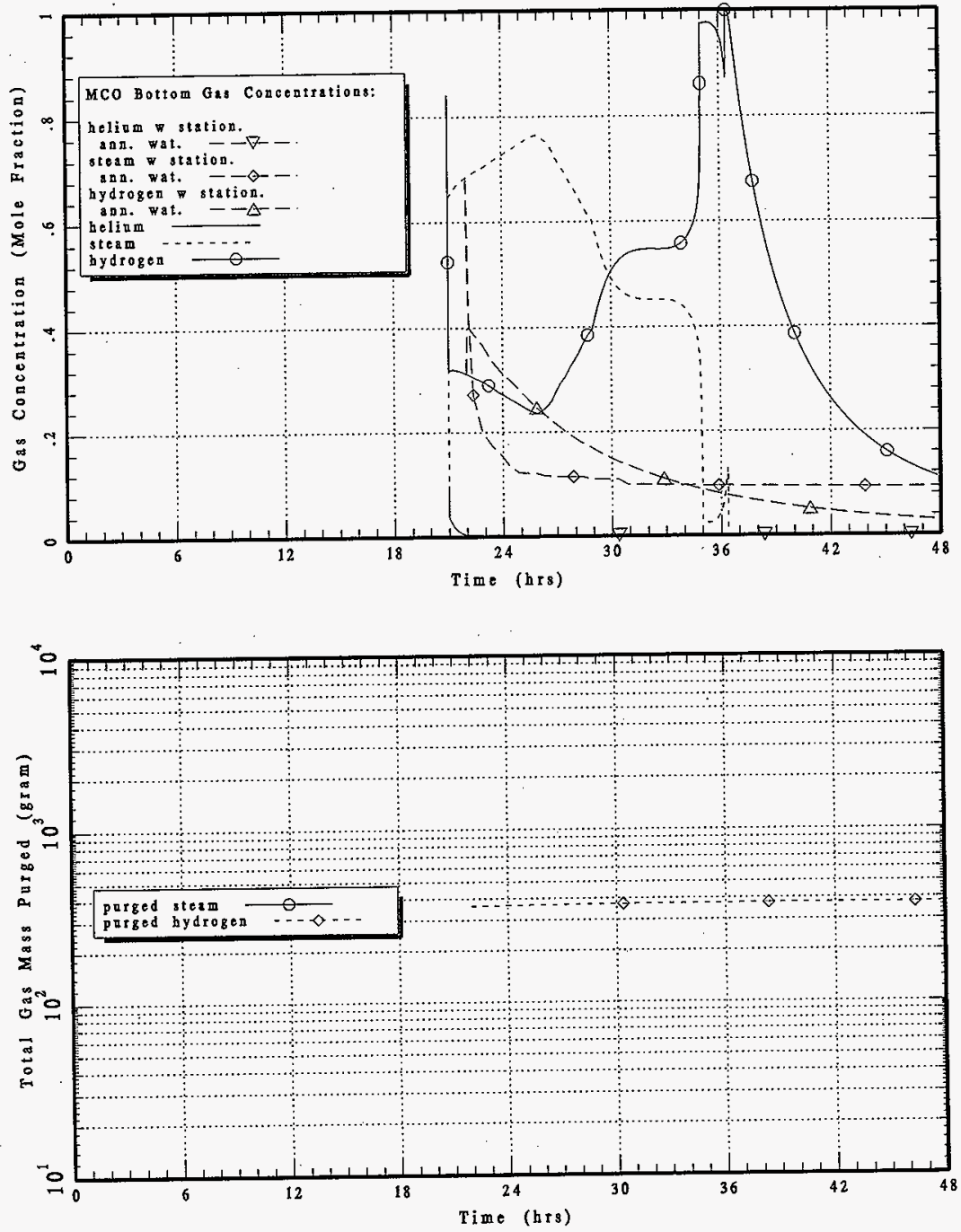


\section{HNF-SD-SNF-CN-023 REV 1}

BLOWREOV: BLOWDOWN w Station. Ann. Recovery from LOC @1 hr aft. blowdown
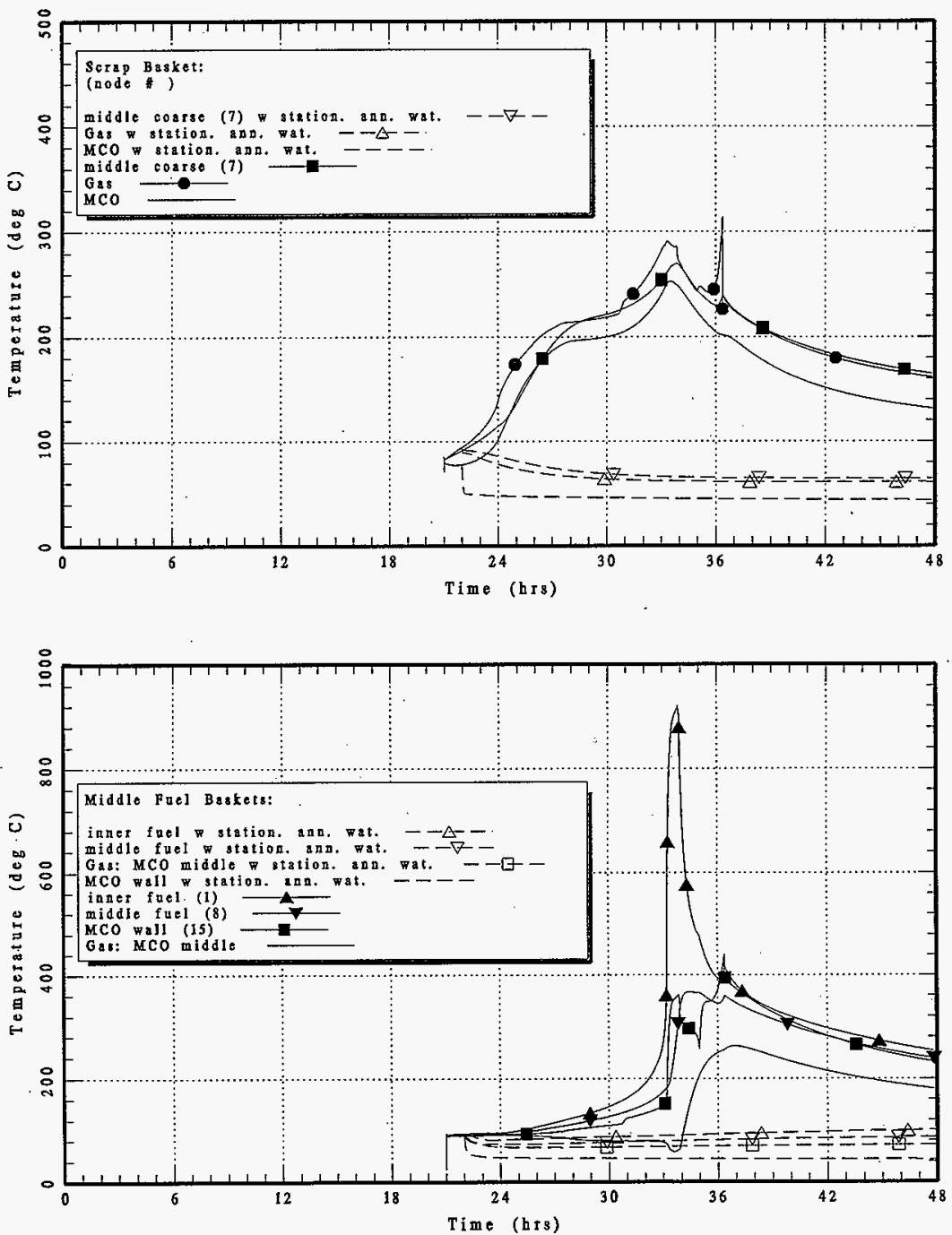


\section{HNF-SD-SNF-CN-023 REV 1}

BLOWREOV: BLOWDOWN w Station. Ann, Recovery from LOC@1 hr aft. blowdown
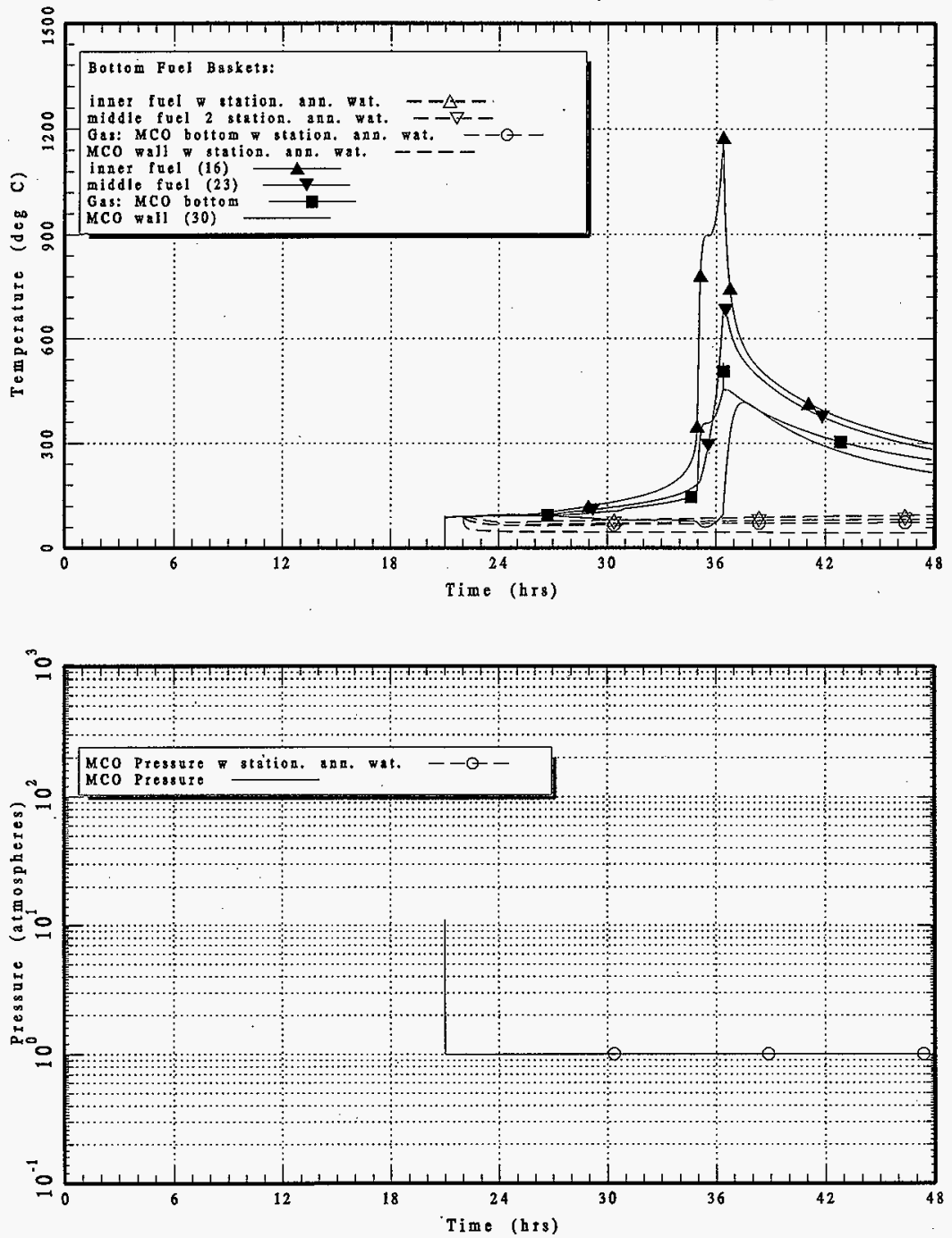
HNF-SD-SNF-CN-023 REV 1

Figure A-42 DSLOCOV2: Low-Pressure Thermal Runaway with 35.5 Kg Water, Loss of Coolant (LOC), and Open Vent 
HNF-SD-SNF-CN-023 REV 1

This page intentionally left blank. 
HNF-SD-SNF-CN-023 REV 1

DSLOCOV2: LO-PRES THERM RUNAWAY $35.5 \mathrm{~kg}$ Water, Loss of Cool., Open Vent
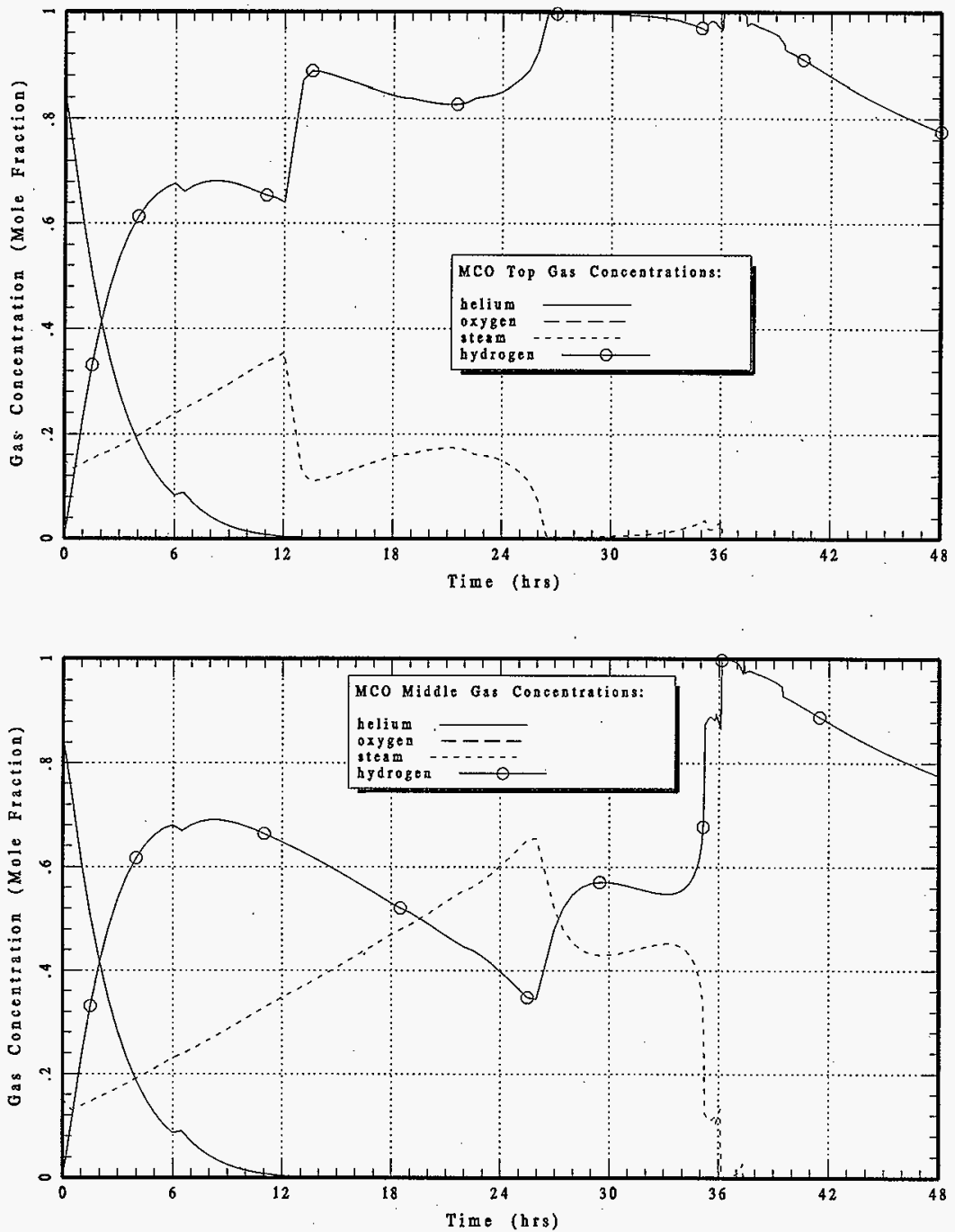


\section{HNF-SD-SNF-CN-023 REV 1}

DSLOCOV2: LO-PRES THERM RUNAWAY w $35.5 \mathrm{Kg}$ Water, Loss of Cool., Open Vent
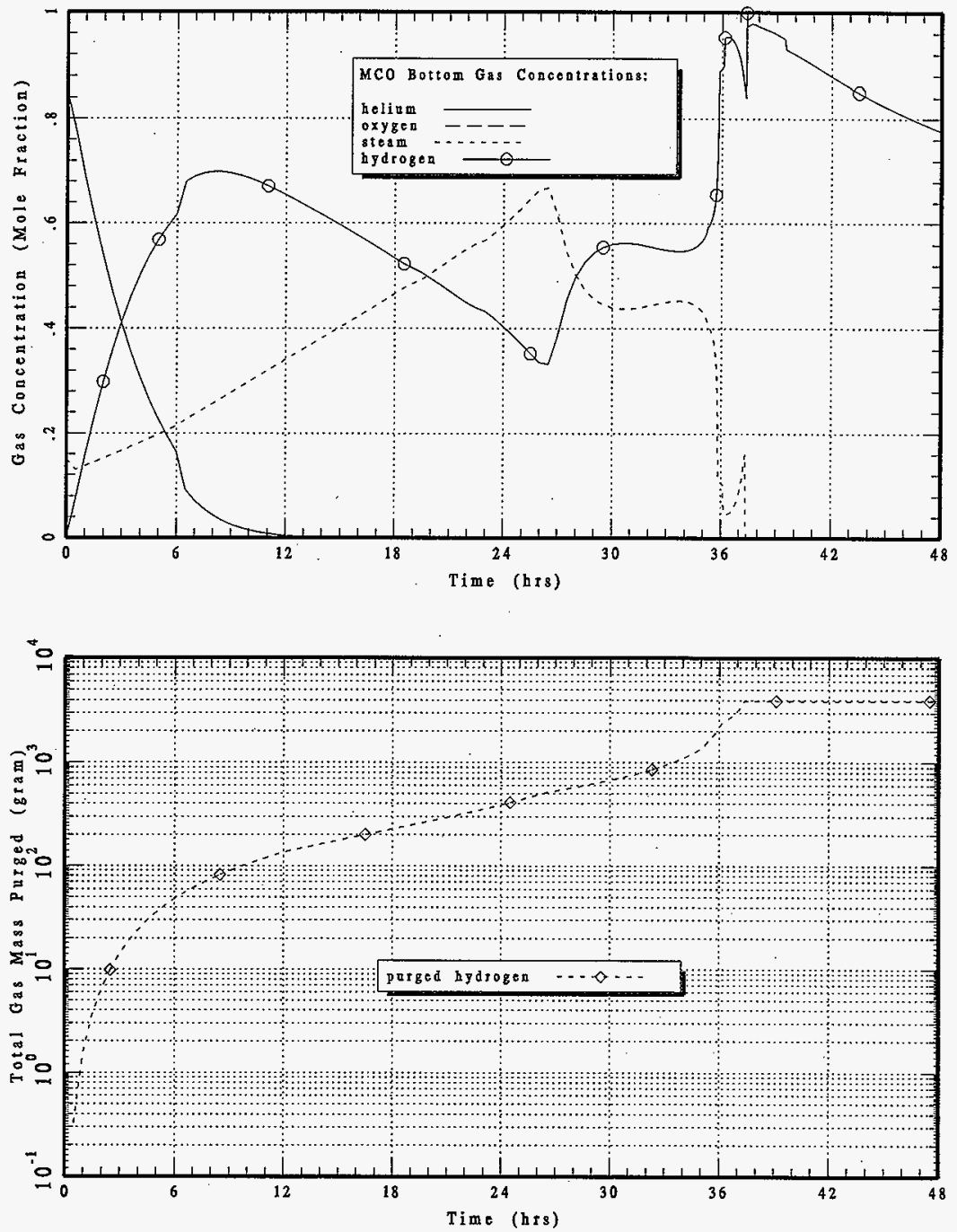
DSLOCOV2: LO-PRES THERM RUNAWAY w $35.5 \mathrm{Kg}$ Water, Loss of Cool, Open Vent
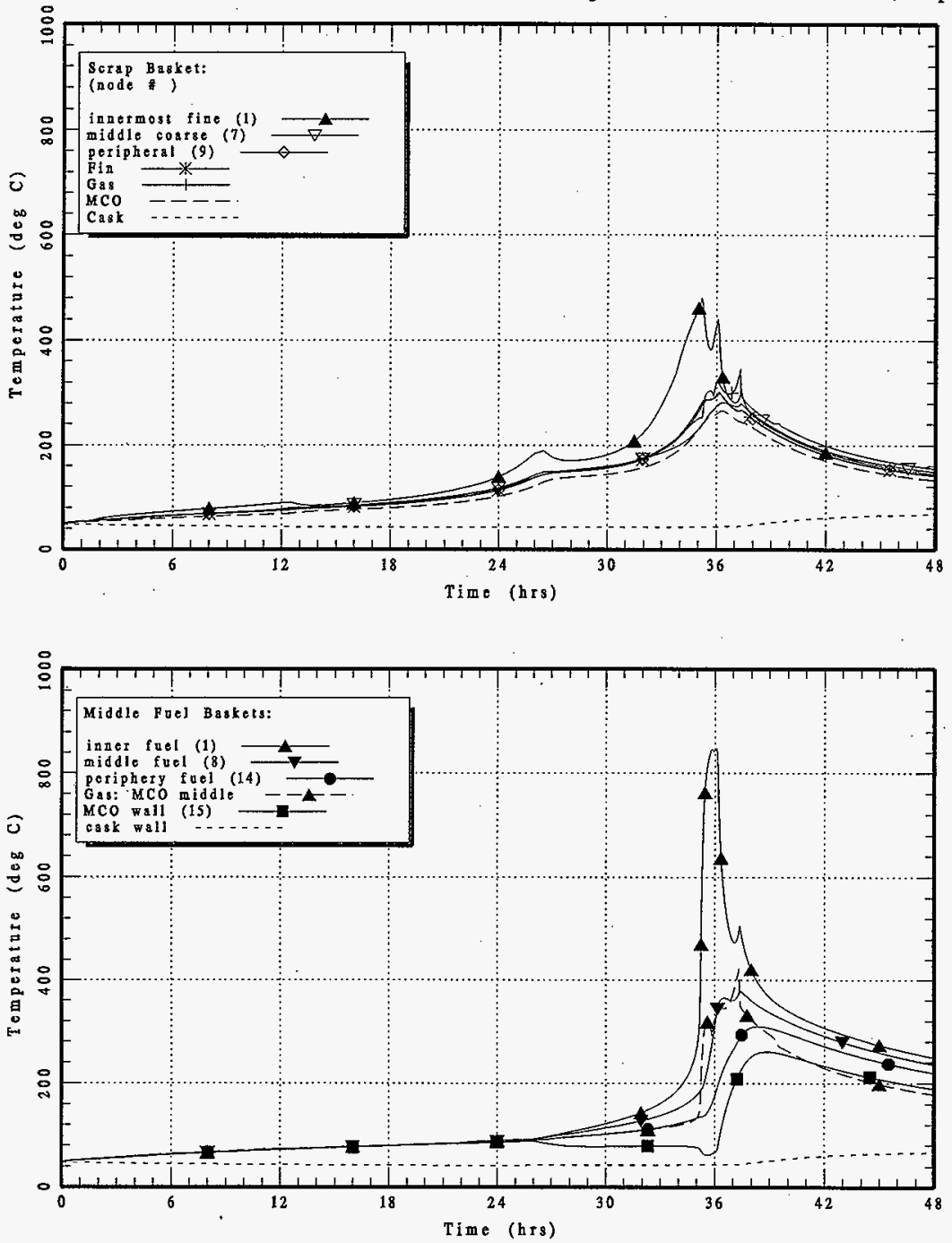


\section{HNF-SD-SNF-CN-023 REV 1}

DSLOCOV2: LO-PRES THERM RUNAWAY w $35.5 \mathrm{Kg}$ Water, Loss of Cool., Open Veat
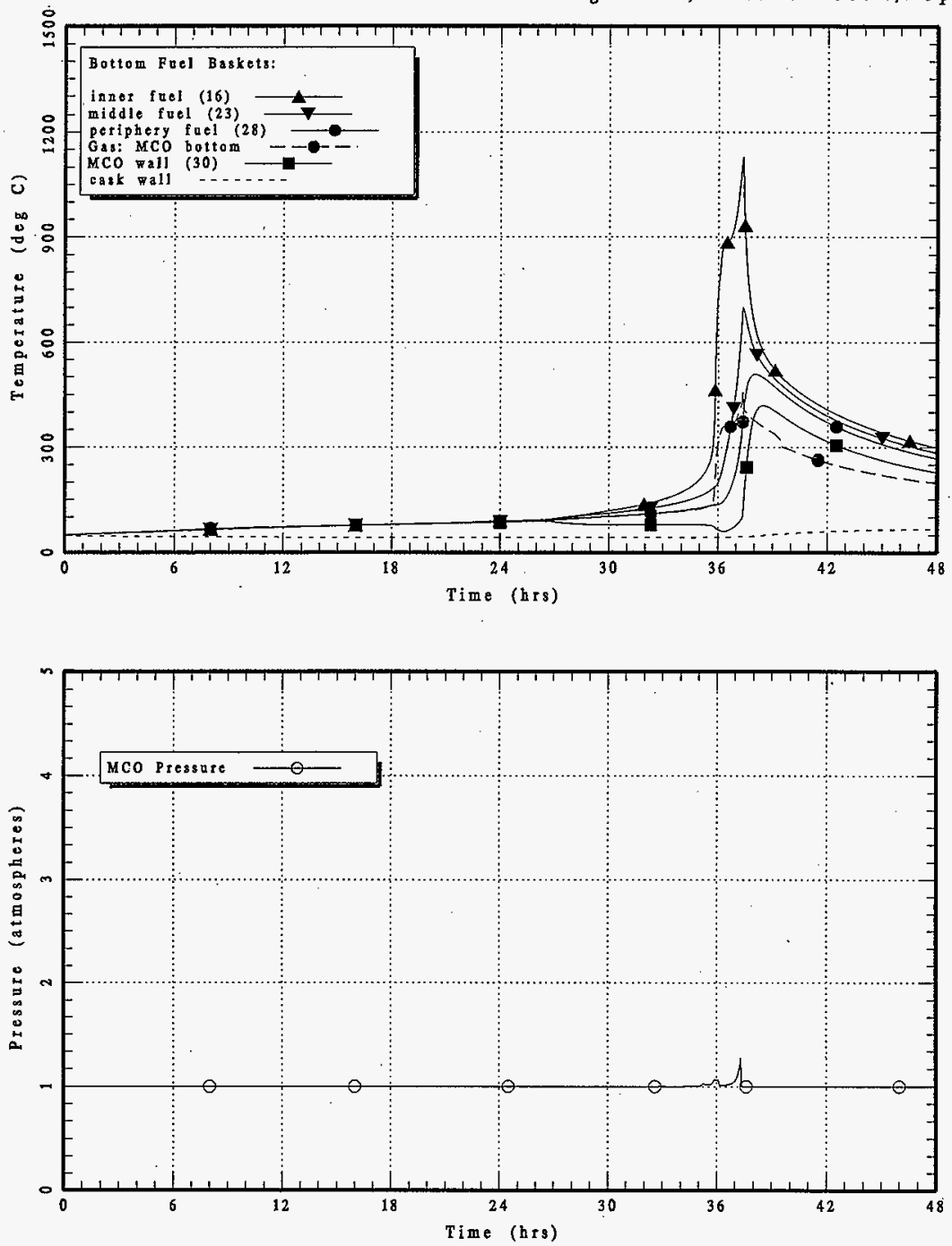
HNF-SD-SNF-CN-023 REV 1

APPENDIX B

INPUT FILE AND INPUT DIFFERENCES 


\section{HNF-SD-SNF-CN-023 REV 1}

This page intentionally left blank. 


\section{APPENDIX B \\ INPUT FLE AND INPUT DIFFERENCES}

The input file for the HANSF code, version 1.2 (Plys et al, 1998) for the VACUUM case (case 1) is listed below. Then input files for cases 2 through 18 are compared to the VACUUM input so that only the differences show up (ignoring format or comment differences). After the DSTOP input (case 18) differences are listed, the next files are compared with DSTOP because these cases (group IV) are closer to DSTOP than to VACUUM. The air ingress cases (group V) are compared to VACUUM input and the last five cases (group VI) are compared to DSTOP because they are more similiar to it than to the VACUUM input.

CASE 1, VACURM, INPUT FLEE

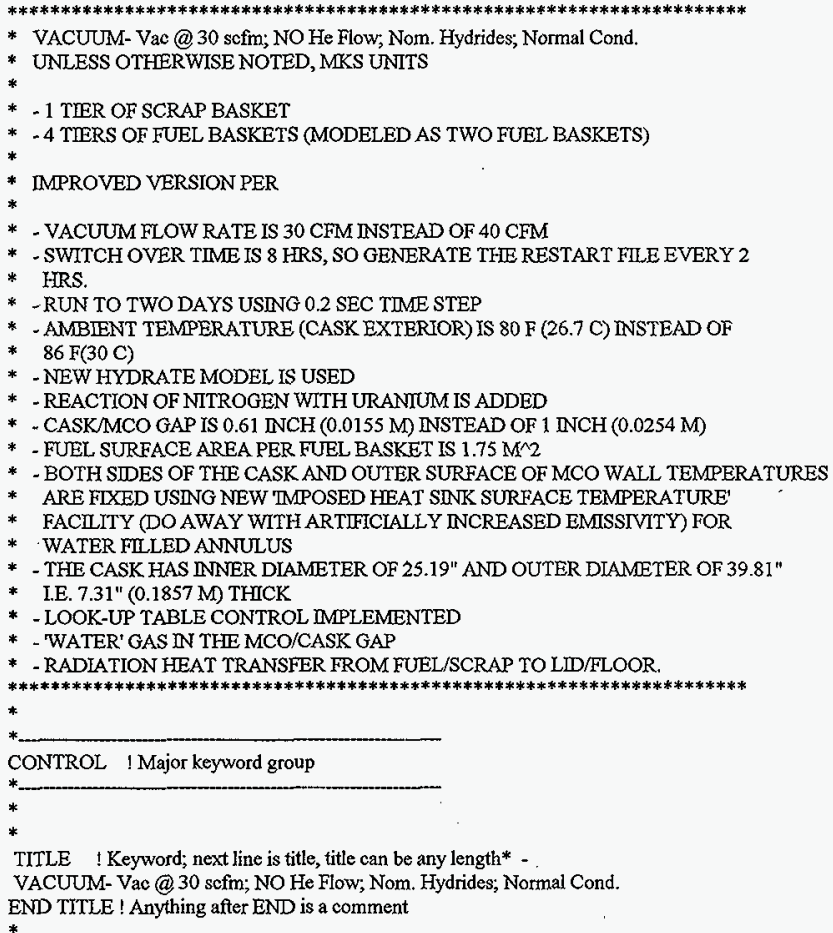




\section{HNF-SD-SNF-CN-023 REV 1}

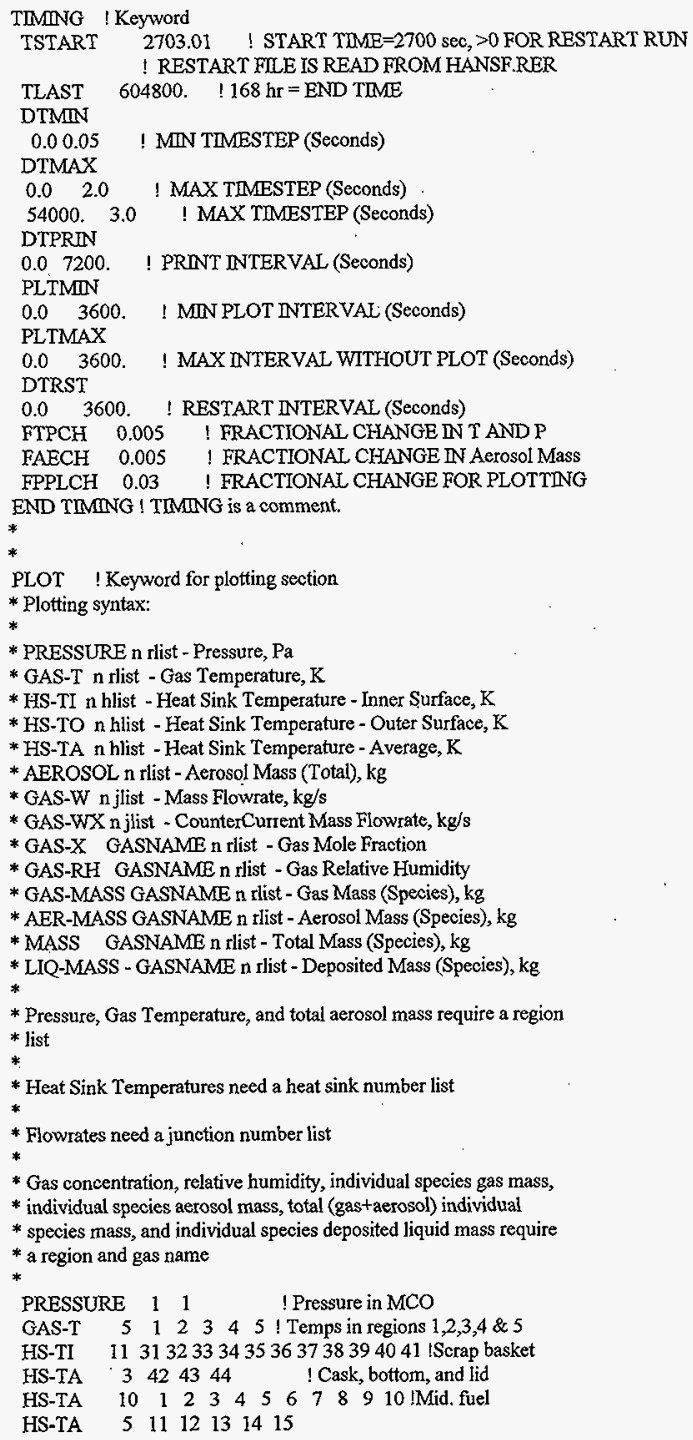




\section{HNF-SD-SNF-CN-023 REV 1}

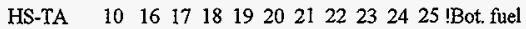
HES-TA 52627282930

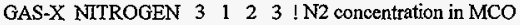

GAS-X OXYGEN $3 \begin{array}{lllllll} & 1 & 2 & 3 & \text { ! } 2 & \text { concentration in } \mathrm{MCO}\end{array}$

GAS-X STEAM $\quad 3 \quad 1 \quad 2 \quad 3$ ! H2O concentration in MCO

GAS-X HYDROGEN $3 \quad 1 \quad 2 \quad 3$ ! H2 concentration in MCO

GAS-X HELIUM 3 l 223 ! He concentration in MCO

GAS-W $\quad 3 \quad 1 \quad 23$ ! Uni-directional mass flowrate

GAS-WX $\quad 3123$ ! Counter-current mass flowrate

GAS-MASS HYDROGEN I 5 ! Mass of hydrogen in region 5

GAS-MASS STEAM 15 ! Mass of steam in region 5

END PLOT ! PLOT is a comment

*

ACTIVE MODELS ! Keyword; MODELS is a comment; $I=$ on, $0=$ off

IJUNC 1 IJunction flow model

ICCFLW 1 ! Counter-current flow model

IHSNNK 1 ! Heat sinks

ICNDS 0 ! Condensation

IASED 0 ! Aerosol Sedimentation

IALEAK 0 I Aerosol Leakage

IFOG 0 ! Fog formation

ISRC 1 ! User-defined sources

IMCO 1 ! MCO models

ISENS 0 ! Sensitivity runs

END ACTIVE MODELS ! ACTIVE MODELS is a comment

*

C SOURCE GROUP: GROUPS REPEATED FOR INPUT \# OF REGTONS

C END OF GROUP DESIGNATED BY 'REGION' OR 'END' KEYWORDS

C ENTER: TIME, TEMP, FLOWRATES, POWER

C SYNTAX EXAMPLE:

*SOURCES 1 I- KEYWORD AND \# SOURCE GROUPS

* REGION 3 GASES 1 !-REGION\#,\# GASES

* HELIUM !- GAS NAMES MUST BE ON NEXT LINE

* $0 \quad 26.71 .23 \mathrm{E}-40.0$ ! 1.23E-4 kg/s=He sour@1.6 cfn@26.7 C

* 1.0E9 26.7 1.23E-4 0.0 ! He dens $=0.163 \mathrm{~kg} / \mathrm{m} 3 @ 26.7 \mathrm{C}, 1 \mathrm{cfm}=4.72 \mathrm{E}-4 \mathrm{~m} 3 / \mathrm{s}$

* END REGION !-- ENDS A REGION SOURCE

*END SOURCES

* !-FOR AEROSOL, SPECIFY -IVE REGION

* REGION -1 GASES 1

* NA2O

* $0.300 .0 \quad 4.44 \mathrm{E}-1 \quad 0 . \mathrm{EO}$

* $10.300 .0 \quad 4.44 \mathrm{E}-1 \quad 0 . \mathrm{E} 0$

* $900.300 .04 .44 \mathrm{E}-1 \quad 0 . \mathrm{EO}$

* $901.300 .0 \quad 0 . \mathrm{EO} \quad 0 . \mathrm{E} 0$

* I.E5 300.0 0.E0 0.E0

* END REgION !- ENDS A REGION SOURCE

* END SOURCE !- ENDS ALL SOURCE INPUT

*

END CONTROL ! End of CONTROL keyword group

*

*

VOLUMES 5 ! total number of control volumes

* total MCO gas volume is $0.55 \mathrm{~m}^{\wedge} 3,0.55 / 3 \approx 0.183$ per each node

* No more than 5 columns (regions) at a time 


\section{HNF-SD-SNF-CN-023 REV 1}

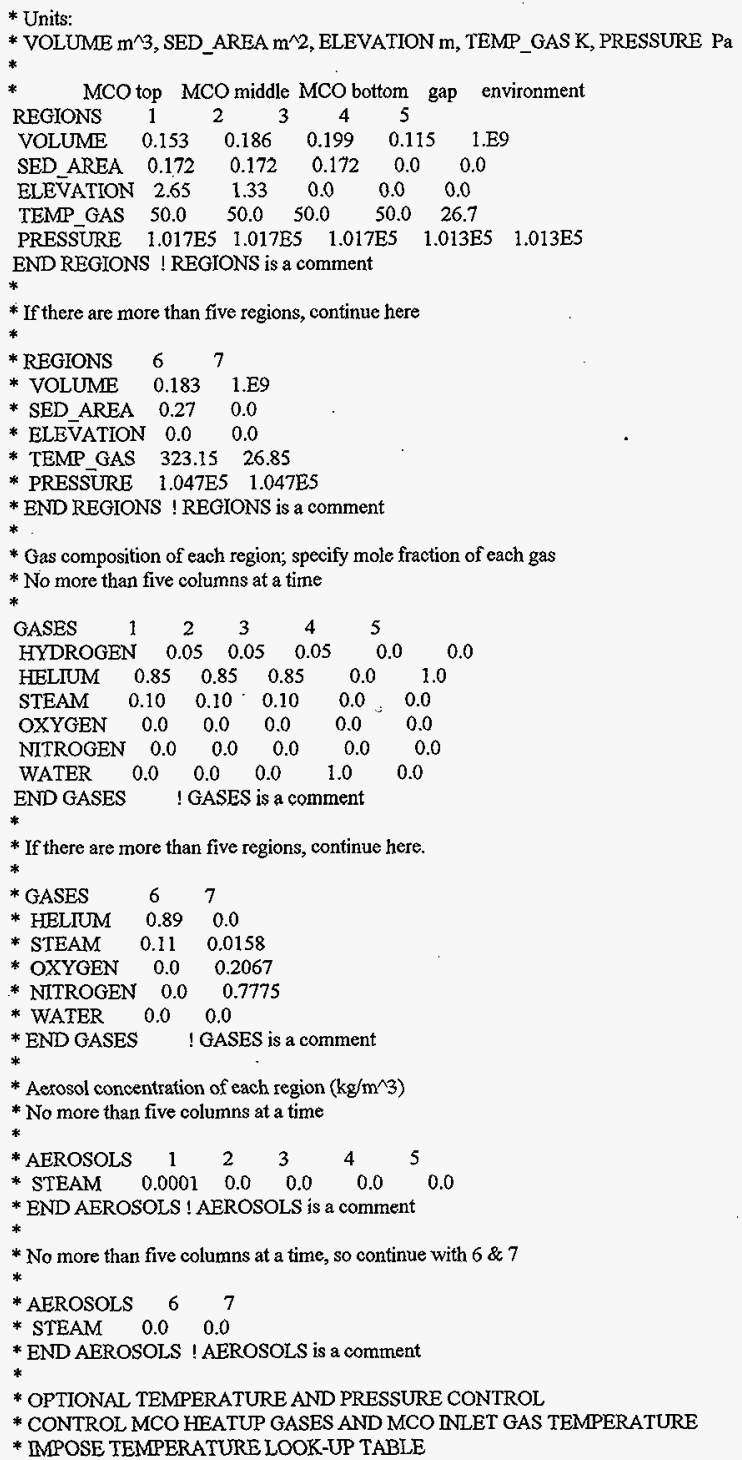




\section{HNF-SD-SNF-CN-023 REV 1}

* STNTAX:

* OFFSET TIMETG

* EXTRAṔolation_tIMETG

* TIMETG IREG TIME1, TIME2...TIMELAST

* TGFIX IREG TEMPI, TEMP2... TEMPLAST TEMPS ARE IN K!!!

* linear interpolation betweEn values

* SIMILAR syNTAX For PRESSURE:

* ofFSET tIMETG

* extRAPOLATION TIMEPG

* tIMEP IREg tIME1, TIME2...

* PRFIX IREG PRES1, PRES2...PRESSURES ARE IN PA!!!

* OFFSET_TIMETG= OFFSET TIME; ENTER LOOKUP TABLE WTTH

* TIME+OFFSET_TIMETG

* EXTRAPOLATION_TIMETG= LAST TO USE LAST VALUE IN THE TABLE,

* $\quad$ = EXTRÁP TO EXTRAPOLATE FROM LAST TWO POINTS,

* $\quad$ = PERIOD TO WRAP AROUND.

* OFFSET TIMETG 50.

* eXTRAPOLATION TIMETG LAST

* TIMETG $1 \quad 0.0 \quad 100.200$.

* TGFIX I $293.15373 .15 \quad 473.15$

* CONTROL MCO BOUNDARY P,

* OFFSET TIMEPG 30.

* EXTRAPOLATION_TIMEPG EXTRAP

* TIMEP $1 \quad 0.0 \quad 100.200$.

* PRFIX 1 1.E5 1.2E5 1.4E5

END VOLUMES ! VOLUMES is a comment

*

C SOURCES 1

C REGION 1 GASES 1

! - KEYWORD AND \# SOURCE GROUPS

C HELIUM !- REGION \#, \# GASES

$\begin{array}{llll}\text { C } 0 & 323.15 & 2.2027 \mathrm{E}-3 & 0 . \mathrm{E} 0\end{array}$

C $36000323.15 \quad 2.2027 \mathrm{E}-3 \quad$ O.EO

C END REGION

!- ENDS A REGION SOURCE

C END SOURCE

* Major keyword-

HEAT_SINKS 44 ! Total number of heat sinks

* decay power based on $740 \mathrm{~W}$ per MCO.(776 W/5 FBs)

* No more than 5 columns at a time,

* Repeat the following structure,

* SINKS

*.

*.

$*$

* END

* Syntax:

* IGEOM 1 for plane, 0 or 2 for cylinder

* RHO Density $\left(\mathrm{kg} / \mathrm{m}^{\wedge} 3\right)$

* KHS Thermal Conductivity $(\mathrm{W} / \mathrm{m} / \mathrm{K})$

* CPHS Specific Heat $(\mathrm{J} / \mathrm{kg} / \mathrm{K})$

* QV Volumetric Heat Generation ( $\left.\mathrm{W} / \mathrm{m}^{\wedge} 3\right)$

* XRI Inner Radius (m)

* XRO Outer Radius (m); for plane wall, thickness = XRO-XRI

* AHS Onc-sided heat sink area $\left(\mathrm{m}^{\wedge} 2\right)$ 
HNF-SD-SNF-CN-023 REV 1

* TINIT Initial inside surface temperature (C)

* TOINIT Initial outside surface temperature (C)

* IMSLAB Number of slabs; 3 is minimum

* IREGI Region index for inner surface or 0 (insulated)

* or -1 for constant temperature

* TIHS Region surface temperature when IREGI = -1 (C)

* IREGO Region index for outer surface or 0 (insulated)

* or -1 for constant temperature

* TOHS Region surface temperature when IREGO = -1 (C)

* XIHS Characteristic length for natural convection (m)

* EHSI Emissivity of inner surface

* EHSO Emissivity of outer surface

*

* Fuel Basket \#1 heat sinks 1 through 15

$\begin{array}{llllll}\text { SINKS } & 1 & 2 & 3 & 4 & 5\end{array}$

IGEOM 00000000

$\begin{array}{llllll}\text { RHO } & 18573.3 & 18573.3 & 18573.3 & 18573.3 & 18573.3\end{array}$

$\begin{array}{llllll}\text { KHS } & 24.2 & 24.2 & 24.2 & 24.2 & 24.2\end{array}$

$\begin{array}{llllll}\text { CPHS } & 122.67 & 122.67 & 122.67 & 122.67 & 122.67\end{array}$

$\begin{array}{llllll}\text { QV } & 1955.20 & 1955.20 & 1955.20 & 1955.20 & 1955.20\end{array}$

$\begin{array}{llllll}\text { XRI } & 0.00610 & 0.02160 & 0.00610 & 0.02160 & 0.00610\end{array}$

$\begin{array}{llllll}\text { XRO } & 0.01625 & 0.03075 & 0.01625 & 0.03075 & 0.01625\end{array}$

$\begin{array}{llllll}\text { AHS } & 0.557 & 1.310 & 0.557 & 1.310 & 0.557\end{array}$

$\begin{array}{llllll}\text { TINIT } & 50.00 & 50.00 & 50.00 & 50.00 & 50.00\end{array}$

$\begin{array}{llllll}\text { TOINIT } & 50.00 & 50.00 & 50.00 & 50.00 & 50.00\end{array}$

$\begin{array}{llllll}\text { MSLAB } & 3 & 3 & 3 & 3 & 3\end{array}$

$\begin{array}{lcclll}\text { IREGI } & 2 & 2 & 2 & 2 & 2 \\ \text { TIHS } & 0.0 & 0.0 & 0.0 & 0.0 & 0.0\end{array}$

$\begin{array}{llcccc}\text { IREGO } & 2 & 2 & 2 & 2 & 2\end{array}$

$\begin{array}{llllll}\text { TOHS } & 0.0 & 0.0 & 0.0 & 0.0 & 0.0\end{array}$

$\begin{array}{llllll}\text { XLHS } & 0.661 & 0.663 & 0.661 & 0.663 & 0.661\end{array}$

$\begin{array}{llllll}\text { EHSI } & 0.43 & 0.43 & 0.43 & 0.43 & 0.43\end{array}$

$\begin{array}{llllll}\text { EHSO } & 0.43 & 0.43 & 0.43 & 0.43 & 0.43\end{array}$

END

$\begin{array}{lllllll} & \text { SINKS } & 6 & 7 & 8 & 9 & 10\end{array}$

IGEOM 0000000

$\begin{array}{llllll}\text { RHO } & 18573.3 & 18573.3 & 18573.3 & 18573.3 & 18573.3\end{array}$

$\begin{array}{llllll}\text { KHS } & 24.2 & 24.2 & 24.2 & 24.2 & 24.2\end{array}$

$\begin{array}{llllll}\text { CPHS } & 122.67 & 122.67 & 122.67 & 122.67 & 122.67\end{array}$

$\begin{array}{llllll}\text { QV } & 1955.20 & 1955.20 & 1955.20 & 1955.20 & 1955.20\end{array}$

$\begin{array}{lllllll}\text { XRI } & 0.02160 & 0.00610 & 0.02160 & 0.00610 & 0.02160\end{array}$

$\begin{array}{llllll}\text { XRO } & 0.03075 & 0.01625 & 0.03075 & 0.01625 & 0.03075\end{array}$

$\begin{array}{llllll}\text { AHS } & 1.310 & 1.114 & 2.620 & 0.557 & 1.310\end{array}$

$\begin{array}{llllll}\text { TINIT } \quad 50.00 & 50.00 & 50.00 & 50.00 & 50.00\end{array}$

$\begin{array}{lrrrrr}\text { TONNT } & 50.00 & 50.00 & 50.00 & 50.00 & 50.00\end{array}$

$\begin{array}{llllll}\text { IMSLAB } & 3 & 3 & 3 & 3 & 3\end{array}$

$\begin{array}{lcclcc}\text { IREGI } & 2 & 2 & 2 & 2 & 2 \\ \text { THHS } & 0.0 & 0.0 & 0.0 & 0.0 & 0.0\end{array}$

$\begin{array}{lrrrrr}\text { IREGO } & 2 & 2 & 2 & 2 & 2\end{array}$

$\begin{array}{llllll}\text { TOHS } & 0.0 & 0.0 & 0.0 & 0.0 & 0.0\end{array}$

$\begin{array}{llllll}\text { XLHS } & 0.663 & 0.661 & 0.663 & 0.661 & 0.663\end{array}$

$\begin{array}{llllll}\text { EHSI } & 0.43 & 0.43 & 0.43 & 0.43 & 0.43\end{array}$

$\begin{array}{llllll}\text { EHSO } & 0.43 & 0.43 & 0.43 & 0.43 & 0.43\end{array}$

END

*

MCO WALL

$\begin{array}{llllll}\text { SINKS } & 11 & 12 & 13 & 14 & 15\end{array}$ 


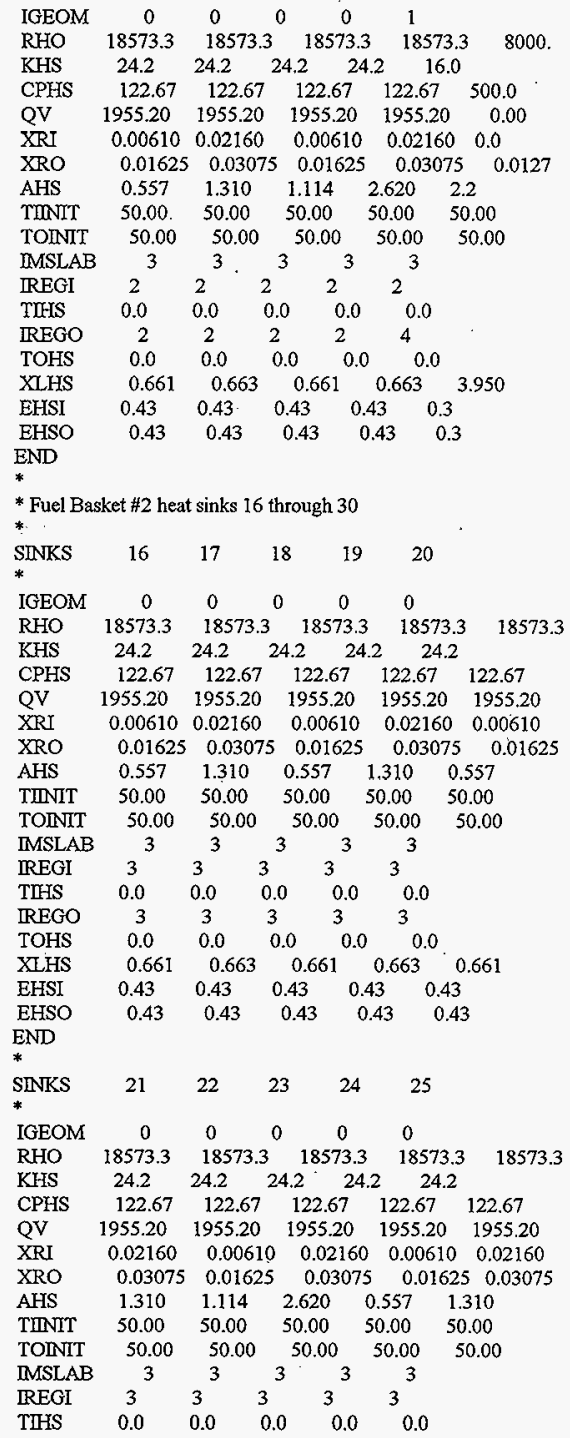




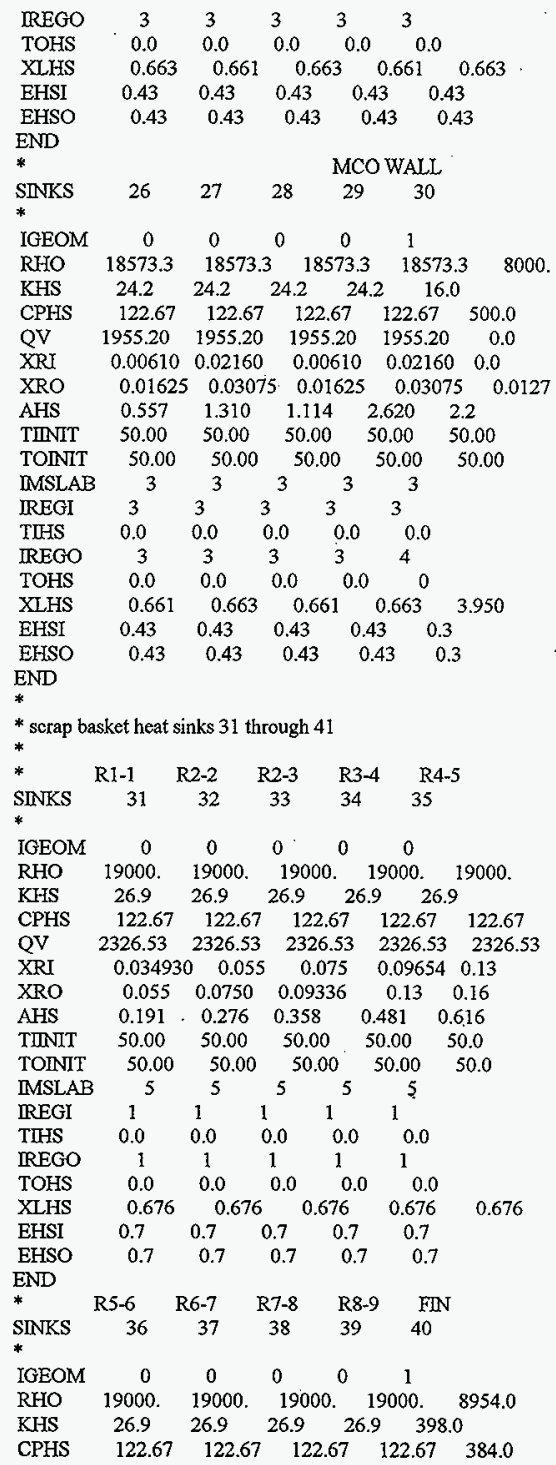




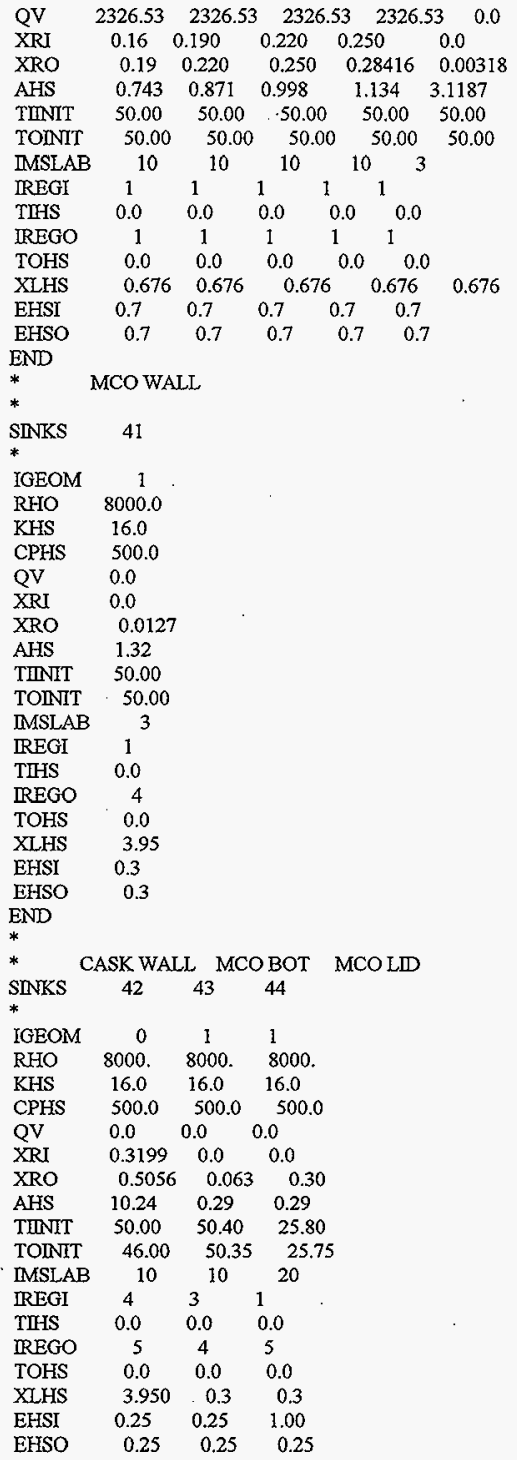




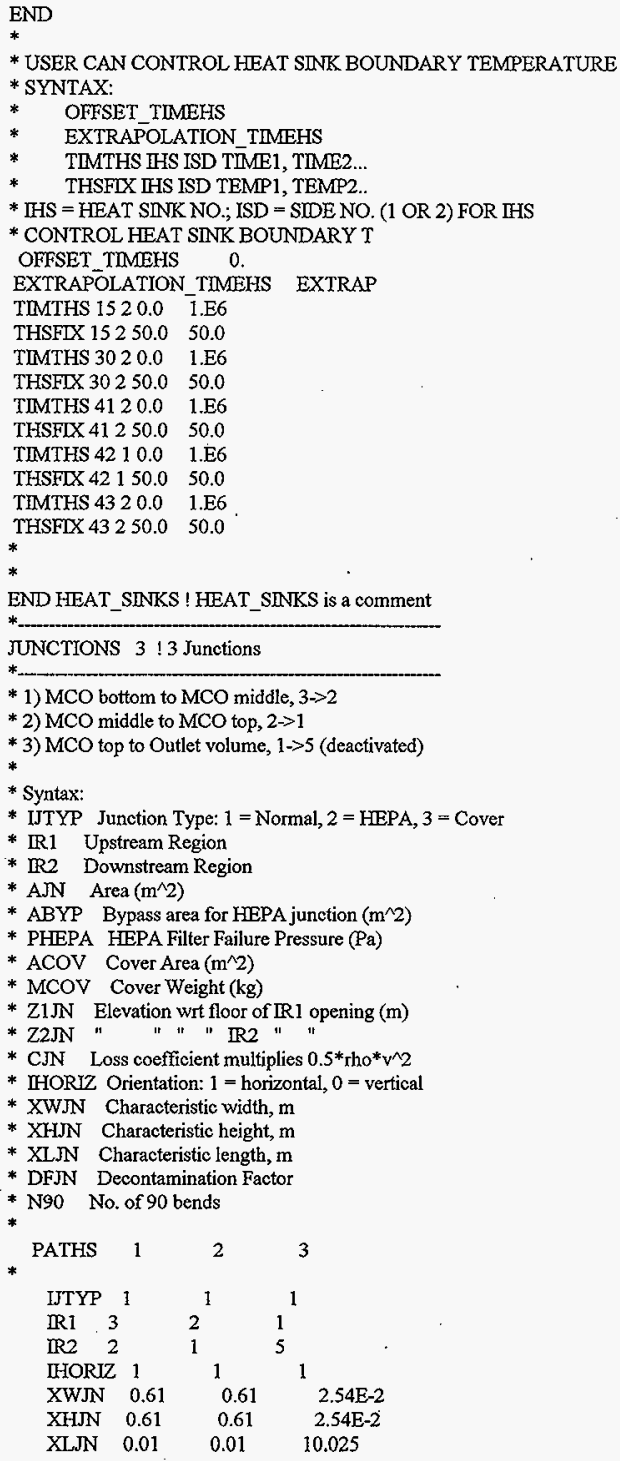




$\begin{array}{lccc}\text { AJN } & 0.10 & 0.013 & 0 . \\ \text { Z1JN } & 1.2 & 1.2 & 1.2 \\ \text { Z2JN } & 0.0 & 0.0 & 4.0 \\ \text { CJN } & 1.0 & 1.0 & 4.0 \\ \text { DFJN } & 1.0 & 1.0 & 1.0 \\ \text { N90 } & 0 & 0 & 3 \\ \text { END PATHS ! PATHS is a comment. }\end{array}$

END JUNCTIONS I JUNCTIONS is a comment.
MCO IMCO Major Keyword
GENERAL ! Keyword for general inputs
IOXDTN $1 \quad !=1$, do oxidation of fuel/scrap $!=0$, disable oxidation of fuel/serap
IHYD $0 \quad !=1$, do hydriding/dehydriding calculation $!=0$, disable hydriding/dehydriding calculation
IDIVRT $1 \quad !=1$, divert heat transfer to gas $1=0$, do not divert heat transfer to gas
IEVAP $1 \quad !=1$, do evaporation/condensation of water $!=0$, do not do evaporation/condensation
LAW 1 ! oxidation rate law, 0 - McGillivrary/Ritchie

$$
1 \text { 1- Pearce }
$$
DEENT $0 \quad 1=1$, de-entrainment of aerosol due to scrap basket $!=0$, disable de-entrainment calculation
IENTR $0 \quad !=1$, do entrainment of sludge particle calculation $!=0$, disable entrainment calculation

IHYDRA $1 \quad !=1$, do decomposition of fuel oxide hydrate $!=0$, disable hydrate decomposition calculation

INITRI $0 \quad l=1$, do nitriding calculation $1=0$, disable nitriding calculation

IRADIO $0 \quad !=1$, do radiolysis calculation $!=0$, disable radiolysis calculation

XDHYD 2.E-5 ! average diameter of hydride particle (m)

IHSCSK 42 ' ! define the cask heat sink

IRGAP 4 ! define the gap node (between $\mathrm{MCO}$ wall and the cask) ! radiative/convective h.t. between the MCO wall and !the cask is computed and some of the heat is diverted ! to gas for stability

XGPCSK 0.0152 ! gap distance between the MCO wall and the cask

FHTLID $1.0 \quad !=0$, turn off the raditive heat transfer between the ! fuel/scrap and the lid/floor $!=1$, fully account for the radiative heat transfer

RHOSL 5000. ! sludge particle density $\left(\mathrm{kg} / \mathrm{m}^{\wedge} 3\right)$

SASL 1000. ! sludge specific area $\left(\mathrm{m}^{\wedge} 2 / \mathrm{m}^{\wedge} 3\right)$

XDSL 1.E-6 ! sludge particle diameter (m)

* Hydrate Model: two-step decomposition,

* input curves for $\ln P$ and $\ln K$

* first step for $\mathrm{x}>\mathrm{XHYD} 2$, second step for $\mathrm{x}<\mathrm{XHYD} 2$

* $10 \%$ weight fraction of sludge being water is equivalent to $90 \%$

* of sludge being hydrated with 2 moles of

* water per mole of uranium oxide

*

FHYSL 0.5 ! fraction of sludge that is hydrated

XHYSL 2.0 ! stoichiometry number of hydrate: no. of moles of I water per mole of uranium oxide (UO3. $\mathrm{H} 2 \mathrm{O}$ )

XHYD2 1.0 ! $\mathrm{H} 2 \mathrm{O} / \mathrm{U}$ ratio (stoich. number) to switch I from first to second correlation 


\title{
HNF-SD-SNF-CN-023 REV 1
}

\author{
XHYD3 $0.5 ! \mathrm{H} 20 / \mathrm{U}$ ratio (stoich. number) to switch \\ ! from second to third correlation \\ AHYEQ1 15.912 !' $A$ ' IN LN $P=A+B / T$ FOR $X>X H Y D 2$ \\ BHYEQ1 -6131.E0 ! 'B' IN LN $\mathrm{L}=\mathrm{A}+\mathrm{B} / \mathrm{T}$ FOR $\mathrm{X}>\mathrm{XHYD} 2$ \\ AHYEQ2 18.382 !'A'IN LN P $=\mathrm{A}+\mathrm{B} / \mathrm{T}$ FOR X $<$ XHYD2 \\ BHYEQ2 -7766.EO ! 'B' IN LN P = A + B/T FOR X $<$ XHYD2 \\ AHYEQ3 18.408 !'A' $N L N P=A+B / T$ FOR $\mathrm{X}<\mathrm{XHYD} 3$ \\ BHYEQ3 -8488.EO ! B' $\mathrm{N}$ LN $\mathrm{P}=\mathrm{A}+\mathrm{B} / \mathrm{T}$ FOR X $<$ XHYD3 \\ ADEHY1 2.793E0 !'A' IN LNK $=A+B / T$ FOR X $>$ XHYD2 \\ BDEHY1 -5111.E0 ! 'B' IN LNK $=A+B / T$ FOR $X>X H Y D 2$ \\ ADEHY2 6.348E0 I'A'IN LNK $=\mathrm{A}+\mathrm{B} / \mathrm{T}$ FOR X $<\mathrm{XHYD2}$ \\ BDEHY2 -7241.E0 ! 'B' IN LN K $=A+B / T$ FOR $X<X H Y D 2$ \\ ADEHY3 4.632E0 !'A'INLNK $=A+B / T$ FOR $X<X H Y D 3$ \\ BDEHY3 -7548.E0 ! 'B' $\mathbb{N} L N K=A+B / T$ FOR X $<$ XHYD3 \\ DHHY1 2.86E6 ! Decomposition enthalpy $\mathrm{J} / \mathrm{kg} \mathrm{H} 2 \mathrm{O}$ : 1st step \\ DHHY2 3.70E6 ! Decomposition enthalpy $\mathrm{J} / \mathrm{kg} \mathrm{H} 2 \mathrm{O}:$ 2nd step \\ DHHY3 3.70E6 I Decomposition enthalpy $\mathrm{J} / \mathrm{kg} \mathrm{H} 2 \mathrm{O}: 3 \mathrm{rd}$ step \\ FPROHY 1.0 ! hydride production rate law multiplier \\ FCONHY 1.0 ! hydride consumption rate law multiplier \\ FNITRI 1.0 ! nitriding rate law multiplier \\ * \\ * PUMP, FEED, AND CONDENSER MODELS \\ * Syntax \\ * PUMP IRPUM IROPUM ICONPM ITFEED WVPUMP WVFEED TGFEED TCONPM \\ * Definitions: \\ * IRIPUM - Pump inlet region \\ * IROPUM - Pump outlet region \\ * ICONPM - Node to which the condensed steam is dumped for book-keeping \\ * ITFEED - If non-zero, overides TGFEED with the desingated region \\ * temperature. Used to specified time-varying feed temperature \\ * WVPUMP - Pump volumetric flowrate $\left(\mathrm{m}^{\wedge} 3 / \mathrm{s}\right)$ \\ * WVFEED - Feed volumetric flowrate $\left(\mathrm{m}^{\wedge} 3 / \mathrm{s}\right)$ \\ * TGFEED - Feed temperature (K) \\ * TCONPM - Condenser cooling coil temperature (K) \\ * $30 \mathrm{FT}^{\wedge} 3 / \mathrm{MTN} * 1 \mathrm{MTN} / 60 \mathrm{SEC} * 0.02832 \mathrm{M}^{\wedge} 3 / 1 \mathrm{FT}^{\wedge} 3=0.01416 \mathrm{M}^{\wedge} 3 / \mathrm{SEC}$ \\ * $4 \mathrm{ft} 3 / \mathrm{min}=0.0022027 \mathrm{~m} 3 / \mathrm{s}$ \\ $* 1.6 \mathrm{ft} 3 / \mathrm{min} * 1 \mathrm{~min} / 60 \mathrm{sec} * 0.02832 \mathrm{~m} 3 / \mathrm{ft} 3 * 299.85 / 273.15=0.000829 \mathrm{~m} 3 / \mathrm{s}$ \\ * PUMP IRIPUM IROPUM ICONRM ITFEED WVPUMP WVFEED TGFEED TCONPM

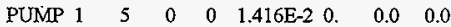 \\ * \\ * Radiolysis parameters \\ FRAD 1.0 ! multiplier for radiolysis \\ FALPHA 0.197 ! alpha fractional heat load \\ FBETA 0.486 ! beta fractional heat load \\ FGAMMA 0.317 ! gamma fractional heat load \\ QPHOTO 2.4E-6 ! heat deposition rate in $\mathrm{MCO}$ free water per gram \\ ! per MTU of fuel loading \\ END GENERAL ! GENERAL is a comment \\ * \\ SOLAR_RAD \\ * \\ * pointers to heat sinks representing the cask wall and the top \\ * solar radiation impinges on these \\ IHCASK 42 \\ IHTOP 44
}




\section{HNF-SD-SNF-CN-023 REV 1}

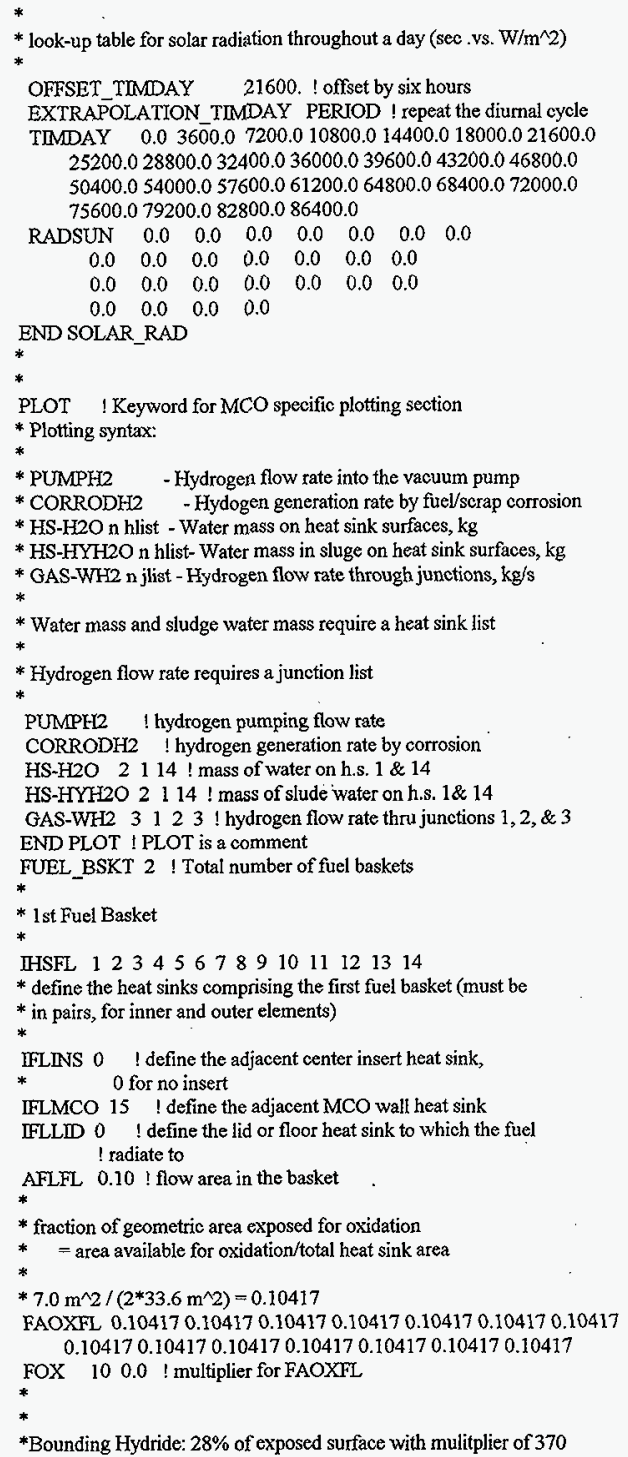




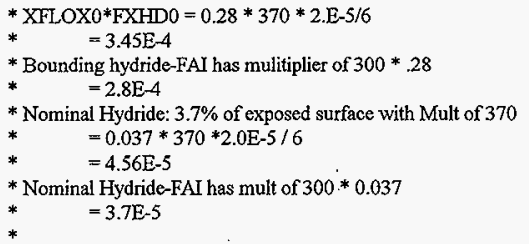

XFLOXO $4.56 \mathrm{E}-5 \quad 4.56 \mathrm{E}-5 \quad 4.56 \mathrm{E}-5 \quad 4.56 \mathrm{E}-5 \quad 4.56 \mathrm{E}-5 \quad 4.56 \mathrm{E}-5 \quad 4.56 \mathrm{E}-5$ 4.56E-5 4.56E-5 4.56E-5 4.56E-5 4.56E-5 4.56E-5 4.56E-5

! initial oxide/Hydride thickness on the exposed surface (m)

FXFYDO $1.0 \quad 1.0 \quad 1.0 \quad 1.0 \quad 1.0 \quad 1.0 \quad 1.0$

$\begin{array}{llllllll}1.0 & 1.0 & 1.0 & 1.0 & 1.0 & 1.0 & 1.0\end{array}$

! fraction of oxide which is hydride

* initial amount $(\mathrm{kg})$ of water per geometric surface area $\left(\mathrm{m}^{\wedge} 2\right)$ of fuel

$* 24 \mathrm{~kg} /\left(2 * 33.6 \mathrm{~m}^{\wedge} 2\right)=0.3571$

$* 480 \mathrm{~kg} /(2 * 33.53 \mathrm{~m} 2)=20 * 0.3571$

$* 8.6 / 2 / 17.0=0.256 \mathrm{~kg} / \mathrm{m}^{\wedge} 2$ (per side)

$\begin{array}{llllllllll}\text { FWFLO } & 0.3571 & 0.3571 & 0.3571 & 0.3571 & 0.3571 & 0.3571 & 0.3571\end{array}$

$\begin{array}{llllllll}0.3571 & 0.3571 & 0.3571 & 0.3571 & 0.3571 & 0.3571 & 0.3571\end{array}$

FWHLIO 0.00 ! on the outer surface of the insert

FWHLMO 0.00 ! on the inner surface of the $\mathrm{MCO}$ wall

FAWFL 0.1 ! wetted fraction of fuel surface

FAWFLM 1.0 ! wetted fraction of MCO wall

MSLFL 5.9 ! mass of sludge particles $(\mathrm{kg})$ in the fuel basket

! $11.8 \mathrm{~kg}$ per furel basket $\mathrm{x} 2$ basket $=23.6 \mathrm{~kg}$

* view factor matrix between the insert,

* outer surface of outer fuel elements,

* and the MCO wall. Therefore, the dimension of the square matrix is

* 1+number of fuel rods+1. If there is no insert, number of fuel rods +1 .

*

$\begin{array}{llllllllllll}\text { FVIEW } & 0.473 & 0.320 & 0.181 & 0.028 & 0.000 & 0.000 & 0.000 & 0.000\end{array}$

$\begin{array}{lllllllllll}0.320 & 0.028 & 0.306 & 0.306 & 0.028 & 0.014 & 0.000 & 0.000\end{array}$

$\begin{array}{llllllllll}0.181 & 0.306 & 0.000 & 0.334 & 0.153 & 0.000 & 0.028 & 0.000\end{array}$

$\begin{array}{lllllllll}0.014 & 0.153 & 0.167 & 0.167 & 0.153 & 0.153 & 0.167 & 0.028\end{array}$

$\begin{array}{lllllllll}0.000 & 0.028 & 0.153 & 0.306 & 0.000 & 0.028 & 0.306 & 0.181\end{array}$

$\begin{array}{lllllllllll}0.000 & 0.014 & 0.000 & 0.306 & 0.028 & 0.000 & 0.306 & 0.348\end{array}$

$\begin{array}{llllllllll}0.000 & 0.000 & 0.014 & 0.167 & 0.153 & 0.153 & 0.049 & 0.466\end{array}$

$\begin{array}{lllllllllll}0.000 & 0.000 & 0.000 & 0.0354 & 0.1146 & 0.2202 & 0.5898 & 0.040\end{array}$

* gap distance for micro-convection calculation

$\begin{array}{llllllllllllllllll}\text { XGAP } & 0.000 & 0.021 & 0.021 & 0.073 & 0.000 & 0.000 & 0.000 & 0.000\end{array}$

$\begin{array}{lllllllllll}0.021 & 0.000 & 0.021 & 0.021 & 0.073 & 0.073 & 0.000 & 0.000\end{array}$

$\begin{array}{lllllllll}0.021 & 0.021 & 0.000 & 0.021 & 0.021 & 0.000 & 0.073 & 0.000\end{array}$

$\begin{array}{llllllllll}0.073 & 0.021 & 0.021 & 0.000 & 0.021 & 0.021 & 0.021 & 0.083\end{array}$

$\begin{array}{llllllllll}0.000 & 0.073 & 0.021 & 0.021 & 0.000 & 0.073 & 0.021 & 0.058\end{array}$

$\begin{array}{llllllllll}0.000 & 0.073 & 0.000 & 0.021 & 0.073 & 0.000 & 0.021 & 0.026\end{array}$

$\begin{array}{llllllllllll}0.000 & 0.000 & 0.073 & 0.021 & 0.021 & 0.021 & 0.000 & 0.016\end{array}$

$\begin{array}{lllllllllllllllll}0.000 & 0.000 & 0.000 & 0.083 & 0.058 & 0.026 & 0.016 & 0.000\end{array}$

END JHSFL for first fuel basket

*

* 2nd Fuel Basket

*

* heat sink pairs for second fuel basket 


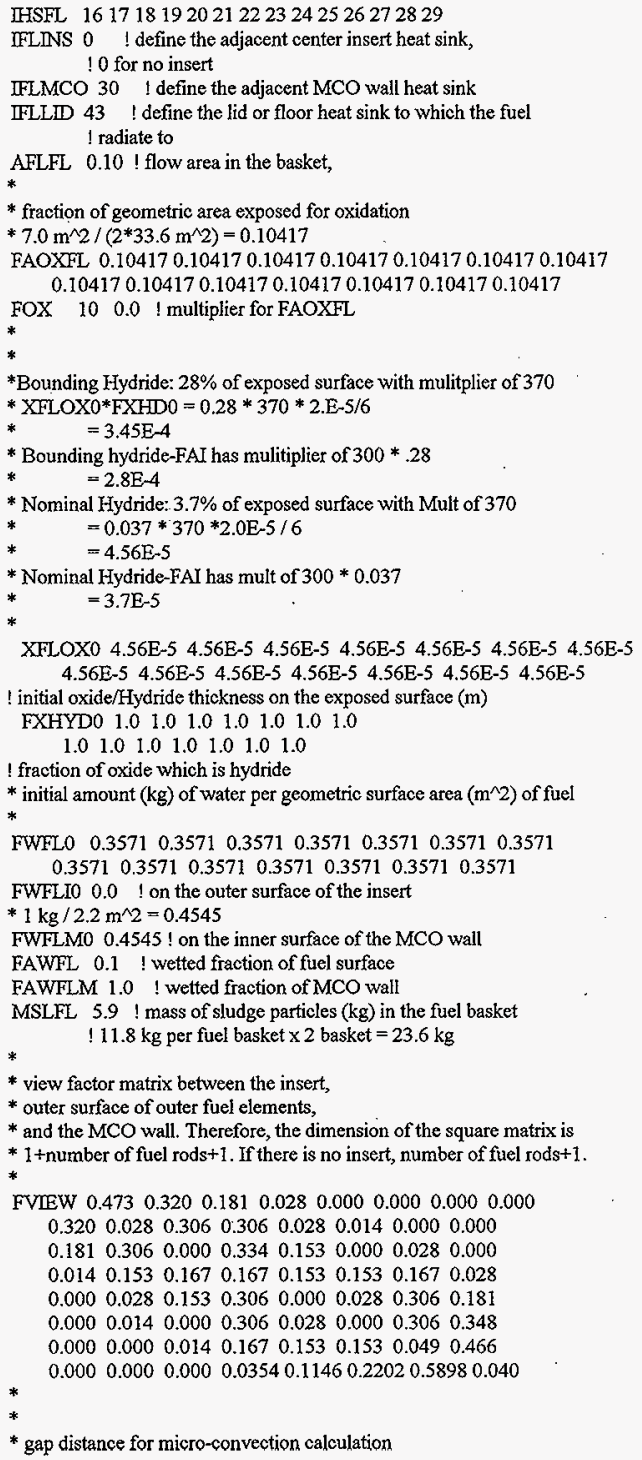




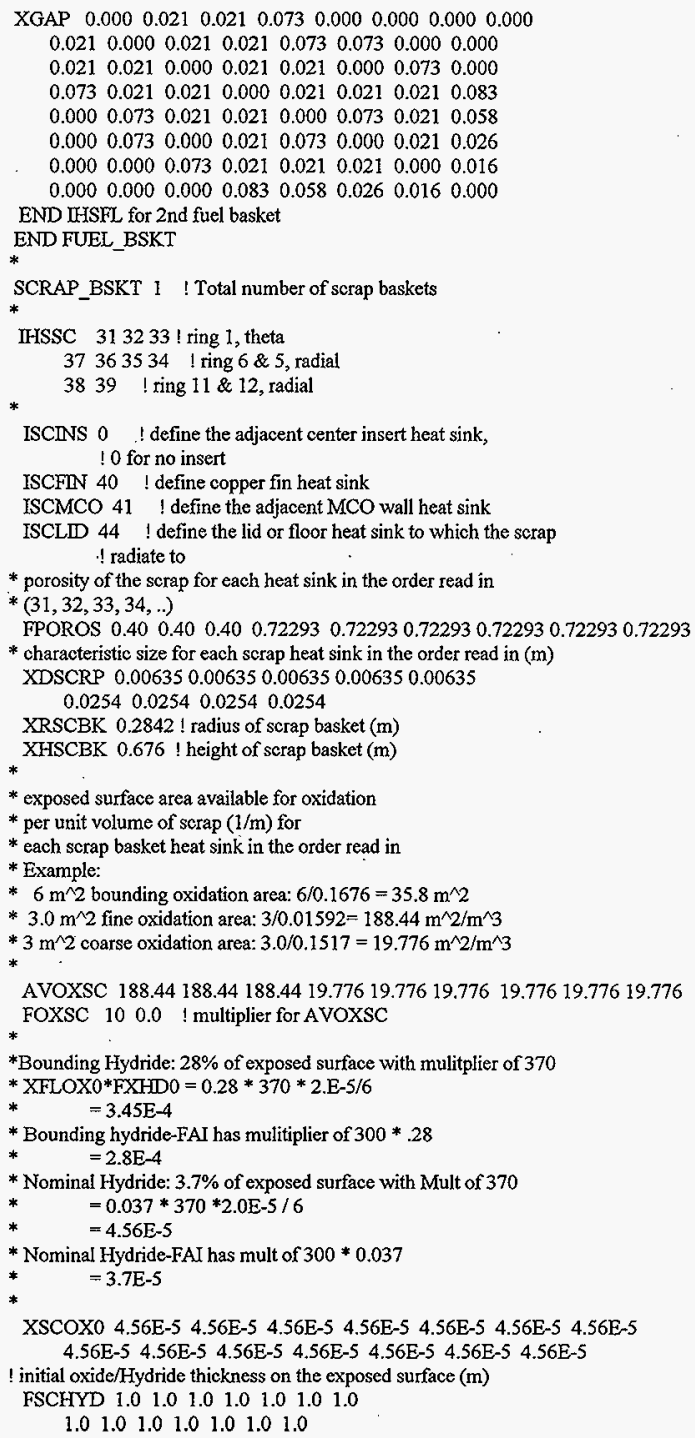




\section{HNF-SD-SNF-CN-023 REV 1}

I fraction of oxide which is hydride

$* 1.5 \mathrm{~kg}$ of water total for scrap basket; $1.5 / 0.16782=8.949 \mathrm{~kg} / \mathrm{m}^{\wedge} 3$

* $148.18 \mathrm{~kg}$ of water total for scrap basket; $148.18 / 0.17491 \mathrm{~m} 3=847.18$

MVWSC0 $8.949 ! 1.5 \mathrm{~kg}$ initial amount $(\mathrm{kg})$ of water per unit bulk volume

! $\left(\mathrm{m}^{\wedge} 3\right)$ of scrap

FWSCI0 0.0 ! on the outer surface of the insert ! (per unit area, $\mathrm{m}^{\wedge} 2$ )

FWSCM0 0.0 ! on the inner surface of the $\mathrm{MCO}$ wall

! (per unit area, $\mathrm{m}^{\wedge} 2$ )

FAWSC 0.1 ! wetted fraction of surface area

FAWSCM 1.0 ! wetted fraction of MCO wall

XSCINS 0.00 !gap distance between the insert and scrap basket

! 1/4" gap for scrap basket and moo wall

XSCMCO 0.00635 ! gap distance between scrap basket and MCO wall

MSLSC 8.94 ! mass of sludge particles (kg) in the scrap basket

END IHSSC for 1st scrap basket

END SCRAP_BSKT

END MCO 
CASE 0, NORMAL (initial run PURGENH0), INPUT DFFERENCES with VACUUM

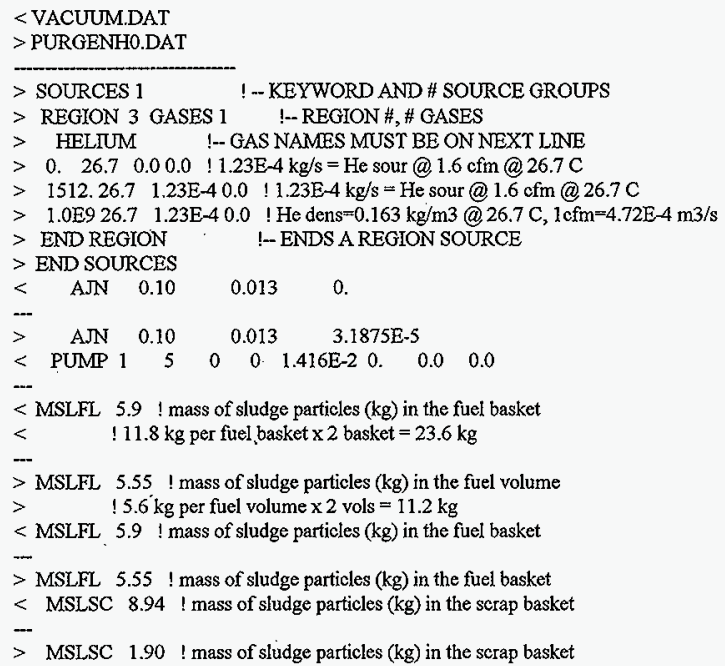




\title{
HNF-SD-SNF-CN-023 REV 1
}

\author{
$>$ END REGION \\ 1- ENDS A REGION SOURCE \\ $>$ END SOURCES
}

CASE 4, PURGE, INPUT DIFFERENCES

<VACUUM.DAT

$>$ PURGE.DAT

$>$ SOURCES 1 ! - KEYWORD AND \# SOURCE GROUPS

$>$ REGION 3 GASES 1 !- REGION \#, \# GASES

$>$ HELIUM !-GAS NAMES MUST BE ON NEXT LINE

$>0.026 .7 \quad 1.23 \mathrm{E}-40.0 ! 1.23 \mathrm{E}-4 \mathrm{~kg} / \mathrm{s}=\mathrm{He}$ sour @ $1.6 \mathrm{cfm} @ 26.7 \mathrm{C}$

$>1.0 \mathrm{E} 926.71 .23 \mathrm{E}-40.0$ ! He dens $=0.163 \mathrm{~kg} / \mathrm{m} 3 @ 26.7 \mathrm{C}, 1 \mathrm{cfm}=4.72 \mathrm{E}-4 \mathrm{~m} 3 / \mathrm{s}$

$>$ END REGION

$>$ END SOURCES

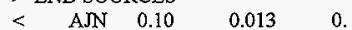

$\begin{array}{lllll}> & \text { A.JN } & 0.10 & 0.013 \quad 3.1875 \mathrm{E}-5\end{array}$

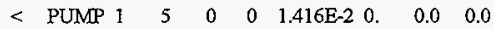

CASE 5, VACHOT, INPUT DIFFERENCES

$\angle$ VACUUM.DAT

$>$ VACHOT.DAT

$<$ THSFIX $15250.0 \quad 50.0$

-

$>$ THSFIX $15285.0 \quad 85.0$

$<$ THSFTX $30250.0 \quad 50.0$

$-$

$>$ THSFIX $30285.0 \quad 85.0$

$<$ THSFIX $41250.0 \quad 50.0$

$-$

$>$ THSFTX $41285.0 \quad 85.0$

$<$ THSFIX $42150.0 \quad 50.0$

$-$

$>$ THSFIX $42185.0 \quad 85.0$

$<$ THSFIX 43250.050 .0

$>$ THSFIX $43285.0 \quad 85.0$

CASE 6, VPURHOT, INPUT DIFEERENCES

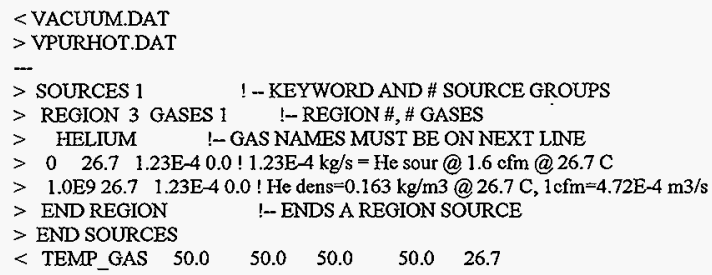




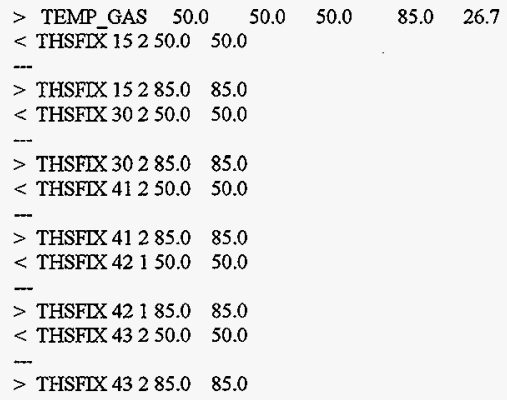

$-$

$>$ THSFIX $41285.0 \quad 85.0$

$<$ THSFIX $42150.0 \quad 50.0$

$>$ THSFIX 42 I $85.0 \quad 85.0$

$<$ THSFIX $43250.0 \quad 50.0$

$-$

$>$ THSFLX $43285.0 \quad 85.0$

CASE 7, PURHOT, INPUT DIFFERENCES

$<$ VACUUM.DAT

$>$ PURHOT.DAT

$-$

$>$ SOURCES 1 !- KEYWORD AND \# SOURCE GROUPS

$>$ REGION 3 GASES 1 !- REGION \#,\# GASES

$>$ HELIUM !- GAS NAMES MUST BE ON NEXT IINE

$>0.026 .7 \quad 1.23 \mathrm{E}-40.0 \quad 11.23 \mathrm{E}-4 \mathrm{~kg} / \mathrm{s}=$ He sour $@ 1.6 \mathrm{cfm} @ 26.7 \mathrm{C}$

$>1.0 \mathrm{E} 926.71 .23 \mathrm{E}-40.0$ ! He dens $=0.163 \mathrm{~kg} / \mathrm{m} 3 @ 26.7 \mathrm{C}, 1 \mathrm{cfm}=4.72 \mathrm{E}-4 \mathrm{~m} 3 / \mathrm{s}$

$>$ END REGION !--ENDS A REGION SOURCE

$>$ END SOURCES

$\begin{array}{llllll}<\text { TEMP_GAS } & 50.0 & 50.0 & 50.0 & 50.0 & 26.7\end{array}$

$\begin{array}{llllll}>\text { TEMP GAS } & 50.0 & 50.0 & 50.0 & 85.0 & 26.7\end{array}$

$<$ THSFIX 15250.050 .0

$-$

$>$ THSFIX $15285.0 \quad 85.0$

$<$ THSFIX 30250.050 .0

$-$

$>$ THSFXX $30285.0 \quad 85.0$

$<$ THSFIX $41250.0 \quad 50.0$

$-$

$>$ THSFIX $41285.0 \quad 85.0$

$<$ THSFIX $42150.0 \quad 50.0$

$-$

$>$ THSFLX $42185.0 \quad 85.0$

$<$ THSFIX $43250.0 \quad 50.0$

$>$ THSFIX $43285.0 \quad 85.0$

$\begin{array}{llll}\text { AJN } 0.10 & 0.013 & 0 .\end{array}$

$\begin{array}{lllll}> & \text { ANN } & 0.10 & 0.013 & 3.1875 \mathrm{E}-5\end{array}$

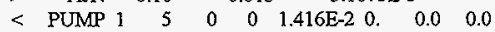

CASE 8, VACLOF, INPUT DIFFERENCES

$<$ VACUUM.DAT

$>$ VACLOF.DAT 


\section{HNF-SD-SNF-CN-023 REV 1}

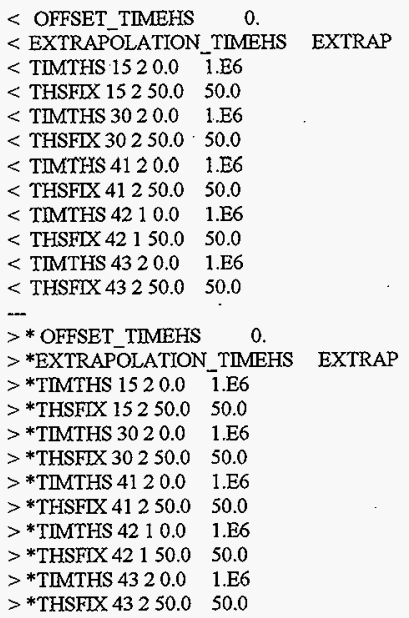

CASE 9, VLOFHOT, INPUT DIFFERENCES

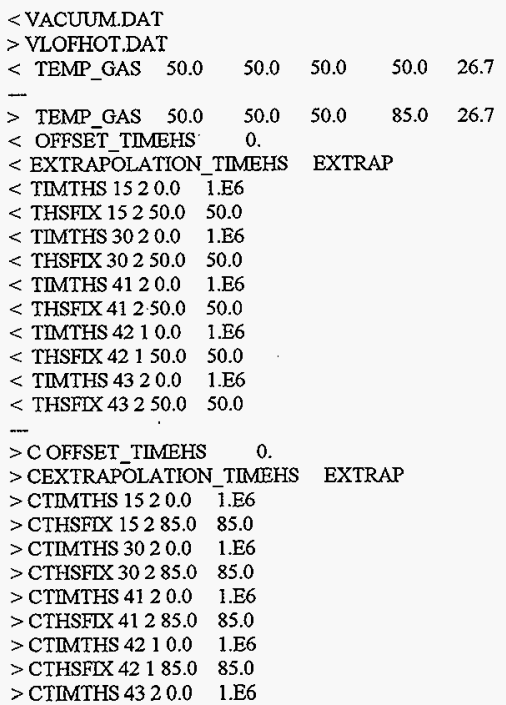




\section{HNF-SD-SNF-CN-023 REV 1}

$>$ CTHSFIX $43285.0 \quad 85.0$

CASE 10, VACLOC, INPUT DIFFERENCES

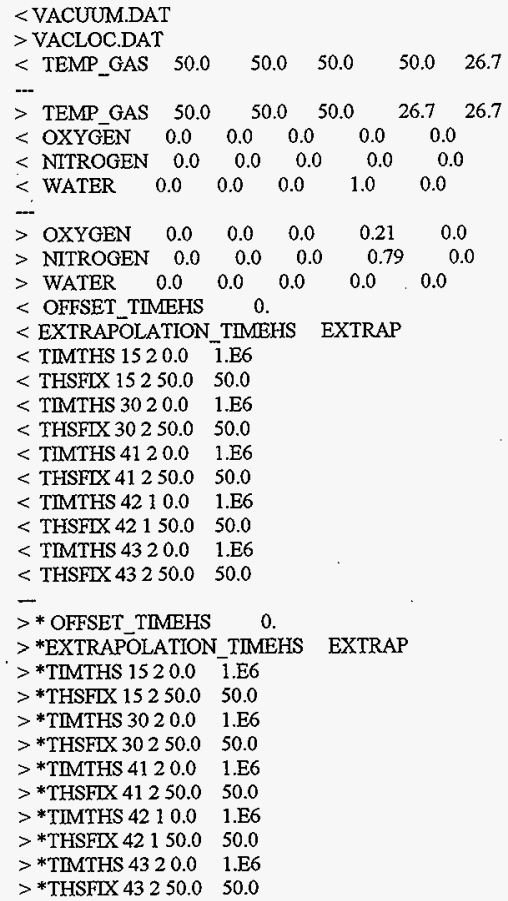

CASE 11, VPURLOC, INPUT DIFFERENCES

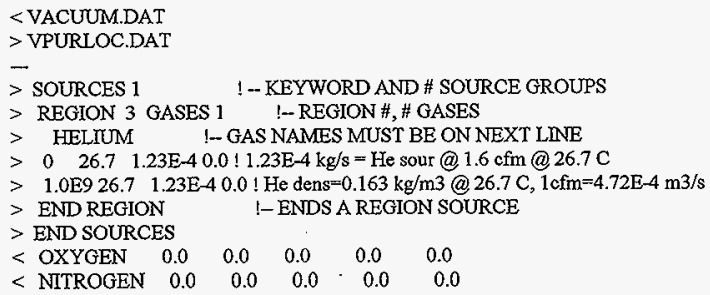




\section{HNF-SD-SNF-CN-023 REV 1}

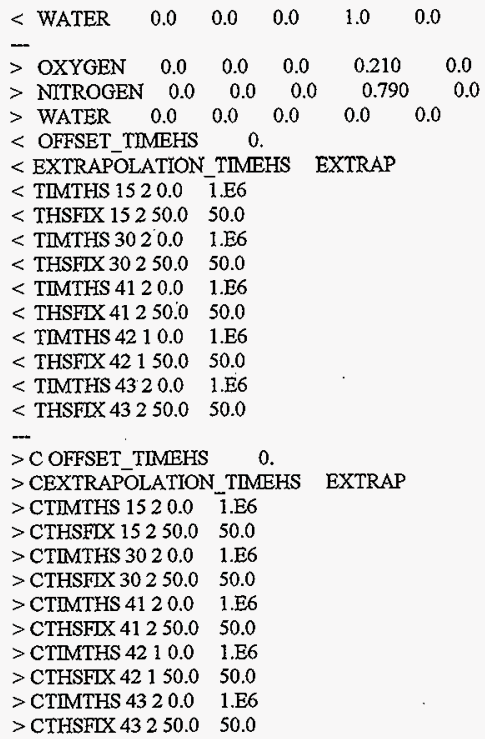

CASE 12, PURLOF, INPUT DIFFERENCES

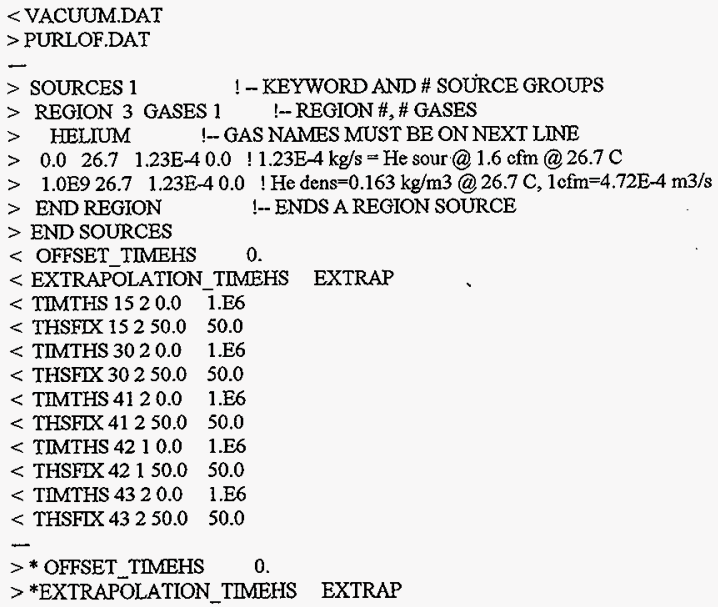




\section{HNF-SD-SNF-CN-023 REV 1}

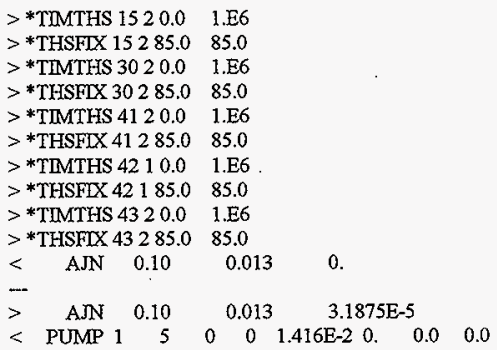

\section{CASE 13, PURLOC, INPUT DIFFERENCES}

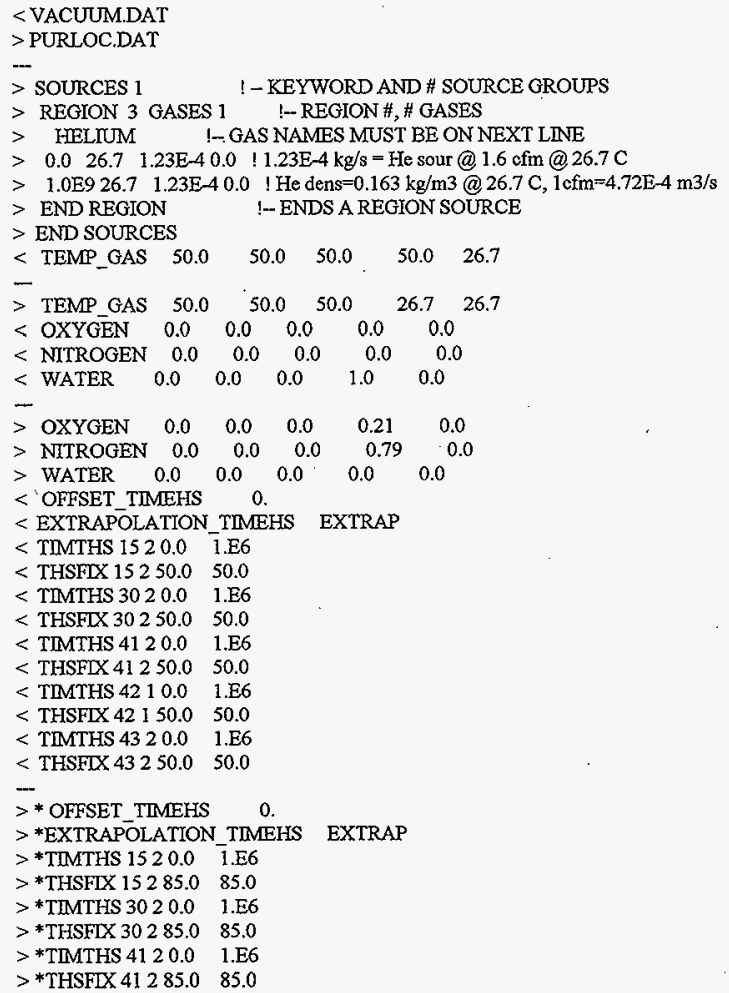




\section{HNF-SD-SNF-CN-023 REV 1}

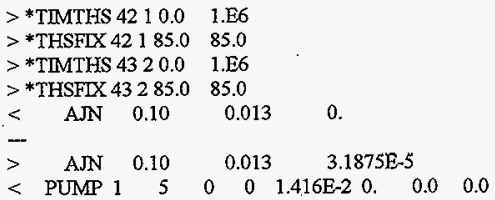

CASE 14, DSTOP, INPUT DIFFERENCES with VACUUM

$<$ VACUUM.DAT

$>$ DSTOP.DAT

-

$>$ * SOURCES 2 I- KEYWORD AND \# SOURCE GROUPS

$>$ * REGION 1 GASES 2 !- REGION \#, \# GASES

$>$ * STEAM HYDROGEN !-GAS NAMES MUST BE ON NEXT LINE

$>$ * 0 300 1.E-3 1.E-3 0.E0

$>* 10300$ 1.E-3 1.E-3 0.E0

$>$ * END REGION !-ENDS A REGTON SOURCE

< PRESSURE 1.017E5 1.017E5 1.017E5 1.013E5 1.013ES

$\begin{array}{llllll}>\text { PRESSURE } & 1.013 \mathrm{ES} & 1.013 \mathrm{E} 5 & 1.013 \mathrm{E} 5 & 1.013 \mathrm{E} 5 & 1.013 \mathrm{E} 5\end{array}$

$\begin{array}{lllllllll}<\text { PUMP } 1 & 5 & 0 & 0 & 1.416 \mathrm{E}-2 & 0 . & 0.0 & 0.0\end{array}$

CASE 15, DS75KG, INPUT DIFFERENCES with DSTOP

$\angle$ DSTOP.DAT

$>$ DS75KG.DAT

$\begin{array}{lllllllll}<\text { FWFLO } & 0.3571 & 0.3571 & 0.3571 & 0.3571 & 0.3571 & 0.3571 & 0.3571\end{array}$

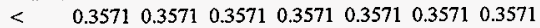

$--$

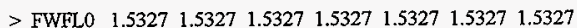

$>\quad \begin{array}{llllllll}> & 1.5327 & 1.5327 & 1.5327 & 1.5327 & 1.5327 & 1.5327 & 1.5327\end{array}$

$<$ FWFLM0 0.4545 ! on the inner surface of the MCO wall

$-$

$>$ FWFLMO 4.545 ! on the inner surface of the MCO wall

CASE 16, DSTOPOV, INPUT DIFFERENCES with DSTOP

$<$ DSTOP.DAT

$>$ DSTOPOV.DAT

$\begin{array}{llll}<\quad \text { ANN } 0.10 \quad 0.013 & 0.000\end{array}$

$\begin{array}{lllll}> & \text { ANN } & 0.10 & 0.013 & 3.1875 \mathrm{E}-5\end{array}$

CASE 17, DSLOF, NPUT DIFFERENCES with DSTOP

$<$ DSTOP.DAT

$>$ DSLOF.DAT

$<$ OFFSET_TMEHS 0. 


\section{HNF-SD-SNF-CN-023 REV 1}

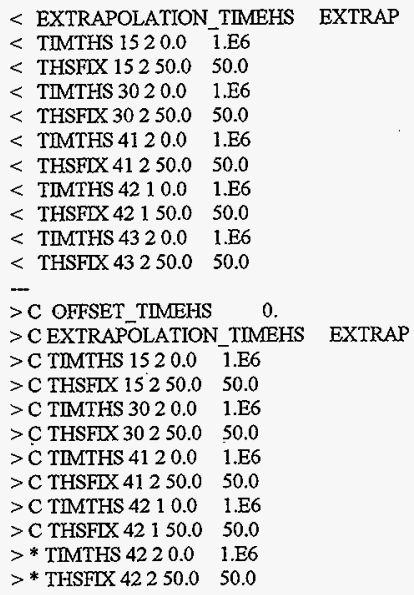

CASE 18, DLOF75KG, INPUT DIFFERENCES with DSTOP

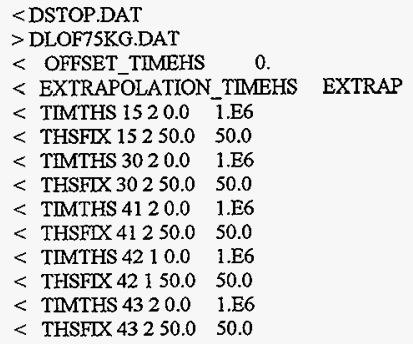




\section{HNF-SD-SNF-CN-023 REV 1}

$>\quad \begin{array}{llllllll}1.5327 & 1.5327 & 1.5327 & 1.5327 & 1.5327 & 1.5327 & 1.5327\end{array}$

$<$ FWFLMO 0.4545 ! on the inner surface of the MCO wall

$-$

$>$ FWFLM0 4.545 ! on the inner surface of the MCO wall

CASE 19 , DSLOFOV, INPUT DIFFERENCES with DSTOP

\begin{tabular}{|c|c|c|}
\hline \\
\hline \multicolumn{3}{|c|}{$\begin{array}{l}<\text { DSTOP.DAT } \\
>\text { DSLOFOV.DAT }\end{array}$} \\
\hline \multicolumn{3}{|c|}{$\begin{array}{l}>\text { DSLOFOV.DAT } \\
<\text { OFFSET TIMEHS } \quad 0 .\end{array}$} \\
\hline \multicolumn{2}{|c|}{$<$ EXTRAPOLLATION_TIMEHS } & \multirow[t]{11}{*}{ EXTRAP } \\
\hline$<$ TIMTHS 1520.0 & \multirow{2}{*}{$\begin{array}{l}1.66 \\
50.0\end{array}$} & \\
\hline$<$ THSFIX 15250.0 & & \\
\hline$<$ TIMTHS 3020.0 & $\begin{array}{l}50.0 \\
1 . \mathrm{E} 6\end{array}$ & \\
\hline $\begin{array}{l}<\text { THSFTX } 30250.0 \\
<\text { TTMTHS } 4120.0\end{array}$ & 50.0 & \\
\hline \multirow{2}{*}{$\begin{array}{l}<\text { TIMTHS } 4120.0 \\
<\text { THSFIX } 41250.0\end{array}$} & 1.E6 & \\
\hline & 50.0 & \\
\hline$<$ TIMTHS 4210.0 & 1.E6 & \\
\hline$<$ THSFIX 42150.0 & 50.0 & \\
\hline$<$ TMMTHS 4320.0 & \multirow{2}{*}{$\begin{array}{l}1 . E 6 \\
50.0\end{array}$} & \\
\hline THSFIX 43250.0 & & \\
\hline \multirow{2}{*}{\multicolumn{3}{|c|}{$\begin{array}{l}>\text { C OFFSET_TMEHS } 0 . \\
\end{array}$}} \\
\hline & N_TMEHS & \multirow[t]{11}{*}{ EXTRAP } \\
\hline$>$ C TMTHS 1520.0 & $1 . \mathrm{E} 6$ & \\
\hline$>C$ THSFIX 15250.0 & 50.0 & \\
\hline > C TIMTHS 3020.0 & 1.E6 & \\
\hline$>C$ THSFEX 30250.0 & 50.0 & \\
\hline$>$ C TIMTHS 4120.0 & 1.E6 & \\
\hline$>$ C THSFLX 41250.0 & 50.0 & \\
\hline$>$ C TMMTHS 4210.0 & 1.E6 & \\
\hline$>$ C THSFIX 42150.0 & 50.0 & \\
\hline$>$ * TLMTHS 4220.0 & 1.E6 & \\
\hline * THSFTX 42250.0 & 50.0 & \\
\hline ANN 0.10 & 0.013 & 0.000 \\
\hline AJN $\quad 0.10$ & & \\
\hline
\end{tabular}

CASE 20, DSLOC, INPUT DIFFERENCES with DSTOP

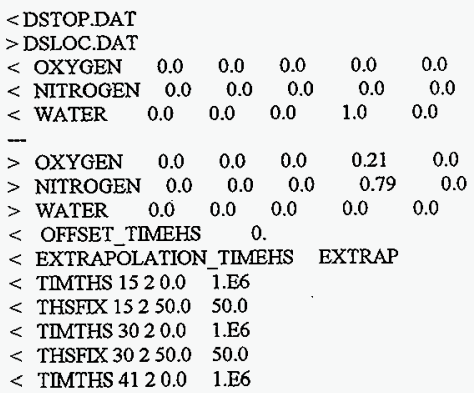




\section{HNF-SD-SNF-CN-023 REV 1}

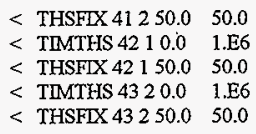

$-$

$>$ C OFFSET_TIMEHS 0 .

$>$ CEXTRAPOLATION TIMEHS EXTRAP

$>C$ TIMTHS $1520.0 \quad$ 1.E6

$>C$ THSFTX $15250.0 \quad 50.0$

$>C$ TIMTHS $3020.0 \quad 1 . E 6$

$>$ C THSFIX $30250.0 \quad 50.0$

$>$ C TIMTHS $4120.0 \quad$ 1.E6

$>$ C THSFIX $41250.0 \quad 50.0$

$>$ C TIMTHS $4210.0 \quad 1 . \mathrm{E} 6$

$>$ C THSFIX $42150.0 \quad 50.0$

$>$ * TIMTHS 4220.0 1.E6

$>$ * THSFIX $42250.0 \quad 50.0$

CASE 21, DLOC75KG, INPUT DIFFERENCES with DSTOP

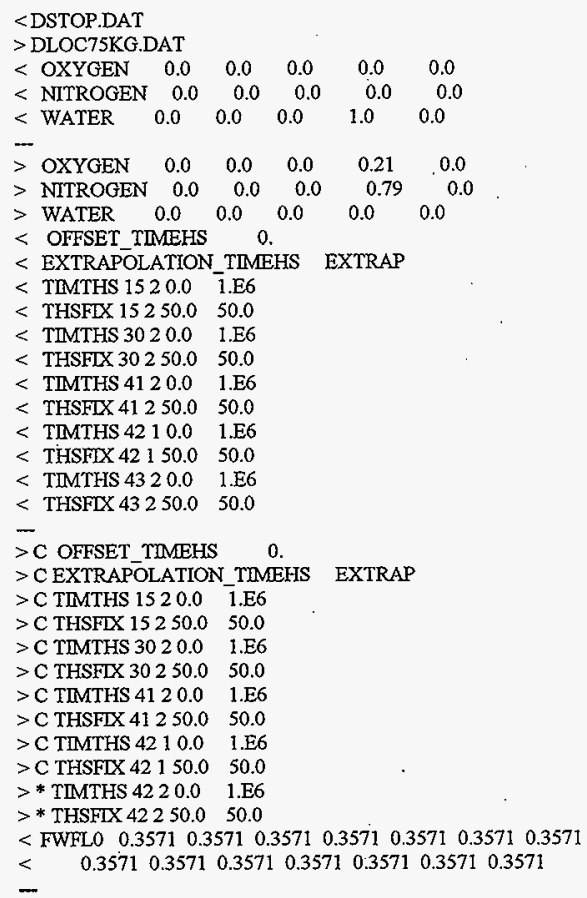$$
>\text { C OFFSET_TMMEHS } 0 \text {. }
$$$$
>\text { CEXTRAPOLATION_TMMEHS EXTRAP }
$$$$
>C \text { TIMTHS } 1520.0 \text { 1.E6 }
$$$$
>\text { C THSFLX } 15250.0 \quad 50.0
$$$$
>\text { C TIMTHS } 3020.0 \quad 1 . E 6
$$$$
>\text { C THSFLX } 30250.0 \quad 50.0
$$$$
>\text { C TIMTHS } 4120.0 \quad \text { 1.E6 }
$$$$
>\text { C THSFIX } 41250.0 \quad 50.0
$$$$
>\text { C TIMTHS } 4210.0 \quad 1 . E 6
$$$$
>C \text { THSFT } 42150.0 \quad 50.0
$$$$
>\text { * TIMTHS } 4220.0 \quad \text { 1.E6 }
$$$$
>* \text { THSFIX } 42250.0 \quad 50.0
$$$$
\begin{array}{lllllllll}
<\text { FWFLO } & 0.3571 & 0.3571 & 0.3571 & 0.3571 & 0.3571 & 0.3571 & 0.3571
\end{array}
$$$$
\begin{array}{llllllllll}
< & 0.3571 & 0.3571 & 0.3571 & 0.3571 & 0.3571 & 0.3571 & 0.3571
\end{array}
$$$$
-
$$ 


\section{HNF-SD-SNF-CN-023 REV 1}

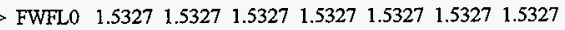

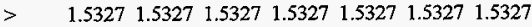

< FWFLM0 0.4545 ! on the inner surface of the MCO wall

$--$

$>$ FWFLM0 4.545 ! on the inner surface of the MCO wall

CASE 22, DSLOCNOM, INPUT DIFFERENCES with DSTOP

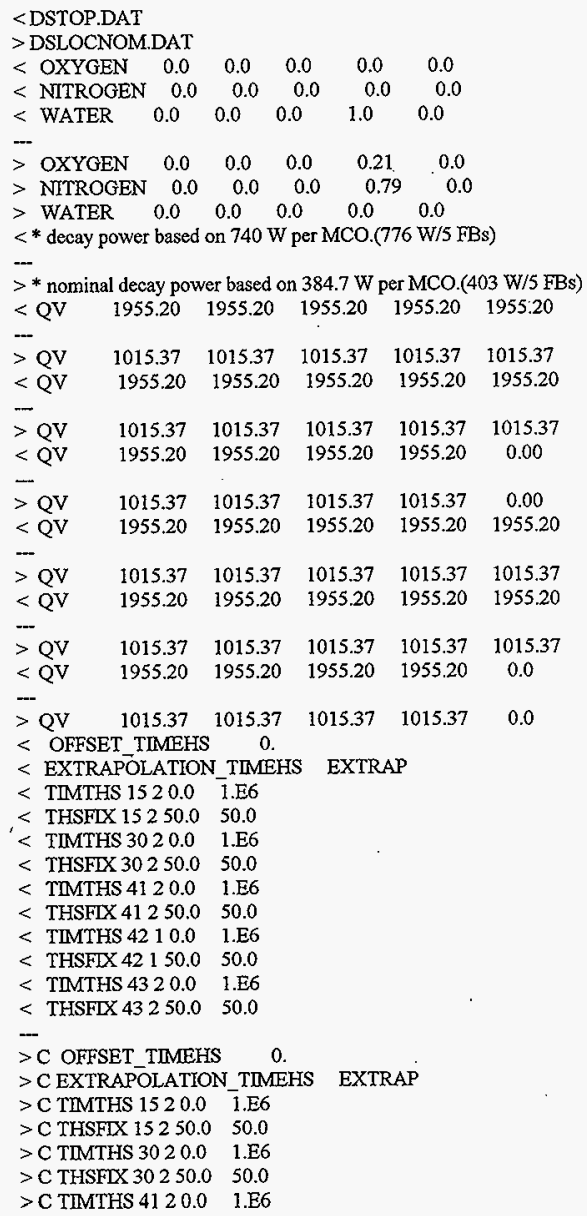




\section{HNF-SD-SNF-CN-023 REV 1}

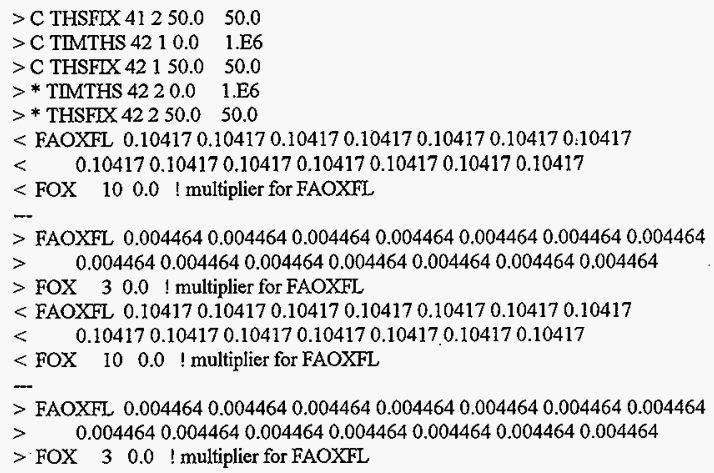

$>$ FAOXFL 0.0044640 .0044640 .0044640 .0044640 .0044640 .0044640 .004464 $>\quad 0.0044640 .0044640 .0044640 .0044640 .0044640 .0044640 .004464$

$>$ FOX 30.0 ! multiplier for FAOXFL

CASE 23, DSLOCREC, INPUT DIFFERENCES with DSTOP

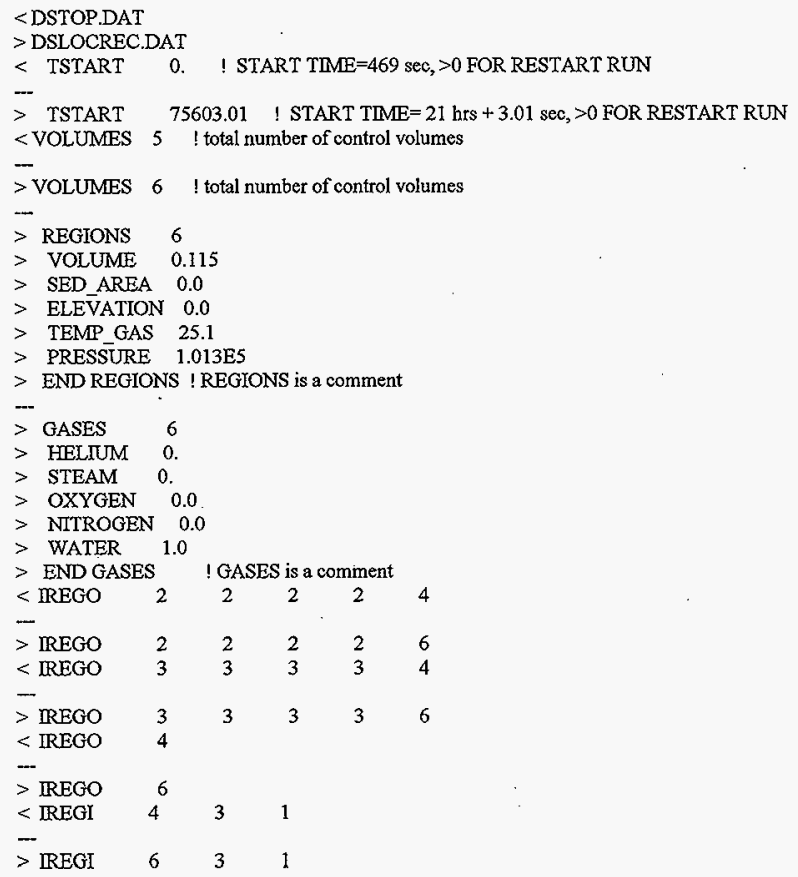$$
-
$$$$
>\text { IREGO } 6
$$$$
\begin{array}{llll}
<\text { IREGI } & 4 & 3 & 1
\end{array}
$$$$
>\text { IREGI } 6 \quad 3 \quad 1
$$ 


\section{HNF-SD-SNF-CN-023 REV 1}

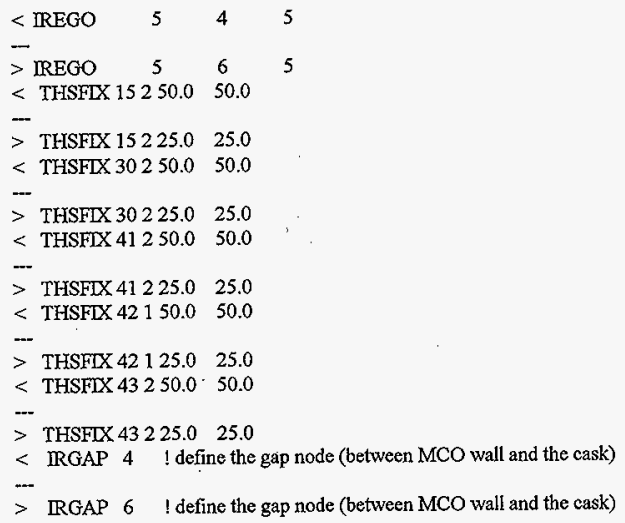

.

$>$ THSFIX $42125.0 \quad 25.0$

$<$ THSFIX $43250.0-50.0$

$--$

$>$ THSFIX 43225.025 .0

$<$ IRGAP 4 ! define the gap node (between MCO wall and the cask)

$>$ IRGAP $6 \quad$ I define the gap node (between MCO wall and the cask)

CASE 24, DSLOCRE2, INPUT DIFFERENCES with DSTOP

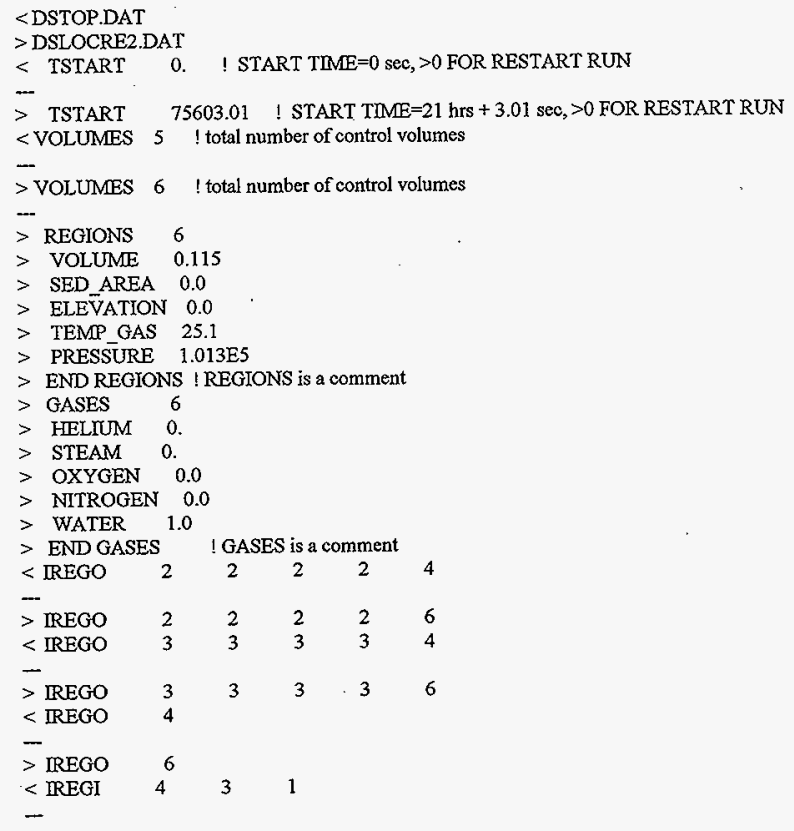




$$
\begin{aligned}
& \begin{array}{lccc}
>\text { IREGI } & 6 & 3 & 1 \\
<\text { IREGO } & 5 & 4 & 5
\end{array} \\
& >\text { REGO } 5 \quad 6 \quad 5 \\
& <\text { OFFSET_TMEEHS } 0 \text {. } \\
& <\text { EXTRAPOLATION_TIMEHS EXTRAP } \\
& <\text { TIMTHS } 1520.0 \quad 1 \text {.E6 } \\
& <\text { THSFIX } 15250.0 \quad 50.0 \\
& <\text { TIMTHS } 3020.0 \quad 1 . E 6 \\
& <\text { THSFTX } 30250.050 .0 \\
& <\text { TIMTHS } 4120.0 \quad 1 . E 6 \\
& <\text { THSFIX } 41250.0 \quad 50.0 \\
& <\text { TIMTHS } 4210.0 \quad 1 . E 6 \\
& <\text { THSFCX } 42150.0 \quad 50.0 \\
& <\text { TIMTHS } 4320.0 \quad 1 . E 6 \\
& <\text { THSFDX } 43250.050 .0
\end{aligned}
$$

$>C$ OFFSET TIMEHS 0 .

$>$ C EXTRAPOLATION TIMEHS EXTRAP

$>$ C TIMTHS $1520.0 \quad 1$.E6

$>$ C THSFLX $15225.0 \quad 25.0$

$>$ C TIMTHES $3020.0 \quad 1$.E6

$>$ C THSFIX $30225.0 \quad 25.0$

$>$ C TIMTHS $4120.0 \quad 1 . E 6$

$>$ C THSFIX $41225.0 \quad 25.0$

$>$ C TIMTHS $4210.0 \quad$ 1.E6

$>$ C THSFIX $42125.0 \quad 25.0$

$>$ C TMMTHS $4320.0 \quad$ 1.E6

$>$ C THSFIX $43225.0 \quad 25.0$

$<\operatorname{RGAP} 4$ ! define the gap node (between MCO wall and the cask)

-

$>\operatorname{RGAP} 6$ ! define the gap node (between MCO wall and the cask)

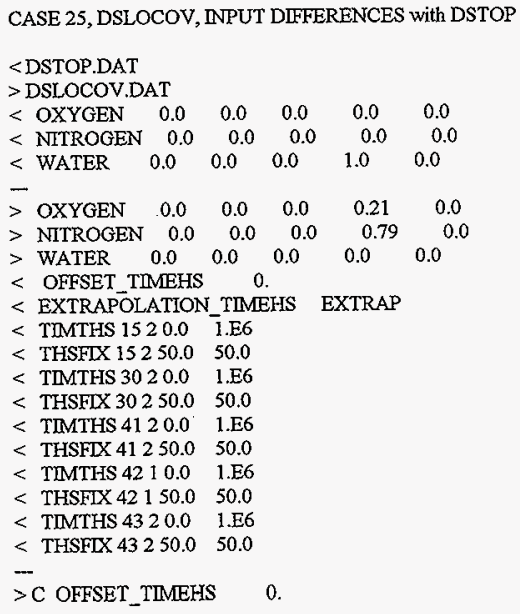




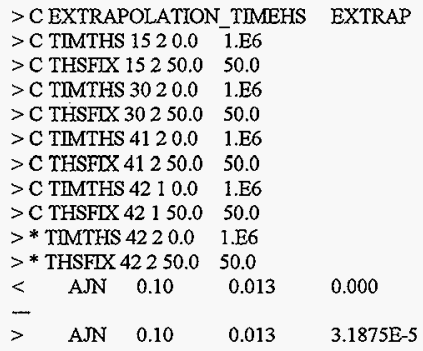

CASE 26, DS46DEG, INPUT DIFFERENCES with DSTOP

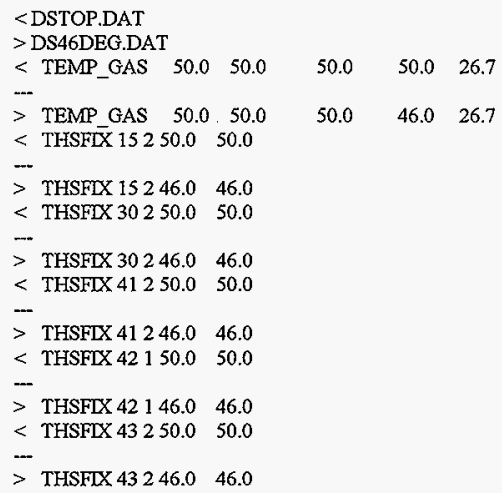

$>$ THSFIX $43246.0 \quad 46.0$

CASE 27, DS55DEG, INPUT DIFFERENCES with DSTOP

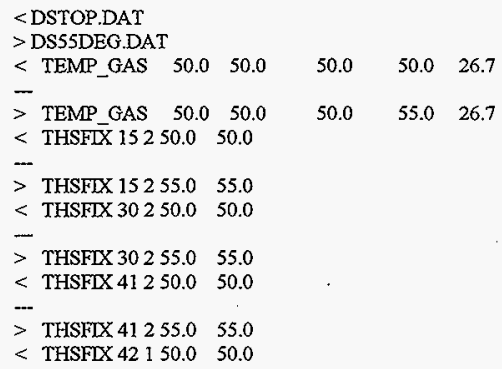




\section{HNF-SD-SNF-CN-023 REV 1}

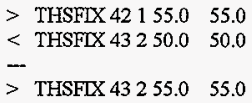

CASE 28, DS75DEG, INPUT DIFFERENCES with DSTOP

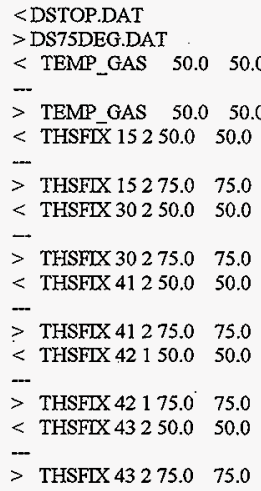

CASE 29, DSHOT, INPUT DIFFERENCES with DSTOP

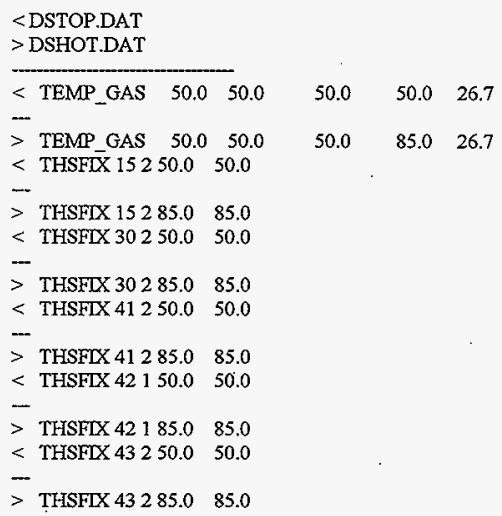


CASE 30, DHOT75KG, INPUT DIFFERENCES with DSTOP

$<$ DSTOP.DAT

$>$ DHOT75KG.DAT

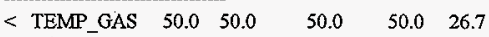

$-$

$\begin{array}{llllll}>\text { TEMP_GAS } & 50.0 & 50.0 & 50.0 & 85.0 & 26.7\end{array}$

$<$ THSFX̄ $15250.0 \quad 50.0$

$-$

$>$ THSFLX $15285.0 \quad 85.0$

$<$ THSFIX 30250.050 .0

$-$

$>$ THSFIX $30285.0 \quad 85.0$

$<$ THSFIX $41250.0 \quad 50.0$

$-$

$>$ THSFIX $41285.0 \quad 85.0$

$<$ THSFIX $42150.0 \quad 50.0$

$-$

$>$ THSFIX $42185.0 \quad 85.0$

$<$ THSFX $43250.0 \quad 50.0$

-

$>$ THSFLX $43285.0 \quad 85.0$

$\begin{array}{lllllllll}<\text { FWFL0 } & 0.3571 & 0.3571 & 0.3571 & 0.3571 & 0.3571 & 0.3571 & 0.3571\end{array}$

$\begin{array}{llllllllllllllll}< & 0.3571 & 0.3571 & 0.3571 & 0.3571 & 0.3571 & 0.3571 & 0.3571\end{array}$

$-$

$\begin{array}{lllllllll}> & \text { FWFLO } & 1.5327 & 1.5327 & 1.5327 & 1.5327 & 1.5327 & 1.5327 & 1.5327\end{array}$

$>\quad \begin{array}{llllllll}> & 1.5327 & 1.5327 & 1.5327 & 1.5327 & 1.5327 & 1.5327 & 1.5327\end{array}$

$<$ FWFLM0 0.4545 ! on the inner surface of the MCO wall

$\ldots$

$>$ FWFLMO 4.545 ! on the inner surface of the MCO wall

CASE 31, DSHOTOV, INPUT DIFFERENCES with DSTOP

$<$ DSTOP.DAT

$>$ DSHOTOV.DAT

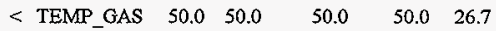

$\cdots$

$\begin{array}{llllll}>\text { TEMP GAS } & 50.0 & 50.0 & 50.0 & 85.0 & 26.7\end{array}$

$<$ THSFDX $15250.0 \quad 50.0$

$\cdots$

$>$ THSFIX $15285.0 \quad 85.0$

$<$ THSFEX $30250.0 \quad 50.0$

$-$

$>$ THSFEX $30285.0 \quad 85.0$

$<$ THSFTX $41250.0 \quad 50.0$

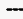

$>$ THSFIX $41285.0 \quad 85.0$

$<$ THSFIX $42150.0 \quad 50.0$

-

$>$ THSFIX 42185.085 .0

$<$ THSFIX $43250.0 \quad 50.0$

$-$

$>$ THSFIX $43285.0 \quad 85.0$

$\begin{array}{llll}< & \text { A.JN } 0.10 & 0.013 & 0.000\end{array}$

$\begin{array}{llll}> & \text { ANN } & 0.10 & 0.013\end{array}$ 


\section{HNF-SD-SNF-CN-023 REV 1}

CASE 32, VACARI, INPUT DIFFERENCES with VACUUM

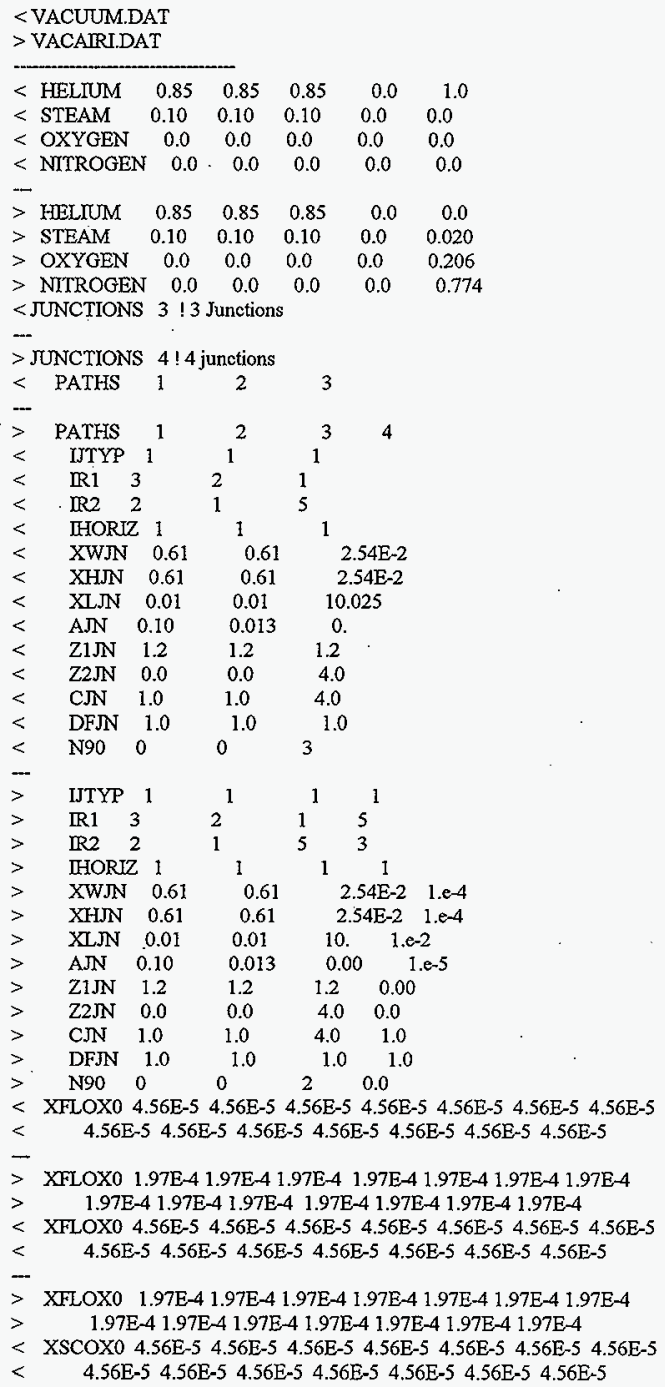


$-$

$>\quad \mathrm{XSCOX0} 3.7 \mathrm{E}-4 \quad 3.7 \mathrm{E}-4 \quad 3.7 \mathrm{E}-4 \quad 3.7 \mathrm{E}-4 \quad 3.7 \mathrm{E}-4 \quad 3.7 \mathrm{E}-4 \quad 3.7 \mathrm{E}-4$

$>\quad 3.7 \mathrm{E}-4$ 3.7E-4 3.7E-4 3.7E-4 3.7E-4 3.7E-4 3.7E-4

CASE 33, VARRHOT, INPUT DIFFERENCES with VACUUM

\begin{tabular}{|c|c|c|c|c|c|c|}
\hline \multicolumn{7}{|c|}{$\begin{array}{l}\text { < VACUUM.DAT } \\
>\text { VAIRIHOT.DAT }\end{array}$} \\
\hline$<$ & HELIUM & 0.85 & 0.85 & 0.85 & 0.0 & 1.0 \\
\hline$<$ & STEAM & 0.10 & 0.10 & 0.10 & 0.0 & 0.0 \\
\hline$<$ & OXYGEN & 0.0 & 0.0 & 0.0 & 0.0 & 0.0 \\
\hline$<$ & NITROGEN & 0.0 & 0.0 & 0.0 & 0.0 & 0.0 \\
\hline$>$ & HELIUM & 0.85 & 0.85 & 0.85 & 0.0 & 0.0 \\
\hline$>$ & STEAM & 0.10 & 0.10 & 0.10 & 0.0 & 0.020 \\
\hline$>$ & OXYGEN & 0.0 & 0.0 & 0.0 & 0.0 & 0.206 \\
\hline & NITROGEN & $\quad 0.0$ & 0.0 & 0.0 & 0.0 & 0.774 \\
\hline & \multicolumn{5}{|c|}{--} & \\
\hline \multicolumn{3}{|c|}{$\begin{array}{l}>\text { THSFIX } 15285.0 \\
<\text { THSFIX } 30250.0\end{array}$} & 85.0 & & & \\
\hline & \multicolumn{5}{|c|}{-} & \\
\hline \multicolumn{3}{|c|}{$\begin{array}{l}>\text { THSFIX } 30285.0 \\
<\text { THSFIX } 41250.0\end{array}$} & 85.0 & & & \\
\hline \multicolumn{7}{|c|}{$\ldots$} \\
\hline \multicolumn{3}{|c|}{$>$ THSFLX 41285.0} & 85.0 & · & & \\
\hline \multicolumn{3}{|c|}{$<$ THSFIX 42150.0} & \multicolumn{4}{|c|}{-} \\
\hline \multicolumn{3}{|c|}{$>$ THSFIX 42185.0} & 85.0 & & & \\
\hline \multicolumn{3}{|c|}{$<$ THSFIX 43250.0} & \multicolumn{4}{|c|}{--} \\
\hline \multicolumn{3}{|c|}{$>$ THSFIX 43285.0} & 85.0 & & & \\
\hline \multicolumn{4}{|c|}{$<$ JUNCTIONS 3 ! 3 Junctions } & & & \\
\hline \multicolumn{2}{|c|}{$>$ JUNCTIONS } & $4 ! 4 j$ & unctions & & & \\
\hline$<$ & PATHS & 1 & 2 & 3 & & \\
\hline$>$ & PATHS & 1 & 2 & 3 & 4 & \\
\hline$<$ & IJTYP & 1. & 1 & 1 & & \\
\hline$<$ & IR1 3 & & 2 & 1 & & \\
\hline \multirow{2}{*}{$<$} & IR2 2 & & 1 & 5 & & \\
\hline & IHORIZ & 1 & 1 & 1 & & \\
\hline$<$ & XWJN & 0.61 & 0.61 & & $2.54 \mathrm{E}-2$ & \\
\hline$<$ & XHIN & 0.61 & 0.61 & & $2.54 \mathrm{E}-2$ & \\
\hline$<$ & XLNN & 0.01 & 0.01 & & .025 & \\
\hline$<$ & AJN & 0.10 & 0.013 & & & \\
\hline$<$ & Z1JN & 1.2 & 1.2 & 1.2 & & \\
\hline$<$ & Z2JN & 0.0 & 0.0 & 4. & & \\
\hline$<$ & CJN & 1.0 & 1.0 & 4.0 & & \\
\hline$<$ & DEJN & 1.0 & 1.0 & 1. & & \\
\hline$<$ & N90 & 0 & 0 & 3 & & \\
\hline- & & & & & & \\
\hline$>$ & IJTYP & 1 & 1 & 1 & 1 & \\
\hline$>$ & IR1 3 & & 2 & 1 & 5 & \\
\hline$>$ & IR2 2 & & 1 & 5 & 3 & \\
\hline$>$ & IHORIZ & 1 & I & 1 & 1 & \\
\hline$>$ & XWJN & 0.61 & 0.61 & & $2.54 \mathrm{E}-2$ & 1.e-4 \\
\hline
\end{tabular}




\section{HNF-SD-SNF-CN-023 REV 1}

\begin{tabular}{lllllll}
$>$ & XHJN & 0.61 & 0.61 & \multicolumn{2}{c}{$2.54 \mathrm{E}-2$} & $1 . \mathrm{e}-4$ \\
$>$ & XLJN & 0.01 & 0.01 & & 10. & $1 . \mathrm{e}-2$ \\
$>$ & AJN & 0.10 & 0.013 & 0.00 & $1 . \mathrm{e}-5$ \\
$>$ & Z1JN & 1.2 & 1.2 & 1.2 & 0.00 \\
$>$ & Z2JN & 0.0 & 0.0 & 4.0 & 0.0 \\
$>$ & CJN & 1.0 & 1.0 & 4.0 & 1.0 \\
$>$ & DFJN & 1.0 & 1.0 & 1.0 & 1.0 \\
$>$ & N90 & 0 & 0 & 2 & 0.0
\end{tabular}

XFLOX0 4.56E-5 4.56E-5 4.56E-5 4.56E-5 4.56E-5 4.56E-5 4.56E-5

$<\quad 4.56 \mathrm{E}-5 \quad 4.56 \mathrm{E}-5 \quad 4.56 \mathrm{E}-5$ $4.56 \mathrm{E}-5 \quad 4.56 \mathrm{E}-5 \quad 4.56 \mathrm{E}-5 \quad 4.56 \mathrm{E}-5$

XFLOX0 1.97E-4 1.97E-4 1.97E-4 1.97E-4 1.97E-4 1.97E-4 1.97E-4

$1.97 \mathrm{E}-41.97 \mathrm{E}-41.97 \mathrm{E}-4 \quad 1.97 \mathrm{E}-41.97 \mathrm{E}-4 \quad 1.97 \mathrm{E}-41.97 \mathrm{E}-4$

XFLOXO 4.56E-5 4.56E-5 4.56E-5 4.56E-5 4.56E-5 4.56E-5 $4.56 \mathrm{E}-5$ $4.56 \mathrm{E}-5 \quad 4.56 \mathrm{E}-5 \quad 4.56 \mathrm{E}-5 \quad 4.56 \mathrm{E}-5 \quad 4.56 \mathrm{E}-5 \quad 4.56 \mathrm{E}-5 \quad 4.56 \mathrm{E}-5$

XFLOX0 1.97E-4 1.97E-4 1.97E-4 1.97E-4 1.97E-4 1.97E-4 1.97E-4

$1.97 \mathrm{E}-41.97 \mathrm{E}-4$ 1.97E-4 1.97E-4 1.97E-4 1.97E-4 1.97E-4

XSCOX0 4.56E-5 4.56E-5 4.56E-5 4.56E-5 4.56E-5 4.56E-5 $4.56 \mathrm{E}-5$

$4.56 \mathrm{E}-5$ 4.56E-5 4.56E-5 4.56E-5 4.56E-5 4.56E-5 4.56E-5

$-$

$\mathrm{XSCOX0} \quad 3.7 \mathrm{E}-4 \quad 3.7 \mathrm{E}-4 \quad 3.7 \mathrm{E}-4 \quad 3.7 \mathrm{E}-4 \quad 3.7 \mathrm{E}-4 \quad 3.7 \mathrm{E}-4 \quad 3.7 \mathrm{E}-4$

3.7E-4 3.7E-4 3.7E-4 3.7E-4 3.7E-4 3.7E-4 3.7E-4

CASE 34, VAIRULOC, INPUT DIFFERENCES with VACUUM

\begin{tabular}{|c|c|c|c|c|c|}
\hline \multicolumn{5}{|c|}{ < VACUUM.DAT } & \\
\hline < HELIUM & 0.85 & 0.85 & 0.85 & 0.0 & 1.0 \\
\hline$<$ STEAM & 0.10 & 0.10 & 0.10 & 0.0 & 0.0 \\
\hline$<$ OXYGEN & 0.0 & 0.0 & 0.0 & 0.0 & 0.0 \\
\hline$<$ NIROGEN & 0.0 & 0.0 & 0.0 & 0.0 & 0.0 \\
\hline$<$ WATER & 0.0 & 0.0 & 0.0 & 1.0 & 0.0 \\
\hline \multicolumn{6}{|l|}{$m$} \\
\hline$>$ HELIUM & 0.85 & 0.85 & 0.85 & 0.0 & 0.0 \\
\hline$>$ STEAM & 0.10 & 0.10 & 0.10 & 0.0 & 0.020 \\
\hline$>$ OXYGEN & 0.0 & 0.0 & 0.0 & 0.21 & 0.206 \\
\hline$>$ NITROGEN & 0.0 & 0.0 & 0.0 & 0.79 & 0.774 \\
\hline$>$ WATER & 0.0 & 0.0 & 0.0 & 0.0 & 0.0 \\
\hline \multicolumn{6}{|c|}{$<$ OFFSET_TMMEHS $\quad 0}$. \\
\hline \multicolumn{6}{|c|}{$<$ EXTRAPOLATION TMMEHS EXTRAP } \\
\hline \multicolumn{6}{|c|}{$<$ TIMTHS 1520.0 1.E6 } \\
\hline \multicolumn{6}{|c|}{$<$ THSFIX $15250.0 \quad 50.0$} \\
\hline \multicolumn{2}{|c|}{$<$ TIMTHS 3020.0} & 1.E6 & & & \\
\hline \multicolumn{2}{|c|}{$<$ THSFIX 30250.0} & 50.0 & & & \\
\hline \multicolumn{2}{|c|}{$<$ TIMTHS 4120.0} & 1.E6 & & & \\
\hline \multicolumn{2}{|c|}{$<$ THSFDX 41250.0} & 50.0 & & & \\
\hline \multicolumn{2}{|c|}{$<$ TIMTHS 4210.0} & 1.E6 & & & \\
\hline \multicolumn{2}{|c|}{$<$ THSFIX 42150.0} & 50.0 & & & \\
\hline \multicolumn{2}{|c|}{$<$ TMMTHS 4320.0} & 1.E6 & & & \\
\hline \multicolumn{2}{|c|}{$<$ THSFLX 43250.0} & 50.0 & & & \\
\hline \multicolumn{6}{|c|}{-} \\
\hline \multicolumn{6}{|c|}{$>$ C OFFSET TIMEHS } \\
\hline \multicolumn{4}{|c|}{$>$ CEXTRAPOLATION TIMEHS } & EXTRAP & \\
\hline \multicolumn{4}{|c|}{$>$ CTIMTHS 1520.0 1.E6 } & & \\
\hline \multicolumn{2}{|c|}{$>$ CTHSFIX 15285.0} & 85.0 & & & \\
\hline \multicolumn{2}{|c|}{$>$ CTMMTHS 3020.0} & 1.E6 & & & \\
\hline \multicolumn{2}{|c|}{$>$ CTHSFIX 30285.0} & 85.0 & & & \\
\hline
\end{tabular}




\section{HNF-SD-SNF-CN-023 REV 1}

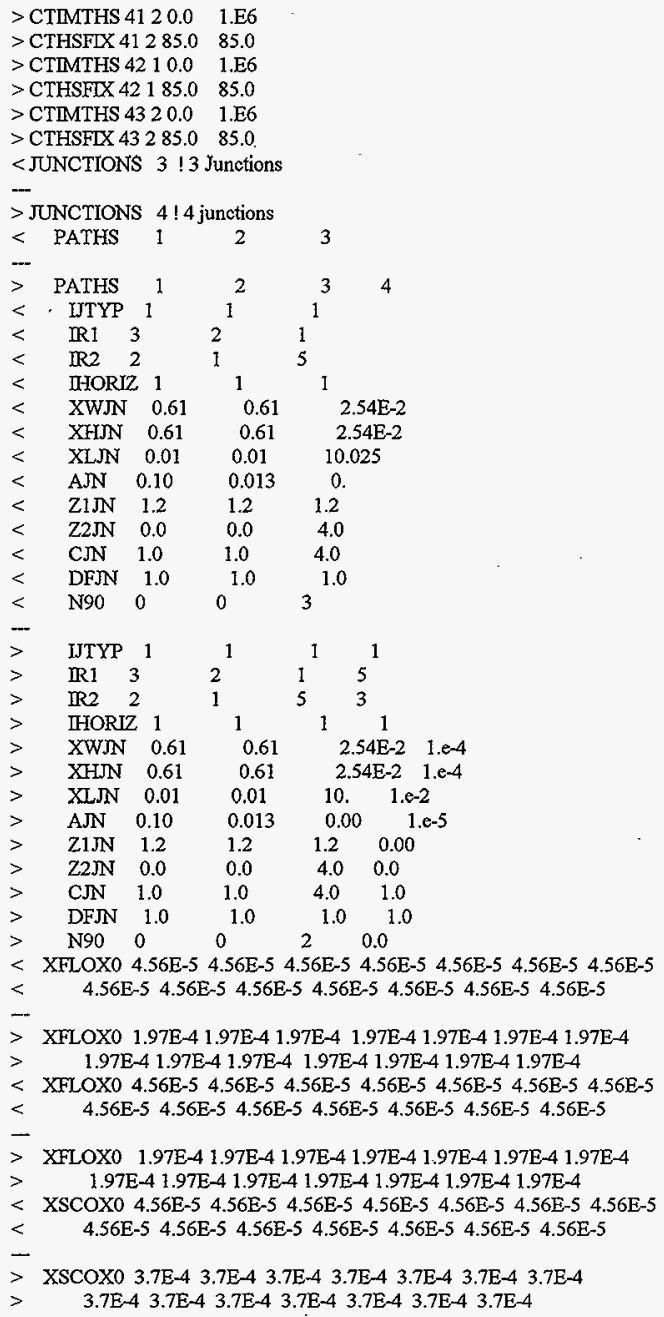

CASE 35, PURAIR, INPUT DIFFERENCES with VACUUM

$<$ VACUUM.DAT 


\section{HNF-SD-SNF-CN-023 REV 1}

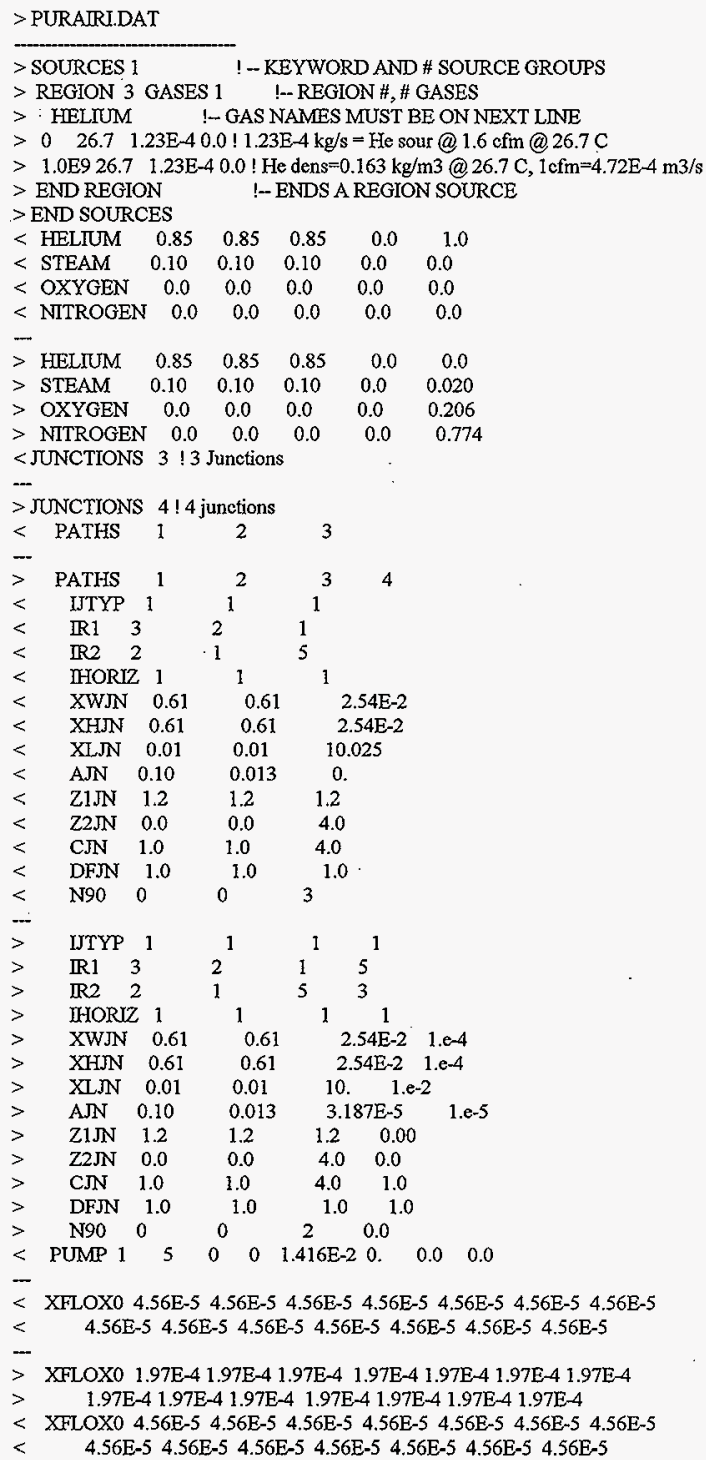




\section{HNF-SD-SNF-CN-023 REV 1}

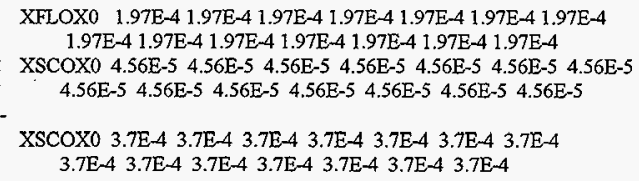

CASE 36, PARIHOT, INPUT DIFFERENCES with VACUUM

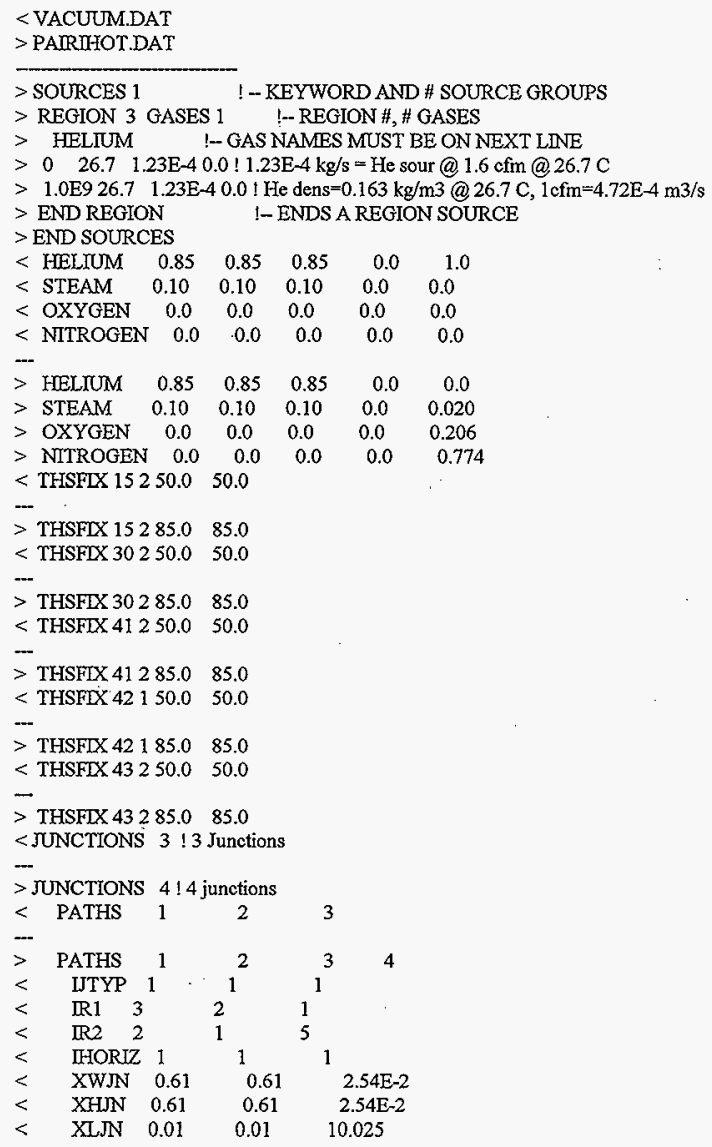




\section{HNF-SD-SNF-CN-023 REV 1}

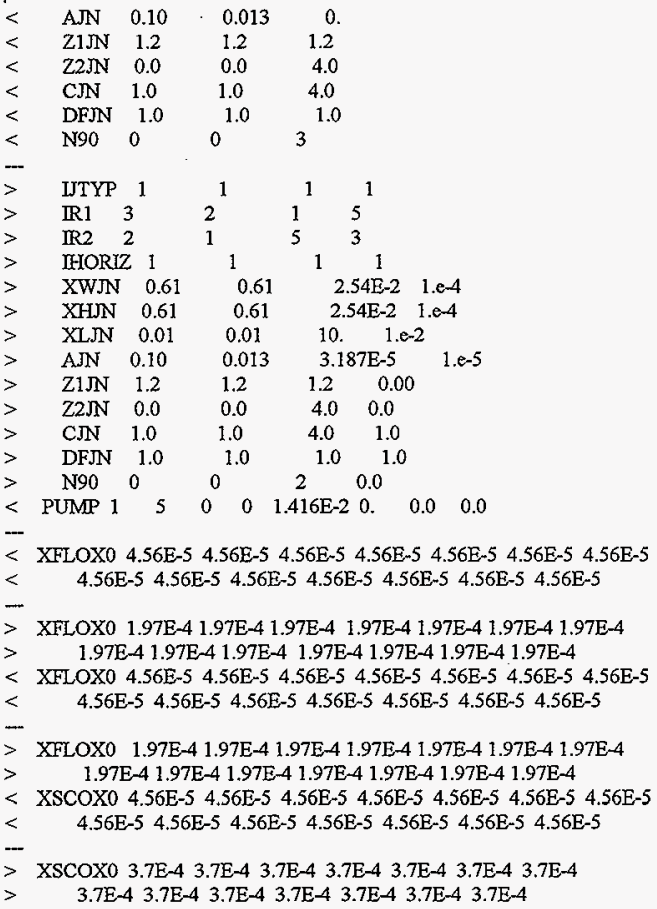

CASE 37, VACAIRI2, INPUT DIFFERENCES with VACUUM

\begin{tabular}{|c|c|c|c|c|c|}
\hline \multicolumn{6}{|c|}{ < VACUUM.DAT } \\
\hline$<$ HELIOM & 0.85 & 0.85 & 0.85 & 0.0 & 1.0 \\
\hline < STEAM & 0.10 & 0.10 & 0.10 & 0.0 & 0.0 \\
\hline$<$ OXYGEN & 0.0 & 0.0 & 0.0 & 0.0 & 0.0 \\
\hline $\begin{array}{l}<\text { NITROGEN } \\
-\end{array}$ & 0.0 & 0.0 & 0.0 & 0.0 & 0.0 \\
\hline > HELIUM & 0.85 & 0.85 & 0.85 & 0.0 & 0.0 \\
\hline > STEAM & 0.10 & 0.10 & 0.10 & 0.0 & 0.020 \\
\hline$>$ OXYGEN & 0.0 & 0.0 & 0.0 & 0.0 & 0.206 \\
\hline > NITROGEN & 0.0 & 0.0 & 0.0 & 0.0 & 0.774 \\
\hline $\begin{array}{l}<\text { JUNCTIONS } \\
-\end{array}$ & \multicolumn{5}{|c|}{3 ! 3 Junctions } \\
\hline$>$ JUNCTIONS & \multicolumn{5}{|c|}{$4 ! 4$ junctions } \\
\hline $\begin{array}{l}<\quad \text { PATHS } \\
--\end{array}$ & 1 & 2 & 3 & & \\
\hline PATHS & 1 & 2 & $3^{3}$ & 4 & \\
\hline LTTYP & 1 & 1 & 1 & & \\
\hline
\end{tabular}




\section{HNF-SD-SNF-CN-023 REV 1}

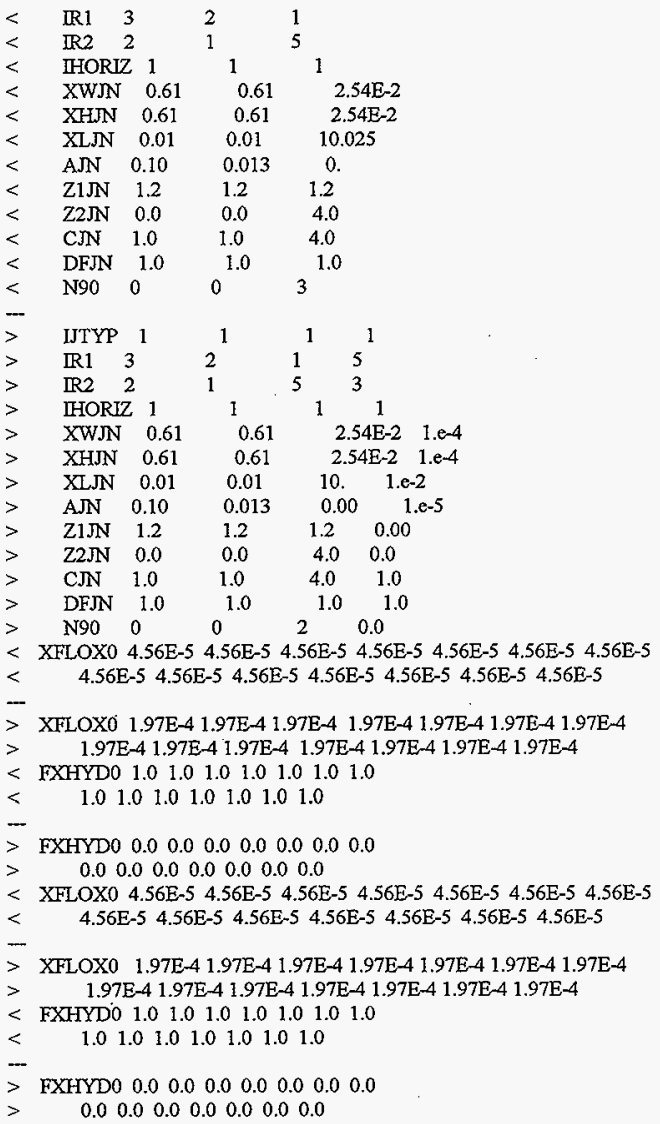

\section{CASE 38, DSLOCSA4, INPUT DIFFERENCES with DSTOP}

\begin{tabular}{|c|c|c|c|c|c|}
\hline \multicolumn{6}{|c|}{$\begin{array}{l}<\text { DSTOP.DAT } \\
>\text { DSLOCSA4.DAT }\end{array}$} \\
\hline < HELIUM & 0.85 & 0.85 & 0.85 & 0.0 & 1.0 \\
\hline < STEAM & 0.15 & 0.15 & 0.15 & 0.0 & 0.0 \\
\hline$<$ OXYGEN & 0.0 & 0.0 & 0.0 & 0.0 & 0.0 \\
\hline$<$ NITROGEN & 0.0 & 0.0 & 0.0 & 0.0 & 0.0 \\
\hline$<$ WATER & 0.0 & 0.0 & 0.0 & 1.0 & 0.0 \\
\hline
\end{tabular}




\section{HNF-SD-SNF-CN-023 REV 1}

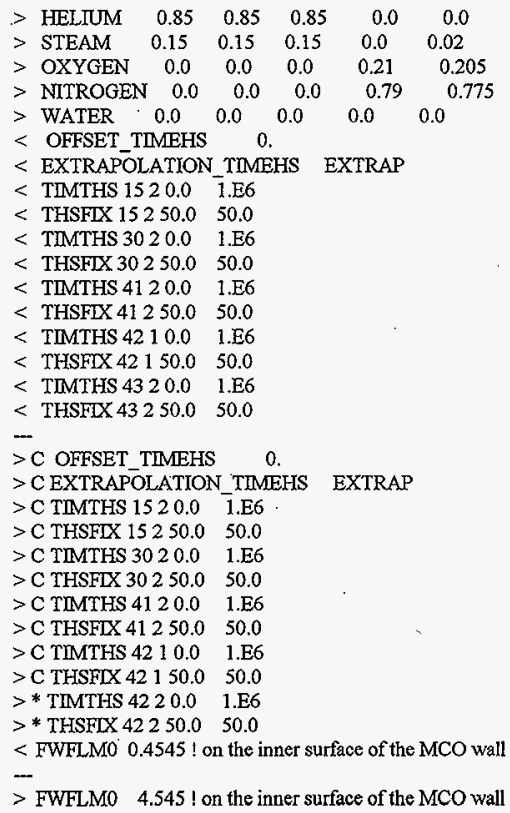

CASE 39, BLOW4N, INPUT DIFFERENCES with DSTOP

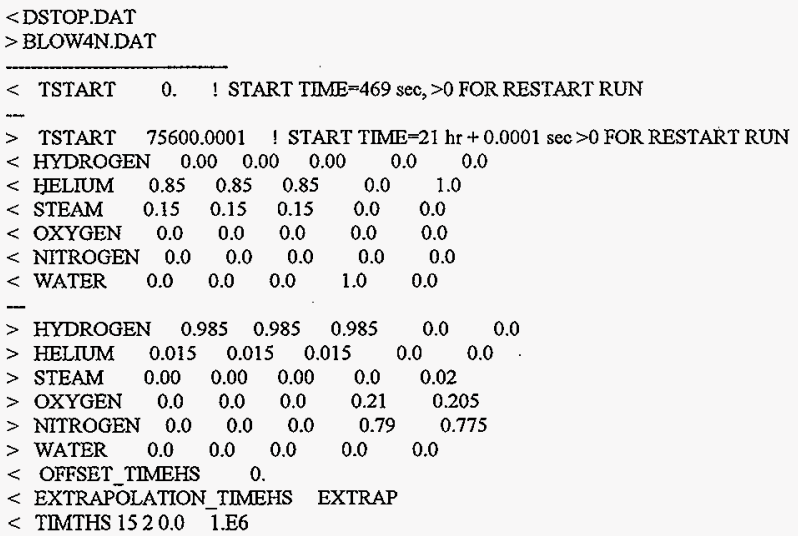




\section{HNF-SD-SNF-CN-023 REV 1}

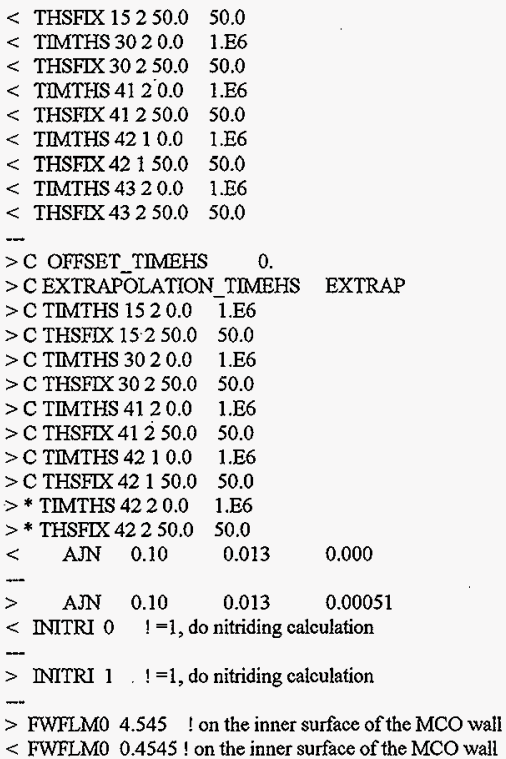

CASE 40, DSSA4REC, INPUT DIFFERENCES with DSTOP

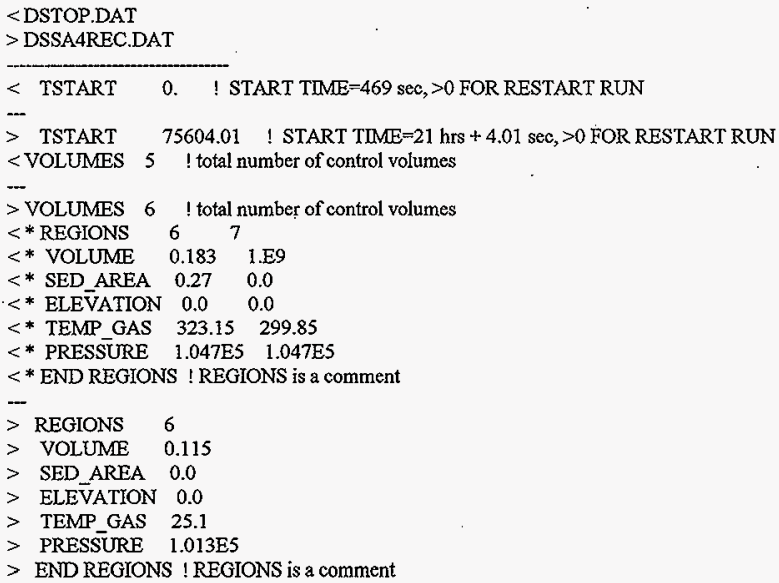




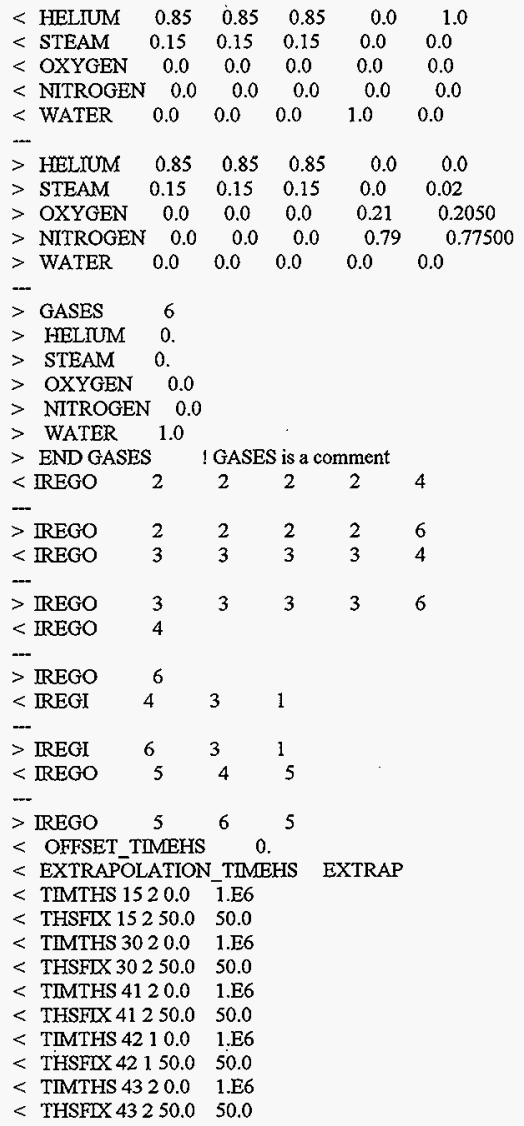

$>$ C OFFSET TIMEHS 0 .

$>$ C EXTRAPOLATION_TIMEHS EXTRAP

$>$ C TIMTHS 1520.0 1.E6

$>$ C THSFIX $15225.0 \quad 25.0$

$>C$ TIMTHS $3020.0 \quad 1 . E 6$

$>$ C THSFIX 30225.025 .0

$>C$ TIMTHS $4120.0 \quad 1 . E 6$

$>$ C THSFIX $41225.0 \quad 25.0$

$>\mathrm{C}$ TIMTHS $4210.0 \quad$ 1.E6

$>$ C THSFIX $42125.0 \quad 25.0$

$>C$ TMMTHS $4320.0 \quad$ l.E6

$>C$ THSFIX 43225.0 .25 .0

$<$ MGAP 4 ! define the gap node (between MCO wall and the cask) 


\section{HNF-SD-SNF-CN-023 REV 1}

$>$ IRGAP 6 ! define the gap node (between MCO wall and the cask)

$<$ FWFLMO 0.4545 ! on the inner surface of the MCO wall

$>$ FWFLMO 4.545 ! on the inner surface of the MCO wall

CASE 41, BLOWREOV, INPUT DIFFERENCES with DSTOP

$\angle$ DSTOP.DAT

$>$ BLOWREOV.DAT

$<$ TSTART 0. ! START TIME=469 sec, >0 FOR RESTART RUN

$-$

$>$ TSTART 79203.01 ! START TMME=22hr + $3.01 \mathrm{sec}>>0$ FOR RESTART RUN

$<$ VOLUMES 5 ! total number of control volumes

-

$>$ VOLURES 6 ! total number of control volumes

$>$ REGIONS 6

$>$ VOLUME 0.115

$>$ SED AREA 0.0

$>$ ELEVATION 0.0

$>$ TEMP GAS 25.1

$>$ PRESSURE 1.013E5

$>$ END REGIONS ! REGIONS is a comment

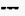

$>$ GASES 6

$>$ HELIUM 0 .

$>$ STEAM 0.

$>$ OXYGEN 0.0

$>$ NITROGEN 0.0

$>$ WATER 1.0

$>$ END GASES ! GASES is a comment

$\begin{array}{llllll}<\mathrm{IREGO} & 2 & 2 & 2 & 2 & 4\end{array}$

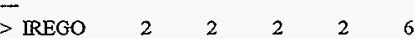

$\begin{array}{llllll}<\text { IREGO } & 3 & 3 & 3 & 3 & 4\end{array}$

$\begin{array}{llllll}>\text { IREGO } & 3 & 3 & 3 & 3 & 6\end{array}$

$<$ REGO 4

$-$

$>$ IREGO 6

$<$ IREGI 4

$\begin{array}{llll}>\text { REGI } & 6 & 3 & 1\end{array}$

$<$ IREGO $5 \quad 4$

$>$ REGO $5 \quad 6 \quad 5$

$<$ OFFSET_TIMEHS 0 .

$<$ EXTRAPOLATION TIMEHS EXTRAP

< TIMTHS 1520.0 1.E6

$<$ THSFIX $15250.0 \quad 50.0$

$<$ TIMTHS $3020.0 \quad 1 . \mathrm{E} 6$

$<$ THSFLX $30250.0 \quad 50.0$

$<$ TMTHS $4120.0 \quad$ 1.E6

$<$ THSFIX $41250.0 \quad 50.0$

$<$ TIMTHS 4210.0 1.E6

$<$ THSFIX $42150.0 \quad 50.0$

$<$ TIMTHS $4320.0 \quad 1 . E 6$ 
$<$ THSFIX $43250.0 \quad 50.0$

$-$

$>C$ OFFSET TIMEHS 0.

$>$ CEXTRAPOLLATION_TIMEHS EXTRAP

$>$ C TIMTHS $1520.0 \quad 1 . \mathrm{E} 6$

$>$ C THSFIX $15225.0 \quad 25.0$

$>$ C TIMTHS 3020.0 1.E6

$>C$ THSFIX $30225.0 \quad 25.0$

$>$ C TIMTHS $4120.0 \quad$ l.E6

$>$ C THSFIX $41225.0 \quad 25.0$

$>$ C TUMTHS $4210.0 \quad$ 1.E6

$>$ C THSFIX $42125.0 \quad 25.0$

$>$ C TIMTHS $4320.0 \quad 1 . E 6$

$>$ C THSFIX $43225.0 \quad 25.0$

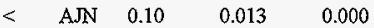

$>\quad$ AN $\quad 0.10 \quad 0.013 \quad 5.1 \mathrm{E}-4$

$<$ RGAP $4 \quad \ddagger$ define the gap node (between MCO wall and the cask)

$-$

$>$ RGAP 6 ! define the gap node (between MCO wall and the cask)

$<$ FWFLM0 0.4545 ! on the inner surface of the MCO wall

$-$

$>$ FWFLM0 4.545 ! on the inner surface of the $\mathrm{MCO}$ wall

CASE 42, DSLOCOV2, INPUT DIFFERENCES with DSTOP

$<$ DSTOP.DAT

$>$ DSLOCOV2.DAT

$\begin{array}{lccccc}\text { < HELIUM } & 0.85 & 0.85 & 0.85 & 0.0 & 1.0 \\ \text { < STEAM } & 0.15 & 0.15 & 0.15 & 0.0 & 0.0 \\ \text { < OXYGEN } & 0.0 & 0.0 & 0.0 & 0.0 & 0.0 \\ \text { < NITROGEN } & 0.0 & 0.0 & 0.0 & 0.0 & 0.0 \\ \text { < WATER } & 0.0 & 0.0 & 0.0 & 1.0 & 0.0\end{array}$

$-$

$\begin{array}{llllll}>\text { HELIUM } & 0.85 & 0.85 & 0.85 & 0.0 & 0.0\end{array}$

$\begin{array}{llllll}>\text { STEAM } & 0.15 & 0.15 & 0.15 & 0.0 & 0.02\end{array}$

$\begin{array}{llllll}>\text { OXYGEN } & 0.0 & 0.0 & 0.0 & 0.21 & 0.205\end{array}$

$\begin{array}{llllll}>\text { NTROGEN } & 0.0 & 0.0 & 0.0 & 0.79 & 0.775\end{array}$

$\begin{array}{llllll}>\text { WATER } & 0.0 & 0.0 & 0.0 & 0.0 & 0.0\end{array}$

$<$ IGEOM $\quad 0 \quad 000000$

$\overline{<}$ OFFSET TIMEHS 0 .

$<$ EXTRAPÖLATION_TIMEHS EXTRAP

$<$ TIMTHS 1520.0 1.E6

$<$ THSFIX 15250.050 .0

$<$ TIMTHS $3020.0 \quad 1 . \mathrm{E} 6$

$<$ THSFIX $30250.0 \quad 50.0$

$<$ TIMTHS $4120.0 \quad 1 . E 6$

$<$ THSFIX $41250.0 \quad 50.0$

$<$ TIMTHS 4210.0 1.E6

$<$ THSFTX $42150.0 \quad 50.0$

$<$ TIMTHS $4320.0 \quad$ 1.E6

$<$ THSFIX 43250.050 .0

$>C$ OFFSET TIMEHS 0

$>$ C EXTRAPOLATION_TIMEHS EXTRAP

$>$ C TIMTHS 1520.0 1.E6 


\section{HNF-SD-SNF-CN-023 REV 1}

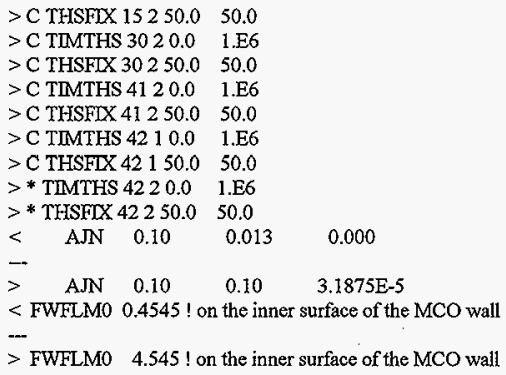




\section{HNF-SD-SNF-CN-023 REV 1}

This page intentionally left blank. 
HNF-SD-SNF-CN-023 REV 1

APPENDIX C

KEY INPUT PARAMETERS 


\section{HNF-SD-SNF-CN-023 REV 1}

This page intentionally left blank. 
HNF-SD-SNF-CN-023 REV 1

\section{APPENDIX C}

\section{KEY INPUT PARAMETERS}

Key input parameters used in the analysis for the bounding and nominal MCO with one Mark IV scrap basket and four Mark IV fuel baskets are shown in Table C-1. Notes are provided following the table.

Table C-1. Key Input Parameters for Bounding and Nominal Multi-Canister Overpack. (3 sheets)

\begin{tabular}{|c|c|c|}
\hline Parameter & Value & Reference \\
\hline \multicolumn{3}{|c|}{ 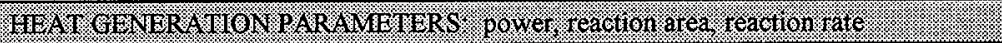 } \\
\hline $\begin{array}{l}\text { Bounding decay power } \\
\text { ( } 776 \mathrm{~W} \text { for five fuel baskets) }\end{array}$ & $740.8 \mathrm{~W}$ per MCO & $\begin{array}{c}\text { Reilly } 1998 \\
\text { Note } 1 \\
\end{array}$ \\
\hline $\begin{array}{l}\text { Nominal decay power } \\
\text { (403 W for five fuel baskets) }\end{array}$ & 384.7 W per MCO & $\begin{array}{l}\text { Reilly } 1998 \\
\text { Note } 2 \\
\end{array}$ \\
\hline Scrap fuel reaction surface area & $\begin{array}{l}6 \mathrm{~m}^{2} \text { - bounding } \\
1.7 \mathrm{~m}^{2}-\text { nominal }\end{array}$ & Reilly 1998 \\
\hline Fuel reaction area & $\begin{array}{l}7 \mathrm{~m}^{2} \text { - bounding } \\
0.3 \mathrm{~m}^{2}-\text { nominal }\end{array}$ & Reilly 1998 \\
\hline Reaction rate multiplier & $\begin{array}{l}10 \text { - bounding } \\
3 \text { - nominal }\end{array}$ & Reilly 1998 \\
\hline $\begin{array}{l}\text { Nominal effective rate multiplier for } \\
\text { hydrides (nominal hydride mass) }\end{array}$ & $\begin{array}{c}13.7 \text { - fuel basket } \\
13.7 \text { - scrap basket } \\
(2.4 \mathrm{~kg} \text { per MCO) }\end{array}$ & $\begin{array}{l}\text { Plys and Duncan } 1998 \\
\text { Note } 3\end{array}$ \\
\hline $\begin{array}{l}\text { Bounding effective rate multiplier for } \\
\text { hydrides (bounding hydride mass) }\end{array}$ & $\begin{array}{c}59.2 \text { - fuel basket } \\
111 \text { - scrap basket } \\
(14.6 \mathrm{~kg} \text { per MCO) }\end{array}$ & $\begin{array}{l}\text { Plys and Duncan } 1998 \\
\text { Note } 4\end{array}$ \\
\hline \multicolumn{3}{|c|}{ 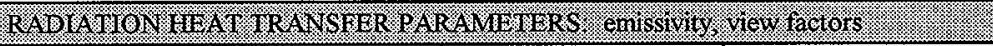 } \\
\hline Scrap fuel emissivity & 0.7 & Reilly 1998 \\
\hline Cladding emissivity & 0.43 & $\begin{array}{l}\text { Scott } 1965 \\
\text { Note } 5 \\
\end{array}$ \\
\hline Inner shield plug emissivity & 1.0 & $\begin{array}{c}\text { Plys et al. } 1998 \\
\text { Note } 6 \\
\end{array}$ \\
\hline MCO wall emissivity & 0.3 & Reilly 1998 \\
\hline $\begin{array}{l}\text { Cask, MCO bottom, and outer shield } \\
\text { plug emissivity }\end{array}$ & 0.25 & $\begin{array}{l}\text { Plys et al. } 1998 \\
\text { Note } 7\end{array}$ \\
\hline
\end{tabular}


Table C-1. Key Input Parameters for Bounding and Nominal Multi-Canister Overpack. (3 sheets)

\begin{tabular}{|c|c|c|}
\hline Parameter & Value & Reference \\
\hline $\begin{array}{l}\text { View factors between fuel rods and } \\
\text { MCO wall }\end{array}$ & $8 \times 8$ matrix & $\begin{array}{l}\text { Plys et al. } 1998 \\
\text { Note } 8\end{array}$ \\
\hline \multicolumn{3}{|c|}{ 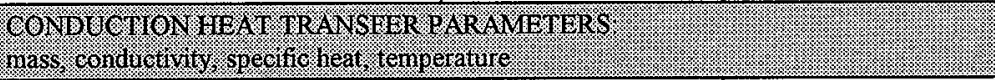 } \\
\hline Effective fuel-cladding mass density & $18,573.3 \mathrm{~kg} / \mathrm{m}^{3}$ & Note 9 \\
\hline $\begin{array}{l}\text { Uranium (scrap) mass density at } \\
100^{\circ} \mathrm{C}\end{array}$ & $19,000 \mathrm{~kg} / \mathrm{m}^{3}$ & $\begin{array}{c}\text { Holden } 1958 \\
\text { Note } 10 \\
\end{array}$ \\
\hline Stainless steel mass density at $100^{\circ} \mathrm{C}$ & $8,000 \mathrm{~kg} / \mathrm{m}^{3}$ & $\begin{array}{l}\text { ORNL } 1987 \\
\text { Note } 11\end{array}$ \\
\hline $\begin{array}{l}\text { Maximum fuel mass load } \\
\text { (Mark IV fuel) }\end{array}$ & $\begin{array}{l}980 \mathrm{~kg} \text { - scrap basket } \\
1,268 \mathrm{~kg} \text { - fuel basket } \\
6,052 \mathrm{~kg} \text { per MCO }\end{array}$ & Reilly 1998 \\
\hline $\begin{array}{l}\text { Effective fuel/clad thermal } \\
\text { conductivity }\end{array}$ & $24.2 \mathrm{~W} / \mathrm{m} / \mathrm{K}$ & Note 12 \\
\hline Stainless steel thermal conductivity & $16.0 \mathrm{~W} / \mathrm{m} / \mathrm{K}$ & ORNL 1987 \\
\hline $\begin{array}{l}\text { Effective fuel-cladding and uranium } \\
\text { specific heat }\end{array}$ & $122.67 \mathrm{~J} / \mathrm{kg} / \mathrm{K}$ & Note 13 \\
\hline Stainless steel specific heat & $500.0 \mathrm{~J} / \mathrm{kg} / \mathrm{K}$ & ORNL 1987 \\
\hline $\begin{array}{l}\text { Free residual water after draining } \\
\text { ( } 1.5 \mathrm{~kg} \text { per scrap basket, } 6.0 \mathrm{~kg} \text { per } \\
\text { fuel basket, } 1.0 \mathrm{~kg} \text { per bottom) }\end{array}$ & $26.5 \mathrm{~kg}$ per $\mathrm{MCO}$ & Duncan and Ball 1997 \\
\hline $\begin{array}{l}\text { Water in uranium hydrates, } \\
\mathrm{UO}_{3} \cdot 2 \mathrm{H}_{2} \mathrm{O}\end{array}$ & $\begin{array}{c}1.16 \mathrm{~kg} \\
(0.72 \mathrm{~kg})^{*}\end{array}$ & Note 14 \\
\hline $\begin{array}{l}\text { Helium purge and process bay } \\
\text { temperature }\end{array}$ & $\begin{array}{l}26.7^{\circ} \mathrm{C} \\
\left(80^{\circ} \mathrm{F}\right) \\
\end{array}$ & Irwin et al. 1998 \\
\hline Normal annulus water temperature & $50^{\circ} \mathrm{C}$ & Irwin et al. 1998 \\
\hline \multicolumn{3}{|c|}{ 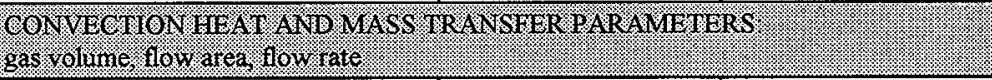 } \\
\hline Scrap basket gas volume & $0.153 \mathrm{~m}^{3}$ & Note 15 \\
\hline Upper fuel (2 fuel baskets) volume & $0.186 \mathrm{~m}^{3}$ & Note 16 \\
\hline Lower fuel ( 2 fuel baskets) volume & $0.199 \mathrm{~m}^{3}$ & Note 17 \\
\hline Fine scrap porosity & 0.40 & Note 18 \\
\hline Course scrap porosity & 0.7392 & Note 19 \\
\hline Flow area in scrap basket bottom & $0.013 \mathrm{~m}^{2}$ & Note 20 \\
\hline
\end{tabular}


Table C-1. Key Input Parameters for Bounding and Nominal Multi-Canister Overpack. (3 sheets)

\begin{tabular}{|l|c|c|}
\hline \multicolumn{1}{|c|}{ Parameter } & Value & Reference \\
\hline Vacuum pumping rate & $0.01416 \mathrm{~m}^{3} / \mathrm{s}$ & Irwin et al. 1998 \\
& $(30 \mathrm{scm})$ & \\
\hline Base helium mass purge rate & $1.23 \mathrm{E}-04 \mathrm{~kg} / \mathrm{s}$ & Irwin et al. 1998 \\
& $(1.6 \mathrm{scfm})$ & \\
\hline
\end{tabular}

* The hydrate water mass for case 0 (NORMAL) is $0.72 \mathrm{~kg}$.

$\mathrm{MCO}=$ multi-canister overpack.

Note 1 Bounding decay heat rate - The bounding decay power (i.e., decay heat rate) is given as $776 \mathrm{~W}$ per MCO with five Mark IV fuel baskets (155.2 W per fuel basket or $620.8 \mathrm{~W}$ for four fuel baskets), so the specific heat rate is $0.1224 \mathrm{~W} / \mathrm{kgU}$ for Mark IV fuel (Duncan 1998). The scrap basket for Mark IV fuel has a maximum fuel loading of $980 \mathrm{~kg}$ (Kessler and Peck 1998), so the scrap basket has a maximum decay power of about $120 \mathrm{~W}(980 \mathrm{kgU} \times 0.1224 \mathrm{~W} / \mathrm{kgU})$. Hence, the bounding decay power (i.e., decay heat rate) is $740.8 \mathrm{~W}$ per MCO $(620.8 \mathrm{~W}+120 \mathrm{~W})$ with four Mark IV fuel baskets and one Mark IV scrap basket.

Note 2 Nominal decay power - The nominal decay power is given as $403 \mathrm{~W}$ per MCO (Duncan 1998) with five Mark IV fuel baskets (80.6 W per fuel basket or $322.4 \mathrm{~W}$ for four fuel baskets), the specific heat rate is $0.06357 \mathrm{~W} / \mathrm{kgU}$ based on bounding Mark IV fuel mass loading. The bounding mass loadings of Mark IV fuel is used in order to be consistent with Note 1 and conservative in the sense of maximizing the nominal decay power per MCO. The decay power for the $980 \mathrm{~kg}$ scrap basket is $62.3 \mathrm{~W}(980 \mathrm{kgU} \times 0.06357 \mathrm{~W} / \mathrm{kgU})$. Hence, the bounding decay power is 384.7 per MCO (322.4 W +62.3 W) with four Mark IV fuel baskets and one Mark IV scrap basket.

Note 3 Nominal effective rate multiplier for hydrides $\left(\mathrm{CH}_{3}\right)$ - Air (oxygen) reacts faster with uranium hydride (Plys et al. 1997) than with just uranium metal. The current hydride model (Plys and Duncan 1998) models the enhanced reaction rate by increasing the effective surface area of reaction through the use of a rate multiplier. In the current hydride model (Plys and Duncan 1998), the hydrides in the MCO are strongly coupled thermally to the uranium fuel. Hence, any increase in hydride temperature is dissipated in the larger uranium fuel mass, resulting in a temperature increase for the entire fuel element. This analysis uses hydride loadings from an earlier model (Plys et al. 1997) which were revised downward later, but kept higher here in order to increase the margin for safety purposes. Otherwise, this analysis keeps the hydride model the same as in Plys and Duncan (1998). Because of this margin of safety, the nominal values for hydride mass loadings are used in all simulated cases with the bounding MCO except for the air-ingress simulations, 
which used bounding hydride mass loadings. The equivalent rate multiplier for hydrides is expressed as a product of the fraction of fuel surface containing hydrides and the enhanced reaction rate (relative to literature values). The nominal hydrides cover 3.7\% of the exposed fuel (Plys and Duncan 1998), and the enhanced reaction rate used was 370 (Plys et al. 1997). This means that $3.7 \%$ of the exposed fuel has a rate multiplier of 370 due to hydrides. Hence, the nominal effective rate multiplier for hydrides is $13.7(0.037 \times 370)$. The nominal mass loading of $\mathrm{UH}_{3}$ in the $\mathrm{MCO}$ is $2.4 \mathrm{~kg}(1.3 \mathrm{~kg}$ in fuel elements, $1.1 \mathrm{~kg}$ in scrap fuel).

Note 4 Bounding effective rate multiplier for hydrides $\left(\mathrm{UH}_{3}\right)$ - The bounding rate multiplier is calculated in the same way as the nominal value, shown in Note 3 , with the probability of the high effective rate of 370 increasing to $16 \%$ ( 99.99 percentile value based on Markov chain model with average reaction time of 30 minutes in Plys and Duncan [1998], Appendix G) for the fuel elements and 30\% for the scrap fuel. Hence, the bounding rate multiplier for hydrides is 111.0 for the scrap fuel $(0.30 \times 370)$, and 59.2 for the fuel elements $(0.16 \times 370)$. The bounding mass loading of $\mathrm{UH}_{3}$ in the $\mathrm{MCO}$ is $14.6 \mathrm{~kg}$ (5.6 kg in fuel elements, $9.0 \mathrm{~kg}$ in scrap fuel).

Preliminary data from dry-oven experiments with five damaged $\mathrm{N}$ Reactor fuel elements suggest that the maximum hydride mass per outer fuel element is $37 \mathrm{~g}$ and the average hydride mass without the maximum one is about $4.8 \mathrm{~g}$ per outer fuel element. ${ }^{1}$ There are approximately 256 fuel assemblies per MCO, so using the preliminary data and assuming no hydrides exist on the inner elements, results in an average hydride mass of about $1.2 \mathrm{~kg}$ per MCO ( $0.0048 \mathrm{~kg} \mathrm{x} 256$ assemblies) for damaged fuel. This calculated $1.2 \mathrm{~kg}$ of $\mathrm{UH}_{3}$ per $\mathrm{MCO}$ is half of the $2.4 \mathrm{~kg}$ used in most of the cases in this report. Using the maximum hydride measured mass of $37 \mathrm{~g}$ to estimate a large upper bound results in about $9.5 \mathrm{~kg}$ of $\mathrm{UH}_{3}$ per $\mathrm{MCO}$ rather than the $14.6 \mathrm{~kg}$ used in the air ingress cases. Therefore, the hydride mass loadings in this report include a large margin, as they are much higher than the mass loadings suggested by the preliminary data.

Note 5 Cladding emissivity - Cladding emissivity is used for the combined fuel-cladding composite heat element in the model because the cladding covers the fuel element on the outside, keeping the uranium fuel hidden. The emissivity of Zircaloy-2 ranges from 0.43 to 0.46 (Scott 1965) at high temperatures. The more conservative lower value of 0.43 was chosen, which will cause less heat to radiate from the fuel-cladding heat element. This emissivity value, which is reported for high temperatures, is assumed to be the same at lower temperatures.

Note 6 Inner shield plug emissivity - The bottom of the MCO shield plug was given a high emissivity value of 1.0 (Plys and Duncan 1998) in order to increase the radiative heat transfer rate between the scrap basket fuel and the shield plug.

'Personnel communication with S. C. Marschman, Pacific Northwest National Laboratory, on June 10, 1998. 
The increased heat transfer was needed to compensate for the lack of thermal conduction in the axial direction.

Note 7 Cask, MCO bottom, and outer shield plug emissivity - The emissivity of the cask, MCO bottom plate, and the outer shield plug was decreased to 0.25 (from 0.30 ) in order to conservatively reduce the heat removal rate from the MCO (Plys and Duncan 1998).

Note 8 View factors between fuel rods and MCO wall - The view factors between the fuel rods in the fuel basket and the MCO wall, which are used in the radiative heat transfer model for an MCO fuel basket, are documented in the HANSF code document (Plys et al. 1998). However, the view factors used in this analysis differ slightly from those in the code document. The view factors for this analysis, and for the two-scrap basket report (Plys and Duncan 1998), are described in detail in Appendix D.

Note 9 Effective fuel-cladding mass density - Since the cladding volume is merged with the fuel volume in the HANSF code (Plys et al. 1998), an effective mass density is needed for the combined fuel and cladding. To simplify the derivation, the inner fuel element and cladding are assumed to have the same effective mass density as the outer fuel element and its cladding. The total volume for the fuel elements and cladding in the HANSF code is $0.31752 \mathrm{~m}^{3}$ (Plys et al. 1998). Since the maximum fuel mass for 216 Mark IV elements (four fuel baskets) is $5,072 \mathrm{~kg}$ (23.48 kg per element [Reilly 1998]), the volume of the fuel is about $0.26695 \mathrm{~m}^{3}$, which is calculated by dividing the volume by the fuel density, $19,000 \mathrm{~kg} / \mathrm{m}^{3}$ at $100{ }^{\circ} \mathrm{C}$ (Holden 1958). The cladding volume is found by subtracting the fuel volume from the total volume:

$$
V_{\text {cladding }}=V_{\text {total }}-V_{\text {fuel }}=0.31752 \mathrm{~m}^{3}-0.26695 \mathrm{~m}^{3}=0.05057 \mathrm{~m}^{3}
$$

Multiplying the density of the Zircaloy-2 cladding, $6,541 \mathrm{~kg} / \mathrm{m}^{3}$ (Weakley 1979 ), by the volume of cladding gives a cladding mass of $330.8 \mathrm{~kg}$ :

$$
\mathrm{M}_{\text {cladding }}=6,541 \mathrm{~kg} / \mathrm{m}^{3} \times 0.26695 \mathrm{~m}^{3}=330.8 \mathrm{~kg} .
$$

For thermal calculations, it is essential that the effective mass (and density) and specific heat product be conserved and, therefore, equal to the sum of the fuel and cladding parts:

$$
\left(\mathrm{M} \times \mathrm{C}_{\mathrm{p}}\right)_{\text {eff }}=\mathrm{M}_{\text {fuel }} \times \mathrm{C}_{\mathrm{p} \text {-furel }}+\mathrm{M}_{\text {cladding }} \times \mathrm{C}_{\mathrm{p} \text {-cladding }}
$$

where $\mathrm{C}_{\mathrm{p} \text {-fuel }}=122.67 \mathrm{~J} / \mathrm{kg} / \mathrm{K}$ (Duncan 1998) and $\mathrm{C}_{\text {p-cladding }}=306.1 \mathrm{~J} / \mathrm{kg} / \mathrm{K}$ (Scott 1965). 


\section{HNF-SD-SNF-CN-023 REV 1}

For convenience, the effective specific heat is set equal to the specific heat of uranium and the effective mass calculated, which can be done since it's the product that must be conserved. Hence, the equation above becomes the following after dividing by the uranium specific heat:

$$
\begin{aligned}
M_{\text {eff }} & =M_{\text {fuel }}+M_{\text {cladding }} \times C_{\text {p-cladding }} / C_{\text {p-fiuel }} \\
& =5,072 \mathrm{~kg}+330.8 \mathrm{~kg} \times(306.1 \mathrm{~J} / \mathrm{kg} / \mathrm{K} \div 122.67 \mathrm{~J} / \mathrm{kg} / \mathrm{K}) \\
& =5,897.4 \mathrm{~kg} .
\end{aligned}
$$

Since the Zircaloy- 2 cladding has a higher heat capacity than uranium, the effective mass (in regards to mass times heat capacity product) is larger than just the sum of the masses. Using the calculated effective combined mass of the fuel and cladding above, the effective density of the fuel-cladding composite is simply the effective mass divided by the total volume:

$$
\begin{aligned}
\rho_{\text {eff }}= & M_{\text {eff }} / V_{\text {total }} \\
& =5,897.4 \mathrm{~kg} / 0.31752 \mathrm{~m}^{3} \\
& =18,573.3 \mathrm{~kg} / \mathrm{m}^{3} .
\end{aligned}
$$

The temperature dependence of densities, specific heats, and conductivities is ignored in the analysis because the HANSF code does not have the capability to handle temperature-dependent material properties (Plys et al. 1998). In order to be consistent, the material parameter values were chosen at around $100^{\circ} \mathrm{C}$ and rounded off.

Note 10 Uranium mass density - The mass density of uranium is about $19,000 \mathrm{~kg} / \mathrm{m}^{3}$ at $100^{\circ} \mathrm{C}$. Since the HANSF code (Plys et al. 1998) does not include temperaturedependent material parameters, approximate values are used. The standard reference temperature of $100^{\circ} \mathrm{C}$ was chosen because it's higher than normal operating temperatures but lower than most temperatures during off-normal conditions.

Note 11 Stainless steel mass density - The mass density of 304L stainless steel is about $8,000 \mathrm{~kg} / \mathrm{m}^{3}$ at $100^{\circ} \mathrm{C}$ (ORNL 1987). See the discussion above in Note 10 about temperature-dependent material properties.

Note 12 Effective fuel-cladding thermal conductivity - Since the fuel elements and cladding are combined in the model, an effective thermal conductivity is needed to represent the combined materials. Although the cladding has a lower conductivity, the conductivity of both metals is high, so the calculation of an effective thermal conductivity is not important to the calculational results. 


\section{HNF-SD-SNF-CN-023 REV 1}

The effective thermal conductivity, $\mathrm{K}_{\text {eff }}$, was estimated using the following equation, which is valid for conductors connected in series such as the fuel and cladding in the radial direction:

$$
\mathrm{x}_{\text {total }} / \mathrm{K}_{\text {cff }}=\mathrm{x}_{\text {fucl }} / \mathrm{K}_{\text {fuel }}+\mathrm{x}_{\text {cladding }} / \mathrm{K}_{\text {cladding }}
$$

where

$$
\begin{aligned}
& \mathrm{K}_{\text {fucl }}=\text { thermal conductivity of spent fuel }(26.9 \mathrm{~W} / \mathrm{m} / \mathrm{K} \text { [Kaufman 1962]) } \\
& \mathrm{K}_{\text {cladding }}=\text { thermal conductivity of Zircaloy- } 2 \text { cladding }(13.4 \mathrm{~W} / \mathrm{m} / \mathrm{K} \text { [Scott 1965]) } \\
& \mathrm{X}_{\text {total }}=\text { total radial thickness of fuel element and cladding }\left(\mathrm{x}_{\text {fuel }}+\mathrm{X}_{\text {cladding }}\right) .
\end{aligned}
$$

Since the cladding mass is about 7\% of the spent fuel mass (Duncan 1998) and the cladding density is about one-third of the fuel density, the cladding was estimated to have about $20 \%(\sim 7 \% \times 3)$ of the combined fuel-cladding volume for both inner and outer fuel elements on the average. The thickness is proportional to the volume, therefore the cladding thickness is estimated to be $0.2 \times \mathrm{x}_{\text {fuel }}$ making the total thickness $1.2 \times \mathrm{x}_{\text {full }}$. Substituting these values into the equation above, the value of $\mathrm{K}_{\text {eff }}$ is derived to be $24.2 \mathrm{~W} / \mathrm{m} / \mathrm{K}$, which is close to fuel conductivity value.

Note 13 Effective fuel-cladding (and uranium) specific heat - As discussed in Note 9, which derived the effective mass density, the effective specific heat for the combined fuel and cladding elements was chosen to be equal to the uranium specific heat, $122.67 \mathrm{~J} / \mathrm{kg} / \mathrm{K}$ at $100^{\circ} \mathrm{C}$ (Kaufman 1962). This choice was in conjunction with the effective mass density calculation since it is the product of mass density and specific heat that must be conserved (i.e., the specific heat of the cladding is included in the effective mass density [see Note 9]).

Note 14 The water in hydrates was increased to $1.16 \mathrm{~kg}$ for this report in order to provide extra margin over the hydrate water reported elsewhere (e.g., $0.65 \mathrm{~kg}$ [Reilly 1998]). However, for the "normal" suite of 13 runs, case 0 , which simulates a complete drying cycle with tests, the hydrate water was reduced to $0.72 \mathrm{~kg}$ (Sloughter 1997) because the decomposing hydrates can affect the rebound pressure tests after vacuum drying.

Note 15 Scrap basket volume - Based on the latest design drawings (Smith 1998), the scrap basket has a free volume of $0.153 \mathrm{~m}^{3}$ when it contains $980 \mathrm{~kg}$ of uranium metal. This volume includes the $0.0533-\mathrm{m}$ ( 2.1 -in) gap between the scrap basket and the bottom of the MCO assembly (below the shield plug) and $0.159 \mathrm{~m}^{3}$ void space (manifold) in the MCO assembly (Pajunen and Klimper 1998) that is always open to the MCO on top. The scrap basket volume excludes the volume of the stainless steel parts, support post inner volumes, and insert inner volume. The total length of the inner MCO is $3.6 \mathrm{~m}$ (141.85 in.) which includes a $0.0533-\mathrm{m}$ (2.1-in.) gap above the scrap basket and a $0.0381-\mathrm{m}$ (1.5-in) gap between the bottom fuel basket and the top of MCO bottom plate. The inner radius of the MCO is $0.2921 \mathrm{~m}$ (11.5 in.). 
Note 16 Upper fuel volume (two fuel baskets) - The two upper fuel baskets are combined into one control volume in the HANSF model (Plys et al. 1998). The free volume for the two fuel baskets, excluding the stainless steel volume and inner volume of support posts and insert, is $0.186 \mathrm{~m}^{3}$ based on the design drawings (Smith 1998).

Note 17 Lower fuel volume (two fuel baskets) - The bottom two fuel baskets have a combined free volume of $0.199 \mathrm{~m}^{3}$. This volume includes the $0.0381-\mathrm{m}(1.5-\mathrm{in})$ gap below the bottom fuel basket and above the MCO bottom plate and excludes the stainless steel volume and inner volume of support posts and insert.

Note 18 Fine scrap porosity - The porosity of the fine scrap fuel $(0.25$ in. to 1 in. maximum dimension) in the scrap basket is the void or gas space fraction (void volume divided by total volume) in the total scrap volume when the scrap is completely dry. The porosity of porous media such as a course sand is about 0.35 to 0.45 . The porosity of fine scrap was calculated to be in the same range (Plys and Malinovic 1997): A fine scrap porosity of 0.40 was chosen for this analysis.

Note 19 Course scrap porosity - The largest dimension of the course scrap will not be less than 1 in. or greater than 3 in. The total open volume of an empty scrap basket is $0.16762 \mathrm{~m}^{3}$ (total inner volume minus the insert and copper fin volumes). The fine scrap volume is $0.01592 \mathrm{~m}^{3}$, and the course scrap volume is $0.1517 \mathrm{~m}^{3}$. The total solid scrap volume is calculated by dividing the total bounding scrap mass, $980 \mathrm{~kg}$, by the fuel mass density, $19,000 \mathrm{~kg} / \mathrm{m}^{3}$, resulting in a total solid volume of $0.05158 \mathrm{~m}^{3}$. The solid (fuel) volume in the fine portion is 0.6 (1-porosity) times the total fine scrap volume, $0.01592 \mathrm{~m}^{3}$, resulting in $0.009552 \mathrm{~m}^{3}$. Hence, the coarse scrap solid volume is $0.05158 \mathrm{~m}^{3}$ minus the fine scrap solid volume, $0.009552 \mathrm{~m}^{3}$, for a value of $0.042028 \mathrm{~m}^{3}$. Dividing the coarse scrap solid volume by the total coarse scrap volume gives the solid fraction of $0.042028 \mathrm{~m}^{3} \div 0.1517 \mathrm{~m}^{3}=0.27707$ for the coarse portion. Hence, the porosity of the coarse scrap is just $1.0-0.27707$ for a coarse scrap porosity value of 0.72293 .

Note 20 Flow area in scrap basket bottom - The flow area at the bottom of the scrap basket is the only flow area available for the scrap and the total gas release out of the top of the $\mathrm{MCO}$ during vacuum drying. Since copper shims have been added between the outer scrap basket and MCO wall, the upward flow has nowhere to go except through the bottom of the scrap basket. The scrap basket bottom has 108 open 0.5 -in. diameter holes (Smith 1998) in it. Hence, the total flow area is calculated as follows:

$$
\begin{aligned}
A_{\mathrm{SB}} & =108 \times 3.14159 \times(0.5 \times 0.0254 / 2)^{2} \mathrm{~m}^{2} \\
& =108 \times 1.2668 \times 10^{-4} \mathrm{~m}^{2} \\
& =0.0137 \mathrm{~m}^{2}
\end{aligned}
$$

which was truncated to $0.013 \mathrm{~m}^{2}$ in order to constrict the gas flow through the scrap basket a little more to account for the wire screen covering part of the holes. 


\section{REFERENCES}

Duncan, D. R., and D. E. Ball, 1997, Thermal Analysis of Cold Vacuum Drying of Spent Nuclear Fuel, HNF-SD-SNF-CN-023, Rev. OA, Fluor Daniel Hanford, Incorporated, Richland, Washington.

Holden, A. N., 1958, Physical Metallurgy of Uranium, Addison-Wesley Publishing Company, Reading, Massachusetts.

Irwin, J. J., C. R. Miska, C. C. Pitkoff, and R. Whitehurst, 1998, Spent Nuclear Fuel Project Cold Vacuum Drying Facility Operations Manual, SNF-2356, Rev. OA, Fluor Daniel Hanford Incorporated, Richland, Washington.

Kaufman, A. R., 1962, Nuclear Reactor Fuel Elements, Interscience Publication, New York, New York.

Kessler, S., and S. Peck 1998, Criticality Safety Evaluation Report for the K Basin Fuel Retrieval Subproject, HNF-SD-SNF-CSER-010, Rev. 0, Fluor Daniel Hanford, Incorporated, Richland, Washington.

ORNL, 1987, Nuclear Systems Material Handbook, Volume 1, "Design Data," TID 26666, Oak Ridge National Laboratory, Oak Ridge, Tennessee.

Pajunen, A. L., and S. C. Klimper, 1998, Inert Gas Requirements for Cask Loading, HNF-2833, Rev. 0, Fluor Daniel Hanford, Incorporated, Richland, Washington.

Plys, M. G., and B. Malinovic, 1997, Scrap Reactive Surface Area Estimates, FAI/97-1 13, Rev. 1, Fauske \& Associates, Inc., Burr Ridge, Illinois.

Plys, M. G., and D. R. Duncan, 1998, Simulation of Normal and Off-Normal Multi-Canister Overpack Behavior, HNF-2256, Rev. 1, Fluor Daniel Hanford, Incorporated, Richland, Washington.

Plys, M. G., S. J. Lee, and M. Epstein, 1997, Application of N-Reactor Fuel Oxidation Data to Simulation of Air Ingress into a Multi-Canister Overpack, FAI/97-138, Fauske \& Associates, Inc., Burr Ridge, Illinois.

Plys, M. G., S. J. Lee, B. Malinovic, and M. Epstein, 1998, Hanford Spent Nuclear Fuel Safety Analysis Model HANSF 1.2: User's Manual, FAl/98-40, Rev. 0, Fauske \& Associates, Incorporated, Burr Ridge, Illinois.

Reilly, M. A., 1998, Spent Nuclear Fuel Project Technical Databook, HNF-SD-SNF-TI-015, Rev. 4, Fluor Daniel Hanford, Incorporated, Richland, Washington. 


\section{HNF-SD-SNF-CN-023 REV 1}

Scott, D. B., 1965, Physical and Mechanical Properties of Zircaloy-2 and 4, WCAP-3269-41, Westinghouse Electric Corporation, Pittsburgh, Pennsylvania.

Sloughter, J. P., 1997, Estimates of Particulate Mass in Multi-Canister Overpacks, HNF-1527, Rev. 0, Fluor Daniel Hanford, Incorporated, Richland, Washington.

Smith, K. E., 1998, Multi-Canister Overpack Design Report, HNF-SD-SNF-DR-003, Rev. 1, Fluor Daniel Hanford, Incorporated, Richland, Washington.

Weakley, E. A., 1979, Fuels Engineering Technical Handbook, UNI-M-61, United Nuclear Industries, Richland, Washington. 
HNF-SD-SNF-CN-023 REV 1

APPENDIX D

DERIVATION OF VIEW FACTORS FOR RADIATIVE THERMAL MODEL 


\section{HNF-SD-SNF-CN-023 REV 1}

This page intentionally left blank. 


\section{倞}

Fauske \& Associates, Inc.

DATE: June 8,1998

TO: Melvin G. Piepho, FDNW

Martin G. Plys

Boro Malinovic

FROM: Sung Jin Lee A.y.

\section{SURJECT: Calculation of View Factors Between Fuel Rods in MCQ}

\subsection{NTRODUCTION}

In HANSF code, the radiation heat transfer between individual fuel elements inside the 30-degree sector of a fuel basket in MCO is considered. This 30-degree sector defines the computational unit cell, as shown in Figure 1. The view factor between the inner and oyter elements of each fuel rod is obviously one, a trivial result. Therefore, an analysis was done to determine the view factors between the outer elements and the MCO wall.

\subsection{METHODS}

It should be noted that view factors for direct radiation from an in-sector donor to an outof-sector receiver must be incorporated by effectively adding that view factor to the in-sector mirror-image of the actual receiver node. For example (refer to Figure 1), the view factor which accounts for "Shine" from heat sink 6 that passes between heat sinks 4 and 8 is simply added to the view factor for radiation from 6 to 8 . This way, all direct radiation paths are accounted for.

A close examination of the fuel rods arrangement inside the MCO reveals that the complete view factor matrix can be derived from the view factors of three basic configurations:

1. View factor to a adjacent fuel rod, $\mathrm{F}_{\mathrm{a}}$.

2. View factor to a second tier fuel rod through the gap, $F_{b}$.

3. View factor to a second tier fuel rod partially blocked by an adjacent rod, $\mathrm{F}_{\mathrm{c}}$.

These, with the requirement that sum of view factors from a surface must be one, and the symmetry relationship, $A_{i-j} F_{i-j}=A_{j-i} F_{j-i}$, provide sufficient information to determine the complete view factor matrix.

16W070 West 83rd Street - Burr Ridge, Illinois 60521 - Phone: (630) 323-8750

Telefax: (630) 986-5481 •E-Mail: fai@fauske.com 
MEMO: Calculation of

Figure 1: A 30-Degree Unit Sector of a Fuel Basket.

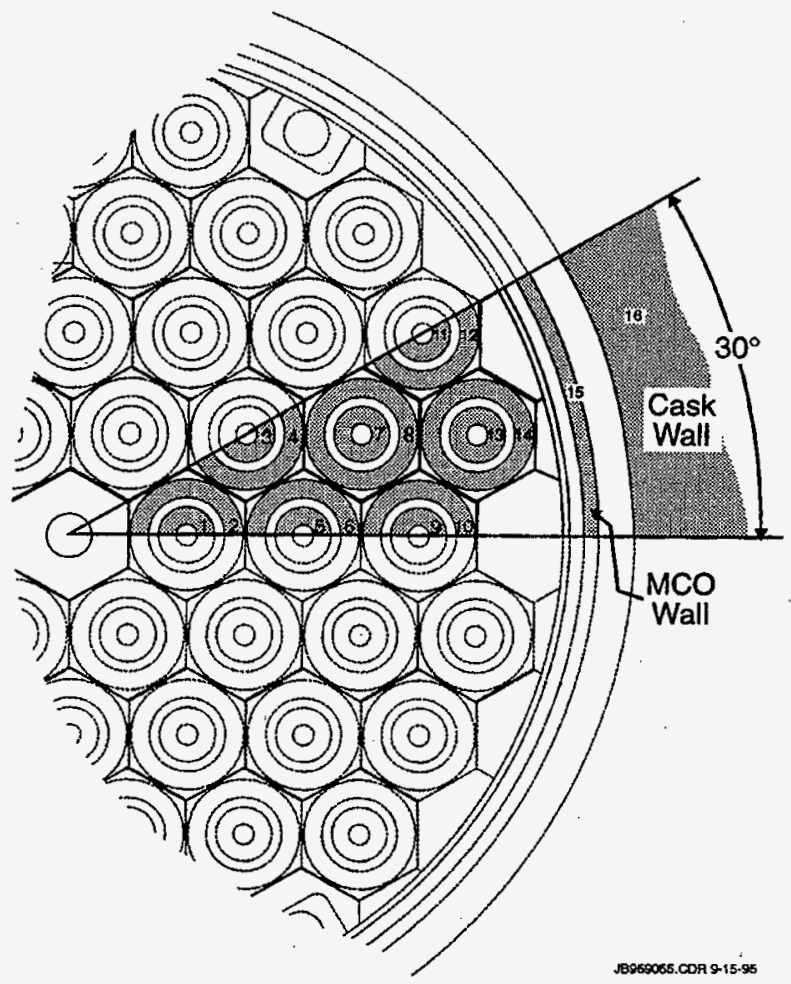




\section{HNF-SD-SNF-CN-023 REV 1}

MEMO: Calculation of

Page 3

June 8, 1998

View Factors Between

Fuel Rods in MCO

A computer program VIEWF was used to calculate the view factors for the above three basic configurations. This program computes the view factor matrix for a network of multiple planar or circular surfaces using the first principle view factor definition. The description of this program is included in Attachment 1. Six fuel rods and a 60 degree sector of the MCO wall were chosen as inputs to this code, as shown in Figure 2. They were chosen judiciously so that the result can provide the view factors for above three configurations $\left(F_{a}, F_{b}\right.$, and $\left.F_{c}\right)$.

\subsection{RESULTS}

The input deck to VIEWF is shown in Table 1. The output from the program is shown in Table 2. Since seven surfaces are specified in the input deck (the MCO wall is the seventh surface), the output lists a 14-by-14 view factor matrix because each surface has inside and outside. Therefore,
A. view factor to an adjacent fuel rod $=F_{\mathrm{a}}=0.153$,
B. view factor to a second tier fuel rod through the gap $=F_{b}=0.014$, and
C. view factor to a second tier fuel rod when the path is partially covered $=\mathrm{F}_{\mathrm{c}}=0.049$.

Now, the derivation of the actual view factor between individual fuel rods and the MCO wall inside the 30-degree sector is shown in Table 3. These are documented in Table 3-3 of the HANSF 1.2 User's Manual [1], and are provided as inputs to the HANSF code.

\subsection{REFERENCE}

[1] FAI/98-40, Rev. 0, "Hanford Spent Nuclear Fuel Safety Analysis Model HANSF 1.2: User's Manual," May 1998. 
MEMO: Calculation of

View Factors Between

Fuel Rods in MCO

Figure 2: Input Configuration to VIEWF Program.

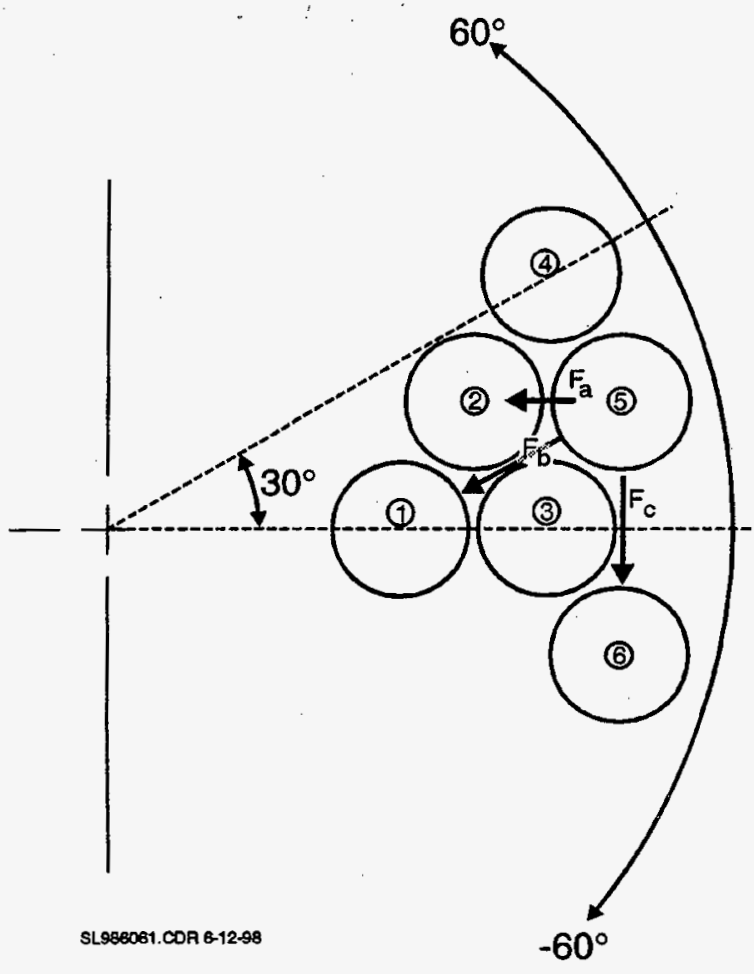


HNF-SD-SNF-CN-023 REV 1

MEMO: Calculation of Page 5

June 8, 1998

View Factors Between

Fuel Rods in MCO

Table 1

Input Deck to VIEWF Program

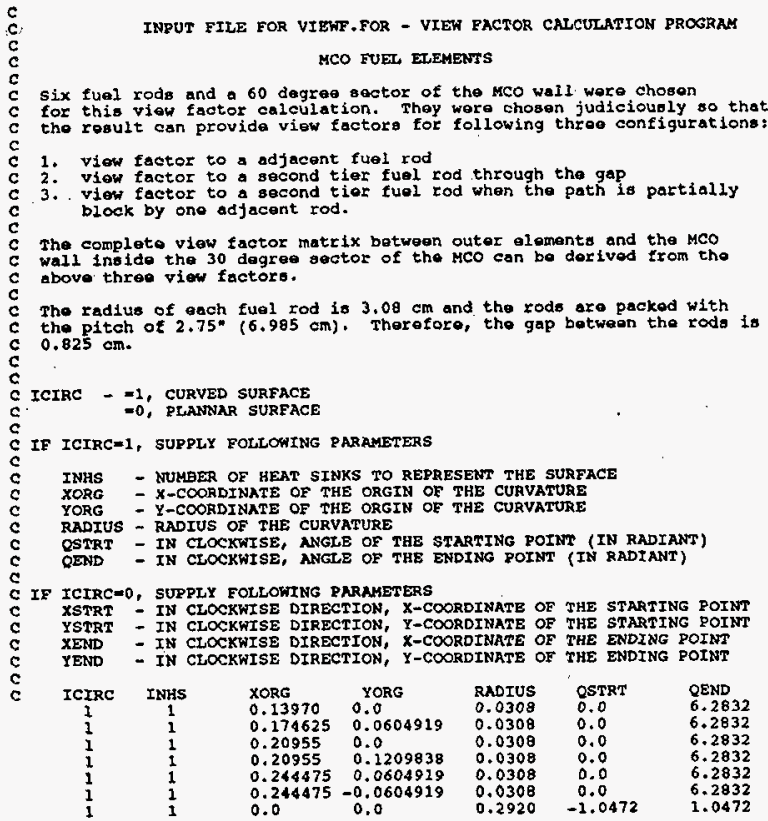


HNF-SD-SNF-CN-023 REV 1

MEMO: Calculation of

Page 6

June 8, 1998

View Factors Between

Fuel Rods in MCO

Table 2

Output of VIEWF Program

VIEW FACTORS

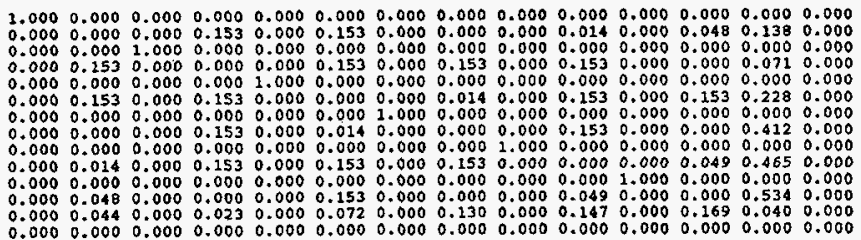


Table 3: Derivation of View Factors

\begin{tabular}{|c|c|c|c|c|c|c|c|c|c|}
\hline & 2 & 4 & 6 & 8 & 10 & 12 & 14 & 15 & $\sum F_{i-j}$ \\
\hline 2 & $\begin{array}{c}3 \mathrm{~F}_{\mathrm{a}}+2 \mathrm{~F}_{\mathrm{b}}-\mathrm{F}_{\mathrm{b}} \\
=0.473\end{array}$ & $\begin{array}{l}2 F_{a}+F_{b} \\
=0.320\end{array}$ & $\begin{array}{l}F_{a}+2 P_{b} \\
=0.181\end{array}$ & $\begin{aligned} & 2 F_{b} \\
= & 0.028\end{aligned}$ & 0 & 0 & 0 & 0 & 1,002 \\
\hline 4 & $\begin{aligned} & F_{2-4} \\
= & 0.320\end{aligned}$ & $\begin{aligned} & 2 F_{b} \\
= & 0.028\end{aligned}$ & $\begin{aligned} & 2 F_{\mathrm{a}} \\
= & 0.306\end{aligned}$ & $\begin{aligned} & 2 \mathrm{~F}_{\mathrm{a}} \\
= & 0.306\end{aligned}$ & $\begin{aligned} & 2 F_{b} \\
= & 0.028\end{aligned}$ & $\begin{aligned} & F_{\mathbf{b}_{1}} \\
= & 0.014\end{aligned}$ & 0 & 0 & 1.002 \\
\hline 6 & $\begin{aligned} & F_{2-6} \\
= & 0.181\end{aligned}$ & $\begin{aligned} & F_{4-6} \\
= & 0.306\end{aligned}$ & 0 & $\begin{array}{l}2 F_{a}+2 F_{b} \\
=0.334\end{array}$ & $\begin{aligned} & F_{\mathrm{a}} \\
= & 0.153\end{aligned}$ & 0 & $\begin{aligned} & 2 F_{b} \\
= & 0.028\end{aligned}$ & 0 & 1.002 \\
\hline 8 & $\begin{array}{l}F_{2-8} / 2 \\
=0.014\end{array}$ & $\begin{array}{l}F_{4-8} / 2 \\
=0.153\end{array}$ & $\begin{array}{l}F_{6-8} / 2 \\
=0.167\end{array}$ & $\begin{array}{l}F_{a}+F_{b} \\
=0.167\end{array}$ & $\begin{aligned} & \mathbf{F}_{\mathrm{a}} \\
= & 0.153\end{aligned}$ & $\begin{aligned} & F_{\mathrm{a}} \\
= & 0.153\end{aligned}$ & $\begin{array}{l}F_{a}+F_{b} \\
=0.167\end{array}$ & $\begin{aligned} & 2 F_{\mathrm{b}} \\
&= 0.028 \\
&\end{aligned}$ & 1.002 \\
\hline 10 & $\begin{array}{c}F_{2-10} \\
=0\end{array}$ & $\begin{aligned} & F_{4-10} \\
= & 0.028\end{aligned}$ & $\begin{aligned} & F_{6-10} \\
= & 0.153\end{aligned}$ & $\begin{aligned} & 2 F_{8-10} \\
= & 0.306\end{aligned}$ & 0 & $\begin{aligned} & 2 F_{b} \\
= & 0.028\end{aligned}$ & $\begin{aligned} & 2 \mathrm{~F}_{\mathrm{a}} \\
= & 0.306\end{aligned}$ & $\begin{array}{l}F_{a}+2 F_{b} \\
=0.181\end{array}$ & 1.002 \\
\hline 12 & $\begin{array}{c}\mathrm{F}_{2-12} \\
=0\end{array}$ & $\begin{array}{c}F_{4-12} \\
=0.014\end{array}$ & $F_{6-12}$ & $\begin{array}{l}2 F_{8-12} \\
=0.306\end{array}$ & $\begin{aligned} & F_{10-12} \\
= & 0.028\end{aligned}$ & 0 & $\begin{aligned} & 2 F_{\mathrm{a}} \\
= & 0.306\end{aligned}$ & $\begin{array}{r}2 \mathrm{~F}_{\mathrm{a}}+3 \mathrm{~F}_{\mathrm{b}} \\
=0.348\end{array}$ & 1.002 \\
\hline 14 & $\begin{array}{c}\mathrm{F}_{2-14} / 2 \\
=0\end{array}$ & $\underset{4-14}{=} / 2$ & $\begin{array}{l}\mathrm{F}_{6-14} / 2 \\
=0.014\end{array}$ & $\begin{array}{c}F_{8-14} \\
=0.167\end{array}$ & $\begin{array}{c}F_{10-14} / 2 \\
=0.153\end{array}$ & $\begin{array}{c}F_{12-14} / 2 \\
=0.153\end{array}$ & $\begin{aligned} & F_{\mathrm{c}} \\
= & 0.049\end{aligned}$ & $\begin{aligned} 3 F_{a}+4 F_{b} \\
-F_{c} \\
=0.466\end{aligned}$ & 1.002 \\
\hline 15 & $\begin{array}{l}\frac{A_{2}}{A_{15}} F_{2 \cdot 15} \\
\quad=0\end{array}$ & $\begin{array}{l}\frac{A_{4}}{A_{15}} F_{4-15} \\
\quad=0\end{array}$ & $\begin{array}{l}\frac{A_{6}}{A_{15}} \mathrm{~F}_{6-15} \\
\quad=0\end{array}$ & $\begin{array}{l}\frac{A_{8}}{A_{15}} F_{8-15} \\
=0.0354\end{array}$ & $\begin{array}{l}\frac{A_{10}}{A_{15}} F_{10-15} \\
=0.1146\end{array}$ & $\begin{array}{l}\frac{A_{12}}{A_{15}} F_{12-15} \\
=0.2202\end{array}$ & $\begin{array}{l}\frac{A_{14}}{A_{15}} F_{14-15} \\
=0.5898\end{array}$ & $\begin{array}{c}1-F_{15-8} \\
-F_{15-10} \\
-F_{15-12} \\
-F_{15-14} \\
=0.04\end{array}$ & 1.000 \\
\hline
\end{tabular}

$$
\begin{array}{ll}
\mathrm{F}_{\mathrm{a}}=0.153 & \mathrm{~A}_{2}=\mathrm{A}_{4}=\mathrm{A}_{6}=\mathrm{A}_{10}=\mathrm{A}_{12}=2 \pi(0.0308) / 2=0.09676 \\
\mathrm{~F}_{\mathrm{b}}=0.014 & \mathrm{~A}_{8}=\mathrm{A}_{14}=2 \pi(0.0308)=0.19352 \\
\mathrm{~F}_{\mathrm{c}}=0.049 & \mathrm{~A}_{15}=(30 / 360) 2 \pi(0.292)=0.15289
\end{array}
$$


HNF-SD-SNF-CN-023 REV 1

\section{ATTACHMENT 1}




\section{公}

Fauske \& Associates, Int.

DATE: August 22, 1995

TO: $\quad$ All FAI Engineers

FROM: Sung Jin Lee $\Delta d$.

\section{SUBJECT: Program VIEWF: View Factor Calculation Program}

\subsection{INTRODUCTION}

Fortran program VIEWF.FOR computes view factors for multiple surfaces. Currently, the program is written to handle two-dimensional configurations, but the algorithm as described herein is generalized to three-dimensional configurations. All surfaces must be either planar or sectors of a cylindrical shell. In two dimensions, these cortesponds to either a line segment or the arc of a circle. The user may subdivide a sector into a number of equal size "sub-sectors". Each surface has an inside and an outside face. Therefore, the computed view factor matrix for a system of $\mathrm{N}$ surfaces would be of dimension $2 \mathrm{~N}-\mathrm{by}-2 \mathrm{~N}$.

\subsection{HOW TO USE THE PROGRAM}

- Currently, the Fortran program and the executable code (VIEWF.EXE) reside in the directory:

\section{\$2\$DIA2:[MAAP4.LEE.PWR.HOT.MCO.VIEW]}

The user will be prompted to enter the input and the output file names. Each line in the input file contains a sequence of integers or real numbers (separated by one or more blanks) to describe one surface completely. Several such lines define a system of surfaces for which the view factors are to be computed. The tormat of an input line is:

or

ICIRC INHS XORG YORG RADIUS QSTRT QEND

ICIRC XSTRT YSTRT XEND YEND

where ICIRC $=1$, for a sector

$=0$, for a planar surface.

If $\operatorname{ICIRC}=1$, the tirst format is used,

16W070 West 83rd Sireer • Burr Ridge. Illinois 6052I • (708) 323-8750

Telefax (708) 986-5481 
where INHS = number of subdivisions in the sector,

XORG $=\mathrm{X}$-coordinate of the origin of the sector,

YORG $=$ Y-coordinate of the origin of the sector,

RADIUS = radius of the sector,

QSTRT = angle (in radians) of the starting point (counter-clockwise from $\mathrm{X}$-axis), and

QEND $\quad=$ angle (in radians) of the ending point.

If $\operatorname{ICIRC}=0$, the second format is used,

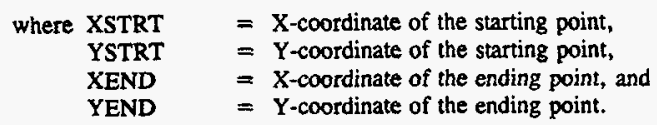

Also, comment lines can be added freely to the input file with " $C$ " in the first column. Sample input files (Appendix B) contain sufficient comment lines to guide the user to prepare a new input file.

The program writes the computed view factors to the output file in matrix format where element $f_{i j}$ designates the view factor $F_{i-j}$. Since there are two sides for each surface, the index$i$ is sequenced in the order of surface-1 inside, surface- 1 outside, surface- 2 inside, surface-2 outside, surface- 3 inside, etc. For example, $F_{5-8}$ designates the view factor of surface- 3 inside seeing surface- 4 outside.

To define inside and outside of a surface, it is instructive to draw a vector parallel to the surface as defined by the starting and the ending points of the surface. Then, rotate the vector 90 degrees clockwise to obtain the normal vector of the surface. The face in the same direction as the normal vector is herein defined as outside and the other as inside. Figure 1 illustrates how inside and outside are defined for surfaces.

\subsection{ALGORTTHM}

\subsection{Step 1}

Subdivide each surface into 10 nodes. For each surface node, determine its position coordinate $\left(x_{0}, y_{0}, z_{0}\right)$ and define a normal vector $\vec{n}=(a, b, c)$, such that the magnitude of the normal vector represents the area of the surface. Then, the equation of the plane passing through a point $P_{0}\left(x_{0}, y_{0}, z_{0}\right)$ with the normal vector $\vec{n}=(a, b, c)$ is given by

$$
a\left(x-x_{0}\right)+b\left(y-y_{0}\right)+c\left(z-z_{0}\right)=0
$$


MEMO: Program VIEWF:

View Factor Calculation Program
Page 3

August 22, 1995

Figure 1: Inside /Outside.
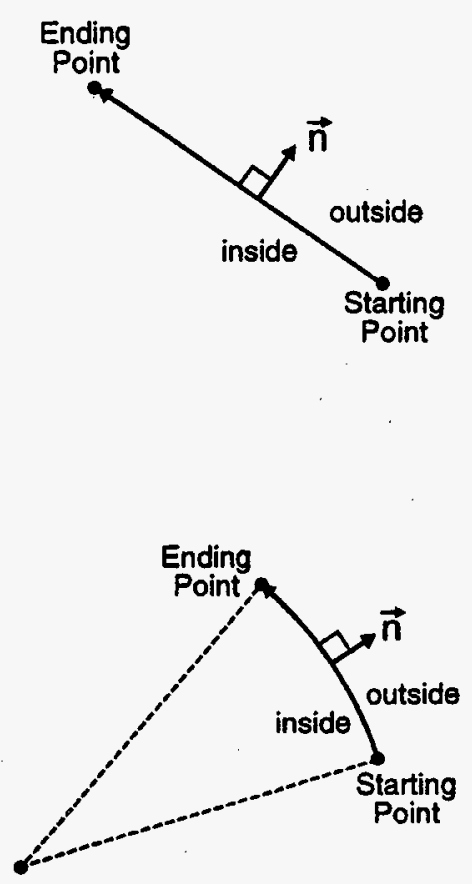

SL958093.CDR 8.21.05 


\section{HNF-SD-SNF-CN-023 REV 1}

MEMO: Program VIEWF:

Page 4

August 22, 1995

View Factor Calculation Program

\subsection{Sten2}

For each surface node, determine the view factor to every other surface node as follows:

a. Determine the vector joining the two surfaces as shown in Figure 2.

$$
\begin{aligned}
\vec{v} & =(\alpha, \beta, \gamma) \\
& =\left(x_{\mathrm{O}_{2}}-\mathrm{x}_{\mathrm{O}_{1}}, \mathrm{y}_{\mathrm{o}_{2}}-\mathrm{y}_{\mathrm{O}_{1}}, \mathrm{z}_{\mathrm{O}_{2}}-\mathrm{z}_{\mathrm{o}_{1}}\right)
\end{aligned}
$$

b. Equation of the line joining the two surfaces is represented by parametric equations:

$$
\begin{aligned}
& x=x_{0_{1}}+t \alpha \\
& y=y_{0_{1}}+t \beta \\
& z=z_{0_{1}}+t \gamma
\end{aligned}
$$

c. Determine whether the line joining the two surfaces is intercepted by a third surface node as shown in Figure 3. Hence, for every possible third surface, do the following calculation. The line intersects the third plane at $t=t$ * such that:

$$
\begin{aligned}
& a_{3}\left(x_{o_{1}}+t \alpha-x_{o_{3}}\right)+b_{3}\left(y_{o_{1}}+t \beta-y_{o_{3}}\right)+c_{3}\left(z_{o_{1}}+t \gamma-z_{o_{3}}\right)=0 \\
& \text { or } \\
& t *=\frac{-a_{3}\left(x_{o_{1}}-x_{o_{3}}\right)-b_{3}\left(y_{o_{1}}-y_{0_{3}}\right)-c_{3}\left(z_{o_{1}}-z_{o_{3}}\right)}{a_{3} \alpha+b_{3} \beta+c_{3} \gamma}
\end{aligned}
$$

Note that if $a_{3} \alpha+b_{3} \beta+c_{3} \gamma=0$, there is no intersection. Therefore, it intersects at $\left(x^{*}, y^{*}, z^{*}\right)$ where

$$
\begin{aligned}
& x *=x_{0_{1}}+t * \alpha \\
& y *=y_{0_{1}}+t * \beta \\
& z *=z_{0_{1}}+t * \gamma
\end{aligned}
$$

d. Check if the distance between the intersection point $\left(x^{*}, y^{*}, z^{*}\right)$ and the third surface coordinate $\left(\mathrm{x}_{\mathrm{O}_{3}}, \mathrm{y}_{\mathrm{O}_{1}}, \mathrm{z}_{\mathrm{O}_{3}}\right)$ is less than the square root of the surface area. That is, 


\section{HNF-SD-SNF-CN-023 REV 1}

MEMO: Program VIEWF:

Page 5

August 22, 1995

View Factor Calculation Program

Figure 2: A Vector Joining Two Surfaces.

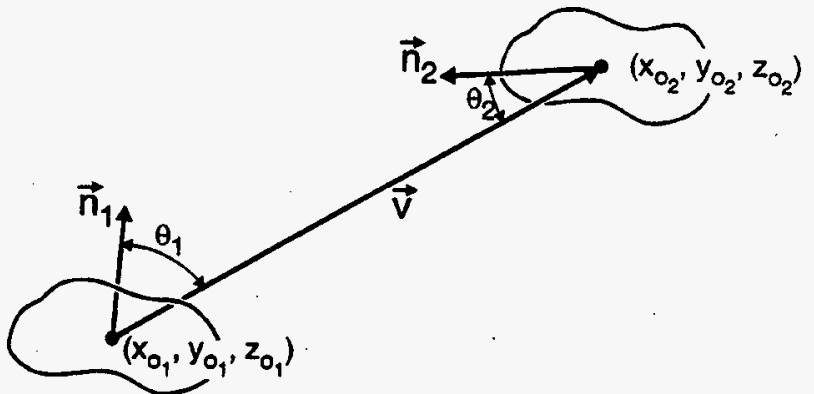

SL958005.CDR Q-21-05 
Figure 3: Line Joining Two Surfaces Intercepted by a Third Surface.

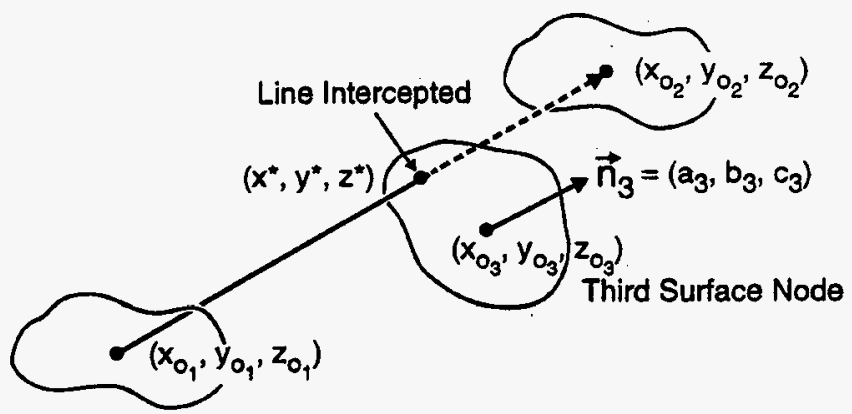

SL958097.COR 8.21 .95 
MEMO: Program VIEWF:

$$
\sqrt{\left(x^{*}-x_{a}\right)^{2}+\left(y^{*-1} y_{0_{3}}\right)^{2}+\left(z^{*}-z_{o_{3}}\right)^{2}}<\left(a_{3}^{2}+b_{3}{ }^{2}+c_{3}^{2}\right)^{1 / 4}
$$

If the inequality of equation (7) is satisfied, the line is intercepted by the third surface and the two surfaces cannot see each other.

Hence,

$$
F_{12}=0
$$

Otherwise, the subnode view factor can be computed as

$$
F_{12}=\frac{\cos Q_{i} \cos Q_{2}\left|\overrightarrow{n_{2}}\right|}{\pi|\vec{v}|^{2}}
$$

\section{$3.3 \quad \operatorname{sten} 3$}

Sum up subnode view factors to determine view factors between surfaces.

$$
F_{i j}=\sum_{k \in i} \sum_{l \in j} F_{k \ell}
$$

\subsection{VALIDATION}

The program was validated against analytical solutions for a variety of two-dimensional configurations. Seven configurations selected from page 459 of A Heat Transfer. Textbook by John $H$. Lienthard were tested. The results are summarized in Figure 4 . In general, the error was less than $3 \%$. Only for two concentric circles, $6 \%$ error was observed. It should be noted that the resolution can be improved by using finer mesh. Currently 10 meshes are used for each surface. Since the number of meshes is hardwired in the program, the program needs to be changed to increase the number of meshes. The input files for all seven cases are included in the Appendix B.

SJL:vdl 
MEMO: Program VIEWF:

Figure 4: View Eactors for a Variety of Two-Dimensional Configurations. (infinite in extent normal to the paper)

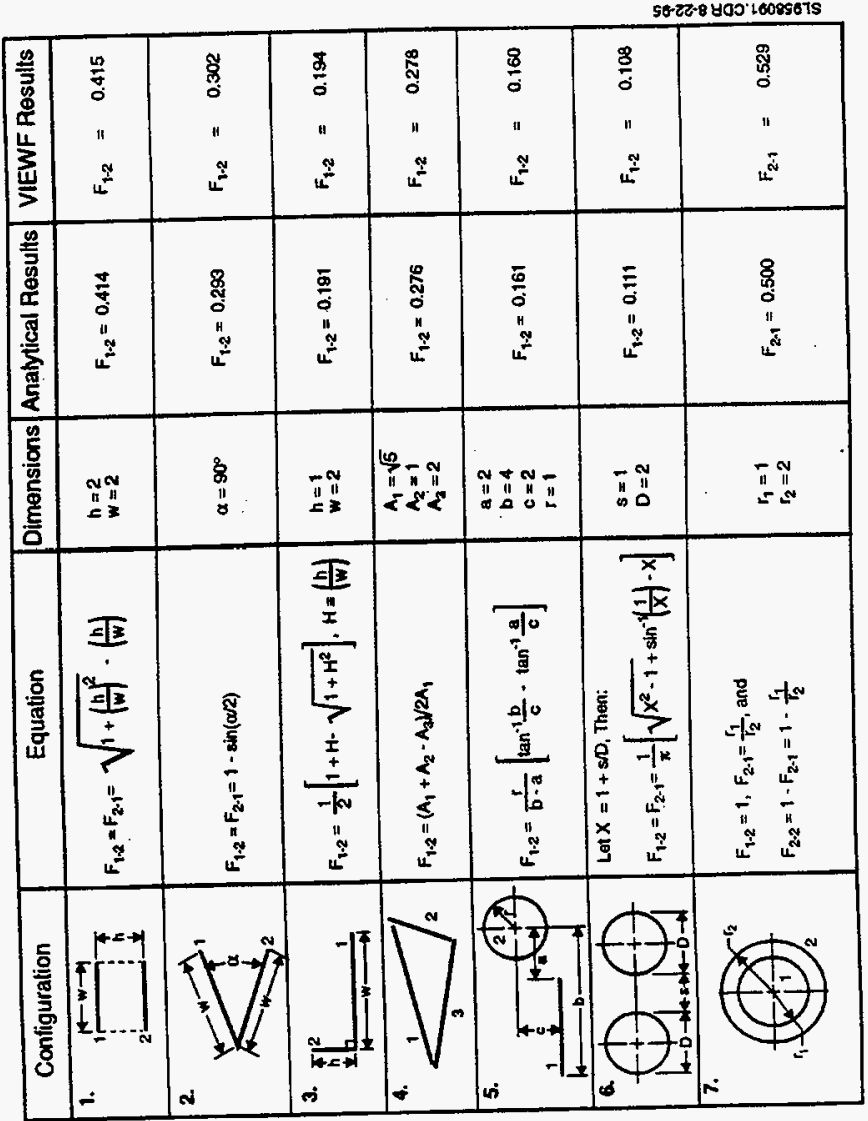


HNF-SD-SNF-CN-023 REV 1

\section{APPENDIX A}

\section{PROGRAM LISTING}


F11e: \$2SDIA2:[MAAP4,LEE. PUR, HOT.MCO.VIEU]VIEUR,FOR,40 Thu Aug 17 15:01:41 1995 Page 1

IHPLICIT RBAL (A-B, R-2)

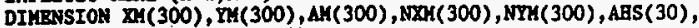

e $P(30,2,30,2)$, İSIM $(300)$

CHARACTBA +30 INEILB, OUTPIL, NUL

CBARACTER $* 132$ A

DATA PI/3.141593BO/,TINY/1.E-3/,AES/30*0.EO/, P/3600*0.EO/

NUL:,

C FOR NON, SUBDIVIDE EACE GEAT SIMR INTO 10 MBSEES

INMESA -20

IES $=0$

IMLO

URTTB $(*, *)$ 'That $1 \mathrm{~s}$ the input file nane ?'

RBAD $(*, 50)$ INPILB

50 PORKAT (A30)

VRITB $(*, *)$ 'What is the output file name ?'

$\operatorname{RBAD}(*, 50)$ OUTRIL

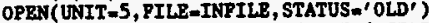

IF (OUTRIL +NB. NUL) OPEN(UNIT-6, PILE=OUTFIL, STATUS=' 'UNKNONN')

C LOOP POR READIKG LINBS FROH INTUT PILB

100 CONTINUB

$\operatorname{READ}(5,110, \mathrm{END}=1000) \mathrm{A}$

110 PORYAT (A132)

IP $(A(1: 1), B Q . ' C$ ') Goro 100

$\operatorname{RRAD}(A, *)$ ICIRC

IF (ICIRC . BO. 1) THBN

$\operatorname{RBAD}(A, *)$ ICIRC, INHS, YORG, YORG, RADIUS, OSTRT, OBND

C COORDINATB OR TAB STARTIKC POIN

XSTRT $=R A D I U S * \cos ($ OSTRT) + XORG

YSTRT-RADIUS *SIN(OSTRT) + YORG

C TOTAL ARC AHGLB

QARCT =OBND-OSTRT

IF (QARCT . LT. 0.BO) OARCT-OARCT+2. BO*PI

BLSB

RRAD (A, *) ICIRC, INHS, ISTRT, YSTRT, XBND, IBND

C VECTOR JOINING THB THO BND POINTS

L12X-XEND-XSTRT

L12\%-TEND-YSTRT

C MAGNITUDB OP THB VBCTOR

EAGL12 $=S O R T(L 12 X \star L 12 X+L 12 Y \star L 12 Y)$

C NORHALIZB THE VBCTOR

L12X-L12X/MAGL12

L12Y $=$ L12Y/MAGL12

BNDIF

$X 1=X S T R T$

Y1-YSTRI

DO 200 I-1, INAS

IHS $=\mathrm{IES}+1$

DO $300 \mathrm{~J}=1$, INIBSE

IH-IY +1

IHSIM(IH) $=$ IBS

IP (ICIRC . BQ. O) TERE.

$X 2=X S T R T+((I-1) *$ INIESB $+J) * L 12 X *$ KAGL12/INES/IMIASB

$72=7 S T R T+((I-1) * I N I A B S+J) * L 12 Y * M A G L 12 / I N B S / I N M B S B$ BLSB

$0-((I-1) *$ IMRBSB $+J) * 0 A R C T / I N H S /$ INRES

X2-(XSTRT-XORG)*COS $(Q)-($ YSTRT - YORG $) * S I N(0)+$ XORG BNDIP

$72=($ XSTRT - XORG $) \star S I N(0)+($ YSTRT -YORG $) * \operatorname{COS}(0)+$ YORG

C COORDINATE OP THB MESH 
File: \$2\$DIA2:[MAAP4.LBB.PHR.BOT.MCO.VIBI]VIEUT.POR;40 Thu Aug 17 15:01:41 1995 Page 2

c ARRA OF THB IBSA

$\mathrm{XH}(\mathrm{IM})=(\mathrm{X} 1+\mathrm{X2}) / 2 \cdot \mathrm{BO}$

$\mathrm{H}(\mathrm{IX})=(\mathrm{Y} 1+\mathrm{Y2}) / 2, \mathrm{BO}$

$A M(I K)=\operatorname{SORT}((X 2-Z 1) *(X 2-X 1)+(Y 2-Y 1) *(Y 2-Y 1))$

C INIT NORKAL VECTOR OP TBB MBSE

NXH(IM) $=-(Y 2-71)$

$\operatorname{NM}(I H)=X 2-X 1$

MAGM-SORT (NMI(IM) *NXH(IM) + NMA(IM) *WTM(IM))

NXI(IM) $=$ NXN (IM) / MAGNA

NYM(IH) $=N$ YH (IH) / LACNM

$\mathrm{X} 1=\mathbf{X 2}$

$Y 1=Y 2$

300 CONIINUB

200 CONIINUB

C READ TBE NEXT INAUT LINB GOTO 100

C BND OR INPUT LINB

1000 CONTINUB

c

INK=IK

IHSX Ins

DO 600 IMI-1, InX

IHSI =IASIH(IMI)

ARS (IBSI) $=A B S$ (IBSI) + AM (IMI)

DO 700 IMJ-1, IMX

IHSJ-IHSIM(IMJ)

IF (IKI . BQ. IHJ) GOTO 700

C DBTERHINB THE VBCTOR JOTNING TEB THO SURBACBS

$V \mathbf{X}=\mathrm{DI}(\mathrm{IHJ})-\mathrm{MI}(\mathrm{IHI})$

$V=\mathrm{H}($ IMJ) $-\mathrm{n}$ (IHI)

MAGV $=S O R T(V x * V x+V I * V)$

VX-VX/MAGV

$V T=V Y / M A G V$

C FOR BACE TETRD SURPACB, BVALUATB INRBRCEPTION

DO 800 IHT=1, IFX

IHSR-IBSIM(IHR)

IP (IMR . BO. IMJ , OR. IHR . BO. IHI) GOTO 800

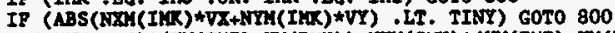

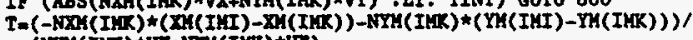

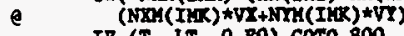

c INTERSECTION POINT

IE (T . LT. 0,80) Coro 800

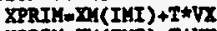

YPRIH $=$ MI (IMI) $+I * V Y$

IP (XPRIH .GT. TH(IKI) .AND. XPRIM .GT. XM(IMJ)) GOTO 800

IP (XPRIH .LT. XI(INI) .AND, XPRIM .LT. XH(IH) ) GOTO 800

IP (TRRII .GT. M(IHI) . AND. YPRIN .GT. YM(IMJ)) GOTO 800

IP (TPRIM ,LT. nI(IMI) .AND. YPRIM .LT. KM(IMJ)) GOTO 800

C DISTAKCB BBTYBSA IABS INTERSBCTIOA POINT AND THB SURFACB COORDINATB

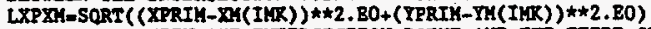

C CEBCK IP DISTANCB BBTUBEN TAB INIERSBCTION POINT AND TEB TEIRD SURACE

C COORDINATE IS LBSS TEAN SOUARB ROOT OF THB SURPACB ARBA.

C IP TRUB, TEBN INTBRCBPTBD

IP (LXPAH .LT. AN(IHL)/2. BO) GOTO 700

800 CONTINUS

VDOTHI $=$ NXI(IMI) $* V A+N M(I M I) * V I$

VDOTHJ $=N \times A 1(I M J) * V \times+N R H(I N J) * V T$

IF (VDOTHI .GB. O.BO) TEEN

C SIDE-1 OR RIRST SURPACB RADIATING TO 
F11e: \$2\$DIA2: [MAAP4.LBB.PUR.FOT.MCO.VIBI]VIBTF.FOR;40 Thu Aug 17 15:01:41 1995 Page 3 IF (VDOTW . GB. O.BO) THBS

C SIDR-2 OR SBCOND SURPACB

BH-VDOTHI*VDOMW*AL(IMI)*AM(IMJ)/2. BO/HAGV BLSB

$F($ IBSI, 1, IBSJ , 2) $=P($ IESI, 1, IESJ , 2) + PH

C. SIDB-1 OP SBCONB SURPACB

PME-VDOTHI *VDOTHJ*AM(IMI) *AM(IMJ) $/ 2.80 / \mathrm{MAGV}$

BLSE

P(IBSI, 1 , IBS , 1) $=$ P(IHSI, 1 , IHSJ , 1) + PH

C SIDE-2 OP PIRST SURFACE RADIATIKG TO

C SIDE-2 OR SECOND SURPACB

IR (VDOTHJ . GB. 0.BO) TaEN

PY=-VDOTHI *VDOTWJ*AH(IMI) *AM(IMJ) $/ 2 . \mathrm{EO} / \mathrm{MAGV}$

ELSB $P($ IHSI, 2, IBSJ , 2) $=P($ IHSI, 2, IHSJ, 2) + PH

C SIDB-1 OP SBCOND SURPACB

PK-VDOTHI *VDOTW J*AY(IMI)*AY (IMJ) $/ 2$, EO/MAGV

BNDTF

$\mathrm{P}(\mathrm{IHSI}, 2, \mathrm{IHSJ}, 1)=F($ IBSI, 2, IESJ, 1$)+\mathrm{FH}$

700 CONFINUS

c

600 contrive

Do 910 IASI=1, IHSX

DO 950 IBSJ 1 , IHSX

$P($ IBSI, 1, IBS J, 1) $=P($ IBSI, 1, IASJ , 1)/ABS(IHSI)

$P($ IBSI, 1, IBSJ , 2 ) - (IHSI, 1 , IBSJ, 2 )/ABS (IBSI)

$P($ IBSI, 2, IESJ, 1) $=$ (IESI, 2, IBSJ, 1)/ABS(IHSI)

950 contrive

P(IESI, 2, IESJ, 2) $=F$ (IASI, 2 , IBSJ, 2)/AHS (IHSI)

c

910 CoNIINUB

$\operatorname{WrTB}(6,1100)$.

1100 BORMAT (1X, 30X, 'VIE' PACTORS'/

e

$\operatorname{LIIR}(6, *)$

$\operatorname{VRIIB}(6, *)$

DO 1200 IHS -1 , IESX

URITB $(6,1210$ ) ((F(IBS, 1, JHS, I2), I2-1, 2), JHS=1, IHSX)

1210 FORMAT $(1 \bar{x}, 20(1), \mathrm{BS} .3))$

1200 CONIINUS

URITE (6,1210) ((P(IHS, 2,JBS, I2), I2-1, 2), JBS=1, IBSX)

STOP

BND 


\section{HNF-SD-SNF-CN-023 REV 1}

\section{APPENDIX B}

\section{INPUT FILES FOR TESTING}




\section{HNF-SD-SNF-CN-023 REV 1}

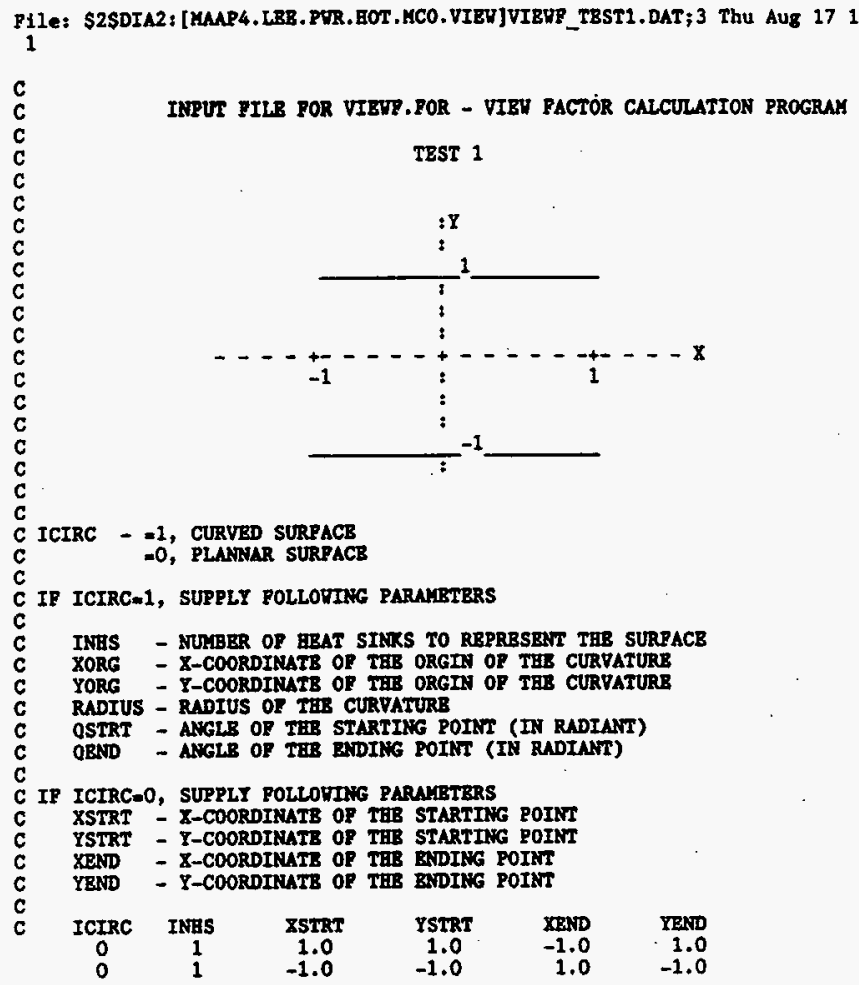


P11e: \$2\$DIA2: [MAAP4.LBE.PUR. BOT.MCO.VIBY]VIBUR_TBST2.DAT; 4 Thu AUg 17 15:01:54 1995 PaA

C INEUT PILB FOR VIBW.POR - VIBY FACTOR CALCULATION PROGRAY

TBST 2 - JOHN H. LIENEARD P459

C

C

C

C ICIRC $-=1$, CURVED SURFACB

C $\quad=0$, PLANMAR SURPACB

C IF ICIRC=1, SUPPLY POLLOUIKG PARAMBTRRS

c

C INES - NUNBBR OF BBAT SINKS TO RBPRESENT THR SURPACB

C XORG - X-COORDINATE OF THB ORGIN OP TES CURVATURB

C YORG - Y-COORDINATB OP THB ORGIN OR THB CURVATURB

C RADIUS - RADIUS OR THB CURVATURR

C OSTRT - ANGLB OP THB STARTING POTNT (IN RADTANT)

C OEND - ANGLB OR THB BNDIKG POIN (IN RADIANT)

C IR ICIRC $=0$, SURPLY POLLOUANG PARAMBTERS

C XSTRT - X-COORDINATB OR THB STARTING POINI

C YSTRT - $\Psi$-COORDINATB OF THB STARTIKG POTNT

C XEND - X-COORDINATB OR THB BHDING POIMI

C YEND - Y-COORDINATB OF TBB ERDING POINT

c

$\begin{array}{ccllll}\text { ICIRC } & \text { INES } & \text { XSTRT } & \text { YSTRT } & \text { XEND } & \text { YEFD } \\ 0 & 1 & 0.7071 & 0.7071 & 0.0 & 0.0 \\ 0 & 1 & 0.0 & 0.0 & 0.7071 & -0.7071\end{array}$




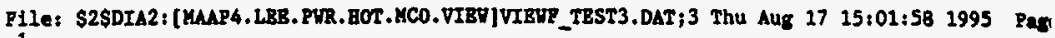
1

c

C INPUT FILB FOR VIBTP.FOR - VIBV PACTOR CALCULATION PROGRAM

c

c

$c$

C ICIRC - $=1$, CURVED SURPACR

C $=0$, PLANNAR SURFACB

C IP ICIRC-1, SUPPLY POLLOHING PARAMETERS.

C

c INES - NUABER OR GRAT SINXS TO RRPRESBAT THB SURPACB

C XORG - X-COORDINATE OP THB ORGTN OF THE CURVATURB

c YORG - Y-COORDINATB OR THB ORGIN OR THB CURVATURB

C RADIUS - RADIUS OP THE CURVATURB

c QSTRT - ANGLB OF THB STARTIIKG POIMT (IN RADIANT)

C OEND - ANGLE OF THE BNDING POINT (IN RADIANT)

c IP ICIRC-0, SUPPLY POLLOUTHG PARAKBTTERS

c XSTRT - X-COORDINATE OF TAB STARTING POINT

c YSTRT - Y-COORDINATB OP THB STARTIIIG POINT

c XBRD - X-COORDINATE OF THB BNDING POINT

c TEND - I-COORDINATS OP THE ENDING POINT

C ICIRC INES YSTRT ISTRT XBND YEND

$\begin{array}{cccccc} & & & & \\ 0 & 1 & 0.0 & 0.0 & 2.0 & 0.0 \\ 0 & 1 & 0.0 & 1.0 & 0.0 & 0.0\end{array}$


P11e: S2SDIA2: [MAAP4.LBE.PWR. HOT.MCO.VIBV]VIETE_TEST4.DAT; 3 Thu Aug 17 15:02:02 1995 Pa1 1

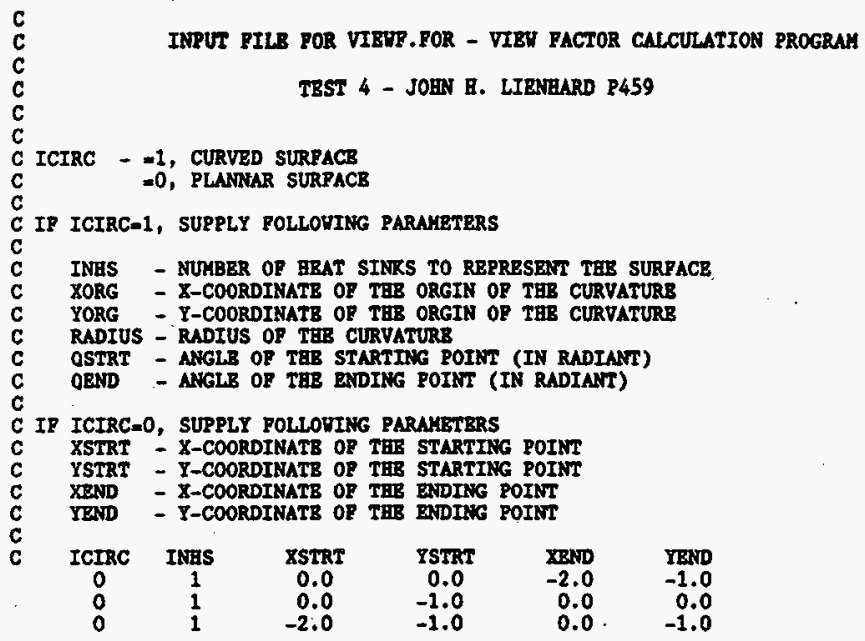


F11e: \$2SDIA2:[MAP4.LBE,PUR. BOT.MCO.VIBV]VIBUP_TESTS.DAT;10 Thu Aug 17 15:02:18 1995 P* e 1

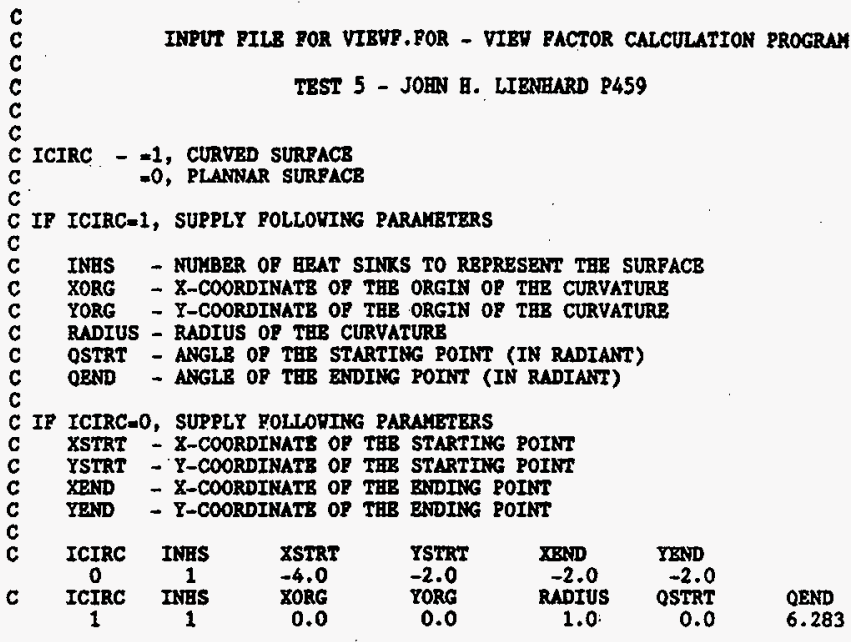




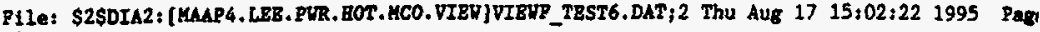
1

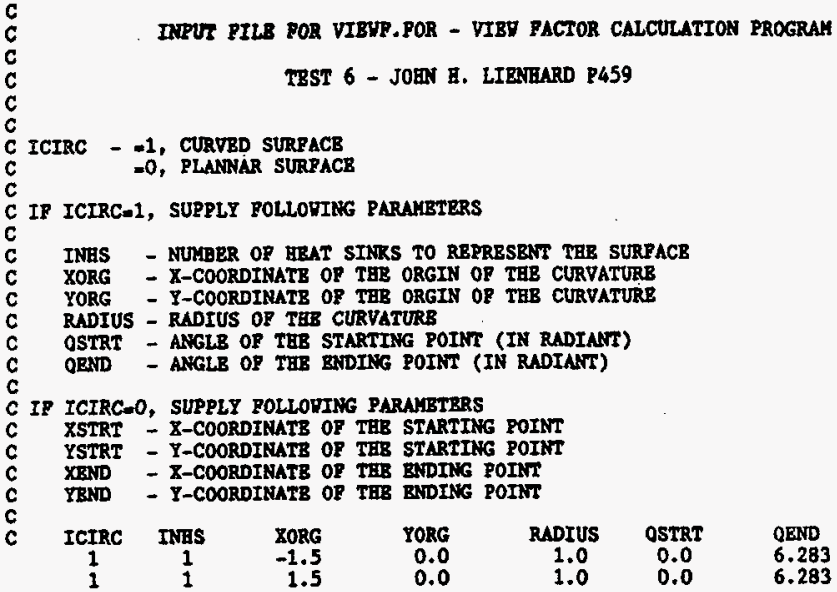


F1le: \$2SDIA2: [MAAP4.LBB.PTR. HOT.MCO.VIBU]VIBWF_TEST7.DAT;2 Thu Aug 17 15:02:28 1995 Pa4 1

C
c

C TBST 6 - JOBN H. LIENEARD P459

$\mathrm{C}$

C ICIRC - -1 , CURVBD SURPACB

c $=0$, PLANAMAR SURPACB

IF ICIRC-1, SUPPLY POLLOUIHG PARARTTBRS

C INBS - NUTBER OP BRAT SINTSS TO REPRBSENT THB SURFACB

C XORG - X-COORDIMATE OP THB ORGIN OP THE CURVATURR

c YORG - Y-COORDINATB OF THE ORGIN OF THE CURVATURB

C RADIUS - RADIUS OR THB CURVATURB

c QSTRT - ANGLB OP TEB STARTING POINT (IN RADIANT)

c OBND - ANGLB OP THB WNDING POINT (IN RADIANT)

C IP ICIRC=0, SUPPLI POLLOVING PARAKBTBRS

c XSTRT - X-COORDINATB OF THB STARTING POINT

c YSTRT - Y-COORDINATB OR THB STARTING POTNT

c XBND - X-COORDIMATB OP THB ENDING POINT

c TEND - Y-COORDINATB OR THB BNDING POINT

c

$\begin{array}{ccccccc}\text { ICIRC } & \text { INIS } & \text { XORG } & \text { TORG } & \text { RADIUS } & \text { OSTRT } & \text { OBND } \\ 1 & 1 & 0.0 & 0.0 & 1.0 & 0.0 & 6.283 \\ 1 & 1 & 0.0 & 0.0 & 2.0 & 0.0 & 6.283\end{array}$


HNF-SD-SNF-CN-023 REV 1

APPENDIX E

HANSF CODE QUALITY ASSURANCE 
HNF-SD-SNE-CN-023 REV 1

This page intentionally left blank. 


\section{APPENDIX E}

\section{HANSF CODE QUALITY ASSURANCE}

This appendix describes the quality assurance that was performed on version 1.2 of the HANSF code (Plys et al. 1998) by personnel at the Hanford Site following the software practices described in HNF-PRO-437, Software Practices - Software Application.

The primary quality assurance for the HANSF code was performed by the developers at Fauske \& Associates, Inc. (FAI) ${ }^{1}$ FAI maintains configuration control on the source code, and performs the verification and validation of the HANSF code (Plys et al. 1998).

Personnel at the Hanford Site demonstrated that the final (earlier beta versions existed) executable version (1.2) supplied by FAI on July 2, 1998, produced the same results on the Hanford Site computer used for calculating the results for this report as it did on the FAI computers, which have been documented in detail (Plys et al. 1998). The Hanford Site computer was a $200 \mathrm{Mhz}$ Pentium PC (AST, Bravo MS 5200M) with 32 MBytes of memory. This was accomplished by running the test case input files ( 25 in all) on the Hanford Site computer, and then comparing the Site-generated output files with the corresponding output files from FAI. The comparison of the output files was performed in detail by performing a "diff" operation on each pair of files being compared. The "diff" operation detects all differences between the two files being compared. The only differences detected for each of the 25 cases were the date and file names, which means all of the calculated variables were exactly the same to the number of significant digits printed in the output files (up to 7 digits for some variables) for all cases. Hence, the HANSF code (version 1.2) runs the same on the Hanford Site computer as it does on the FAI computers.

Most of the 25 test input files were originally created by FAI personnel to test 15 specific effects or physical processes. The code results for each separate effects test were compared to experimental data and/or analytical solutions and documented (Plys et al. 1998, Section 7). The separate effects tests included the following physical phenomena:

1. Region thermodynamics

2. Fog formation

3. Intercompartmental flow

4. Heat transfer by conduction

5. Aerosol transport and deposition

6. Countercurrent flow

7. Aerosol de-entrainment

8. Evaporation/condensation

9. Hydride formation and decomposition

${ }^{1}$ Fauske \& Associates, Inc., 16W070 West 83rd Street, Burr Ridge, Illinois 60521, with phone number 630-323-8750. 


\section{HNF-SD-SNF-CN-023 REV 1}

10. Uranium oxidation

11. Entrainment

12. Hydrate decomposition

13. Fuel and scrap basket heat transfer

14. Nitride formation

15. Vacuum and recirculation pump.

For some of the physical processes, more than one test was performed. Altogether, 22 test input files were created for the HANSF code to test the 15 physical processes. Some of the processes, such as aerosol entrainment and de-entrainment, were not used by this analysis, but most of the others were.

In addition to the specific effects testing, three integral tests that illustrate use of the code for typical multi-canister overpack transients, which include several physical processes, were developed by FAI personnel (Plys et al. 1998). The three integral tests demonstrate reasonable performance consistent with expectation in the following areas:

1. Vacuum cycle simulation of cold vacuum drying process

2. Shipping simulation

3. Interim storage.

In summary, the HANSF code (version 1.2) runs the same at the Hanford Site as it was meant to run and demonstrated to run at FAI. Furthermore, the HANSF code has the capability to model the physical processes that are important to the Cold Vacuum Drying Facility. .

\section{REFERENCES}

HNF-PRO-437, Software Practices - Software Application, Fluor Daniel Hanford, Incorporated, Richland, Washington.

Plys, M. G., S. J. Lee, B. Malinovic, and M. Epstein, 1998, Hanford Spent Nuclear Fuel Safety Analysis Model HANSF 1.2: User's Manual, FAl/98-40, Rev. 0, Fauske \& Associates, Incorporated, Burr Ridge, Illinois. 


\section{HNF-SD-SNF-CN-023 REV 1}

\section{APPENDIX F}

\section{PEER REVIEW CHECKLIST}




\section{HNF-SD-SNF-CN-023 REV 1}

This page intentionally left blank. 
HNF-SD-SNF-CN-023 REV 1

\section{CaECKTIST FOR PLER REVTEW}

Document Reviewed: HIFF-SD-SNF-CN-023, Revision 1, Thermul Anatysis of Cold Vacumm Drying of Spent Nuclioar Fut!

Scope of Review: Entire docurient

Yer No NA

Provious reviears complete and cover analygis, up to scope of this review,

[ [ ] [ ] with no geps.

$B[][]$

Rrublem conpletely defined.

Q [] [ 1

Acsident scanarios develuped in a clear and logical manner.

$\Delta[][]$

Necesstary assumptions explicitly stated and supported.

Computer codes and data files documented.

Date used in caloulations explicitly stated in docurent.

b] [ ] [ ]

Data checked for consirtency wish oripian source information as applicable.

\& $[1]$

Mathenetical derivations checked including dimentional connistency of results.

$\infty[1]$

Model eppropriate and unod within range of validity or ure outside tange of established validity justifiec.

$\triangle[][]$

Hend ogloulations checked for arrors. Spreadsheot results should be treated exactly the same as hand calculations.

B. [] [ ] Softwaro inpul correct and consigtent with document reviowed.

A [ ] [ ]

Software output consistent with input and with results reported in docament. reviewed.

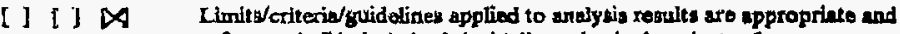
roferenced. I-inits/criteris/guid olinos ehooked aguinat roforeoces.

$\left.\begin{array}{llll}\infty & {[} & ] & {[}\end{array}\right]$ Safety margins consistent with good ungirleering practioes.

Conchusions consistent with analyticel results and epplicable limits. Results and conchosions address all pointa required in the problem stetement. Format consistent with appropriate NRC Rogulatery Guide of other atundards Review calculations, commenta, and/ar nutey ure attached.

\section{I I I Docuinent spproved.}

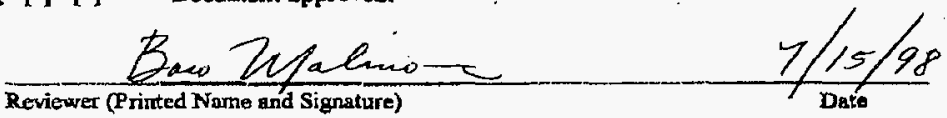

- Any calculations, comrnents, or notes generated as pert of this roviow should be slgred, dated and attached to this checklist. Such material should be iaboled and rocorded in bueh a manner as to be inteiltigible to a technically qualified third party. 


\section{HNF-SD-SNF-CN-023 REV 1}

This page intentionally left blank. 


\section{DISTRIBUTION SHEET}

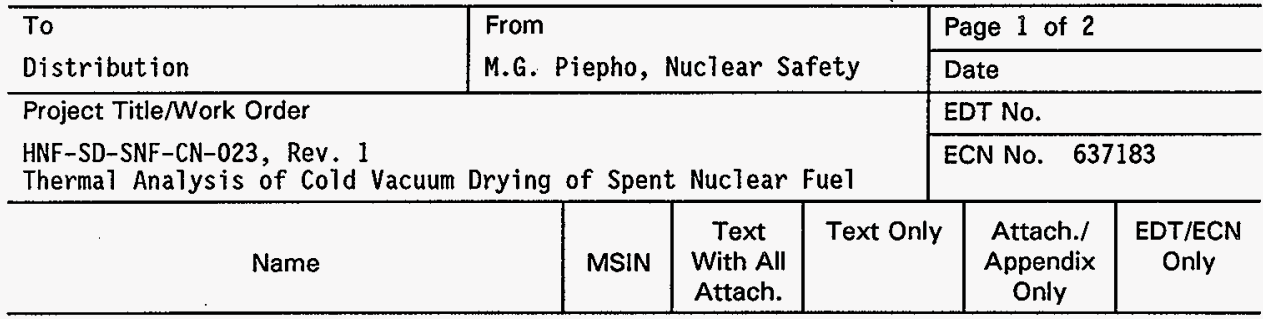

\section{DESH}

W.C. Alaconis

R3-86

D.W. Bergmann

$\times 3-79$

R.L. Besser

D.R. Duncan

J.R. Frederickson

L.H. Goldmann

L.A. Lawrence

B.J. Makenas

R.G. Morgan

R.P. Omberg

K.E. Smith

A.M. Segrest

D.L. Sherrell

R3-26

R3-86

R3-86

R3-86

$\mathrm{HO}-40$

HO- 40

R3-26

R3-26

R3-86

R3-11

R3-86

J.A. Swenson

R3-11

FDNW

R.D. Crowe

R3-26

B4-47

B.E. Hey

M.J. Higuera

M.G. Piepho (5)

SO-04

R3-26

P.D. Rittmann

R3-26

NHC

G.D. Bazinet

T. Choho

J.J. Irwin

W.C. Miller

C.R. Miska

C. Pilj-Vincens

J.P. SToughter

S8-06

R3-86

R3-86

H5-25

R3-86

R3-26

H5-49

$x$
$x$
$x$
$x$
$x$
$x$
$x$
$x$
$x$
$x$
$x$
$x$
$x$
$x$

COGEMA

A.L. Pajunen

R3-86

PNNL

S.C. Marschman

P7-27 X

TRI

D.E. Ball

R.A. Sexton

R3-86

R3-86

$\mathrm{X}$

XWest

S.B. Harrington

B.D. Lorenz 


\section{DISTRIBUTION SHEET CONTINUED}

Files

SNF Project Files

Central Files

R3-11

B1-07

$x$
$x$

$\underline{\text { Offsite }}$

G. Banken

$x$

Q-Metrics

12025 115th Ave., NE

B]dg. D, Suite 250

Kirkland, WA 98034

M.G. Plys, (3)

B. Malinovic, S.J. Lee

$x$

Fauske \& Associates, Inc.

162070 W. 83rd St.

Burr Ridge, IL 60521

M.J. Thurgood

John Marvin, Inc.

5335 W. Van Giesen St.

West Richland, WA 99352 